\title{
Hydrogeology and Water Quality of the Leetown Area, West Virginia
}

By Mark D. Kozar, Kurt J. McCoy, David J. Weary, Malcolm S. Field, Herbert A.

Pierce, William Bane Schill, and John A. Young

Open-File Report 2007-1358

U.S. Department of the Interior

U.S. Geological Survey 


\title{
U.S. Department of the Interior DIRK KEMPTHORNE, Secretary
}

\author{
U.S. Geological Survey \\ Mark D. Myers, Director
}

\section{U.S. Geological Survey, Reston, Virginia: 2007}

For product and ordering information:

World Wide Web: http://www.usgs.gov/pubprod

Telephone: 1-888-ASK-USGS

For more information on the USGS--the Federal source for science about the Earth, its natural and living resources, natural hazards, and the environment:

World Wide Web: http://www.usgs.gov

Telephone: 1-888-ASK-USGS

Any use of trade, product, or firm names is for descriptive purposes only and does not imply endorsement by the U.S. Government.

Although this report is in the public domain, permission must be secured from the individual copyright owners to reproduce any copyrighted materials contained within this report.

Suggested citation:

Geohydrology and water quality of the Leetown Area, West Virginia, by Mark D. Kozar, Kurt J. McCoy, David J. Weary, Malcolm S. Field, Herbert A. Pierce, William B. Schill, and John A. Young: U.S. Geological Survey Open-file Report 2007-1358, 100 p, http://pubs.usgs.gov/of/2007/1358. 


\section{Contents}

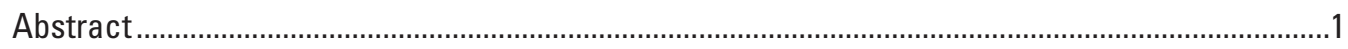

Introduction - by Mark D. Kozar and Kurt J. McCoy …….........................................................

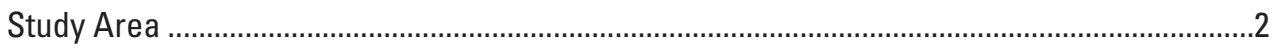

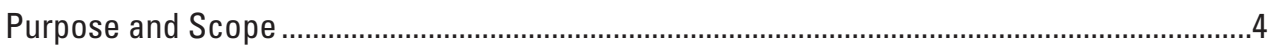

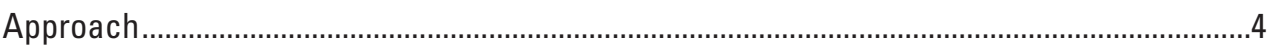

Previous Investigations ...................................................................................................

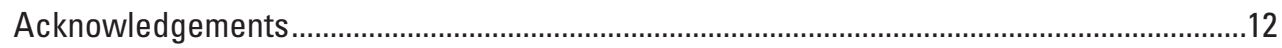

Hydrogeology - By M. D. Kozar, K. J. McCoy, D. J. Weary, and H. A. Pierce....................................12

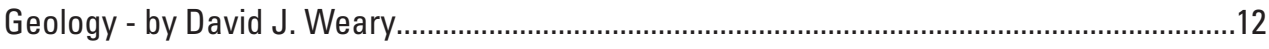

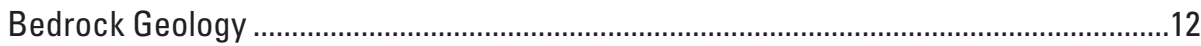

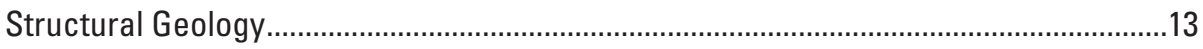

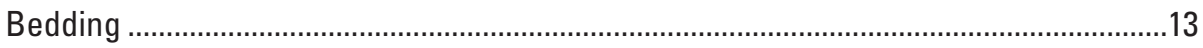

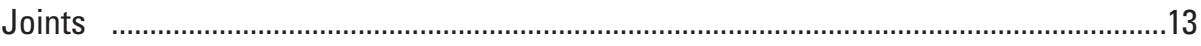

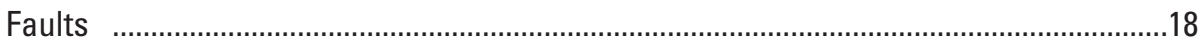

Cleavage

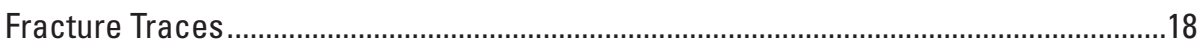

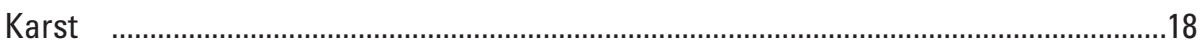

Geophysics - By Herbert A. Pierce and Kurt J. McCoy........................................................22

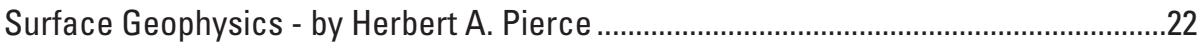

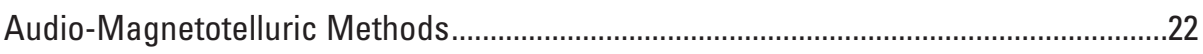

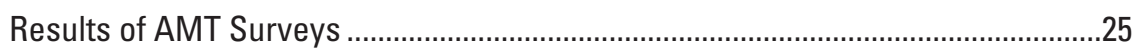

Borehole Geophysics - by Kurt J. McCoy.................................................................2

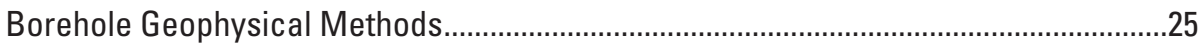

Results of Borehole Geophysical Surveys ..........................................................25

Hydrology - by Mark D. Kozar, Kurt J. McCoy, and John A. Young ........................................34

Precipitation, Surface Drainage, and Streamflow -

by Mark D. Kozar and Kurt J. McCoy ..................................................................

LiDAR Data Acquisition and Processing for Landform Analysis - by John A. Young.....38

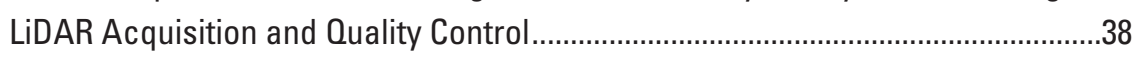

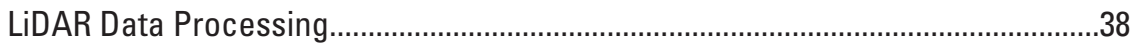

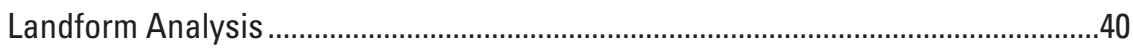

Landform Interpretation to Identify Sinkholes .......................................................40

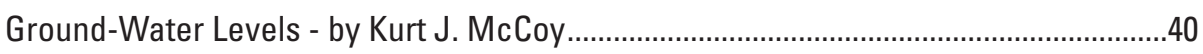

Base-Flow Discharge Measurements - by Mark D. Kozar and Kurt J. McCoy...............46

Ground-Water Recharge/Discharge - by Mark D. Kozar ...............................................46

Water Budgets - by Mark D. Kozar ...........................................................................52

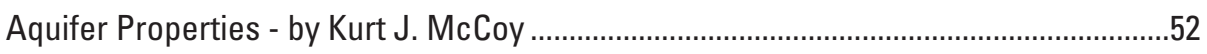

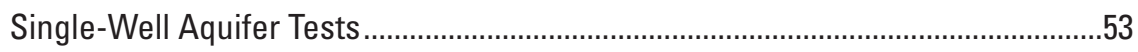

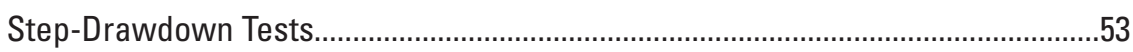

Multiple-Well Aquifer Tests ............................................................................5

Straddle-Packer Tests...................................................................................... 56

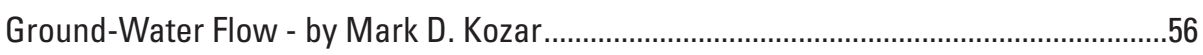

Dye Tracer Tests and Analyses - by Malcolm S. Field...................................................58

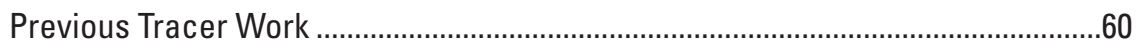

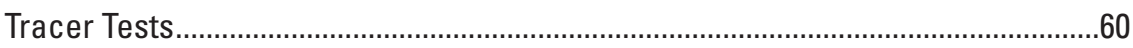

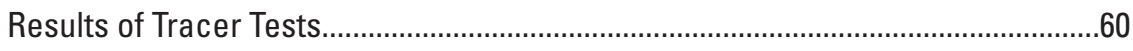

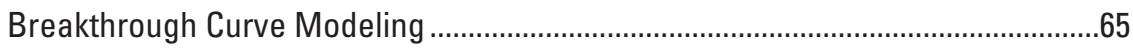

Spring Recharge Delineation - by Mark D. Kozar .........................................................67 


\section{Contents-continued}

Water Quality - by Mark D. Kozar and William B. Schill ...............................................................69

Field Measurements and Inorganic Constituents - by Mark D. Kozar....................................69

Specific Conductance, $\mathrm{pH}$, and Temperature .............................................................69

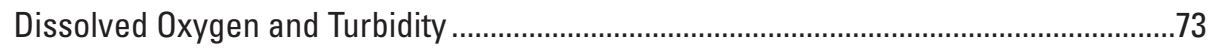

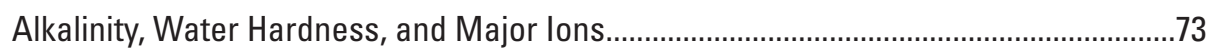

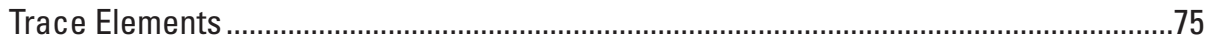

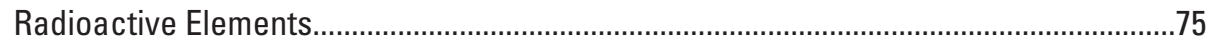

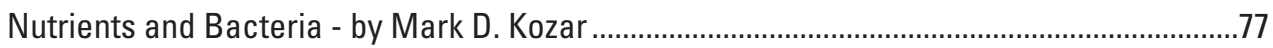

Nitrogen and Phosphorous Compounds...........................................................................77

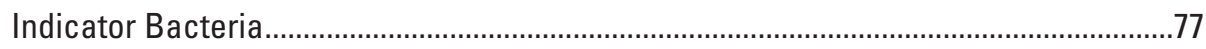

Microbial and Molecular Studies - by William B. Schill ......................................................77

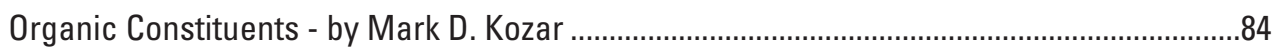

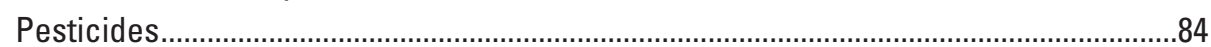

Volatile and Semi-Volatile Organic Compounds ........................................................84

Ground-Water Age Constituents and Radionuclides - by Mark D. Kozar ..............................84

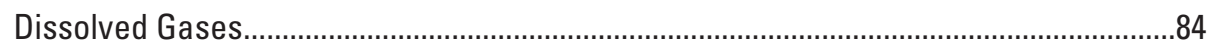

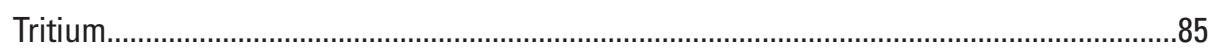

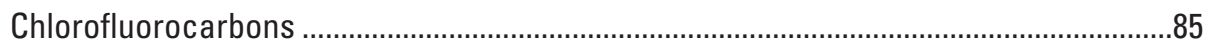

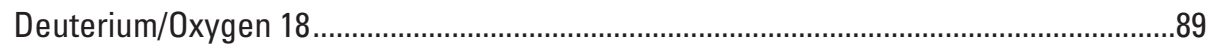

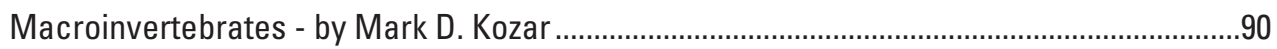

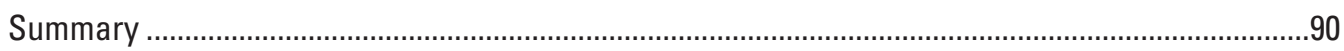

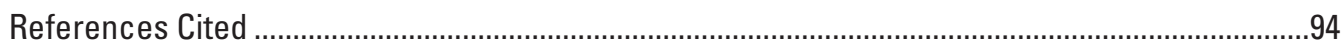

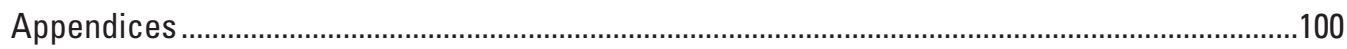




\section{Figures}

1-2: Maps showing:

1. Location of study area with sites sampled or measured during the study and boundary of the ground-water flow model for the Leetown area, West Virginia.

2. A) Geology, B) geologic cross section, and C) stratigraphic column of the Hopewell Run surface water drainage basin, and the USGS Leetown Science Center, West Virginia.

3. Conceptual diagram showing geometric and spatial relations between bedding planes, joints, and drill holes in a tightly-folded terrain, such as that in the Leetown area, West Virginia.

4. Lower hemisphere stereographic projection of poles to bedding from outcrop data collected in the Leetown area, West Virginia.

5. Compass-rose diagram showing the dominant joint trends in the Paleozoic rocks of the Leetown area, West Virginia.

6-7: Lower hemispheric stereographic projections:

6. of poles to joint planes measured at the ground surface (green points and blue contours) and fractures measured in monitoring wells (red squares and purple contours) in the Leetown area, West Virginia.

7. of lineations defined by beta pair intersections of bedding and joints measured at the ground surface in the Leetown area, West Virginia.

8. Map showing Audio-magnetotelluric station locations and electrical resistivity cross sections developed for the Leetown area, West Virginia.

9. Schematic diagram showing a conceptual model of the geologic structure and epikarst weathering typical of the Leetown area, West Virginia.

10. Two-dimensional apparent resistivity map of the AMT data at 33 feet below land surface, Leetown area, West Virginia.

11. Two-dimensional invariant electrical-resistivity section (LL1) across the USGS Leetown Science Center, West Virginia.

12. Composite map showing the 2-dimensional audio-magnetotelluric resistivity at $197 \mathrm{ft}$ below land surface, surficial geologic map, and USGS topographic map of the Leetown area, West Virginia.

13. Rose diagrams of a) cleavage and joints in bedrock of the Leetown area and b) fracture traces in Jefferson and Berkeley Counties, West Virginia.

14. Examples of fracture images from acoustic and optical televiewer logs of boreholes in the Leetown area, West Virginia.

15. Illustration showing the method of determining fracture strike and dip orientation from televiewer logs.

16-17: Schmidt equal-area stereo-net projections

16. of poles to planes for 683 fractures identified in acoustic-televiewer (ATV) logs of 11 wells at the USGS Leetown Science Center, West Virginia.

17. (segregated by geologic structure) of poles to planes for fractures identified in acoustic-televiewer logs of 11 wells at the USGS Leetown Science Center, West Virginia.

18. Potentiometric-surface map of simulated ground-water levels and generalized directions of ground-water flow in the Leetown area, West Virginia.

19. LiDAR derived digital-elevation model for the Leetown area, West Virginia. 


\section{Figures-}

20. Detail of LiDAR derived digital elevation model, color coded by levels of topographic position index, with small circular topographic depressions showing sink holes in the Hopewell Run Watershed, Leetown area, West Virginia 41

21-24. Graphs showing:

21. Precipitation measured at Gray Spring and hydrograph for well Jef-0526 at the USGS Leetown Science Center, West Virginia.

22. Hydrograph of Balch and Gray Springs, USGS Leetown Science Center, West Virginia.

23. Location of base-flow survey sites and flows measured along Hopewell Run and its tributaries in the Leetown area, West Virginia

24. Graph showing the average standardized departures of the minimum stream flows from the record period average for 1930-2002 for five stream gaging stations in the Eastern Panhandle of West Virginia.

25. Ground-water flow connections determined from dye tracer studies conducted in the Leetown area, West Virginia.

26. Estimated recharge areas of Balch, Blue, and Gray Springs during average hydrologic conditions, Leetown, West Virginia.

27-33. Graphs showing:

27. Water temperature, stage, and precipitation for the period from April 2003-November 2005, measured at Gray Spring, Leetown, West Virginia..

28. Distribution of concentrations of major ions, hardness, and total dissolved solids in water samples collected from 8 wells and 3 springs at the USGS Leetown Science Center, West Virginia.

29. Microbial contamination observed in September, 2004 for wells and springs sampled at the USGS Leetown Science Center, West Virginia.

30. Multidimensional scaling analysis showing the relations between abiotic and biotic parameters for 12 ground-water sources in the Leetown area, West Virginia. ....80

31. Multidimensional scaling analysis showing the relations between 12 ground-water sources in the Leetown area, West Virginia.

32. Melting curve analysis of bacterial $16 \mathrm{~S}$ ribosomal DNA gene fragments amplified by polymerase chain reaction from the bacterial assemblage of the new Kaiser farm well, Leetown, West Virginia, on two occasions.

33. Relation of oxygen-18 and deuterium isotopes showing evaporative enrichment trend for sites sampled on the USGS Leetown Science Center, West Virginia......89 


\section{Tables}

1. List of wells, springs, and streams where data was collected in the Leetown area, West Virginia, during the investigation and the type of data collected at each site.

2. Description and application of borehole logging techniques utilized at the USGS Leetown Science Center, West Virginia.

3. Precipitation in inches at the Eastern West Virginia Regional Airport, Martinsburg, West Virginia, 2003-2005.

4. Summary statistics from monthly water level observations, July 2003-0ctober 2005, at the USGS Leetown Science Center, West Virginia

5. Estimates of quarterly ground-water recharge for the Hopewell Run and Opequon Creek watersheds, West Virginia and Virginia, for water years 2003-2005

6. Quarterly and annual estimates of ground-water recharge for the Opequon Creek watershed with statistical rank (highest to lowest) for years 1948-2005

7. Summary statistics for transmissivities $(\mathrm{T})$ in $\mathrm{ft}^{2} / \mathrm{day}$ calculated from single well aquifer tests for geologic units near Leetown, West Virginia . .54

8. Specific capacities ( $\mathrm{gal} / \mathrm{min} / / \mathrm{ft}$ ) calculated from step-discharge tests conducted the USGS Leetown Science Center, West Virginia . .54

9. Radial-flow model results from multiple-well aquifer tests conducted at the USGS Leetown Science Center, West Virginia.

10. Transmissivities computed from straddle packer tests conducted th the USGS Leetown Science Center, West Virginia.

11. Depth of regolith and epikarst as seen in drill logs at the USGS Leetown Science Center, West Virginia

12. Locations and date and time of recent tracer injections conducted in the Leetown area, West Virginia. 62

13. Locations and distance of tracer-resurgence sampling stations from injection sites, Leetown area, West Virginia.

14. Ground-water travel times and velocities for the eight recent tracer tests conducted in the Leetown area, West Virginia.

15. OTRACER2-estimated flow parameters for selected sampling sites in the Leetown area, West Virginia. . .66

16. CXTFIT-estimated parameters for selected breakthrough curves from tracer tests conducted in the Leetown area, West Virginia. 67

17. Summary statistics for constituents and parameters detected in water samples collected at the USGS Leetown Science Center, West Virginia, and U.S. Environmental Protection Agency drinking water and aquatic life standards

18. Wells and springs sampled and analyzed for microbial and DNA studies at the USGS Leetown Science Center, West Virginia . .78

19. Chlorofluorocarbon, tritium, helium, neon, dissolved gas, and isotope data from water samples collected from selected wells and springs sampled at the USGS Leetown Science Center, West Virginia 


\section{Conversion Factors and Datums}

\begin{tabular}{|c|c|c|}
\hline Multiply & By & To obtain \\
\hline \multicolumn{3}{|c|}{ Length } \\
\hline inch (in.) & 2.54 & centimeter $(\mathrm{cm})$ \\
\hline inch (in.) & 25.4 & millimeter $(\mathrm{mm})$ \\
\hline foot $(\mathrm{ft})$ & 0.3048 & meter $(\mathrm{m})$ \\
\hline mile (mi) & 1.609 & kilometer (km) \\
\hline millimeter (mm) & 0.03937 & inch (in) \\
\hline \multicolumn{3}{|c|}{ Area } \\
\hline Acre & 0.004047 & square kilometer $\left(\mathrm{km}^{2}\right)$ \\
\hline square mile $\left(\mathrm{mi}^{2}\right)$ & 2.590 & square kilometer $\left(\mathrm{km}^{2}\right)$ \\
\hline \multicolumn{3}{|c|}{ Volume } \\
\hline gallon (gal) & 3.785 & liter (L) \\
\hline gallon (gal) & 0.003785 & cubic meter $\left(\mathrm{m}^{3}\right)$ \\
\hline million gallons (Mgal) & 3,785 & cubic meter $\left(\mathrm{m}^{3}\right)$ \\
\hline cubic foot $\left(\mathrm{ft}^{3}\right)$ & 0.02832 & cubic meter $\left(\mathrm{m}^{3}\right)$ \\
\hline cubic centimeter $\left(\mathrm{cm}^{3}\right)$ & 0.06102 & cubic inch $\left(\mathrm{in}^{3}\right)$ \\
\hline \multicolumn{3}{|c|}{ Mass } \\
\hline ounce, avoirdupois (oz) & 28.35 & $\operatorname{gram}(\mathrm{g})$ \\
\hline pound, avoirdupois & 0.4536 & kilogram (kg) \\
\hline picogram (pg) & $1 \times 10^{-12}$ & $\operatorname{gram}(\mathrm{g})$ \\
\hline kilogram $(\mathrm{kg})$ & & $\operatorname{gram}(\mathrm{g})$ \\
\hline \multicolumn{3}{|c|}{ Flow rate } \\
\hline foot per day (ft/d) & 0.3048 & meter per day (m/d) \\
\hline cubic foot per second $\left(\mathrm{ft}^{3} / \mathrm{s}\right)$ & 0.02832 & cubic meter per second $\left(\mathrm{m}^{3} / \mathrm{s}\right)$ \\
\hline $\begin{array}{l}\text { cubic foot per second per square mile } \\
{\left[\left(\mathrm{ft}^{3} / \mathrm{s}\right) / \mathrm{mi}^{2}\right]}\end{array}$ & 0.01093 & $\begin{array}{l}\text { cubic meter per second per square kilo- } \\
\text { meter }\left[\left(\mathrm{m}^{3} / \mathrm{s}\right) / \mathrm{km}^{2}\right]\end{array}$ \\
\hline cubic foot per day $\left(\mathrm{ft}^{3} / \mathrm{d}\right)$ & 0.02832 & cubic meter per day $\left(\mathrm{m}^{3} / \mathrm{d}\right)$ \\
\hline gallon per minute (gal/min) & 0.06309 & liter per second $(\mathrm{L} / \mathrm{s})$ \\
\hline gallons per day (gal/d) & 0.003785 & cubic meter per day $\left(\mathrm{m}^{3} / \mathrm{d}\right)$ \\
\hline inch per year (in/yr) & 25.4 & millimeter per year (mm/yr) \\
\hline \multicolumn{3}{|c|}{ Specific capacity } \\
\hline gallon per minute per foot $(\mathrm{gal} / \mathrm{min}) / \mathrm{ft}$ & 0.2070 & liter per second per meter $[(\mathrm{L} / \mathrm{s}) / \mathrm{m}]$ \\
\hline \multicolumn{3}{|c|}{ Hydraulic conductivity } \\
\hline foot per day (ft/d) & 0.3048 & meter per day $(\mathrm{m} / \mathrm{d})$ \\
\hline \multicolumn{3}{|c|}{ Hydraulic gradient } \\
\hline foot per mile (ft/mi) & 0.1894 & meter per kilometer $(\mathrm{m} / \mathrm{km})$ \\
\hline \multicolumn{3}{|c|}{ Transmissivity* } \\
\hline foot squared per day $\left(\mathrm{ft}^{2} / \mathrm{d}\right)$ & 0.09290 & meter squared per day $\left(\mathrm{m}^{2} / \mathrm{d}\right)$ \\
\hline
\end{tabular}




\section{Conversion Factors and Datums—continued}

Vertical coordinate information is referenced to the North American Vertical Datum of 1988 (NAVD 88) and horizontal coordinate information is referenced to the North American Datum of 1983 (NAD 83). Altitude and elevation, as used in this report, refer to distance above the vertical datum.

*Transmissivity: The standard unit for transmissivity is cubic foot per day per square foot times foot of aquifer thickness [(ft $\left.\left.\mathrm{ft}^{3} / \mathrm{d}\right) / \mathrm{ft}^{2}\right] \mathrm{ft}$. In this report, the mathematically reduced form, foot squared per day $\left(\mathrm{ft}^{2} / \mathrm{d}\right)$, is used for convenience.

Temperature in degrees Celsius $\left({ }^{\circ} \mathrm{C}\right)$ may be converted to degrees Fahrenheit $\left({ }^{\circ} \mathrm{F}\right)$ as follows:

$$
{ }^{\circ} \mathrm{F}=\left(1.8 \times{ }^{\circ} \mathrm{C}\right)+32
$$

Specific conductance is given in microsiemens per centimeter at 25 degrees Celsius $(\mu \mathrm{S} / \mathrm{cm}$ at $\left.25^{\circ} \mathrm{C}\right)$.

Concentrations of chemical constituents in water are given in either milligrams per liter (mg/L) or micrograms per liter $(\mu \mathrm{g} / \mathrm{L})$.

Dissolved-gas concentrations are presented in units of $\mathrm{mg} / \mathrm{L}$ or as cubic centimeters of gas at standard temperature and pressure per gram water (ccSTP/g $\left.\mathrm{H}_{2} \mathrm{O}\right)$.

Excess-air content is given in cubic centimeters per kilogram of water $\left(\mathrm{cm}^{3} / \mathrm{kg} \mathrm{H}_{2} \mathrm{O}\right)$.

Concentrations of chlorofluorocarbons in water are given in units of picograms per kilogram $(\mathrm{pg} / \mathrm{kg})$, and concentrations of chlorofluorocarbons in air are given in units of parts per trillion by volume (pptv).

Frequency, as it pertains to audio-magnetotellurics discussions in this report is referred to in Hertz $(\mathrm{Hz})$, an expression of cycles per second.

Fluorescence, as discussed in this report is presented in relative fluorescence units (RFU).

Turbidity is expressed within this report in nephelometric turbidity units (NTU). 


\title{
Hydrogeology and Water Quality of the Leetown Area, West Virginia
}

\author{
By Mark D. Kozar, Kurt J. McCoy, David J. Weary, Malcolm S. Field, Herbert A. Pierce, William Bane Schill, \\ and John A. Young
}

\section{Abstract}

The U.S. Geological Survey's Leetown Science Center and the co-located U.S. Department of Agriculture's National Center for Cool and Cold Water Aquaculture both depend on large volumes of cold clean ground water to support research operations at their facilities. Currently, ground-water demands are provided by three springs and two standby production wells used to augment supplies during periods of low spring flow. Future expansion of research operations at the Leetown Science Center is dependent on assessing the availability and quality of water to the facilities and in locating prospective sites for additional wells to augment existing water supplies. The hydrogeology of the Leetown area, West Virginia, is a structurally complex karst aquifer. Although the aquifer is a karst system, it is not typical of most highly cavernous karst systems, but is dominated by broad areas of fractured rock drained by a relatively small number of solution conduits. Characterization of the aquifer by use of fluorometric tracer tests, a common approach in most karst terranes, therefore only partly defines the hydrogeologic setting of the area. In order to fully assess the hydrogeology and water quality in the vicinity of Leetown, a multi-disciplinary approach that included both fractured rock and karst research components was needed.

The U.S. Geological Survey developed this multidisciplinary research effort to include geologic, hydrologic, geophysical, geographic, water-quality, and microbiological investigations in order to fully characterize the hydrogeology and water quality of the Leetown area, West Virginia. Detailed geologic and karst mapping provided the framework on which hydrologic investigations were based. Fracture trace and lineament analysis helped locate potential water-bearing fractures and guided installation of monitoring wells. Monitoring wells were drilled for borehole geophysical surveys, water-quality sampling, water-level measurements, and aquifer tests to characterize the quality of water and the hydraulic properties of the aquifer. Surface geophysical surveys provided a 3-dimensional view of bedrock resistivity in order to assess geologic and lithologic controls on ground-water flow. Borehole geophysical surveys were conducted in monitoring wells to assess the storage and movement of water in subsurface fractures. Numerous single-well, multi-well, and straddle packer aquifer tests and step-drawdown tests were conducted to define the hydraulic properties of the aquifer and to assess the role of bedrock fractures and solution conduits in the flow of ground water. Water samples collected from wells and springs were analyzed to assess the current quality of ground water and provide a baseline for future assessment. Microbiological sampling of wells for indicator bacteria and human and animal DNA provided an analysis of agricultural and suburban development impacts on ground-water quality. Light detection and ranging (LiDAR) data were analyzed to develop digital elevation models (DEMs) for assessing sinkhole distribution, to provide elevation data for development of a ground-water flow model, and to assess the distribution of major fractures and faults in the Leetown area.

The flow of ground water in the study area is controlled by lithology and geologic structure. Bedrock, especially low permeability units such as the shale Martinsburg Formation and the Conococheague Limestone, act as barriers to water flowing down gradient and across bedding. This retardation of cross-strike flow is especially pronounced in the Leetown area, where bedding typically dips at steep angles. Highly permeable fault and fracture zones that disrupt the rocks in crossstrike directions provide avenues through which ground water can flow laterally across or through strata of low primary permeability. Significant strike parallel thrust faults and crossstrike faults typically coincide with larger solution conduits and act as drains for the more pervasive network of interconnected diffuse fractures.

Results of borehole geophysical surveys indicate that although numerous fractures may intersect a borehole, only one or two of the fractures typically transmit most of the water to a well. The diffuse-flow dominated network of fractures that provides the majority of storage occupies only a small proportion of the total aquifer volume but constitutes the majority of porosity within the aquifer. Solution conduits, while occupying a relatively small volume of the overall aquifer, are especially important because they serve as primary drains for the groundwater flow system. Surface resistivity maps and cross-sections 
show anomalous areas of low resistivities coincident with the prevailing geologic strike at N. $20^{\circ}$ E., with major cross-strike faults, and with major springs in the region.

Transmissivity derived from straddle packer tests was highly variable, and ranged over three orders of magnitude $\left(1.8 \times 10^{-6}\right.$ to $\left.5.9 \times 10^{-3} \mathrm{ft}^{2} / \mathrm{d}\right)$ in diffuse-flow fractures. A similar large variability in transmissivity was documented by single- and multi-well aquifer tests conducted in conduit-flow dominated portions of the aquifer $\left(2.0 \times 10^{3}\right.$ to $\left.1.4 \times 10^{4} \mathrm{ft}^{2} / \mathrm{d}\right)$ in lowland areas immediately adjacent to the Leetown Science Center.

A stream-gaging station installed on Hopewell Run near the point where the stream exits the Leetown watershed indicates average daily streamflow for the Hopewell Run of approximately $11.2 \mathrm{ft}^{3} / \mathrm{s}$, and ranged from a minimum of $1.80 \mathrm{ft}^{3} / \mathrm{s}$ on September 28, 2005, to a maximum of $73.0 \mathrm{ft}^{3} / \mathrm{s}$ on December 11, 2003. Base-flow (ground-water) discharge surveys identified numerous small seeps adjacent to streams in the area. Hydrographs of the stage of Balch Spring show rapid response to individual storms. Strong correlation of the flow of Hopewell Run and Balch Spring indicates the nearby losing stream reach is partly responsible for higher fluctuations in the stage of Balch Spring. A water budget for the study period (2003-2005), based on measured precipitation and hydrograph analyses, is expressed as Precipitation (38.60 in/yr) = Surface Runoff (1.36 in/yr) + Ground-Water Discharge (17.73 in/yr) + Evapotranspiration (24.23 in/yr) - Change in storage (4.72 in/ yr).

Flow of ground water through the epikarst, a shallow zone of intensely weathered rock and regolith, can be rapid (on the order of days or weeks) as flow is concentrated in solution conduits. Flow within the intermediate and deeper zones is typically much slower. Eight dye-tracer tests conducted in the Leetown area found ground-water flow patterns to be divergent, with velocities ranging from about 12.5 to $610 \mathrm{ft} /$ day and a median velocity of $50 \mathrm{ft} /$ day. Estimates of groundwater age in carbonate rocks in the region are on the order of 15 years in the shallower portions of the aquifer to 50 years or older for deeper portions of the aquifer. Shallow springs can have a significant component of fairly young water $(<5$ years in age).

Ground-water samples collected from 16 sites (12 wells and 4 springs) in the Leetown area were analyzed for more than 340 constituents. Only turbidity, indicator bacteria, and radon were typically present in concentrations exceeding U.S. Environmental Protection Agency (USEPA) drinking-water or aquatic life standards.

\section{Introduction - by Mark D. Kozar and Kurt J. McCoy}

In Jefferson and Berkeley Counties in West Virginia, fractured-carbonate aquifers are relied upon to supply the rapidly increasing demand of water for domestic, commercial, and government users. In such carbonate aquifer settings, well and spring yields are generally high and ground-water supply is considered abundant. In part, these yields can be explained with detailed geologic mapping, yet the heterogeneity of the subsurface system remains poorly understood. However, an understanding of flow and long-term availability of water from such a complex heterogeneous system is essential before engineering solutions to production development can be considered. Therefore, there is a need to further define the aquifer at depth and the characteristics of subsurface flow.

Aquifer permeability can range over several orders of magnitude within a few tens of feet, making adequate conceptualization of the nature of the fractured-carbonate aquifer in the Great Valley difficult at a regional scale. The Great Valley is a sub-region of the Valley and Ridge geomorphic province (Fenneman, 1938) and is one of the most important karst carbonate aquifers in the Eastern United States. Accounting for the spatial distribution and connectivity of smaller less pervasive fractures on a more limited local scale permits a comprehensive analysis of additional aquifer complexities. Comprehensive conceptual and mathematical models are best employed where multiple tools have been used to characterize the aquifer such that the density and degree of interconnectedness of a given fracture system and resulting conduit drains can be better understood regionally.

At the U.S. Geological Survey (USGS) Leetown Science Center near Kearneysville, West Virginia, (fig. 1) scientists evaluated the carbonate aquifer during a 4-year comprehensive study (2002-2006). Detailed work using multiple approaches was conducted to further the understanding of aquifer characteristics and the lithologic and structural controls on groundwater flow in this complex hydrogeologic setting. Such characterization involved surficial geologic mapping, borehole and surface geophysical surveys, open-hole and packer aquifer testing, dye tracing, numerical modeling, continuous waterlevel and streamflow monitoring, and analyses of groundwater quality. This report presents the results of this multidisciplinary investigation.

\section{Study Area}

The Leetown Science Center (hereafter referred to as the Center) is an approximately 455-acre research facility operated by the USGS Biological Resources Discipline and is located in the eastern panhandle of West Virginia near Kearneysville, about 70 miles west of Washington, DC. The primary mission of the Center is to conduct research and investigate the health and habitats of aquatic species, including studies of fish diseases, declining species, invasive species, genetics, aquaculture, and ecology. The U.S. Department of Agriculture's (USDA) National Center for Cool and Cold Water Aquaculture (NCCWA) is co-located at the facility. Large quantities of good-quality cold water are needed to support the diverse research activities at these facilities. 


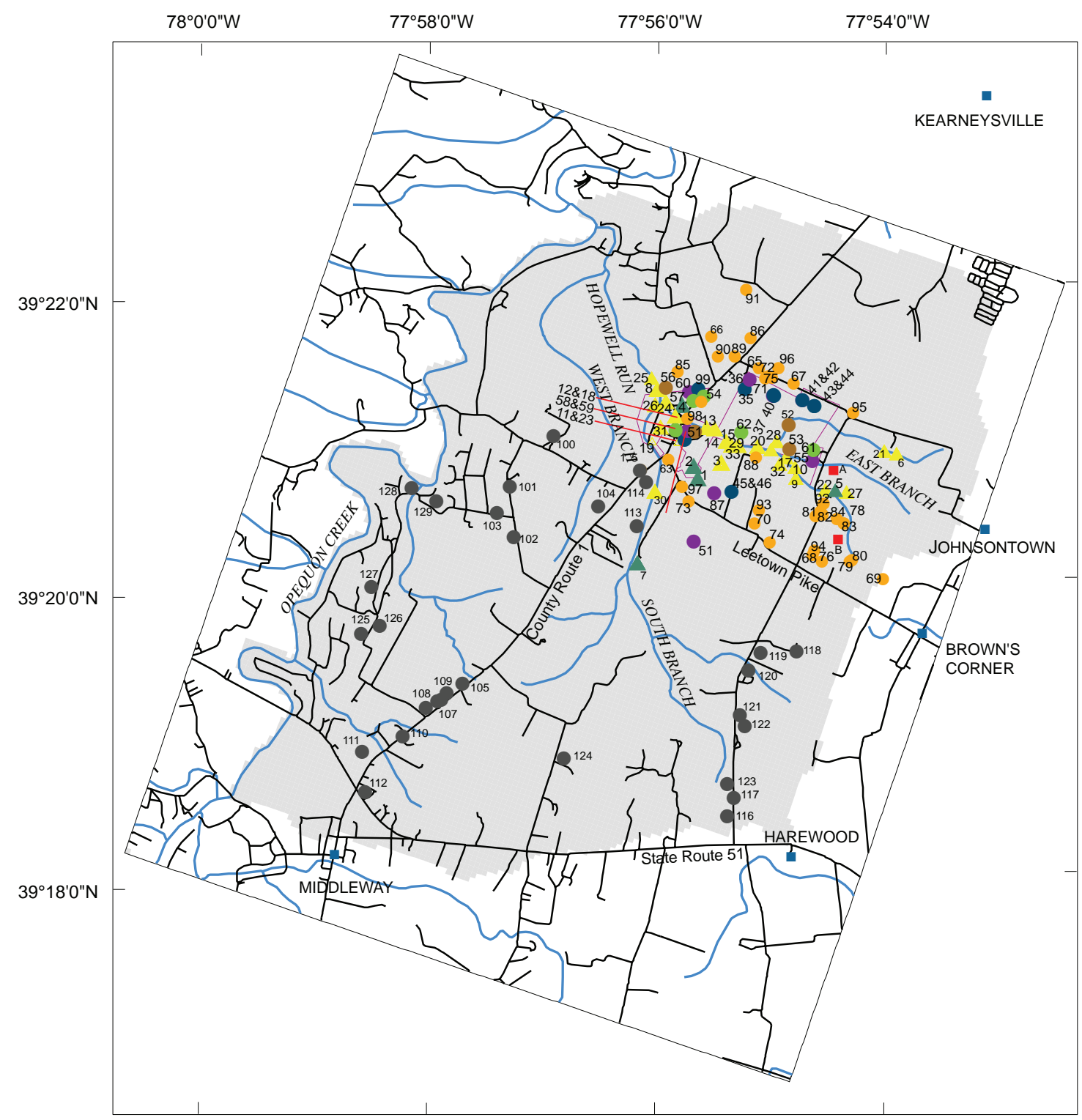

EXPLANATION

Location of study area in West Virginia

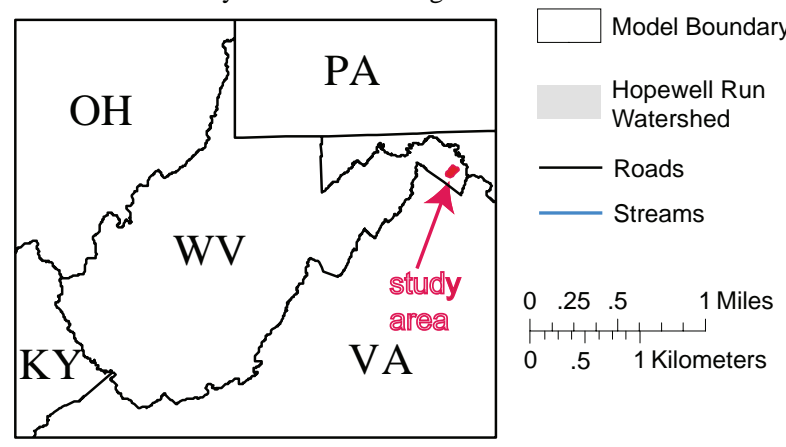

Study Sites

Spring or streamflow measuring site

- Spring and streamflow measuring with water quality monitoring

- Potential contaminant sources

- Ground-water model head observation well

- Ground-water model head observation well and aquifer test

- Ground-water model head observation well and monthly water level well

- Ground-water model, aquifer test, and production well

- Ground-water model, aquifer test, and monthly water level well

- Ground-water model, aquifer test, montly head observation, and water quality monitoring well

Figure 1. Location of study area with sites sampled or measured during the study and boundary of the ground-water flow model for the Leetown area, West Virginia. 
Hydrogeology and Water Quality of the Leetown Area, West Virginia

\section{Purpose and Scope}

This report presents the results of a four-year assessment of the hydrogeology of the Leetown area, West Virginia, and includes: (1) revision of the conceptual model of ground water flow in the fractured karst aquifer that supplies water to the Center; (2) discussion of borehole geophysical surveys and water level and water quality data collected during the study; (3) presentation of data from detailed aquifer tests conducted to determine hydraulic properties of the aquifer (4) assessment of the impact of ground-water withdrawals in certain portions of the aquifer on the yield and long term availability of existing spring flows, (4) delineation of the potential areas of recharge to the Center's major springs to protect the availability and quality of water necessary for operations, and (5) analysis of the water-quality and geochemistry of the karst aquifer in the Leetown area.

\section{Approach}

A multi-disciplinary assessment of the resource was used to describe the karst aquifer from which the Center obtains its water. Geologic mapping, fracture-trace and lineament analysis, and surface-geophysical surveys provided the framework from which hydrologic investigations were conducted. Hydrologic investigations included monitoring well installation, stream seepage surveys, stream gaging of Hopewell Run and Gray and Balch Springs, hydrograph analysis, estimation of ground-water recharge rates, development of water budgets, water-level monitoring, water-quality sampling, borehole geophysical surveys, and single-, multi-, step-drawdown, and packer aquifer tests. A light detection and ranging (LiDAR) survey provided additional data on locations of sinkholes and a digital-elevation model (DEM) was developed from the data. The DEM was used to define the upper surface of a groundwater flow model developed for the area. Dye tracer tests confirmed previously mapped ground-water flow patterns and velocities. Microbial and DNA studies helped improve understanding of the potential contaminants entering the aquifer as well as their mechanisms of transport and potential fate. A listing of the wells, springs, and stream sites where data were collected in support of this investigation, along with the types of data collected at each site, is shown in table 1.

\section{Previous Investigations}

The relation between geology and ground-water supply and quality in the study area was first discussed by Jeffords (1945a, 1945b). Graeff (1953) and Beiber (1961) further elaborated and explained the lithologic control that carbonate units have on the quality and quantity of ground water, and on the direction of flow in the aquifers of Jefferson and Berkeley Counties, West Virginia. Large springs discharging in excess of 1,000 gallons per minute ( $\mathrm{gal} / \mathrm{min}$ ) from these carbonate units were correlated with the faults in the area by Hobba and others (1972). Taylor (1974) concluded that systematic fracturing of the carbonate bedrock, attributed to a four-phase deformation history, is partially evident from topographic analysis of the area. He found that well yields and spring locations in lowland areas are related to structural features, such as joints, faults, and fractures, that allow large quantities of ground water to flow down gradient. Seasonal and annual fluctuations in ground-water storage and base flow to streams associated with these features can be high (Hobba, 1976, 1981). Base-flow stream discharge and water-level data from Kozar and others (1991) and Shultz and others (1995) were used to calculate aquifer transmissivity values that range over an order of magnitude due to the anisotropic nature of fracturing in the carbonate rocks. Preferential flow in the direction of strike was verified by the dye tracing work of Jones (1991), Kozar and others (1991), and Shultz and others (1995). Previous dye tracing work at the Center by Jones and Deike (1981) concluded that the aquifer is characterized by steeply dipping bedding planes with a diffuse network of fractures which may retard travel times and force circulation to depths below that common to other karst systems. McCoy and Kozar (2007b) found that vertical flow of ground water in the Great Valley could be described as down-gradient along continuous interconnected fractures in the direction of bedding that is eventually forced to the surface along structural offsets perpendicular to strike. In nearby Frederick County, Virginia, Harlow and others (2005) modified the conceptual model of Wolfe and others (1997) to describe the influence of structural features on karst development at moderate depths.

Ground-water flow patterns in the Great Valley are complex. The once flat-lying sedimentary rocks have been folded, faulted, and intensely weathered such that a variably thick layer of regolith overlies steeply dipping deformed bedrock units. Recharge in the form of infiltration of precipitation initially moves into the regolith where much of it is stored. Water moves to the underlying bedrock by way of leakage to open fractures, faults, and bedding planes or by direct runoff into surficial karst features. Flow within the bedrock is controlled by the orientation and connectivity of the fracture system and the location of solution-enlarged conduits. Relict structure in the regolith and continuous bedding planes apparently force flow parallel to regional gradients (Jones, 1991). Frazier and others (1988) conducted a detailed surfacewater assessment of the Center and adjacent property using watershed models to assess flooding potential and long-term stability of engineered ponds proposed for construction. A major conclusion of the study, supported by the work of Jones and Deike (1981), was that sufficient water for operations at the Center is not available during drought years and operations at the Center would have to be adjusted to compensate for reduced water availability under drought conditions or periods of prolonged below normal ground-water levels. Additional borehole-log and surface geophysical data were collected by Mayle and Schnabel (1998) as part of geotechnical investigations prior to construction of the NCCWA facility. 


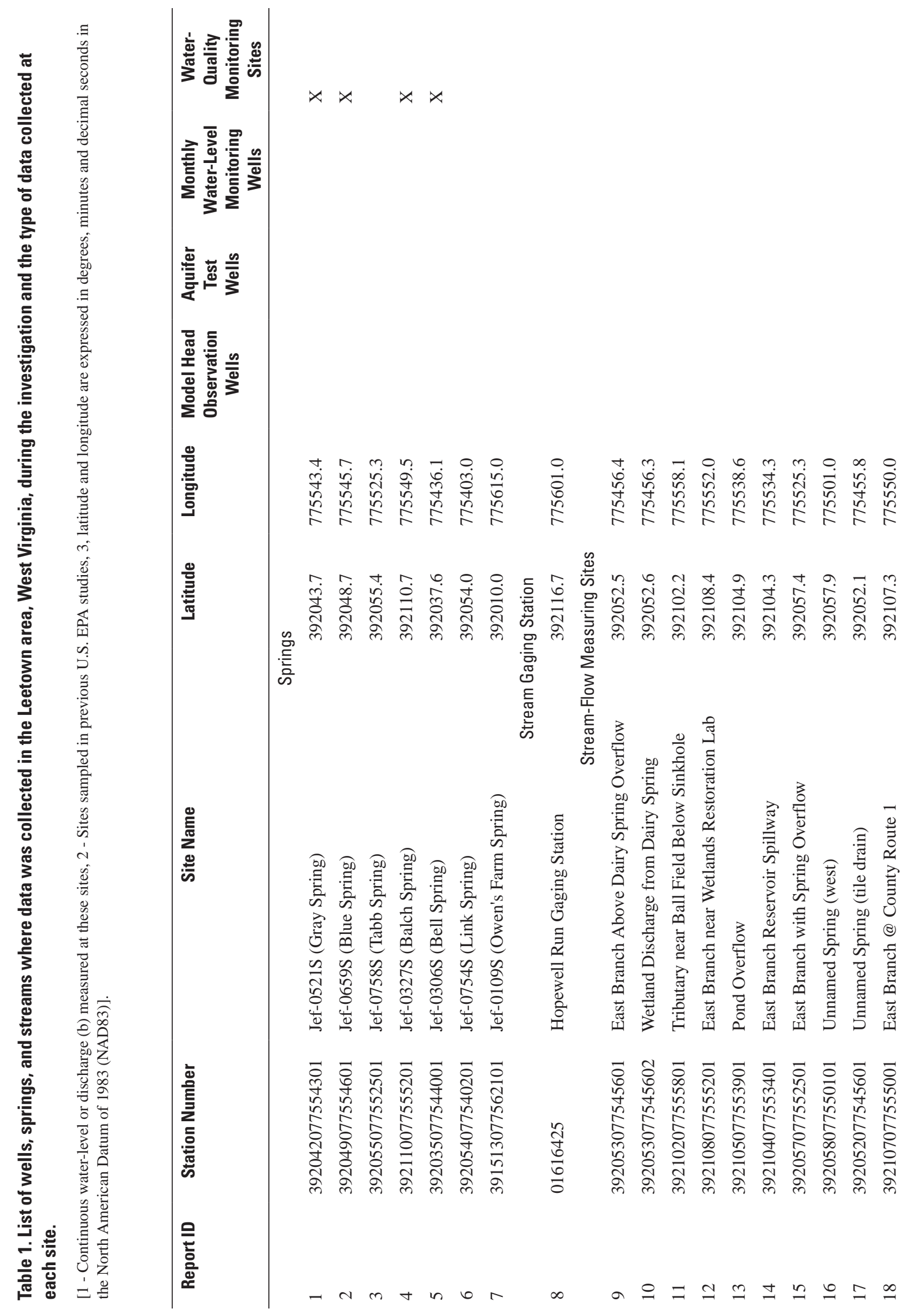




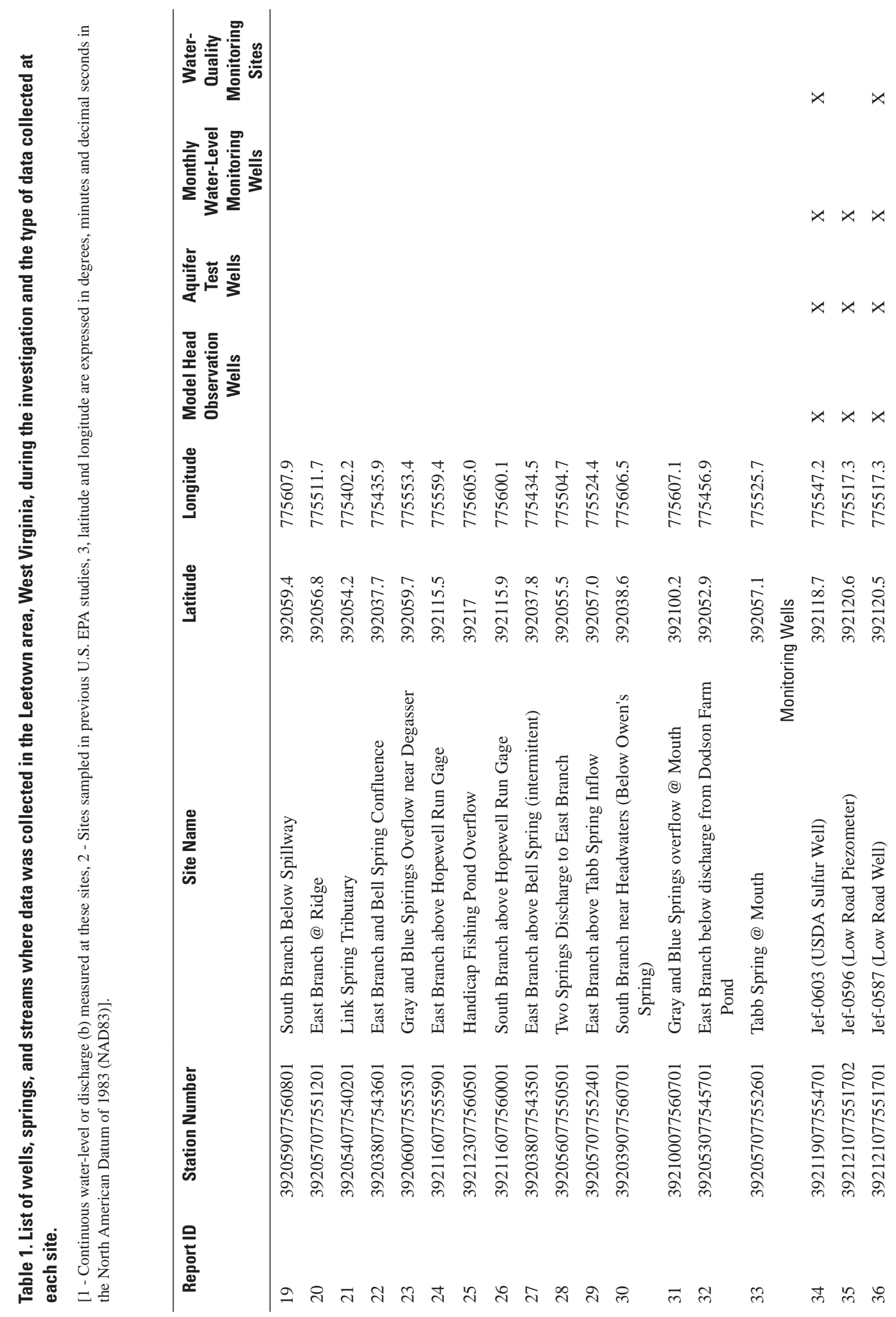




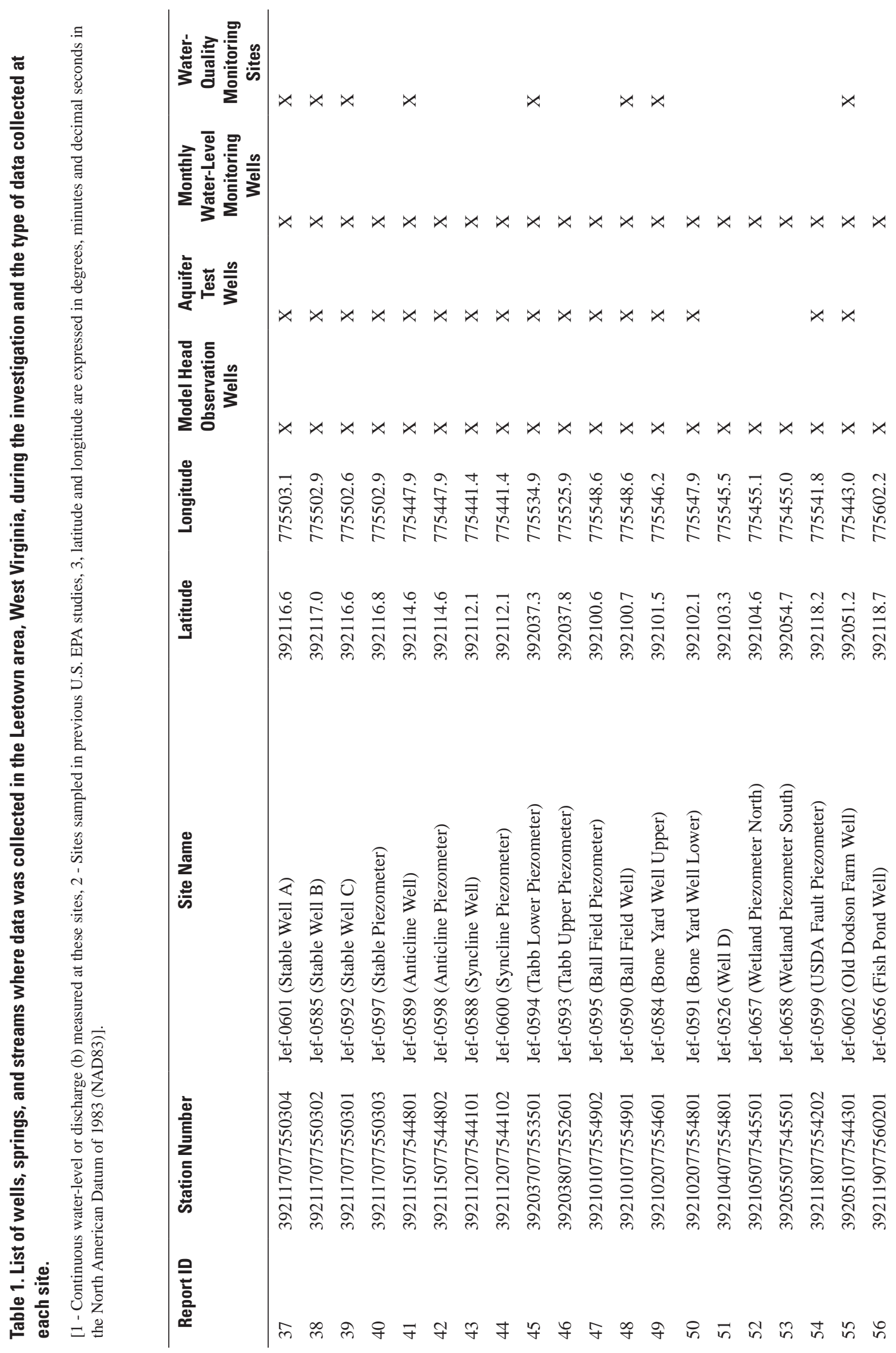




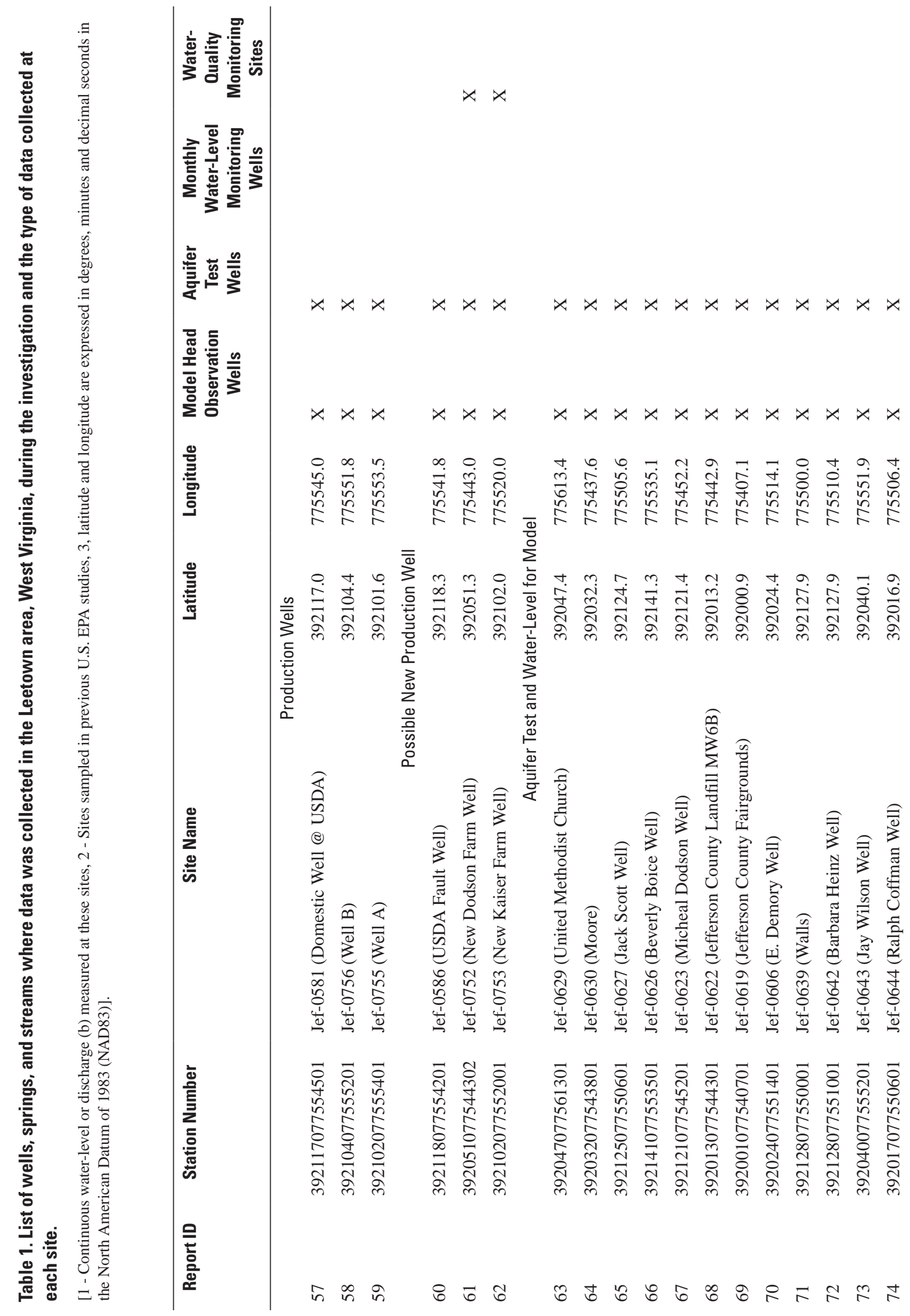




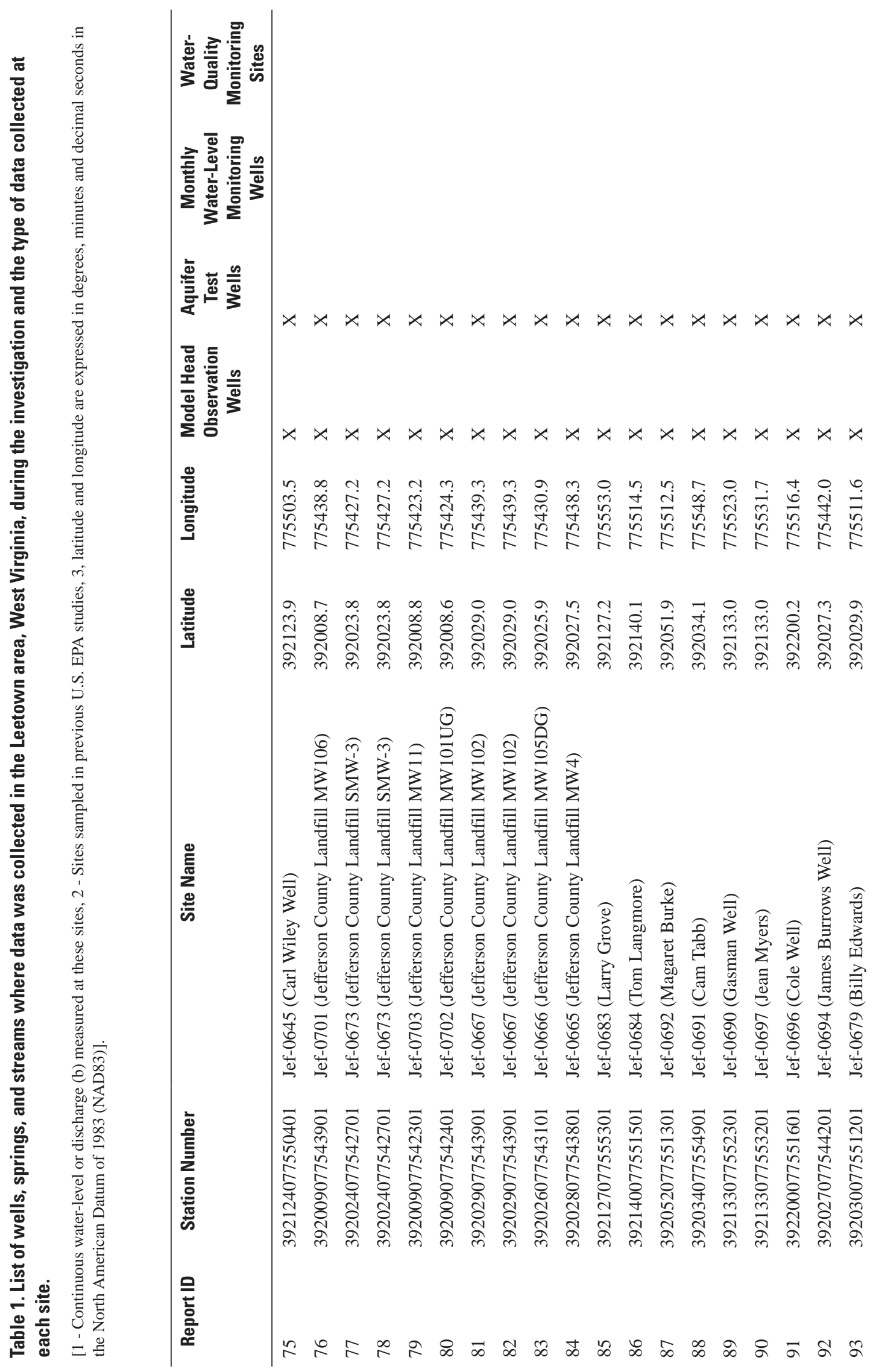



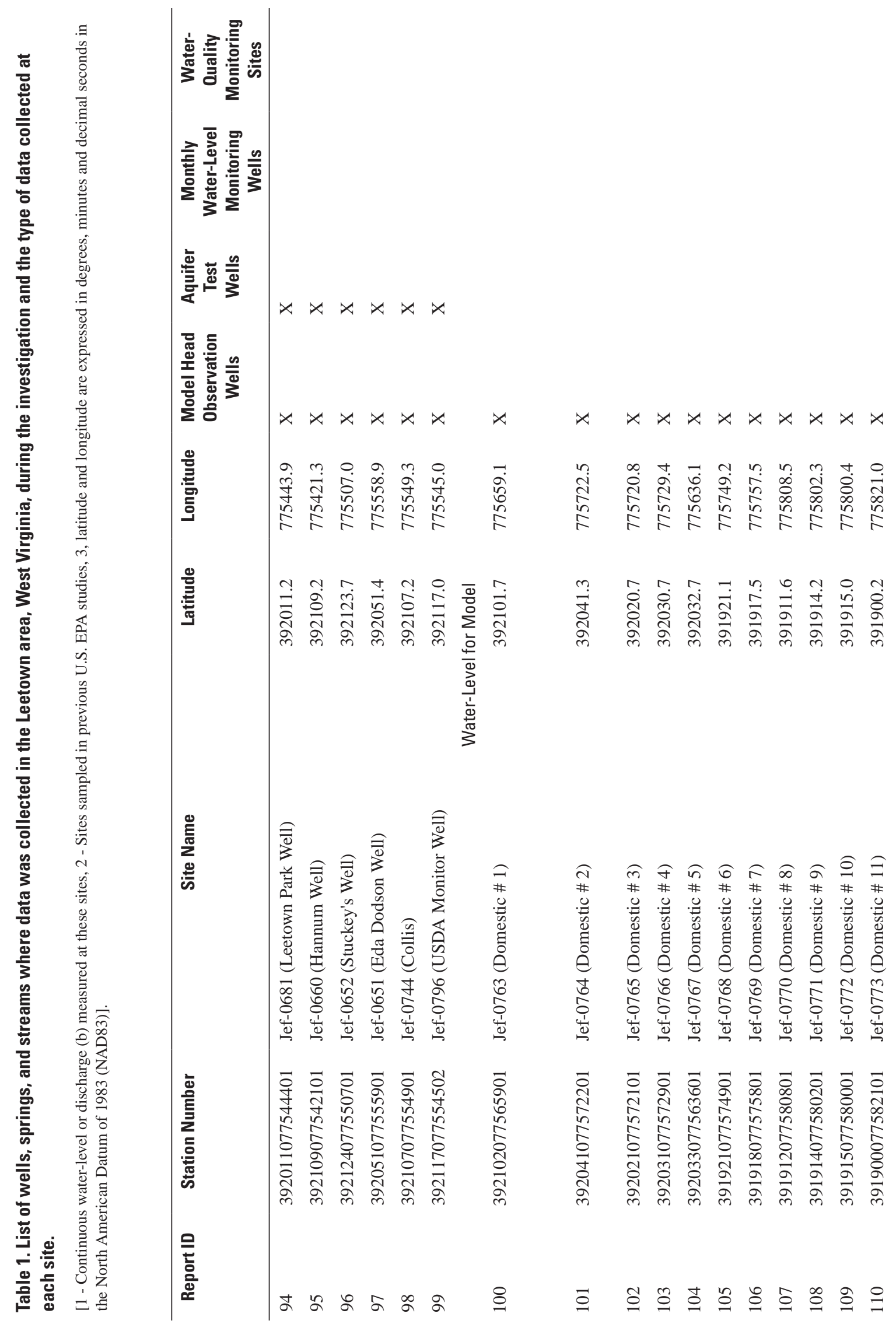


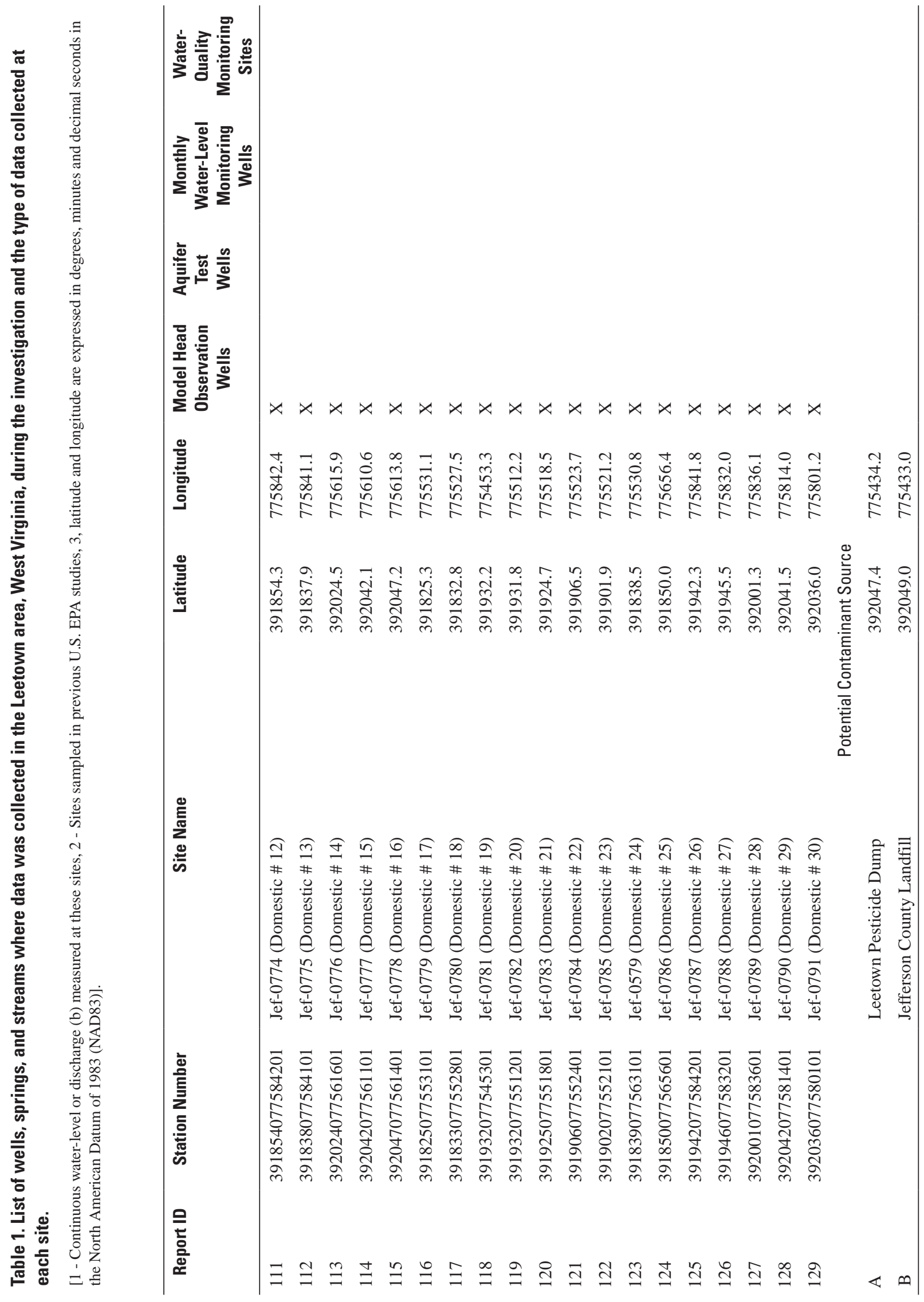




\section{Acknowledgements}

This work was supported by the U.S. Geological Survey Biologic Resources Discipline Leetown Science Center. The authors would like to thank all who contributed time and assistance to the project. Much appreciation is due the following individuals: Allen Shapiro, Carol Johnson, and Neil Plummer of the USGS for advice from their prospective areas of expertise and to Wil Orndorff of the Virginia Department of Conservation and Recreation (Natural Heritage Karst Program) for his collection and analysis of macroinvertebrates within the karst aquifer of the Leetown area. Also, appreciation goes to the residents of Leetown and the surrounding area who allowed access to their wells and property for collection of scientific data during the course of this investigation. The study could not have been completed without the support of all the aforementioned individuals.

\section{Hydrogeology - By M. D. Kozar, K. J. McCoy, D. J.}

Weary, and H. A. Pierce

The hydrogeologic setting of the study area is complex and ground-water flow is affected by both lithologic and structural geologic controls. The lithology of the bedrock in the study area is important with respect to rock permeability, fracture density, solution conduit development, and hydraulic conductivity. Rocks with a high content of calcium carbonate tend to be more soluble than those with interbedded sandstone and shale. Conduits that develop in more calcite rich bedrock tend to be larger more dominant solution conduits. The Martinsburg Formation and the Conococheague Limestone are important controls on ground-water flow in the Leetown area due to their low hydraulic conductivity (Kozar and others, 2007). Portions of the Conococheague Limestone are resistant to weathering, especially where siliceous interbeds crop out, and tend to form upland areas within the study area. The low hydraulic conductivity of the Martinsburg Formation, a predominantly gray to dark brown shale, impedes ground water as it flows down gradient towards Opequon Creek. This effectively dams ground water behind the Martinsburg Formation forcing it to flow laterally along bedding planes and thrust faults that parallel the general geologic strike of bedrock in the region (generally N. $20^{\circ}$ E. or S. $200^{\circ}$ W.). Cross-strike faults and fracture zones provide avenues for ground water to flow across or through lower permeability units. Bedrock fractures occur at various orientations within the rock matrix and will be discussed in detail in the following section of the report.

\section{Geology - by David J. Weary}

The Center is located in the Great Valley of the Valley and Ridge geomorphic province (Fenneman, 1938). Most of the sedimentary rocks in this area were deposited in shallow marine environments over about a 200 million year (m.y.) period of relative tectonic quiescence from the Late Cambrian period (about 540 m.y.) into the Mississippian period (about 340 m.y.). From about 340 m.y. to about 280 m.y. ago, collision between the continents of North America and Africa, the Alleghenian orogeny, produced most of the folds, faults, and joints seen in the Great Valley today. Earlier episodes of tectonism evident in rocks to the east of the Blue Ridge, such as the Taconic and Acadian orogenies, apparently did not affect the rocks of the Great Valley (Southworth and others, 2006). Post-Paleozoic erosion has removed younger sediments to expose Cambrian and Ordovician-aged rocks at the land surface today.

A geologic map of the Middleway 1:24,000 quadrangle, containing the Leetown area, has been published by the West Virginia Geologic and Economic Survey (Dean and others, 1990). This map was used as a guide for the more detailed geologic mapping by the USGS concentrated in the immediate Center area and the surface-water drainage basin of Hopewell Run. This mapping included location of bedrock contacts, and the measurement of the orientation of cleavage, fractures, and other structural features. Audio-magnetotelluric (AMT) soundings were collected on the Center property in an attempt to image buried geologic structures and potentially assess ground-water content. A detailed discussion of the AMT technique and studies follows later in this report. Updates to previous geological interpretations of the area include slight adjustments in the location of some of the bedrock contacts within the Hopewell Run drainage basin and the recognition of the existence of at least two northwest-trending cross-strike faults on Center property that affect the ground-water hydrology (fig. 2).

\section{Bedrock geology}

The bedrock of the Leetown area is primarily fractured limestone and dolomite of the Upper Cambrian and Lower Ordovician Conococheague Limestone; Lower Ordovician Stonehenge Limestone, Rockdale Run Formation, and Pinesburg Station Dolomite; the Middle Ordovician New Market and Chambersburg Limestones; and the Upper and Middle Ordovician Martinsburg Formation (fig. 2).

The Conococheague Limestone in the Center area is chiefly a thick bedded light-gray limestone, with thin-wispy bands or interbeds of dolomite. Some beds contain rip-up clasts, forming flat-pebble edgewise conglomerates. The sandstone-rich, basal Big Springs Station Member of the Conococheague Limestone is not present in the immediate Center area. The largest sinkholes in the study area are formed in the Conococheague Limestone. The Conococheague Limestone is exposed in two north-northeast trending belts, one just east of the main Center facilities, and the other just east of Jefferson Orchard Road in the eastern part of the study area. These mark the western and eastern limbs of the Blizzard Syncline (Dean and others, 1990). The Conococheague Limestone is about 2,400 ft thick in this part of Jefferson County, West Virginia. 
The base of the Conococheague Limestone is not exposed in the study area. The upper contact with the Stonehenge Limestone is transitional and marked by an increase in siliceous silt content and darker colored limestone.

The Ordovician aged Stonehenge Limestone is a thick to massive-bedded, dark-gray, siliceous limestone. The silt is commonly in wispy laminae that often weather out in raisedrelief in natural exposures. The silt content of the rock has allowed a pervasive axial planar cleavage, related to Alleghenian folding, to develop. In some exposures the cleavage is so penetrative that it has obscured or obliterated the bedding planes. In such areas, the cleavage probably has a greater effect on the hydrologic properties of the rocks than does the bedding. The lower part of the Stonehenge Limestone has been differentiated from the rest as the Stoufferstown Member. This member is distinguished by the anastomosing crinkly siliceous laminae permeating the limestone, and commonly forms distinct strike-parallel linear ridges and fins in outcrop. The Stoufferstown Member was not mapped as a separate unit in this study. The Stonehenge Limestone grades into the overlying Rockdale Run Formation; the contact is placed where the rock becomes less silty, less cleaved, lighter colored, and begins to contain thin interbeds of dolomite.

The Rockdale Run Formation and the superjacent Pinesburg Station Dolomite were combined as one unit for this study. The Pinesburg Station Dolomite is removed by faulting and does not crop out in any areas near the Center. The Rockdale Run comprises thick-and medium-bedded light-gray limestone and minor dolomite in cyclic, peritidal deposits. It is characteristically lighter colored and less cleaved than the underlying Stonehenge Limestone and tends to weather as blocky ledges with bedding better defined than the Stonehenge. The upper Pinesburg Station Dolomite is in unconformable contact with the overlying Middle Ordovician New Market Limestone. The Rockdale Run Formation is usually about 2,500 ft thick in this part of the Great Valley (Dean and others, 1990).

The New Market Limestone is a pure, dove-gray, limemudstone. It is quarried extensively at various locations in the region. The New Market Limestone has been removed by faulting and is not exposed in the immediate vicinity of the Center, although a few belts of it exist within the southwestern part of the drainage basin of Hopewell Run. The New Market Limestone ranges from 40 to $250 \mathrm{ft}$ thick in the Leetown area (Dean and others, 1990).

The Middle Ordovician Chambersburg Limestone conformably overlies the New Market Limestone. The Chambersburg Limestone comprises thin to medium-bedded dark gray limestone with thin, silty interbeds. The Chambersburg Limestone is poorly exposed in the western part of the Hopewell Run drainage basin. This unit underlies the Center to the west of West Virginia County Route 1. The Chambersburg Limestone is about $500 \mathrm{ft}$ thick in the Leetown area.

The Martinsburg Formation is the youngest stratigraphic unit in the study area. The Martinsburg Formation contains brownish to black shales and siltsone, commonly weather- ing to a light yellowish or orange-brown color. Axial planar cleavage is well developed along folds and in places obscures the bedding. As a primarily siliciclastic unit, the Martinsburg Formation is the only formation in the study area that does not have any karst features. The Martinsburg Formation is confined to the western edge of the Hopewell Run basin and underlies the fish ponds on the western edge of the Center. The total thickness of the Martinsburg Formation exceeds 1,500 ft in the Leetown area (Dean and others, 1990).

\section{Structural Geology}

The geologic structure of the area is complex, with numerous thrust faults oriented parallel or sub-parallel to the regional bedrock strike and fault traces trending approximately N $20^{\circ}$ E. Cross-strike longitudinal and oblique faults also occur with traces at attitudes of approximately $\mathrm{N} 80^{\circ} \mathrm{W}$ and $\mathrm{N} 65^{\circ} \mathrm{E}$ respectively (fig. 2). The rocks are tectonically deformed, and the numerous upright and overturned folds in the area affect ground-water flow. The overturned folds verge to the northwest with limbs dipping steeply toward the southeast.

Because the Paleozoic bedrock underlying the Center comprises lithologies with low primary permeability, groundwater flow is dependant on secondary permeability produced by bedrock fractures or karst solution features. This secondary permeability is especially important in areas like the Center where the strike of the bedrock is predominantly to the northnortheast, but the hydrologic gradient is towards the outflow of Hopewell Run, to the northwest. Bedrock fractures include tectonically induced faults and joints as well as partings between bedding planes (fig. 3).

\section{Bedding}

Rock beds underlying the Center are folded as a result of tectonism in the geologic past. Bedding is generally steeply dipping, although it can range from nearly flat-lying in some areas to nearly vertical or overturned in others. The predominant strike direction of bedding planes is about N. $20^{\circ} \mathrm{E}$. and most dips are steep and directed towards the southeast (fig. 2 and fig. 4).

\section{Joints}

Joints were measured at the ground surface during geologic mapping and were also measured in the subsurface in monitoring wells via acoustic-televiewer images. The surface joints were characterized by their orientation, spacing, and persistence. Joints confined to individual beds are classified as non-through-going, and joints extending across bedding planes into surrounding beds are classified as through-going. A rose diagram (fig. 5) showing joints measured as part of geologic mapping illustrates the dominant directions of joint planes within the bedrock in the vicinity of the Center. Two dominant 


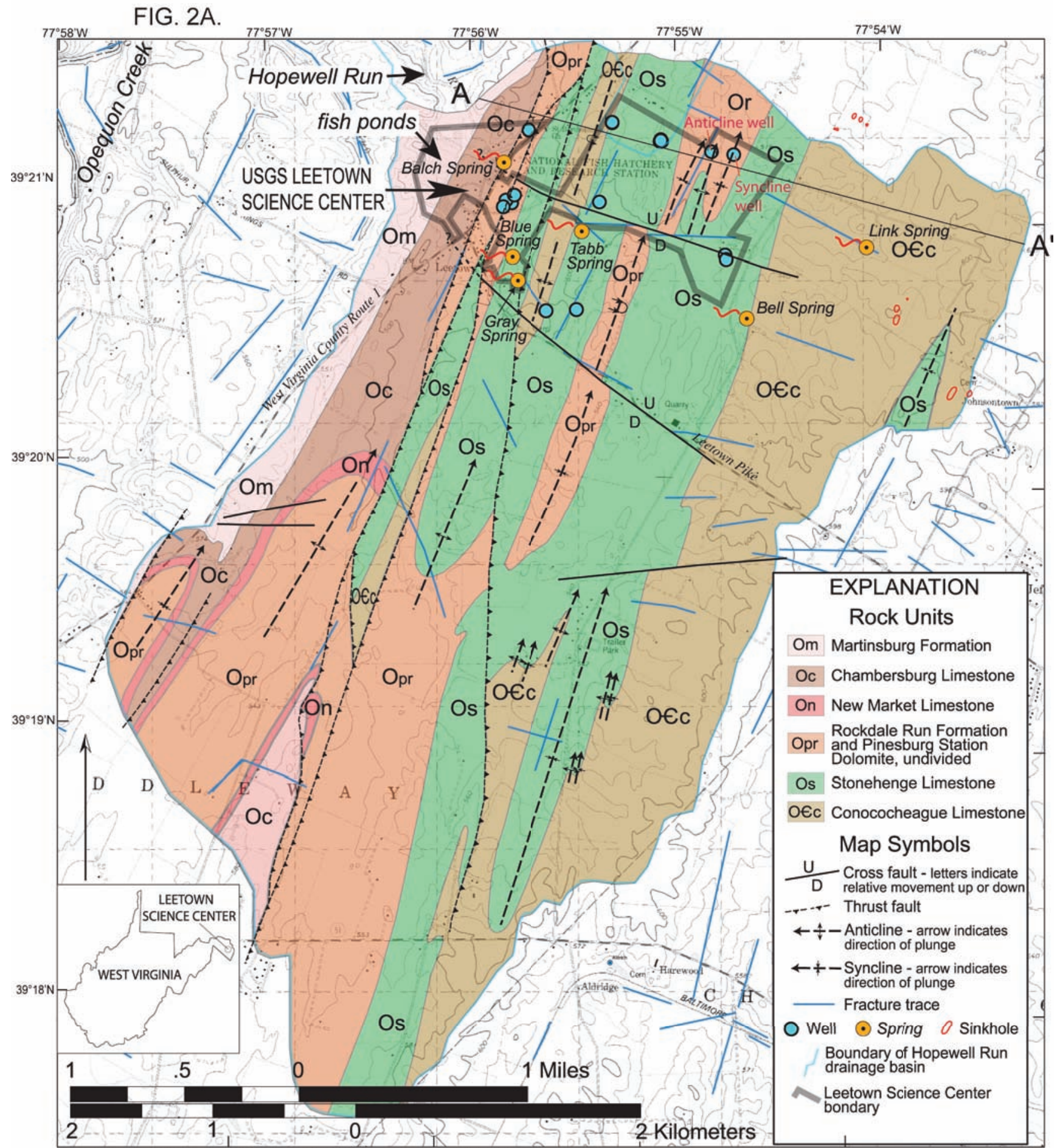

Base from U.S. Geological Survey Middleway, WV quadrangle, 1978, scale 1:24,000

Geology modified from Dean and others, 1990

West Virginia coordinate system, north zone (Lambert conformable conic), 1927 North American Datum

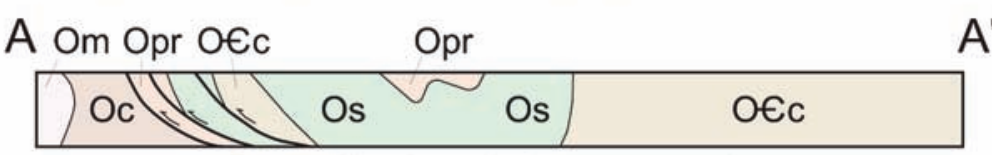

FIG. 2B.

\section{Generalized geologic cross section}

Figure 2. A) Geology, B) geologic cross section, and C) stratigraphic column of the Hopewell Run surface water drainage basin, and the USGS Leetown Science Center, West Virginia. [Geology modified from Dean and others, 1990] 


\section{EXPLANATION}

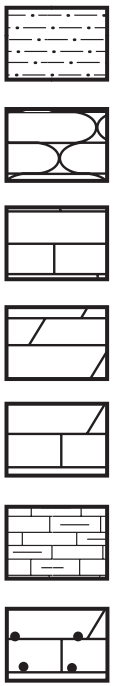

shale and siltstone

knobbly limestone and calcareous shale

limestone

dolomite

interbedded dolomite and limestone

shaly limestone

sandy interbedded dolomite and limestone

$1,000 \mathrm{ft}$

Geologic

Age

Lithologic Unit (thickness)

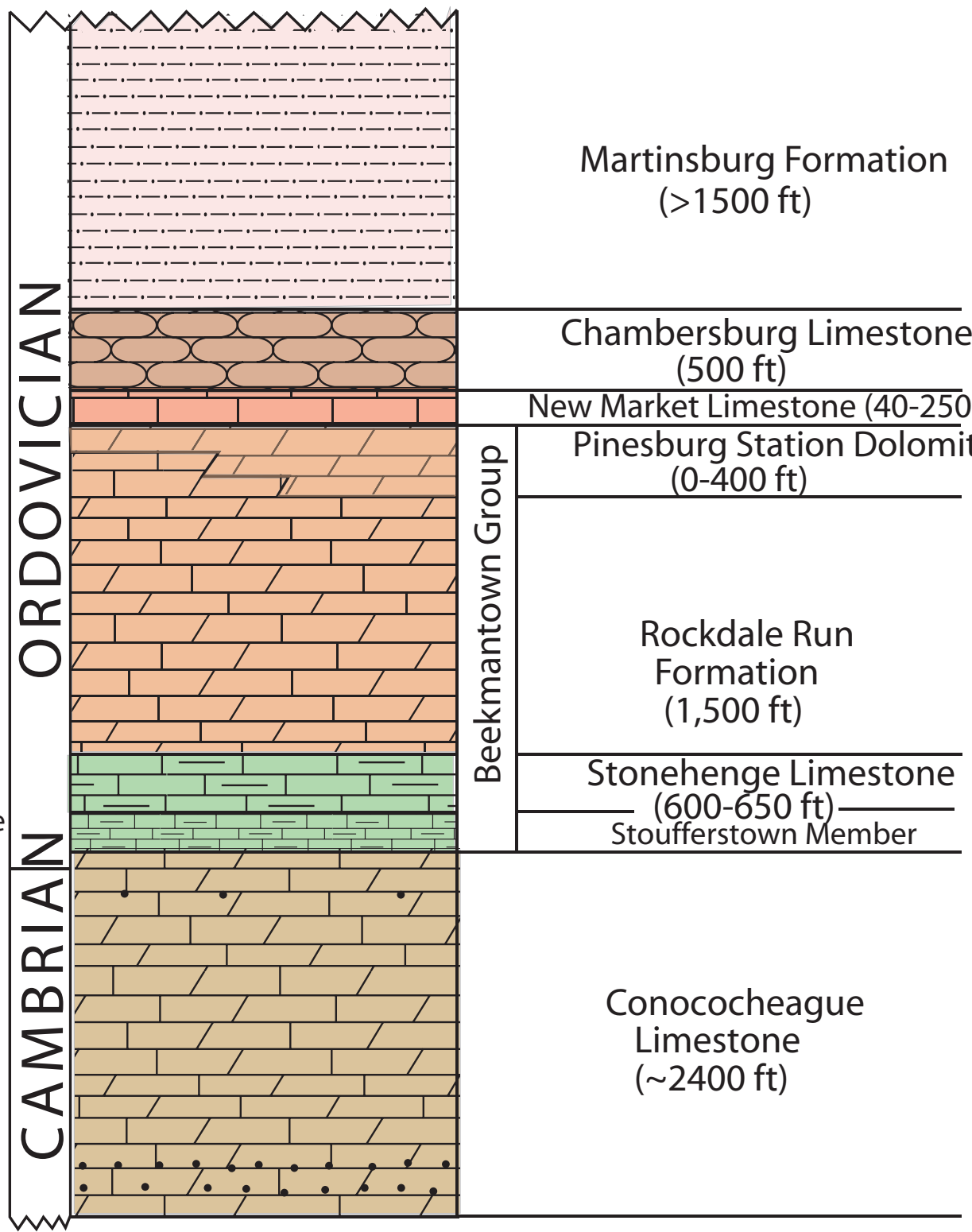

FIG. 2C. 

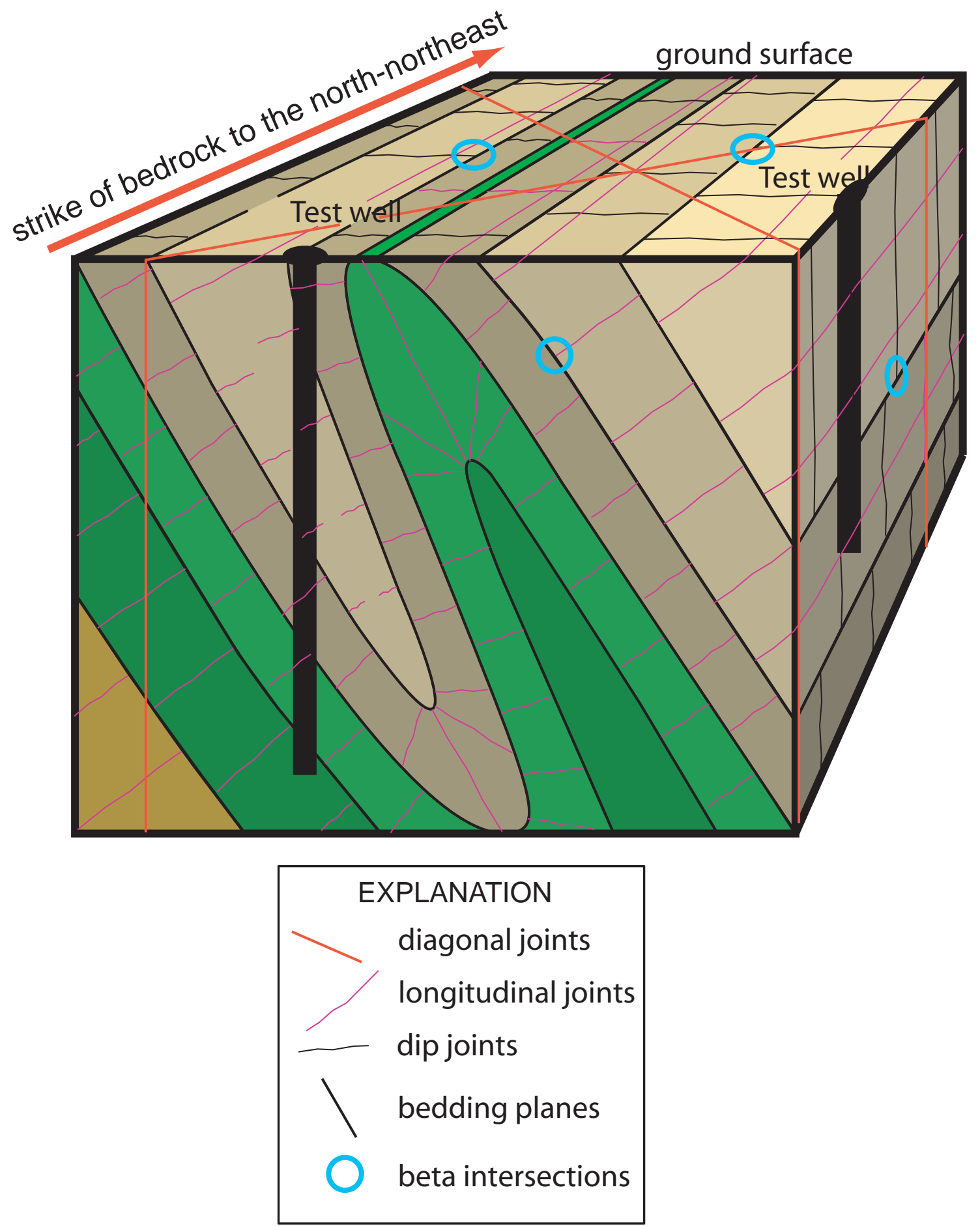

Figure 3. Conceptual diagram showing geometric and spatial relations between bedding planes, joints, and drill holes in a tightly-folded terrain, such as that in the Leetown area, West Virginia. [Beta intersections are calculated based on the attitudes of lineations created by intersections of bedding planes, joints, or other fractures]. 


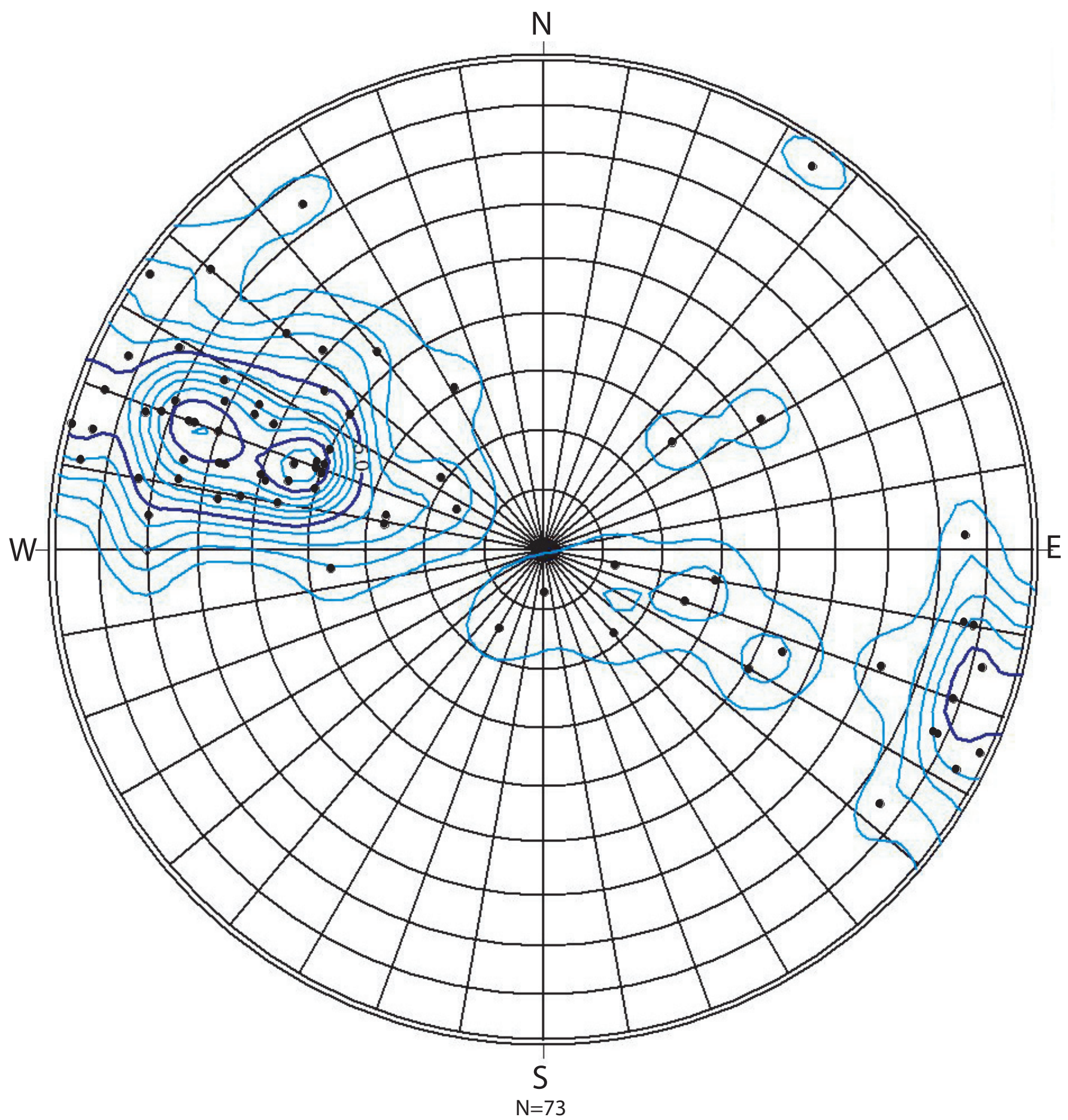

Figure 4. Lower hemisphere stereographic projection of poles to bedding from outcrop data collected in the Leetown area, West Virginia. [N, S, E, and W are compass azimuths, solid circles are individual dip measurements, and blue lines show clusters of measurements that pertain to certain structural features]. 
directions are apparent; one oriented approximately normal (dip joints) to and the other approximately parallel to (longitudinal joints) the regional strike of bedrock. The traces of the dip joints strike in a range from about N. $90^{\circ} \mathrm{W}$. to N. $60^{\circ} \mathrm{W}$. and the longitudinal joints from about due North to N. $40^{\circ} \mathrm{E}$. The dip joints are over-represented in this sampling due to the linear geometry of the outcrops, which typically exposes them more clearly than the longitudinal set (fig. 3). Fractures measured via acoustic-televiewer images in nine of the monitoring wells were plotted on a stereogram with the surface joint data for comparison (fig. 6). The well data are undifferentiated, including both joints and bedding-plane fractures. The plot of the well data indicate the majority of fractures have a north-northeast strike and dips to the southeast centered on an attitude of about N. $30^{\circ} \mathrm{E}$. and dipping $40^{\circ} \mathrm{E}$., which is the predominant bedding plane direction in the area. A large subset of the data indicate planes striking to the northeast and dipping to the northwest centered on an attitude of about N. $30^{\circ} \mathrm{E}$. and dipping $50^{\circ} \mathrm{W}$. These fractures are a combination of bedding from a well drilled on the axis of an anticline (the only well in west-dipping bedrock) and the longitudinal joint set from the other wells (fig. 3 ).

Intersections of bedding plane fractures and joints can become important conduits for ground-water movement, at least locally, as they can form the loci for enhanced solutional enlargement of voids in the carbonate bedrock and provide an avenue for water to move along or across the strike of the bedding. Calculations of the attitudes of lineations created by these intersections, known as beta intersections, were completed for the data collected in this study (fig. 7).

The stereogram indicates abundant intersections in the bedding-parallel direction, produced by the bedding and longitudinal joints, striking to the north-northeast with chiefly shallow dips north-northeast or south-southwest. A second set of abundant intersections occurs in the dip direction, produced by the bedding and dip joints, striking west-northwest to eastsoutheast and dipping moderately to steeply to the west-northwest or east-southeast (fig. 7).

\section{Faults}

Two types of faults are found in the Hopewell Run basin, thrust faults and high-angle cross-strike faults. The locations of all thrust faults, and some of the cross-strike faults in the study area were identified by previous workers (Dean and others, 1990) and confirmed by field work for this study. Two new cross-strike faults were identified in the course of this study. One lies nearly beneath and parallel to Leetown Pike, which traverses the Hopewell Run basin just to the south of the Center in a southeastern to northwestward direction (fig. 2). The trace of the fault has a strike of about $\mathrm{N} 55^{\circ} \mathrm{W}$. This fault is inferred on the basis of: 1) a sudden attenuation in the width of the outcrop belt of the Rockdale Run Formation and concomitant dislocation of the contact between the Rockdale Run Formation and the underlying Stonehenge Limestone as the beds cross Leetown Pike from south to north; 2) the syncline of Stonehenge Limestone with the Rockdale Run Formation in its axis is open and upright to the south of Leetown Pike, and overturned to the west to the north of the road; and, 3) AMT soundings of the area show a marked and almost linear offset of subsurface resistivity values along the trend of the inferred fault. The other cross-strike fault lies further to the north (fig. 2), crossing the Hopewell Run basin along the major stream axis from the east-southeast to west-northwest. The trace of this fault has a strike of about N. $70^{\circ} \mathrm{W}$. Evidence for this fault is the offset of the bedrock contacts between the Rockdale Run Formation and Stonehenge Limestone. Both of these faults are interpreted to be normal faults showing vertical displacement down to the south. Both faults break at least the upper thrust sheet and may also penetrate the entire thrust sheet underlying the Center and extend into the outcrop belt of the Martinsburg Formation to the west. Data are not currently available to constrain this concept.

\section{Cleavage}

Cleavage is produced by alignment of platey minerals in rocks under tectonic stress and usually forms in planes normal to the direction of maximum compression. Some fanning of cleavage direction also occurs in relation to the axes of folds. At the Center, cleavage is common in the Martinsburg Formation and in the Stonehenge Limestone. The Stonehenge has a silty component, especially within the basal Stoufferstown Member. The predominant attitude of cleavage planes at the Center have a strike of about N. $20^{\circ}$ E. and dip near-vertically either to the east or west, with east dips being more numerous. Cleavage in the Stonehenge Limestone is so well developed, especially in the Stoufferstown Member, that it completely obscures the bedding in places and results in a massive rock with low primary permeability.

\section{Fracture Traces}

Linear features identified on aerial photographs and topographic maps have been noted for more than a half century (Lattman, 1958). These features are believed to be traces of fractures in the underlying bedrock, which result in zones of increased porosity and permeability. A fracture trace analysis, based on stereo aerial photographic analysis was done for the Center as part of a larger hydrogeologic study of Jefferson County, West Virginia (McCoy and others, 2005b). Fracture traces identified in that report are shown on the geologic map (fig. 2).

\section{Karst}

While dissolution of limestone in karst areas is common, the Leetown area does not exhibit classic mature karst topography. Sinkholes occur, but are sparse and confined primarily to the Conococheague Limestone in the eastern part of the study area (fig. 2). Although dye traces in the area have 


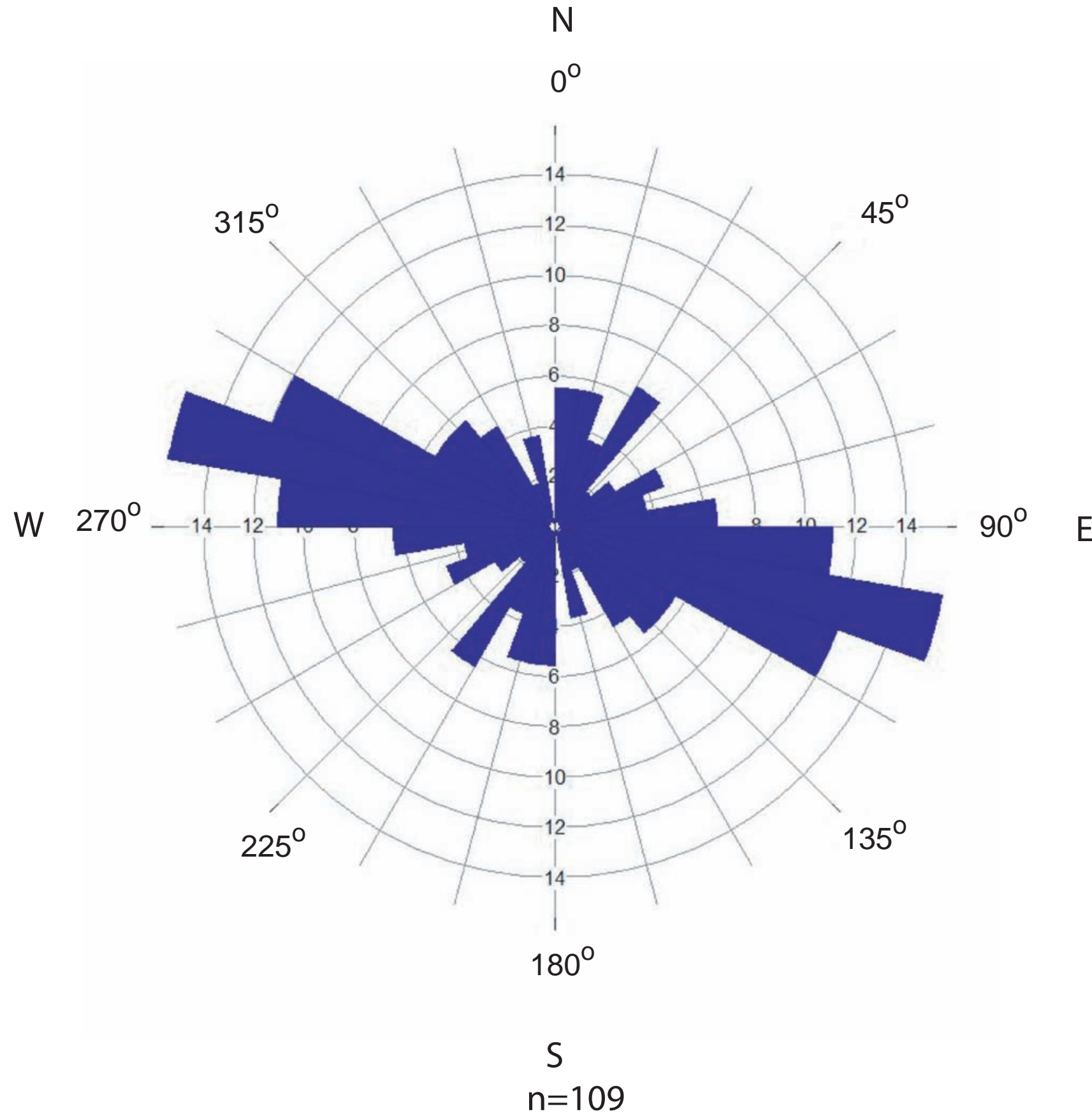

Figure 5. Compass-rose diagram showing the dominant joint trends in the Paleozoic rocks of the Leetown area, West Virginia. [Joint sets were weighted by counting closely spaced joint sets three times, moderately spaced sets two times, and widely spaced sets one time. This system approximates the importance of each set relative to the volume of rocks. Numbers labeling concentric circles on diagram are percent of total number ( $n$ ) of joints]. 


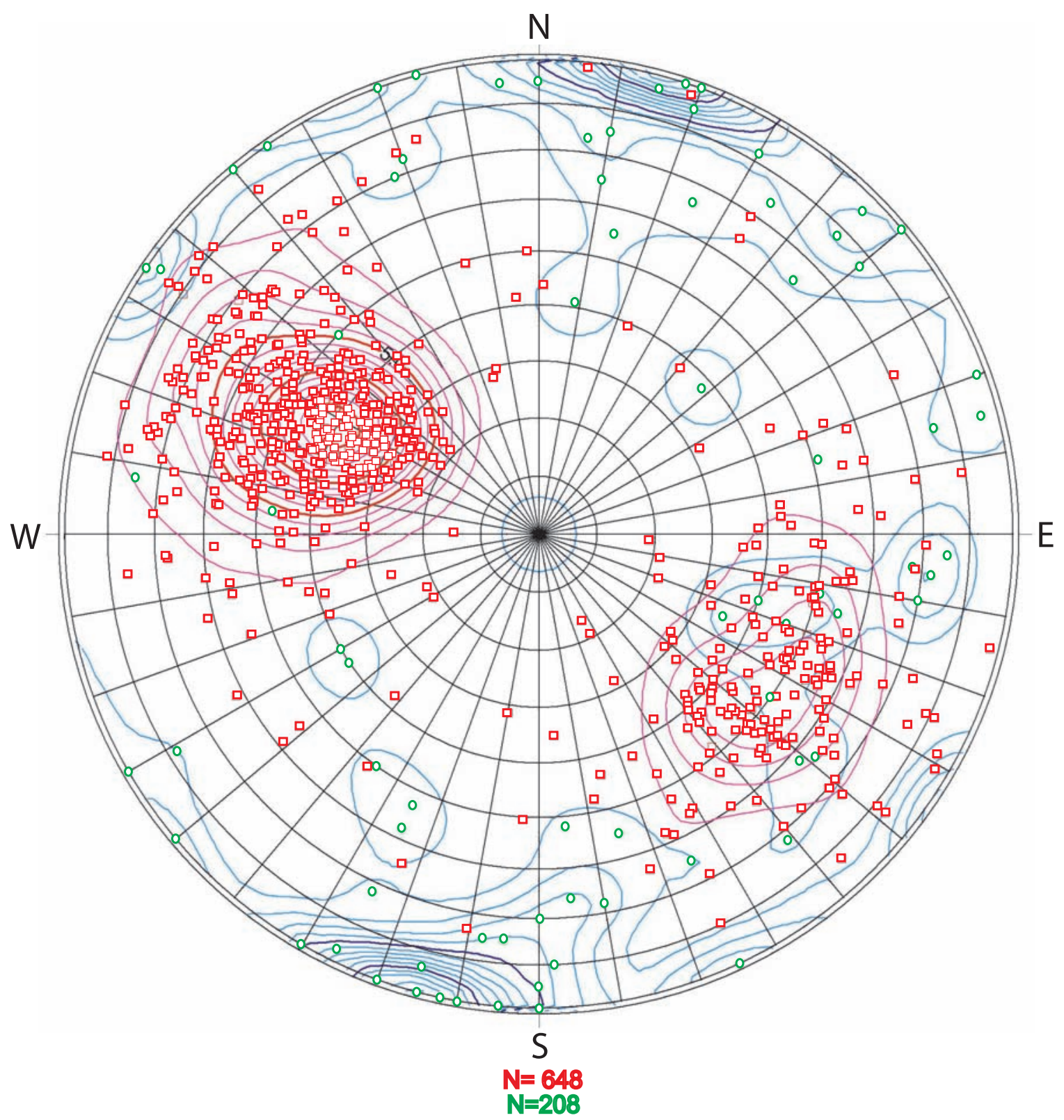

Figure 6. Lower hemisphere stereographic projection of poles to joint planes measured at the ground surface (green points and blue contours) and fractures measured in monitoring wells (red squares and purple contours) in the Leetown area, West Virginia. [N, $\mathrm{S}, \mathrm{E}$, and $\mathrm{W}$ are compass azimuths; $\mathbf{N}=$ number of joints or fractures available for the analysis; concentric circles represent the degree of dip of the feature with points plotting at the center of the plot indicating horizontal features and those plotting near the edge representing vertical features]. 


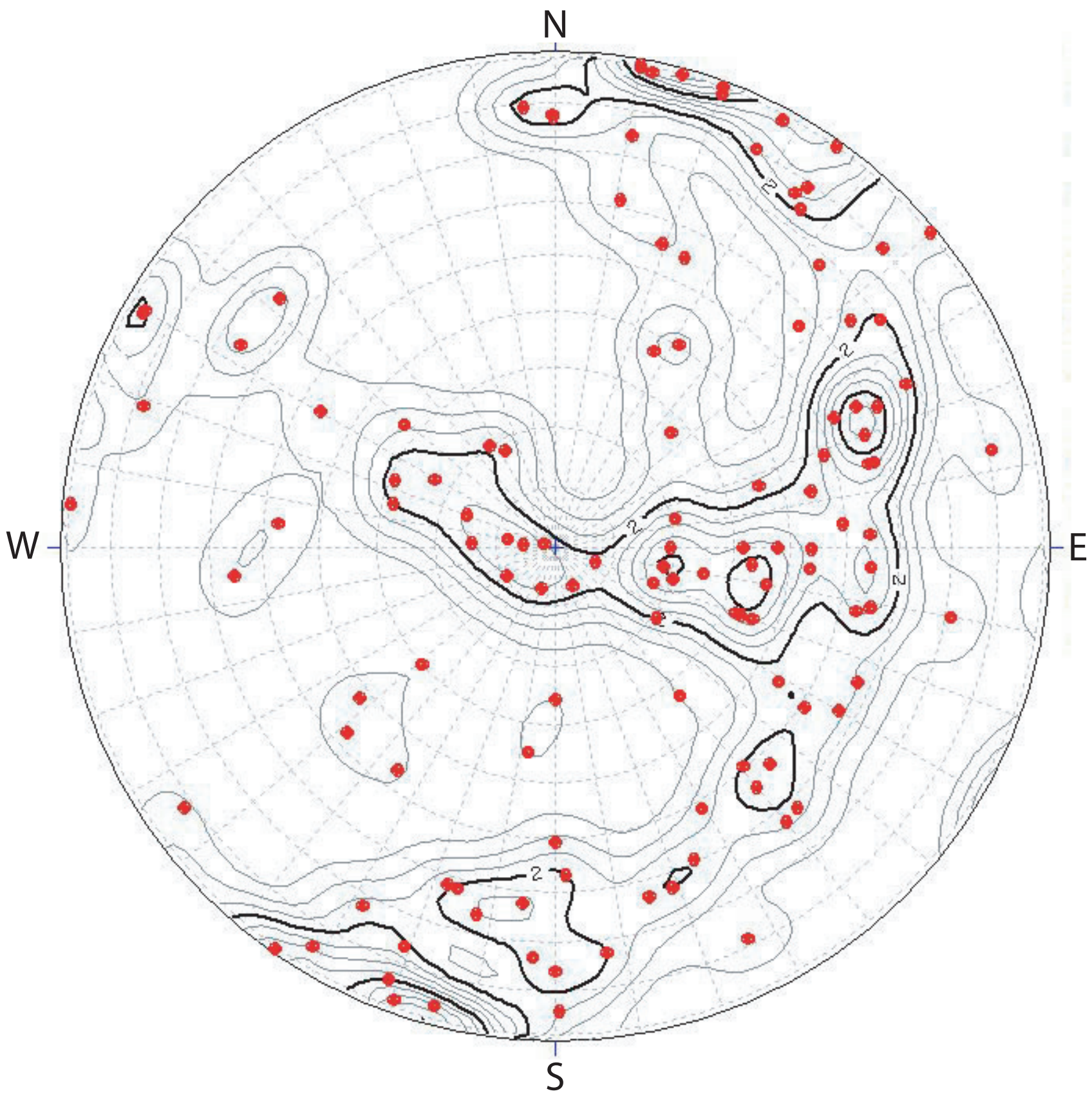

$\mathrm{N}=237$

Figure 7. Lower hemisphere stereographic projection of lineations defined by beta pair intersections of bedding and joints measured at the ground surface in the Leetown area, West Virginia. [ $\mathrm{N}=237$ is the number of individual points plotted and $\mathbf{N}, \mathrm{S}, \mathrm{E}$, and $\mathrm{W}$ are compass azimuths and concentric circles represent the degree of dip of the feature with points plotting at the center of the plot indicating horizontal features and those plotting near the edge of the plot representing vertical features]. 
yielded very slow travel times, and the quantity of dye recovery is typically very low, springs in the area indicate that a karst conduit ground-water flow component is present (Jones, 1997).

\section{Geophysics - By Herbert A. Pierce and Kurt J. McCoy}

Borehole and surface geophysical surveys were conducted to better define the composition and distribution of the fracture network within the study area and to refine the conceptual understanding of how these fractures relate to ground-water flow. Investigation of fractures in both conduit dominated and diffuse dominated portions of the aquifer were conducted to identify the connectivity of solution conduits with the more dominant diffuse-flow fracture network. An investigation of the nature and extent of the epikarst, the highly fractured and solutionally enlarged upper interval of karst bedrock immediately below the soil zone, was also conducted by close examination of borehole video logs and interpretation of borehole geophysical data. The borehole data provided a better understanding of the nature and extent of fracture occurrence and aperture width, fracture orientation, and ground-water flow within the aquifer. Surface geophysical surveys using Audio-magnetotelluric soundings provided a horizontal and vertical distribution of electrical resistivity within the aquifer. Electrical resistivity is a measurable physical property of the earth that can vary widely both in the horizontal and vertical dimensions. This wide range of resistivities is the result of the complex interplay of physical parameters such as rock porosity, temperature, lithology, fluid, and electrolyte content. The resistivity data was used to assess structural and lithologic controls on ground-water flow.

\section{Surface geophysics - by Herbert A. Pierce}

Surface geophysical surveys use remote sensing methods on the Earth's surface to determine the properties, and the spatial distribution of those properties, of the underlying near-surface materials composing the Earth's crust. Audiomagnetotelluric methods were used in this investigation to characterize and better understand the properties of the materials underlying the Center,

\section{Audio-magnetotelluric Methods}

Audio-magnetotelluric soundings are made to determine variations in the electrical resistivity of the earth with depth (Cagniard, 1950, 1953; Tikhonov, 1950; Wait, 1962; Keller and Frischknecht, 1966; Hoover and Long, 1976; Hoover and others, 1976; Hoover and others, 1978; Dmitriev and Berdichevsky, 1979; Vozoff, 1986, 1991). The AMT method uses natural-source multi-frequency electromagnetic signals from lightning or atmospheric disturbances as an energy source.
These natural signals diffuse into the earth and the diffusion governs the electromagnetic (EM) induction. For this survey, a controlled-source transmitter was used to supplement natural source EM signals when signal strength from the natural source was low.

These AMT soundings consist of electric and magnetic field measurements over a range of frequencies from 10- to 100,000-Hertz with fixed receiver and transmitter locations. The distribution of currents induced in the earth depends on the earth's electrical resistivity, earth's magnetic permeability, and frequency measured. Since low-frequency signals penetrate to greater depths than high-frequency signals, measurements of the electromagnetic (EM) response at several frequencies contain information on the variation of resistivity at depth. These soundings are inverted and stitched together to form pseudo sections at various angles to the geologic structures. For a more complete discussion of AMT theory the reader is referred to publications by Weaver, 1994; Simpson, and Bahr, 2005; Mackie and others, 1997; Tikhonov, 1950; Cagniard, 1950, 1953; Swift, 1962; and Gamble and others 1979a, 1979b.

During calendar years 2003, 2004, and 2005, fifty-three AMT soundings were collected within and outside of Center property (fig. 8, app. 1 table 1). Three soundings were parallel sensor tests of the AMT instrument providing a total of fifty AMT soundings. The soundings were collected to improve understanding of the geologic structure and hydrology, as well as provide widespread vertical resistivity information for the Center area (fig. 8). AMT soundings were recorded using a Geometrics EH-4 system. No vertical magnetic field $\left(\mathrm{H}_{\mathrm{z}}\right)$ data were recorded because the system is limited to four channels (Ex, Ey, Hx, and Hy). About 2,000 frequencies were collected and then reduced to approximately 40 frequencies for each direction (Ex and Ey) from 10- to 100,000-Hertz. The EH-4's system includes a $60 \mathrm{~Hz}$ notch filter to reduce power-line interference. Inversions that are invariant with rotation angle were chosen to assess the data and models in order to compare them with the known geology and hydrology.

Limestone rocks in the Leetown area are broken into roughly orthogonal blocks that have weathered along fractures (fig. 9). Soils and clays (karstic weathering products) between the fractured limestone blocks are not as permeable as the fractured rocks (see tables 1 and 8 ) and are more electrically conductive than the limestone blocks (fig. 10).

Once a series of 2-dimensional models are generated, resistivity cross sections and associated maps can be made of different depths below land surface. The electrical sections and maps at various depth slices are compared with the known surficial geology, borehole data, and hydrologic information. Additional hydrologic and geologic interpretations can be made and the interpretations modified. 


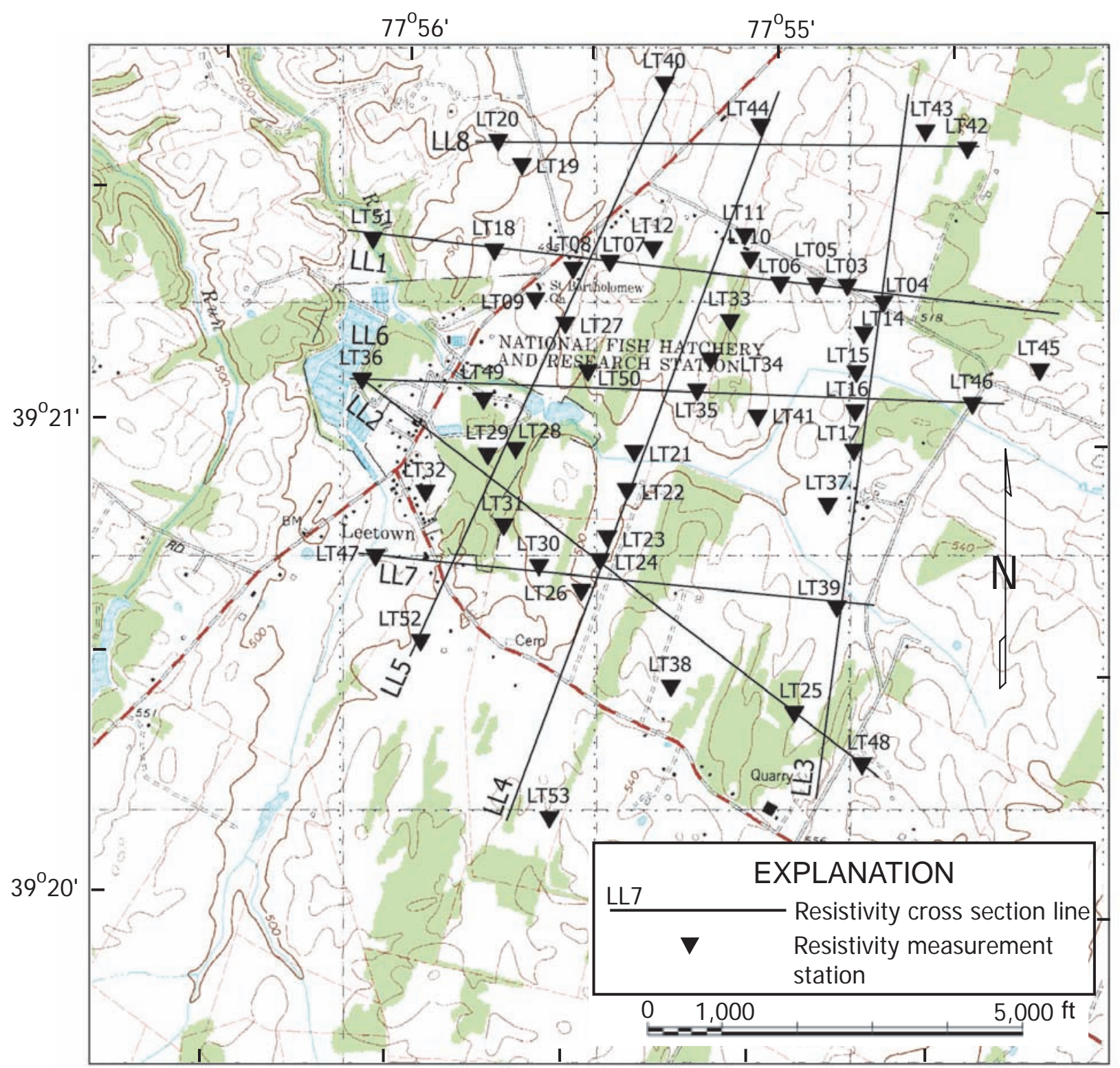

Base from USGS 1:24,000 Middleway, W.Va. topographic quadrangle

Figure 8. Map showing Audio-magnetotelluric station locations and electrical resistivity cross sections developed for the Leetown area, West Virginia. [Line locations labeled LL1 through LL8 are 2-D invariant electrical sections. AMT station locations are labeled LT3-LT12 and LT14-LT53]. 


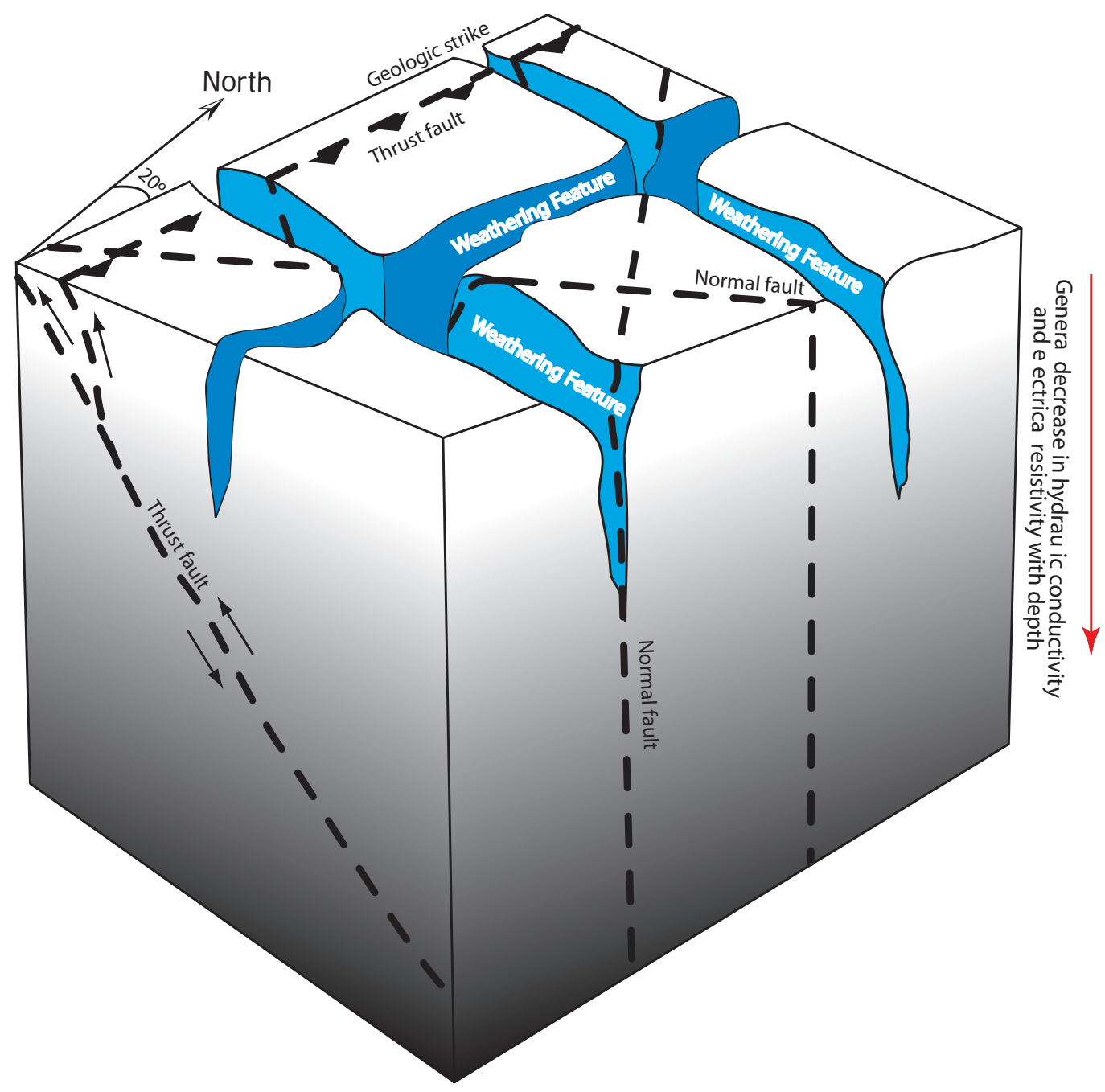

Figure 9. Schematic diagram showing a conceptual model of the geologic structure and epikarst weathering typical of the Leetown area, West Virginia. [Resistivity lows are associated with the block epikarst weathering features (solution conduits), steeply dipping thrust and cross-strike faults, and major springs]. 


\section{Results of AMT Surveys}

AMT profiles and maps of inverted data reveal gradients and areas of high and low resistivities coincident with the prevailing geologic strike, N. $20^{\circ}$ E. (figs. 10, 11, and 12). One example (fig. 12) includes a resistive anticline (Dave Weary, oral commun., 2005). Low resistivity examples were measured along a syncline and near faults and fractures, especially thrust and cross-strike normal faults. Springs show up as low resistivity areas due to the increased porosity and higher fluid content in the rock. Even with the uncertainty of interpreting electromagnetic data in a two- to three-dimensional environment, electrical sections correlate well with the mapped geologic units, geologic structure, and the sub-surface hydrology. Resistivity lows positively correlate with areas (figs.

10-12) where water is near-surface (near springs) or near high yield wells verified by drilling or aquifer tests (syncline well Jef-0588).

A map view of the invariant resistivity model at a depth of $197 \mathrm{ft}$ below land surface shows correlation to features identified by surface geologic mapping (fig. 12). A general pattern of high resistivity in most areas underlain by the Stonehenge Limestone and lower resistivity in areas underlain by other units demonstrates differences in resistivity between the lithologic units. Faults appear as linear anomalies or gradients separating areas of relatively high or low bedrock resistivity.

The resistivity map (fig. 12) indicates three areas of profoundly lower resistivity. Anomaly 1 is an area in the north central part of the study area and coincides with a synclinal feature in the Rockdale Run Formation that underlies the Stonehenge Limestone. This resistivity low is interpreted as ground water saturating and filling the trough of the syncline with perhaps some solution enhancement of the porosity of the bedrock, especially the Rockdale Run Formation. One of the monitoring wells, drilled in the axis of a syncline (Jef-0588), is located in this anomaly and is one of the most productive wells based on aquifer tests conducted on the Center and in the surrounding area (McCoy and others, 2005b). A second area of low resistivity (Anomaly 2) is located at the north edge of the study area. This area may indicate a ground-water saturated fracture zone, or may be the result of edge effect from contouring the data, as it is outside of the extent of the AMT stations. A third area (Anomaly 3) lies beneath the Center facility in the western part of the study area. This area has enhanced ground-water flow and storage associated with springs, multiple thrust faults, and two cross-strike faults.

AMT apparent resistivity data in the study area can be correlated with the mapped geology and provides a series of useful cross sections and map images around the Center. These data can be used to identify areas of low resistivity that correspond to productive areas for wells. Potential productive areas for development of additional wells include the synclinal axes of fold structures, especially overturned structures. In this case, cross-strike faults also enhance the productivity of wells drilled near or through such structures. Thrust faults with enhanced fracturing may enhance well yields, but conduit development along some faults may preclude water-supply development as conduit dominated areas may yield water with high turbidity levels that are unacceptable for the Center. This phenomenon is discussed in more detail in the water-quality section of this report.

\section{Borehole Geophysics - by Kurt J. McCoy}

In bedrock terranes such as the Great Valley in West Virginia, complex aquifer properties are the result of hydraulic interaction among an intricate network of fractures. Fractures that are open, water saturated, and hydraulically connected serve to store and transmit water in the subsurface. A general understanding of subsurface fracturing in the Leetown area of the Great Valley can be obtained by surficial measurement of steeply dipping joint and cleavage planes of the area as shown in figure 13, the orthogonal orientation of which can also be viewed at much larger scales (McCoy and others 2005a, 2005 b). Information on the distribution, orientation, and flow properties of subsurface fractures at depth requires the use of advanced borehole geophysical techniques.

\section{Borehole Geophysical Methods}

Fracture analysis at the Center was accomplished through collection of caliper, natural gamma, fluid-resistivity, fluidtemperature, electromagnetic (EM) or heat-pulse flow-meter, spontaneous-potential, electromagnetic-induction, acousticteleviewer (ATV), and optical-televiewer (OTV) logs (table 2).

The ATV and OTV logs are used to define the location and orientation of fractures and bedding intersecting the borehole. Imaged fractures appear as planar features that parallel the borehole in the case of vertical fracturing, are perpendicular to the borehole in the case of flat lying structures, or as sinusoids in the case of fractures intersecting the borehole at other angles (fig. 14). Once a fracture is identified, the strike and dip are determined using methods as shown in figure 15.

\section{Results of Borehole Geophysical Surveys}

Complete ATV, OTV, heat-pulse flow-meter, and fracture orientation (tadpole) logs for 11 wells (fig. 1 and table 1) at the Center are presented in Appendix 2. Profiles of fracture orientations, determined from ATV logs of 11 wells at the Center, are included in Appendix 3. Four of these wells are located along fault zones, four in diffuse-flow dominated areas, two along fold structures, and one near the contact with the Martinsburg Formation. A total of 683 fractures were mapped and plotted on a Schmidt equal-area stereo-net projection of poles to planes of fractures (fig. 16). The dominant orientation fractures align with strike-parallel fractures of dip generally ranging from $15^{\circ}$ to $70^{\circ}$ to the northwest and southeast. These trends are consistent with surficial mapping of strike parallel fractures in the Great Valley of West Virginia. However, numerous cross-strike joints seen in outcrops during this and previous studies (Jones and Deike, 1981) are not 

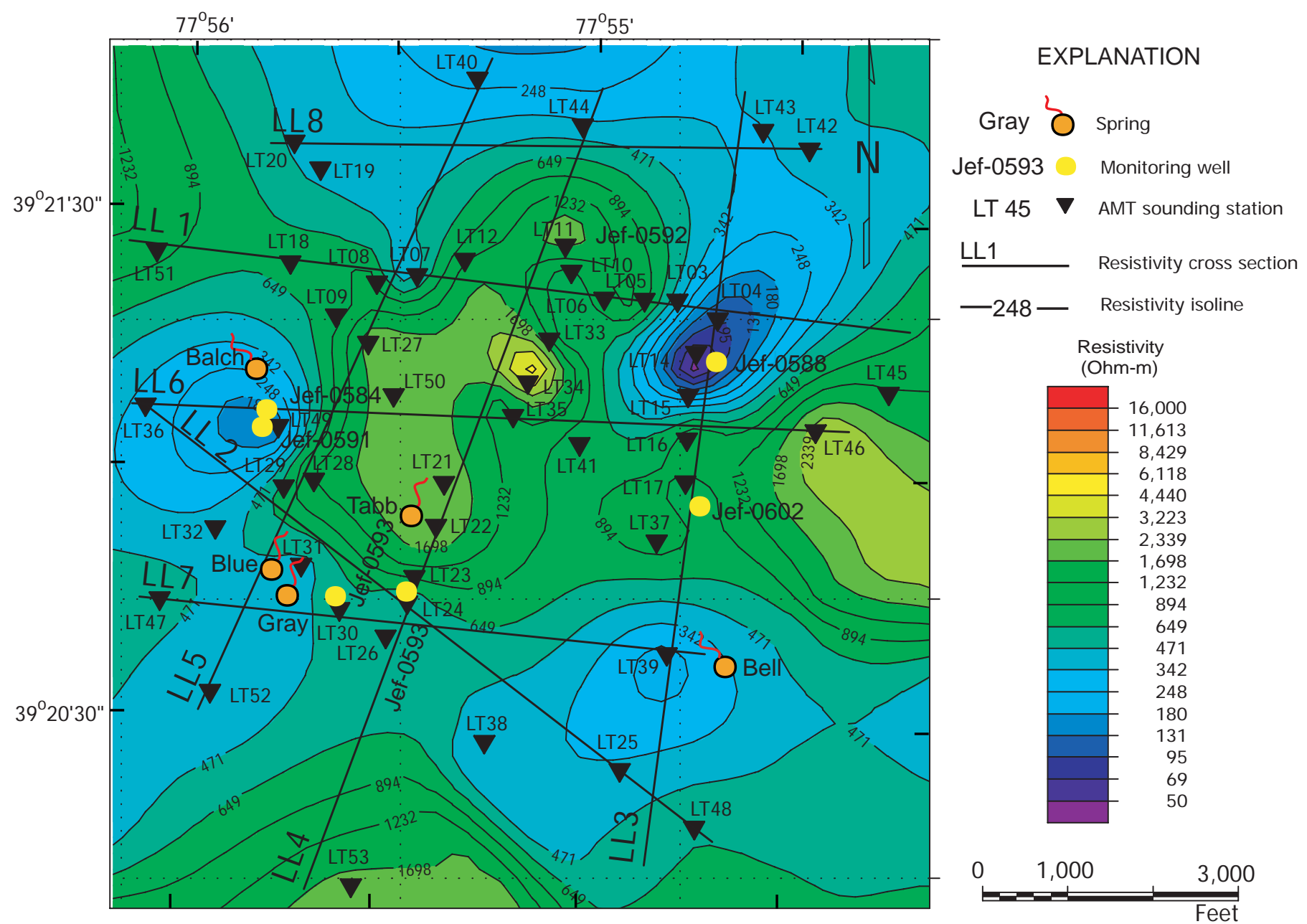

Figure 10. Two-dimensional apparent resistivity map of the AMT data at 33 feet below land surface, Leetown area, West Virginia. [All springs except Tabb Spring are in resistivity lows ( $<6500 \mathrm{hm}-\mathrm{m}$ ) and Balch, Blue, and Gray Springs are near one or more thrust faults. Tabb Spring is on a resistivity high but near a NE-SW trending resistivity gradient and a normal fault (see fig 3$)$. Wells with high transmissivity $\left(2,000 \mathrm{ft}^{2} / \mathrm{d}\right.$ or higher) are plotted and all but two are also in areas of low resistivity. The shallow old Dodson farm well (Jef-0602) has the highest transmissivity $\left(1,900 \mathrm{ft}^{2} / \mathrm{d}\right)$ of all wells tested on the Center and is located in a subtle NW-SE cross fault]. 
EXPLANATION

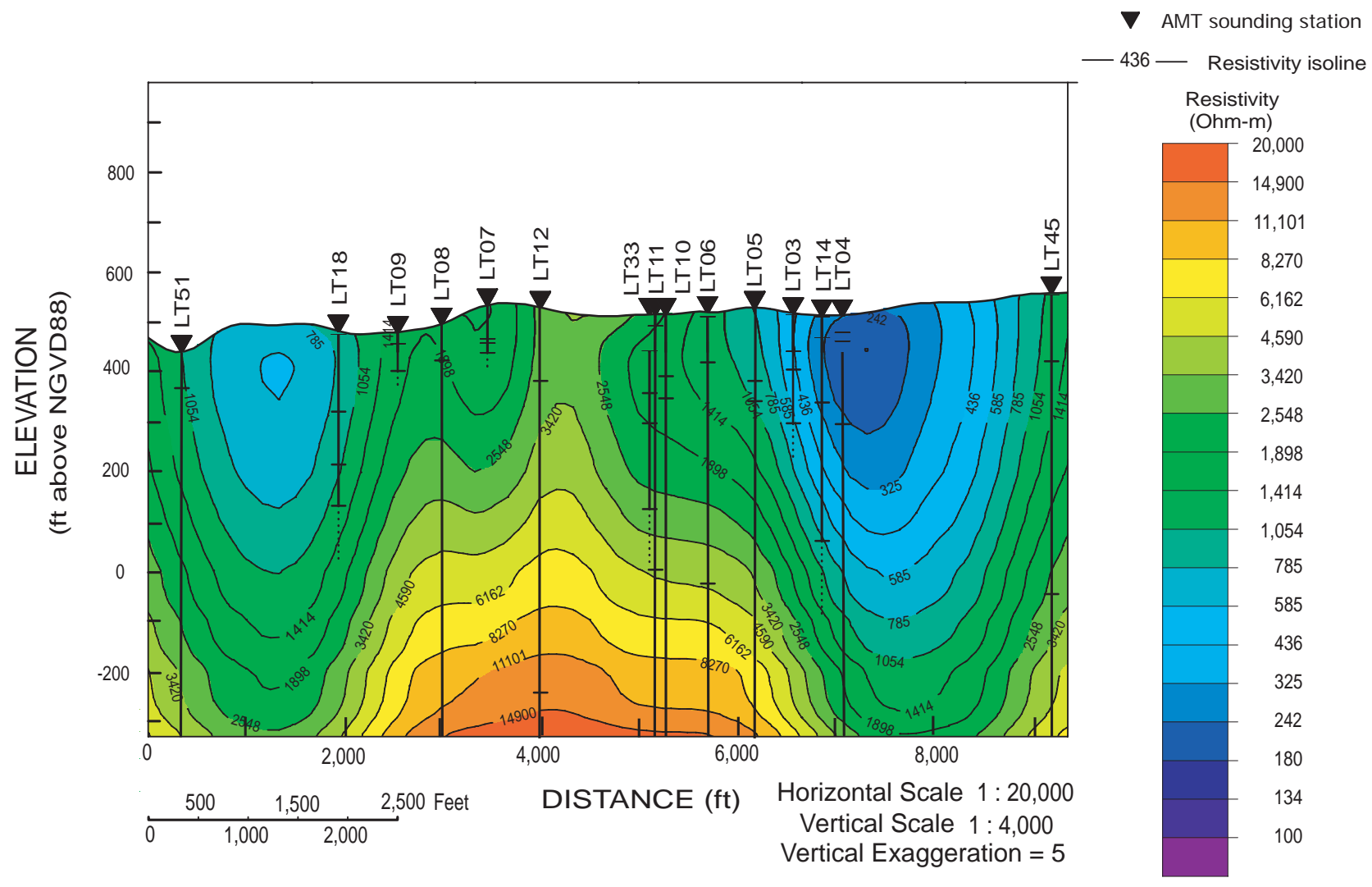

Figure 11. Two-dimensional invariant electrical-resistivity section (LL1) across the USGS Leetown Science Center, West Virginia. [The resistivity low on the left of the section is coincident with steeply dipping $\left(60^{\circ} \mathrm{E}\right.$.) thrust faults and the low on the right is coincident with a synclinal fold and the well (Jef-0588) with the highest transmissivity on the Center. The broad resistivity high is coincident with an area of exposed low-permeability limestone ridges. ft, feet; NAVD88, North American Vertical Datum of 1988; AMT, audio-magnetotellurics] 


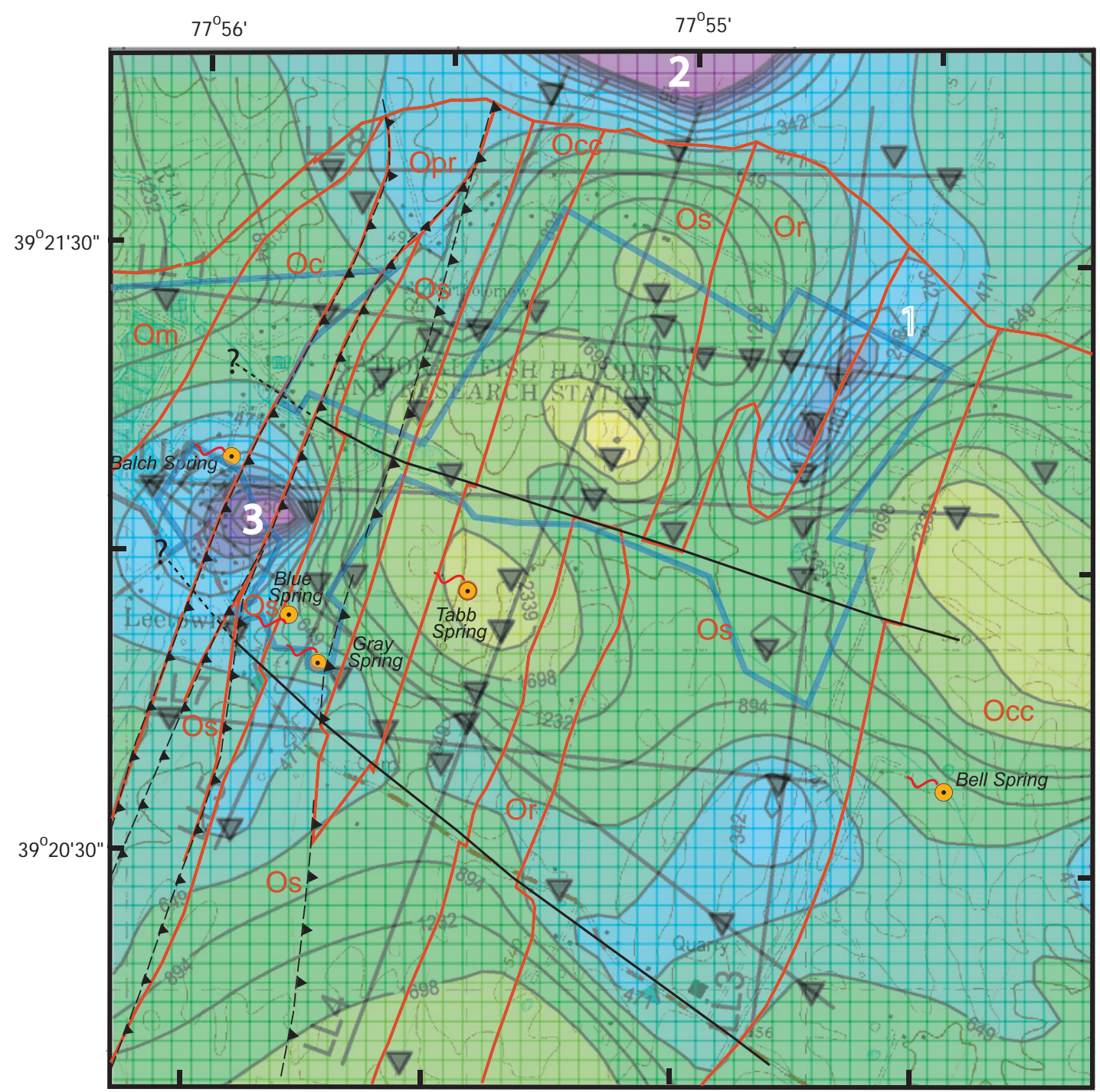

Resistivity Ohm-m

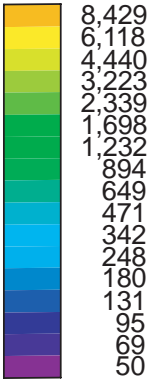

\section{EXPLANATION}

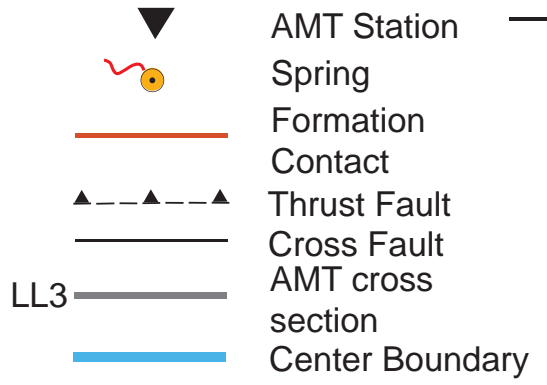

342 - Resistivity isoline

Om Martinsburg Formation

Oc Chambersburg Limestone Rocckdale Run and

Opr Pinesburg Station Dolomite

Os Stonehenge Limestone

$\mathrm{O} \in \mathrm{C}$ Conococheague Limestone

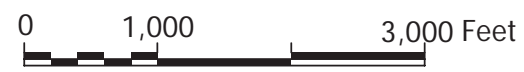

Figure 12. Composite map showing the 2-dimensional audio-magnetotelluric resistivity at $197 \mathrm{ft}$ below land surface, surficial geologic map, and USGS topographic map of the Leetown area, West Virginia. [White numbers are low-resistivity anomalies; anomaly 1 is the productive syncline area, anomaly $\mathbf{2}$ is a potential productive area but may be influenced by grid edge effects, and anomaly 3 is the productive area near Balch Spring]. 


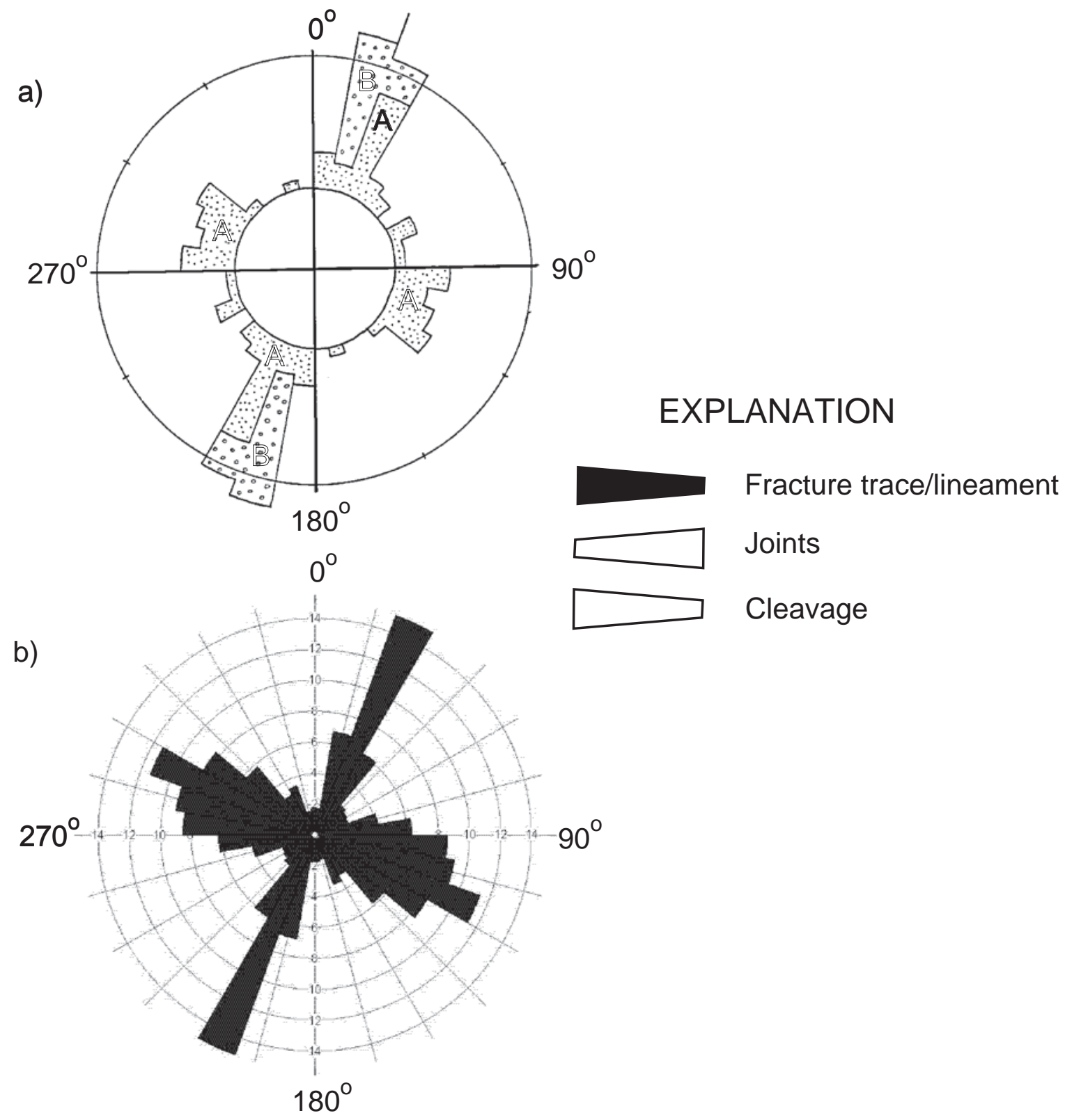

Figure 13. Rose diagrams of a) cleavage and joints in bedrock of the Leetown area (Jones and Deike, 1981) and b) fracture traces (McCoy and others, 2005 a; 2005b) in Jefferson and Berkeley Counties, West Virginia. [Concentric circles mark the percentage of total observations grouped in each "vector class", at 10 intervals. The values indicated by the length of the rose "petals" for each hemisphere of the plot sums to 100]. 
Table 2. Description and application of borehole logging techniques utilized at the USGS Leetown Science Center, West Virginia

\begin{tabular}{|c|c|}
\hline Type of borehole-geophysical log & Description and application \\
\hline Caliper log & $\begin{array}{l}\text { Mechanical calipers with spring loaded arms record the } \\
\text { borehole diameter and with change in depth. Acoustic } \\
\text { calipers calculate the distance to the borehole wall for the } \\
\text { travel time of an acoustic signal from an acoustic televiewer } \\
\text { (Keys, 1990). Caliper logs are used in conjunction with } \\
\text { ATV, OTV, fluid resistivity, fluid temperature, and heat- } \\
\text { pulse flowmeter logs to identify fractures or flow zones in } \\
\text { the borehole. }\end{array}$ \\
\hline Natural-gamma log & $\begin{array}{l}\text { Records the total gamma radiation emitted by rocks surround- } \\
\text { ing the borehole (Keys, 1990). Clay minerals within rocks } \\
\text { may be indicated by elevated gamma responses. Gamma } \\
\text { logs are most commonly used for lithologic correlations. }\end{array}$ \\
\hline Fluid-resistivity log & $\begin{array}{l}\text { Records the electrical resistivity of the water in a borehole and } \\
\text { is related to its dissolved-solids concentration (Williams } \\
\text { and Conger, 1990). Logs are collected under pumping and } \\
\text { ambient conditions to identify zones where water moves } \\
\text { into and out of the borehole. }\end{array}$ \\
\hline Fluid-temperature log & $\begin{array}{l}\text { Records the temperature of the water in the borehole as a } \\
\text { function of depth. Temperature contrasts if present provide } \\
\text { information to support the movement of water into or out of } \\
\text { the borehole at discrete fracture zones (Keys, 1990). }\end{array}$ \\
\hline Heat-pulse flowmeter log & $\begin{array}{l}\text { Measures the vertical flow in a borehole using a thermal tracer } \\
\text { and is used to determine which fractures are accepting } \\
\text { or contributing water to the borehole under pumping and } \\
\text { nonpumping conditions (Keys, 1990). }\end{array}$ \\
\hline Spontaneous-potential log & $\begin{array}{l}\text { Records the naturally occurring electrical potential differences } \\
\text { along the borehole wall and are used to identify changes in } \\
\text { lithology and bed thickness (Keys, 1990). }\end{array}$ \\
\hline Electromagnetic-induction log & $\begin{array}{l}\text { Records the electrical conductivity of the rocks and water } \\
\text { surrounding the borehole. Induction logs are used for } \\
\text { lithologic interpretations and in delineations of porosity and } \\
\text { dissolved-solid concentrations of water in the rock matrix } \\
\text { (Williams and others, 1993). }\end{array}$ \\
\hline Acoustic-televiewer log & $\begin{array}{l}\text { Provides high resolution, magnetically oriented, } 360^{\circ} \text { image } \\
\text { of acoustic energy reflection and travel time. Fractures of } \\
\text { greater than } 0.1 \text { in. can be detected and their orientation } \\
\text { determined on ATV images (Keys, 1990). }\end{array}$ \\
\hline Optical televiewer logs & $\begin{array}{l}\text { High-resolution } 360^{\circ} \text { optical image of the borehole (Williams } \\
\text { and Lane, 1998). The OTV log can be used to produce a } \\
\text { virtual core to permit visualization of fractures as they oc- } \\
\text { cur in the borehole. Fractures apertures and orientation can } \\
\text { be determined from OTV logs. }\end{array}$ \\
\hline
\end{tabular}




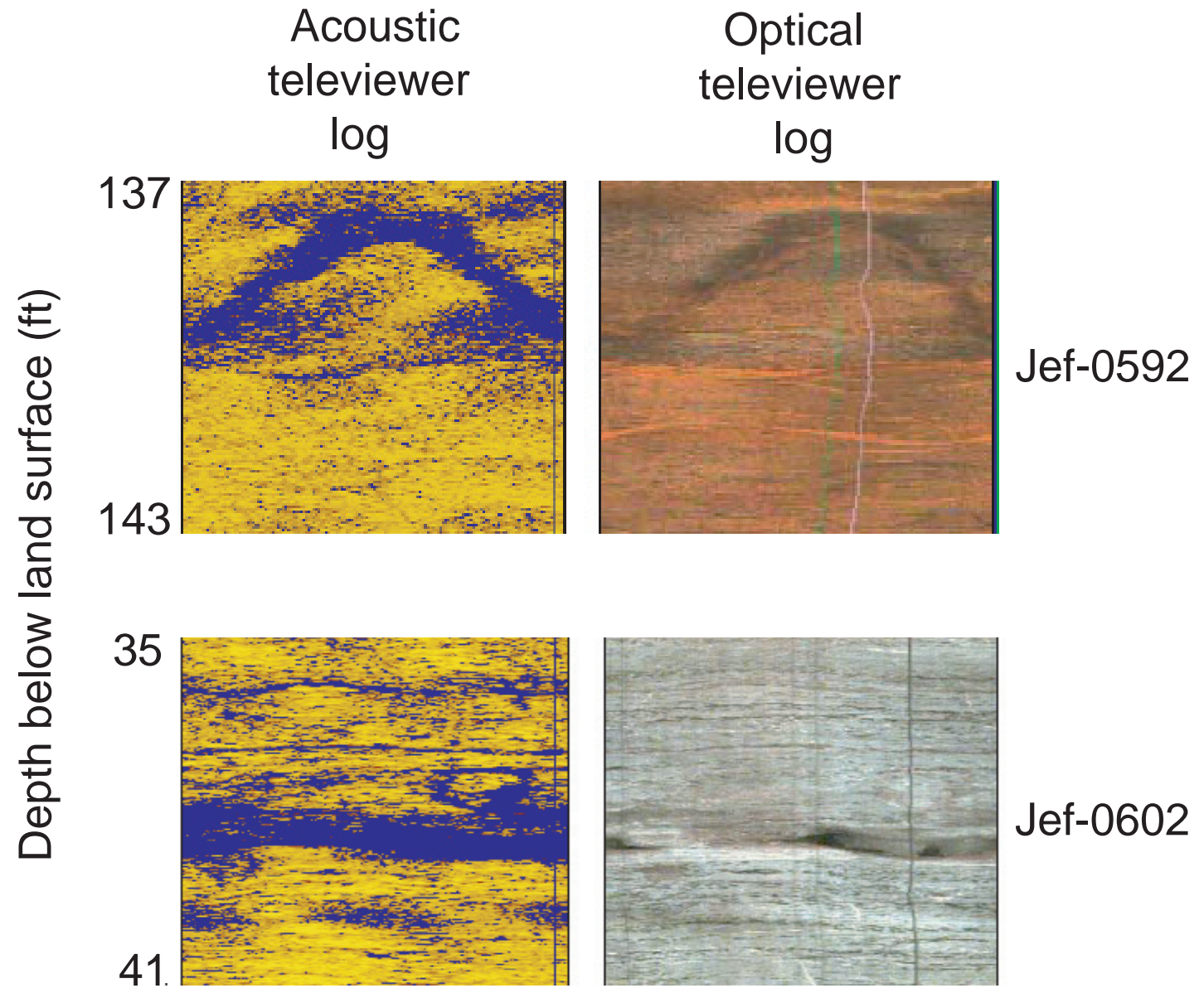

Figure 14. Examples of fracture images from acoustic and optical televiewer logs of boreholes in the Leetown area, West Virginia. [Note sinusoidal of fracture imaged in borehole Jef-0592 indicative of fracture dipping 73 degrees and parallel to regional strike of about N. $20^{\circ}$ E. A fracture of dip 19 degrees and parallel to regional strike of about $\mathrm{N} . \mathrm{20}^{\circ} \mathrm{E}$. in borehole Jef-0602 is imaged as a sub-horizontal feature]. 


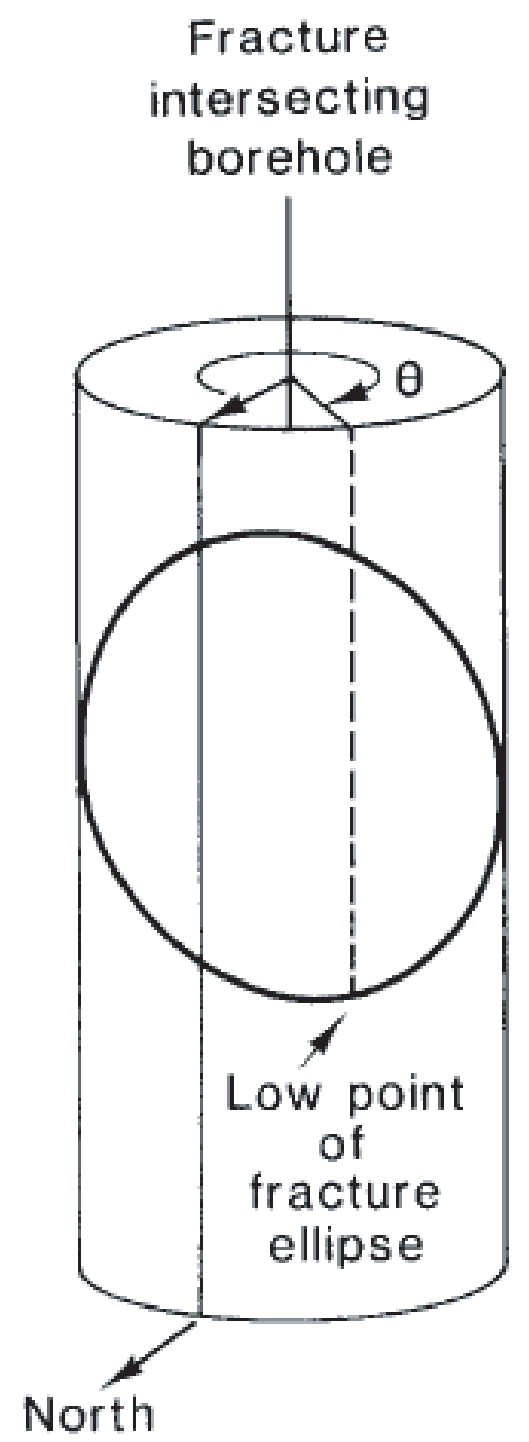

\section{Televiewer}

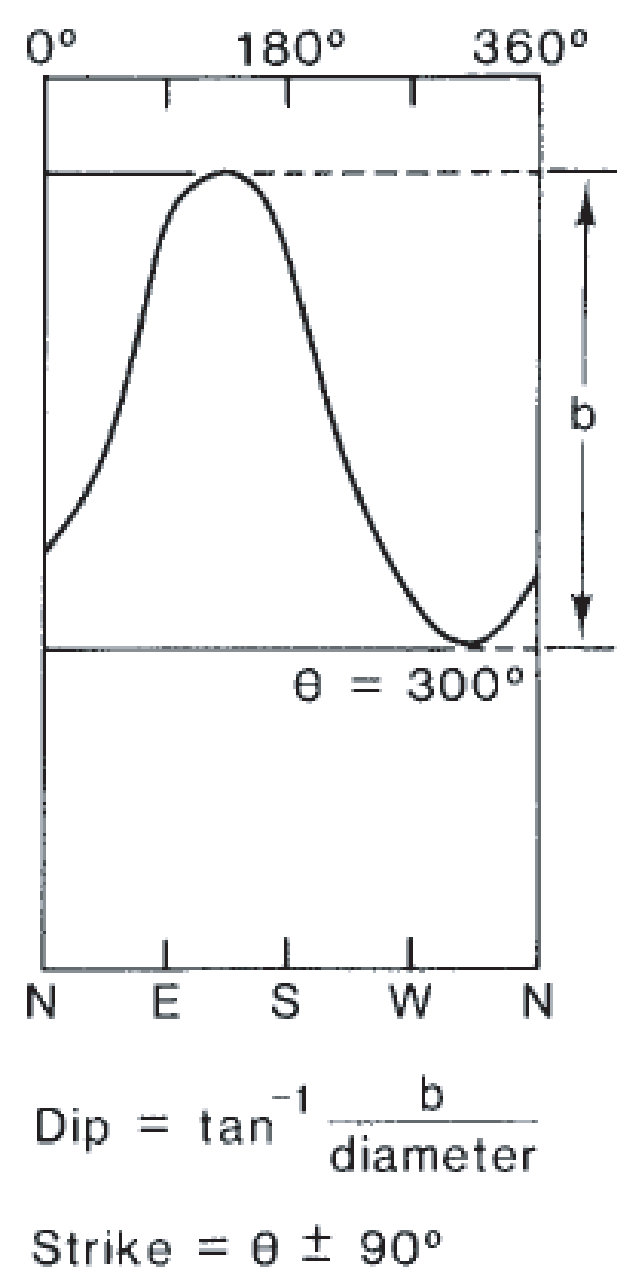

Figure 15. Illustration showing the method of determining fracture strike and dip orientation from televiewer logs (Paillet and others, 1987). 


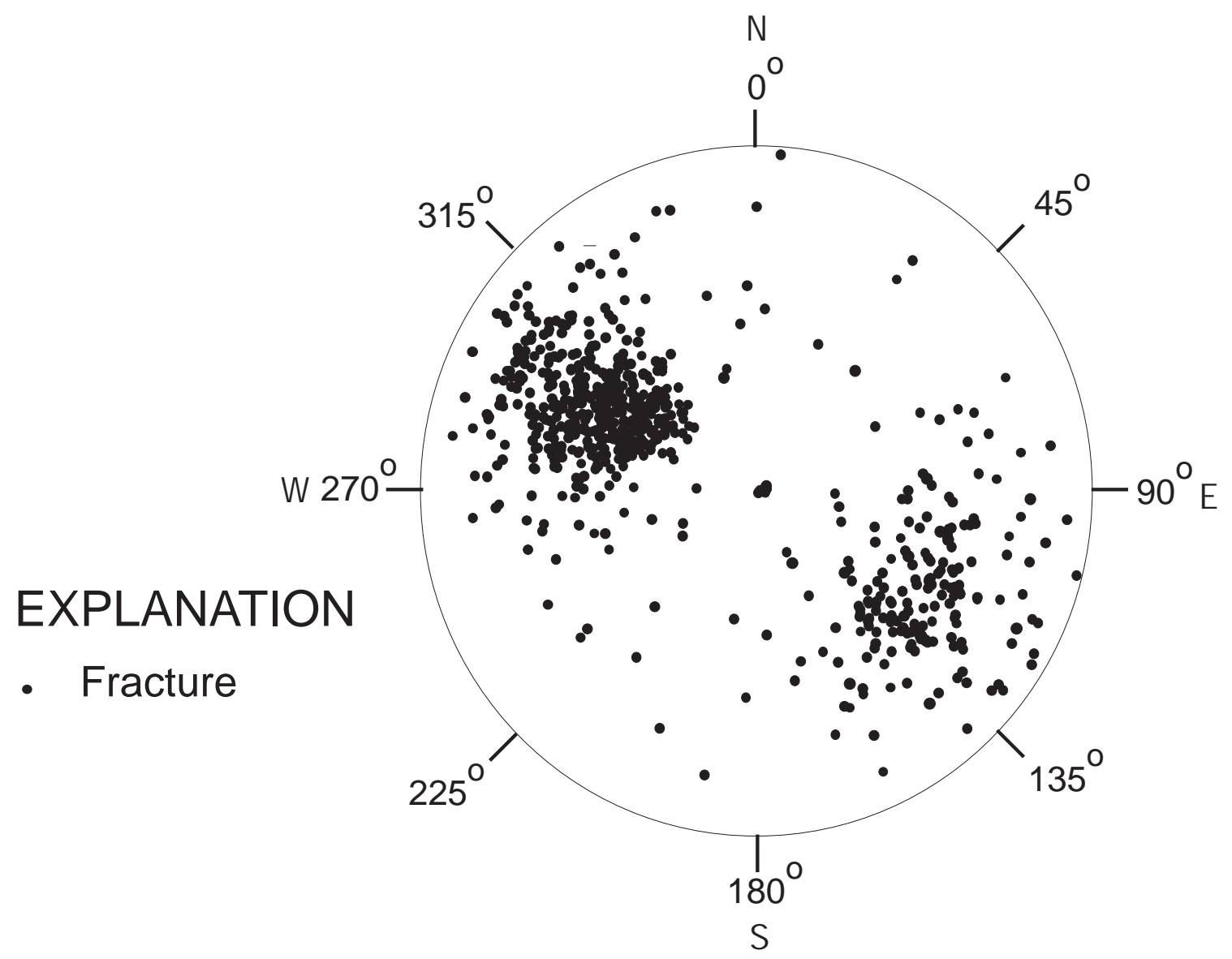

Figure 16. Schmidt equal-area stereo-net projections of poles to planes for 683 fractures identified in acousticteleviewer (ATV) logs of 11 wells at the USGS Leetown Science Center, West Virginia. 
well represented by ATV log analysis. The discordance likely represents sample bias because vertical boreholes are not effective for imaging high-angle fractures (Kaehler and Hsieh, 1994). Cross strike fractures have been shown to correlate with high yield wells (McCoy and Kozar, 2007b). Dip angles of cross-strike joints mapped at the Center commonly exceed $60^{\circ}$ (Jones and Deike, 1981), and are likely under-represented in the present dataset.

Generally, numerous fractures intersect a borehole, but typically only one or two fractures transmit most of the water to a well. Matrix porosity and permeability are negligible and occur in micro fractures with little or no effective porosity. Many of the smaller fractures provide storage potential for water but are not major avenues of ground-water flow. These less dominant fractures may provide storage of water and yield water to larger water-bearing fractures, which in turn are drained by solution conduits within the carbonate rock. The conduits typically occur along thrust and cross-strike faults and drain water over a wide area. Less prominent conduits may also form along fracture zones not associated with faults. The diffuse-flow dominated network of fractures that provides the majority of storage occupies only a small proportion of the total aquifer volume but constitutes the majority of porosity within the aquifer. Solution conduits occupy an even smaller proportion of the overall volume of the aquifer, but are important because they constitute the primary drains for the ground-water flow system. Based on individual well log analyses (appendices 2a and 2b), appendix 2c includes detailed description of the geologist's well logs with depths of clay, depth to bedrock, static water level, potential water-bearing fractures and their depth, and estimated yield of water to the well. Overall orientations of the major water bearing fractures are presented in Appendix 3 and are illustrated in fig. 17.

\section{Hydrology - by Mark D. Kozar, Kurt J. McCoy, and John A. Young}

Within the study area, diffuse fractures are a dominant pathway for ground-water flow. Conduit-dominated flow appears to be concentrated at the major thrust and cross-strike faults. These higher permeability faults and conduits act as drains, collecting water from an intricate network of diffuse fractures over a broad area. Zones of high hydraulic conductivity, indicated by surface geophysical data in areas where faults are not mapped, are most likely highly transmissive fracture zones but may also be unmapped faults. Previous conceptual models of ground-water flow in the area (Kozar and others, 1991; and Shultz and others, 1995) recognized the importance of solution-enlarged fractures and conduits along bedding planes in governing ground-water flow but did not fully recognize the importance of cross-strike faults or complex geologic structures such as overturned or tightly folded anticlines and synclines in controlling ground-water flow.

\section{Precipitation, surface drainage, and streamflow - by Mark D. Kozar and Kurt J. McCoy}

Precipitation records for the National Weather Service station at the Eastern West Virginia Regional Airport, located in Martinsburg, West Virginia (hereafter referred to as the Martinsburg Airport) (NOAA, 2006), which is 4 mi northeast of the study area, recorded annual precipitation totals of 53.94, 46.41 , and 30.38 inches per year (in/yr) for 2003, 2004, and 2005 respectively (table 3 ). Long-term average precipitation (1892-2004) for the Martinsburg airport is $39.39 \mathrm{in} / \mathrm{yr}$ (NOAA, 2004). The mean precipitation of $38.39 \mathrm{in}$. for the two-year period 2004-2005 is within an inch of the long-term average. Precipitation also was measured at a rain gage located on the Center at Gray Spring (Jef-0521S in table 1 on fig. 1) for the period of this study (Kozar and others, 2007). Periods of heaviest precipitation generally occur in March through May but the largest precipitation event of more than 5 in. of rainfall occurred in October of 2005, a result of the remnants of a tropical storm that crossed the region. Precipitation and ground-water recharge do not necessarily correlate, primarily due to higher rates of evapotranspiration in late spring to early fall. Thus, ground-water recharge is typically highest in late Fall to Early Spring when evapotranspiration is at a minimum.

Surface drainage in the Leetown area is topographically controlled and mostly exhibits a trellis type pattern. The trellis drainage is a reflection of structural features, such as bedding, cleavage planes, thrust faults, and by cross-strike joints and faults within the bedrock. Lithology also is an important factor governing surface drainage and ground-water flow. Water flows primarily from topographically higher areas in the east towards Opequon Creek to the west. The lower permeability of the Martinsburg Formation, however, retards ground-water flow and funnels water toward the Leetown area, where Hopewell Run turns north-west along a zone of enhanced fracturing, eventually flowing into Opequon Creek (fig. 18). The south branch of Hopewell Run flows northward towards the Center, parallel to bedrock strike and several areally extensive thrust faults. The east branch of Hopewell Run flows primarily westward towards the Center and parallels a large cross-strike fault.

A gaging station was constructed on Hopewell Run at Leetown to aid in determining a water budget and to provide calibration data for a numerical ground-water flow model for the area (Kozar and others, 2007). Average daily flow of Hopewell Run at the Leetown gaging station for the period April 2003 through March 2006 was approximately 11.2 cubic feet per second $\left(\mathrm{ft}^{3} / \mathrm{s}\right)$, and ranged from a minimum of 1.80 $\mathrm{ft}^{3} / \mathrm{s}$ on September 28, 2005 to a maximum of $73.0 \mathrm{ft}^{3} / \mathrm{s}$ on December 11, 2003. Streamflow exhibits seasonal fluctuations, with highest flows in the winter months when evapotranspiration is low and minimum flows in late summer when evapotranspiration is high. 
Boreholes located along fault zones

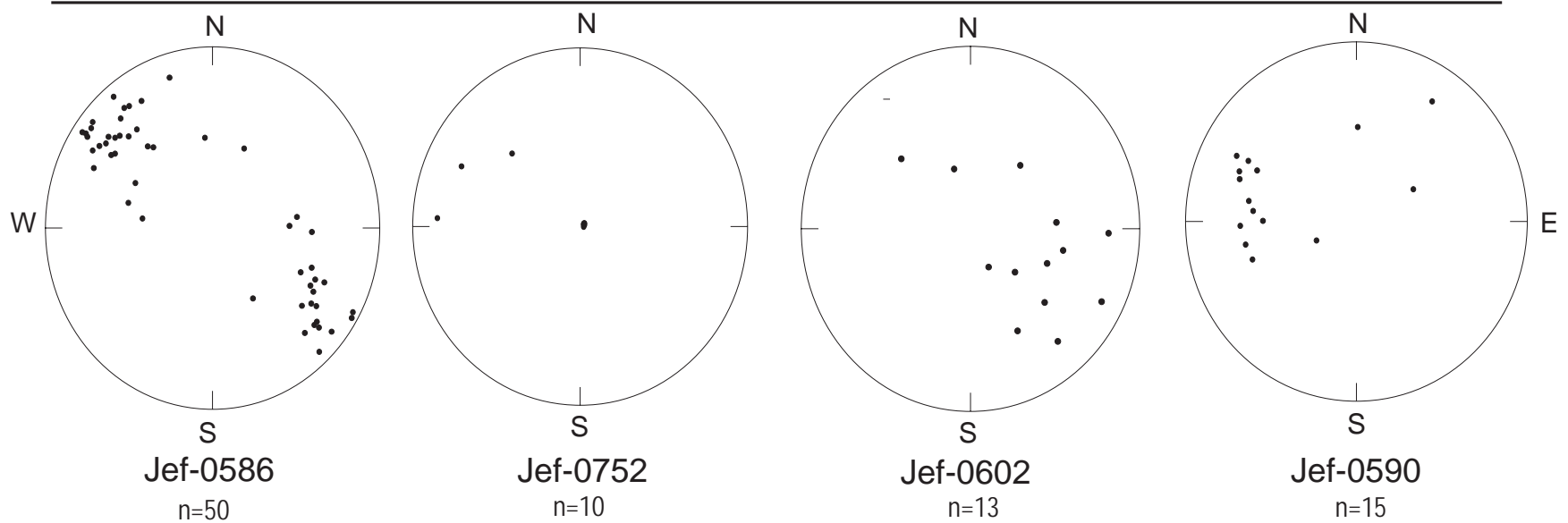

Boreholes located near fold hinges or lithologic contact zones

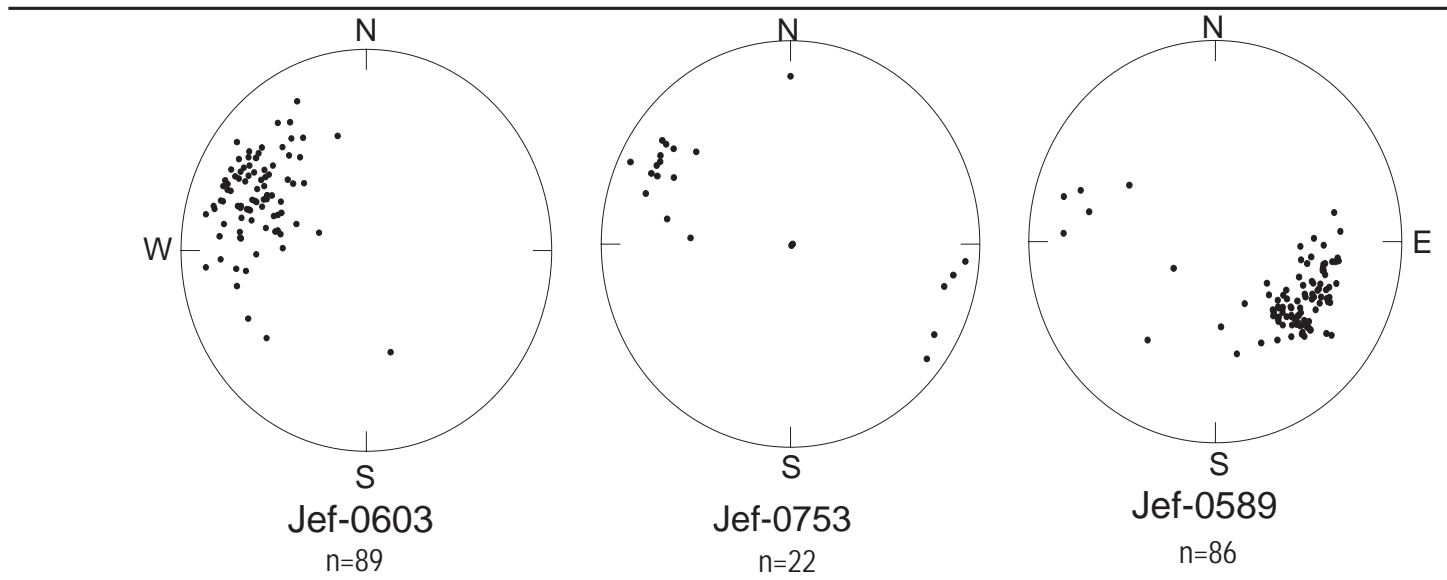

Boreholes located in diffuse-flow dominated portions of the aquifer

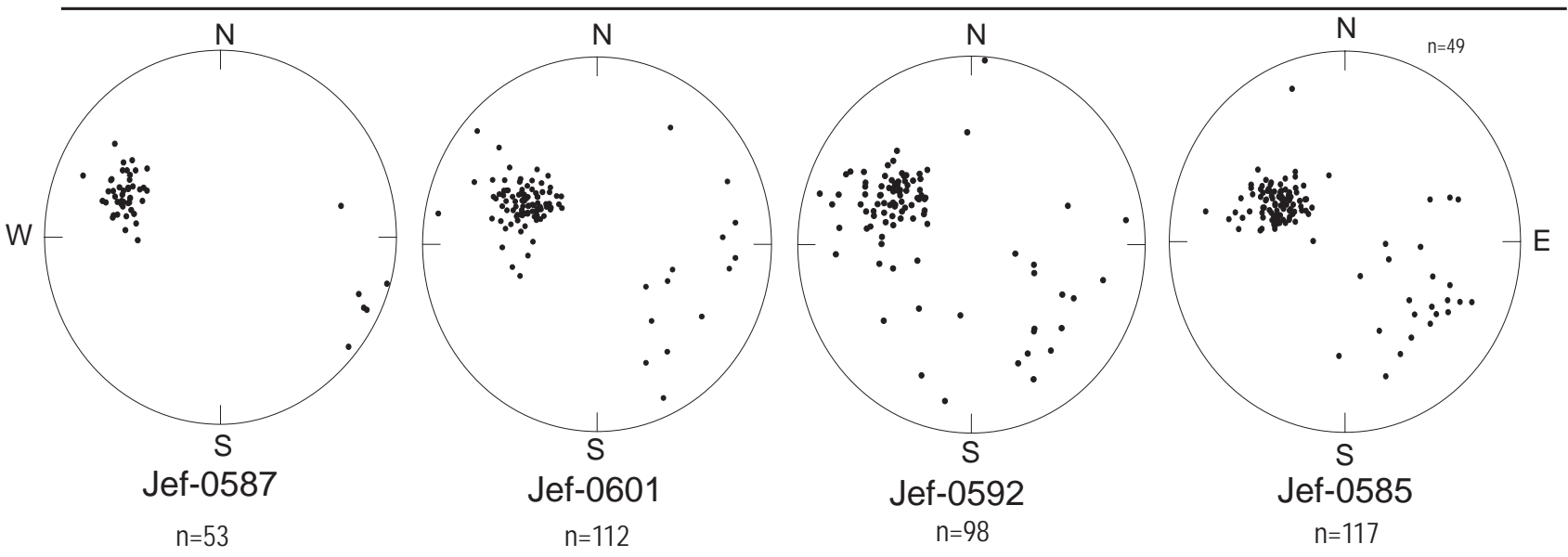

Figure 17. Schmidt equal-area stereo net projections (segregated by geologic structure) of poles to planes for fractures identified in acoustic-televiewer logs of 11 wells at the USGS Leetown Science Center, West Virginia. 
Table 3. Precipitation in inches at the Eastern West Virginia Regional Airport, Martinsburg, West Virginia, 2003-2005.

\begin{tabular}{llll}
\hline \multicolumn{1}{c}{ Month } & \multicolumn{3}{c}{ Year } \\
& $\mathbf{2 0 0 3}$ & $\mathbf{2 0 0 4}$ & $\mathbf{2 0 0 5}$ \\
\hline January & 2.31 & 1.78 & 2.05 \\
February & 4.49 & 3.43 & 1.38 \\
March & 3.12 & 1.92 & 4.44 \\
April & 2.92 & 5.84 & 2.63 \\
May & 7.53 & 7.06 & 2.03 \\
June & 9.20 & 4.49 & 1.64 \\
July & 3.80 & 4.04 & 2.92 \\
August & 3.43 & 2.13 & 2.92 \\
September & 6.50 & 7.75 & 0.14 \\
October & 3.01 & 2.38 & 5.29 \\
November & 3.75 & 3.11 & 3.63 \\
December & 3.88 & 2.48 & 1.31 \\
Annual total & & & \\
Departure from long-term average ${ }^{1}$ & 53.94 & 46.41 & 30.38 \\
\hline${ }^{1}$ The departure from normal is the difference between & the current annual precipitation and \\
the long-term average precipitation (39.39 in/yr) for the station for the period of record $(1898$ \\
to 2005).
\end{tabular}




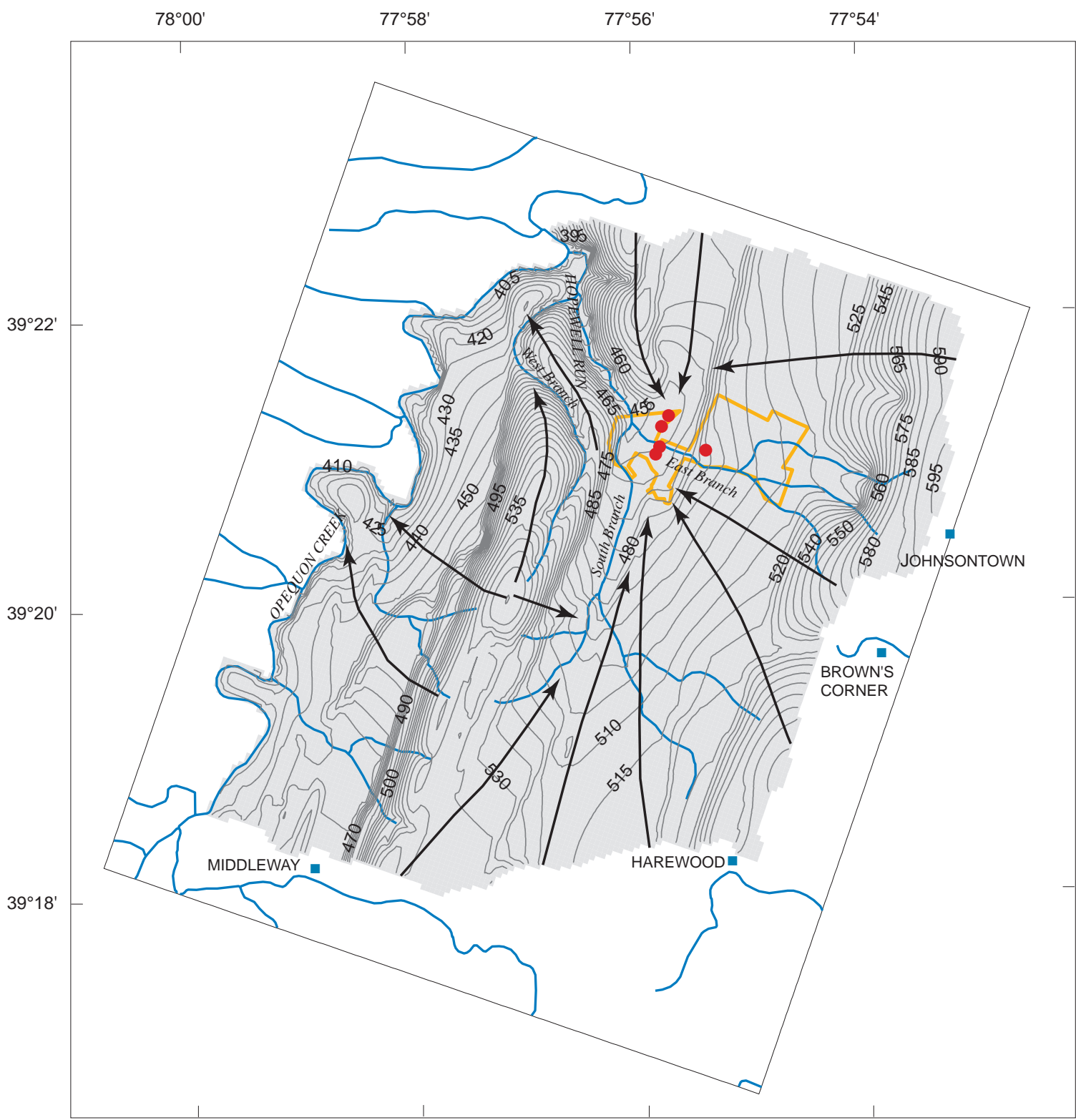

\section{EXPLANATION}

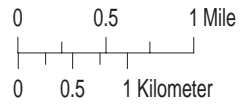

Model cell assignment

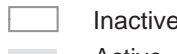

Active

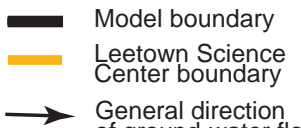

$\longrightarrow \quad \begin{aligned} & \text { General direction } \\ & \text { of ground-water flow }\end{aligned}$

- Production well

\section{- Stream}

Potentiometric contour-- shows altitude at which water level would have stood in tightly cased wells. Contour interval is

5 feet. Datum is North American Vertical Datum of 1988

Figure 18. Potentiometric-surface map of simulated ground-water levels and generalized directions of groundwater flow in the Leetown area, West Virginia. 


\section{LiDAR Data Acquisition and Processing for Landform Analysis - by John A. Young}

Hydrologic analyses often benefit from high-quality digital representations of terrain to assist in determination of runoff, streamflow, and ground-water levels. These "digitalelevation models" (DEMs) have been used extensively in geographic information system (GIS) applications for spatial modeling. DEMs have been created at a variety of scales (most commonly at 1:24,000 and 1:250,000) using various photogrammetric, stereoscopic, and height-finding methods. While very useful for regional or watershed-scale studies, these elevation models are limited by the technology used in their creation to moderate spatial resolutions (for example, 100 -ft horizontal spacing between observations) and are often plagued by systematic errors that influence the accurate depiction of topography and surface-water flow paths.

The advent of laser-based Light Detection and Ranging (LiDAR) technology in recent years promises a new era of accurate, fine resolution DEMs. These remote sensing systems resolve surface height by sending out laser pulses in a scanning pattern from an aircraft-mounted sensor, and computing the time required for returned laser backscatter to reach the sensor. The time required for the laser pulse to travel to the surface and back is converted to distance (that is to say, range); this distance is then compared to the altitude of the plane as determined by a differential global positioning system (GPS) at the time of acquisition (Wehr and Lohr 1999). Because of the precision of laser and GPS measurements, very accurate surface topography can be computed (generally less than 6 in. vertical accuracy). When laser pulses are scanned as a dense series of postings, extremely detailed DEMs can result (for instance, a $3.3 \mathrm{ft}$ pixel resolution). DEMs resulting from laser scanning can for the first time provide detailed topographic data for site-specific hydrologic applications, as well as for a host of other applications in earth sciences, mapping, and forestry (Lefsky and others, 2002).

LiDAR data for the watershed surrounding the Center were acquired and processed through a partnership with the USDA Natural Resources Conservation Service (NRCS). Flight planning, a quality-control ground survey, and post-processing of the acquired LiDAR data were conducted to assist the NRCS. While the primary goal of the USGS portion of the project was to develop fine-scale DEMs to delineate sinkholes and identify other features relevant to ground-water recharge in the vicinity of Center, the DEMs created are generally useful in other applications including ground-water modeling (fig. 18) and mapping of geologic structure.

\section{LiDAR Acquisition and Quality Control}

The NRCS contracted with a private remote sensing firm in March of 2005 to acquire LiDAR data over Jefferson County, West Virginia, at an average resolution of 1 meter (3.28 ft) point spacing or better, and vertical accuracy of 15 centimeters (6 in.) root mean square error (RMSE), on bare, flat ground. The primary purpose of the data acquisition was to develop a high resolution DEM for Jefferson County to use in hydrologic applications. Coincidentally, scientists at the Center were preparing to acquire LiDAR data for a study of the locations of sinkholes potentially affecting ground water used by the Center and by the surrounding community. Rather than duplicate efforts, the USDA-NRCS and USGS combined efforts to acquire and process LiDAR data (fig. 19) to meet the needs of both agencies. The LiDAR data were also used to assign elevations to nodes and head-observation and pumping wells in the upper layer of a ground-water model developed for the Leetown area, West Virginia (Kozar and others, 2007).

LiDAR data were acquired over Jefferson County, WV, between April 11-18, 2005, prior to vegetation leaf-out, to maximize ground surface visibility. Data were acquired using an Optech ALTM LiDAR system at an altitude of approximately 4,000 ft, an airspeed of 140 knots, and a laser pulse rate of 50,000 Hertz. Two GPS systems were used by the vendor during data collection, one located at the Martinsburg Airport, and one located in eastern Jefferson County. Postprocessing of the data consisted of GPS trajectory and laserrange corrections, first and last return extraction, and vegetation and building removal for a "bare earth" surface model. Vendor-derived estimates of accuracy during in-flight quality assurance tests over the Martinsburg Airport averaged $0.10 \mathrm{ft}$ RMSE in surface height.

USGS Center scientists were asked by the NRCS to initiate a quality-control survey as an independent source of validation for the data collected. The USGS conducted ground surveys using survey-grade differential GPS instruments to measure surface elevations of different land cover types in Jefferson County. These elevation measurements were compared to LiDAR data postings provided by the vendor. The accuracy standard was met in 36 of 37 (97 percent) of the field measured, quality-control stations, and the overall root mean square error (RMSE) of the data provided was $0.30 \mathrm{ft}(0.09 \mathrm{~m}$ vertical), well within the specified accuracy requirements.

\section{LiDAR Data Processing}

LiDAR data were delivered as unprocessed $\mathrm{x}, \mathrm{y}, \mathrm{z}$ (surface location and elevation) data files, and as "bare earth" models that were processed to remove trees, vegetation, and buildings in order to represent a "bare" ground surface. However, close inspection of these models revealed that numerous vegetation artifacts remained, reducing their effectiveness for modeling fine surface features such as small sinkholes. Evans and Hudak (2006) proposed a method of processing LiDAR data to remove vegetation artifacts that is based on a "progressive curvature filter". This filtering method fits a series of thin-plate splines to a local cluster of laser returns (points), and determines which returns are anomalous in elevation compared to surrounding returns. Returns that are anomalies at multiple scales, such as those coming from tree tops (that is to say, those higher than the surrounding ground surface) are filtered out of the resulting models. This technique is 

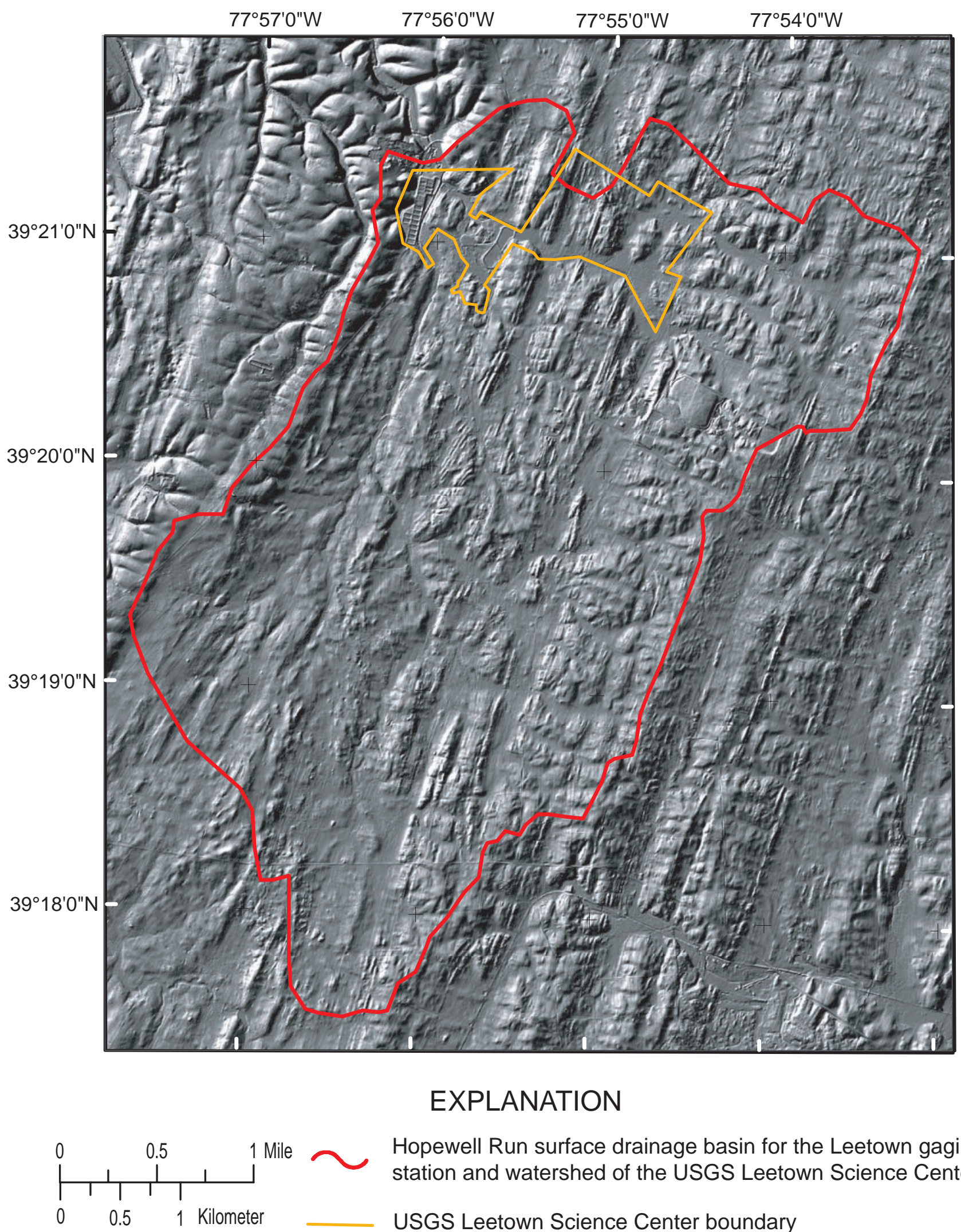

Hopewell Run surface drainage basin for the Leetown gaging station and watershed of the USGS Leetown Science Center USGS Leetown Science Center boundary

Figure 19. LiDAR derived digital-elevation model for the Leetown area, West Virginia. 
potentially much more effective at identifying the true groundsurface elevation than single pass algorithms or other iterative algorithms, because it considers the inherent scale of features in the determination of surface form.

Progressive curvature filtering algorithms provided by Evans and Hudak (2006) were used to filter LiDAR data points to remove returns from vegetation and buildings. After filtering, the resulting point dataset was interpolated to a gridbased surface-elevation model at a resolution of $6.6 \mathrm{ft}$ using a finite differencing algorithm available in the TopoGrid module of the Arc-GIS software version 9.1 (copyright ESRI Inc., 380 New York Street, Redlands, CA 92373-8100) (fig. 20). Due to the data volume inherent in LiDAR imagery, the data were processed in tiles equivalent to 1/16th of a USGS 1:24,000 quadrangle. Processed tiles were merged together to create a seamless DEM at a 6.6-ft spatial resolution.

\section{Landform Analysis}

Once a filtered DEM was prepared for the drainage area encompassing the Center, landform analysis was conducted to reveal small topographic depressions that may indicate sinkhole development. A topographic position index (TPI) was calculated using routines developed by Jenness (2005). This algorithm scores each $43 \mathrm{ft}^{2}\left(2-\mathrm{m}^{2}\right)$ area (referred to as a pixel) on the surface model with a value representing the difference between the elevation at each pixel and elevations in surrounding pixels. Positive TPI values indicate local topographic highs while negative TPI values indicate local topographic depressions. TPI values around zero indicate topographically flat terrain.

By varying the size of the area considered around each pixel, different scales of landforms can be determined. In addition to varying the area size, the area shape can be varied to capture surface forms in different configurations (such as a circle or square), or to evaluate surface forms within a specified distance range (doughnut), or direction (wedge). A doughnut shaped area was used to calculate TPI in an area between 6.6 and $33 \mathrm{ft}$ ( 2 and 10-m) around each pixel on the DEM. The scale and area shape were maximized for determining locations of small, circular topographic depressions.

\section{Landform Interpretation to Identify Sinkholes}

The TPI values were grouped into 13 classes for visual interpretation; each class represented 0.25 standard deviations from the mean TPI value (fig. 20). This classification was useful for depicting anomalous bowl-shaped areas. Anomalies were compared in this classification to 1-meter (3.28 foot) resolution color infrared aerial photographs of the same area flown in 2003. Areas that appeared as circular local depressions (especially in forests) that could not be easily explained as farm ponds, road depressions, or other man-made features were flagged as points for further investigation. A total of 94 such small circular depressions were flagged as potential sinkholes in the Leetown area.
Potential sinkholes flagged in this manner were compared to sinkholes mapped in the area by other investigators. David J. Weary (coauthor of this report) mapped 11 sinkholes in the Leetown area with a GPS as part of geologic mapping conducted for this study(fig. 2). Kozar and others (1991) mapped 687 sinkholes in Jefferson County, West Virginia, in a ground-reconnaissance survey. Nine of 11 sinks mapped by Weary corresponded to topographic depressions identified in our analysis. Most of the sinkholes mapped by Kozar and others (1991) were also in close proximity but varied in accuracy due to limitations of field mapping technology available prior to the common availability of GPS.

Attempts were made to visually inspect all mapped topographic depressions in the field by navigating to locations with handheld GPS. Of the 94 sites mapped, 39 could not be field assessed due to private property access restrictions. Of the 55 sites visited in the field, 47 (85 percent) were depressional features, but 14 of these were observed to be other than sinkholes (such as home site excavations, ditches, old road beds, and so on). Approximately 63 percent (35 of 55) of sites visited were natural depressions that are possible sinkholes, including 9 with obvious drainage holes. While identifying and locating landscape depressions using LiDAR proved successful, not all depressions are obvious sinkholes, and more work needs to be completed to fine tune methods for mapping active sinks. However, the LiDAR-derived DEM developed for this project improved the ground-water flow model developed for the Leetown area by refining the upper surface elevations assigned within the model. Finally, high-resolution topographic maps constructed using LiDAR data also shows great promise for fracture trace and lineament analysis to locate surface expressions of subsurface faults or fracture zones.

\section{Ground-Water Levels - by Kurt J. McCoy}

Ground-water levels are critical to understanding groundwater flow processes in the complicated flow system of the study area. Water-level data for 17 monitoring wells was analyzed for this study (app. 1 in Kozar and others, 2007). Topographic variability in water levels is pronounced, with shallower water levels (sites Jef-0584, 590, 591, 594, 595, 600, 602,656 , and 657; table 1, fig. 1) common in lowland areas (valleys and topographic depressions) and deeper water levels (sites Jef-0585-587, 589, 592, 593, 596-599, and 601; table, fig. 1) in upland areas (hillside and hilltop settings). Depth to water in upland wells is approximately twice that in lowland wells. There is also significant seasonal variability in water levels between the two settings. Water levels are typically lowest in late summer to early fall and highest in the winter to early spring (fig. 21). This corresponds with ground-water recharge rates that are typically lowest in late spring through early fall and highest in late Fall through Early Spring.

The average maximum and minimum monthly water levels for well Jef-0526 for the period of record (1985-2005) occur respectively in the months of April (average April water level is $21.39 \mathrm{ft}$ bls) and September (average September water 


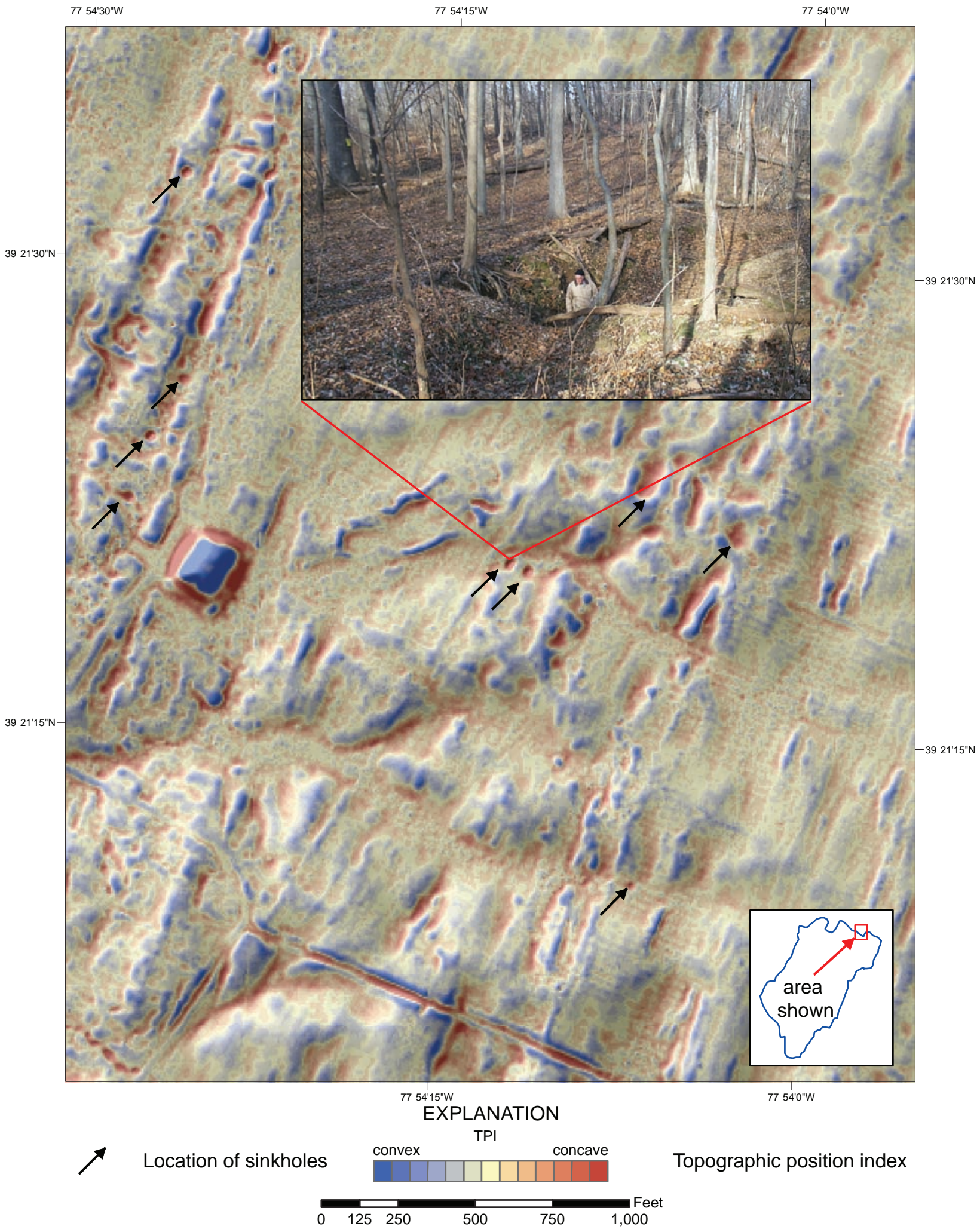

Figure 20. Detail of LiDAR derived digital elevation model, color coded by levels of topographic position index, with small circular topographic depressions showing sink holes in the Hopewell Run Watershed, Leetown area, West Virginia. 


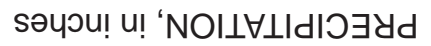

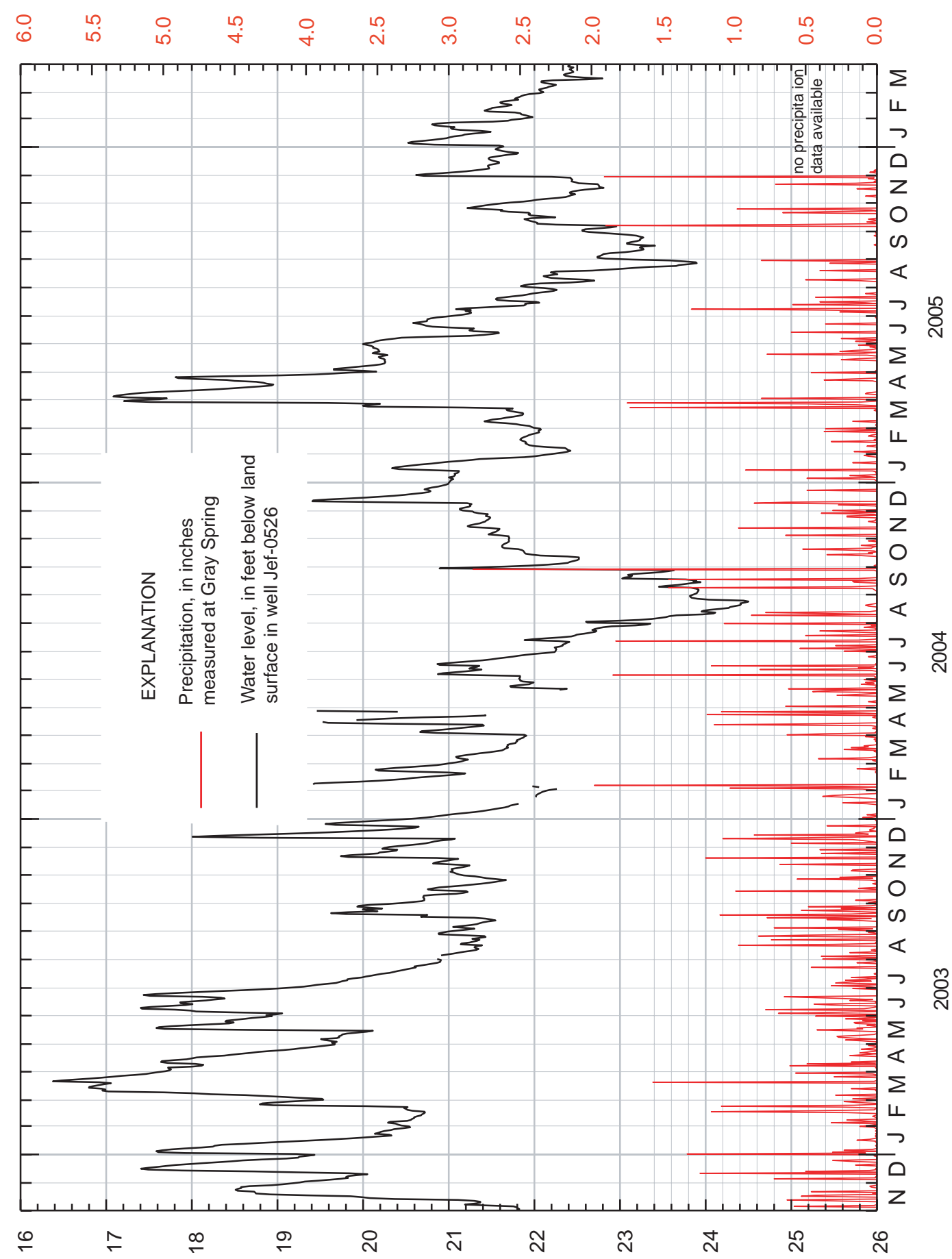

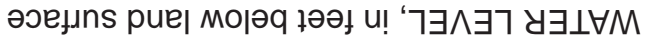

Figure 21. Precipitation measured at Gray Spring and hydrograph for well Jef-0526 at the USGS Leetown Science Center, West Virginia. [Gaps in water level plot denote periods of missing record]. 
level is $23.06 \mathrm{ft}$ bls). Summary statistics for ground-water levels in the Leetown area during July 2003 through September 2005 are presented in table 4. In 2003 ground-water levels stayed above normal for the entire year due to above average precipitation during the period. The water-level hydrograph for well Jef-0526 shows that ground-water levels in the Leetown area respond quickly to precipitation (fig. 21). Response to rainfall is dependent upon season. Generally, intense rainfall produces more substantial increases in ground-water levels when evapotranspiration (ET) is low (winter and early spring) than in periods when ET is high (summer months). The exceptions to this general trend are tropical storms and hurricanes which can produce a significant increase in ground-water levels even during periods of high ET.

Hydraulic gradients may be determined by comparing water levels for pairs of co-located wells completed at different depths within the aquifer. Eight such well pairs (well pairs Jef-0588/600, 590/595, 589/598, 587/596, 586/599, 601/597, $585 / 597$, and 592/597 in table 1, fig. 1) were installed as part of this study. Typically, water-level elevations of the well pairs differed only slightly. This most likely is due to the deeper wells being constructed as open-rock boreholes, thus measurements represent a composite hydraulic head which is dominated by the more permeable fractures typically encountered in the upper portion of the borehole.

For a typical hydrograph in a karst setting, the response time to individual precipitation events is dependent on the origin of recharge, structure of the conduit system, area of the contributing ground-water basin, and antecedent hydrologic conditions (White, 2002). Often in such settings, conduit and basin geometry are difficult to define, but the interaction of matrix storage and conduits can be determined with careful analysis of hydrograph data. Florea and Vacher (2006) found that the magnitude and associated accessibility of karst matrix storage during individual precipitation events is reflected in the "flashiness" of a hydrograph. At the Center, hydrographs for Balch and Gray Springs (fig. 22) indicate a rapid response to individual storm pulses by these springs that may be related to a number of factors including (1) losing stream reaches, (2) epikarst characteristics, (3) regional geology, (4) climatic conditions, and (5) antecedent moisture levels (White, 2002; Florea and Vacher, 2006). The stage-only data are consistent with other karst settings in Kentucky and Missouri where the limestone rock matrices contain minimal storage. Similar to those settings, the limestone rock matrix in the Leetown area is impervious and flow is limited to secondary fractures and conduits (Jones and Deike, 1981). The result is an aquifer that displays unmodified secondary fractures and a system of wellconnected solution-enlarged conduits similar to that described by Shuster and White (1971) in nearby Central Pennsylvania.

Loss of stream flow in the east branch of Hopewell Run adjacent to Balch Spring (Evaldi and Paybins, 2006) indicates that rapid infiltration of precipitation from storm pulses flowing into the nearby losing stream reach are partly responsible for higher water-level fluctuations at Balch Spring than those noted in the hydrograph of Gray Spring. Examination of the recession curves for both springs indicates that the stage of Gray Spring declines at a much slower rate than the stage of Balch Spring. It is uncertain whether this difference is related to the area of the aquifer draining to either spring. Both springs exhibit a mixture of both conduit "quick flow" and diffuse "slow flow" draining to the springs. However, Balch spring exhibits a more pronounced conduit flow signature than does Gray Spring, which appears to exhibit a significant component of diffuse flow. Continuous monitoring data for well Jef-0526 (fig. 21) illustrates that the rapid response of the aquifer at the Center is not limited to shallow flow to springs. Well Jef-0526 is in an area dominated by solution-enlarged coalescing thrust fault zones and had depths to water ranging from 18.0 to $24.5 \mathrm{ft}$ bls during the study period (fig. 21).

Pumping withdrawals from Balch Spring during periods of low flow resulted in numerous rapid drawdown spikes throughout the period of record. The marked decline in spring stage during August and September 2004 is a result of the coupled effects of dry weather and pumping from the spring. Monthly water-level data collected from 23 wells at the Center during the period of study from July 2003 through September 2005 (app. 1 in Kozar and other, 2007) also show this short period of water level decline and indicate the potential of rapidly draining the aquifer during periods of high evapotranspiration and low recharge. Following the period of dry weather in 2004, wells located in discharge zones began to rebound one month prior to similar rebound measured in upland wells.

In upland or recharge areas, depths to water are generally deeper and water level fluctuations greater than those near discharge areas (table 4). However, the two deepest wells at the Center (Jef-0603 and Jef-0587 on fig. 1 and in table 1) are located in upland areas, yet the fluctuation in water level more closely resembles discharge area wells. These two wells are located in areas of low permeability and are sufficiently deep to limit the influences of shallow ground water and short-term precipitation on their ground-water levels. Fluctuations in shallow and deep well pairs were in general agreement and showed occasional reversal of vertical gradients.

During the spring of 2004, water levels were measured in 83 wells on and adjacent to the Center and were used in the calibration of a steady-state ground-water flow model for the Leetown area (Kozar and others, 2007). Measured water levels ranged from $571 \mathrm{ft}$ above NAVD88 in the far southeastern part of the study area to $440 \mathrm{ft}$ above NAVD88 near the mouth of Hopewell Run. Examination of the potentiometric surface (fig. 18) for the Hopewell Run watershed simulated by the model provides insight into ground-water flow processes in the watershed. Ground water in the Leetown area moves towards discharge points along Hopewell Run. In the southern part of the watershed (south of the Center) ground water flows primarily from the southeast to the northwest along thrust faults and permeable bedding parallel features or westward along two primary cross-strike faults. In the northern portion of the watershed (north of the Center) ground-water flows primarily from the northeast to the southwest along thrust faults and permeable bedding parallel features. Small topographic ridges 


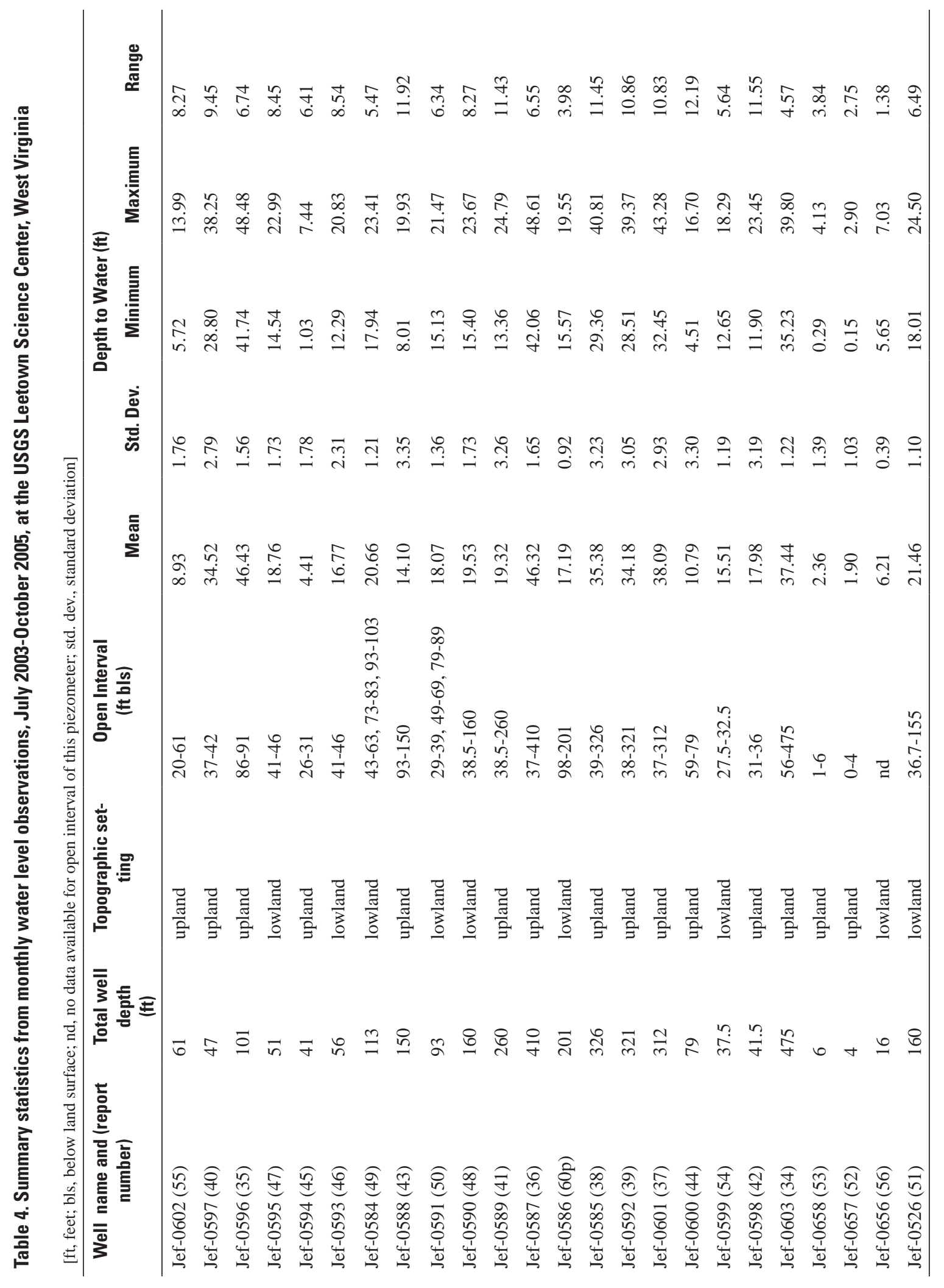




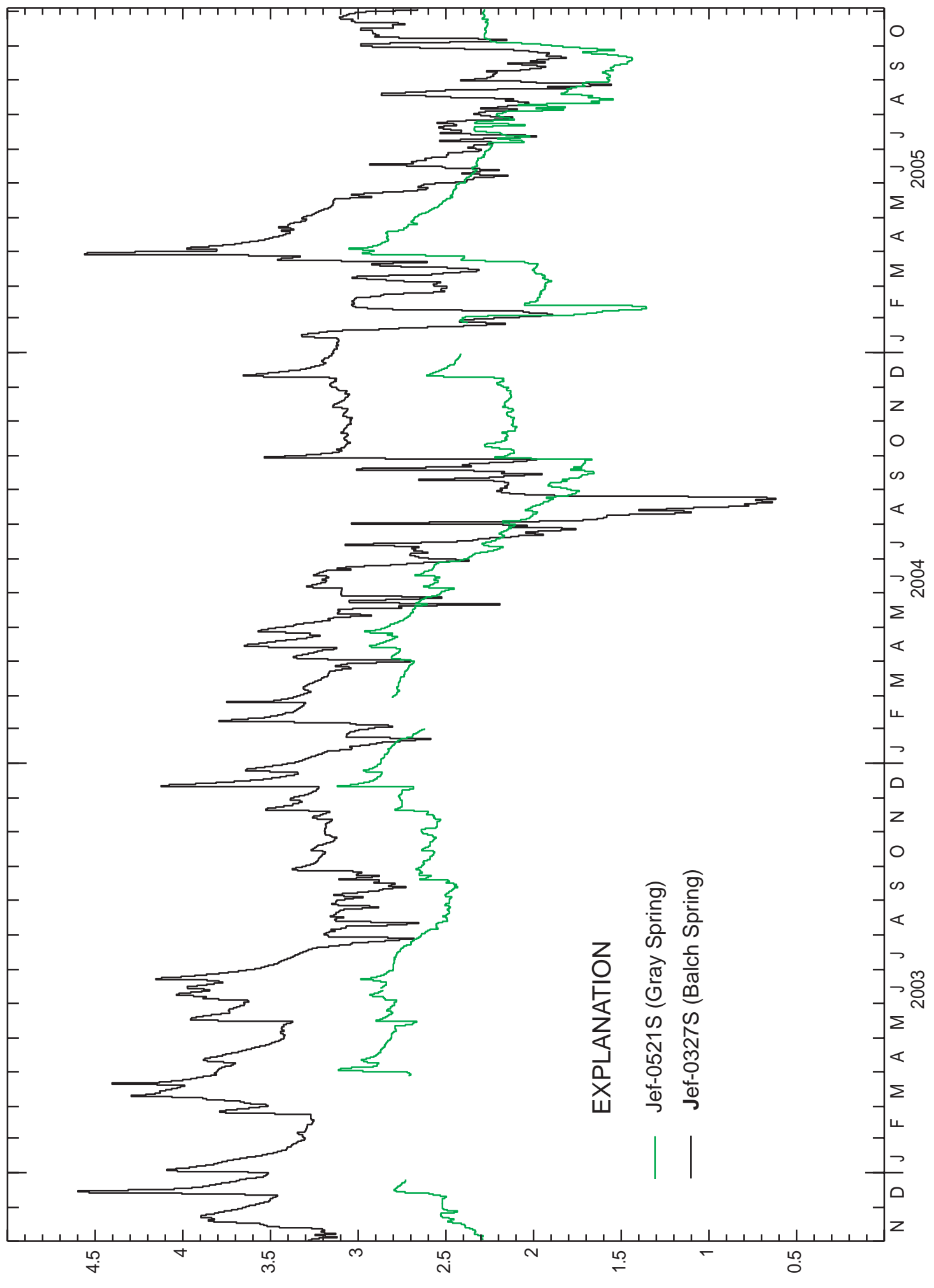

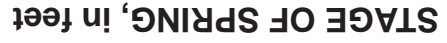

Figure 22. Hydrograph of Balch and Gray Springs, USGS Leetown Science Center, West Virginia. [Gaps in water level plot denote periods of missing record]. 
underlain by the Conococheague Limestone, just east of the Center, form hydrologic boundaries separating the headwaters of Hopewell Run from larger perennial discharge areas to the west. During wet seasons, several ephemeral springs discharge in the headwater area along the banks of Hopewell Run.

\section{Base-flow discharge measurements - by Mark D. Kozar and Kurt J. McCoy}

Base-flow discharge measurements were made in the study area as part of a survey to document channel gains and losses and to assess ground-water discharge to streams. Numerous small seeps were encountered during the base-flow surveys and discharge measurements were made at specific intervals along stream channels and at major points of tributary or apparent ground-water inflow. Generally, most measurements showed an increase in stream flow from upstream to downstream areas. There were a few notable exceptions to this trend, and significant losses of streamflow to ground water were documented at several locations. A series of major thrust faults traverse the Leetown area in a southwest to northeast direction. The East Branch of Hopewell Run and the channel that drains the Blue and Gray Spring complex both traverse the thrust faults at right angles. Base-flow measurements were made at numerous sites in the Hopewell Run watershed (fig. 23) on two separate occasions, June 29 to July 1 and October 25-27, 2004. A loss of streamflow was measured across the thrust faults at two separate locations during both periods. A loss of $0.350 \mathrm{ft}^{3} / \mathrm{s}$ was documented in the Gray and Blue Spring tributary on June 30, 2004, and a smaller loss of $0.002 \mathrm{ft}^{3} / \mathrm{s}$ was measured on the same tributary during a lower base-flow period on October 26, 2004. For the East Branch of Hopewell Run a loss of $0.870 \mathrm{ft}^{3} / \mathrm{s}$ was measured across the same series of faults on June 30, 2004, and a corresponding smaller loss of $0.170 \mathrm{ft}^{3} / \mathrm{s}$ was also measured for the East Branch near West Virginia County Route 1 on October 26, 2004. The losses are attributed to the streams losing water to the aquifer when they traverse the faults. Since the stage of Balch Spring is artificially lowered due to pumping and Balch Spring and the Center's production wells A and B (sites 58 and 59 on fig. 1 and in table 1) are along the same fault, it is likely that ground-water withdrawals from the spring and wells may induce additional capture of stream water from the fault.

\section{Ground-water recharge/discharge - by Mark D. Kozar}

Ground-water recharge is an essential component for assessing ground-water availability, calculating water budgets, and developing ground-water flow models. The Hopewell Run at Leetown gaging station was installed (fig. 1) in April 2003 to provide data for model development and calibration and to provide data from which estimates of ground-water recharge could be made. Streamflow data for a 30-month period was evaluated by hydrograph analysis (Rutledge, 1998) to estimate ground-water recharge and to provide base-flow discharge data (Kozar and others, 1997). As a result of the analysis, an average value of $16.5 \mathrm{in} / \mathrm{yr}$ of recharge (table 5) was estimated for the Hopewell Run watershed for the period from September 2003 through October 2005.

Streamflow data were available for the Hopewell Run at Leetown gaging station for only a 3-year period; therefore recharge was also estimated for the Opequon Creek at Martinsburg, West Virginia. Streamflow data has been collected at the Opequon Creek at Martinsburg gage since 1947, and provides a measure of the variability of stream flow and ground-water recharge during average and drought periods. The long-term average recharge for the Opequon Creek watershed was estimated to be $9.8 \mathrm{in} / \mathrm{yr}$ (Kozar and Mathes, 2001). The higher recharge rate of $16.5 \mathrm{in} / \mathrm{yr}$ for the Hopewell Run watershed is due to the higher proportion of surface exposures of karstic limestone bedrock in the Hopewell Run basin, as compared to the Opequon Creek watershed, which has substantial exposures of the less permeable Martinsburg Formation. A review of meteorological records (Cornell University, 2006) indicates the most recent drought in the area occurred from November 1998 - February 2000. This was the fourth worst drought on record, dating back to 1895 , and the longest drought on record, lasting for approximately 16 months. An analysis of potential recharge for the Opequon Creek watershed (table 6), to which Hopewell Run drains, was conducted to estimate recharge for the Hopewell Run watershed during droughts. Estimated ground-water recharge for the Opequon Creek watershed for the period November 1998 - February 2000 drought was $6.19 \mathrm{in} / \mathrm{yr}$. Using simple linear regression, a correlation of the recharge data from the two gages was conducted and a regression equation developed to estimate the magnitude of the drought for the Hopewell Run watershed. The correlation yielded an estimate of $8.3 \mathrm{in} / \mathrm{yr}$ for the drought period for the Hopewell Run watershed. This value was used in the drought simulation included in the report documenting the ground-water flow model that was developed for the Hopewell Run watershed (Kozar and others, 2007). It should be noted that low-flow stream flow statistics for the Eastern Panhandle of West Virginia clearly show that stream flow conditions for the period 1970 through 2002 are anomalously high (fig. 24) when compared to the period from 1930 to 1970 (Wiley, 2006). The data plotted on fig. 24 results in a unit-less number, that is the average of the normalized departures for five gaging stations, where the departure is the annual minimum streamflow minus the average annual minimum streamflow for each station, and the station departures are normalized by dividing by the standard deviation of the departure for each station. Prudent water use planning should consider the possibility that conditions prior to 1970 will return, and that as a result of climate and land-use change, more severe and frequent droughts are possible. 

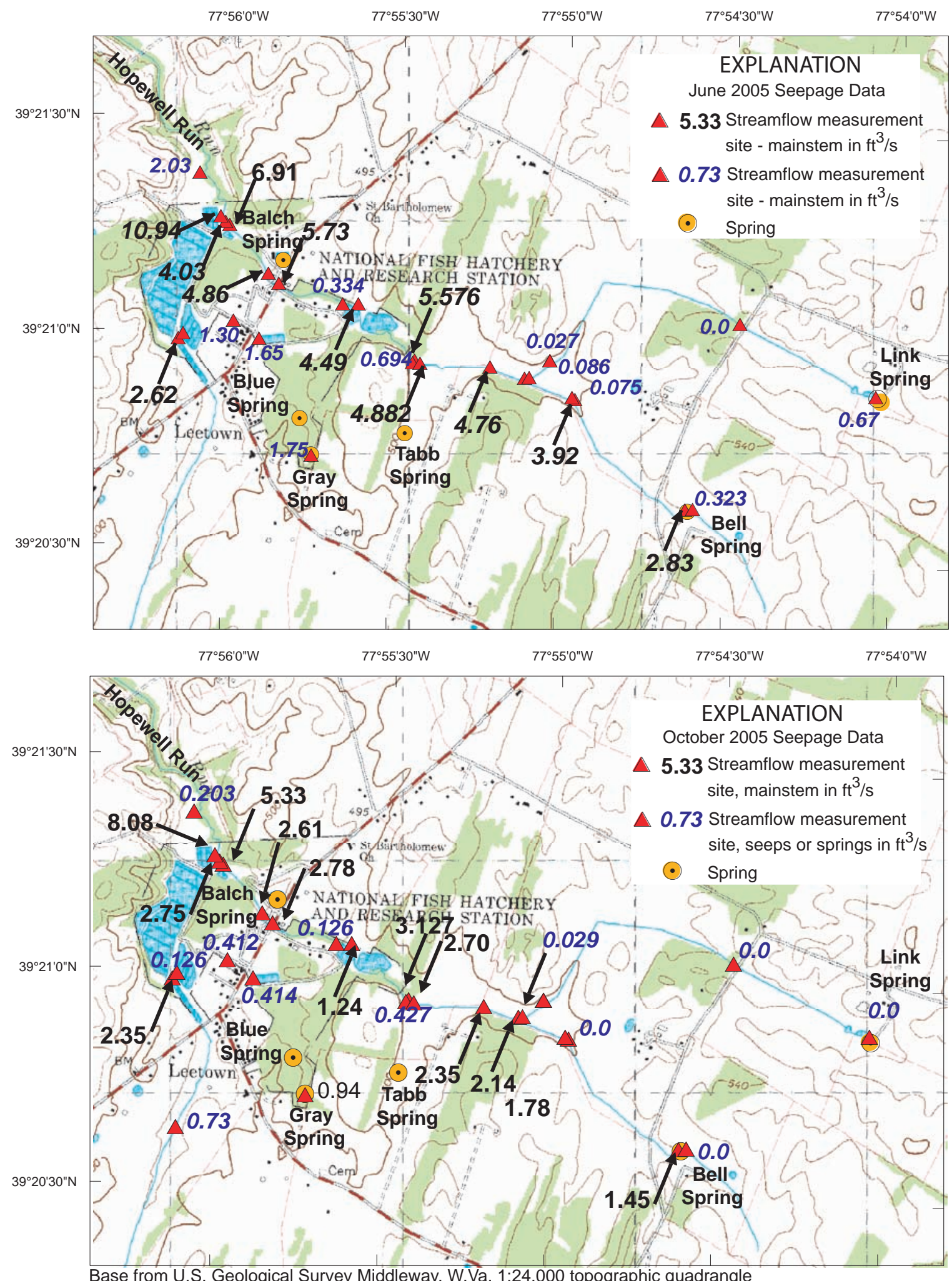

Figure 23. Location of base-flow survey sites and flows measured along Hopewell Run and its tributaries in the Leetown area, West Virginia. [ft $/ \mathbf{s}$, cubic feet per second] 
Table 5. -- Estimates of quarterly ground-water recharge for the Hopewell Run and Opequon Creek watersheds, West Virginia and Virginia, for water years 2003-2005

[nd, no data; na, not applicable; WY (water year), the period from October 1st through September 30th]

\begin{tabular}{|c|c|c|c|c|c|c|}
\hline \multicolumn{6}{|c|}{$\begin{array}{c}\text { Quarterly Recharge - Water Year Statistics (inches) } \\
\text { Hopewell Run At Leetown, West Virginia }\end{array}$} & \\
\hline & $\begin{array}{l}\text { Oct- } \\
\text { Dec }\end{array}$ & $\begin{array}{l}\text { Jan- } \\
\text { Mar }\end{array}$ & $\begin{array}{l}\text { Apr- } \\
\text { June }\end{array}$ & $\begin{array}{l}\text { July- } \\
\text { Sept }\end{array}$ & $\begin{array}{c}\text { Annual } \\
\text { Total }\end{array}$ & \\
\hline WY 2003 & nd & nd & 8.35 & 2.61 & na & \\
\hline WY 2004 & 6.46 & 5.21 & 6.01 & 3.54 & 21.22 & \\
\hline WY 2005 & 3.48 & 5.76 & 1.65 & 0.97 & 11.86 & \\
\hline Median & 4.97 & 5.49 & 6.01 & 2.61 & 16.54 & \\
\hline Mean & 4.97 & 5.49 & 5.34 & 2.37 & 16.54 & \\
\hline \multicolumn{7}{|c|}{$\begin{array}{l}\text { Quarterly Recharge - Water Year Statistics (inches) } \\
\text { Opequon Creek near Martinsburg, West Virginia }\end{array}$} \\
\hline & $\begin{array}{l}\text { Oct- } \\
\text { Dec }\end{array}$ & $\begin{array}{l}\text { Jan- } \\
\text { Mar }\end{array}$ & $\begin{array}{l}\text { Apr- } \\
\text { June }\end{array}$ & $\begin{array}{l}\text { July- } \\
\text { Sept }\end{array}$ & $\begin{array}{c}\text { Annual } \\
\text { Total } \\
\end{array}$ & $\begin{array}{c}\text { Statistical } \\
\text { Rank }^{1}\end{array}$ \\
\hline WY 2003 & 3.75 & 6.33 & 5.68 & 2.86 & 18.62 & 2 nd or $3 r d$ \\
\hline WY 2004 & 4.77 & 3.93 & 4.42 & 2.92 & 16.04 & 3rd to 4th \\
\hline WY 2005 & 3.25 & 5.02 & 1.05 & 1.10 & 10.42 & 16 th to 17 th \\
\hline Median & 3.75 & 5.02 & 4.42 & 2.86 & 16.05 & \\
\hline Mean & 3.92 & 5.09 & 3.72 & 2.29 & 15.02 & \\
\hline
\end{tabular}


Table 6. -- Quarterly and annual estimates of ground-water recharge for the Opequon Creek watershed with statistical rank (highest to lowest) for years 1948-2005

[nd, no data; na, not applicable; WY (water year), the period from October 1st through September 30th]

\begin{tabular}{|c|c|c|c|c|c|c|}
\hline & Jan-Mar & Apr-June & July-Sept & Oct-Dec & Annual Total & $\begin{array}{c}\text { Annual Statis- } \\
\text { tical Rank }\end{array}$ \\
\hline 1948 & 1.62 & 2.17 & 0.90 & 4.84 & 9.53 & 20th \\
\hline 1949 & 3.71 & 2.12 & 1.45 & 1.56 & 8.85 & 26th \\
\hline 1950 & 3.01 & 1.84 & 1.52 & 3.66 & 10.03 & 17 th \\
\hline 1951 & 6.01 & 2.65 & 1.26 & 0.57 & 10.49 & 16 th \\
\hline 1952 & 4.02 & 4.28 & 1.49 & 2.58 & 12.36 & 13th \\
\hline 1953 & 5.03 & 2.40 & 0.83 & 0.72 & 8.99 & 24th \\
\hline 1954 & 1.34 & 0.98 & 0.45 & 1.83 & 4.60 & 55 th \\
\hline 1955 & 2.14 & 0.91 & 2.00 & 0.80 & 5.85 & $51 \mathrm{st}$ \\
\hline 1956 & 3.41 & 1.23 & 1.23 & 2.30 & 8.17 & $32 \mathrm{nd}$ \\
\hline 1957 & 2.99 & 1.93 & 0.64 & 1.27 & 6.83 & 46th \\
\hline 1958 & 3.81 & 2.34 & 1.36 & 0.53 & 8.03 & $33 \mathrm{rd}$ \\
\hline 1959 & 1.18 & 1.81 & 0.56 & 1.34 & 4.89 & 54 th \\
\hline 1960 & 3.51 & 2.27 & 1.09 & 0.49 & 7.36 & $43 \mathrm{rd}$ \\
\hline 1961 & 4.32 & 2.62 & 0.88 & 1.07 & 8.89 & 25 th \\
\hline 1962 & 4.89 & 1.75 & 0.90 & 0.96 & 8.50 & 28th \\
\hline 1963 & 3.47 & 1.24 & 0.46 & 1.02 & 6.19 & 50 th \\
\hline 1964 & 4.82 & 1.89 & 0.80 & 0.77 & 8.28 & $31 \mathrm{st}$ \\
\hline 1965 & 4.18 & 1.30 & 0.57 & 0.46 & 6.51 & 49th \\
\hline 1966 & 1.58 & 1.59 & 0.81 & 1.51 & 5.50 & 53rd \\
\hline 1967 & 3.26 & 1.18 & 1.43 & 1.96 & 7.84 & 35 th \\
\hline 1968 & 3.95 & 1.55 & 0.81 & 1.21 & 7.52 & 40th \\
\hline 1969 & 1.17 & 0.83 & 0.93 & 0.77 & 3.70 & 57 th \\
\hline 1970 & 2.44 & 3.29 & 1.29 & 2.51 & 9.53 & 20th \\
\hline 1971 & 5.27 & 2.26 & 2.17 & 2.69 & 12.38 & 12 th \\
\hline 1972 & 4.77 & 5.86 & 1.03 & 4.60 & 16.26 & $3 \mathrm{rd}$ \\
\hline 1973 & 3.20 & 4.97 & 1.25 & 3.74 & 13.16 & 10th \\
\hline 1974 & 4.14 & 1.25 & 0.90 & 2.16 & 8.44 & 30th \\
\hline 1975 & 4.18 & 3.15 & 3.82 & 2.27 & 13.43 & 9th \\
\hline 1976 & 3.75 & 1.71 & 1.01 & 3.36 & 9.82 & 18th \\
\hline 1977 & 2.39 & 1.91 & 0.68 & 2.46 & 7.44 & $42 \mathrm{nd}$ \\
\hline 1978 & 5.09 & 1.65 & 2.60 & 1.71 & 11.05 & 15 th \\
\hline 1979 & 6.06 & 2.63 & 2.14 & 3.87 & 14.70 & 6th \\
\hline 1980 & 3.46 & 2.99 & 1.19 & 0.83 & 8.46 & 29th \\
\hline 1981 & 1.14 & 1.66 & 0.86 & 0.84 & 4.50 & 56th \\
\hline 1982 & 3.84 & 2.57 & 1.33 & 1.01 & 8.75 & 27 th \\
\hline
\end{tabular}


Table 6. -- Quarterly and annual estimates of ground-water recharge for the Opequon Creek watershed with statistical rank (highest to lowest) for years 1948-2005

[nd, no data; na, not applicable; WY (water year), the period from October 1st through September 30th]

\begin{tabular}{|c|c|c|c|c|c|c|}
\hline & Jan-Mar & Apr-June & July-Sept & Oct-Dec & Annual Total & $\begin{array}{l}\text { Annual Statis- } \\
\text { tical Rank }\end{array}$ \\
\hline 1983 & 3.11 & 4.46 & 0.71 & 3.56 & 11.84 & 14 th \\
\hline 1984 & 10.42 & 1.03 & 1.71 & 2.17 & 15.32 & 4th \\
\hline 1985 & 2.45 & 1.22 & 0.90 & 3.11 & 7.68 & 37th \\
\hline 1986 & 4.37 & 1.26 & 0.54 & 1.61 & 7.78 & 36th \\
\hline 1987 & 2.46 & 3.44 & 1.63 & 1.90 & 9.44 & 22nd \\
\hline 1988 & 2.11 & 3.59 & 1.02 & 0.85 & 7.57 & 39th \\
\hline 1989 & 2.80 & 2.56 & 0.90 & 1.18 & 7.45 & $41 \mathrm{st}$ \\
\hline 1990 & 1.86 & 2.03 & 1.32 & 4.61 & 9.82 & 18th \\
\hline 1991 & 4.13 & 1.29 & 0.78 & 1.02 & 7.23 & 44th \\
\hline 1992 & 2.35 & 2.01 & 1.20 & 2.48 & 8.03 & $33 \mathrm{rd}$ \\
\hline 1993 & 7.61 & 2.75 & 1.34 & 3.31 & 15.02 & 5 th \\
\hline 1994 & 8.20 & 1.16 & 1.51 & 1.55 & 12.41 & 11 th \\
\hline 1995 & 2.63 & 1.83 & 0.53 & 2.68 & 7.66 & 38th \\
\hline 1996 & 7.51 & 4.12 & 6.18 & 6.15 & 23.96 & $1 \mathrm{st}$ \\
\hline 1997 & 4.23 & 1.36 & 0.98 & 2.66 & 9.22 & $23 \mathrm{rd}$ \\
\hline 1998 & 9.09 & 3.15 & 0.93 & 0.85 & 14.01 & 8th \\
\hline 1999 & 1.95 & 1.01 & 1.51 & 1.22 & 5.69 & 52nd \\
\hline 2000 & 2.75 & 1.55 & 1.55 & 0.96 & 6.81 & 47 th \\
\hline 2001 & 3.16 & 1.46 & 1.06 & 0.91 & 6.60 & 48th \\
\hline 2002 & 0.86 & 1.49 & 0.86 & 3.75 & 6.96 & 45th \\
\hline 2003 & 6.33 & 5.68 & 2.86 & 4.77 & 19.64 & $2 \mathrm{nd}$ \\
\hline 2004 & 3.93 & 4.42 & 2.92 & 3.25 & 14.52 & 7 th \\
\hline 2005 & 5.02 & 1.05 & 1.10 & ND & NA & NA \\
\hline Max & 10.42 & 5.86 & 6.18 & 6.15 & 23.96 & \\
\hline Min & 0.86 & 0.83 & 0.45 & 0.46 & 3.70 & \\
\hline Median & 3.51 & 1.91 & 1.06 & 1.71 & 8.46 & \\
\hline Mean & 3.82 & 2.27 & 1.33 & 2.08 & 9.50 & \\
\hline
\end{tabular}




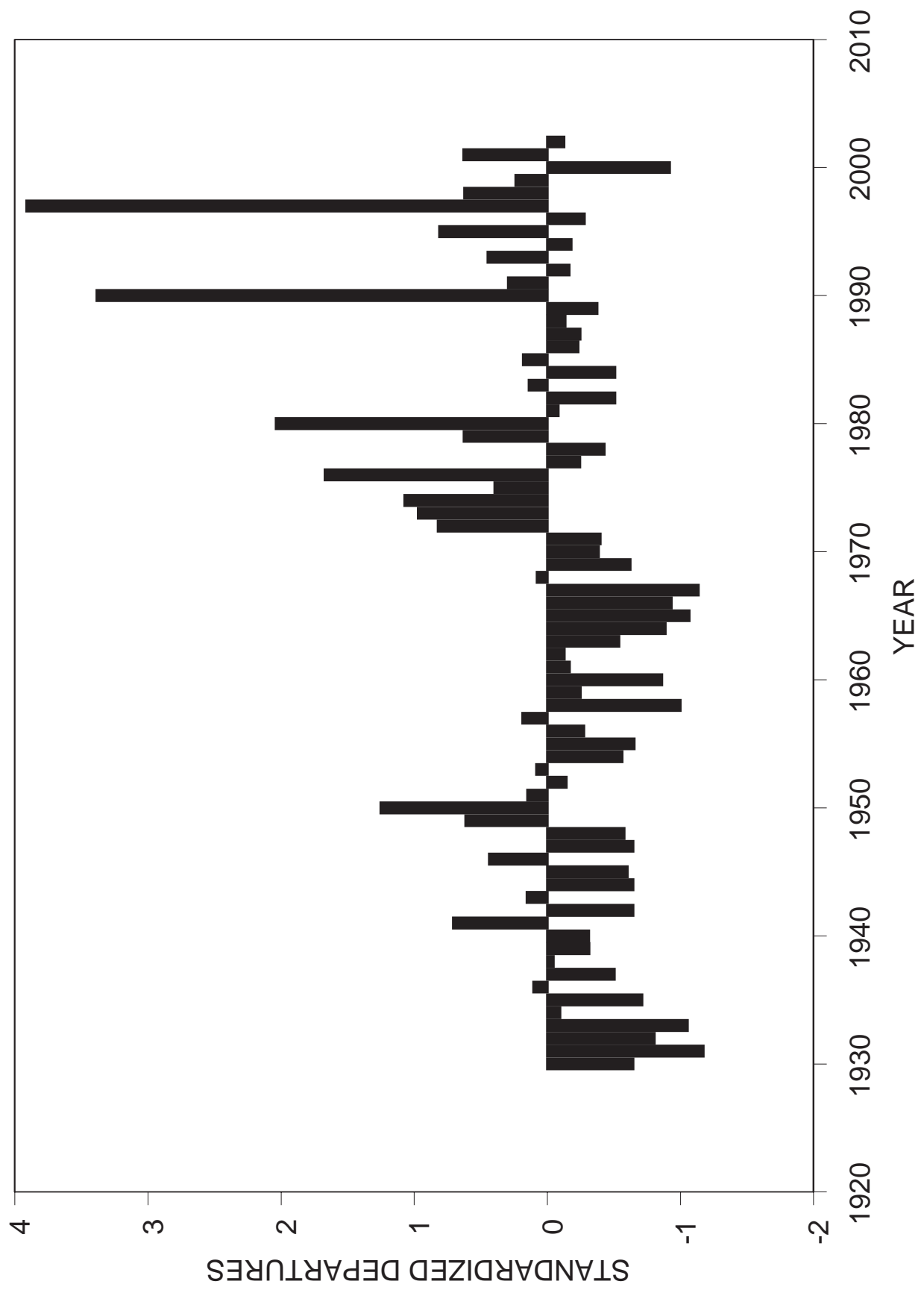

Figure 24. Graph showing the average standardized departures of the minimum stream flows from the record period average for 1930-2002 for five stream gaging stations in the Eastern Panhandle of West Virginia. [The standardized departure is a dimensionless number and the gaging stations in West Virginia analyzed were the Shenandoah River at Millville, Cacapon River near Great Cacapon, South Branch Potomac River near Springfield, South Branch Potomac River near Petersburg, and the North Fork Shenandoah River at Cootes Store in Virginia]. 


\section{Water budgets - by Mark D. Kozar}

A water budget is a simple mass balance of inputs to and outputs from a drainage basin. The major input for the budget was recharge from precipitation. Recharge estimated for the simulated period by hydrograph analysis of streamflow data for the Hopewell Run at Leetown gaging station using separation methods (Rutledge, 1998) was $16.5 \mathrm{in} / \mathrm{yr}$. No other major inputs to the basin, such as interbasin transfer of water, are known to occur in the Hopewell Run watershed. Outputs from the basin include stream flow, withdrawal of water from wells, evaporation of water from land and water surfaces, and transpiration of water by trees, grasses, and other vegetation. Precipitation was measured on the Center (app. 4 in Kozar and others, 2007) and at the nearby Martinsburg Airport (table 3). The major output, stream discharge from Hopewell Run, was measured by the Hopewell Run at Leetown gaging station just downstream of the Center and adjusted to account for a small diversion. The only component to the water budget which was not directly measured was evapotranspiration, which was estimated by difference of the precipitation and total streamflow.

A mathematical representation of the water budget can be expressed by the equation

$\mathrm{P}=\mathrm{SRO}+\mathrm{GWD}+\mathrm{ET} \pm \delta \mathrm{S}$

where $\mathrm{P}$ is the total precipitation, $\mathrm{SRO}$ is the component of stream flow that occurs as a result of surface runoff, GWD is the streamflow that occurs as a result of ground-water discharge to the stream (base stream flow), ET is evapotranspiration, and $\delta \mathrm{S}$ is the change in ground water storage. Changes in storage $(\delta S)$ were computed by comparing the difference in mean discharge between the beginning and ending periods of the water year and estimating the net change in storage over the $8.95 \mathrm{mi}^{2}$ drainage basin. As streamflow decreased over the two year period, the average change in storage was $-4.72 \mathrm{in} / \mathrm{yr}$. Therefore, the only unmeasured quantity was ET, which was estimated by difference. Given average measured precipitation of $38.60 \mathrm{in} / \mathrm{yr}$ over the 2-year period, total measured stream flow of $19.09 \mathrm{in} / \mathrm{yr}$ (surface runoff of $1.36 \mathrm{in} / \mathrm{yr}$ and groundwater discharge of $17.73 \mathrm{in} / \mathrm{yr}$ ) based on hydrograph separation techniques, the water budget equation was rearranged to solve for ET by filling in the known terms:

$\mathrm{ET}=\mathrm{P}-(\mathrm{SRO}+\mathrm{GWD} \pm \delta \mathrm{S})$ and

$\mathrm{ET}=38.60-(1.36+17.73-4.72)=24.23 \mathrm{in} / \mathrm{yr}$.

Having solved for ET, the complete water budget equation can then be written as:

$\mathrm{P}=\mathrm{SRO}+\mathrm{GWD}+\mathrm{ET} \pm \delta \mathrm{S}$ and

$38.60=1.36+17.73+24.23-4.72$,

with all terms being expressed as in/yr. The average precipitation for the two-year period at the Martinsburg airport of $38.60 \mathrm{in} / \mathrm{yr}$ and base-flow discharge estimated by hydrograph separation of stream-flow data from Hopewell Run of 17.73 in/yr (Rutledge, 1998) compare favorably to the long-term average precipitation for the Martinsburg airport of $39.39 \mathrm{in} / \mathrm{yr}$ and recharge of $16.5 \mathrm{in} / \mathrm{yr}$ estimated by hydrograph analysis of stream-flow data for Hopewell Run using Rorabaugh methods (Rutledge, 1998). The difference in the base-flow groundwater discharge and recharge estimates may be attributed to the relatively minor amounts of water lost to riparian evapotranspiration. Also, on the basis of hydrograph separation, approximately 93 percent of water in Hopewell Run is derived from discharge of ground water and only 7 percent is estimated to be derived from surface runoff.

\section{Aquifer Properties - by Kurt J. McCoy}

Ground-water flow is controlled by a network of fractures, in both carbonate and shale areas in the Leetown area. The hydraulic system in the carbonate rocks has been conceptualized as a heterogeneous network of fractures and conduits separated by a relatively impermeable crystalline mass. The ability of the aquifer to transmit water is almost solely related to the degree of connectivity of these fracture networks. Representation of ground-water movement through this intricate fracture network requires knowledge of the orientation of fractures and quantification of aquifer properties such as transmissivity (T) and storativity (S). Aquifer properties are most commonly defined by conducting tests in which wells are pumped to disturb the flow system and the aquifer response (drawdown or recovery in pumping or observation wells) is monitored. At the Center and surrounding area, a rigorous program of aquifer testing was developed to evaluate the spatial variability of aquifer properties. To assess the issues of scale, well productivity, and the role of structural boundaries, a series of single-well, step-drawdown, multiple-well, and packer tests were conducted.

In fractured rock environments, aquifer properties are routinely evaluated using analytical techniques that by design may be insufficient to characterize the heterogeneity of the system. Characteristics such as fracture aperture, spacing, orientation, and hydraulic connectivity that are unique to different portions of the carbonate aquifer at the Center make the interpretation of analytical results difficult. The type-curve matching method of Theis (1935) is the most commonly used analytical technique for aquifer test analysis. However, use of the Theis method or other radial-flow methods based on an equivalent porous media (EPM) approach may be problematic for analysis of well data in this terrain. Nevertheless, the aquifer has commonly been conceptualized as homogeneous and isotropic and the fracture network assumed to behave as an EPM (Trainer and Watkins, 1975; Jones, 1991; Shultz and others, 1995). Although the Theis method relies on hydrogeological assumptions that are unrealistic given the field situation at the Center, it can provide a comparison of the relative magnitude of aquifer properties in different portions of the carbonate aquifer. Simple radial-continuum models can be successfully 
applied in fractured carbonates with an understanding of their limitations (Allen and Michel, 1998).

\section{Single-well aquifer tests}

Single-well aquifer tests were conducted at 57 well locations on and adjacent to the Center (fig. 1 and table 1). All constant-discharge test data were plotted on log-log and semilog graphs to evaluate and enhance certain features of the data. Analysis of the data in this manner allows the application of appropriate type-curve solutions. In this case, type-curve analysis was preferentially limited, if applicable, to periods in which radial flow was evident. More complicated methods yielding solutions for fractured rock aquifers that evaluate both early and late-time data were not used for the single-well tests. Although likely applicable, fractured-rock solutions require longer pumping periods, which were not practical for most of the private domestic wells tested. The majority of the data were analyzed using the Cooper-Jacob straight-line (Cooper and Jacob, 1946) or Theis curve-matching (Theis, 1935) methods.

Water levels were initially measured and recorded at each test site at the time of arrival of field personnel on the site. Additional measurements were made as test preparations were completed and finally when the pressure transducer was secured in place. In most cases, two to three background water-level measurements were made with an electric tape in the 15-30 minutes prior to starting the aquifer test. Some tests were conducted using a portable, submersible pump. A control box was used to start and maintain the pumping rate. In other cases, drawdown tests were conducted using in-place residential homeowner well pumps. Outside spigots were used to start and control the pump, and homeowners were asked to avoid using additional water for the duration of the tests. For all tests, outflow of the well was metered with a flow-through totaling meter. A discharge rate was recorded at the start of the test and checked periodically. Final discharge rates were computed as the total flow volume divided by the time of duration of pumping. The period of pumping generally lasted 30 minutes and recovery data were observed and recorded for at least 100 minutes after pumping ceased. Transmissivity data from the single-well aquifer tests are summarized in table 7 and clearly show the wide variability in aquifer properties typical of a triple porosity karst ground-water flow system containing matrix, fracture, and conduit porosity.

\section{Step-drawdown tests}

To meet ground-water supply needs, the locations of three potential water-supply wells at the Center were chosen based on the statistical analysis of over 300 specific capacity tests conducted in Jefferson and Berkeley Counties, West Virginia (McCoy and others 2005a, 2005b). The tests were conducted on wells completed in the same formations that crop out in the study area. The statistical analyses indicated that potential high yielding wells in the region are commonly associated with cross-strike faults and thrust faults, complex geologic structures such as overturned anticlines and synclines, and are most prevalent in geologic formations of the Beekmantown Group. These characteristics were used to locate and drill three wells; one located on a thrust fault (Jef-0586 - site 60 on fig. 1 and in tables 1 and 8), a second on a cross-strike fault (Jef-0752 - site 61 on fig. 1 and in tables 1 and 8), and the third on the eastern limb of an overturned anticline (Jef-0753 - site 62 on fig. 1 and tables 1 and 8). At the time of drilling, each well intersected multiple water-bearing fractures with total estimated yields exceeding $100 \mathrm{gal} / \mathrm{min}$.

Optimal pumping schemes for each of the three wells were defined using step-drawdown tests (app. 4, figs. 1-5). Step-drawdown tests provide an evaluation of well performance attributed to incremental changes in pumping rate. For the tests at the Center, specific capacity (pumping rate divided by drawdown in the well) was calculated for each change in pumping rate using the Hantush-Bierschenk method (Hantush 1964; Bierschenk 1963). These methods define incremental drawdown by extrapolating observed data beyond the end of each step and subsequently calculating the difference in drawdown from previous steps over a fixed-time interval. For the step-drawdown tests, the duration of each step for each well was variable. Generally, turbidity of the discharged water was high at the initiation of pumping and following all subsequent increases in rate. In most cases, turbidity failed to clear at the highest pumping rates (> $200 \mathrm{gal} / \mathrm{min}$ ) but was generally absent or significantly reduced at lower withdrawal rates ( $\leq 100 \mathrm{gal} / \mathrm{min})$.

Specific capacity calculated for all steps at each well (table 8) ranged from 6.5 to 313 gallons per minute per foot of drawdown $(\mathrm{gal} / \mathrm{min} / \mathrm{ft})$. The highest values were found in Jef-0753 (well 62 on fig. 1 and table 1) which is located in an area characterized by extensional related fracturing of the eastern limb of an overturned anticline (Dean, 1966). The maximum value $(313 \mathrm{gal} / \mathrm{min} / \mathrm{ft})$ at Jef-0753 represents $0.08 \mathrm{ft}$ of drawdown during pumping at $25 \mathrm{gal} / \mathrm{min}$, but specific capacity remained high $(37.9 \mathrm{gal} / \mathrm{min} / \mathrm{ft})$ with minimal drawdown $(<4.0 \mathrm{ft})$ even at a withdrawal rate of $150 \mathrm{gal} / \mathrm{min}$. Similar values were estimated by McCoy and others (2005a, 2005b) in Jefferson and Berkeley Counties, West Virginia. However, since pumping rates and periods for these tests were typically less than or equal to $15 \mathrm{gal} / \mathrm{min}$ and less than 1 hour in duration, specific capacity estimates for the wells tested in the two county studies may yield slightly different estimates.

Two tests were conducted on Jef-0753 to evaluate the difference in well productivity during the fall and spring seasons. At a pumping rate of approximately $150 \mathrm{gal} / \mathrm{min}$, specific capacity is slightly lower in the fall than in the spring when the well was pumped at a rate of $180 \mathrm{gal} / \mathrm{min}$. For the test conducted in the fall, a short period of pumping at $239 \mathrm{gal} /$ min resulted in an additional $7 \mathrm{ft}$ of drawdown and an increase in turbidity that failed to return to acceptable levels (5 Nephelometric turbidity units [NTU]) once pumping rates were reduced.

The target pumping rate of $300 \mathrm{gal} / \mathrm{min}$ at Jef-0586 (site 60 on fig. 1 and in table 1) was not met before the test was ter- 
Table 7. Summary statistics for transmissivities $(\mathrm{T})$ in $\mathrm{ft}^{2} /$ day calculated from single well aquifer tests for geologic units near Leetown, West Virginia

\begin{tabular}{lcccccc}
\hline & $\begin{array}{c}\text { Conoco- } \\
\text { cheague } \\
\text { Limestone }\end{array}$ & $\begin{array}{c}\text { Stouffer- } \\
\text { stown } \\
\text { Member }\end{array}$ & $\begin{array}{c}\text { Stone- } \\
\text { henge } \\
\text { Lime- } \\
\text { stone }\end{array}$ & $\begin{array}{c}\text { Rockdale } \\
\text { Run } \\
\text { Formation }\end{array}$ & $\begin{array}{c}\text { Middle/Upper } \\
\text { Ordovician } \\
\text { Units }\end{array}$ & $\begin{array}{c}\text { Martinsburg } \\
\text { Formation }\end{array}$ \\
\hline Number of Wells & 12 & 6 & 16 & 19 & 2 & 2 \\
Minimum T & 0.3 & 40 & 3.0 & 2.0 & 100 & 4.0 \\
Maximum T & 20,000 & 10,000 & 40,000 & 10,000 & 3,000 & 102 \\
Median T & 55.0 & 700 & 1,250 & 2,000 & 1,550 & 102 \\
Mean T & 1,890 & 2,920 & 5,300 & 3,100 & 1,550 & 139 \\
Standard deviation & 5,731 & 4,145 & 10,115 & 3,479 & 2,051 & $132 \%$ \\
Coefficient of variation & $303 \%$ & $142 \%$ & $191 \%$ & $112 \%$ & $136 \%$ \\
\hline
\end{tabular}

Table 8. Specific capacities (gal/min//ft) calculated from step-discharge tests conducted at the USGS Leetown Science Center, West Virginia

[gal, gallon, min, minute, ft, foot]

\begin{tabular}{lllll}
\hline \multicolumn{1}{c}{ Well } & Step & \multicolumn{1}{c}{$\begin{array}{c}\text { Discharge } \\
\text { (gal/min) }\end{array}$} & $\begin{array}{c}\text { Specific Capacity } \\
\text { (gal/min/ft) }\end{array}$ & $\begin{array}{c}\text { Duration of Step } \\
\text { Interval (min) }\end{array}$ \\
\hline Jef-0753 (spring 2006) & 1 & 25 & 313 & 100 \\
(site \# 62p on fig. 1) & 2 & 157 & 32.9 & 100 \\
& 3 & 183 & 30.3 & 100 \\
Jef-0753 (fall 2005) & 1 & 105 & 32.6 & 100 \\
(site \# 62p on fig. 1) & 2 & 150 & 37.9 & 100 \\
& 3 & 176 & 26.4 & 100 \\
& 4 & 203 & 26.6 & 180 \\
Jef-0586 & 1 & 94 & 10.8 & 180 \\
(site \# 60p on fig. 1) & 2 & 170 & 13.8 & 240 \\
& & & & 240 \\
Jef-0752 & 1 & 78 & 11.4 & 240 \\
(site \# 61p on fig. 1) & 2 & 149 & 6.5 & 7.5 \\
\hline
\end{tabular}


minated due to drawdown in nearby Balch Spring. Additional monitoring at wells Jef-0793, Jef-0792, Jef-0526, and Jef-0490 showed near-instantaneous response to incremental changes in pumping rate of the production well at radial distances of 302; 770; 1,540; and 1,600 ft, respectively. The thrust faults (fig. 2 ) on which the wells are located are inferred to be a series of well-connected preferential ground-water pathways. Drawdown of well Jef-0586 rapidly changed from $13.4 \mathrm{ft}$ to 23.4 $\mathrm{ft}$ at a pumping rate of $254 \mathrm{gal} / \mathrm{min}$. Concerns of subsidence, turbidity, and disruption of flow to Balch Spring precluded the continuation of the test at higher pumping rates.

Overall there were no water-level trends with regards to time of pumping or increased pumping rate among the wells. From the data, it appears (app. 4, figs. 1-5) that extensional related fractures along the eastern limb of an overturned anticline may provide more sustainable water volumes than comparable locations along compression or shear zones. With considerations for turbidity, the threshold values for pumping determined for the wells Jef-0753, Jef-0586, and Jef-0752 are 150,100 , and $100 \mathrm{gal} / \mathrm{min}$, respectively.

\section{Multiple-well aquifer tests}

At the Center, radial and linear flow models were used to evaluate the results of seven multiple-well aquifer tests. Results from single-well tests (McCoy and others, 2005a, 2005b) have shown that aquifer hydraulic properties range over several orders of magnitude within tens of feet. While single-well analysis can be used to define structural controls on flow, understanding the complexities attributed to preferential karst and fracture ground-water pathways requires a more comprehensive evaluation with the use of monitoring wells. The objectives of the multiple-well aquifer tests were to describe the storage properties of the aquifer and assess hydraulic behavior of the aquifer attributed to fracture flow.

During this phase of aquifer testing emphasis was placed on characterization of the faults and adjacent rock mass near the Center's main research buildings. This area coincides with the conduit dominated area of coalescing thrust faults and cross-strike faults. All aquifer tests were of constant-discharge type, ranging in duration from 100 minutes to 72 hours, and with discharge rates of $8 \mathrm{gal} / \mathrm{min}$ to $93 \mathrm{gal} / \mathrm{min}$.

Evaluation of time-series data from aquifer tests requires careful consideration of well-bore storage. Well-bore storage effects occur when most of the water discharged from a well is attributed to water stored in the borehole and not to inflow from the tested formation. Well-bore storage is noted by a 1:1 slope on a log-log plot of time versus drawdown, or a distinct "hump" in first-derivative plots of drawdown against the logarithm of time (app. 4, fig. 6).

Derivative plots can be used to identify the effects of well-bore storage and hydrologic boundaries, and periods of radial flow (Spane and Wurstner, 1993). The derivative of pressure with respect to the log of time enhances less obvious features unnoted in time-drawdown plots, as it is more sensitive to small variation in the pressure change during testing. Different segments of drawdown curves can be used to identify dominant flow regimes and valid periods of testing for radial-flow analysis. The result is a more rigorous estimate of aquifer properties and a better conceptual understanding of the aquifer.

Assumptions of radial flow and use of radial-flow solutions are adequate when the pressure derivative curve is horizontal. Non-radial flow, evidenced by the test data, plot linearly on a log-log plot and are shown as deviations from the horizontal in derivative curves. This depicts the importance of identifying periods of radial flow, for which radial-flow solutions are most valid. Attempting to fit radial-flow solutions to time segments before or after these periods could result in significant error in transmissivity estimates. Plots of each test are shown in Appendix 4 and figures 7-12, and resulting aquifer properties, calculated using radial flow solutions, are shown in table 9.

At all locations, steep drawdown gradients were observed in the pumped well during pumping. Substantially less drawdown was typically observed in associated monitoring wells. Analysis of monitoring well data such as these can easily be misinterpreted in diffuse flow portions of the aquifer, subsequently producing transmissivity estimates that are much higher than actual values. It is likely that the hydraulic connection between wells in diffuse flow portions of the aquifer is much lower than estimates of transmissivity would suggest.

In one example from a diffuse portion of the aquifer, pumping well Jef-0601 (site 37 on fig. 1 and in table 1) produced instantaneous drawdown in Jef- 0585 (site 38 on fig. 1 and in table 1) that is along strike of bedding. A one-minute delayed response in drawdown at wells Jef-0597 (site 40 on fig. 1 and in table 1) and Jef-0592 (site 39 on fig. 1 and in table 1), that are perpendicular to strike, is presumably attributed to bed-limited permeability (app. 4, fig. 13). Similar delayed responses of 10 to 17 minutes were noted in wells located perpendicular to longitudinal faults (app. 4, figs. 10-11). Values of transmissivity from these monitor wells represent the ability of the fracture network adjacent the fault to transmit water. Instantaneous response to pumping along strike of the longitudinal faults was seen at distances ranging from 10 to $266 \mathrm{ft}$, and is evidence of laterally continuous fracturing along that zone. Although similarly delayed in response, pumping in karstic areas at wells Jef-0591 (site 50 on fig. 1, in table 1, and in app. 4, fig. 9) and Jef-0584 (site 49 on fig. 1 , in table 1 , and in app. 4 , fig. 12) produced near uniform amounts of drawdown in both strike parallel and strike perpendicular directions. In addition, time-drawdown curves from observation wells in those tests are of similar shape. In these areas, the highly fractured network may allow nearradial flow or the karst area may be located at the intersection of two orthogonal fracture systems where flow is great in either direction. 


\section{Straddle-packer tests}

The carbonate aquifer in the Leetown area is highly heterogeneous, and its hydraulic properties vary by orders of magnitude that can be attributed to the diversity of fracture orientation, size, and connectivity. The ability of the aquifer to transmit water depends entirely upon the network of interconnecting fractures, as the surrounding rock mass is mostly impervious. Aquifer hydraulic properties determined from aquifer response to extended periods of pumping incorporate many fractures over a large area. Results from these aquifer tests are indicative of a composite fracture network and require careful consideration of aquifer heterogeneity. However, these tests fail to fully characterize the roles of individual fractures within the karst continuum. Further, discrete fracture zones may be appropriately characterized by assuming that laminar and parallel flow conditions are bulk hydraulic properties of a nearly radial flow regime (Carlsson and Olson, 1992).

Using the BAT3 (Bedrock Aquifer Transportable Testing Tool) (Shapiro, 2001) system developed by the USGS, a series of packer tests were conducted in wells Jef-0601, Jef-0585, and Jef-0592 (sites 37, 38, and 39, on fig. 1 and in table 1) at the Center to evaluate the ability of individual fractures to transmit water in a diffuse-flow dominated portion of the aquifer. Test intervals were determined from borehole log analyses. A packer assembly is simply a rubber bladder that is expanded against the side of the borehole to prevent leakage of water between the intervals above and below the packer. Two packers were used for the tests, which isolated an approximately 5 -ft interval of the rock allowing individual fractures to be hydraulically tested. Three pressure transducers, one above the upper packer, one below the lower packer, and a third in between the packers, were used to measure pressure (piezometric) head changes in those zones. A pump and a fluid injection port were installed in the interval between the packers to allow fluid injection or pumping of the individual fractures for aquifer test analyses.

Transmissivity results were analyzed from isolated intervals and are summarized in table 10. From data in table 10 it is evident that transmissivity ranges over three orders of magnitude $\left(1.8 \times 10^{-6}\right.$ to $5.9 \times 10^{-3}$ to feet squared per day $\left.\left[\mathrm{ft}^{2} / \mathrm{d}\right]\right)$ in the diffuse-flow dominated portion of the aquifer, indicating a high variability in the hydraulic properties of individual fracture zones. Although a general decrease in transmissivity with depth is evident, it does not appear to be correlated with a decrease in fracture aperture. Despite the large number of fractures in these boreholes, it is thought that most are unproductive, discontinuous, and poorly interconnected. Supporting evidence from borehole logs indicate that in diffuse-flow portions of the aquifer, the majority of flow occurs only through one or two of the fractures intersecting the borehole.

In summary, the extreme range in transmissivity among individual fractures in the diffuse-flow dominated portion of the aquifer $\left(5.9 \times 10^{-3}\right.$ to $\left.1.8 \times 10^{-6} \mathrm{ft}^{2} / \mathrm{d}\right)$ and the solutionally enlarged fractures (conduits) within the conduit dominated portion of the aquifer $\left(2.0 \times 10^{3}\right.$ to $\left.1.4 \times 10^{4} \mathrm{ft}^{2} / \mathrm{d}\right)$ is com- mon in karst aquifers and can be even more pronounced in areas with large caves and interconnected solution conduits. The flow system in the Leetown area is a triple-porosity flow system with small matrix porosity representing one end of the karst continuum and solutionally enlarged conduits representing the other end of the continuum. Fractures of various aperture width fall in the intermediate interval between these extremes and typically have transmissivities somewhere between $5.9 \times 10^{-3}$ and $2.0 \times 10^{3} \mathrm{ft}^{2} / \mathrm{d}$. Proper management of such aquifers, including mathematical modeling of groundwater flow in the aquifer, requires detailed knowledge of the distribution of fractures across the entire continuum, both vertically and horizontally within the aquifer.

\section{Ground-water flow - by Mark D. Kozar}

The conceptual model of ground-water flow in the Jefferson and Berkeley County, West Virginia, areas has been modified on the basis of borehole- and surface-geophysical data and geologic mapping conducted as part of this investigation. A ground-water flow model developed as part of this investigation (Kozar and others 2007) also helped test and revise the conceptual model of ground-water flow in the Leetown area. Focused recharge is a dominant process only when surface runoff occurs, typically as a result of intense local rainfall. While focused recharge to sinkholes can and does occur, the dominant process of ground-water recharge is areally diffuse precipitation over a broad area. Precipitation falling on the surface quickly infiltrates the soil and regolith and percolates into the upper epikarst, a zone of intense weathering that extends from land surface to a depth of approximately 30 to 60 $\mathrm{ft}$ (table 11).

The ground-water flow system is a triple-porosity aquifer matrix with intergranular porosity and small micro fractures providing minor storage of water. A dominant set of diffuse fractures provide the majority of storage, and a system of solutionally enlarged fractures act as drains for the intricate network of primary and secondary porosity features (Kozar and others, 2007). The majority of solutionally enlarged conduits occur in a relatively thin zone within the epikarst but some smaller conduits occur at depths as great as $200 \mathrm{ft}$ bls. The epikarst is characterized by the presence of solutionally enlarged bedding plane separations and high angle joints which allow rapid infiltration of water to the deeper bedrock aquifer. Below the epikarst, a zone of less weathered bedrock is present.

This zone of moderately fractured bedrock does not typically contain a high density of solutionally enlarged conduits and the hydraulic conductivity is approximately 2 or 3 times less than the epikarst. Below a depth of about $250 \mathrm{ft}$ bls, the aperture of bedrock fractures decreases significantly, and the estimated hydraulic conductivity, from aquifer test and surface geophysical resistivity data, is approximately half that of the intermediate zone (Kozar and others, 2007).

Flow of ground water through the epikarst can be rapid, on the order of weeks, especially if flow is concentrated in 
Table 9. Radial-flow model results from multiple-well aquifer tests conducted at the USGS Leetown Science Center, West Virginia

[gpm, gallons per minute; ft, foot; ft2,/d, feet squared per day; C-J, Cooper-Jacob method]

\begin{tabular}{|c|c|c|c|c|c|c|c|}
\hline Test No. & Pumping well ${ }^{1}$ & $\begin{array}{c}\text { Pumping rate } \\
\text { (gpm) }\end{array}$ & $\begin{array}{c}\text { Observation } \\
\text { well }^{1}\end{array}$ & $\begin{array}{c}\text { Radial dis- } \\
\text { tance (ft) }\end{array}$ & $\begin{array}{l}\text { Transmissiv- } \\
\text { ity }\left(\mathrm{ft}^{2} / \mathrm{d}\right)\end{array}$ & $\begin{array}{c}\text { Storativity } \\
\text { (1) }\end{array}$ & Method \\
\hline 1 & Jef-0318(59) & 90.0 & Jef-0490(58p) & 266 & 3,900 & 0.0003 & C-J (1946) \\
\hline 2 & Jef-0490(58) & 93.0 & Jef-0318(59p) & 266 & 3,900 & 0.0022 & C-J (1946) \\
\hline \multirow[t]{2}{*}{3} & Jef-0591(50) & 14.0 & Jef-0590(48) & 147 & 19,700 & 0.0001 & C-J (1946) \\
\hline & & & Jef-0584(49) & 141 & 19,700 & 0.0001 & C-J (1946) \\
\hline \multirow[t]{4}{*}{4} & Jef-0581(57) & 80.0 & Jef-0793(99) & 10 & 11,300 & 0.0031 & Theis (1935) \\
\hline & & & Jef-0603(34) & 260 & & & \\
\hline & & & Jef-0599(54) & 413 & 7,400 & 0.0037 & Theis (1935) \\
\hline & & & Jef-0586(60p) & 433 & 9,900 & 0.0055 & Theis (1935) \\
\hline \multirow[t]{3}{*}{5} & Jef-0490(58) & 69.0 & Jef-0318(59p) & 266 & 5,600 & 0.0086 & Theis (1935) \\
\hline & & & Jef-0591(50) & 387 & 4,800 & 0.0900 & Theis (1935) \\
\hline & & & Jef-0590(48) & 434 & 4,800 & 0.0900 & Theis (1935) \\
\hline \multirow[t]{2}{*}{6} & Jef-0584(49) & 15.0 & Jef-0591(50) & 141 & 9,900 & 0.0077 & C-J (1946) \\
\hline & & & Jef-0526(51) & 180 & 7,200 & 0.0026 & C-J (1946) \\
\hline \multirow[t]{3}{*}{7} & Jef-0601(65) & 8.20 & Jef-0597(40) & 25 & 110 & 0.0027 & C-J (1946) \\
\hline & & & Jef-0585(38) & 50 & & & \\
\hline & & & Jef-0592(39) & 50 & 110 & 0.0027 & C-J (1946) \\
\hline
\end{tabular}

Table 10. Transmissivities computed from straddle packer tests conducted at the USGS Leetown Science Center, West Virginia

[Site locations shown on fig. 1 and in table 1. Abbreviations: $\mathrm{ft}$ bls, feet below land surface; $\mathrm{ft}{ }^{2} / \mathrm{d}$, feet squared per day; BD, below detection limits; I, injection test; $\mathrm{P}$, pumping test; --, no analysis]

\begin{tabular}{|c|c|c|c|c|c|c|}
\hline Well & $\begin{array}{l}\text { Interval top } \\
\text { (ft bls) }\end{array}$ & $\begin{array}{l}\text { Interval bottom } \\
\text { (ft bls) }\end{array}$ & $\begin{array}{c}\text { Transmissivity } \\
\left(\mathrm{ft}^{2} / \mathrm{d}\right)\end{array}$ & $\begin{array}{c}\text { Test } \\
\text { Method }\end{array}$ & Analysis Method & $\begin{array}{l}\text { Total fracture aper- } \\
\text { ture for interval (ft) }\end{array}$ \\
\hline \multirow[t]{9}{*}{ Jef-0601 } & 36.2 & 42.9 & $8.6 \times 10-4$ & I & Transient Radial & 0.02 \\
\hline & 52.6 & 59.4 & $5.4 \times 10-4$ & I & Steady-State Radial & 0.60 \\
\hline & 68.1 & 74.9 & $1.5 \times 10-4$ & I & Steady-State Radial & 0.29 \\
\hline & 91.1 & 97.9 & $\mathrm{BD}$ & I & -- & 0.32 \\
\hline & 109.5 & 116.3 & $1.5 \times 10-3$ & I & Steady-State Radial & 0.65 \\
\hline & 144.4 & 151.2 & $\mathrm{BD}$ & I & -- & 0.39 \\
\hline & 218.0 & 224.8 & $6.2 \times 10-4$ & I & Steady-State Radial & 0.74 \\
\hline & 242.1 & bottom of hole & $1.5 \times 10-5$ & I & Steady-State Radial & 1.46 \\
\hline & 265.1 & bottom of hole & $\mathrm{BD}$ & I & Steady-State Radial & 0.31 \\
\hline \multirow[t]{6}{*}{ Jef-0585 } & 40 & 46.78 & $7.5 \times 10-4$ & I & Transient Radial & 0.19 \\
\hline & 54.34 & 61.12 & $1.8 \times 10-6$ & I & Steady-State Radial & 0.46 \\
\hline & 69.34 & 76.12 & $8.1 \times 10-6$ & I & Transient Radial & 0.32 \\
\hline & 114.34 & 121.12 & $\mathrm{BD}$ & I & -- & 0.17 \\
\hline & 231.34 & 238.12 & $2.0 \times 10-5$ & I & Steady-State Radial & 0.44 \\
\hline & 285.31 & bottom of hole & $2.7 \times 10-5$ & $\mathrm{P}$ & Steady-State Radial & 0.30 \\
\hline \multirow[t]{2}{*}{ Jef-0592 } & Top Hole & 47.89 & $5.9 \times 10-3$ & $\mathrm{P}$ & Steady-State Radial & 1.03 \\
\hline & 60.41 & 67.19 & $2.0 \times 10-3$ & I & Steady-State Radial & 0.25 \\
\hline
\end{tabular}


Table 10. Transmissivities computed from straddle packer tests conducted at the USGS Leetown Science Center, West Virginia

[Site locations shown on fig. 1 and in table 1. Abbreviations: $\mathrm{ft}$ bls, feet below land surface; ft²/d, feet squared per day; BD, below detection limits; I, injection test; P, pumping test; --, no analysis]

\begin{tabular}{|c|c|c|c|c|c|c|}
\hline Well & $\begin{array}{l}\text { Interval top } \\
\text { (ft bls) }\end{array}$ & $\begin{array}{l}\text { Interval bottom } \\
\quad \text { (ft bls) }\end{array}$ & $\begin{array}{c}\text { Transmissivity } \\
\left(\mathrm{ft}^{2} / \mathrm{d}\right)\end{array}$ & $\begin{array}{c}\text { Test } \\
\text { Method }\end{array}$ & Analysis Method & $\begin{array}{l}\text { Total fracture aper- } \\
\text { ture for interval (ft) }\end{array}$ \\
\hline & 78.41 & 85.19 & $2.3 \times 10-5$ & I & Steady-State Radial & 0.52 \\
\hline & 91.41 & 98.19 & $1.8 \times 10-5$ & I & Steady-State Radial & 0.22 \\
\hline & 125.41 & 132.19 & $\mathrm{BD}$ & I & -- & 0.38 \\
\hline & 138.41 & 145.19 & $1.8 \times 10-4$ & $\mathrm{P}$ & Steady-State Radial & 0.50 \\
\hline & 151.41 & 158.19 & $3.8 \times 10-4$ & I & Steady-State Radial & 0.10 \\
\hline & 174.41 & 181.19 & $7.3 \times 10-6$ & I & Steady-State Radial & 0.19 \\
\hline & 216.41 & 223.19 & $2.7 \times 10-6$ & I & Steady-State Radial & 0.22 \\
\hline & 239.11 & bottom of hole & $4.6 \times 10-6$ & I & Steady-State Radial & 1.23 \\
\hline
\end{tabular}

solutionally enlarged conduits. Flow within the intermediate zones is much slower, with estimates of ground-water age for the carbonate rocks in the region ranging from 15 to 50 years (McCoy and Kozar, 2007a). There are few data to approximate the age of ground water in the deeper portions of the aquifer. It is likely that ground water flows slowly at depths greater than about $300 \mathrm{ft}$ bls; one chlorofluorocarbon (CFC) analysis of water from a $475 \mathrm{ft}$ deep well on the Center indicated an apparent ground-water age of approximately 50 years. Water from this well is likely a mixture of some older and younger components and water from greater depths is likely much older.

Topography also has a major effect on ground-water flow. Depth to water on hilltops is typically greater than that in valley or hillside settings. Uplands usually are in areas of more resistive rock. The bedrock underlying the Center comprises sedimentary rocks, chiefly limestone, dolomite, and shale. The bedrock, especially low permeability lithologic units such as the Martinsburg Formation and the Conococheague Limestone (fig. 2), controls ground-water flow by acting as a barrier to water moving down the hydrologic gradient and across the strike of the bedding. This retardation of cross-strike flow is especially pronounced in the Leetown area, where the bedding typically dips at steep angles. Geologic structures that disrupt the rocks in cross-strike directions, especially highly permeable cross-strike faults and fracture zones, provide avenues through which water can flow laterally across or through strata with low primary permeability. These rock formations also typically have lower hydraulic conductivities than the more permeable bedrock in lowland areas. The Conococheague Limestone and Martinsburg Formation, and to a lesser extent the New Market Limestone (fig. 2), are the principal lowerpermeability units which tend to act as barriers to water flowing down topographic gradients (Kozar and others, 2007). Within the study area, local ground-water flow is primarily from the topographically higher uplands to the east towards Opequon Creek to the west. Although ground-water flow in lower permeability units is impeded on its westward path, cross-strike faults and oblique faults provide avenues along which ground water can flow either across or through the less permeable units. The lower permeability Martinsburg Formation exerts a dominant control on ground-water flow, impeding westward flow of ground-water towards Opequon Creek and forcing water to flow along solutionally enlarged faults which cross the Center (Kozar and others, 2007). The hydrogeologic setting of the Leetown and Center area is desirable from a ground-water development perspective, as large quantities of ground water are funneled through the area. This is the primary reason for the highly productive springs that have historically supplied ground water for Center operations.

\section{Dye Tracer Tests and Analyses - by Malcolm S. Field}

Ground-water flow rates and trajectories at the Leetown Science Center are an issue of concern. The primary concern is the low flows of Balch, Blue, and Gray Springs during drought, but additional concerns are the recharge areas to the springs. For example, to the east and up gradient of the Center are the Leetown Pesticide Site and the Jefferson County Landfill (sites A and B on fig. 1 respectively and in table 1), a U.S. Environmental Protection Agency Superfund site (CERCLIS I.D. WVD980693402) where pesticide compounds consisting of isomers of benzenehexachloride (BHC), DDT, DDE, DDD, endrin, endosulfan, and aldrin were detected. Potential 


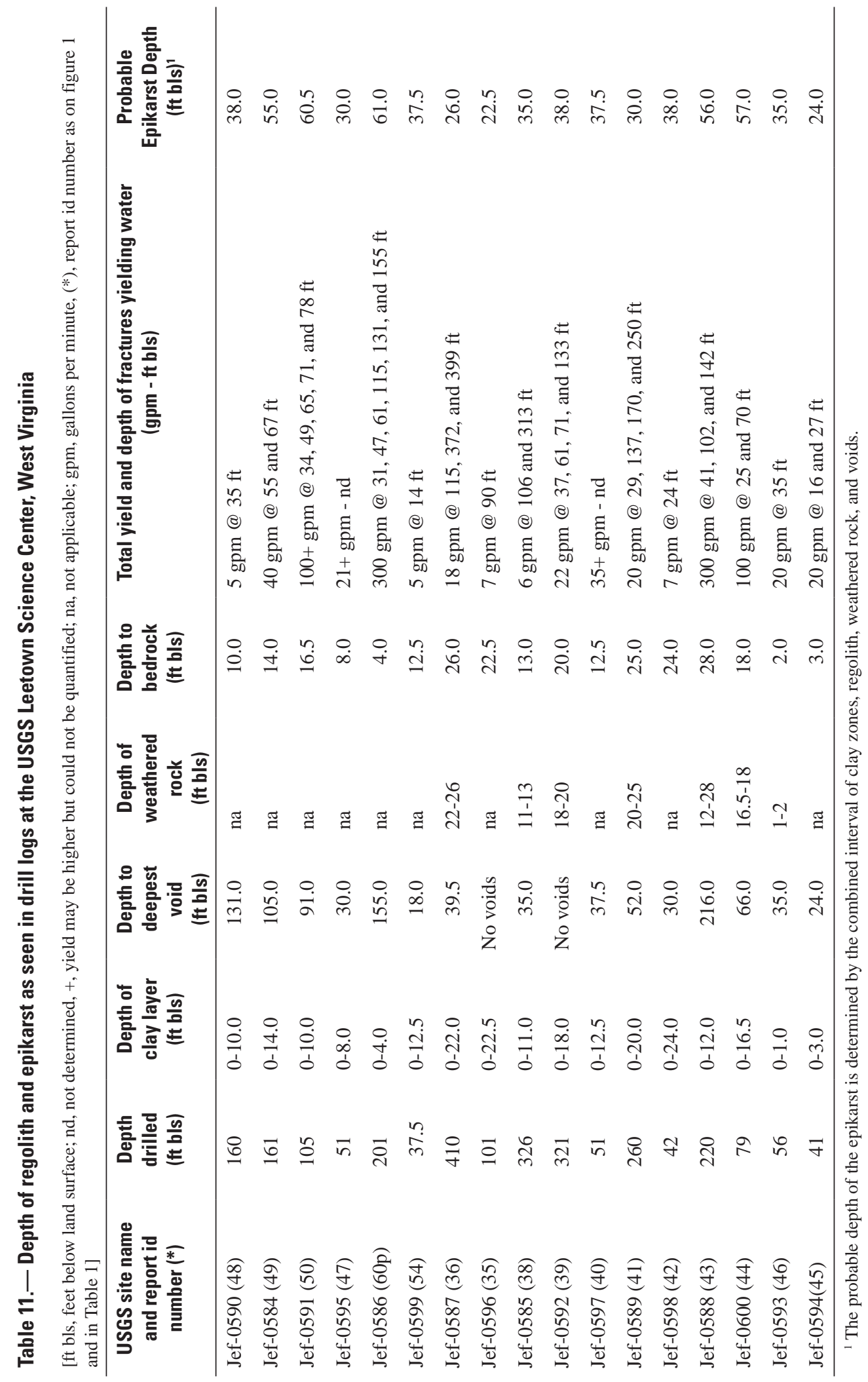


transport of contaminants in ground water from these sites is a concern.

Tracer tests conducted in the Leetown area were limited to the immediate vicinity of the Center to provide additional hydraulic information about general flow directions, velocities, and mean residence time of ground water. Additionally, the tracer tests provided information on how ground-water flow is affected by withdrawal of water from springs and wells for use at the Center.

\section{Previous Tracer Work}

Seven tracer tests were conducted at the Center in 1979 and 1980 using fluorometric tracers (Jones and Deike, 1981). These early tests were among the first efforts to characterize the flow of ground water in the conduit-dominated portion of the flow system in the region. Travel times for the previous tests all indicated long ground-water transit times for a karst aquifer; 58 to 81 day travel times for dye recovery at resurgence points were documented over distances ranging from 0.9 to 2.21 miles. These early tracer tests show that travel times are uncharacteristically long for a karst aquifer and typically are detected at multiple resurgence points. This is indicative of a karst system with a significant slow-flow component connected to a rapid-flow component typical of more permeable, solutionally enlarged fractures. The tests also determined that dye recovery usually occurs following significant precipitation.

Tracer tests were also conducted at the Leetown Pesticide Site and the Jefferson County Landfill area (NUS, 1986, p. 5-48). Although these tests focused primarily on detecting leakage from the landfill with expected detection in the site monitoring wells, at least one test resulted in recovery at the Center (Gray Spring) 42 days after injection, which is slightly more rapid than reported by Jones and Deike (1981). The time required for tracer breakthrough indicates a flow velocity of 171 feet per day (ft/d), which is extremely slow compared to a more conduit-dominated karst aquifer such as that in Greenbrier County, West Virginia with typical velocities of about 1,000-10,000 ft/d (Jones, 1997). Each of the tracer test recoveries were found to coincide with precipitation events (NUS, 1986, p. 5-55-5-56) suggesting increased flow velocity or flushing after heavy rainfall.

These findings were also seen in additional tracer tests conducted in other areas of Jefferson County, West Virginia in 1987 and 1988 (Kozar and others, 1991). Heavy precipitation was found to mobilize dye that was being sequestered within the subsurface, allowing it to flow down gradient (Kozar and others, 1991). When not mobilized by precipitation, it is believed that a significant portion of the dye either remains relatively immobile within the subsurface or moves slowly down gradient through the less permeable, diffuse-flow matrix of interconnected fractures that are drained by the more permeable solution conduits (Kozar and others, 1991).

\section{Tracer Tests}

Eight dye tracer tests were conducted during 2004-2005 in the Leetown area (fig. 25) as part of this investigation to provide additional data on ground-water flow paths, determine typical ground-water flow velocities in the conduit dominated portion of the aquifer, to better understand the role of conduits and large solutionally interconnected fractures in conveying ground water, and to refine the conceptual model of groundwater flow in the Leetown area. These tests were conducted using fluorescent tracers, primarily Rhodamine WT (C.I. AR 388) and to a lesser extent sodium fluorescein (C.I. AY 73).

Dye was either released into surface streams (Tests 1 and 2 ) or injected into piezometers in highly permeable bedrock (Tests 4 and 6) or sinkholes (Tests 3, 7, and 8) (fig. 25 and table 12). An additional tracer test (Test 5) was conducted by injecting dye into a hole augered in a dry stream bed coincident with a thrust fault (fig. 25 and table 12). Except for the stream tracer tests, which were conducted to assess the potential for stream leakage into ground water, all injections consisted of mixing and delivering the dyes into the piezometers or sinkholes with a constant stream of water, followed by flushing with 2,000 gallons of water to assure dye entry into ground water. Suspected resurgence points, consisting of down-gradient springs, wells, and streams (fig. 25 and table 13), were then monitored by grab samples or by use of automated water samplers on a regular schedule. The sampling interval ranged from less than one per hour to one per day depending on the length of the test and distance from the point of injection. A prime emphasis of the tracer tests was to determine transport rates and trajectories from injection points to recovery sites. No effort was made to determine tracer mass recoveries because the manner in which water is pumped from the Center springs made it impossible to establish accurate discharge estimates needed to assess flux changes.

\section{Results of Tracer Tests}

A discussion of each of the eight tracer tests conducted for this investigation are presented in appendix 5A. Table 14 lists the peak times of travel and peak velocities for the eight tracer tests. It is apparent from table 14 that flow times and velocities varied considerably throughout the investigation, probably as a result of subsurface conditions developed during wet and dry periods. The raw data for the individual tracer tests are presented in appendix 5B. Tracer tests conducted as part of this investigation agree well with the ground-water flow velocities and directions obtained by Jones and Deike (1981) and NUS (1986). The data provided by these tracer tests indicate relatively slow ground-water flow velocities when tracer dye was released into sinkholes and augured holes (table 14). Coupled with the relatively poor tracer recoveries obtained, this indicates that much of the tracer dye is retained in the epikarstic zone, flow in phreatic solution conduits may be blocked by fallen rocks or sediment, or both. These slow flow velocities and weak recoveries are not typical of most karstic terranes but are easily explained. 


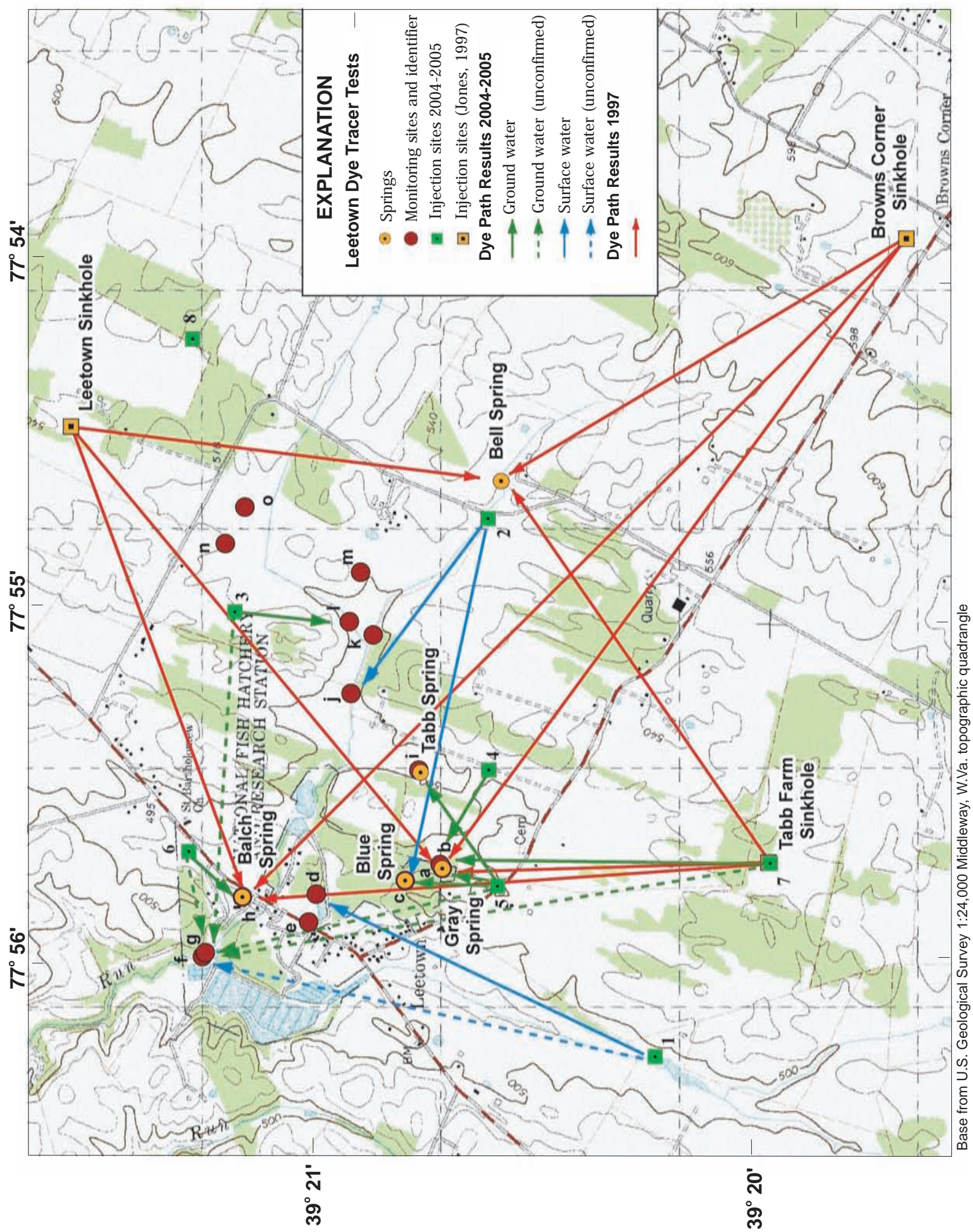

Figure 25. Ground-water flow connections determined from dye tracer studies conducted in the Leetown area, West Virginia. [Numbers next to injection site symbols designate the number of the test and letters next to monitoring site symbols designate the letter for the monitoring sites discussed in the dye tracer test section of the report and in Appendix 
Table 12. Locations and date and time of recent tracer injections conducted in the Leetown area, West Virginia

[lbs, pounds; ' , degrees; ', minutes, “, decimal seconds; N, north; W, West]

\begin{tabular}{|c|c|c|c|c|c|c|c|}
\hline \multirow[t]{2}{*}{ Test No. } & \multicolumn{2}{|c|}{ Tracer Dye Type } & \multicolumn{2}{|c|}{ Injection Location } & \multicolumn{2}{|c|}{ When Injected } & \multirow{2}{*}{$\begin{array}{c}\text { Mass Injected, } \\
\text { (Ibs) }\end{array}$} \\
\hline & Common Name & Color Index & Latitude ( ${ }^{\circ} \mathrm{N}$ ) & Longitude $\left({ }^{\circ} \mathbf{W}\right)$ & Date & Time & \\
\hline 1 & Rhodamine WT & Acid Red 388 & $39^{\circ} 20^{\prime} 14.0^{\prime \prime}$ & $77^{\circ} 56^{\prime} 15.0^{\prime \prime}$ & $04 / 20 / 2004$ & 11:34 AM & 0.635 \\
\hline 2 & Rhodamine WT & Acid Red 388 & $39^{\circ} 20^{\prime} 39.0^{\prime \prime}$ & $77^{\circ} 54^{\prime} 42.0^{\prime \prime}$ & 05/17/2004 & 10:30 AM & 0.635 \\
\hline 3 & Rhodamine WT & Acid Red 388 & $39^{\circ} 21^{\prime} 13.0^{\prime \prime}$ & $77^{\circ} 54^{\prime} 59.7^{\prime \prime}$ & 06/17/2004 & 11:20 AM & 1.05 \\
\hline 4 & Rhodamine WT & Acid Red 388 & $39^{\circ} 20^{\prime} 37.8^{\prime \prime}$ & $77^{\circ} 55^{\prime} 25.9^{\prime \prime}$ & $07 / 22 / 2004$ & 9:30 AM & 1.05 \\
\hline 5 & Rhodamine WT & Acid Red 388 & $39^{\circ} 20^{\prime} 36.1^{\prime \prime}$ & $77^{\circ} 55^{\prime} 46.1^{\prime \prime}$ & 08/31/2004 & 11:20 AM & 3.5 \\
\hline 6 & Fluorescein & Acid Yellow 73 & $39^{\circ} 20^{\prime} 18.2^{\prime \prime}$ & $77^{\circ} 55^{\prime} 41.8^{\prime \prime}$ & $10 / 07 / 2004$ & 10:20 AM & 0.66 \\
\hline 7 & Rhodamine WT & Acid Red 388 & $39^{\circ} 20^{\prime} 59.2^{\prime \prime}$ & $77^{\circ} 55^{\prime} 40.6^{\prime \prime}$ & $10 / 07 / 2004$ & 12:30 PM & 6.0 \\
\hline 8 & Rhodamine WT & Acid Red 388 & $39^{\circ} 20^{\prime} 19.9^{\prime \prime}$ & $77^{\circ} 54^{\prime} 12.3^{\prime \prime}$ & $04 / 19 / 2005$ & 11:22 AM & 11.9 \\
\hline
\end{tabular}

Table 13. Locations and distance of tracer-resurgence sampling stations from injection sites, Leetown area, West Virginia.

[ft, feet; ${ }^{\circ}$, degrees; ', minutes, “, decimal seconds; N, north; W, West]

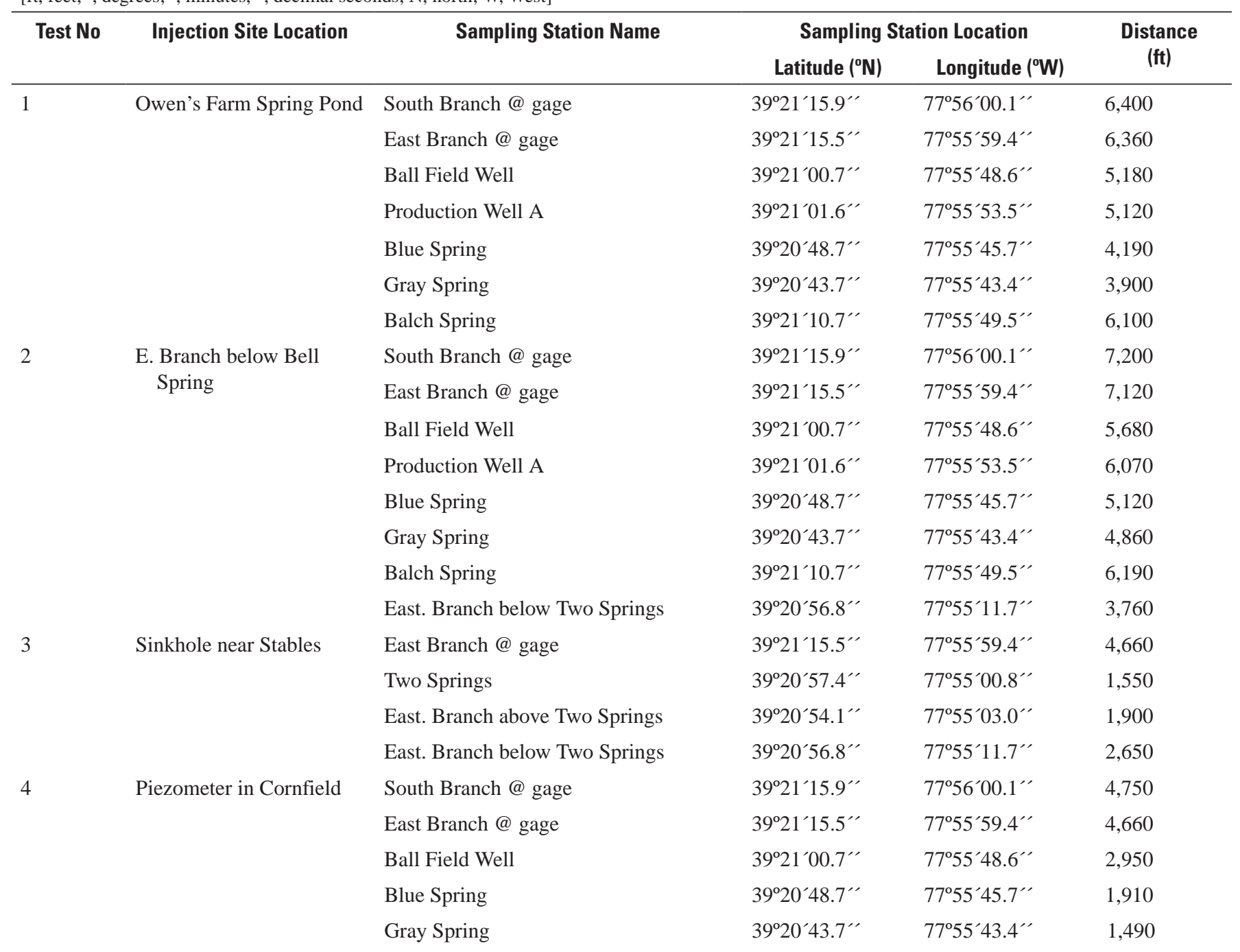


Table 13. Locations and distance of tracer-resurgence sampling stations from injection sites, Leetown area, West Virginia.

[ft, feet; ' , degrees; ', minutes, “, decimal seconds; N, north; W, West]

\begin{tabular}{|c|c|c|c|c|c|}
\hline \multirow[t]{2}{*}{ Test No } & \multirow[t]{2}{*}{ Injection Site Location } & \multirow[t]{2}{*}{ Sampling Station Name } & \multicolumn{2}{|c|}{ Sampling Station Location } & \multirow{2}{*}{$\begin{array}{l}\text { Distance } \\
\quad \text { (ft) }\end{array}$} \\
\hline & & & Latitude ( $\left.{ }^{\circ} \mathrm{N}\right)$ & Longitude ( $\left.{ }^{\circ} \mathrm{W}\right)$ & \\
\hline \multirow{5}{*}{5} & \multirow{5}{*}{ Augured Hole near Pike } & Gray Spring Overflow & $39^{\circ} 20^{\prime} 44.0^{\prime \prime}$ & $77^{\circ} 55^{\prime} 42.7^{\prime \prime}$ & 1,490 \\
\hline & & Balch Spring & $39^{\circ} 21^{\prime} 10.7^{\prime \prime}$ & $77^{\circ} 55^{\prime} 49.5^{\prime \prime}$ & 3,860 \\
\hline & & South Branch@ gage & $39^{\circ} 21^{\prime} 15.9^{\prime \prime}$ & $77^{\circ} 56^{\prime} 00.1^{\prime \prime}$ & 4,200 \\
\hline & & East Branch @ gage & $39^{\circ} 21^{\prime} 15.5^{\prime \prime}$ & $77^{\circ} 55^{\prime} 59.4^{\prime \prime}$ & 4,140 \\
\hline & & Ball Field Well & $39^{\circ} 21^{\prime} 00.7^{\prime \prime}$ & $77^{\circ} 55^{\prime} 48.6^{\prime \prime}$ & 2,500 \\
\hline \multirow{9}{*}{6} & \multirow{9}{*}{$\begin{array}{l}\text { Piezometer on USDA } \\
\text { Fault }\end{array}$} & Tabb Spring & $39^{\circ} 20^{\prime} 55.4^{\prime \prime}$ & $77^{\circ} 55^{\prime} 25.3^{\prime \prime}$ & 1,910 \\
\hline & & Blue Spring & $39^{\circ} 20^{\prime} 48.7^{\prime \prime}$ & $77^{\circ} 55^{\prime} 45.7^{\prime \prime}$ & 1,260 \\
\hline & & Gray Spring & $39^{\circ} 20^{\prime} 43.7^{\prime \prime}$ & $77^{\circ} 55^{\prime} 43.4^{\prime \prime}$ & 810 \\
\hline & & Balch Spring & $39^{\circ} 21^{\prime} 10.7^{\prime \prime}$ & $77^{\circ} 55^{\prime} 49.5^{\prime \prime}$ & 3,540 \\
\hline & & South Branch @ gage & $39^{\circ} 21^{\prime} 15.9^{\prime \prime}$ & $77^{\circ} 56^{\prime} 00.1^{\prime \prime}$ & 1,470 \\
\hline & & East Branch@gage & $39^{\circ} 21^{\prime} 15.5^{\prime \prime}$ & $77^{\circ} 55^{\prime} 59.4^{\prime \prime}$ & 1,390 \\
\hline & & Ball Field Well & $39^{\circ} 21^{\prime} 00.7^{\prime \prime}$ & $77^{\circ} 55^{\prime} 48.6^{\prime \prime}$ & 1,860 \\
\hline & & Tabb Spring & $39^{\circ} 20^{\prime} 55.4^{\prime \prime}$ & $77^{\circ} 55^{\prime} 25.3^{\prime \prime}$ & 3,360 \\
\hline & & Blue Spring & $39^{\circ} 20^{\prime} 48.7^{\prime \prime}$ & $77^{\circ} 55^{\prime} 45.7^{\prime \prime}$ & 3,020 \\
\hline \multirow{5}{*}{7} & \multirow{5}{*}{ Tabb Sinkhole } & Gray Spring & $39^{\circ} 20^{\prime} 43.7^{\prime \prime}$ & $77^{\circ} 55^{\prime} 43.4^{\prime \prime}$ & 3,520 \\
\hline & & Balch Spring & $39^{\circ} 21^{\prime} 10.7^{\prime \prime}$ & $77^{\circ} 55^{\prime} 49.5^{\prime \prime}$ & 970 \\
\hline & & South Branch@gage & $39^{\circ} 21^{\prime} 15.9^{\prime \prime}$ & $77^{\circ} 56^{\prime} 00.1^{\prime \prime}$ & 7,970 \\
\hline & & East Branch @ gage & $39^{\circ} 21^{\prime} 15.5^{\prime \prime}$ & $77^{\circ} 55^{\prime} 59.4^{\prime \prime}$ & 7,910 \\
\hline & & Ball Field Well & $39^{\circ} 21^{\prime} 00.7^{\prime \prime}$ & $77^{\circ} 55^{\prime} 48.6^{\prime \prime}$ & 6,290 \\
\hline \multirow{12}{*}{8} & \multirow{12}{*}{$\begin{array}{l}\text { Sinkhole north of Hite } \\
\text { Road }\end{array}$} & Blue Spring & $39^{\circ} 20^{\prime} 48.7^{\prime \prime}$ & $77^{\circ} 55^{\prime} 45.7^{\prime \prime}$ & 5,070 \\
\hline & & Gray Spring & $39^{\circ} 20^{\prime} 43.7^{\prime \prime}$ & $77^{\circ} 55^{\prime} 43.4^{\prime \prime}$ & 4,550 \\
\hline & & Tabb Spring & $39^{\circ} 20^{\prime} 55.4^{\prime \prime}$ & $77^{\circ} 55^{\prime} 25.3^{\prime \prime}$ & 5,030 \\
\hline & & Balch Spring & $39^{\circ} 21^{\prime} 10.7^{\prime \prime}$ & $77^{\circ} 55^{\prime} 49.5^{\prime \prime}$ & 7,330 \\
\hline & & East Branch @ gage & $39^{\circ} 21^{\prime} 15.5^{\prime \prime}$ & $77^{\circ} 55^{\prime} 59.4^{\prime \prime}$ & 8,420 \\
\hline & & Blue Spring & $39^{\circ} 20^{\prime} 48.7^{\prime \prime}$ & $77^{\circ} 55^{\prime} 45.7^{\prime \prime}$ & 8,030 \\
\hline & & Gray Spring & $39^{\circ} 20^{\prime} 43.7^{\prime \prime}$ & $77^{\circ} 55^{\prime} 43.4^{\prime \prime}$ & 8,070 \\
\hline & & Balch Spring & $39^{\circ} 21^{\prime} 10.7^{\prime \prime}$ & $77^{\circ} 55^{\prime} 49.5^{\prime \prime}$ & 7,700 \\
\hline & & Two Springs & $39^{\circ} 20^{\prime} 57.4^{\prime \prime}$ & $77^{\circ} 55^{\prime} 00.8^{\prime \prime}$ & 4,440 \\
\hline & & East. Branch below Two Springs & $39^{\circ} 20^{\prime} 56.8^{\prime \prime}$ & $77^{\circ} 55^{\prime} 11.7^{\prime \prime}$ & 6,240 \\
\hline & & Syncline Well & $39^{\circ} 21^{\prime} 12.1^{\prime \prime}$ & $77^{\circ} 54^{\prime} 41.4^{\prime \prime}$ & 2,870 \\
\hline & & Anticline Well & $39^{\circ} 21^{\prime} 14.6^{\prime \prime}$ & $77^{\circ} 54^{\prime} 47.9^{\prime \prime}$ & 2,450 \\
\hline
\end{tabular}


Table 14. Ground-water travel times and velocities for the eight recent tracer tests conducted in the Leetown area, West Virginia.

[ft, feet; d, day; ft/d, feet per day]

\begin{tabular}{|c|c|c|c|c|}
\hline $\begin{array}{c}\text { Tracer Test } \\
\text { No. }\end{array}$ & Sampling Stations & $\begin{array}{c}\text { Transport } \\
\text { Distance } \\
\text { (ft) }\end{array}$ & $\begin{array}{c}\text { Peak Time of } \\
\text { Travel } \\
\text { (d) }\end{array}$ & $\begin{array}{c}\text { Peak Flow } \\
\text { Velocity } \\
\text { (ft/d) }\end{array}$ \\
\hline 1 & Balch Spring & 6,100 & 6 & 1,020 \\
\hline 1 & Ball Field Well & 5,180 & 12 & 430 \\
\hline 1 & East Branch Hopewell Run & 6,360 & 4 & 1,600 \\
\hline 2 & Balch Spring & 6,190 & $2-5^{1}$ & $1,240-3,100^{1}$ \\
\hline 2 & Blue Spring & 5,130 & 5 & 1,030 \\
\hline 2 & Gray Spring & 4,860 & 4 & 1,220 \\
\hline 2 & Two Springs & 3,760 & 7 & 540 \\
\hline 2 & Ball Field Well & 5,680 & 0.88 & $6,490^{2}$ \\
\hline 3 & Two Springs & 1,575 & 21 & 75 \\
\hline 4 & Balch Spring & 3,860 & 12 & 320 \\
\hline 4 & Blue Spring & 1,910 & 6 & 320 \\
\hline 4 & Gray Spring & 1,490 & 7 & 210 \\
\hline 5 & Balch Spring & 3,540 & 15 & 240 \\
\hline 5 & Blue Spring & 1,260 & 29 & 44 \\
\hline 5 & Gray Spring & 810 & 29 & 28 \\
\hline 5 & Tabb Spring & 1,910 & 28 & 68 \\
\hline 6 & Balch Spring & 970 & $64-71^{1}$ & $14-15^{1}$ \\
\hline 6 & East Branch Hopewell Run & 1,390 & 25 & 56 \\
\hline 7 & Balch Spring & 7,180 & $12-45^{1}$ & $160-600^{1}$ \\
\hline 7 & Blue Spring & 5,020 & 104 & 48 \\
\hline 7 & Gray Spring & 4,540 & $142-146^{1}$ & $31-32^{1}$ \\
\hline 8 & Balch Spring & 7,700 & 22 & 350 \\
\hline 8 & Blue Spring & 8,030 & 15 & 540 \\
\hline 8 & Gray Spring & 8,070 & 19 & 430 \\
\hline 8 & Two Springs & 6,240 & 15 & 420 \\
\hline 8 & Anticline Well & 2,450 & 199 & $12^{3}$ \\
\hline 8 & Syncline Well & 2,870 & 199 & $14^{3}$ \\
\hline
\end{tabular}

${ }^{1}$ Two possible travel times and flow velocities are listed as multiple peaks of dye were recovered during the tests.

${ }^{2}$ This result may have been affected by recovery of dye from the previous tracer test

${ }^{3}$ These two wells were not continuously sampled and were not sampled earlier during the test.

Therefore, flow velocity to these wells could be faster than indicated in this table. 
More rapid transit times and generally stronger recoveries were obtained when dye was released in the losing stream reaches providing evidence that losing stream reaches provide some recharge to the Center springs and wells (app. 5B, figs. $2,3,6,7,8,9$, and 10). Leakage through losing stream beds complicated the design of the first two tracer tests and led to the modification of the Efficient Hydrologic Tracer Test Design (EHTD) program which was used for this project to assist in the design of the tracer tests (Field, 2003, 2006). It is possible that leakage from the losing branches of Hopewell Run caused ground-water to accumulate in subsurface flow channels beneath the site slowing ground-water transit times and resulting in poor dye recoveries when dye was released into sinkholes and augured holes. The effect of leakage of streamflow to subsurface flow channels would be to reduce the flow of the dye released in the sinkholes or augured holes and dilution of the dye resulting in very low recovery concentrations.

A significant issue associated with the dye-tracing study relates to the repeated use of Rhodamine WT for most of the traces (sodium fluorescein was only used for Tracer test No. 6). The potential for recovery of dye from earlier traces (Rhodamine WT and sodium fluorescein) may confound the results. (It should be noted that all rhodamines have been found to degrade to a greenish compound that fluoresces very near to that of sodium fluorescein.) However, the potential cross-over effect is not considered to be a major problem because dye injections were intentionally staggered between the north and south sides of the east branch of Hopewell Run to avoid cross contamination. On the date that both sodium fluorescein and Rhodamine WT were released, a large separation distance coupled with injection locations north and south of Hopewell Run were used to prevent cross contamination.

Most significant in addressing potential cross contamination was the reliance on conducting dye analysis on water samples using a fluorometer. Dye concentrations in water are additive so increasing background is not a concern when directly analyzing water samples for dye. In this sense, a positive dye recovery may be established if the recovered dye peak(s) represent a proportionally significant increase over the background.

Travel times obtained for this study were found to be comparable with those obtained by Jones and Deike (1981) which further leads to confidence in the results obtained for this study. Although some of the transport velocities obtained for this study were slightly faster than those obtained by Jones and Deike, the difference is most likely a reflection of differing hydrologic conditions which facilitated faster transport velocities.

Consider, for example, on April 20, 2004, $288 \mathrm{~g}$ of Rhodamine WT was released into the south branch of Hopewell Run. The vast majority of this release was recovered downstream at the Hopewell Run at Leetown gaging station on the south branch of Hopewell Run where peak recovery exceeded $15 \mu \mathrm{g} / \mathrm{L}$ (app. 5B fig. 1) and Balch Spring where peak recovery exceeded $10 \mu \mathrm{g} / \mathrm{L}$ (app. 5B fig. 3), but where a reasonably good recovery was also obtained from the ball field well where peak recovery exceeded $1.5 \mu \mathrm{g} / \mathrm{L}$ (fig. 2). On May 17, 2004, another $288 \mathrm{~g}$ of Rhodamine WT was released into the east branch of Hopewell Run. The vast majority of this second dye release was recovered at the downstream Hopewell Run at Leetown gaging station on the east branch of Hopewell Run where peak recovery was approximately $6 \mu \mathrm{g} / \mathrm{L}$ (app. 5B fig. 5) and a reasonably good recovery was obtained at Blue Spring where peak recovery was approximately $3 \mu \mathrm{g} / \mathrm{L}$ (app. 5B fig. 6)

\section{Breakthrough Curve Modeling}

To better understand the results obtained from the tracer tests, selected breakthrough curves were modeled, first using the QTRACER2 program (Field, 2002) to obtain approximate transport parameters and then using the CXTFIT program (Toride and others, 1995) as modified by the author for use with data obtained from tracer tests conducted in karstic systems. QTRACER2 statistically evaluates breakthrough curves and extracts relevant hydraulic data. However, the results obtained from QTRACER2 are approximate and need to be calibrated using a theoretical model. Using CXTFIT for inverse modeling of the data and the results obtained from QTRACER2, the data were calibrated so that a better understanding of the flow properties obtained from the tracer tests may be established.

Unfortunately, the complexity of many of the breakthrough curves obtained from the eight tracer tests cannot adequately be modeled using CXTFIT. Some individuals have advocated using a multi-velocity, multi-dispersion model to address the problem of multiple peaks and long tails in a breakthrough curve (Małoszewski and others, 1992). Modeling of this type utilizes coupling of the advection-dispersion equation to itself as many times as necessary to obtain a near perfect model fit to the data. While the model fits appear excellent, there is little proven basis to support such modeling.

The breakthrough curves selected for analysis using QTRACER2 are listed in table 15 along with selected flow parameters developed using QTRACER2. In general, as determined from the breakthrough curves, flow rates appear to be considerably slower than is typical for karstic aquifers. However, most subsurface flow was still found to be advection dominated as determined from the Peclet numbers. The Peclet number is a measure of the relative contribution of mechanical dispersion and diffusion to solute transport. It relates the effectiveness of mass transport by advection to the effectiveness of mass transport by either dispersion or diffusion (Schiesser and Silebi, 1997, p. 372). Peclet numbers below 0.4 indicate diffusion control; $0.4-6.0$ indicate that diffusion and advection are in transition and thus approximately equal to each other; and $>6.0$ indicates advection control (Fetter, 1993, p. 54-55). In most nonporous media instances of solute transport in karst conduits, Peclet numbers will be greater than 6.0. Often, Peclet numbers will be many times greater than 6.0. Only flow to the ball field well during Tracer Test No. 2 
Table 15. OTRACER2-estimated flow parameters for selected sampling sites in the Leetown area, West Virginia.

[ft, feet, $\mathrm{d}$, days, $\mathrm{ft} / \mathrm{d}$, feet per day, $\mathrm{ft}^{2} / \mathrm{d}$, square feet per day $\}$.

\begin{tabular}{llccccc}
\hline Test No. & Sampling Site & $\begin{array}{c}\text { Transport } \\
\text { Distance } \mathbf{~}^{(\mathbf{f t})}\end{array}$ & $\begin{array}{c}\text { Mean Travel } \\
\text { Time } \\
\text { (d) }\end{array}$ & $\begin{array}{c}\text { Mean Flow } \\
\text { Velocity } \\
\text { (ft/d) }\end{array}$ & $\begin{array}{c}\text { Longitudinal } \\
\text { Dispersion } \\
\left.\text { (ft }{ }^{2} / \mathbf{d}\right)\end{array}$ & $\begin{array}{c}\text { Peclet } \\
\text { Number }\end{array}$ \\
\hline 1 & Balch Spring & 7,929 & 6.4 & 1,289 & 74,897 & 132.2 \\
2 & Blue Spring & 6,663 & 4.9 & 1,394 & 33,298 & 278.9 \\
2 & Gray Spring & 6,316 & 4.0 & 1,584 & 48,482 & 206.4 \\
2 & Ball Field Well & 7,379 & 5.2 & 1,426 & $1,790,812^{1}$ & $5.9^{3}$ \\
4 & Blue Spring & 2,484 & 12.6 & 198 & 29,463 & 16.7 \\
4 & Gray Spring & 1,941 & 14.0 & 138 & 17,859 & 15.0 \\
5 & Balch Spring & 4,603 & 20.3 & 226 & 27,855 & 37.4 \\
5 & Blue Spring & 1,642 & 23.2 & 70.8 & 2,259 & 51.5 \\
5 & Gray Spring & 1,054 & 24.5 & 43.0 & 1,881 & 24.1 \\
5 & Tabb Spring & 2,478 & 21.0 & 118 & 27,200 & 10.8 \\
7 & Balch Spring & 9,528 & 23.2 & 412 & 551,286 & 7.1 \\
7 & Blue Spring & 6,585 & 6.3 & 76.3 & 41,220 & 12.2 \\
7 & Gray Spring & 5,915 & 135.4 & 43.7 & 5,391 & 48.0 \\
8 & Balch Spring & 10,007 & 97.0 & 103 & 225,163 & 4.6 \\
\hline 8 & Blue Spring & 10,436 & 75.6 & 138 & 410,875 & 3.5
\end{tabular}

${ }^{1}$ Corrected for sinuosity $=1.3$.

${ }^{2}$ Dispersion estimate likely too large because of singularity in Chatwin analysis (Field, 2002, pp. 35-38).

${ }^{3}$ Peclet number estimate likely too small because of large dispersion estimate. 
Table 16. CXTFIT-estimated parameters for selected breakthrough curves from tracer tests conducted in the Leetown area, West Virginia.

[ft/d, feet per day; $\mathrm{ft}^{2} / \mathrm{d}$, feet squared per day; $\mathrm{h}^{-1}$, reciprocal of hours; $\mathrm{R}^{2}$, correlation coefficient]

\begin{tabular}{|c|c|c|c|c|c|c|c|c|}
\hline \multirow[t]{2}{*}{ Tracer Test } & \multirow[t]{2}{*}{$\begin{array}{l}\text { Breakthrough } \\
\text { Curve }\end{array}$} & \multicolumn{2}{|c|}{ Flow Velocity } & \multicolumn{2}{|c|}{$\begin{array}{c}\text { Longitudinal Dis- } \\
\text { persion }\end{array}$} & \multirow{2}{*}{$\begin{array}{l}\text { Degree of } \\
\text { Nonequilib- } \\
\text { rium }\end{array}$} & \multirow[t]{2}{*}{$\begin{array}{l}\text { Mass Transfer } \\
\text { Coefficient }\left(\mathbf{h}^{-1}\right)\end{array}$} & \multirow{2}{*}{$\begin{array}{l}\text { Model Fit - } \\
\text { Coefficient of } \\
\text { Variation }\left(R^{2}\right)\end{array}$} \\
\hline & & $\begin{array}{l}\text { Mean } \\
\text { Flow } \\
(\mathrm{ft} / \mathrm{d})\end{array}$ & $\begin{array}{l}\text { Mobile } \\
\text { Fluid } \\
\text { (ft/d) }\end{array}$ & $\begin{array}{l}\text { Mean } \\
\text { Flow } \\
(\mathrm{ft} / \mathrm{d})\end{array}$ & $\begin{array}{c}\text { Mobile } \\
\text { Fluid } \\
\text { (ft/d) }\end{array}$ & & & \\
\hline 1 & Balch Spring & 1,356 & 1,358 & 7,489 & 7,497 & 0.9990 & $5.0 \times 10^{-5}$ & 0.9891 \\
\hline 2 & Blue Spring & 1,248 & 1,432 & 16,673 & 19,127 & 0.8717 & $7.8 \times 10^{-2}$ & 0.9918 \\
\hline 2 & Gray Spring & 1,516 & 1,634 & 4,849 & 5,228 & 0.9274 & $1.8 \times 10^{0}$ & 1.0000 \\
\hline
\end{tabular}

and flow to Balch, Blue, and Gray Springs during Tracer Test No. 8 produced Peclet numbers in which advection equals diffusion.

The program, CXTFIT was used to model the breakthrough curve for Balch Spring developed from Tracer Test No. 1 (app. 5B, fig. 35) and the breakthrough curves for Blue and Gray Springs developed from Tracer Test No. 2 (app. 5B, figs. 36 and 37, respectively). All the model fits to the breakthrough curves were quite good (table 16). The mobile fluid velocities are very close to the mean flow velocities for each of the modeled datasets and the degree of non-equilibrium (ratio of mobile fluid to immobile fluid) for each of the modeled data sets are quite high. These two parameters indicate that the flow channels are not severely restricted by blockages, such as from falling rocks or clay plugs and support the hypothesis that once the tracer dyes reach the phreatic solution conduits transport is relatively unrestricted.

The very low mass transfer coefficient for Balch Spring for the first tracer test indicates that the subsurface water spends almost no time in immobile-flow regions. The larger mass transfer coefficients for Blue and Gray Springs from the second tracer test indicate that the small volume of water detained in immobile-flow regions takes a longer period of time to move back into the mobile-flow regions. The major delaying factor of leakage from the losing streams to the solution conduits is probably the porosity and thickness of the Hopewell Run stream bed and the underlying fractures.

Transport through the vadose zone, as occurs when tracer dyes are released into sinkholes, appears to be more significantly restricted. Data sets from the sinkhole tracer tests could not be modeled because of the multimodal nature of the breakthrough curves. These multimodal breakthrough curves and consequent slow transport rates are indicative of the poor recharge occurring from the limited number of sinkholes in the area. Some recharge to the springs and wells in the vicinity of the Center, as indicated by tracer tests, appears to be from the south and east branches of Hopewell Run as water leaks through the stream beds.

Also of considerable importance to the Center is the quality of recharge water. Because a significant proportion of recharge appears to come from leakage from the east and south branches of Hopewell Run, it is imperative that Hopewell Run be protected from contamination. Whatever gets released into Hopewell Run (e.g. agricultural runoff or wastewater treatment return flows) could easily be transported to the Center springs and wells relatively quickly (see tracers tests 1 and 2 in table 14) and eventually into the Center's processing water.

\section{Spring Recharge Delineation - by Mark D. Kozar}

An analysis of potential recharge areas to the Blue and Gray Spring complex and to Balch Spring was conducted as part of development of the ground-water flow model for the Leetown area (Kozar and others, 2007). Results of the previously discussed dye tracer tests were also used to better define potential recharge areas to the Center's springs and well fields. The probable and possible areas of recharge to the springs are shown in figure 25. Available hydrogeologic data and results of the tracer tests and current ground-water flow model indicate primary recharge areas for Balch Spring to the east and north, for Blue Spring to the south, and for Gray Spring to the east and southeast (fig. 26). It is possible, although unlikely, that an undetermined amount of ground water may flow towards Balch Spring from the area south of Kearneysville, West Virginia, in the northern part of the model area (possible recharge area on fig. 26). Also, the likely contributing area of recharge to Balch Spring is much larger than that of either Blue or Gray Springs. This is due to the fault which crosses the Center and is connected to Balch Spring, providing an added area of potential recharge to the spring that would not normally be considered if the fault were not such a dominant ground-water flow path.

Due to the nature of bedrock fractures in the area, it is difficult to assess the exact recharge areas contributing water to Blue and Gray Springs. Results of a particle-tracking analysis conducted as part of the development of the groundwater flow model indicate that areas to the south are likely to contribute water to Blue Spring and areas to the east are likely to contribute water to Gray Spring. It is probable that the recharge areas to the springs overlap and may shift with changing hydraulic head within the aquifer. While there is 


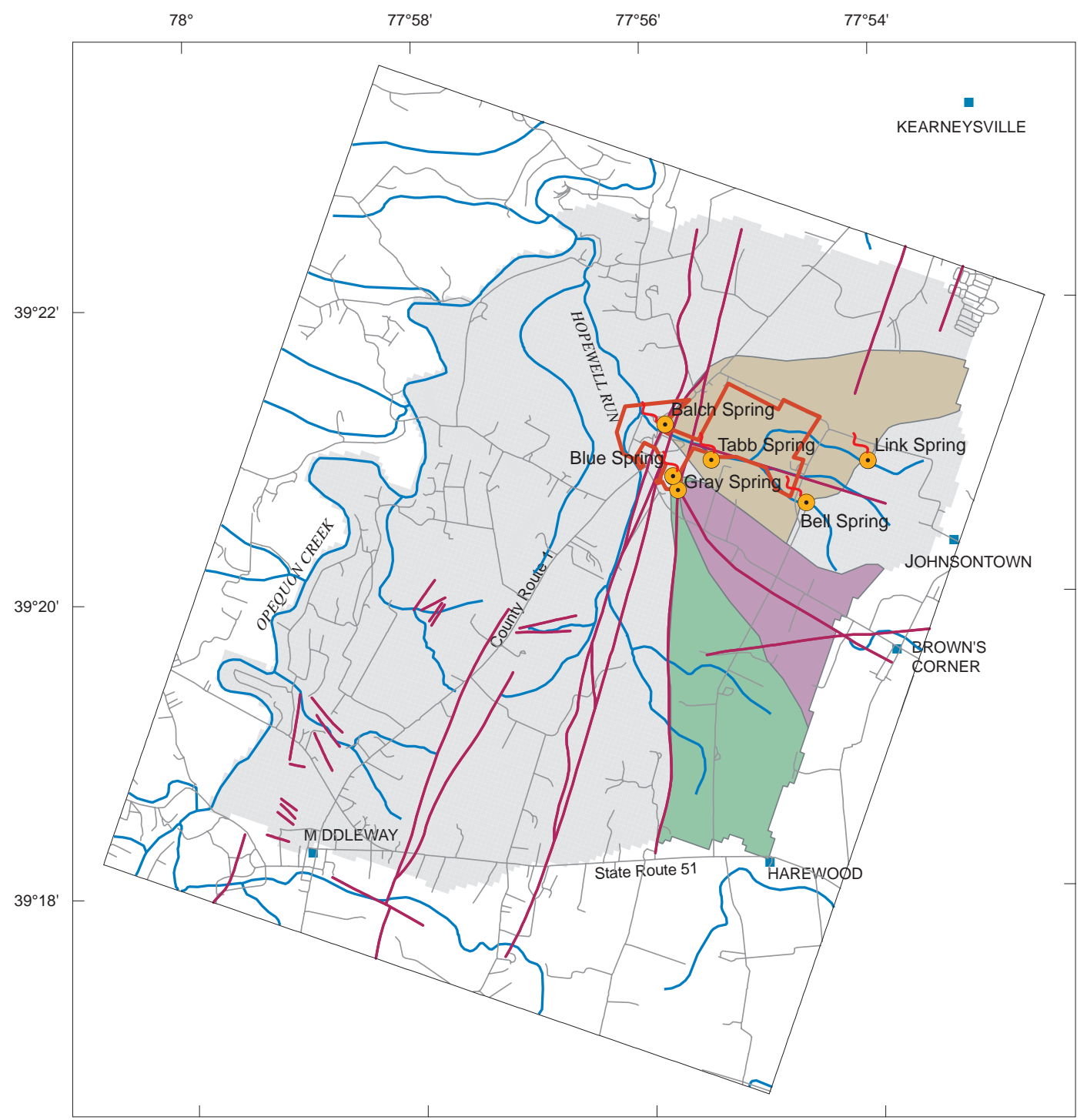

\section{EXPLANATION}

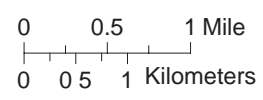

\begin{tabular}{|ccl|}
\hline Potential recharge areas & & Model boundary \\
\hline Blue Spring & Leetown Science Center \\
Gray Spring & boundary \\
\hline Balch Spring & Stream \\
\hline Study area & - & Road \\
Hopewell Run & - & Major Fault \\
Watershed & $\odot$ & Spring \\
\hline
\end{tabular}

Figure 26. Estimated recharge areas of Balch, Blue, and Gray Springs during average hydrologic conditions, Leetown, West Virginia. [Recharge areas delineated are approximate and vary with changing hydrologic conditions.] 
some uncertainty in the results of current (fig. 25) and past dye tracer tests (Jones and Deike, 1981; NUS, 1986) conducted in the Leetown area, they generally confirm the results of the mathematical simulation of ground-water flow to the springs.

Another potential problem in delineation of recharge areas to Blue and Gray Spring is documented flow of ground water across the East Branch of Hopewell Run from an area northeast of the Center (Leetown sinkhole on fig. 22). This appears to contradict the general directions of ground-water flow indicated by the particle-tracking analysis. It does, however, confirm the connection established by a previous tracer test conducted a few decades earlier (Jones and Deike, 1981). The reason for this anomalous connection is uncertain but is most easily explained by leakage of water from the East Branch of Hopewell Run to thrust faults that trend southwest to northeast through the area and connect with Blue and Gray Springs. Additional data would be needed to better quantify the contribution of ground water to Blue, Gray, and Balch Springs. Even with these data; it may be difficult or impractical to determine the exact areas contributing water to the various springs. While a better understanding of the connection between ground water and leakage of water from tributary streams is important, the general ground-water recharge areas delineated here should be more than adequate for purposes of watershed management and protection.

\section{Water Quality - by Mark D. Kozar and William B.}

\section{Schill}

Ground-water samples collected from 16 sites (12 wells and 4 springs) in the Leetown area were analyzed for approximately 340 constituents, including common ions, trace elements, nutrients (including nitrate and phosphorous), indicator bacteria (fecal coliform, E. coli, and total coliform), volatile organic compounds (VOCs), semi-volatile organic compounds (including industrial compounds), pesticides (herbicides, fungicides, and insecticides), radioactive elements (radon-222 and Uranium), stable isotopes (deuterium and oxygen-18), and constituents useful for age dating of water (tritium, helium, and chlorofluorocarbons). Results of the analyses were used to: 1) establish a baseline of ground-water chemistry data for use in assessing potential changes in ground-water quality over time; 2) assess potential impacts of a former USEPA Superfund site (Leetown pesticide dump) and the Jefferson County, West Virginia, landfill east of the Center; 3) characterize the age of water within various hydrogeologic settings; and 4) assess potential impacts of agriculture and rural suburban development on the quality of ground water in the Leetown area.

\section{Field Measurements and Inorganic Constituents} - by Mark D. Kozar

Ground water was sampled using the techniques described in Wilde and others (1999). Springs were sampled with a submersible pump as close as possible to the point of issuance from the bedrock. Field values of $\mathrm{pH}$, specific conductance, dissolved oxygen (DO), water temperature, and turbidity were continuously monitored during purging of the wells or springs and samples were collected only after the values of these parameters stabilized. All samples were filtered and preserved in the field, and subsequently shipped to the U.S. Geological Survey National Water Quality Laboratory (NWQL) in Lakewood, Colorado, where they were analyzed for the constituents listed above. Carbonate alkalinity, bicarbonate alkalinity, and total alkalinity were measured in the field using the techniques described in Wilde and Radtke (1998). Total-coliform, fecal-coliform, and E c coli bacteria were plated on site, incubated, and counted using techniques described in Myers and Wilde (2003).

\section{Specific Conductance, $\mathrm{pH}$, and Temperature}

Water from wells in the carbonate formations exhibited little variation in specific conductance, $\mathrm{pH}$, and temperature, and were within the ranges typical of carbonate rocks in the area (app. 6). Specific conductance varied from 565 to 3,180 microsiemens per centimeter $(\mu \mathrm{S} / \mathrm{cm})$ (app. 6) with a median value of $623 \mu \mathrm{s} / \mathrm{cm}$. Well Jef-0587 (in app. 6 and site 36 on fig. 1 and in table 1) had the highest specific conductance within the carbonate formations $(975 \mu \mathrm{S} / \mathrm{cm})$; was greater than $350 \mu \mathrm{S} / \mathrm{cm}$ above the median, and reflects longer contact and residence time of ground water at depth or mixing with deeper connate waters, or both. Another well (Jef-0603 in app. 6 and site 34 on fig. 1 and in table 1) was completed at the contact between the Chambersburg Limestone and the Martinsburg Formation along a thrust fault. The ground-water chemistry from this well (app. 6) is not typical of the carbonate-rock formations, reflects both interactions from carbonate and non-carbonate bedrock, and is affected by water from deeper within the formation. Specific conductance of water from this well was $3,180 \mu \mathrm{S} / \mathrm{cm}$, reflecting intense mineral dissolution as a result of geochemical reactions between the overlying carbonate and underlying shale strata and mixing with deeper connate waters. The $\mathrm{pH}$ of all water samples varied little and ranged from 6.6 to 7.0 , with a median of 6.7. These $\mathrm{pH}$ values are typical of water from carbonate rocks in the region (table 17).

Water temperature of all samples varied from 11.4 to $15.3^{\circ} \mathrm{C}$ with a median of $13.6^{\circ} \mathrm{C}$. There was no apparent correlation between water temperature and well depth, which may indicate mixing of water from multiple levels within the openbedrock boreholes sampled. Hourly measurements of water temperature were collected at Gray Spring (Jef-0521S - site 1 on fig. 1 and in table 1) from April 2003 through November 


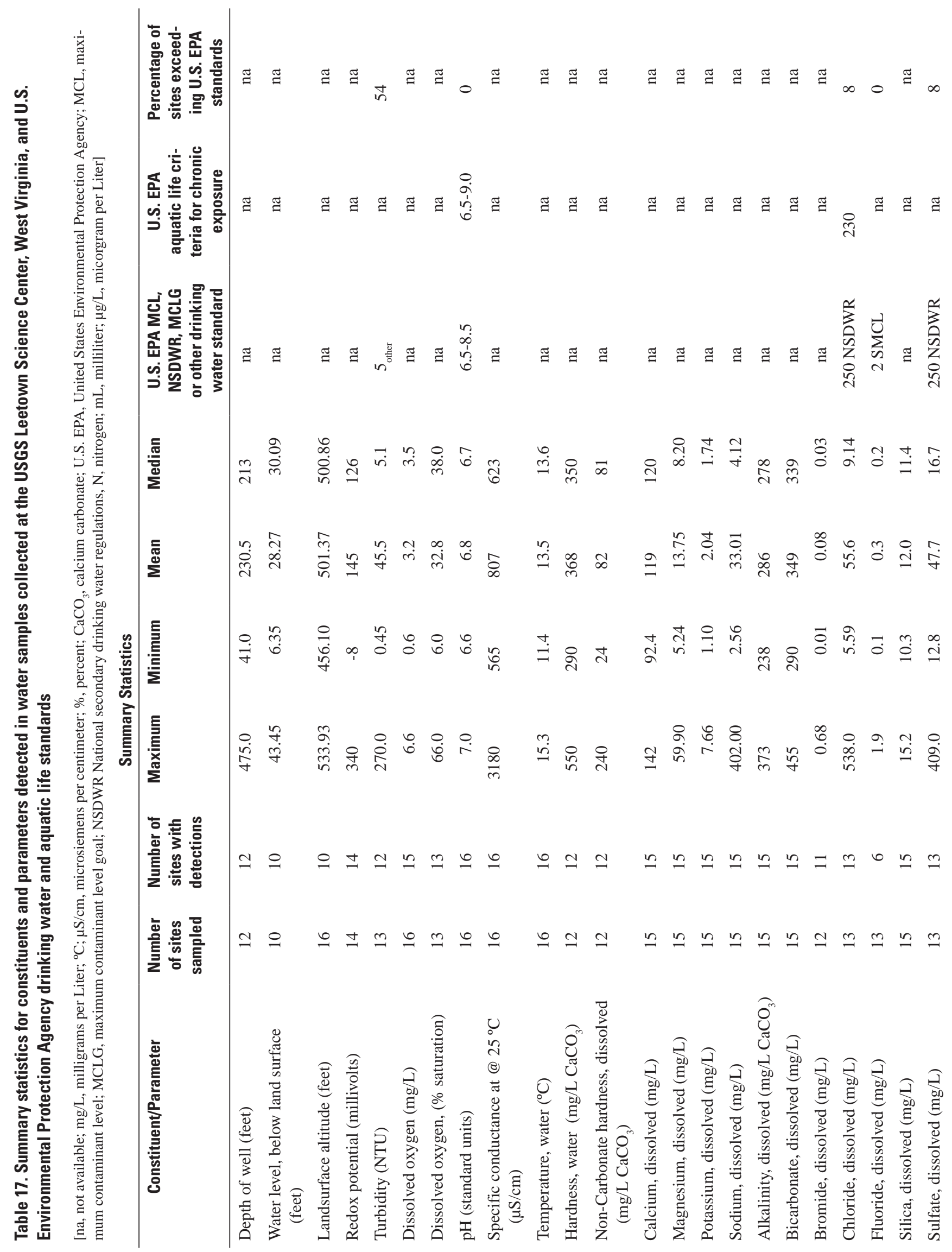




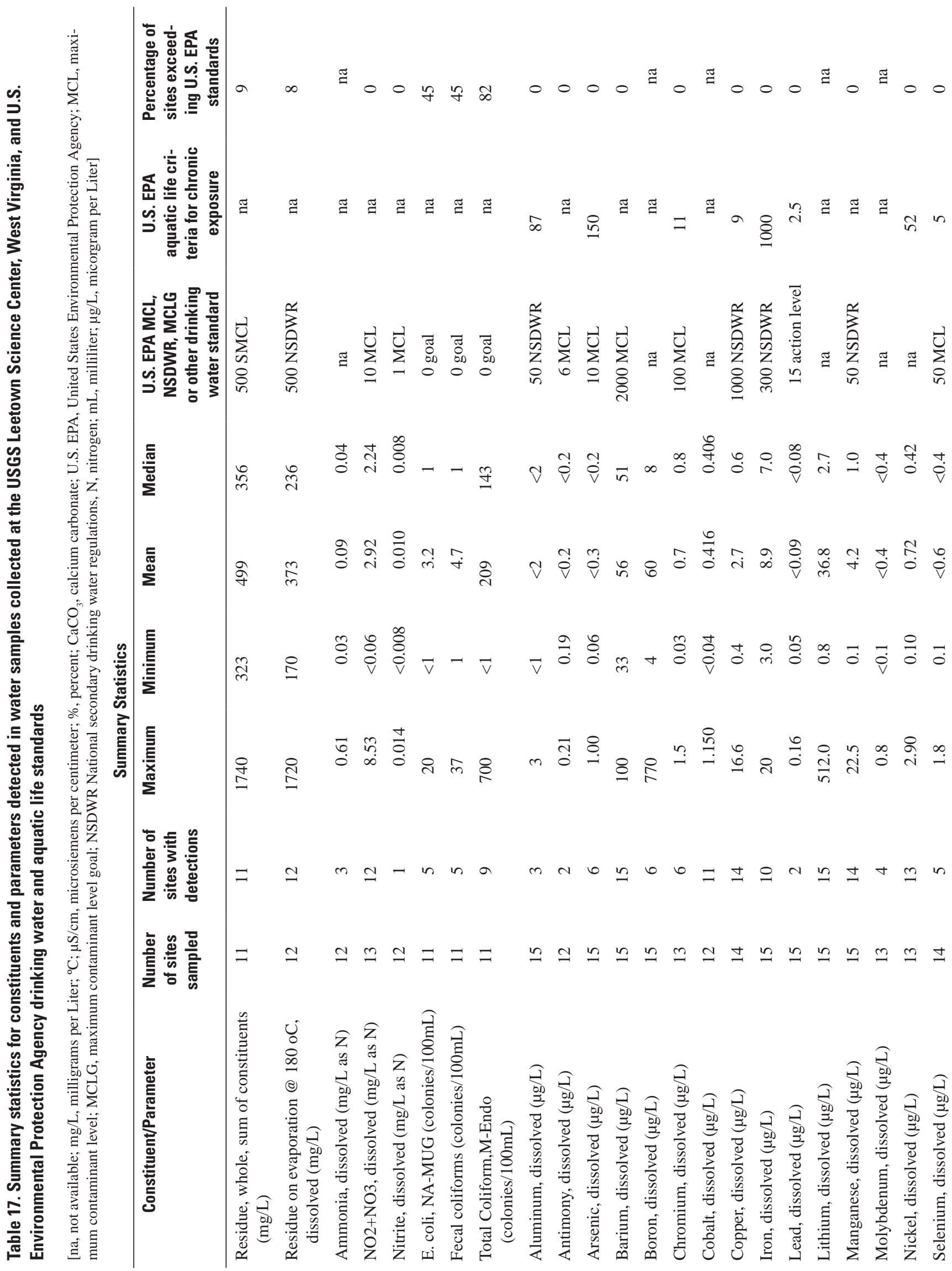




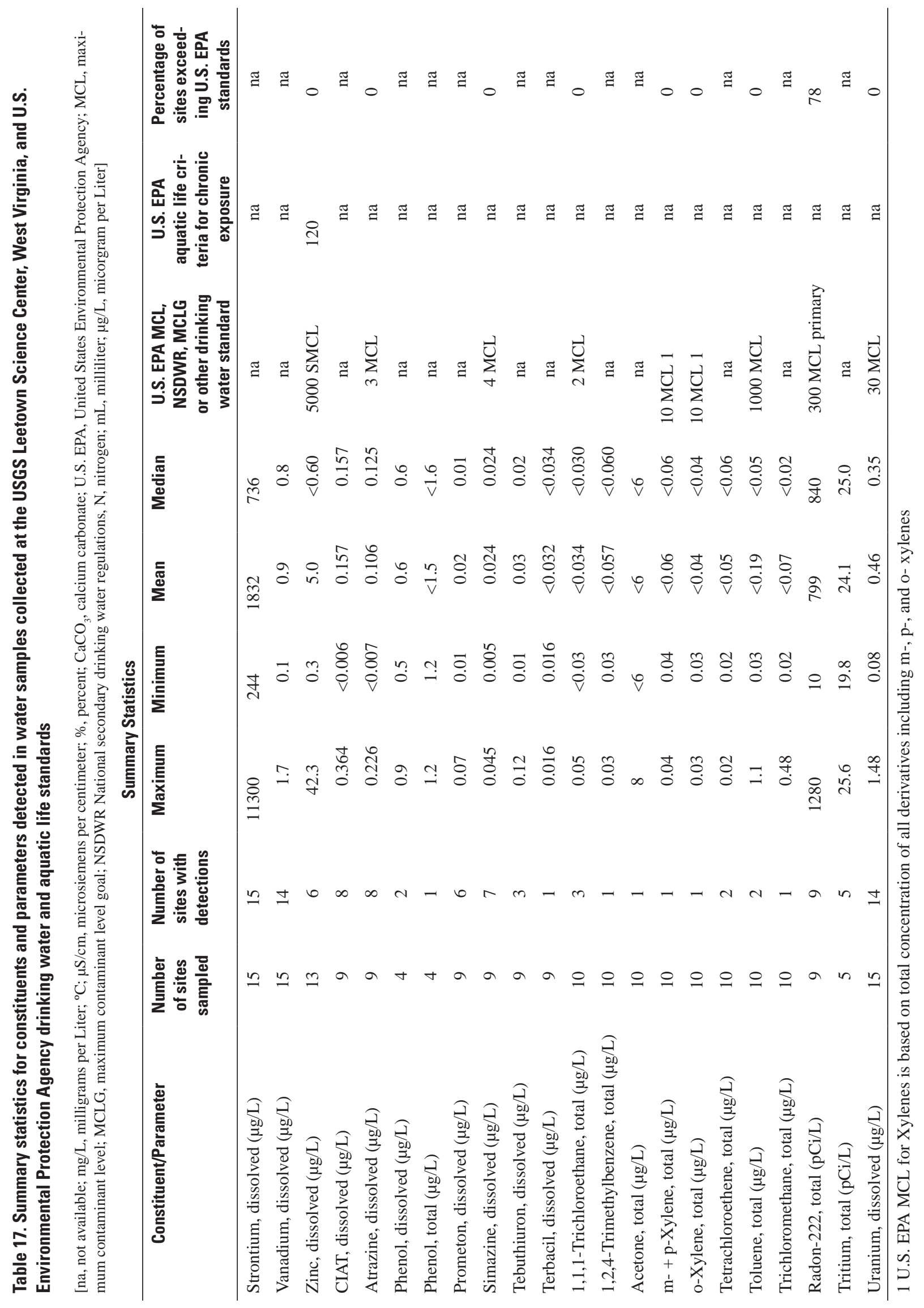


2005. A plot of the data (fig. 27) indicates that water temperature varied seasonally from a low of $10.9^{\circ} \mathrm{C}$ in February 2004 to a high of 12.8 and $12.9^{\circ} \mathrm{C}$ in June 2003 and 2004, respectively. There was no correlation between individual precipitation events and the water temperature of the spring indicating a significant source of water to the spring is derived from storage in the broad interconnected network of diffuse fractures.

\section{Dissolved Oxygen and Turbidity}

Dissolved oxygen concentrations for the wells and springs sampled (app. 6) varied from a minimum of 0.6 milligrams per liter (mg/L) in the $475 \mathrm{ft}$ deep well (Jef-0603 in app. 6 and site 34 on fig. 1 and in table 1) completed at the shale/limestone bedrock interface to a maximum of $6.6 \mathrm{mg} / \mathrm{L}$ in an upland bedrock well (Jef-0601 in app. 6 and site 37 on fig. 1 and in table 1). The dissolved oxygen concentrations are characteristic of wells in carbonate rock of the region with a median dissolved oxygen content of $3.5 \mathrm{mg} / \mathrm{L}$. The median dissolved oxygen concentration for 70 wells sampled in similar bedrock in Jefferson County (Kozar and others, 1991) was $4.4 \mathrm{mg} / \mathrm{L}$. Only the deep well previously discussed (Jef-0603) had a dissolved oxygen concentration of less than $1.0 \mathrm{mg} / \mathrm{L}$. The higher dissolved oxygen concentrations reflect the karstic nature of the bedrock in the region. The shallow epikarst in the Leetown area allows rapid infiltration of recharge to enter ground water which maintains relatively high dissolvedoxygen concentrations in ground water. Many wells in noncarbonate terranes typically have dissolved-oxygen concentrations less than $1 \mathrm{mg} / \mathrm{L}$ (Mathes and others, 1998), as evidenced by the one well (Jef-0603) with a significant contribution of water from the deeper underlying Martinsburg Formation.

Field measured turbidity for 8 wells and 3 springs sampled on the Center ranged from a minimum of 0.45 nephelometric turbidity units (NTU) to a maximum of $270 \mathrm{NTU}$ with a median of 5.1 NTU (app. 6). The USEPA goal for turbidity in drinking water is less than or equal to $5 \mathrm{NTU}$ and there is no USEPA chronic exposure turbidity standard for aquatic life. Turbidity is an important parameter to discuss for the karst ground-water flow system. Borehole video camera inspection of wells drilled at the Center indicate that all conduits intercepted contained some deposits of silt and clay, which are likely by products of dissolution of calcium carbonate bedrock and minerals, but also potentially deposited by flow and transport from upland areas dominated by non-carbonate bedrock such as the Martinsburg Formation.

High levels of turbidity in ground water are caused by several factors. First, the larger conduits tend to have a much higher percentage of silt and clay than smaller conduits. Individual fractures with little dissolution of calcium carbonate have little, if any, silt and clay deposited within them. Second, pumping rates of production wells which intersect such conduits may affect turbidity levels. This was seen during several aquifer tests conducted on the Center. In one instance, pumping a well at rates in excess of $225 \mathrm{gal} / \mathrm{min}$ produced extremely high turbidity (unquantifiable using a standard tur- bidimeter). At a pumping rate of $200 \mathrm{gal} / \mathrm{min}$, turbidity levels fell to a range between 20 and 60 NTU. At pumping rates of $185 \mathrm{gal} / \mathrm{min}$ or less, turbidity was generally not a problem, with turbidity levels less than 5 NTU common. An explanation for the higher turbidity at higher pumping rates is related to the rapid ground-water approach velocity within a conduit. At pumping levels of $225 \mathrm{gal} / \mathrm{min}$ or greater, the velocity and flow of water to the well bore through the conduit is high enough to mobilize sediments deposited within the conduit. At lower pumping rates, flow velocities to the pumping well do not attain sufficient velocity to mobilize sediments.

Unfortunately, there is no easy way to assess the potential turbidity problems of a given well, although the higher yielding wells (200 gal/min or higher) and wells developed in the larger conduits tend to be more prone to turbidity problems than lower yielding wells (100 gal/min or less). Anecdotal reports from homeowners in the area indicate that wells sometimes exhibit turbidity problems, mostly during periods of drought or periods of low-water table and many of the wells return to acceptable quality over time. While the phenomenon is not common, it does indicate the potential for a well intersecting a conduit to experience sporadic turbidity problems. Individuals planning on using ground water as a source of supply should have a contingency plan to address turbidity problems should they occur.

\section{Alkalinity, Water Hardness, and Major lons}

The alkalinity of water is defined as the capacity of the solutes it contains to react with and neutralize acid (Hem, 1992). Alkalinity is proportional to the hardness and total dissolved solids content, as both result from the dissolution of carbonate bedrock and minerals. For the wells and springs sampled at the Center, alkalinity ranged from a minimum of $238 \mathrm{mg} / \mathrm{L}$ to a maximum of $373 \mathrm{mg} / \mathrm{L}$ (app. 6). Such values of alkalinity are characteristic of ground water derived from the carbonate limestone and dolomitic rocks in the region (Kozar and others, 1991).

The hardness of water is a measure of soap-consuming capacity and is also a good indicator of the potential for encrustation of pipes with scale deposits (Hem, 1992). It is primarily a function of calcium and magnesium content but may be affected by other constituents. Because calcium and magnesium are the primary contributors to alkalinity, hardness tends to be elevated in carbonate-rich bedrock such as limestone and dolomite. Water with a hardness of $0-60 \mathrm{mg} / \mathrm{L}$ as $\mathrm{CaCO}_{3}$ is considered soft, $60-120 \mathrm{mg} / \mathrm{L}$ is considered moderately hard, $120-180 \mathrm{mg} / \mathrm{L}$ is considered hard, and more than $180 \mathrm{mg} / \mathrm{L}$ is considered extremely hard (Hem, 1992). Hardness for wells and springs sampled on the Center ranged from 290 to 550 $\mathrm{mg} / \mathrm{L}$, with a median of $350 \mathrm{mg} / \mathrm{L}$ (fig. 28). As such, all the samples are characteristic of extremely hard water and could result in the accumulation of scale deposits in boilers, pipes, or hot water heaters.

The total dissolved solids concentration of water is a function of not only the carbonate but also the non-carbonate 


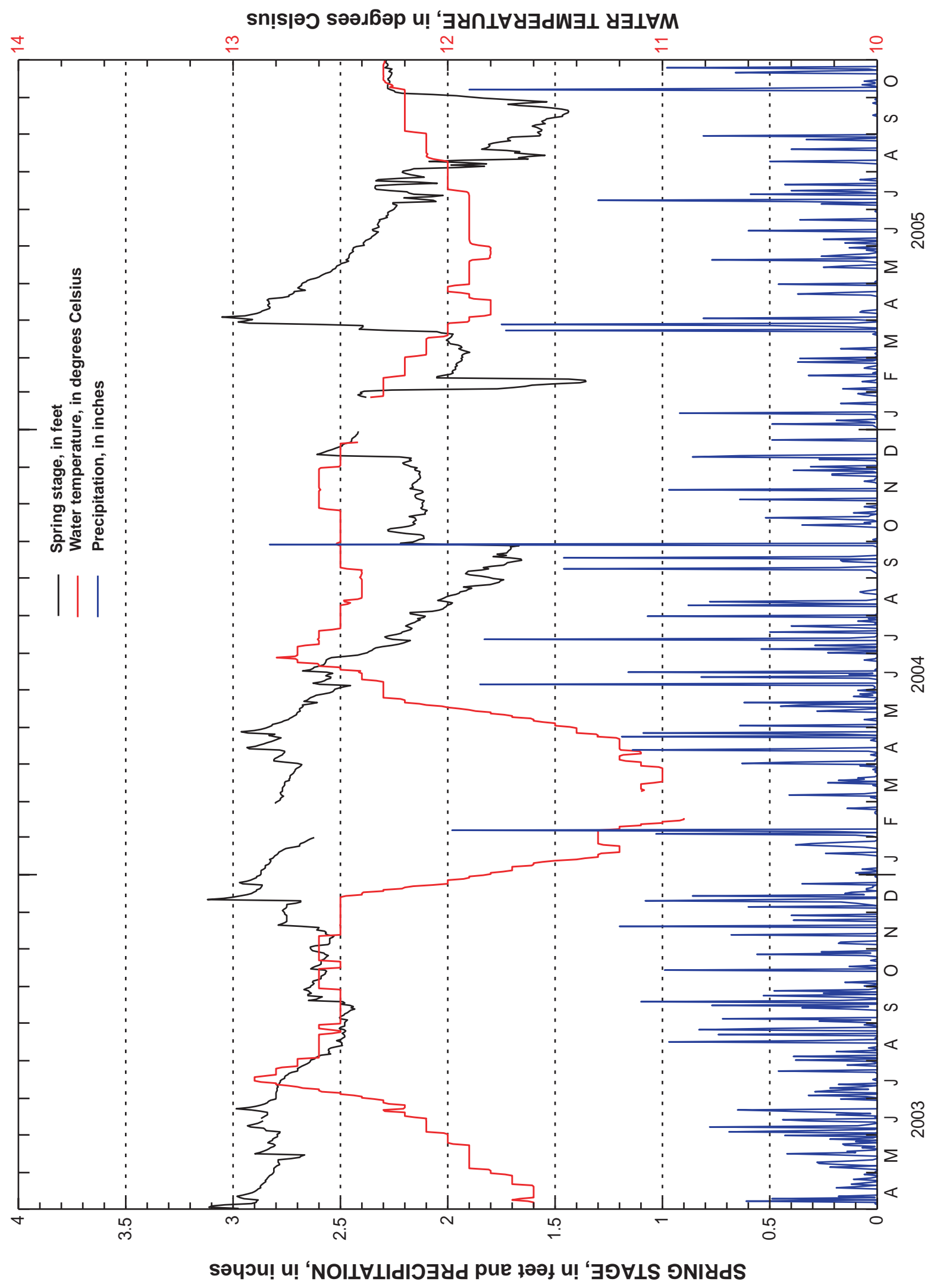

Figure 27. Water temperature, stage, and precipitation for the period from April 2003-November 2005, measured at Gray Spring, Leetown, West Virginia. [Gaps in spring stage and water temperature line plots represent periods for which no data are available.] 
minerals dissolved by contact with bedrock and minerals within the aquifer. Residue on evaporation (total dissolved solids concentration) for the wells and springs sampled at the Center ranged from 170 to $1,720 \mathrm{mg} / \mathrm{L}$ with a median total dissolved solids content of $236 \mathrm{mg} / \mathrm{L}$ (fig. 28). The site with the highest dissolved solids concentration is the well completed at the fault contact between the overlying Chambersburg Limestone and underlying Martinsburg Formation (Jef-0603 site 34 on fig. 1 and in table 1). The more chemically-aggressive water of the Martinsburg Formation mixing with the carbonate rich waters of the Chambersburg Limestone and with deeper connate waters result in a high total dissolved-solids content, with large concentrations of dissolved constituents, including chloride, sodium, sulfate, ammonia, boron, lithium, and strontium, not common in limestone dominated bedrock of the region (app. 6).

Water can be characterized by the dominant cations and anions it contains (fig. 28). With the exception of one well, samples collected from wells and springs at the Center exhibit a calcium-carbonate signature, characteristic of water from limestone and dolomitic rocks. The exception is the well (Jef-0603) tapping the fault and the Martinsburg Formation, which exhibits a sodium chloride signature. Generally, none of the water samples from wells or springs in carbonate rock have concentrations of common ions in excess of USEPA primary maximum contaminant level (MCL) or national secondary drinking water regulations (NSDWR) or aquatic life criteria (table 17). Well Jef-0603, however, exceeds USEPA NSDWRs (table 17) for chloride, sulfate, and total dissolved solids.

\section{Trace Elements}

Water samples from wells and springs sampled at the Center were analyzed for a broad suite of trace elements (app. 6 ). None of the samples had concentrations of trace elements in excess of USEPA primary or secondary drinking water standards or aquatic life criteria (table 17). However, elevated concentrations of boron $(770 \mu \mathrm{g} / \mathrm{L})$ and lithium $(512 \mu \mathrm{g} / \mathrm{L})$ were detected in water from the deep fault well (Jef-0603 in app. 6 and site 34 on fig. 1 and in table 1). Neither boron nor lithium are common in ground water in the region and the source of these constituents is not known. While boron is present in some laundry detergents, lithium is typically not found at such high concentrations in domestic waste water. Boron and lithium are common in brines and in evaporite deposits (Hem, 1992) indicating that a component of water to the well is likely derived from a deeper, connate source.

Two wells, Jef-0603 and Jef-0587, also had elevated concentrations of strontium $(8,450$ and $11,300 \mu \mathrm{g} / \mathrm{L}$ respectively), and are the deepest wells sampled during the study at 475 and $410 \mathrm{ft}$ deep respectively (app. 6). The source of the strontium in samples from these two wells is also not known but deep connate brines or minerals such a strontianite or celestite are possible sources (Hem, 1992). Some agricultural fertilizers may also contain strontium. However, given the fact that well
Jef-0603 exhibits a sodium chloride water signature, connate brines are a strong possibility.

\section{Radioactive Elements}

Samples from selected springs and wells sampled on the Center were also analyzed for the radioactive elements uranium, tritium, and radon-222 (spring samples were not analyzed for radon). Tritium is derived primarily from atmospheric testing of nuclear weapons during the Cold War and typically is present in ground water in only trace amounts. Uranium and radon are naturally-derived radioactive elements present in rock.

Radon-222 is a radioactive gas derived from the natural radioactive decay of the element Radium. Radon decays to form polonium by losing a proton, and emits an alpha particle (Otton and Gundersen, 1993). Radon is a known carcinogen and the primary health effects of inhalation of air with a high concentration of radon is an increased risk of lung cancer. The USEPA MCL for radon in indoor air is 4 picocuries per liter $(\mathrm{pCi} / \mathrm{L})$. The proposed USEPA MCL for radon in drinking water is $300 \mathrm{pCi} / \mathrm{L}$, with an alternate MCL (AMCL) of $4,000 \mathrm{pCi} / \mathrm{L}$ if indoor air mitigation programs are established to minimize the risk of inhalation of radon in indoor air (U.S. Environmental Protection Agency, 1999). Of the 9 wells sampled for radon in the Leetown area, none contained radon in excess of the 4,000 pCi/L AMCL, but 7 sites ( 78 percent) exceed the proposed drinking water standard of $300 \mathrm{pCi} / \mathrm{L}$. The maximum concentration of radon detected in the 9 wells sampled in the Leetown area was $1,280 \mathrm{pCi} / \mathrm{L}$, with a median concentration of $840 \mathrm{pCi} / \mathrm{L}$. None of the springs were sampled for radon due to the potential for degassing of radon in shallow ground water and potential data bias that might result. Radon data from 31 sites sampled between 1989 and 2006 in similar carbonate rocks (8 springs and 23 wells) in Jefferson and Berkeley Counties (U.S. Geological Survey, 2006, NWIS-Web database available at http://nwis.waterdata.usgs.gov/wv/ $n w i s / q w d a t a)$ indicate similar median radon concentrations for the wells $(610 \mathrm{pCi} / \mathrm{L})$ and springs $(695 \mathrm{pCi} / \mathrm{L})$ sampled. Given the elevated concentrations of radon detected in the Leetown area, and because most of the ground water at the Center is used indoors, testing of indoor air for radon would be appropriate. Radon mitigation measures may be needed if radon concentrations in indoor air are found to exceed the 4 pCi/L USEPA indoor air standard.

Uranium and tritium also were analyzed in ground-water samples collected at the Center. Uranium-238 and the less frequently occurring daughter products thorium-232 and uranium-235 are responsible for the majority of naturally occurring radioactivity in natural waters (Hem, 1992). The uranium nuclide is the starting point in a radioactive decay series that includes radon-222 and ends with the stable isotope lead-206. Tritium, a radioactive hydrogen isotope $\left({ }^{3} \mathrm{H}\right)$, was extensively used in the past to determine the relative age of ground water. Its usefulness for dating water declined after airborne concentrations of tritium decreased when nuclear atmospheric testing 

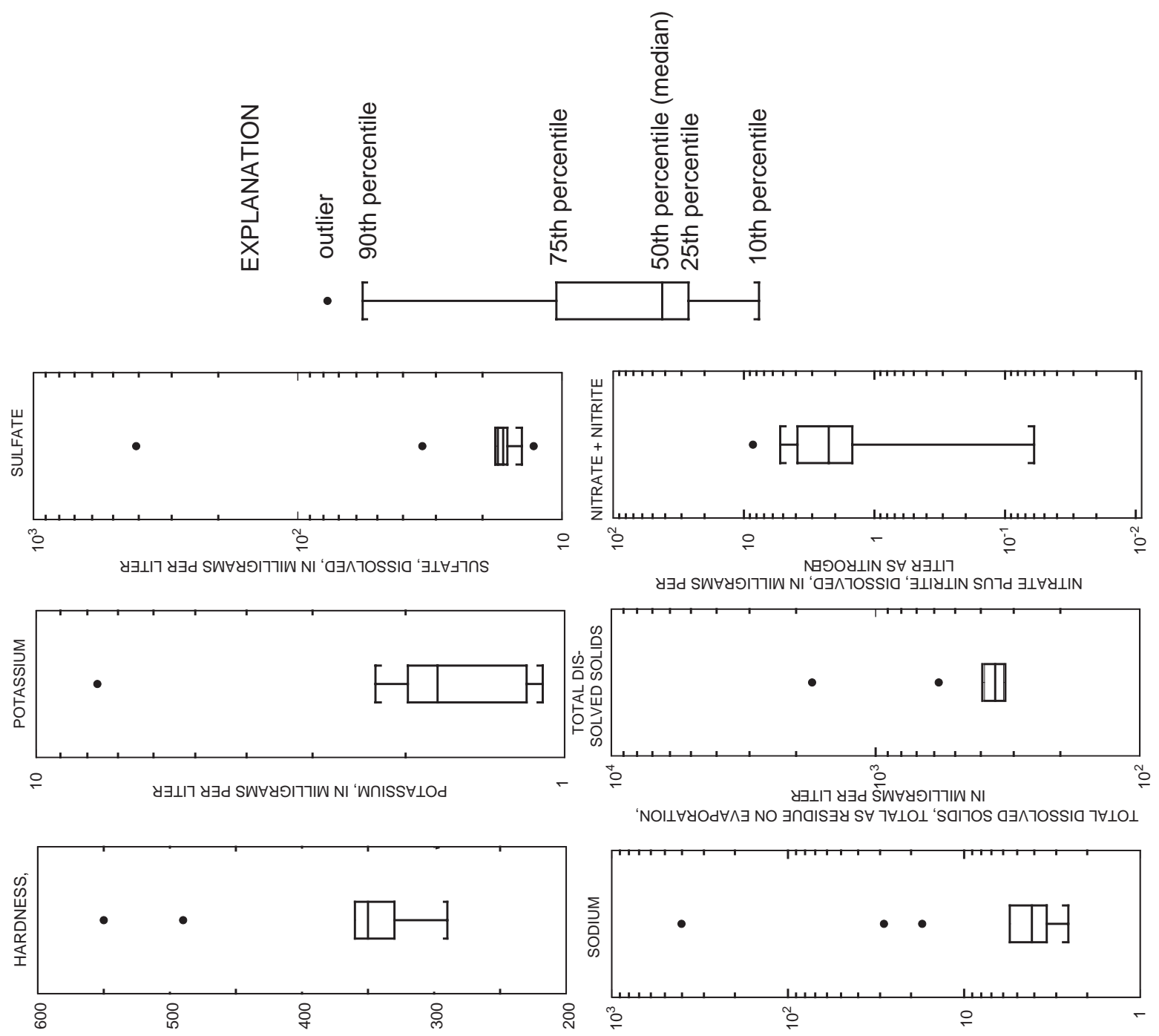

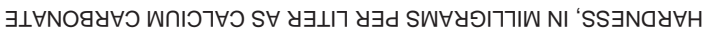
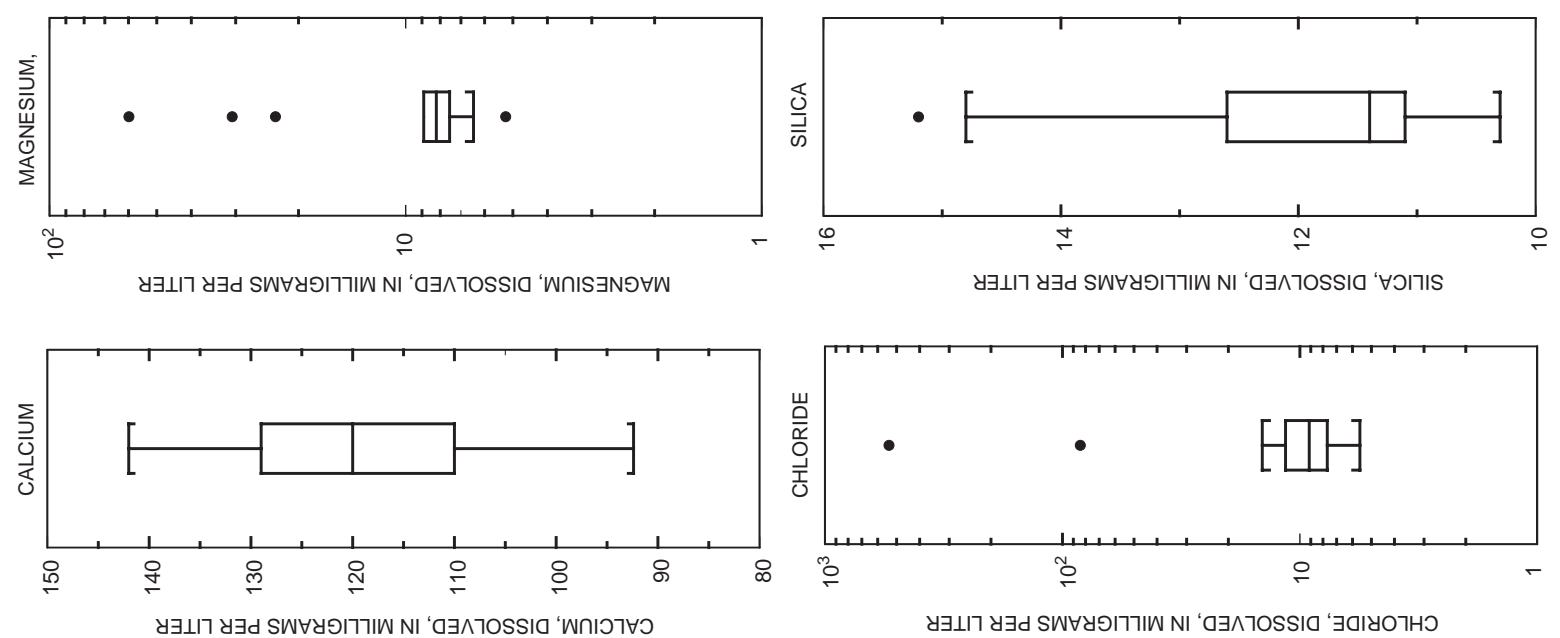

Figure 28. Distribution of concentrations of major ions, hardness, and total dissolved solids in water samples collected from 8 wells and 3 springs at the USGS Leetown Science Center, West Virginia. 
was banned in the late 1960's. It is still used in conjunction with helium as a ground-water age tracer.

The USEPA MCL for uranium in drinking water is 30 $\mu \mathrm{g} / \mathrm{L}$. None of the ground-water samples collected in the Leetown area had uranium concentrations exceeding the MCL. The maximum concentration of uranium detected in samples collected in the Leetown area was $1.48 \mu \mathrm{g} / \mathrm{L}$ with a median concentration of $0.35 \mu \mathrm{g} / \mathrm{L}$ (table 17 and app. 6). Currently, there is no USEPA MCL water standard for Tritium. At the five sites in the Leetown area sampled and analyzed for tritium, concentrations ranged from 19.8 to $25.6 \mathrm{pCi} / \mathrm{L}(6.2-$ 8.0 tritium units [TU]) with a median of $25.0 \mathrm{pCi} / \mathrm{L}(7.8 \mathrm{TU})$. Tritium levels may also be used to derive estimates of groundwater age, which will be discussed later in this report.

\section{Nutrients and Bacteria - by Mark D. Kozar}

Nutrient compounds analyzed for this study included nitrate, nitrite, ammonia, and orthophosphate. Nutrients and bacteria share common sources, primarily fecal material from animals and humans. Synthetic fertilizers, commonly used in agricultural applications, are an additional source of ammonia, nitrite, nitrate, and orthophosphorous, but would not carry the bacterial signatures common to human and animal wastes. Past investigations of ground-water quality in the Leetown area and in surrounding Jefferson and Berkeley Counties, West Virginia, have documented extensive nitrate and bacterial contamination in and around the study area (Hobba, 1976; Hobba, 1981; Kozar and others; 1991; Shultz and others, 1995; and Mathes, 2000). Microbial studies and DNA analyses of human and animal DNA present in water samples were conducted to assess potential sources of contaminants to the aquifer.

\section{Nitrogen and Phosphorous Compounds}

Eleven sites sampled at the Center had detectable concentrations of nitrate, two sites contained detectable concentrations of ammonia, and one site had a detectable concentration of nitrite (app. 6). Ammonia and nitrite are typically not present in highly oxygenated water and therefore were detected at only two sites. The deep well completed at the fault interface between the Martinsburg Formation and Chambersburg Limestone (Jef-0603 - site 34 on fig. 1 and in table 1) had an ammonia concentration of $0.61 \mathrm{mg} / \mathrm{L}$ and a shallow piezometer adjacent to a corn field (Jef-0594 - site 45 on fig. 1 and in table 1) had a very low ammonia concentration of $0.03 \mathrm{mg} / \mathrm{L}$. Nitrite was only detected at one site, (well Jef-0587 - site 36 on fig. 1 and in table 1), at a concentration of $0.014 \mathrm{mg} / \mathrm{L}$. Combined nitrate and nitrite (as nitrogen) concentrations ranged from $<0.06$ to $8.53 \mathrm{mg} / \mathrm{L}$ with a median concentration of $2.24 \mathrm{mg} / \mathrm{L}$ (table 17). None of the sites sampled exceeded the USEPA drinking water MCL of $10 \mathrm{mg} / \mathrm{L}$ for nitrate (as nitrogen) or the $1 \mathrm{mg} / \mathrm{L} \mathrm{MCL}$ for nitrite (as nitrogen) (table 17). In 1988, Kozar and others (1991) sampling for nitrate in Jefferson County, West Virginia, found that 18 of the 70 (26 percent) ground-water sites sampled contained concentrations of nitrate in excess of the $10 \mathrm{mg} / \mathrm{L} \mathrm{MCL}$. The Center does not have the widespread nitrate contamination documented in the previous studies of water quality in Jefferson County. However, a shallow well (Jef-0594 - site 45 on fig. 1 and in table 1) down gradient from a corn field, did contained an elevated concentration of nitrate $(8.53 \mathrm{mg} / \mathrm{L})$.

\section{Indicator Bacteria}

More than half of 70 ground-water samples collected in Jefferson County in 1988 contained indicator bacteria, either fecal coliform or fecal streptococcus bacteria. Ten of 11 sites sampled at the Center as part of this investigation ( 91 percent had total coliform and 5 of 11 (45 percent) sites had fecal coliform and E. coli bacteria (table 17). These frequency of bacteria detections are similar to those documented in 1988 (Kozar and others, 1991), which suggested that animal feedlots and land application of manure as a fertilizer were likely the principal sources of bacteria and nitrate within the aquifer. There has been a shift in land use in Jefferson County since 1988 to less agriculture and more residential-suburban development, principally housing subdivisions and single family homes. The impact of this shift in land use on ground-water quality is not fully understood. Deoxyribonucleic acid (DNA) and other indicators of potential animal and human source contamination were analyzed in ground-water samples collected during the study to further refine the understanding of bacterial contamination of ground water in the study area.

\section{Microbial and Molecular Studies - by William B. Schill}

Ground water in the Leetown area is subject to infiltration of contaminants from the surface that is often manifested by elevated concentrations of bacteria associated with animal and human feces. Determining the animal or human source of bacteria is further complicated by complex patterns of groundwater flow in the karst aquifers of the region. Thus, it is difficult to determine if two wells or springs access the same or different sources of water, or if potential contaminant sources may affect ground water quality narrowly or broadly.

Part of the effort to examine water quality and availability in the Leetown area was to apply, and if possible, develop new approaches and methodologies that might aid in determining quantity, quality, and connectivity of ground-water sources. These efforts focused on the application of statistical analyses and modern, molecular methods to examine the interactions of bacteria and ground-water chemistry and the development of new methods to detect DNA shed by humans and animals that is indicative of fecal contamination when transported to ground water.

Multivariate statistical analysis is a useful tool to determine correlative water chemistry parameters and to highlight relationships of wells and springs by similarities of their 
water chemistries. Incorporation of biotic parameters, such as microbial species composition, makes statistical analysis more robust and can yield clues as to sources of microbial contaminants in particular wells or springs. Because bacteria react quickly to changes in their environment, large shifts in microbial populations can be triggered by subtle environmental cues. Thus, the species composition of bacterial assemblages inhabiting ground-water sources can be a reflection of known and measured, as well as unknown and unmeasured water chemistry or pollutants. A more refined understanding of the interconnectivity of an area's springs and wells can be achieved when this information is coupled with knowledge of land use and an understanding of ground-water flow in the area. Potential recharge areas of ground-water and threats to these recharge areas can also be better defined.

Coliform bacteria, Escherichia coli (E. coli), and Enterococcus, are associated with fecal contamination. Drinking and recreational waters are commonly tested for the presence of these "indicator bacteria". Nine wells and three springs in the Leetown area were sampled and analyzed for microbial contamination (table 18). Standard membrane filtration and plating methodology was used to assay coliform and Enterococcus bacteria. Coliforms and $E$. coli numbers were determined using m-ColiBlue24® (Millipore, Billerica, MA) while Enterococcus was enumerated by growth on m-Enterococcus Agar. Digital photographs of plates were made and bacteria were counted using image-analysis techniques. All wells and springs tested in September, 2004, with the exception of the USDA-Sulfur Well (Jef-0603), contained fecal indicator bacteria. Balch Spring (Jef-0327S), a traditional water source for the old federal hatchery at the Center had (on this occasion) particularly elevated levels of total coliform (fig. 29).

Fluorescence in ground-water samples was measured in an attempt to detect dissolved compounds including laundry brighteners (Hagedorn and others, 2003; McDonald and others, 2006). Emission at $460 \mathrm{nM}$ was measured when samples were excited at $360 \mathrm{nM}$. The fluorometer (RF-Mini-150; Shimadzu Scientific Instruments, Inc., Columbia, MD) gain and scaling were adjusted so that a 0.001 percent $(\mathrm{v} / \mathrm{v})$ solution of Purex ${ }^{\circledR}$ (Dial Corporation, Macustah, IL) laundry detergent in distilled water produced a reading of 1,000 relative fluorescence units (RFU) and distilled water produced a reading of 0 RFU. Microcrystalline cellulose was extensively washed by repeatedly suspending the material in boiling distilled water and recovering it by vacuum filtration. Cycles of boiling and recovery were repeated until the filtrate showed no fluorescence. Samples were treated with 10 percent (w/v) microcrystalline cellulose and re-examined to detect the presence of laundry brighteners (determined by a reduction in fluorescence due to the removal of laundry brighteners binding to the cellulose). Fluorescence in the ground-water samples was not diminished by treating samples with 10 percent (w/v) microcrystalline cellulose. Thus, the fluorescence that was observed is related to unknown dissolved compound(s) that are probably naturally occurring. Wells Jef-0584, Jef-0590, and Jef-0327S shared high relative fluorescence values of 1159 RFU, 1204 RFU, and 909 RFU, respectively, and may be hydraulically connected. This connection is supported by hydrogeological data reported earlier in this report. The spring sources and many of the other well sources yielded much lower or interme-

\section{Table 18. Wells and springs sampled and analyzed for microbial and DNA studies at the USGS Leetown Science Center, West Virginia}

[1, USGS station name and report id as presented on fig. 1 and in Table 1; na, not applicable].

\begin{tabular}{lcll}
\hline \multicolumn{1}{c}{ Station Name } & $\begin{array}{c}\text { Overall Depth } \\
\text { (feet) }\end{array}$ & \multicolumn{1}{c}{ Station Name/Report ID ${ }^{1}$} & \\
\hline USDA sulfur well & 200 & Jef-0603 (34) & Sample Dates \\
USDA fault well & 201 & Jef-0586 (60) 13-17, 2004, May 2-6, 2005 \\
low road well & 410 & Jef-0587 (36) & Aug. 28, 2005 \\
stable A well & 312 & Jef-0601 (37) & Sept. 13-17, 2004, May 2-6, 2005 \\
anticline well & 260 & Jef-0589 (41) & Sept. 13-17, 2004, May 2-6, 2005 \\
ball field well & 160 & Jef-0590 (48) & Sept. 13-17, 2004, May 2-6, 2005 \\
old Dodson farm well & 61 & Jef-0602 (55) & Sept. 13-17, 2004, May 2-6, 2005 \\
boneyard upper well & 105 & Jef-0584 (49) & Sept. 13-17, 2004, May 2-6, 2005 \\
Tabb lower piezometer & 43 & Jef-0594 (45) & Sept. 13-17, 2004, May 2-6, 2005 \\
Balch Spring & na & Jef-0327S (4) & Sept. 13-17, 2004, May 2-6, 2005 \\
Gray Spring & na & Jef-0521S (1) & Sept. 13-17, 2004 \\
Blue Spring & na & Jef-0659S (2) & Sept. 13-17, 2004 \\
\hline
\end{tabular}




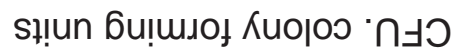

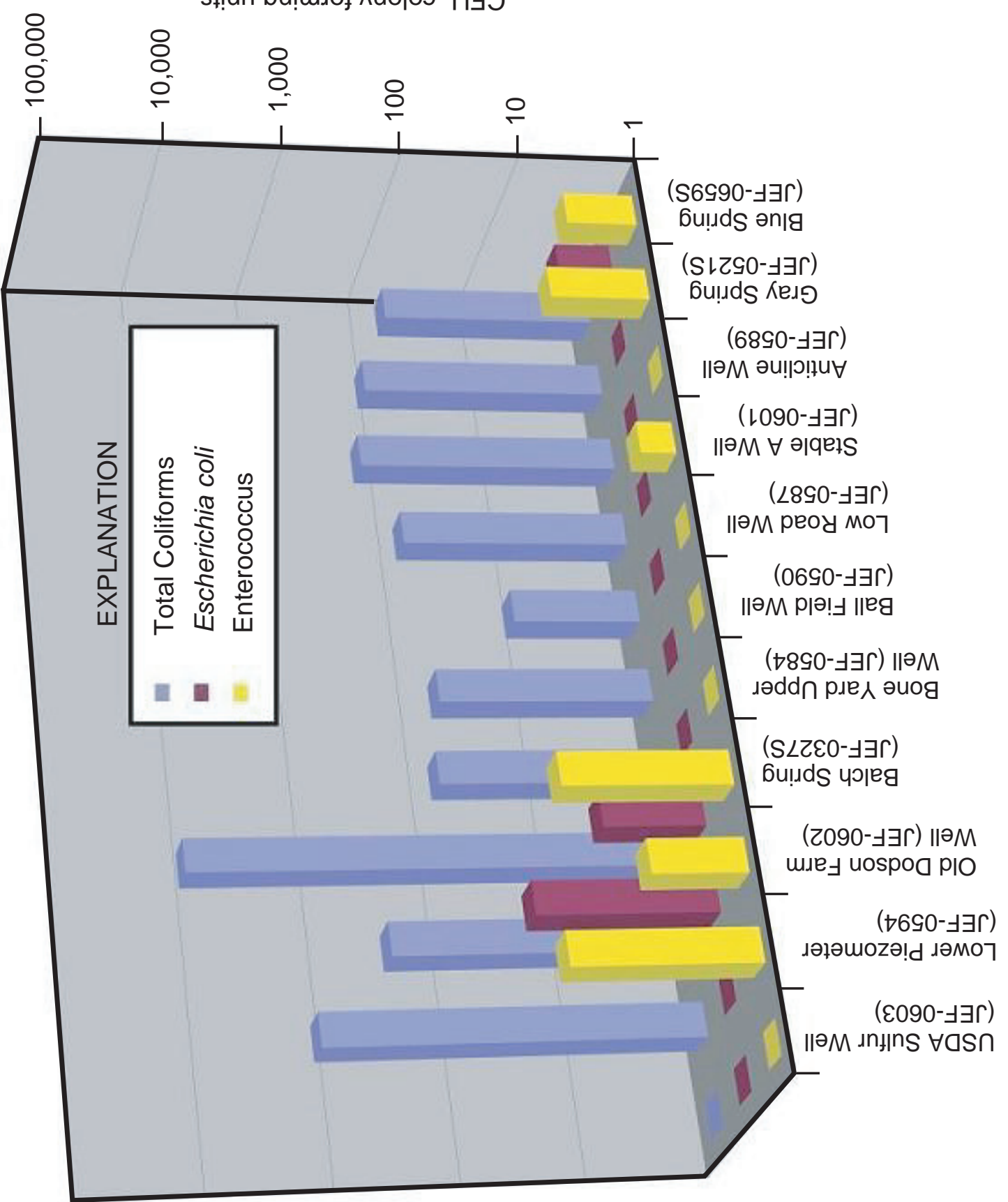

Figure 29. Microbial contamination observed in September, 2004 for wells and springs sampled at the USGS Leetown Science Center, West Virginia. 
diate fluorescence $[$ Jef-0603 $=181$ RFU, Jef-0589 = 272 RFU, Jef-0587 = 409 RFU, Jef-0601 = 431 RFU, Jef-0602 = 568 RFU, Jef-0594 = 659 RFU, Jef-0753 = 256 RFU, Jef-0521S = 272 RFU, Jef-0659S = 318 RFU).

Multivariate statistical analyses were performed to examine relationships among water chemistry (abiotic) and microbial (biotic) water quality parameters (fig. 30). Classical (metric solution) multidimensional scaling (CMDS) as implemented in NCSS (NCSS, Kaysville, UT) revealed some interesting correlations. First, fecal indicator bacteria were directly associated with turbidity and nitrate as might be expected. Second, blue fluorescence measured as described earlier, was directly associated with the stable isotope signatures of $\mathrm{H}^{2}$ and $\mathrm{O}^{18}$ and thus is probably another indicator of surface influence. Dissolved oxygen and phosphate also cluster in this area of the plot. CMDS was also used to examine relationships among Center wells and springs as reflected in abiotic and biotic water quality constituents. Abiotic constituents were first analyzed alone and resulted in the CMDS map shown in figure 31a. The uniqueness of the USDA sulfur well (Jef-0603) is apparent (fig. 31a); as are the similarities of the ball field (Jef-0590), bone yard upper (Jef-0584) wells, and Balch Spring (Jef-0327S). Other possible relations resulting from this analysis include that of Blue Spring (Jef-0659S) and Gray Spring (Jef-0521S) and that of the anticline well (Jef-0589) and the new Kaiser Farm Well (Jef-0753). It is important to understand that while these relations may imply physical connectivity, only similarities of water chemistry are actually indicated. Some relations delineated by water chemistry remain while others are disrupted when the biotic (microbial) parameters are added to the analysis [fig. 31b]. Notable are the shifts of Balch Spring (Jef-0327S) away from the ball field (Jef-0590) and bone yard upper (Jef-0584) wells and the displacement of the position of the old Dodson farm well (Jef-0602). Comparison of the relations depicted in figures 31a and $31 \mathrm{~b}$ reveal potential microbial contamination of otherwise similar (or possibly connected) sources.

Many studies have focused on identification of contamination source by typing bacterial strains thought to be specific to humans or other animals. These efforts have generally not been successful when fully tested (Stoeckel and others, 2004). One reason for these failures is that many targeted bacteria

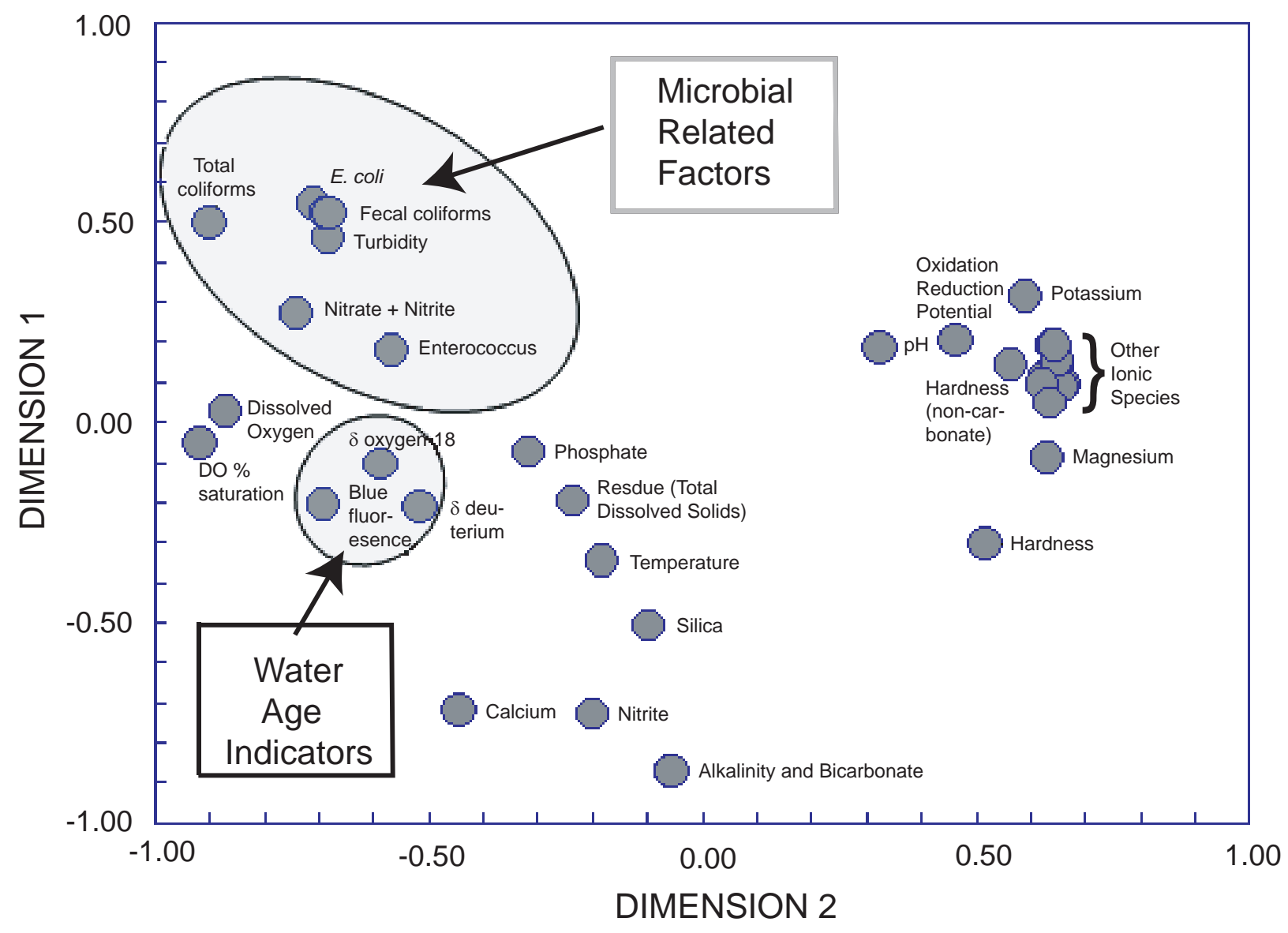

Figure 30. Multidimensional scaling analysis showing the relations between abiotic and biotic parameters for 12 ground-water sources in the Leetown area, West Virginia. [Dimensions 1 and 2 are normalized measures of Euclidian distance determined from pairwise comparisons of parameters projected onto a two-dimensional map. The first shows a correlation of fecal indicators, turbidity, and nitrate + nitrite. The second shows the correlation of blue fluoresence with d oxygen-18 and d deuterium (measures of water age or residence time).] 

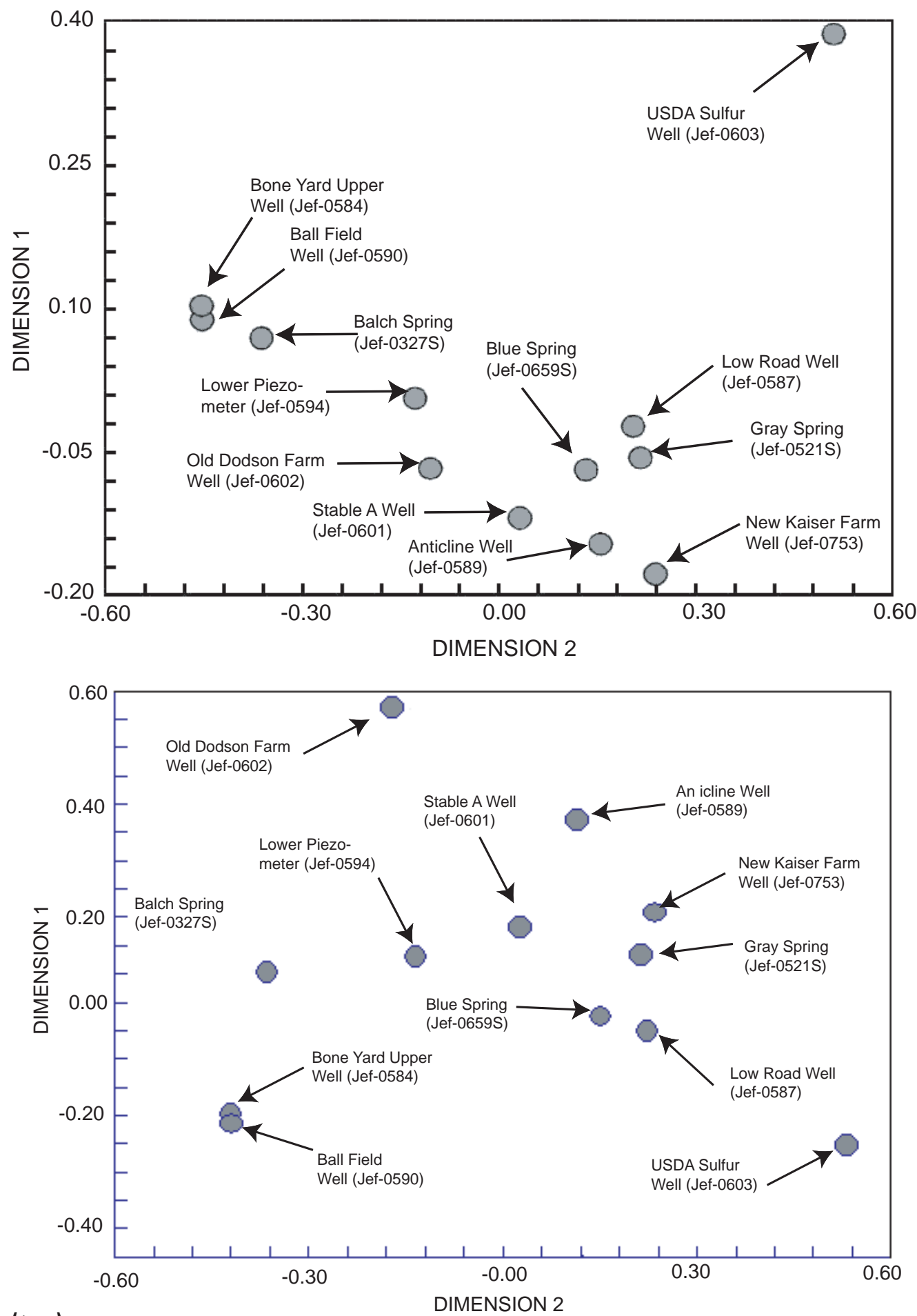

Figure 31a (top). Multidimensional scaling analysis (abiotic parameters only) showing the relations between 12 ground-water sources in the Leetown area, West Virginia. [Dimensions 1 and 2 are the normalized measures of Euclidian distance determined from pairwise comprisons of parameters and projected onto a two-dimensional map. Note the clustering of wells Jef-0584 and Jef-0590 with Balch Spring.]

31b (bottom). Multidimensional scaling analysis (biotic and abiotic parameters) showing the relations between 12 groundwater sources in the Leetown area, West Virginia. [Dimensions 1 and 2 are the normalized measures of Euclidian distance determined from pairwise comprisons of parameters and projected onto a two-dimensional map. Note the relative positions shift somewhat when microbial parameters are added).] 
are not totally specific to any particular host and readily move from one host (animal or human) to another. The detection of human or animal DNA shed from the intestinal tract directly eliminates this confounding factor. During the course of this study, Center scientists applied general approaches typically used for the characterization of ancient DNA (from extinct animals, mummies, and so on) and forensic analysis to the identification of human and animal DNA present in ground and surface waters. Quantitative polymerase chain reaction (PCR) (Heid and others, 1996; Morrison and others, 1998; Wittwer and others, 1997) was used to detect and measure amounts of dissolved human and other animal DNA present.

Water samples $(1,000 \mathrm{ml})$ were filtered $(47 \mathrm{~mm}, 0.45$ micron cellulose acetate) through sterile filtration devices to collect and concentrate bacteria and particulate-bound DNA. Sterilization and decontamination of filtration setups were accomplished by soaking the apparatus (without filters) in 10 percent household bleach for 30 minutes, rinsing thoroughly with sterile distilled water, and autoclaving 20 minutes. Just before use and after installation of the membrane filter, the device was irradiated with ultraviolet light to further insure against laboratory contamination. For quality control, $100 \mathrm{ml}$ of distilled water was passed through the filter apparatus to detect any possible laboratory contamination from filter units and extraction/ purification reagents. Filters were frozen for later processing. DNA from bacteria and particulates retained by filtration was obtained from the frozen filters using a Water Kit (MoBio, Carlsbad, CA) following the manufacturer's instructions. The filtered water was processed to concentrate and purify dissolved DNA. Dissolved DNA was obtained from the filtrate of the samples and was concentrated and purified according to a previously published method (Matsui and others, 2004) with minor modifications. Specifically, 0.25 M EDTA was used to re-dissolve precipitated DNA complexes and chelate calcium and magnesium, rather than the TE buffer used in the original procedure. Recovered DNA was further purified by combining it with the corresponding reserved, frozen filter and extraction with a Water DNA Kit (Epicentre, Madison, WI) following the manufacturer's instructions. The purified DNA was further concentrated by ultra-filtration using an Amicon Ultra-4 30,000 MW spin concentration device (Millipore, Billerica, MA).

Quantitative polymerase chain reaction (QPCR) was used to detect host DNA sequences, specifically the presence of mitochondrial cytochrome b sequences from humans (Homo sapiens) and cows (Bos taurus), using methods developed at the Center during the course of this project. These methods are similar in approach, but developed independently, from that of Martellini and others (2005). Significant differences, that should increase the sensitivity of detection, are that targeted sequences were smaller in this study (approximately 100-200 base pairs) as opposed to those published by Martellini (400-934 base pairs). Targeting smaller sequences should yield increased sensitivity in detecting the DNA expected to be degraded in the environment. Also, Martellini and others (2005) only analyzed DNA that was retained by filters or sedimented by centrifugation while the current study adapted techniques for concentrating and purifying dissolved DNA as described above. Moreover, the current study used QPCR that is inherently more sensitive than the gel electrophoresis used in the previous study.

Reactions $(25 \mu \mathrm{L})$ were conducted using a Corbett RotorGene instrument using SYBR Green detection as described earlier. Absolute standards for mitochondrial sequences were not available, so human placental DNA and calf thymus DNA (Sigma, Chicago, IL) were used as surrogates. Decimal dilutions of the surrogate standard DNAs were used to generate standard curves that were, in turn, used to estimate the amounts of human DNA and cow DNA in samples. During the melting curve analysis, double-stranded DNA products are dissociated (melted) by increasing temperature and monitoring the dissociation of these gene fragments. This is accomplished by following the decrease in the fluorescence of a dye (SYBR Green) that binds specifically to double-stranded DNA as particular fragments dissociate. Each peak represents a fragment with a unique composition and thus represents a particular bacterial species or strain in the assemblage (fig. 32).

Four wells and one spring were tested for the presence of human and cow DNA. Balch Spring (Jef-0327S) had high levels of microbial contamination (total coliform bacteria) but the ball field well (Jef-0590) had very low levels of microbial contamination. Both sources contained human DNA, but the Balch Spring (Jef-0327S) level was greater than 30 times that of the ball field well (Jef-0590) which was just above background. Thus, Balch Spring (Jef-0327S) seems to have some source of fecal contamination not shared with the ball field well (Jef-0590). Streamflow measurements and aquifer tests documented earlier in this report indicate that the East Branch of Hopewell Run loses water to the fault on which Balch Spring is situated. The East Branch has numerous cattle in its upland recharge area, and manure from these animals is believed to be one of the sources of bacterial contamination detected in Balch spring. Another well (USDA fault well; Jef-0586) to the north appears to be connected to Balch Spring (Jef-0327S) and has shown high levels of fecal contamination, the source of which is both human (majority) and cow, as identified directly by DNA analysis. This area is immediately down gradient from pastures and a large cluster of single family homes. A connection between this area and Balch Spring (Jef-0327S) was established by fluorometric dye-tracer tests conducted during the investigation (Test 6 , this report).

Two additional wells were drilled to augment water supplies for the Center. Both are on the eastern parts of the Center property adjacent to Hopewell Run. The first is located on the former Dodson farm property (new Dodson farm well; Jef-0752), while the second is located on the former Kaiser Farm property (new Kaiser farm well; Jef-0753). Both were tested for microbial contamination as well as human and animal DNA. The new Dodson farm well (Jef-0752) was found to be contaminated with coliform bacteria (1,320 colony forming units (CFU) / $100 \mathrm{ml}$ of sample), Escherichia coli (40 


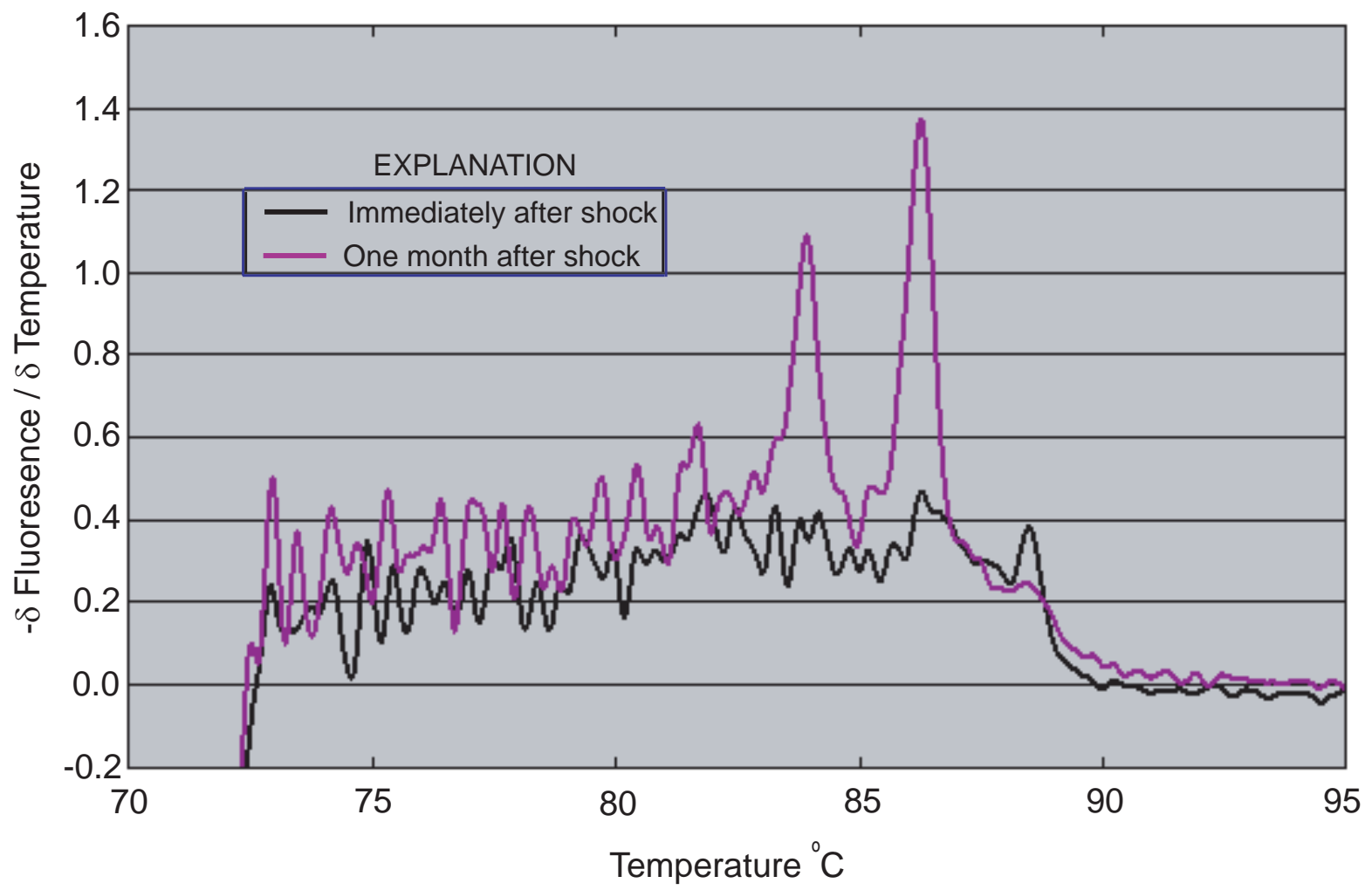

Figure 32. Melting curve analysis of bacterial $16 \mathrm{~S}$ ribosomal DNA gene fragments amplified by polymerase chain reaction from the bacterial assemblage of the new Kaiser farm well, Leetown, West Virginia, on two occasions. $[\delta$ (delta), indicates the change in fluoresence over time]

CFU / $100 \mathrm{ml}$ ), and Enterococcus (30 CFU / $100 \mathrm{ml}$ ). Human DNA was also detected. The new Kaiser Farm well (Jef-0753) initially was only lightly contaminated with fecal indicator bacteria and was further investigated as a potential production source for the Center. The well was shocked with chlorine, purged, and retested. Following the shock on March 14, 2006, no fecal indicator bacteria were identified, and no human or animal DNA was detected. Other bacterial indicators, such as Bacteroides and Cyanobacteria, were only detected at trace levels. Bacteroides is a marker indicative of fecal contamination (Dick and Field, 2004) and Cyanobacteria is a marker associated with a surface connection (Janse and others, 2003). The well was retested approximately one month later (April $16,2006)$ after a small rain event. At this time coliform, $E$. coli, and Enterococcus bacteria were detected, but the levels of Bacteroides, Cyanobacteria, and total bacterial DNA as measured by QPCR (Bertilsson, Cavanaugh, and Polz, 2002) did not change significantly (less than or equal to 3 percent). This seems to rule out a bulk influx of bacteria into the well as a source of the fecal indicator bacteria, and may support the premise that the indicators have re-grown or slowly migrated back into the well from refugia in the aquifer after the chlorine shock. A shift in the bacterial assemblage species composition after the chlorine shock was detected by QPCR and melting curve analysis. The increase of some prominent bacterial species in the second sample relative to the first was observed (fig. 32). After one month and a rainfall event, the bacterial assemblage composition was found to have changed dramatically from that observed immediately after the well was chlorine shocked. These changes are reflected by the differing traces (fig. 32).

Taken together, the bacterial and molecular investigations support the hydrogeological interpretations of potential recharge areas to the Center's springs and wells previously discussed. These are (1) deeper connate water such as that found at the fault contact between the Martinsburg Formation and overlying carbonate units, (2) the Blue and Gray Springs complex whose recharge area is principally to the south and east of the Center along a series of coalescing thrust faults, (3) the large network of diffuse fractures that connects Balch Spring with sources to the north and is influenced by shallow epikarstic flow and leakage of streamflow from the nearby East Branch of Hopewell Run, and (4) a similar diffuse-flow source, but located to the east, north of Hopewell Run and south of Hite Road (northeast of the Center) and is the principal recharge area for the new Kaiser Farm well (Jef-0753). Any future application of these microbial and molecular methods should be directed toward simplifying and standardizing methods to allow wider application of these newly developed molecular approaches to the study of ground water. Further and more frequent sampling of the Center water sources will 
be required to determine what conditions exacerbate or ameliorate ground water contaminant concentrations.

\section{Organic Constituents - by Mark D. Kozar}

A wide variety of pesticides and volatile and semi-volatile compounds were analyzed in water samples collected at the Center to assess the potential migration of contaminants from a former USEPA Superfund pesticide disposal site and the Jefferson County, West Virginia landfill and active refuse transfer station (sites A and B on fig. 1 and in table 1). Both sites are up gradient of the Center and in the recharge areas of the Center's principal springs and well fields.

Most of the inorganic constituents previously discussed, with the exception of the nutrient compounds, are derived primarily from natural geochemical processes. Organic constituents, with a few minor exceptions, are mostly derived from anthropogenic (human) sources. Organic compounds sampled in wells and springs in the Leetown area include triazine, carbamate, and nitrile herbicides, organophosphorous and organochlorine insecticides, volatile organic compounds (VOCs), semi-volatile organic compounds, and waste-water compounds. A full list of all analytes is presented in Appendix 6.

\section{Pesticides}

Of the 82 pesticides analyzed in water samples collected from 6 wells and 3 springs on the Center, only 6 were detected, including atrazine, CIAT, prometon, simazine, tebuthiron, and terbacil at maximum concentrations of 0.226 , $0.364,0.070,0.045,0.120$, and $0.016 \mu \mathrm{g} / \mathrm{L}$ respectively (app. 6). Atrazine and CIAT were commonly detected, found in water from 8 of 9 sites sampled. Simazine was detected in 7 samples, prometon in 6 samples, tebuthiron in 3 samples, and terbacil in 1 sample. Much of the area adjacent to the Center is currently, or was previously, used for agricultural crops (such as corn, soy beans and other crops). There were also several orchards on land now maintained by the Center. None of the sites sampled contained pesticides in concentrations in excess of USEPA drinking water standards or aquatic life criteria.

\section{Volatile and Semi-Volatile Organic Compounds}

Approximately 85 VOCs, 63 semi-volatile compounds, and 67 constituents commonly detected in waste water were also analyzed for in water samples (app. 6) collected from 10 sites, (7 wells and 3 springs). Only 4 sites (1 well and 3 springs) were sampled for the waste water compounds. Of the 215 non-pesticide organic compounds analyzed, 10 were detected in water from at least one of the sites sampled (app. 6 ). These include: 1,1,1-trichloroethane detected in samples from 3 of 10 sites; phenols, tetrachloroethene, and toluene in 4 of 10 sites sampled; and 1,2,4-trimethylbenzene, acetone, $\mathrm{m}+$ p-xylenes, o-xylene, and trichloromethane detected only once. As with the pesticides, none of the sites sampled had concentrations of volatile, semi-volatile, or waste-water compounds that exceeded USEPA drinking-water standards or aquaticlife criteria. Acetone was detected at a concentration of 8.0 $\mu \mathrm{g} / \mathrm{L}$ and toluene was detected at a concentration $1.1 \mu \mathrm{g} / \mathrm{L}$ at separate sites. All other concentrations of non-pesticide organic compounds detected were less than $1.0 \mu \mathrm{g} / \mathrm{L}$. None of the constituents analyzed were present in concentrations exceeding USEPA drinking-water standards or aquatic-life criteria (table 17) The $8.0 \mu \mathrm{g} / \mathrm{L}$ detection of acetone was the highest concentration of any pesticide, VOC, or semi-volatile compound detected and likely was contaminated in an isolated event during drilling or development of the well.

\section{Ground-Water Age Constituents and Radionuclides - by Mark D. Kozar}

Chlorofluorocarbons (CFCs) are stable compounds developed in the late 1930's that are commonly used as refrigerants and solvents. Three CFC compounds, trichlorofluoromethane (CFC-11), dichlorodifluoromethane (CFC-12), and trichlorotrifluoroethane (CFC-113), are commonly used as environmental tracers in ground-water investigations. Because CFCs are relatively stable in an aquifer under ideal conditions, ground water preserves a record of the prevailing CFC atmospheric concentrations at the time infiltration reaches the water table. Therefore, the apparent CFC recharge date of the water sample can be computed by comparing calculated partial pressures of CFCs in solubility equilibrium with the sample to historical concentrations of CFCs in the North American atmosphere from about 1940 to the present (Busenberg and Plummer, 1992; Plummer and others, 1993; and Plummer and Busenberg, 2000).

Ground-water age dating with CFCs is based on partitioning of CFCs between the gas phase and the liquid phase at the base of the unsaturated zone. This partitioning is governed by Henry's Law of solubility and requires knowledge of recharge temperatures estimated from dissolved gas data (Busenberg and Plummer, 1992).

\section{Dissolved Gases}

Ground-water samples were collected for analysis of dissolved gases at five CFC sampling sites to estimate groundwater recharge temperatures (table 19). Dissolved-gas data for the wells at the Center are presented by White and Mathes (2006). To calculate air-equilibrium CFC concentrations in a sample, it is critical that the temperature of water recharging the aquifer be measured or estimated as accurately as possible from $\mathrm{N}_{2}$-Ar solubility data (Heaton, 1981). Recharge temperature estimates are calculated by plotting $\mathrm{N}_{2}$-Ar solubilities, at total pressures of $760 \mathrm{~mm} \mathrm{Hg}$ and excess-air contents of 0 to $20 \mathrm{~cm}^{3} / \mathrm{kg} \mathrm{H}_{2} \mathrm{O}$, against $\mathrm{N}_{2 \text { - }}$ and Ar-concentration data collected from the wells sampled for CFCs (Weiss, 1970). 
Recharge temperature estimates from the 5 wells at the Center ranged from 11.4 to $15.9{ }^{\circ} \mathrm{C}$; mean annual air temperature 10 miles from the Center at Martinsburg, West Virginia is $12.1{ }^{\circ} \mathrm{C}$ (NOAA, 2006).

Like the $\mathrm{N}_{2}$ and Ar data, dissolved-methane concentrations can be used to identify samples for which input parameters into $\mathrm{CFC}$-age calculations need careful consideration. Methane can be of natural origin in reducing environments or produced from microbial degradation of VOCs. The degradation of CFCs in anoxic conditions can affect ground-water recharge temperature and $\mathrm{CFC}$ age estimates. In these reducing environments where CFCs are degraded primarily by dechlorination reactions that produce hydrochlorofluorocarbons (HCFCs), the CFC method results in apparent ages that are older than the actual age of the sample. Only one of the CFC sample sites at the Center (Jef-0603 - site 34 on fig. 1 and in table 1) contained methane $(3.2 \mathrm{mg} / \mathrm{L})$. Jef-0603 is completed at the contact between the Chambersburg Limestone and the underlying Martinsburg Formation.

\section{Tritium}

Water samples from 2 wells and 3 springs were analyzed for tritium; concentrations ranged from 19.8 to 25.6 $\mathrm{pCi} / \mathrm{L}$ with a median of $25.0 \mathrm{pCi} / \mathrm{L}$, roughly equivalent to 7.83 tritium units (TU). Current tritium concentrations in the atmosphere are approximately 8.2 TU and concentrations prior to 1953 typically were less than 8.8 TU. Thus, reconstruction of local tritium atmospheric curves for the Leetown area indicate that such low tritium concentrations (6.2 to $8.0 \mathrm{TU}$ ) are probably representative of either older water, prior to the mid-1960's bomb peak (> 40 years in age) or are very young, recently recharged water $(<6$ years in age). Another possibility is that the tritium data represent a mixture of older and younger ground water. It is probable that significant components of both older and younger water are reflected in the samples. The younger water would represent the rapid flow detected in the epikarst by dye-tracer tests and the older water would represent deeper flow in the diffuse-flow dominated network of interconnected fractures.

\section{Chlorofluorocarbons}

The three chlorofluorocarbon compounds (CFCs) commonly used to estimate the apparent age of a ground-water sample are CFC-11 (trichlorofluoromethane), CFC-12 (dichlorofluoromethane), and CFC-113 (trichlorotrifluoroethane). CFC concentrations were highly variable and ranged from 25 , 17, and 31 to 2,149; 22,839; and 94 picograms per kilogram (pg/kg) of CFC-11, CFC-12, and CFC-113, respectively (table 19). A comprehensive discussion of CFC data-collection techniques, laboratory-analysis methods, and applications is presented in a statewide assessment of ground-water age in West Virginia, and includes the data collected in the Leetown area (McCoy and Kozar, 2007a). The variability in ranges of
CFC concentrations for replicate samples was fairly low; most sites had less than a 10 percent variation. Where variability was greater, it is possible that water of different ages and from separate fracture zones was being intercepted by the well at various times during purging and sampling. Final apparent CFC ground-water age determinations were based on: (1) mixing ratios if any combination of the three CFC compounds fell within mixing and piston flow boundaries and were not degraded or contaminated; (2) piston-flow models if data plot along the piston-flow line; or (3) piston-flow models if only a single tracer was suitable for dating. Of the 5 sample locations at the Center, only CFC samples from sites Jef-0590, Jef-0585, and Jef-0603 (sites 48, 38, and 34, on fig. 1 and in table 1) were suitable for dating. Apparent ages from these wells ranged from 15 to 45 years (table 19) (McCoy and Kozar, 2007a).

Because CFCs were commonly used as refrigerants and solvents in industrial and domestic applications, contamination of ground water with CFCs is common in karst aquifers where such near-surface or atmospheric sources are prevalent. However, gross contamination is readily recognized because calculated concentrations of a particular $\mathrm{CFC}$ in equilibrium with the atmosphere will be much larger than the highest concentration of the CFC used in developing the air-concentration curves. Contamination is evident in samples containing concentrations above potential maximum air-water equilibrium at $10^{\circ} \mathrm{C}$, and such samples cannot be used to calculate apparent ages (table 19). Contamination was found in 4 of the 5 CFC-11 and CFC-12 samples collected at the Center. Nearly all CFC concentrations from a recent study in West Virginia (McCoy and Kozar, 2007a) exceeded the $5 \mathrm{pg} / \mathrm{kg}$ threshold value established by Nelms and others (2003) for aquifer vulnerability in Virginia.

On the basis of CFC data (table 19), the one spring site tested (Blue Spring - Jef-659S) appears to have been contaminated and therefore the age of water for this sample is not reliable. An old disposable area for junked vehicles is located along the strike of bedrock and up gradient of Blue Spring. This area is a suspected source of contamination to the spring. Of the three remaining sites, the ball field well at the Center (Jef-0590 - site 48 on fig. 1 and in table 1) is the shallowest of the wells tested at $160 \mathrm{ft}$ in depth. The well also receives a majority of water from a large cavernous area between 70 and $81 \mathrm{ft}$ bls and a fracture at approximately $36 \mathrm{ft}$ bls. The apparent age of water from well Jef-0590 is fairly young at approximately 15 years in age. The intermediate depth well (Jef-0585) was drilled in a diffuse dominated portion of the aquifer and is $326 \mathrm{ft}$ deep. Water samples collected from this well were taken at a fracture at a depth of between $285 \mathrm{ft}$ and the bottom of the well, by using a packer and submersible pump assembly. The apparent age of water from this well was approximately 23 years. Finally, the deepest interval tested was in the $475 \mathrm{ft}$ deep well (Jef-0603) completed at the fault contact between the overlying Chambersburg Limestone and underlying Martinsburg Formation. The apparent age of water from this well was 45 years, and most of the water entering this well is likely 


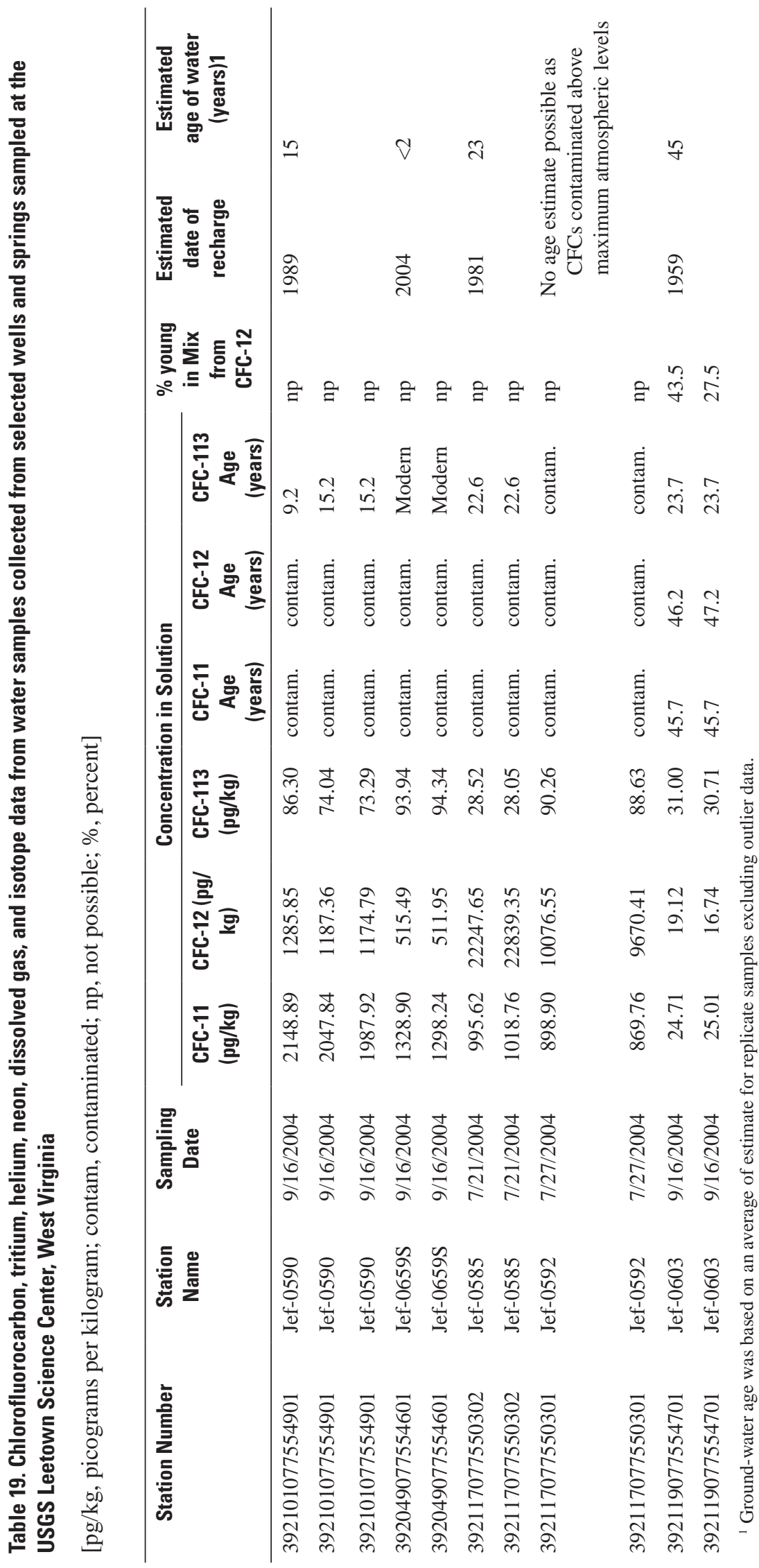




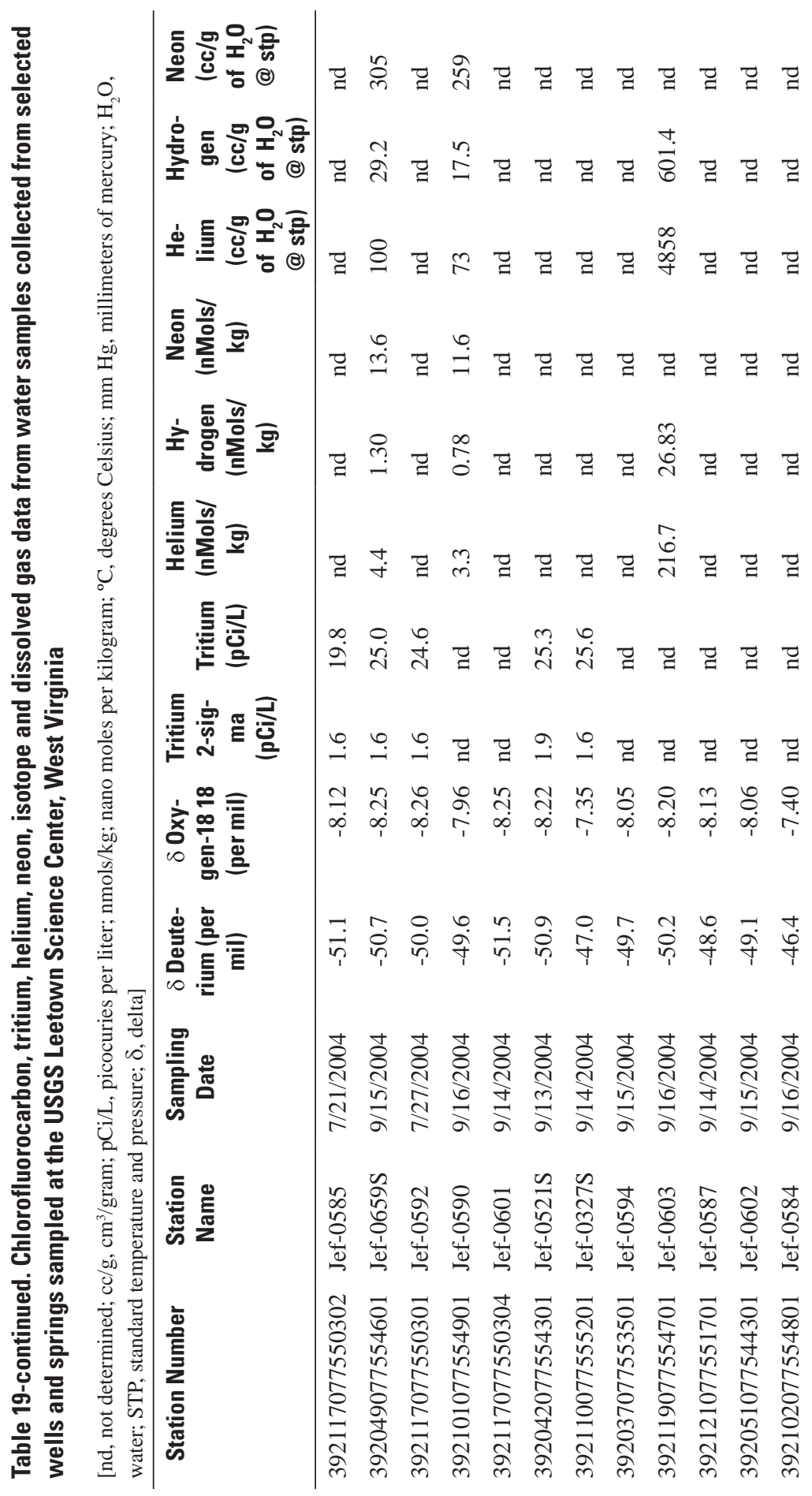




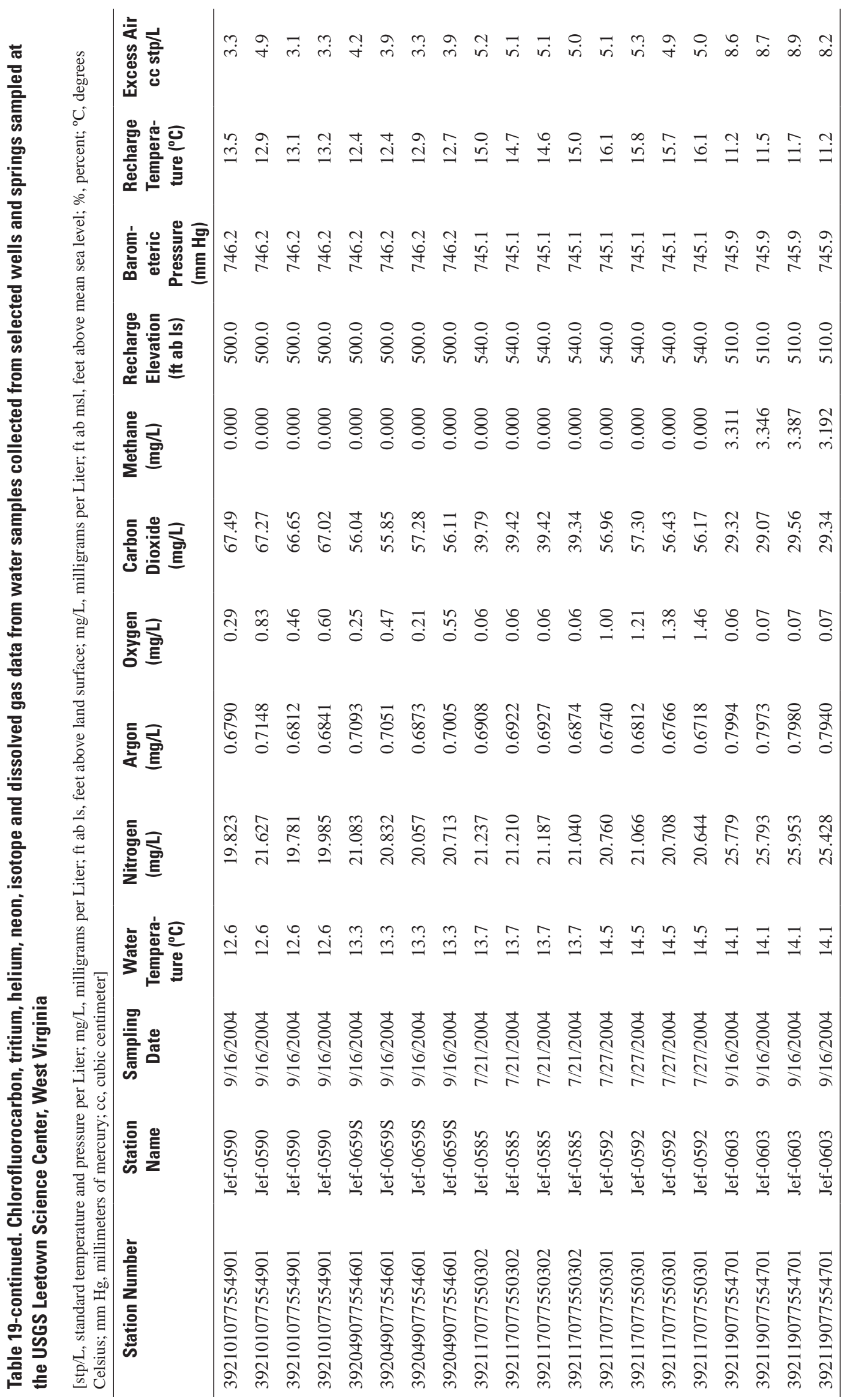


derived from the nearly 2 -ft wide solution void encountered at the bottom of the borehole. The CFC data correlate well with similar ground-water depth relations indicated by deuterium and oxygen-18 samples collected during the investigation.

\section{Deuterium/Oxygen 18}

A total of 11 sites were sampled for analyses of the stable isotopes (table 19$)$ deuterium $\left(\delta^{2} \mathrm{H}\right)$ and oxygen-18 $\left(\delta^{18} \mathrm{O}\right)$ to help qualitatively assess the potential depths of flow and better understand potential areas of recharge. A plot of the $\delta^{18} \mathrm{O}$ and $\delta^{2} \mathrm{H}$ values shows three distinct regions of potential ground-water groupings (fig. 33). The data for Balch Spring (Jef-0327S) and the bone yard upper well (Jef-0584) lie along an evaporative trend away from the average value of the other samples, which lie closer to the meteoric water line (MWL); mean precipitation for the region is represented by the MWL. The slope of this line parallels the Global Meteoric Water Line (GMWL) at approximately 8 (fig. 33); however, the deuterium excess value is greater for this region at 16.1 (Plummer et al, 2001). Thus, these two ground-water sources seem most affected by evaporative enrichment. This could be due to mixing with surface water that has undergone evaporation, such as might be found in nearby wetlands adjacent to Blue and Gray Springs (Jef-0659S and Jef-0521S).

Generally, samples that are isotopically heavier tend to indicate older and deeper waters than isotopically lighter waters which tend to represent younger and shallower water. Ground-water samples that show relatively higher $\delta^{18} \mathrm{O}$ and $\delta^{2} \mathrm{H}$ values indicate waters that have either undergone recharge or mixed with waters derived from precipitation at lower elevations (higher temperatures), or water that may have experienced a certain degree of evaporative enrichment (fig. 33). Evaporative enrichment would be evident by an evolution of water along a slope of approximately 5 (a dimensionless number) away from the meteoric water line (MWL).

Balch Spring (Jef-0327S) is believed to discharge a significant component of relatively shallow ground water based on its water chemistry, its bacteria and DNA composition, and results of aquifer tests conducted in the area. The isotopic data support the premise of a significant proportion of shallow flow as samples from Balch Spring and the nearby bone yard upper well (Jef-0584) both exhibit an isotopically heavier signature than the other local ground waters. The older waters identified as part of CFC dating, the USDA sulfur well (Jef-0603) and stable well B (Jef-0585), exhibit the lowest isotopic signature of the wells sampled and analyzed (group D on fig. 33). The

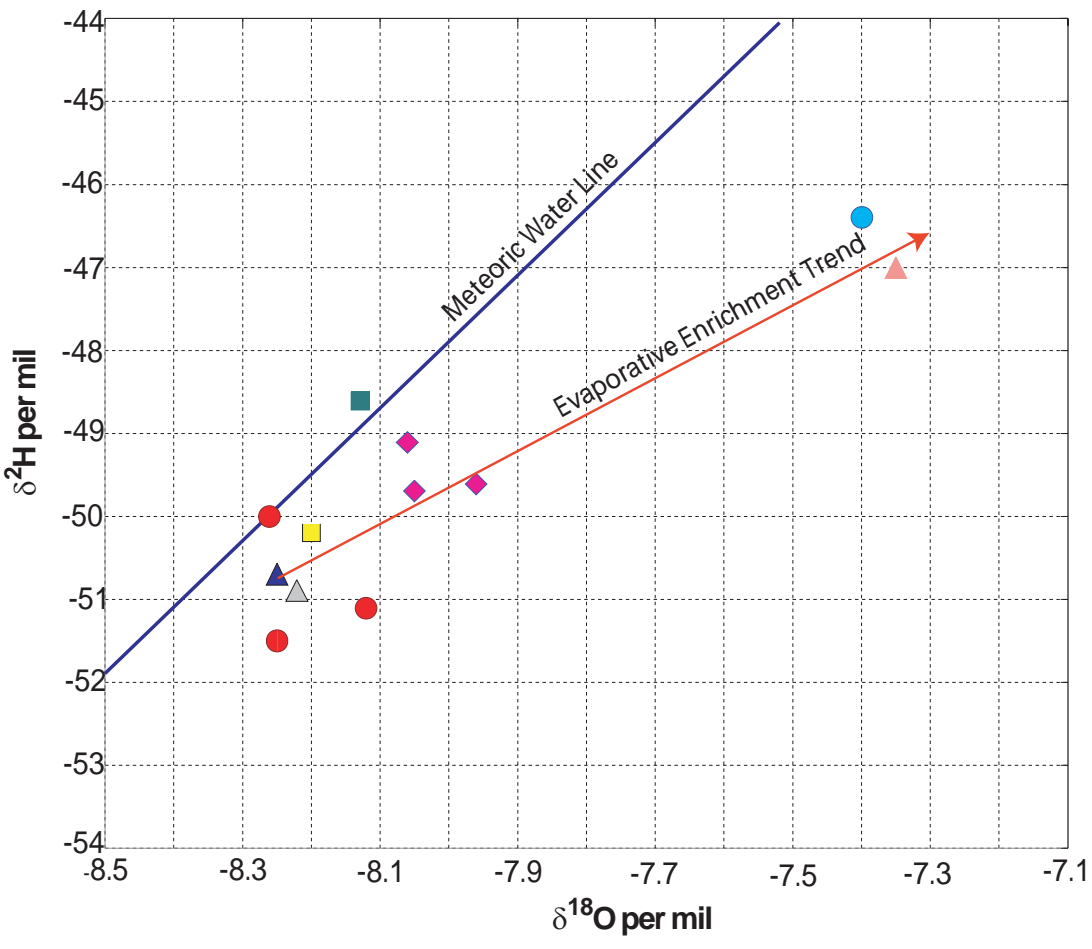

\section{EXPLANATION}

Evaporative Enrich-

$\longrightarrow$ ment Trend Meteoric Water Line - (Plummer et al., 2001)

Blue Spring

- (Jef-0659S)

Gray Spring

$\triangle$ (Jef-0521S)

Balch Spring

- (Jef-0327S)

Stable wells (Jef-0601,

- Jef-0585, and Jef-0592)

USDA Sulfur Well (Jef-0603)

Low Road Well

- (Jef-0587) Boneyard Upper Well

- (Jef-0584)

Other conduit wells

- (Jef-0602, Jef-0594, and Jef-0590)

Figure 33. Relation of oxygen-18 and deuterium isotopes showing evaporative enrichment trend for sites sampled on the USGS Leetown Science Center, West Virginia. 
ball field well (Jef-0590) and several others have isotopic signatures that are intermediate. Even though the bone yard upper well (Jef-0584) and Balch Spring (Jef-0327S) were not sampled for CFCs as part of this investigation, it is likely the ages of water for these two sites would be significantly younger than the 15-year apparent age of water from the ball field well. Finally, Blue and Gray Springs (sites Jef-0659S and Jef-0521S) obviously have a different isotopic signature than Balch Spring. Whereas Balch Spring represents ground water mixing with evaporated surface water, the isotopic data and water-level responses previously discussed for Gray Spring indicate that these springs are more representative of meteoric recharge that has not undergone significant evaporative enrichment.

\section{Macroinvertebrates - by Mark D. Kozar}

On May 4, 2005, Wil Orndorff of the Virginia Natural Heritage Program worked with Mark Kozar and Kurt McCoy of the USGS to sample 6 wells and 1 spring at the Center for macroinvertebrate stygobitic crustaceans (Craig Stihler, West Virginia Division of Natural Resources, oral commun., 2007). The crustaceans were collected using baited traps to assess the range and variability of Antrolana lira, commonly known as the Madison Cave Isopod, a species listed as threatened in the region. The full range of Antrolana lira, especially in the Eastern Panhandle of West Virginia, had not been well documented. Traps consisted of perforated plastic containers, with approximately $500 \mathrm{~mL}$ capacity, with raw shrimp as bait, and were weighted to achieve negative bouyancy. Traps were left for 15 to 16 hours, at levels approximately 50 $\mathrm{ft}$ below the water surface. The wells sampled were: stable A (Jef-0601), low road (Jef-0587), syncline (Jef-0588), old Dodson farm (Jef-0602), ball field (Jef-0590), and the USDA fault (Jef-0599) wells (table 1). In addition, a trap was left in the spring box at Gray Spring (Jef-0521S).

Two of the wells yielded stygobitic macroinvertebrates (aquatic cave animal obligates), the old Dodson farm well (Jef-0602) and the ball field well (Jef-0590). Gray Spring (Jef-0621S) yielded no individuals, and the syncline well (Jef-0588) trap was filled with sediment indicating it had been lowered too deeply into the well. The old Dodson farm well trap (Jef-0602) captured 10 of the Shenandoah Valley Cave Amphipods (Stygobromus gracilipes), up to nearly $2 \mathrm{~cm}$ in length. The ball field well (Jef-0590) yielded similar numbers of Stygobromus gracilipes, and a 1-cm long specimen of Antrolana lira - the federally protected (threatened) Madison Cave Isopod. No macroinvertebrate fauna were detected in traps from the stable A (Jef-0601), low road (Jef-0587), and USDA fault wells (Jef-0599). It should be noted that the two wells in which the crustaceans were trapped are high-yield wells intersected by significant solution voids. This finding indicates a probable relation between high-flow areas and the presence of macroinvertebrate fauna. Additional species commonly found in the epikarst that likely reside in the Leetown area include Caecidotea priceii (Price's Cave Isopod) and Stygobromus biggersi (Biggers Cave Amphipod).

\section{Summary}

This report summarizes a multi-disciplinary assessment of the geology, hydrology, and water quality of the Leetown, West Virginia, area, particularly the U.S. Geological Survey's Leetown Science Center. The primary objectives of the investigation were to:

1. assess current and future availability of ground water at the Center;

2. revise the current conceptual model of ground-water flow in the area;

3. develop a monitoring well program for water levels and water quality;

4. conduct detailed aquifer tests to determine hydraulic properties of the aquifer and to assess the impact of pumping in certain portions of the aquifer on the yield and longterm availability of existing spring flows; and,

5. determine the potential areas of recharge to the Center's major springs to provide information for protecting the availability and quality of water relied on for operations at the Center.

Objective 1 was addressed in an earlier publication summarizing results of simulations made with a ground-water flow model developed for the Leetown area.

A multi-disciplinary assessment of the resource was conducted due to the complicated nature of the karst aquifer from which the Center obtains its water. Geologic mapping, fracture-trace and lineament analysis, and surface-geophysical surveys provided the framework from which hydrologic investigations were conducted. Hydrologic investigations included monitor well installation, stream seepage surveys, stream gaging of Hopewell Run and Gray and Balch Springs, hydrograph analysis, estimation of ground-water recharge rates, development of water budgets, water-level monitoring, water-quality sampling, borehole geophysical surveys, and aquifer tests. A light detection and ranging (LiDAR) survey provided additional data on locations of sinkholes and a digital-elevation model (DEM) was developed from the data. The DEM was the basis for the upper surface of the ground-water flow model developed for the area. Dye tracer tests provided confirming evidence of previously mapped ground-water flow patterns and velocities. Microbial and DNA studies helped to better define the sources of contaminants entering the aquifer as well as their potential fate.

Bedrock underlying the Leetown area is primarily fractured limestone and dolomite of the Lower Ordovician and Upper Cambrian Conococheague Limestone; Lower Ordovician Stonehenge Limestone, Rockdale Run Formation, and 
Pinesburg Station Dolomite; the Middle Ordovician New Market and Chambersburg Limestones; and shale of the Upper and Middle Ordovician Martinsburg Formation. The geologic structure of the area is complex, with numerous thrust faults oriented parallel or sub-parallel to the regional bedrock strike trending approximately N. $20^{\circ}$ E. Cross-strike longitudinal and oblique faults also occur with traces at attitudes of approximately N. $80^{\circ} \mathrm{W}$. and N. $65^{\circ}$ E., respectively. The rocks are tectonically deformed, and the numerous upright and overturned folds in the area affect ground-water flow. The overturned folds verge to the northwest with limbs dipping steeply towards the southeast.

The flow of ground water in the study area is controlled by both lithology and geologic structure. Bedrock, especially low permeability lithologic units such as the shale Martinsburg Formation and the Conococheague Limestone, act as a barrier to water flowing down the hydrologic gradient and across the strike of the bedding. This retardation of cross-strike flow is especially pronounced in the Leetown area, where the bedding typically dips at steep angles. Geologic structures that disrupt the rocks in cross-strike directions, especially highly permeable fault and fracture zones, provide avenues through which ground water can flow laterally across or through strata of low primary permeability. Cross-strike faults are present near the Center, parallel to the East Branch of Hopewell Run and parallel to Leetown Pike east of the Center.

The lithology of the bedrock in the study area is as important as geologic structure in controlling ground-water flow. The relatively low-permeability Conococheague Limestone forms upland areas within the study area. The low hydraulic conductivity of the Martinsburg Formation impedes water as it flows down gradient towards the Opequon Creek. This effectively dams water behind the Martinsburg Formation, forcing water to flow laterally along bedding planes and thrust faults that parallel the general geologic strike of bedrock in the region (generally N. $20^{\circ}$ E.). A ridge of the Conococheague Limestone just east of the Center also acts as a barrier to flow and is primarily responsible for the wetland area that forms to the east of the Center along the East Branch of Hopewell Run.

Audio-magnetotelluric (AMT) surveys were conducted in the area to characterize the resistivity of bedrock and to identify resistivity anomalies. High resistivity areas were found to correlate with low permeability bedrock and resistivity lows were found to correlate with water-bearing fracture zones and faults with a high fluid content or with springs. AMT maps and cross-sections show anomalous areas of high and low resistivities coincident with the prevailing N. $20^{\circ}$ E. geologic strike. Examples include a highly resistive anticline and low resistivity anomalies along a syncline, near several faults and fractures, and along numerous thrust and cross-strike faults. Springs show up as low resistivity areas due to the increased porosity and higher fluid content in the rock.

Borehole geophysical surveys were conducted in 11 wells on the Center to develop a better understanding of the nature and distribution of fractures, bedding planes, and faults in the subsurface. Standard borehole surveys included temperature, electrical and fluid-resistivity, EM induction, spontaneouspotential, and gamma logs. In addition to the standard logs, acoustic and optical-televiewer logs were compiled to identify the location and attitude of fractures within the boreholes. Once the fractures had been identified, electromagnetic and heat-pulse flow logs were used to assess the potential flow of water from the fractures.

Results of the borehole surveys indicate that although numerous fractures may intersect a borehole, only one or two of the fractures typically transmit most of the water to a well. Matrix porosity and permeability are negligible and occur in micro fractures within the rock. Many of the smaller fractures provide storage potential for water but are not major avenues of ground-water flow. These less dominant fractures yield water to larger fractures, which in turn are drained by solutionally enlarged conduits within the carbonate rock. The conduits typically occur along thrust and cross-strike faults or parallel to bedding planes and drain water over a large area. The diffuse-flow dominated network of fractures, while occupying only a minor proportion of the total aquifer volume, constitutes the majority of porosity within the aquifer. Solution conduits, while occupying a relatively small volume of the overall aquifer, are especially important because they are the primary drains for the ground-water flow system.

The majority of solutionally enlarged conduits occur in a relatively thin zone within the epikarst to a depth of between 30 and $60 \mathrm{ft}$, but some smaller conduits are present as deep as $200 \mathrm{ft}$. Below the epikarst, a zone of less weathered and moderately fractured bedrock is present, and permeability of the rock decreases with depth. This intermediate zone of moderately fractured bedrock does not typically contain the high density of solutionally enlarged conduits that are evident within the epikarst.

Numerous single-well, multiple-well, step drawdown, and discrete-zone (packer) aquifer tests were conducted to assess the hydraulic properties of the aquifer; including transmissivity, hydraulic conductivity, and storativity. Representation of ground-water movement through an intricate fracture network drained by solution conduits requires a thorough knowledge of the orientation of fractures and quantification of aquifer properties. Transmissivity, derived from straddle packer tests, was determined to range over three orders of magnitude $(1.8 \mathrm{x}$ $10^{-6}$ to $5.9 \times 10^{-3} \mathrm{ft}^{2} / \mathrm{d}$ ) in the diffuse-flow dominated portion of the aquifer, which indicates a high variability in the hydraulic properties of individual fracture zones. Although a general decrease in transmissivity with depth is evident, it does not appear to be correlated with an associated decrease in fracture aperture. Despite the large number of fractures in these boreholes, most are unproductive, discontinuous, and poorly interconnected. Supporting evidence from borehole logs shows that in diffuse flow portions of the aquifer, most of the flow occurs only through one or two fractures intersecting the borehole.

A large variability in transmissivity also was documented by single- and multi-well aquifer tests conducted in conduitflow dominated portions of the aquifer $\left(2.0 \times 10^{3}\right.$ to $1.4 \mathrm{x}$ 
$10^{4} \mathrm{ft}^{2} / \mathrm{d}$ ) in the lowland areas immediately adjacent to the Leetown Science Center's main administration and laboratory buildings. This area is dominated by coalescing thrust faults and was found to define a broad, well connected aquifer exhibiting nearly radial flow characteristics. Drawdown, as a result of pumping production wells in this area, was almost instantaneously reflected by water levels in monitoring wells approximately a half mile away from the production wells.

The karst ground-water flow system in the Leetown area comprises a triple porosity flow system with small matrix porosity representing one end of the karst continuum and solutionally enlarged conduits representing the other end. Fractures of various aperture widths fall in the intermediate interval between the extremes. Fractures characteristic of the intermediate interval typically have transmissivities between $5.9 \times 10^{-3}$ and $2.0 \times 10^{3} \mathrm{ft}^{2} / \mathrm{d}$. Based on analyses of available aquifer-test data, related extensional fractures along the eastern limb of an overturned anticline may provide more sustainable water volumes than comparable locations along compression or shear zones.

A stream-gaging station was installed on Hopewell Run near the point where the stream exits the Leetown watershed. Average daily streamflow for the Hopewell Run at Leetown gaging station, for the period from April 2003 through March 2006, was approximately $11.2 \mathrm{ft}^{3} / \mathrm{s}$, and ranged from a minimum of $1.80 \mathrm{ft}^{3} / \mathrm{s}$ on September 28, 2005, to a maximum of $73.0 \mathrm{ft}^{3} / \mathrm{s}$ on December 11, 2003. Stream flow exhibits typical seasonal fluctuations, being highest in the winter months when evapotranspiration is least and lowest in late summer when evapotranspiration is highest. Flow-duration statistics, estimated by correlation of the Hopewell Run gage with the longterm record of the nearby gaging station on Opequon Creek at Martinsburg, provides flow data from which management of water availability to the Center may be assessed, especially during periods of low streamflow in late summer to early fall. The flow data can provide a measure of available water resources in the watershed.

Base-flow (ground-water) discharge surveys were also conducted in the study area to document streamflow gains and losses and assess ground-water inputs to stream flow. Numerous small seeps were identified during the surveys. Generally, most measurements showed increases in stream flow from upstream to downstream areas. A few notable exceptions, however, were documented. The East Branch of Hopewell Run and the channel that drains the Blue and Gray Spring complex both traverse thrust faults at right angles. A loss of stream flow was measured across the thrust faults at two separate locations during both periods. A loss of $0.35 \mathrm{ft}^{3} / \mathrm{s}$ was measured in the Gray and Blue Spring tributary on June 30, 2004, and a smaller loss of $0.002 \mathrm{ft}^{3} / \mathrm{s}$ was measured on the same tributary during a lower base flow period on October 26, 2004. For the East Branch of Hopewell Run a loss of $0.87 \mathrm{ft}^{3} / \mathrm{s}$ was measured across the same series of faults on June 30, 2004, and a corresponding smaller loss of $0.17 \mathrm{ft}^{3} / \mathrm{s}$ was measured for the East Branch near West Virginia County Route 1 during a lower base-flow period on October 26, 2004. The losses are attributed to streamflow loss to ground water across the faults. Since the stage of Balch Spring is artificially lowered due to pumping and Balch Spring and the Center's production wells A and B are located along the same fault, it is likely that ground-water withdrawals from the spring and wells may induce additional capture of stream water by the fault.

Water-level measurements were made in 23 wells across the Center to assess potential factors affecting the levels. Topographic variability in water levels is pronounced, with shallower water levels common in lowland areas and deeper water levels common in upland areas (hillside and hilltop settings). Depth to water in upland wells is approximately twice that of lowland wells. There is also a significant seasonal variability in water levels, which are typically lowest in late summer to early fall and highest in the winter to early spring. Continuous water-level data for a long-term monitoring well (Jef-0526) also was analyzed. The average maximum and minimum monthly water levels for well Jef-0526 for the period of record (1985-2005) occur, respectively, in the months of April (21.39 $\mathrm{ft}$ below land surface) and September (23.06 ft below land surface). Close inspection of the water-level hydrograph for the well indicate that ground-water levels in the Leetown area respond quickly to precipitation.

At the Leetown Science Center, hydrographs of the flow of Balch Spring show rapid response to individual storm pulses. Strong correlation of the spring flow with Hopewell Run gage data and loss of flow in the east branch of Hopewell Run adjacent to Balch Spring (Evaldi and Paybins, 2006) indicates the nearby losing stream reach is partly responsible for higher fluctuations in the stage of Balch Spring during storms than those noted in the hydrograph of Gray Spring. Likewise, examination of the recession limbs for both springs indicates that the flow of Gray Spring declines at a much lower rate than the flow of Balch Spring. This may be partly due to a higher proportion of flow in Gray Spring being derived from a broader network of diffuse fractures than in Balch Spring, which appears to have a distinctive conduit signature.

A water budget was prepared for the Hopewell Run basin based on measured streamflow and precipitation. The measured components of the budget include average precipitation of $38.60 \mathrm{in} / \mathrm{yr}$, estimated change in storage of $-4.72 \mathrm{in} / \mathrm{yr}$, and total stream flow of $19.09 \mathrm{in} / \mathrm{yr}$ (surface runoff of $1.36 \mathrm{in} / \mathrm{yr}$ and ground-water discharge of $17.73 \mathrm{in} / \mathrm{yr}$ ) based on hydrograph analyses. Assuming changes in storage to be negligible for steady-state conditions, the water budget equation may be written as: Precipitation $(\mathrm{P})=$ surface runoff $(\mathrm{SRO})+$ groundwater discharge (GWD) + evapotranspiration (ET) \pm storage effects $(\delta \mathrm{S})$; or P (38.60 in/yr) = SRO (1.36 in/yr) + GWD (17.73 in/yr) + ET (24.23 in/yr) - $\delta S$ (4.72 in/yr).

Flow of ground water through the epikarst, a shallow zone of intensely weathered rock and regolith, can be rapid (on the order of days or weeks). This is especially true if flow is concentrated in solution-enlarged conduits. Flow within the intermediate and deeper zones is typically much slower. Estimates of ground-water age in carbonate rocks in the region are on the order of 15 years in the shallower portions 
of the aquifer to 50 years or older for deeper portions of the aquifer (McCoy and Kozar, 2007a). Within the study area, local ground-water flow is primarily from the topographically higher areas in the east toward Opequon Creek to the west. The hydrogeologic setting of the Leetown area is desirable from a ground-water development perspective because large quantities of ground water are funneled through the area where the Center is located. This is also the primary reason for the highly productive springs that have historically supplied ground water for Center operations.

Eight dye-tracer tests were conducted in the Leetown area to further refine the understanding of ground-water flow rates and directions, especially to the Center's principal springs and wells. The tests confirmed the results of previous tracer tests conducted in the area in the early 1980s. Ground-water flow patterns were found to be divergent, with flow velocities ranging from about 12.5 to $610 \mathrm{ft} /$ day with a median velocity of approximately $50 \mathrm{ft} /$ day. The tracer tests also helped document that streams gain and lose water to the aquifer, especially in the vicinity of major faults.

LiDAR data were analyzed to assess potential locations of sinkholes and to provide elevation data for the groundwater flow model described earlier. A 2-m spatial resolution DEM with a root mean square error of $0.30 \mathrm{ft}(0.09 \mathrm{~m})$ provided the elevation data for the upper layer of the model, and was significantly more accurate than the existing 30- or 10-m DEMs typically available for most areas of the country. Using the LiDAR-derived DEM and geographic information systems-based terrain analysis, 94 small circular depressions were mapped as potential sinkholes in the Leetown area. Visual inspection of all mapped depressions in field visits was attempted, but 39 sites were inaccessible. Of the 55 sites that were visited, 63 percent were natural depressions that are possible sinkholes, including 9 features with obvious drainage holes. LiDAR shows great promise as a tool for sinkhole mapping, and applications for fracture-trace and lineament analysis are equally as promising. The low density of sinkholes in the Leetown area further reflects the dominance of the fractured-bedrock aquifer (diffuse-flow component) in respect to the very low density of solution conduits (conduitflow component) known to occur in the area. It also further indicates that focused recharge by way of sinkholes is not a dominant process in the Leetown area and recharge is areally diffuse over the study area.

Ground-water samples collected from 16 sites (12 wells and 4 springs) in the Leetown area were analyzed for a wide variety of chemical constituents to characterize the current quality of ground water and to provide a baseline for assessment of future changes in ground-water quality. Of the more than 340 constituents for which samples were analyzed, only turbidity, indicator bacteria, and radon were typically present in concentrations exceeding U.S. Environmental Protection Agency (USEPA) drinking-water standards or aquatic life criteria. In addition, well Jef-0603 exceeded USEPA secondary drinking-water standards for chloride, sulfate, and dissolved solids.
Of the 9 wells sampled at Leetown for radon, none contained radon in excess of the 4,000 picocurie per Liter $(\mathrm{pCi} / \mathrm{L})$ alternate maximum contaminant level (AMCL) but 7 sites (78 percent) exceeded the $300 \mathrm{pCi} / \mathrm{L}$ proposed primary MCL. The maximum concentration of radon detected was 1,280 $\mathrm{pCi} / \mathrm{L}$ and the median concentration was $840 \mathrm{pCi} / \mathrm{L}$. As large volumes of ground water with potentially high concentrations of radon are used in research operations at the Center, testing of indoor air in laboratory spaces is advisable.

Turbidity exceeded the 5 nephelometric turbidity unit (NTU) USEPA standard in 6 of 11 sites sampled (3 springs and 8 wells). Maximum and minimum turbidity concentrations ranged from $0.45 \mathrm{NTU}$ to $270 \mathrm{NTU}$ with a median of 5.1 NTU. Turbidity was not a problem in the springs sampled, but wells are susceptible to turbidity problems. Typically, shallower wells and wells drilled in solution conduits or wells with yields greater than $200 \mathrm{gal} / \mathrm{min}$ may yield water with high turbidity. Turbidity was also shown to be influenced by the rate at which wells were pumped. Low to moderate turbidity was evident when wells were pumped at low to moderate flow rates (100 gal/min or less), but turbidity concentrations increased dramatically due to increased approach velocity towards the wells when pump output was increased to higher rates (200 gal/min or greater).

For wells and springs sampled at the Center as part of this investigation, 10 of 11 (91 percent) tested positive for total coliform and 5 of 11 (45 percent) tested positive for fecal coliform and $E$. coli bacteria. The bacterial concentrations are similar to those documented in a 1988 ground-water study. Five sites were analyzed for the presence of DNA in addition to indicator bacteria. Human DNA were detected in Balch Spring (Jef-0327S), the new Dodson farm well (Jef-0752), and the ball field well (Jef-0590). Cow DNA was detected in the USDA fault well (Jef-0586) and the new Kaiser farm well (Jef-0753) showed no human or animal DNA. Human DNA was detected in wells immediately down gradient from a cluster of single-family dwellings, and the cattle DNA was detected down gradient from several large pastures. The bacterial and molecular investigations support the hydrogeological interpretations of potential recharge areas to the Center's springs and wells.

Of the 82 pesticides analyzed in water samples collected on the Center, only 6 were detected. The pesticides detected were atrazine, CIAT, prometon, simazine, tebuthiron, and terbacil, at maximum concentrations of $0.226,0.364,0.070$, $0.045,0.120$, and $0.016 \mu \mathrm{g} / \mathrm{L}$, respectively. Atrazine and CIAT were detected in water from 8 of 9 sites sampled. Most of the area adjacent to the Center is currently or was previously used for agricultural crops (e.g. corn, soy beans and other crops). There were also several orchards on land now owned by the Center. Of the 215 non-pesticide organic compounds analyzed, 10 were detected in water from at a least one of the sites sampled. These include toluene in samples from 4 of 10 sites; 1,1,1-trichloroethane in samples from 3 of 10 sites; phenols, tetrachloroethene, and trichloromethane in samples from 2 of 10 sites and; 1,2,4-trimethylbenzene, acetone, $\mathrm{m}+\mathrm{p}$-xylenes, 
o-xylene and trichloromethane were only detected once. None of the pesticides or industrial, waste water, volatile, or semivolatile organic compounds analyzed for were detected in concentrations exceeding USEPA drinking-water standards or aquatic life criteria.

The hardness of water samples from wells and springs on the Center ranged from 290 to $550 \mathrm{mg} / \mathrm{L}$ as $\mathrm{CaCO}_{3}$, with a median of $350 \mathrm{mg} / \mathrm{L}$. As such, all the samples are classified as extremely hard water. Pipe and boiler scale deposits are a problem and could result in corrosion of galvanized or copper pipe commonly used in plumbing.

The apparent age of ground water was determined from analysis of chlorofluorocarbon data and ranged from 15 to 45 years. The oldest water ( 45 years in age) dated was obtained from a thrust fault at a depth of approximately 475 $\mathrm{ft}$. The youngest water ( 15 years in age) was obtained from a shallow 160-ft deep well with dominant fractures from 20 to $50 \mathrm{ft}$ below land surface, which intersects a large cavern. Intermediate-age water (23 years in age) was obtained using a packer and submersible pump assembly from a well drilled in a diffuse-flow dominated portion of the aquifer. The well sampled is $326 \mathrm{ft}$ deep with major fractures at a depth of between $285 \mathrm{ft}$ below land surface and the bottom of the well. Results of the CFC age dating analyses compared favorably with qualitative estimates of circulation depths assessed from deuterium/oxygen-18 isotope samples.

The findings presented in this report are the result of a detailed multi-disciplinary hydrogeologic investigation of a fracture-dominated karst aquifer system within the Great Valley of West Virginia. Such detailed site specific investigations are uncommon, especially one that incorporates such a broad scope of standard methods such as dye-tracing, aquifer tests, potentiometric surface mapping, baseflow seepage surveys, and ground-water modeling with new and innovative applications such as Audio-magnetotellurics, LiDAR sinkhole and fracture analysis, and the application of fractured rock investigative techniques to a karst aquifer. The data and findings discussed within this report are applicable to similar hydrogeologic settings throughout the Great Valley aquifer which spans from Maine to Alabama. The concepts and methods utilized in this investigation are also transferable and may be applied to many similar fracture-dominated karst aquifers worldwide.

\section{References Cited}

Allen, D.M., and Michel, F.A., 1998, Evaluation of multi-well test data in a faulted aquifer using linear and radial flow models: Ground Water, v. 36, no. 6, p 938-948

Beiber, P.B., 1961, Ground-water features of Berkeley and Jefferson Counties, West Virginia: West Virginia Geological Survey Bulletin 21, 81 p.
Bertilsson, S., Cavanaugh, C.M., and Polz, M.F., 2002, Sequencing-independent method to generate oligonucleotide probes targeting a variable region in bacterial $16 \mathrm{~S}$ rRNA by PCR with detachable primers: Applied Environmental Microbiology, v. 68, no. 12, p. 6077-86.

Bierschenk, W.H., 1963, Determining well efficiency by multiple step-drawdown tests: International Association of Science Hydrology Publication 64, p, 493-507.

Bostick, F.X., Jr., 1977, A simple and almost exact method of MT analysis: Geothermal Workshop Report, University of Utah, USGS contract 14-08-0001-G-359, p. 175-177.

Busenberg, E., and Plummer, L.N., 1992, Use of chlorofluorocarbons $\left(\mathrm{CCl}_{3} \mathrm{~F}\right.$ and $\left.\mathrm{CCl}_{2} \mathrm{~F}_{2}\right)$ as hydrologic tracers and age dating tools: the alluvium and terrace system of central Oklahoma: Water Resources Research, v. 28, no. 9, p. 2257-2283.

Cagniard, Louis, 1950, Procedure of geophysical prospecting: French patent no. 1025683.

Cagniard, Louis, 1953, Basic theory of the magneto-telluric method of geophysical prospecting: Geophysics, v. 18, no. 3, p. 605-635.

Carlsson, A., and Olsson, T., 1992, The analysis of fractures, stress, and water flow for rock engineering projects: Comprehensive Rock Engineering, v. 2, Pergamon Press, Oxford England, p. 415-438.

Cooper, H.H., and Jacob, C.E., 1946, A generalized graphical method for evaluating formation constants and summarizing well field history: American Geophysical Union Transactions, v. 27 , no. 4 , p. 526-534.

Cornell University, 2006, West Virginia Drought Periods: Cornell University internet data for drought periods in West Virginia for the period January 1895 through July 2003 - Based on data available from the National Oceanic and Atmospheric Administration National Climatic Data Center in Asheville, NC; web site http://www.nrcc.cornell.edu/ drought/WV_drought_periods.html accessed on February 10, 2006, 4 p.

Dean, S.L., 1966, Geology of the Great Valley of West Virginia: Unpublished Ph.D. Dissertation, West Virginia University, Morgantown, West Virginia, 226 p.

Dean, S.L., Lessing, P., and Kulander, B.R., 1990, Geology of the Berryville, Charles Town, Harpers Ferry, Middleway, and Round Hill quadrangles, Berkeley and Jefferson Counties, West Virginia: West Virginia Geologic and Economic Survey, Map-WV35, scale 1:24,000, 1 sheet.

Dick, L.K., and Field, K.G., 2004, Rapid estimation of numbers of fecal bacteroides by use of a quantitative PCR assay for 16S rRNA genes: Applied Environmental Microbiology, v. 70, no. 9 , p. 5695-5697. 
Dmitriev, V.I., and Berdichevsky, M.N., 1979, The fundamental model of magnetotelluric sounding: Piscataway, New Jersey, Institute of Electrical and Electronics Engineers, IEEE proceedings, v. 67, no. 7, p. 1034-1044.

Evaldi, R.D., and Paybins, K.S., 2006, Channel gains and losses in the Opequon Creek watershed of West Virginia, July 25-28, 2005: U.S. Geological Survey Data Series Report 179, 7 p.

Evans, J.S. and A.T. Hudak. (in press). A progressive curvature filter for identifying ground returns from discrete return LiDAR in forested environments. IEE Transactions on Geoscience and Remote Sensing.

Even, H. I., Margaritz, M. and Gerson, R., 1986, Timing the transport of water through the upper vadose zone in a karstic system above a cave in Israel, Earth Surface Processes and Landforms, Vol. 11, p. 181-191.

Fenneman, N.M., 1938, Physiography of Eastern United States: New York, McGraw-Hill, 534 p

Fetter, C.W., 1993, Contaminant Hydrogeology, Macmillan Publishing Co., New York, 458 p.

Field, M. S., 2002, The QTRACER2 program for tracerbreakthrough curve analysis for hydrological tracer tests: Technical Report EPA/600/R-02/001, U.S. Environmental Protection Agency, Washington, D.C., 179 p.

Field, M. S., 2003, Tracer-test planning using the efficient hydrologic tracer-test design (EHTD) program: Technical Report EPA/600/R-03/034 and EPA/600/CR-03/034, U.S. Environmental Protection Agency, Washington, D.C., 175 p.

Field, M. S., 2006, Tracer-test design for losing stream-aquifer systems, International Journal of Speleology, v. 35, no. 1, p. 25-36.

Florea, L.J., and Vacher, H.L., 2006, Spring flow hydrographs: Eogenetic vs. telogenetic karst: Ground Water, v. 44, no. 3, p 352-361.

Frazier, D.A., Jascott, B.J., and McGowan, M.J., 1988, Construction of experimental research ponds at the National Fisheries Center, Leetown, West Virginia: Report submitted to the U.S. Fish and Wildlife Service by Merrick and Company, Denver Co., 22 p.

Gamble, T.D., Goubau, W.M., and Clarke, J., 1979a, Magnetotellurics with a remote reference: Geophysics, v. 44, p. 53-68.

Gamble, T.D., Goubau, W.M., and Clarke, J., 1979b, Error analysis for remote reference magnetotellurics: Geophysics, v. 44 , p. $959-968$.
Graeff, G.D., Jr., 1953, Ground-water conditions in a typical limestone area near Inwood, West Virginia: U.S. Geological Survey Open-File Report, 6 p.

Hagedorn, C., Reneau, R.B., Saluta, M., and Chapman, A., 2003, Impact of onsite wastewater systems on water quality in coastal regions: Virginia Coastal Resources Management Program Memorandum of Agreement 50312-01-13-PT, Virginia Department of Conservation and Recreation, Virginia Department of Health, Richmond, Virginia, 4 p.

Hantush, M.S., 1964, Hydraulics of wells, in Chow, V.T., ed., Advances in Hydroscience, vol. 1: New York, Academic Press, p. 281-432,

Harlow, G.E., Jr., Orndorff, R.C., Nelms, D.L., Weary, D.J., and Moberg, R.M., 2005, Hydrogeology and ground-water availability in the carbonate aquifer system of Frederick County, Virginia: U.S. Geological Survey Scientific Investigations Report 2005-5161, 30 p.

Heaton, T.H.E., 1981, Dissolved gases: Some applications to groundwater research: Transactions of the Geological Society of South Africa, v. 84, p. 91-97.

Heid, C.A., Stevens, J., Livak, K.J., and Williams, P.M., 1996, Real time quantitative PCR: Genome Research, v. 6, no. 10, p. $986-94$.

Hem, J.D., 1992, Study and interpretation of the chemical characteristics of natural water $\left(3^{\text {rd }}\right.$. ed.): U.S. Geological Survey Water-Supply Paper 2254, 263 p.

Hobba, W.A., Jr., Friel, E.A., and Chisholm, J.L., 1972, Water resources of the Potomac River basin, West Virginia: West Virginia Geologic and Economic Survey, River Basin Bulletin $3,110 \mathrm{p}$.

Hobba, W.A., Jr., 1981, Ground-water hydrology of Jefferson County, West Virginia: West Virginia Geological and Economic Survey Environmental Geology Bulletin EGB-16, 21 p.

Hobba, W.A., Jr., 1976, Ground-water hydrology of Berkeley County, West Virginia: West Virginia Geological and Economic Survey Environmental Geology Bulletin 13, 21 p.

Hoover, D.B., Frischknecht, F.C., and Tippens, C., 1976, Audio-magnetotelluric soundings as a reconnaissance exploration technique in Long Valley, California: Journal of Geophysical Research. v. 81, no. 5, p. 801-809.

Hoover, D.B., and Long, C.L., 1976, Audio-magnetotelluric methods in reconnaissance geothermal exploration: Proceedings of the $2^{\text {nd }}$ United Nations Symposium for the Development of Geothermal Resources, p.1059-1064. 
Hoover, D.B., Frischknecht, F.C., and Tippens, C., 1976, Audio-magnetotelluric soundings as a reconnaissance exploration technique in Long Valley, California: Washington, D.C., American Geophysical Union, Journal of Geophysical Research. v. 81, no. 5, p. 801-809.

Hoover, D.B., Long, C.L., and Senterfit, R. M., 1978, Some results from audio-magnetotelluric investigations in geothermal areas: Geophysics, v. 43, no. 7, p. 1501-1514.

Janse, I., Meima, M., Kardinaal, W.E., and Zwart, G., 2003, High-resolution differentiation of Cyanobacteria by using rRNA-internal transcribed spacer denaturing gradient gel electrophoresis: Applied and Environmental Microbiology, v. 69 , no. 11 , p. $6634-6643$.

Jeffords, R.M., 1945a, Water Supply at Martinsburg, West Virginia: U.S. Geological Survey, unnumbered report, 8 p.

Jeffords, R.M., 1945b, Water supply at the Newton D. Baker Hospital near Martinsburg, West Virginia: U.S. Geological Survey, unnumbered report, $12 \mathrm{p}$.

Jenness, J. 2005, Topographic Position Index (tpi_jen.avx) extension for ArcView 3.x. Jenness Enterprises. Available at: http://www.jennessent.com/arcview/tpi.htm.

Jones, W.K., 1997, Karst Hydrology Atlas of West Virginia: Karst Waters Institute, Special Publication 4, 111 p.

Jones, W.K., 1991, The carbonate aquifer of the northern Shenandoah Valley of Virginia and West Virginia, in Kastning, E.H., and Kastning, K.M. (eds.), Proceedings Appalachian Karst Symposium: National Speleological Society, Huntsville, Alabama, p. 217-222.

Jones, W.K., and Deike, G.H., III, 1981, A hydrogeologic study of the watershed of the National Fisheries Center at Leetown, West Virginia: Prepared for the U.S. Fish and Wildlife Service by Environmental Data, Frankford, West Virginia, 84 p.

Kaehler, C.A., and Hsieh, P.A., 1994, Hydraulic properties of a fractured-rock aquifer, Lee Valley, San Diego County, California: U.S. Geological Survey Water Supply Paper 2394, 64 p.

Keller, G.V., and Frischknecht, F.C., 1966, Electrical methods in geophysical prospecting: London, Great Britain, Pergamon Press, 519 p.

Keys, W.S., 1990, Borehole geophysics applied to groundwater investigations: U.S. Geological Survey Techniques of Water-Resources Investigations, book 2, chap. E2, 150 p.

Kozar, M.D., Weary, D.J., Paybins, K.S., and Pierce, H.A., 2007, Geohydrology and Simulation and Analysis of Ground-Water Flow of the Leetown Area, West Virginia: U.S. Geological Survey Scientific Investigations Report 2006-5066, 70 p.
Kozar, M.D., Hobba, W.A., and Macy, J.A., 1991, Geohydrology, water availability, and water quality of Jefferson County, West Virginia, with emphasis on the carbonate area : U.S. Geological Survey Water Resources Investigation Report 90-4118, 93 p.

Kozar, M.D., and Mathes, M.V., 2001, Aquifer Characteristics Data for West Virginia: U.S. Geological Survey WaterResources Investigations Report 01-4036, 74 p.

Lattman, L.H., 1958, Technique of mapping geologic fracture traces and lineaments on aerial photographs: Photogrammetric Engineering and Remote Sensing, vol. 24, no. 4, p. 568-576.

Lefsky, M.A., W.B. Cohen, G.G. Parker, and D.J. Harding, 2002, LiDAR remote sensing for ecosystem studies: BioScience, v. 52, no. 1, p. 19-30.

Mackie, R.L., Rieven, S., and Rodi, W., 1977, User's Manual and Software Documentation for Two-Dimensional Inversion of Magnetotelluric Data: San Francisco, GSY-USA Inc., $125 \mathrm{p}$.

Małoszewski, P., Harum, T. and Benischke, R., 1992, Mathematical Modeling of Tracer Experiments in the Karst of Lurbach System, in, Himmelsbach, T. and Hötzl, H. and Käß, W. and Leibundgut, Ch. and Małoszewski, P. and Meyer, T. and Moser, H. and Rajner, V. and Rank, D. and Stichler, W. and Trimborn, P. and Veulliet, E., eds., Application of Tracer Models: Steirische Beiträge zur Hydrogeologie, 6th International Symposium on Water Tracing, Transport Phenomena in Different Aquifers (Investigations 1987-1992), v. 43, Joanneum Research, Graz, Germany, p. 116-158.

Mathes, M.V., 2000, Relation of bacteria in limestone aquifers to septic systems in Berkeley County, West Virginia: U.S. Geological Survey Water-Resources Investigations Report 00-4229, 12 p.

Mathes, M.V., Jr., Kozar, M.D., and Brown, D.P., 1998, Summary of ground-water quality in West Virginia: West Virginia Division of Environmental Protection, Office of Water Resources, Ground-Water Program, 54 p.

Matsui, K., Ishii, N., Honjo, M., and Kawabata, Z.I., 2004, Use of the SYBR Green I fluorescent dye and a centrifugal filter device for rapid determination of dissolved DNA concentration in fresh water: Aquatic Microbial Ecology, v. 36, p. 99-105.

Mayle, D., and Schnabel, J.J., 1998, Geotechnical engineering report for the proposed National Center for Cool and Cold Water Aquaculture, Leetown, West Virginia: Report submitted to the U.S. Geological Survey by Schnabel Engineering Associates, Inc., Bethesda, Maryland, 20 p. 
McCoy, K.J., and Kozar, M.D., 2007a, Relation of chlorofluorocarbon ground-water age dates to water quality in aquifers of West Virginia: U.S. Geological Survey Scientific Investigations Report 2006-5221, 36 p.

McCoy, K.J., and Kozar, M.D., 2007b, Use of sinkhole and specific capacity distributions to assess flow directionality in a carbonate aquifer, Great Valley, West Virginia, U.S.A., Environmental Geology, v. (in press), 15 p.

McCoy, Kurt J., Podwysocki, Melvin H., Crider, E. Allen, and Weary, David, J., 2005a, Fracture trace map and singlewell aquifer test results in a carbonate aquifer in Berkeley County, West Virginia: U.S. Geological Survey Open-File Report 2005-1040, 1 Plate.

McCoy, Kurt J., Podwysocki, Melvin H., Crider, E. Allen, and Weary, David, J., 2005b, Fracture trace map and singlewell aquifer test results in a carbonate aquifer in Jefferson County, West Virginia: U.S. Geological Survey Open-File Report 2005-1407, 1 Plate.

McDonald, J.L., Hartel, P.G., Gentit, L.C., Belcher, C.N., Gates, K.W., Rodgers, K., Fisher, J.A., Smith, K.A., and Payne, K.A., 2006, Identifying sources of fecal contamination inexpensively with targeted sampling and bacterial source tracking: Journal of Environmental Quality, v. 35, no. 3, p. 889-897.

Morrison, T.B., Weis, J.J., and Wittwer, C.T., 1998, Quantification of low-copy transcripts by continuous SYBR Green I monitoring during amplification: Biotechniques, v. 24, no. 6, p. 954-8, 960, 962.

Myers, D. N., and Wilde, F. D., 2003, National field manual for the collection of water-quality data - Biological indicators: U.S. Geological Survey Techniques of WaterResources Investigations, Book 9 Chapter A7, 49 p.

Nelms, D.L., Harlow, G.E., Jr., Plummer, L.N., and Busenberg, E., 2003, Aquifer susceptibility in Virginia, 1998-2000: U.S. Geological Survey Water-Resources Investigation Report 03-4278, 58 p.

NOAA, 2006, U.S. Department of Commerce, National Oceanic and Atmospheric Administration website for airport weather data: http://www.erh.noaa.gov/er/lwx/climate/mrb/ mrb0301.txt-mrb1205.txt accessed 3-1-06.

NOAA, 2004, Climatological Data Annual Summary - West Virginia 2004: U.S. Department of Commerce, National Oceanic and Atmospheric Administration, v. 112, no. 113, $21 \mathrm{p}$.

NUS, 1986, Remedial Investigation Report, Leetown Pesticide Site, Jefferson County, West Virginia, EPA Work Assignment 65-3L52, Contract Number 68-01-6699, NUS Project Number S794, 47 p..
Otton, J.K., and Gundersen, L.C.S., 1993, Preliminary geologic radon potential assessment of West Virginia: U.S. Geological Survey Open-File Report 93-0292-C, p.185-206.

Paillet, F.L., Hess, A.E., Cheng, C.H., and Hardin, E., 1987, Characterization of fracture permeability with high-resolution vertical flow measurements during borehole pumping: Groundwater, v. 25 , no. 1, p. 28-40.

Plummer, L.N., and Busenberg, E., 2000, Chlorofluorcarbons, in Cook, P.G., and Herczeg, A., eds., Environmental tracers in subsurface hydrology: Boston, Kluwer Academic Publishers, p. 441-478.

Plummer, L.N., Michel, R.L, Thurman, E.M., and Glynn, P.D., 1993, Environmental tracers for age-dating young ground water, in Alley, W.M., ed., Environmental tracers for age-dating young ground water: New York, Van Nostrand Reinhold, p. 255-294.

Plummer, L.N., Busenburg, E., Bohlke, J.K., Nelms, D.L., Michel, R.L., and Schlosser, P. 2007, Groundwater residence times in Shenandoah National Park, Blue Ridge Mountains, Virginia, USA: a multi-tracer approach: Chemical Geology 179 (2001).p. 93-111.

Rutledge, A. T., 1998, Computer programs for describing the recession of ground-water discharge and for estimating mean ground-water recharge and discharge from stream flow records - update: U.S. Geological Survey WaterResources Investigation Report 98-4148, 43 p.

Schiesser, W.E., and Silebi, C.A., 1997, Computational Transport Phenomena - Numerical methods for the solution of transport problems: Cambridge University Press, Cambridge England, p. 372.

Shapiro, A.M., 2001, Characterizing ground-water chemistry and hydraulic properties of fractured-rock aquifers using the multifunction bedrock-aquifer transportable testing tool (BAT3): U.S. Geological Survey Fact Sheet FS-075-01, 4 p.

Shultz, R.A., Hobba, W.A., and Kozar, M.D., 1995, Geohydrology and ground-water quality of Berkeley County, West Virginia, with emphasis on the carbonate area: U.S. Geological Survey Water Resources Investigation Report 93-4073, 88 p.

Shuster, E.T., and White, W.B., 1971, Seasonal fluctuations in the chemistry of limestone springs: A possible means for characterizing carbonate aquifers: Journal of Hydrology, v. 14 , p. $93-128$.

Simpson, F., and Bahr, K., 2005, Practical Magnetotellurics: Cambridge University Press, New York, 254 p. 
Southworth, S., Drake, A.A. Jr., Brezinski, D.K., Wintsch, R.P., Kunk, M.J., Aleinikoff, J.N., Naeser, C.W., and Naeser, N.D., (in press), Central Appalachian Piedmont and Blue Ridge Tectonic transect, Potomac River Corridor. Geological Society of America Field trip Guidebook 8.

Spane, F.A., Jr., and Wurstner, S.K., 1993, DERIV - A computer program for calculating pressure derivatives for use in hydraulic test analysis: Ground Water, v. 31, no. 5, p. 814-822.

Stoeckel, D.M., Mathes, M.V., Hyer, K.E., Hagedorn, C., Kator, H., Lukasik, J., O’Brien, T.L., Fenger, T.W., Samadpour, M., Strickler, K.M., and Wiggins, B.A., 2004, Comparison of Seven Protocols To Identify Fecal Contamination Sources Using Escherichia coli: Environmental Science Technology, v. 38, no. 22, p. 6109-6117.

Swift, C. M., 1962, A magnetotelluric investigation of an electrical conductivity anomaly in the southwestern United States: Cambridge, Mass, Massachusetts Institute of Technology, unpublished Ph.D. dissertation, $211 \mathrm{p}$.

Taylor, L.E., 1974, Bedrock geology and its influence on ground-water resources in the Hedgesville and Williamsport 71/2 minute quadrangles, Berkeley County, West Virginia: Toledo, Ohio, The University of Toledo, unpublished M.S. thesis, $82 \mathrm{p}$.

Theis, C.V., 1935, The lowering of the piezometer surface and the rate and discharge of a well using ground-water storage: American Geophysical Union Transactions, v. 16, p. 519-524.

Tikhonov, A.N., 1950, The determination of the electrical properties of deep layers of the Earth's crust: Dokl. Acad. Nauk., SSR, 73, 295-297.

Toride, N., Leij, F. J., and van Genuchten, M. Th., 1995, The CXTFIT code for estimating transport parameters from laboratory of field tracer experiments, version 2.0: Research Report No. 137, U.S. Salinity Laboratory, USDA, ARS, Riverside, Calif.

Trainer, F.W., and Watkins, F.A., Jr., 1975, Geohydrologic reconnaissance of the upper Potomac River Basin: United States Geological Survey Water-Supply Paper 2035, 68 p.

U.S. Environmental Protection Agency, 1999, Proposed Radon in Drinking Water Rule: U.S. EPA Publication EPA 815-F-99-006; accessed July 25, 2006 at internet web address http://www.epa.gov/ogwdw000/radon/fact.html.

U.S. Geological Survey, 2006, NWIS-Web database available at http://nwis.waterdata.usgs.gov/wv/nwis/qwdata, accessed 4-18-06.

Vozoff, Keeva, 1986, Magnetotelluric methods: Tulsa, Oklahoma, Society of Exploration Geophysicists, Geophysics Reprint Series Number 5, 763 p.
Vozoff, Keeva, 1991, The Magnetotelluric Method; Chapter 8, in Electromagnetic methods in applied geophysics: Nabighian, M.N., ed., Society of Exploration Geophysicists, Tulsa, Oklahoma, Series, Investigations in Geophysics Number 3, p. 641-712.

Wait, J.R., 1962, Theory of magnetotelluric fields: U.S. Department of Commerce, National Bureau of Standards, Journal of Research, Radio Propagation, v. 66D, p. 509-541.

Weaver, J.T., 1994, Mathematical methods for geo-electromagnetic induction: Kendal, P.C., ed., Wiley, New York, $316 \mathrm{p}$.

Wehr, A. and Lohr, U., 1999, Airborne laser scanning - an introduction and overview: ISPRS Journal of Photogrammetry and Remote Sensing, v. 54, p. 68-82.

Weiss, R.F., 1970, The solubility of nitrogen, oxygen, and argon in water and seawater: Deep-Sea Research, v. 17, p. 721-735.

White, J.S., and Mathes, M.V., 2006, Dissolved gas concentrations in ground water in West Virginia, 1997-2005: U.S. Geological Survey Data Series Report 156, 8 p.

White, W.B., 2002, Karst hydrology: recent developments and open questions: Engineering Geology, v. 65, p. 85-105.

Wilde, F. D., Radtke, D. B., Gibs, Jacob, and Iwatsubo, R. T., 1999, National field manual for the collection of waterquality data - Collection of water samples: U.S. Geological Survey Techniques of Water-Resources Investigations, Book 9, Chapter A4, 156 p.

Wilde, F.D., and Radtke, D.B., 1998, National field manual for the collection of water-quality data - Field measurements: U.S. Geological Survey Techniques of Water-Resources Investigations, Book 9, Chapter A6, variously paged.

Wiley, J. B., 2006, Low-flow analysis and selected flow statistics representative of 1930-2002 for stream flow gaging stations in or near West Virginia: U.S. Geological Survey Scientific Investigations Report 2006-5002, 190 p.

Williams, J.H., and Conger, R.W., 1990, Preliminary delineation of contaminated water-bearing fractures intersected by open-hole bedrock wells: Ground Water Monitoring Review, v. 10, no. 3, p. 118-126.

Williams, J.H., Lapham, W.W., and Barringer, T.H., 1993, Application of electromagnetic logging to contamination investigations in glacial sand and gravel aquifers: Ground Water Monitoring Review, v. 13, no. 3, p. 129-138.

Williams, J.H., and Lane, J.W., Jr., 1998, Advances in borehole geophysics for ground-water investigations: U.S. Geological Survey Fact Sheet 002-98, 4 p. 
Wittwer, C.T., Herrmann, M.G., Moss, A.A., and Rasmussen, R.P., 1997, Continuous fluorescence monitoring of rapid cycle DNA amplification: Biotechniques, v. 22, no. 1, p. 130-1 - 134-8.

Wolfe, W.J., Haugh, C.J., Webbers, Ank, and Diehl, T.H., 1997, Preliminary conceptual models of the occurrence, fate, and transport of chlorinated solvents in karst regions of Tennessee: U.S. Geological Survey Water-Resources Investigations Report 97-4097, 80 p. 


\section{Appendices}

Appendix 1: Audiomagnetotelluric (AMT)

soundings in the Leetown area, West Virginia.

Appendix 2a: Caliper, natural gamma, fluid-

resistivity and fluid-temperature logs for wells at the USGS Leetown Science Center, West Virginia.

Appendix 2b: Optical-televiewer, acousticteleviewer, and heat-pulse flow-meter logs for wells at the USGS Leetown Science Center, West Virginia.

Appendix 2c: Interpretation of borehole logs for 11 wells on the USGS Leetown Science Center, West Virginia

Appendix 3: Depth, strike, and dip of fractures imaged in boreholes, at the USGS Leetown Science Center, West Virginia.

Appendix 4: Single-well, multi-well, step drawdown, and packer aquifer tests conducted at the USGS Leetown Science Center, West Virginia.

Appendix 5a: Interpretation of fluorometric tracer tests done in the USGS Leetown Science Center, West Virginia

Appendix 5b: Data from dye tracing experiments at the Leetown Science Center, West Virginia.

Appendix 6: Water chemistry data for 12 wells and 3 springs sampled in 2004 and 2005 at the USGS

Leetown Science Center, West Virginia 


\section{Appendix 1: Audiomagnetotelluric (AMT) soundings in the Leetown area, West Virginia.}

This appendix includes additional supporting material for the AMT survey of

Leetown Science Center, West Virginia. 
Table 1. Audiomagnettelluric (AMT) soundings in the Leetown area, West Virginia. [Universal Tranverse Mercator and coordinates are in NAD 83 with a central meridian of $-75^{\circ}$ and base latitude of $0^{\circ}$ (zone 18). Latitude-Longitude coordinates are in NAD 83 and elevations are in NGVD88].

\begin{tabular}{|c|c|c|c|c|c|c|}
\hline $\begin{array}{l}\text { Station } \\
\text { Number }\end{array}$ & $\begin{array}{c}\text { UTM } \\
\text { Easting (m) }\end{array}$ & $\begin{array}{l}\text { UTM } \\
\text { Northing } \\
(\mathrm{m})\end{array}$ & Latitude & Longitude & $\begin{array}{c}\text { GPS } \\
\text { Elevation } \\
(\mathrm{m})\end{array}$ & $\begin{array}{c}\text { GPS } \\
\text { Elevation }(\mathrm{ft})\end{array}$ \\
\hline LT03 & 248992.4 & 4360066.5 & 392113.0 & 775447.0 & 158 & 518.4 \\
\hline LT04 & 249134.0 & 4360000.2 & 392111.0 & 775441.0 & 147 & 482.3 \\
\hline LT05 & 248872.7 & 4360070.3 & 392113.0 & 775452.0 & 163 & 534.8 \\
\hline LT06 & 248729.0 & 4360075.0 & 392113.0 & 775458.0 & 157 & 515.1 \\
\hline LT07 & 248060.7 & 4360158.3 & 392115.0 & 775526.0 & 166 & 544.6 \\
\hline LT08 & 247916.1 & 4360132.1 & 392114.0 & 775532.0 & 158 & 518.4 \\
\hline LT09 & 247768.5 & 4360013.4 & 392110.0 & 775538.0 & 155 & 508.6 \\
\hline LT10 & 248612.3 & 4360171.3 & 392116.0 & 775503.0 & 162 & 531.5 \\
\hline LT 11 & 248591.4 & 4360264.6 & 392119.0 & 775504.0 & 170 & 557.8 \\
\hline LT 12 & 248230.3 & 4360214.6 & 392117.0 & 775519.0 & 170 & 557.8 \\
\hline LT14 & 249058.2 & 4359879.1 & 392107.0 & 775444.0 & 157 & 515.1 \\
\hline LT15 & 249029.3 & 4359725.7 & 392102.0 & 775445.0 & 156 & 511.8 \\
\hline LT16 & 249024.3 & 4359571.6 & 392057.0 & 775445.0 & 158 & 518.4 \\
\hline LT17 & 249019.4 & 4359417.4 & 392052.0 & 775445.0 & 153 & 502.0 \\
\hline LT 18 & 247606.9 & 4360203.9 & 392116.0 & 775545.0 & 146 & 479.0 \\
\hline LT19 & 247713.7 & 4360540.0 & 392127.0 & 775541.0 & 145 & 475.7 \\
\hline LT 20 & 247620.9 & 4360635.6 & 392130.0 & 775545.0 & 151 & 495.4 \\
\hline LT 21 & 248156.5 & 4359414.4 & 392051.0 & 775521.0 & 157 & 515.1 \\
\hline LT 22 & 248127.5 & 4359261.0 & 392046.0 & 775522.0 & 159 & 521.7 \\
\hline LT 23 & 248049.7 & 4359078.3 & 392040.0 & 775525.0 & 158 & 518.4 \\
\hline LT 24 & 248022.8 & 4358986.6 & 392037.0 & 775526.0 & 154 & 505.3 \\
\hline LT 25 & 248784.1 & 4358386.6 & 392018.4 & 775453.4 & 154 & 505.3 \\
\hline LT 26 & 247947.0 & 4358865.6 & 392033.0 & 775529.0 & 144 & 472.5 \\
\hline LT 27 & 247885.2 & 4359917.1 & 392107.0 & 775533.0 & 163 & 534.8 \\
\hline LT 28 & 247696.3 & 4359634.6 & 392057.6 & 775540.5 & 149 & 488.9 \\
\hline LT 29 & 247580.9 & 4359402.2 & 392050.0 & 775545.0 & 147 & 482.3 \\
\hline LT30 & 247782.4 & 4358963.5 & 392036.0 & 775536.0 & 151 & 495.4 \\
\hline LT31 & 247643.7 & 4359122.3 & 392041.0 & 775542.0 & 144 & 472.5 \\
\hline LT32 & 247336.5 & 4359255.8 & 392045.0 & 775555.0 & 150 & 492.2 \\
\hline LT33 & 248532.5 & 4359927.0 & 392108.0 & 775506.0 & 152 & 498.7 \\
\hline LT34 & 248455.7 & 4359775.1 & 392103.0 & 775509.0 & 152 & 498.7 \\
\hline LT35 & 248403.9 & 4359653.3 & 392059.0 & 775511.0 & 146 & 479.0 \\
\hline LT36 & 247087.1 & 4359696.0 & 392059.0 & 775606.0 & 133 & 436.4 \\
\hline LT37 & 248916.6 & 4359204.6 & 392045.0 & 775449.0 & 156 & 511.8 \\
\hline LT38 & 248302.9 & 4358696.6 & 392027.9 & 775513.9 & 162 & 531.5 \\
\hline LT39 & 248951.6 & 4358802.2 & 392032.0 & 775447.0 & 156 & 511.8 \\
\hline LT40 & 248275.2 & 4360861.3 & 392138.0 & 775518.0 & 150 & 492.2 \\
\hline LT 41 & 248640.3 & 4359553.1 & 392056.0 & 775501.0 & 151 & 495.4 \\
\hline LT 42 & 249465.1 & 4360606.8 & 392131.0 & 775428.0 & 159 & 521.7 \\
\hline LT43 & 249299.5 & 4360673.9 & 392133.0 & 775435.0 & 160 & 525.0 \\
\hline LT 44 & 248653.2 & 4360694.8 & 392133.0 & 775502.0 & 153 & 502.0 \\
\hline LT 45 & 249748.5 & 4359733.4 & 392103.0 & 775415.0 & 170 & 557.8 \\
\hline LT 46 & 249480.9 & 4359389.0 & 392051.6 & 775425.7 & 170 & 557.8 \\
\hline LT 47 & 247134.9 & 4358791.0 & 392029.7 & 775602.8 & 148 & 485.6 \\
\hline LT 48 & 249051.4 & 4358181.7 & 392012.0 & 775442.0 & 180 & 590.6 \\
\hline LT49 & 247564.0 & 4359618.8 & 392057.0 & 775546.0 & 146 & 479.0 \\
\hline LT50 & 247974.9 & 4359728.9 & 392101.0 & 775529.0 & 157 & 515.1 \\
\hline LT51 & 247129.1 & 4360250.3 & 392117.0 & 775605.0 & 140 & 459.3 \\
\hline LT52 & 247317.4 & 4358669.9 & 392026.0 & 775555.0 & 150 & 492.2 \\
\hline LT53 & 247822.2 & 4357974.4 & 392004.0 & 775533.0 & 156 & 511.8 \\
\hline
\end{tabular}


a) 10 meters bls

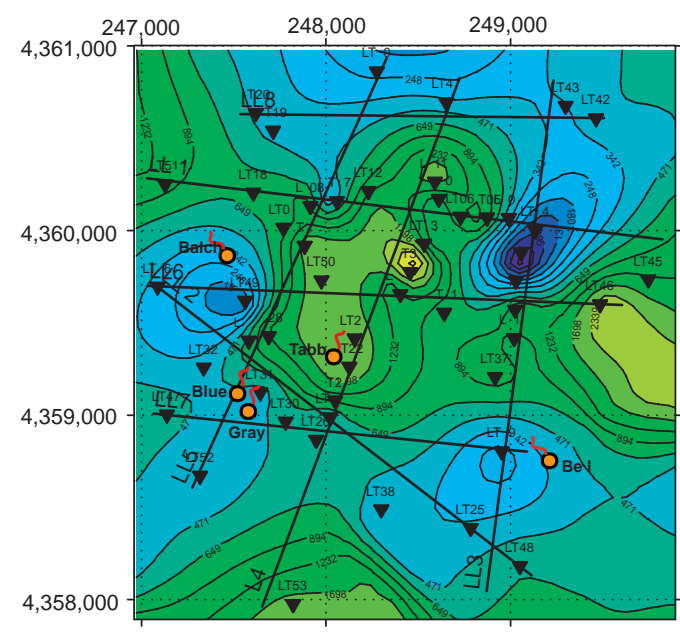

b) 20 meters bls

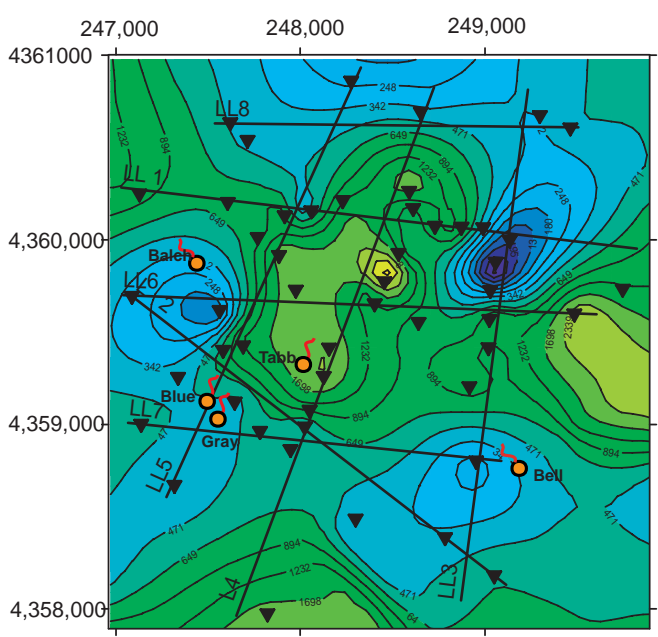

\section{EXPLANATION}

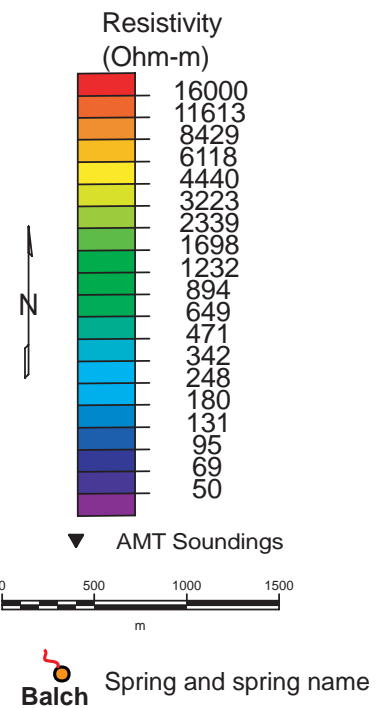

\section{c) 30 meters bls}

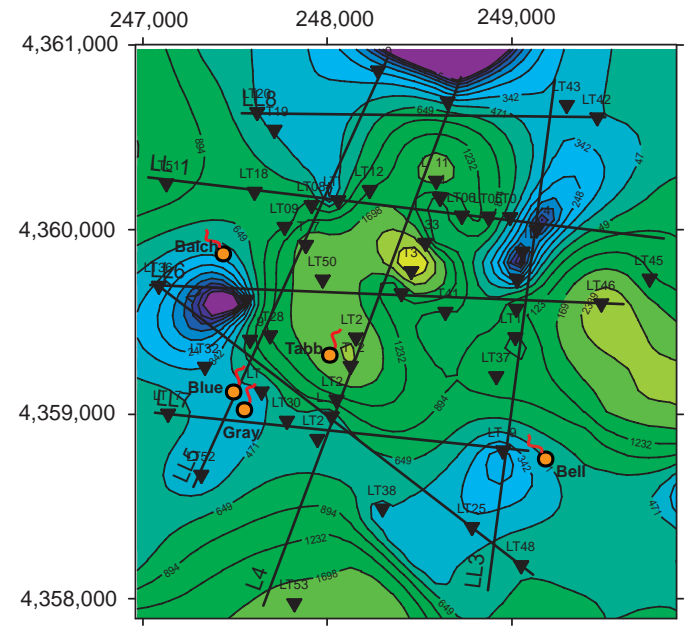

d) 60 meters bls

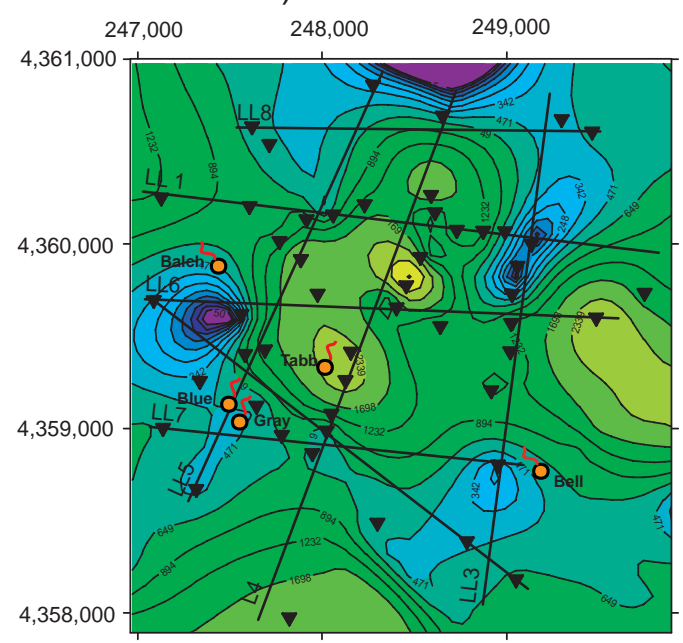

Figure 1. A series of 2-dimensional resistivity maps made for 10, 20, 30, and 60 meters below land surface (bls). These maps show that the rocks become progressively more resistive with depth, most likeley as a function of decreasing weathering, porosity, fluid storage, or fracture density. 

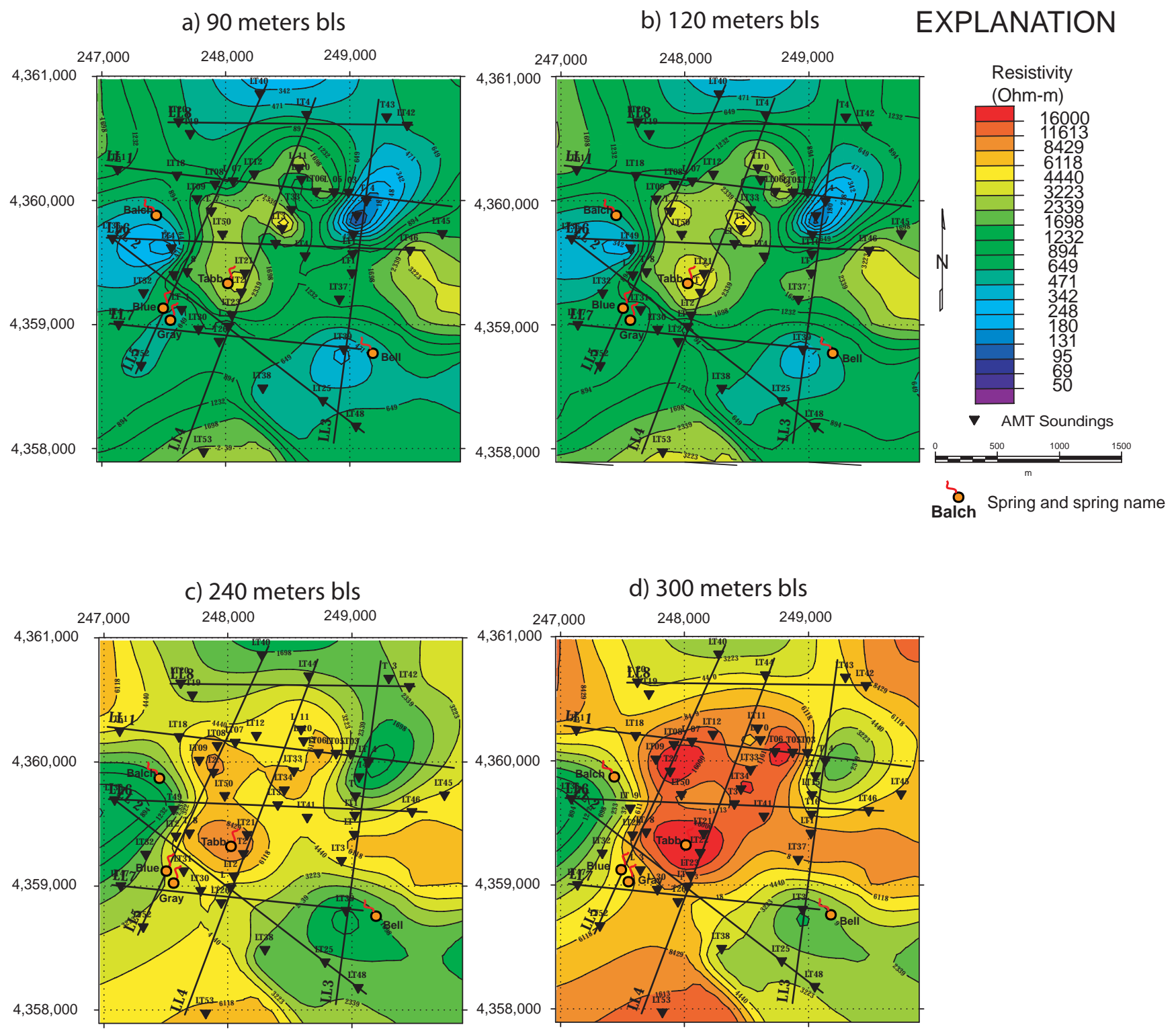

Figure 2. A series of 2-dimensional resistivity maps made for 90, 120, 240, and 300 meters below land surface (bls). These maps show that the rocks become progressively more resistive with depth, most likeley as a function of decreasing weathering, porosity, fluid storage, or fracture density. 


\section{LL1}

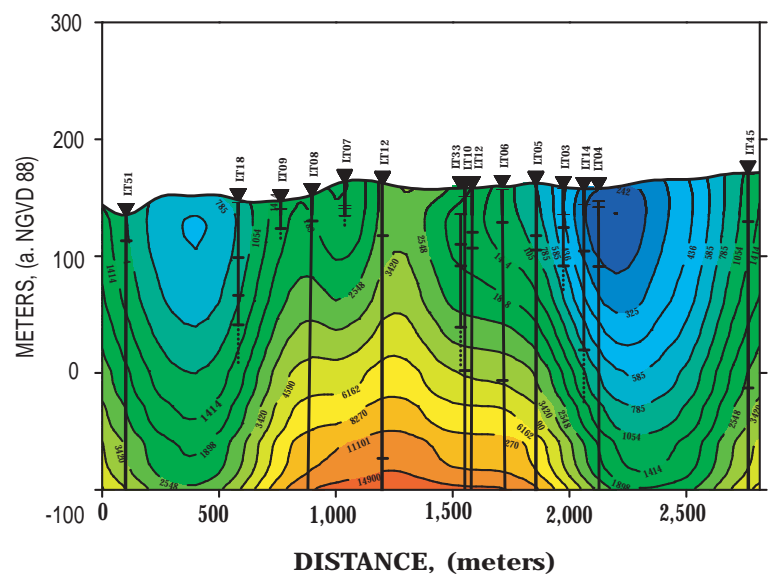

LL2

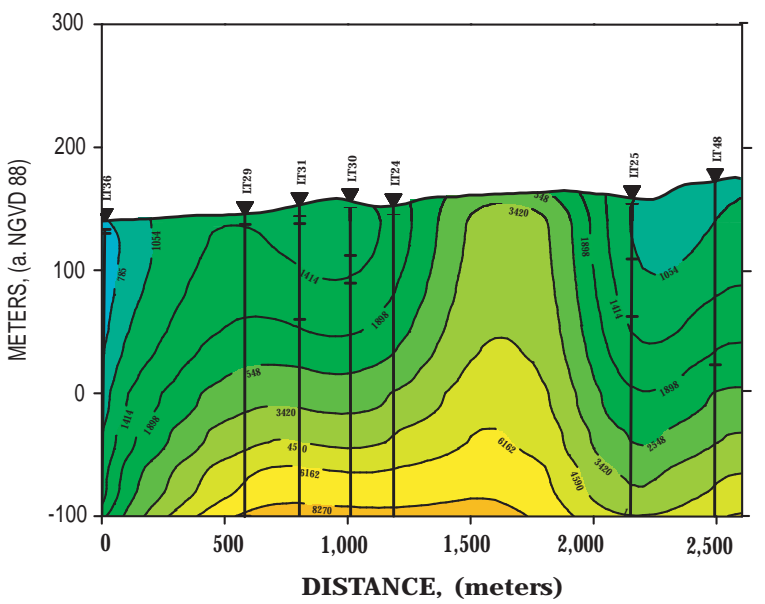

LL3

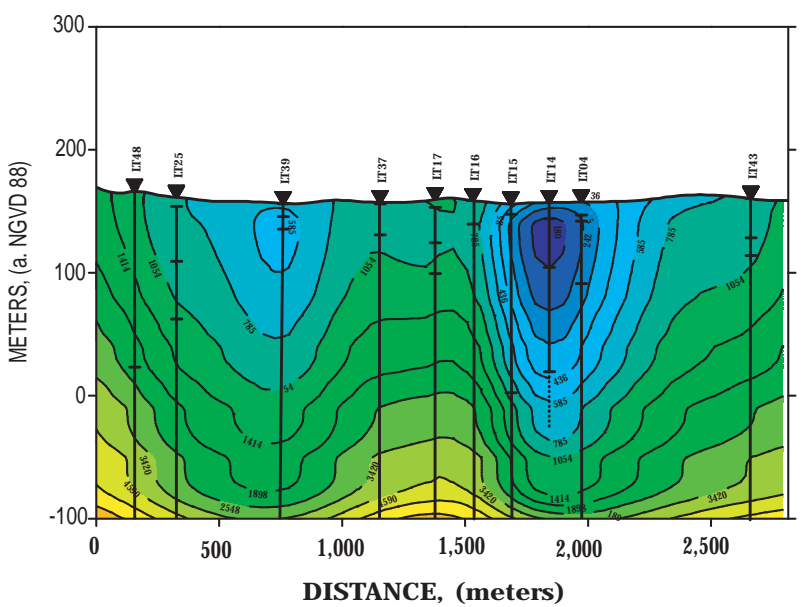

LL4

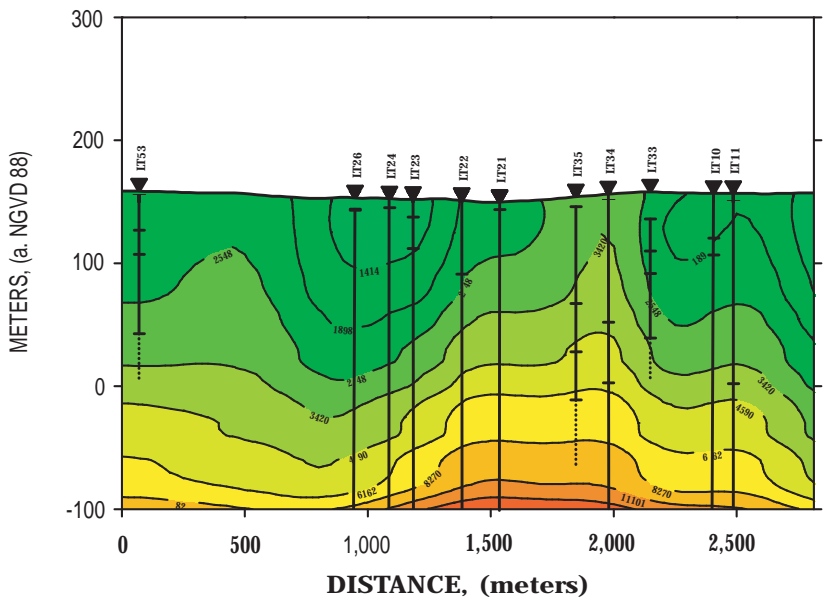

EXPLANATION

Resistivity (Ohm-m)

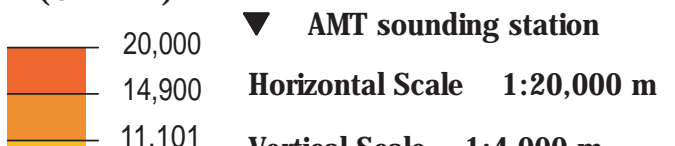

11,101 Vertical Scale $1: 4,000 \mathrm{~m}$

8,270 Vertical Exaggeration $=5$

6,162 Vertical Exaggeration $=5$

4,590 Resistivity

3,420

2,548

1,898

1,414

1,054

785

585

436

325

242

180

134

100

Figure 3. A series of 2-dimensional resistivity cross sections (LL1 - LL4) across the USGS Leetown Science Center area.

[See fig. 8 in main text for locations of the sections]. 


\section{LL5}

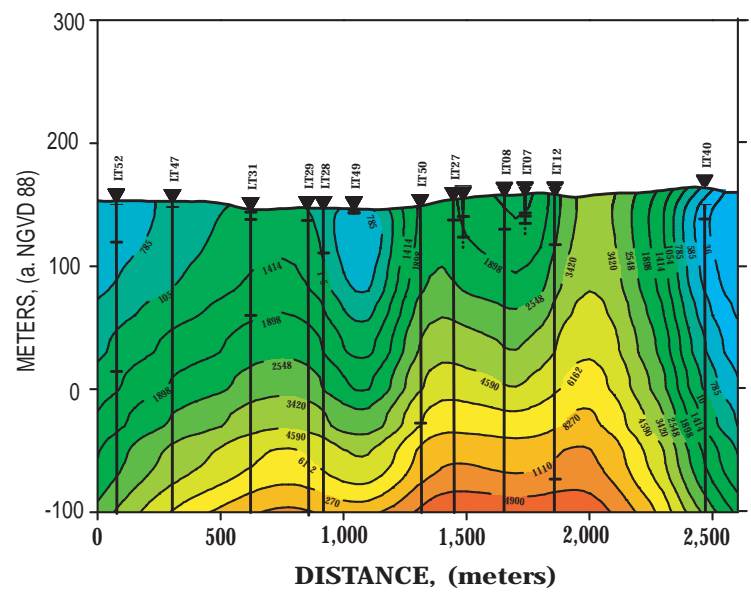

\section{LL6}

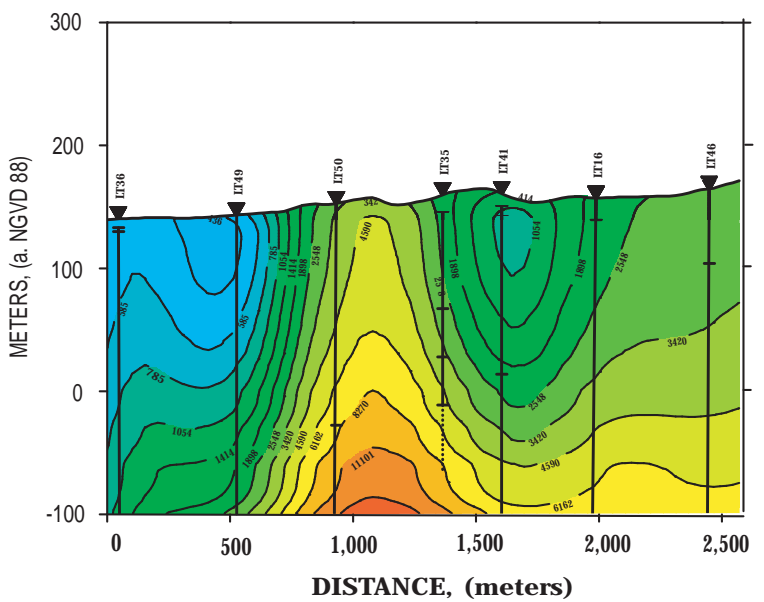

LL7
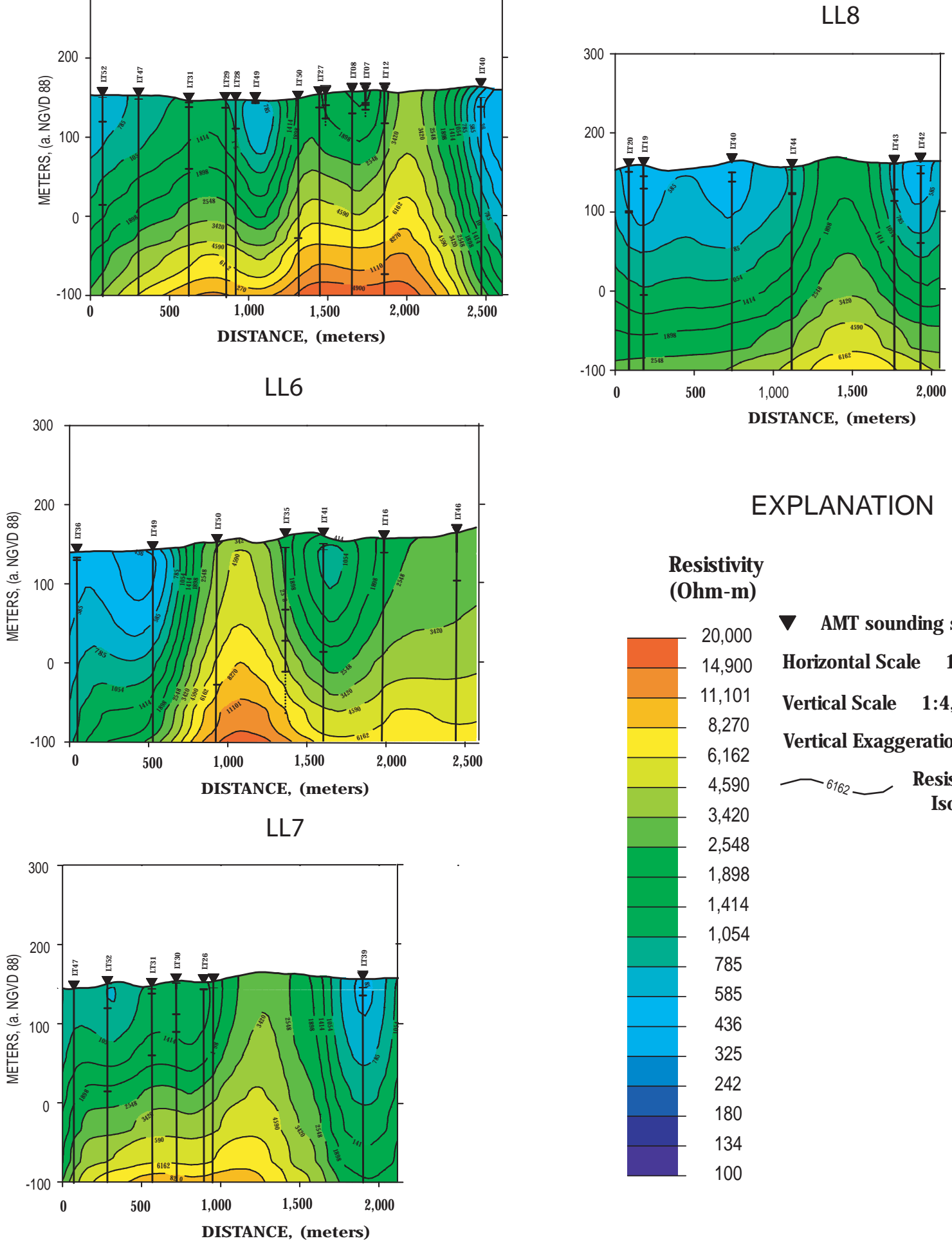

\section{EXPLANATION}

Resistivity

(Ohm-m)

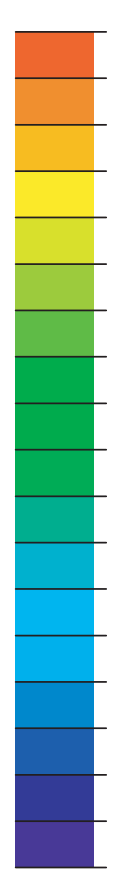

20,000

14,900

11,101

8,270

6,162

4,590

3,420

2,548

1,898

1,414

1,054

785

585

436

325

242

180

134

100

V AMT sounding station

Horizontal Scale 1:20,000 m

Vertical Scale 1:4,000 m

Vertical Exaggeration $=5$

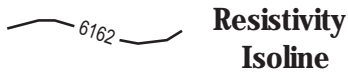

Figure 4. A series of 2-dimensional resistivity cross sections (LL5 - LL8) across the USGS Leetown Science Center area.

[See fig. 8 in main text for locations of the sections]. 
Appendix 2a: Caliper, natural gamma, fluid resistivity, and fluid temperature borehole logs for wells at the Leetown Science Center, Leetown West Virginia. 

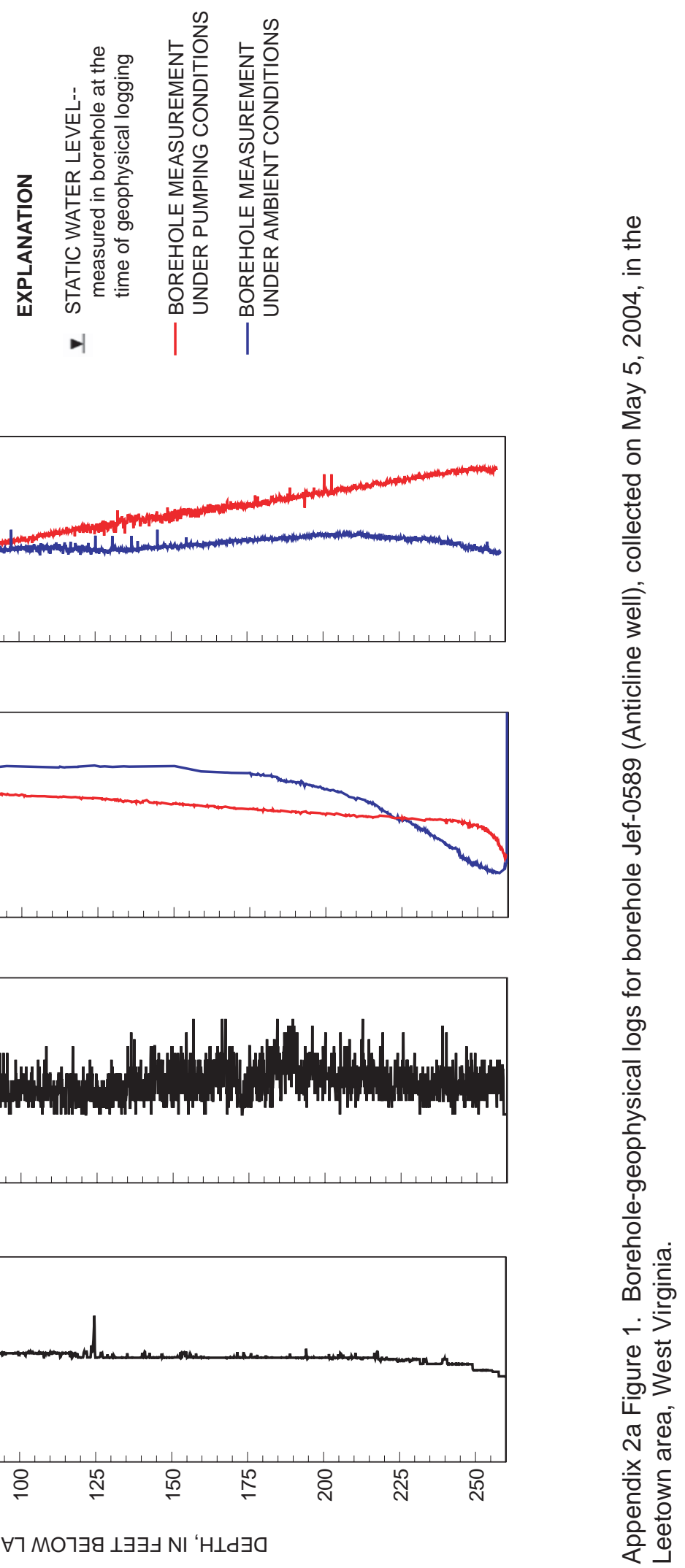

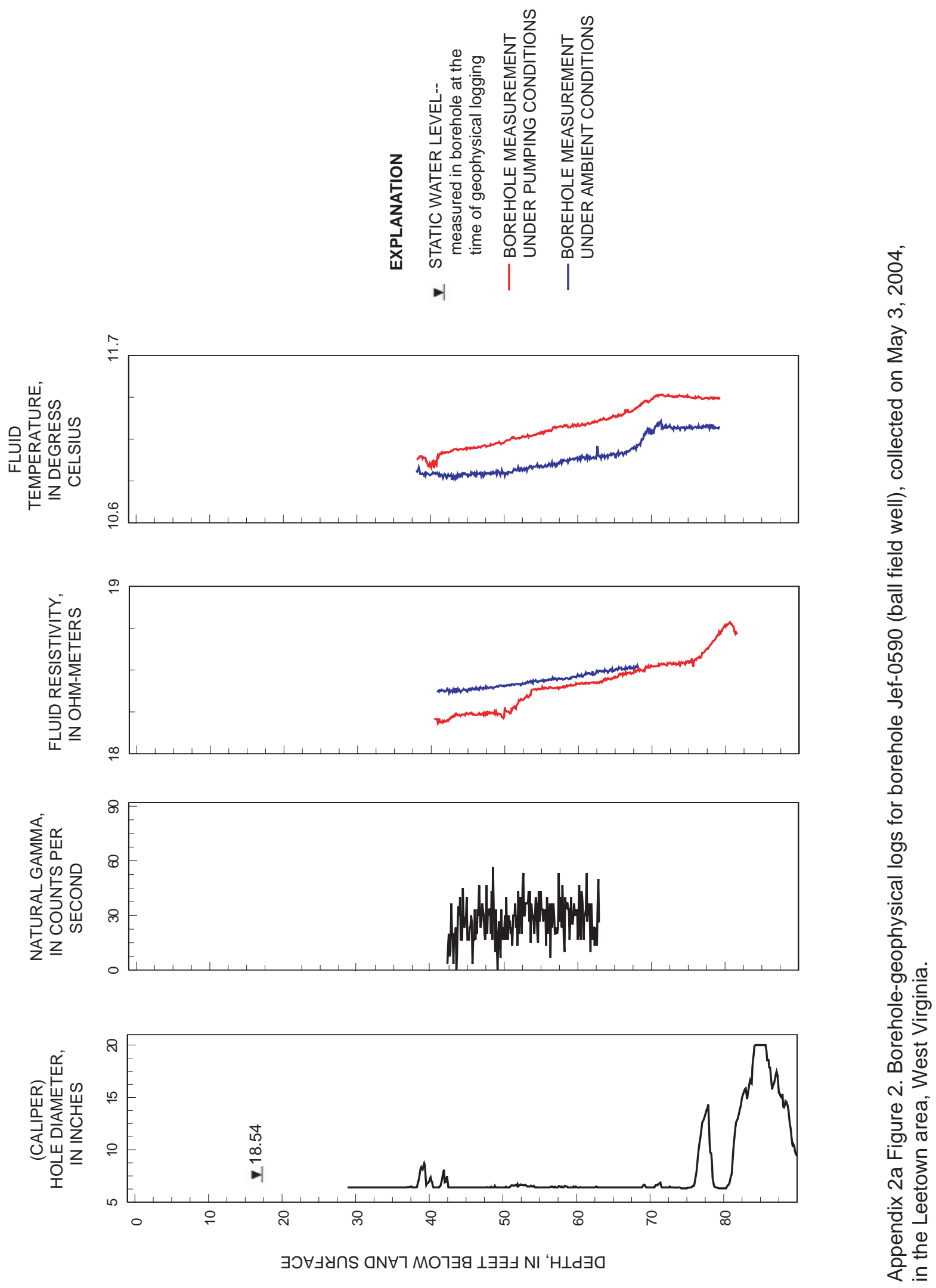


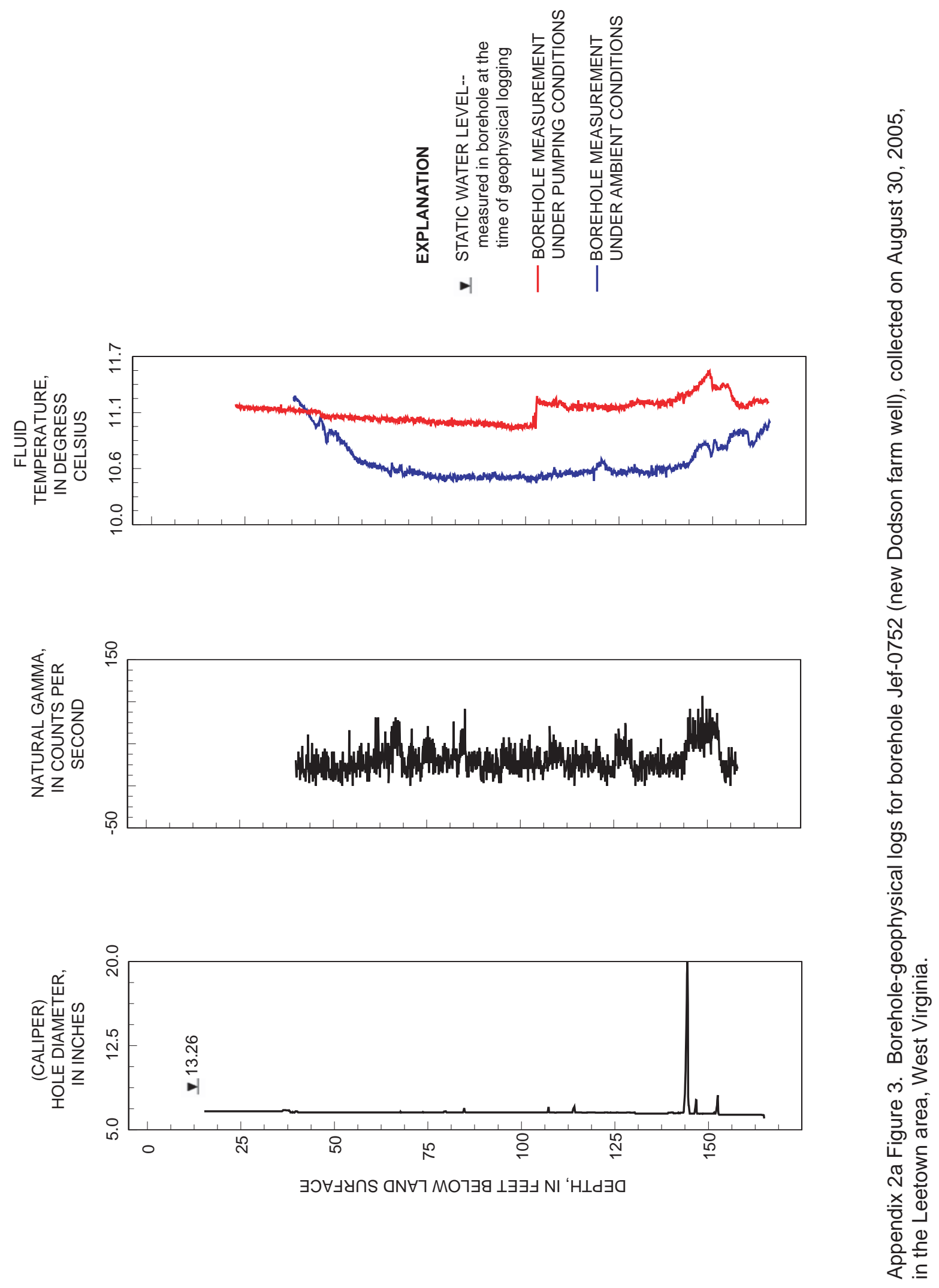



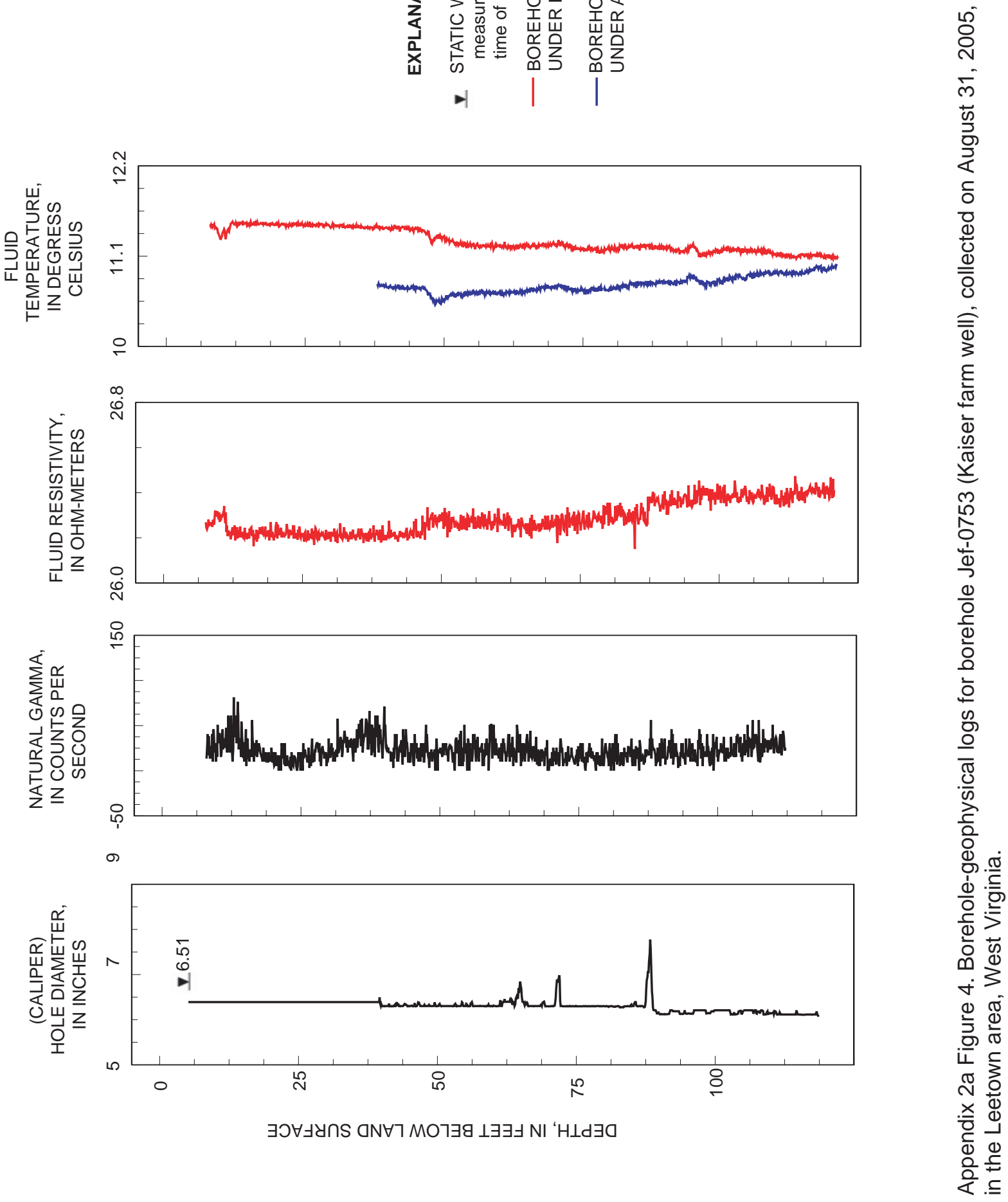


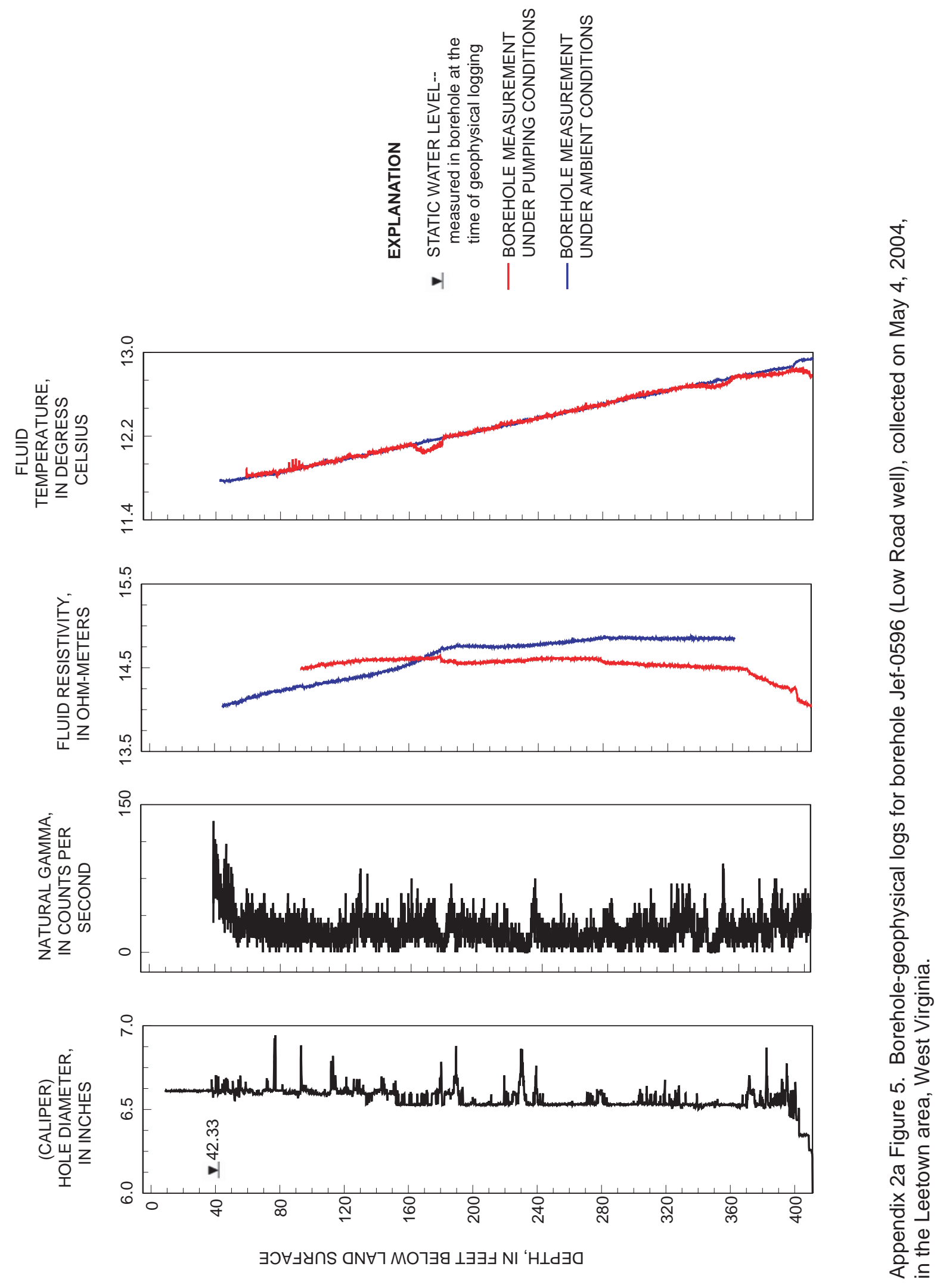



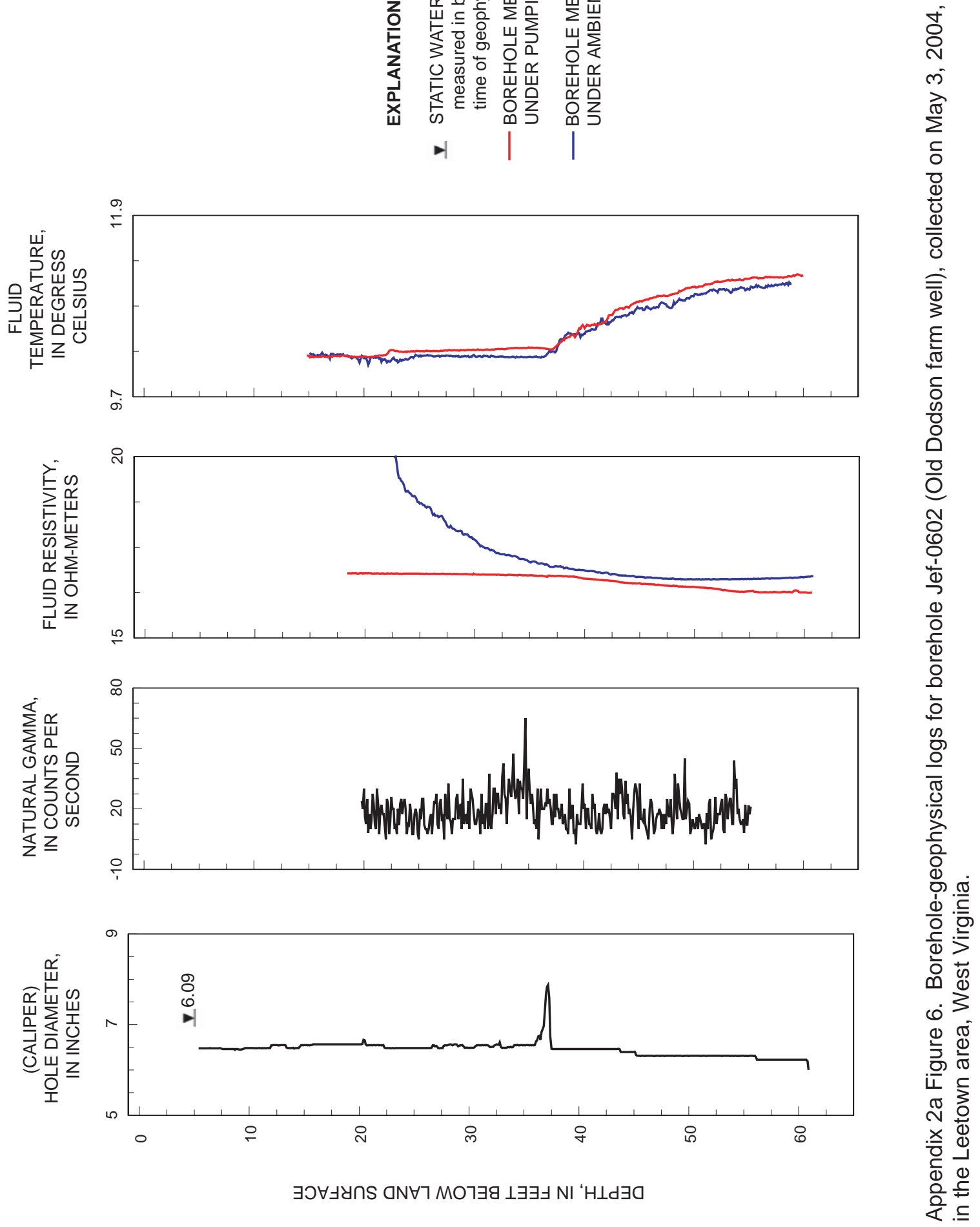

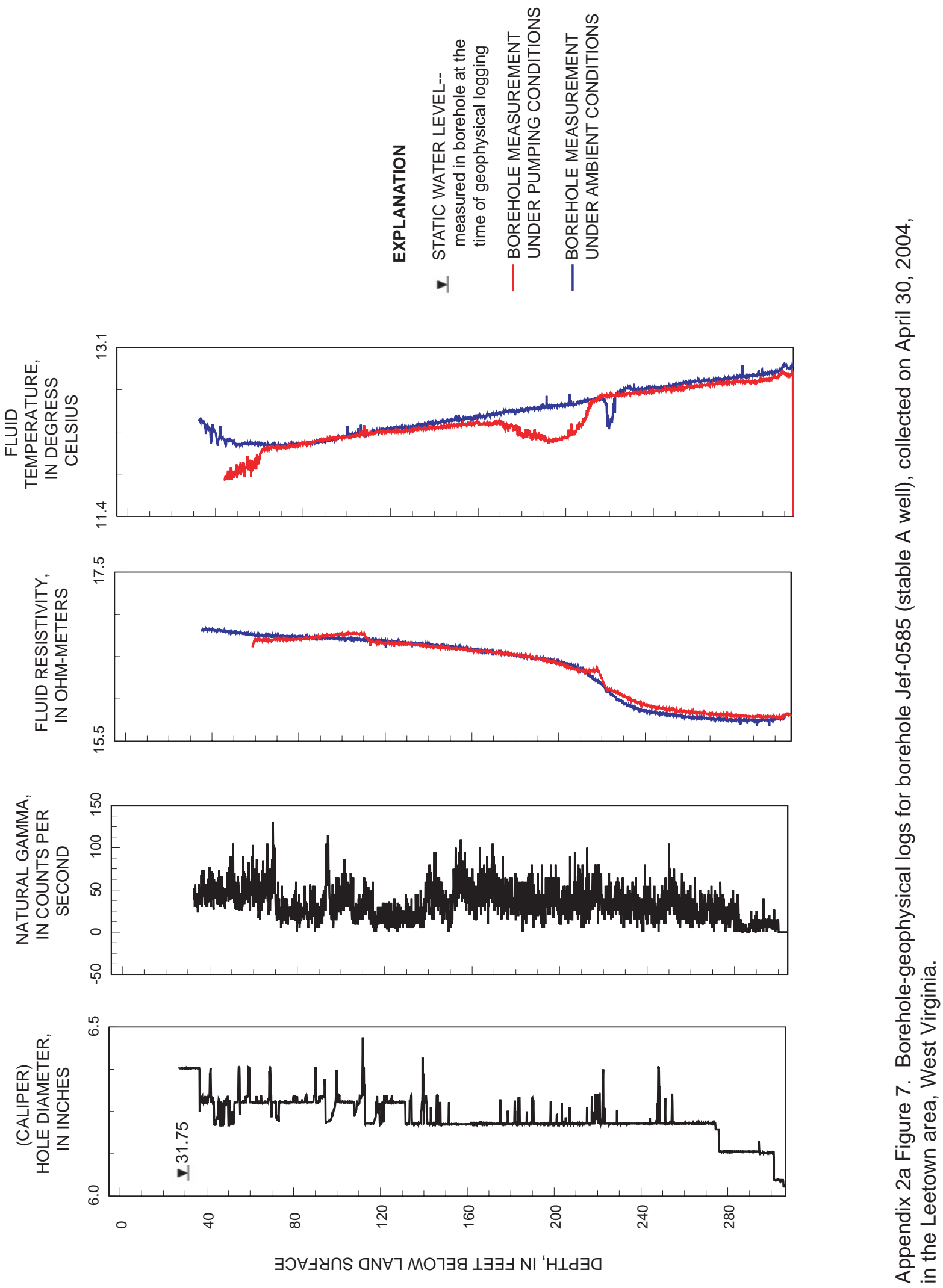


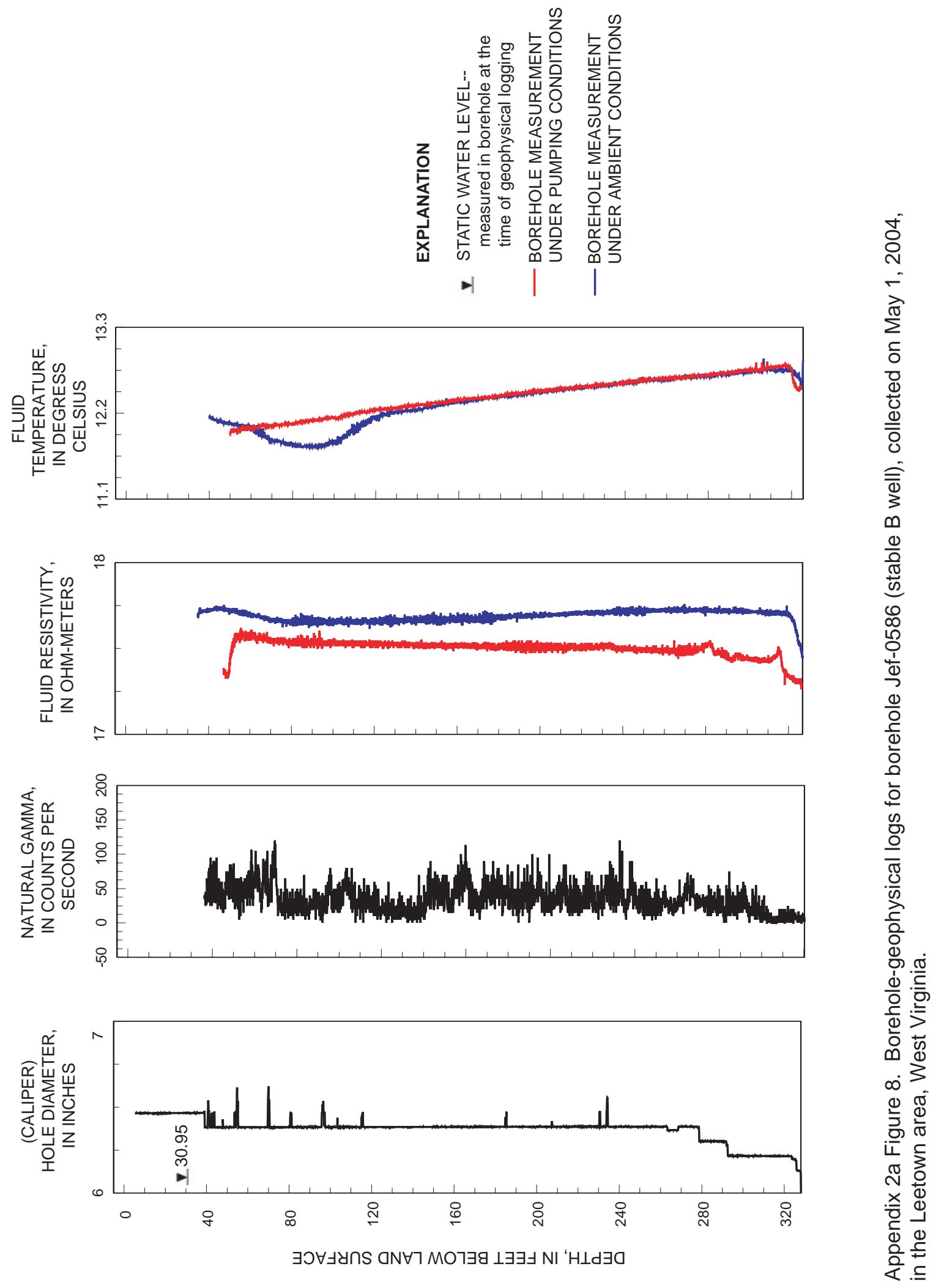




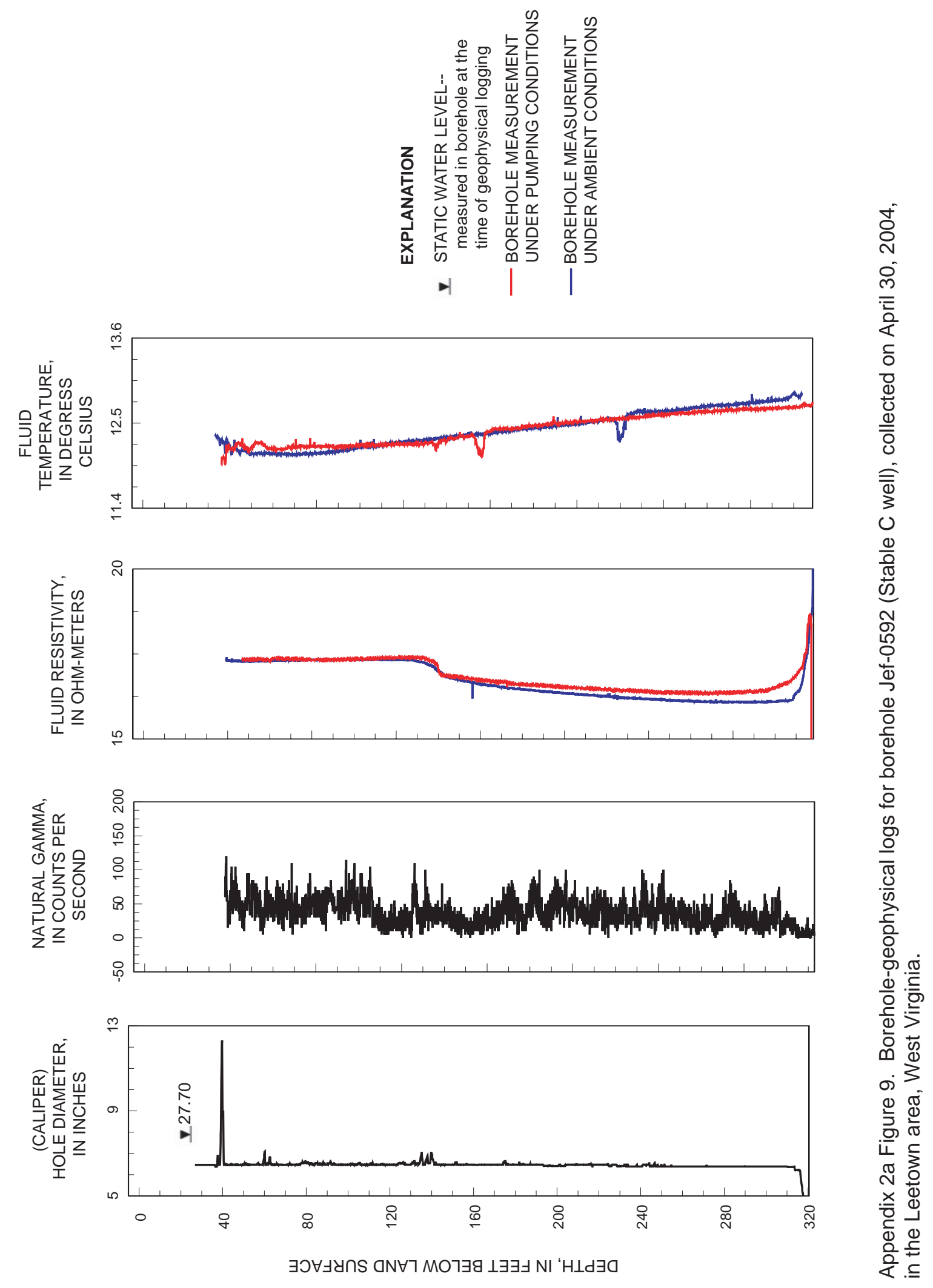



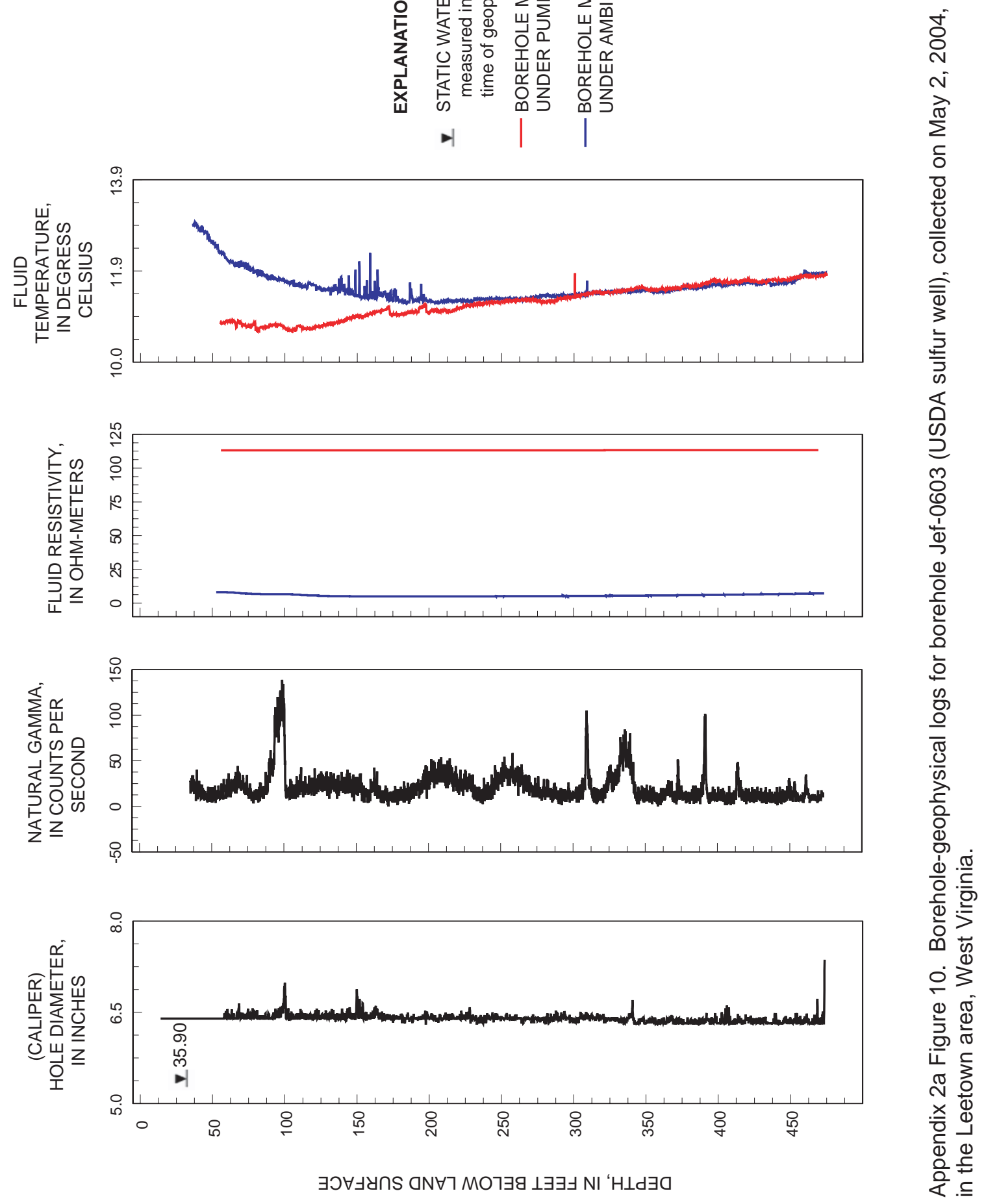


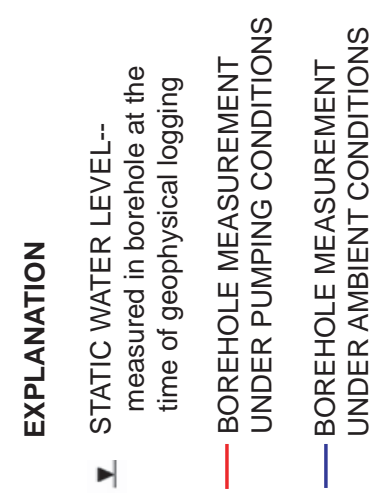

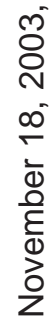

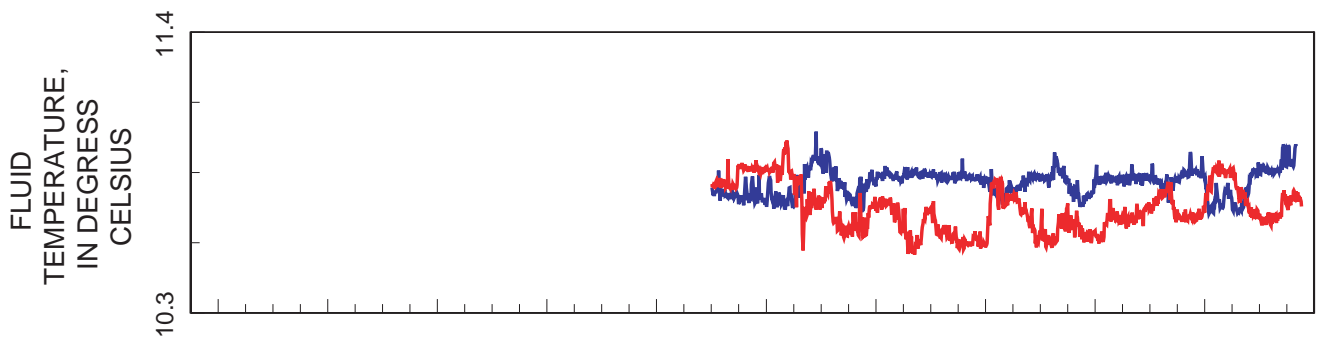

○े
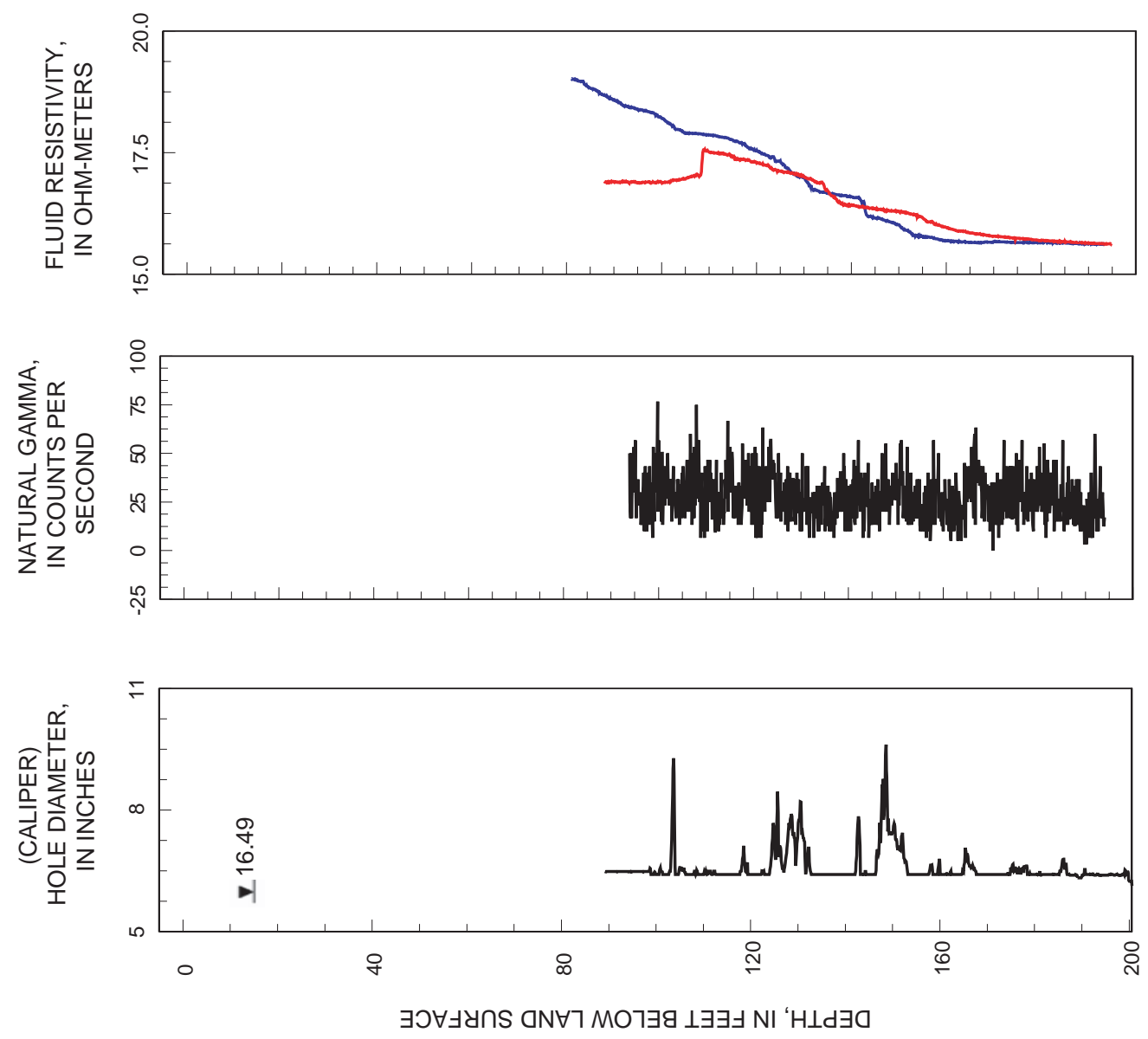
Appendix 2b: Optical televiewer, acoustic televiewer, and heat-pulse flow meter logs for wells at the USGS Leetown Science Center, Leetown, West Virginia 


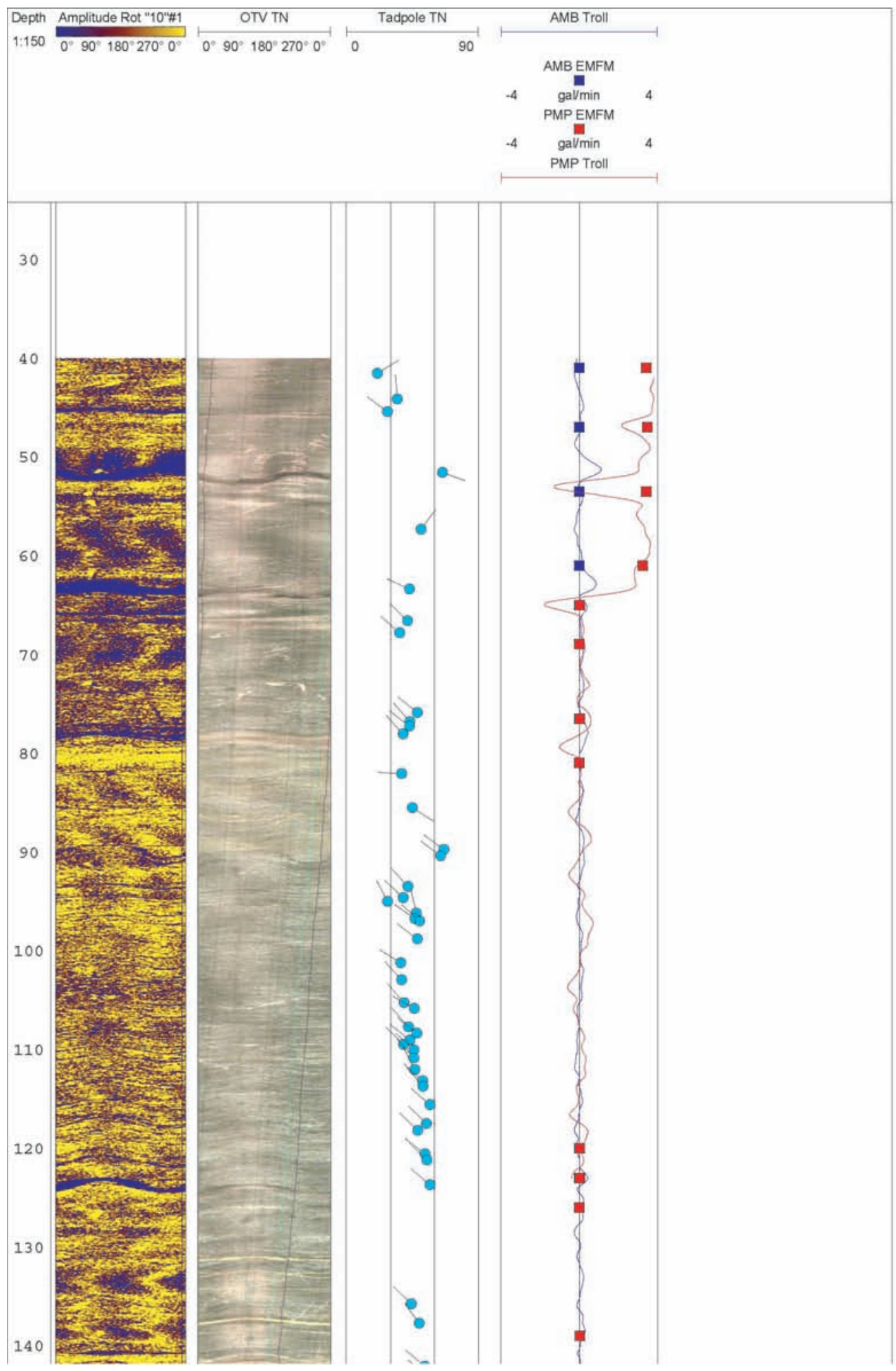

Appendix $2 \mathrm{~b}$ fig. 1 Optical televiewer, acoustic televiewer, and heat pulse flow meter logs for well Jef-0589 (anticline well) in the Leetown area, West Virginia.

[See first page of appendix $2 \mathrm{~b}$ for explanation of symbols used in the borehole logs] 


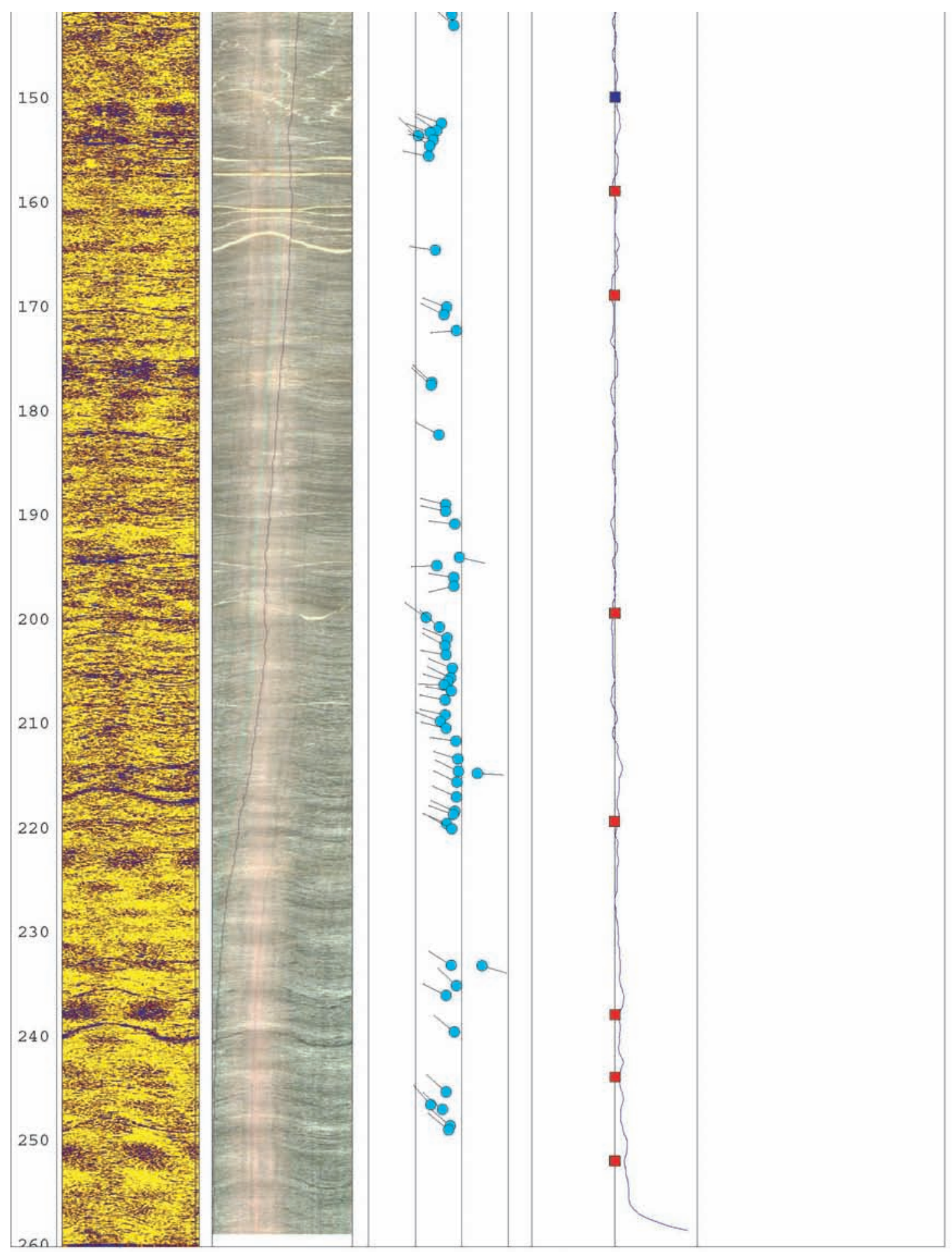

Appendix 2b fig. 1 (Continued) Optical televiewer, acoustic televiewer, and heat pulse flow meter logs for well Jef-0589 (anticline well) in the Leetown area, West Virginia.

[See first page of appendix $2 \mathrm{~b}$ for explanation of symbols used in the borehole logs] 


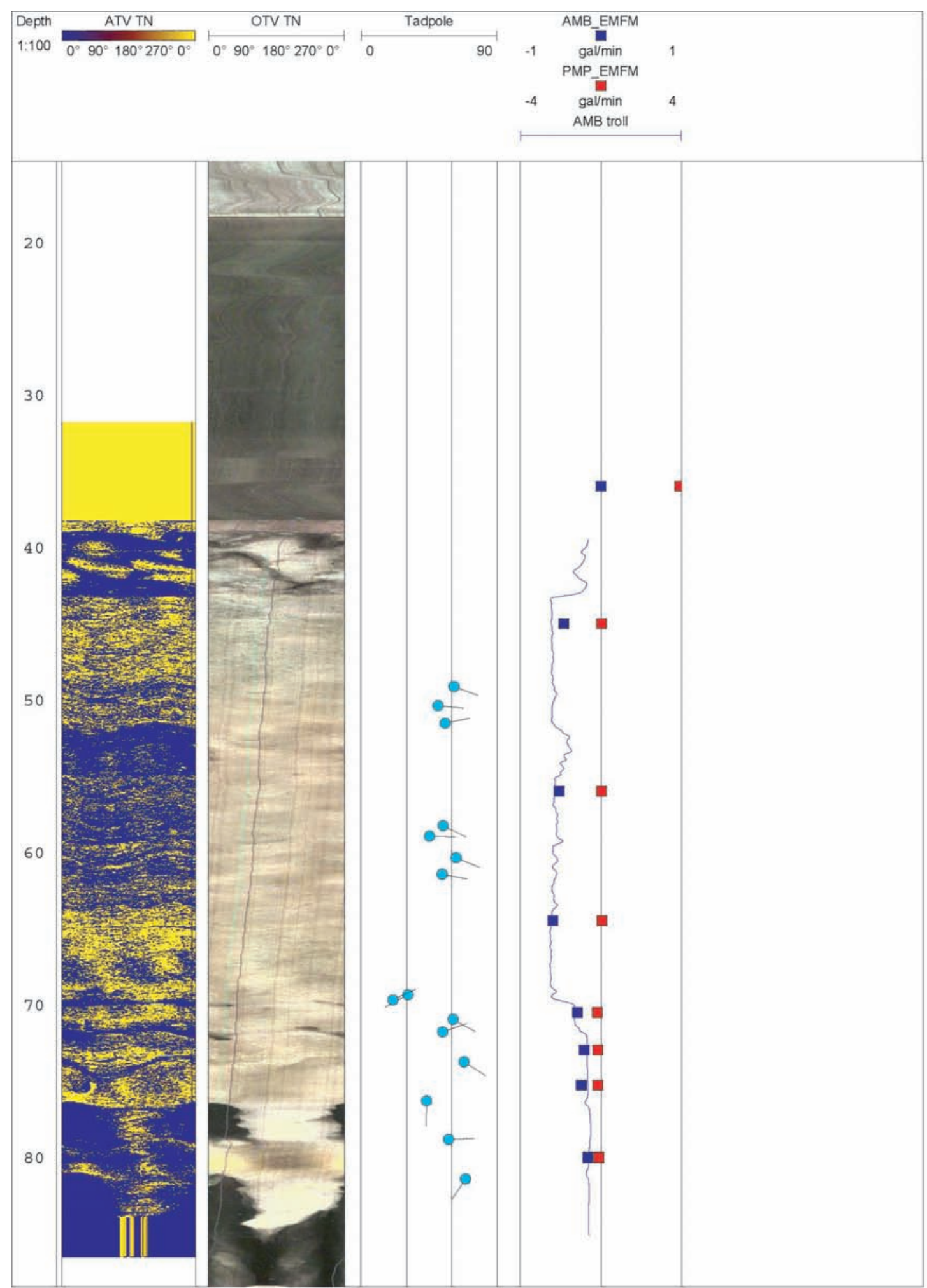

Appendix 2b fig. 2 Optical televiewer, acoustic televiewer, and heat pulse flow meter logs for well Jef-0590 (ball field well) in the Leetown area, West Virginia.

[See first page of appendix $2 b$ for explanation of symbols used in the borehole logs] 


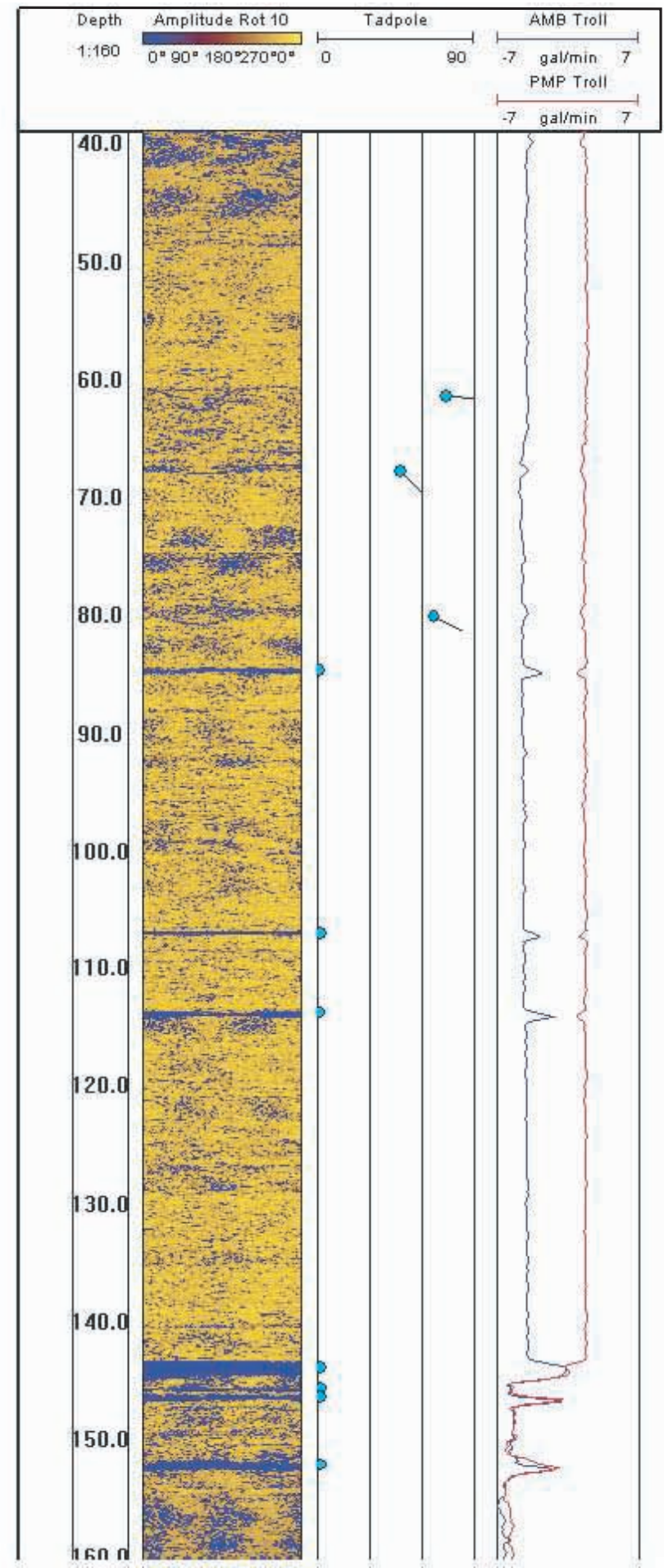

Appendix 2b fig. 3 Optical televiewer, acoustic televiewer, and heat pulse flow meter logs for well Jef-0752 (new Dodson farm well) in the Leetown area, West Virginia [See first page of appendix $2 b$ for explanation of symbols used in the borehole logs] 


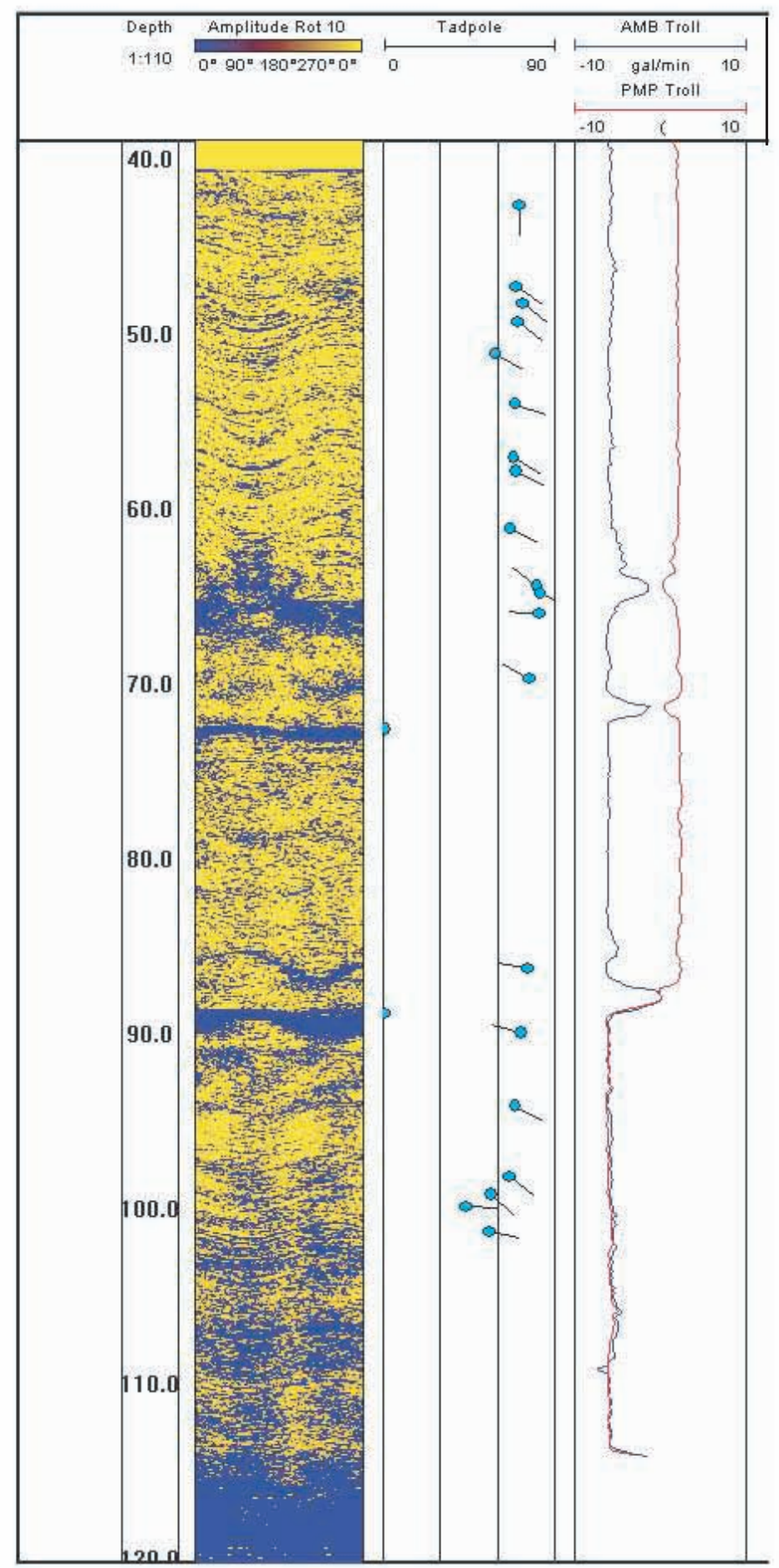

Appendix 2b fig. 4 Optical televiewer, acoustic televiewer, and heat pulse flow meter logs for well Jef-0753 (new Keyser farm well) in the Leetown area, West Virginia [See first page of appendix $2 b$ for explanation of symbols used in the borehole logs] 


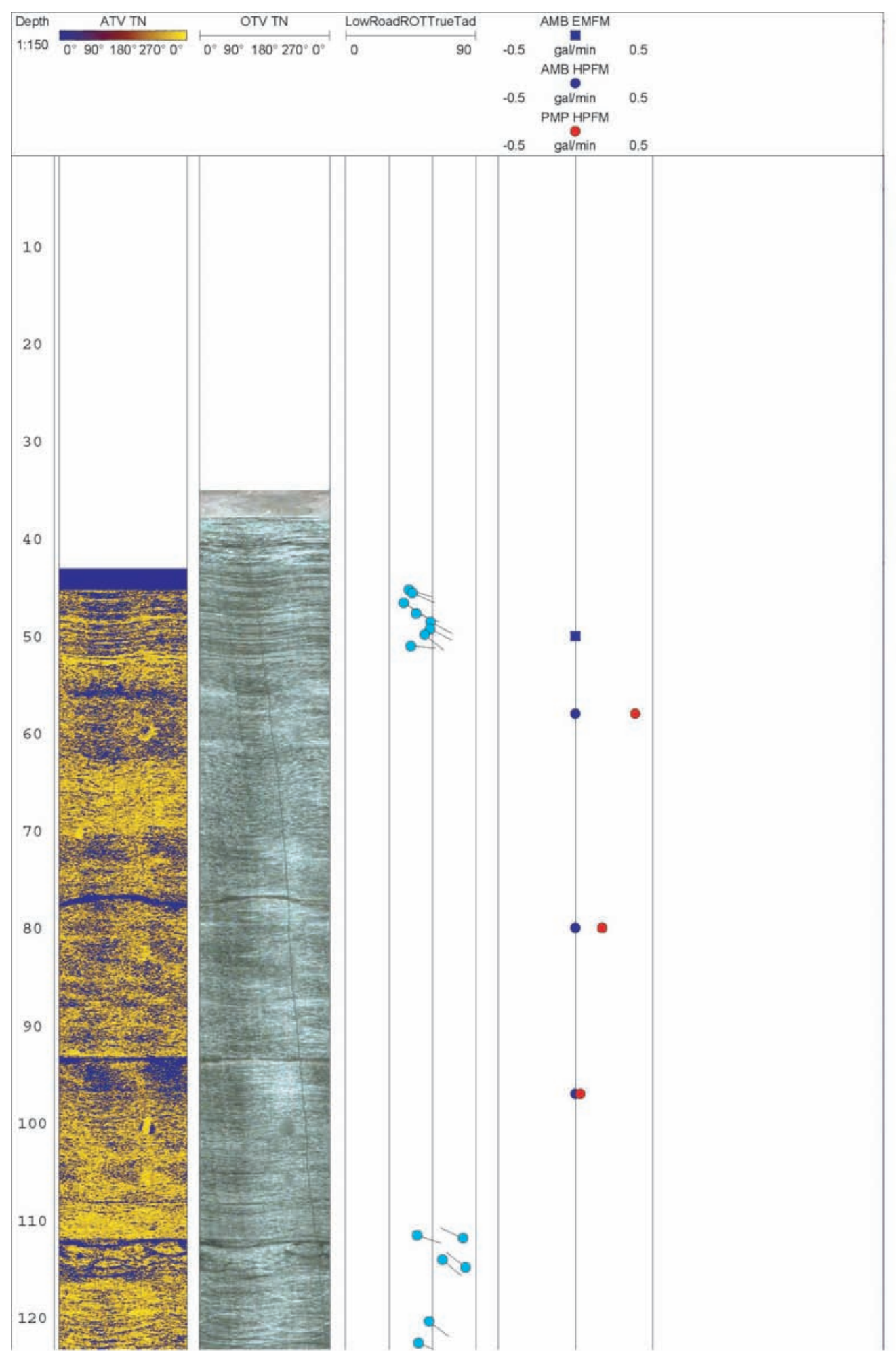

Appendix 2b fig. 5 Optical televiewer, acoustic televiewer, and heat pulse flow meter logs for well Jef-0587 (low road well) in the Leetown area, West Virginia

[See first page of appendix $2 b$ for explanation of symbols used in the borehole logs] 

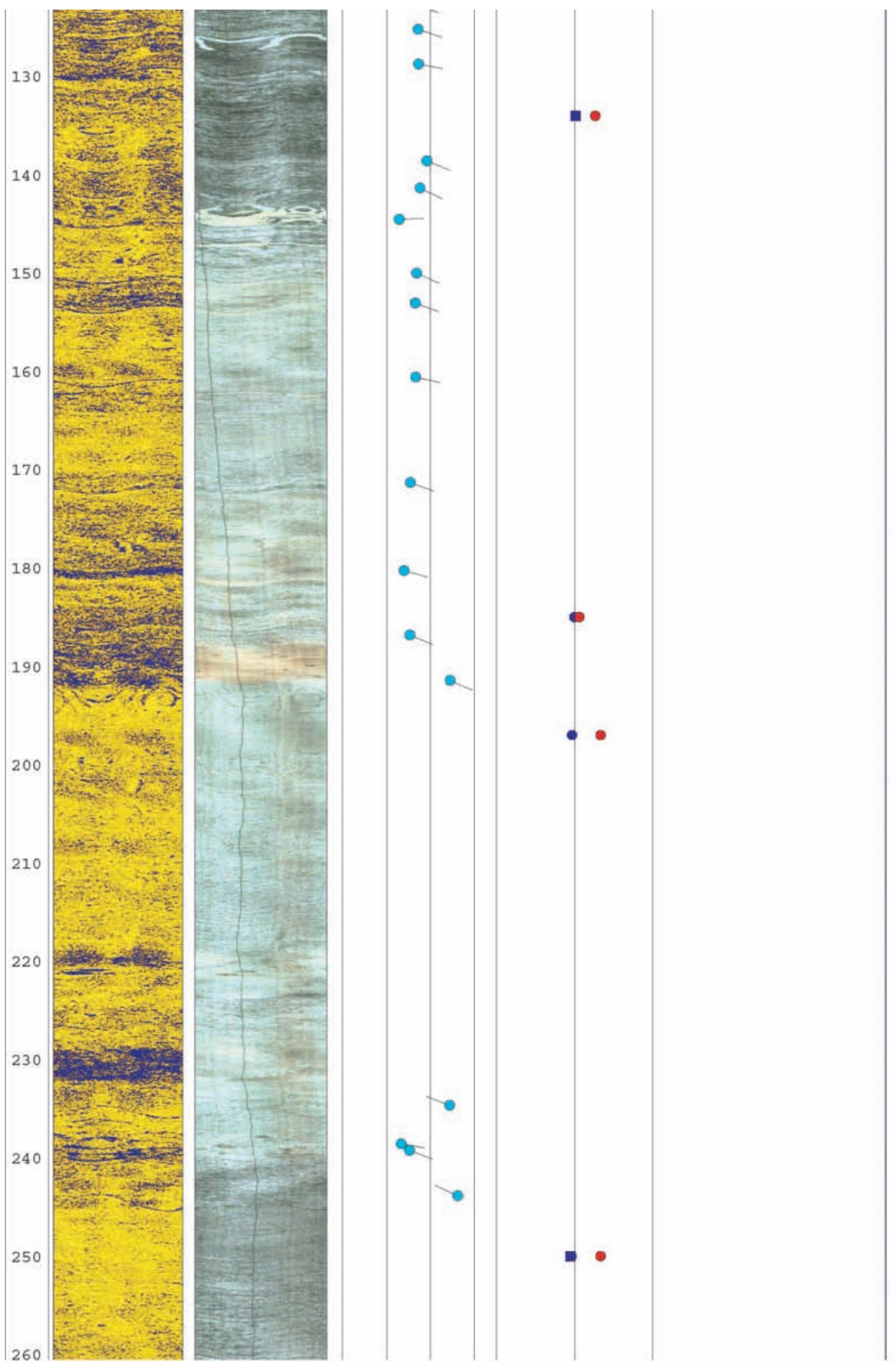

Appendix 2b fig. 5 (Continued) Optical televiewer, acoustic televiewer, and heat pulse flow meter logs for well Jef-0587 (low road well) in the Leetown area, West Virginia [See first page of appendix $2 b$ for explanation of symbols used in the borehole logs] 

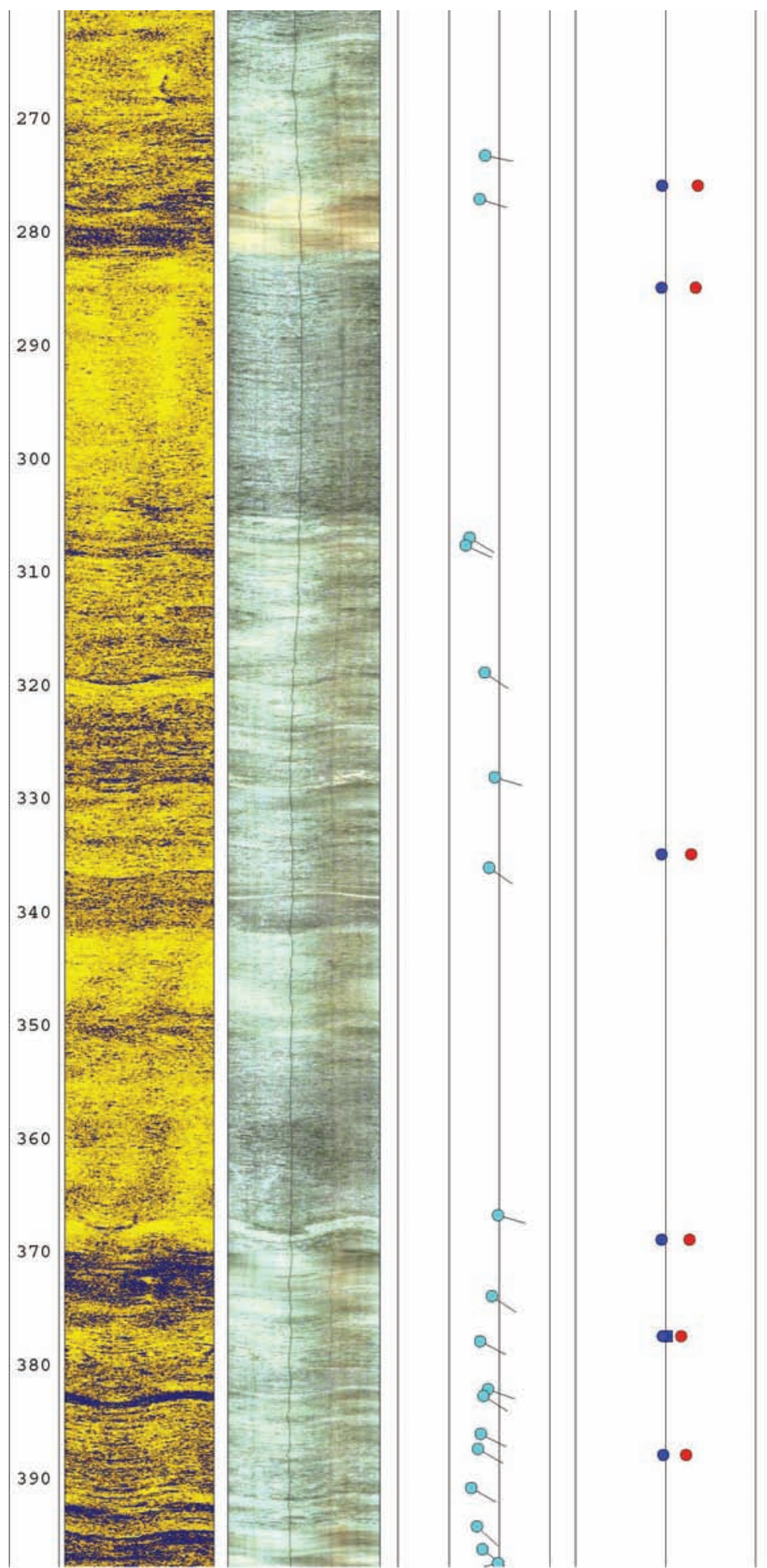

$$
\mid
$$

Appendix 2b fig. 5. (Continued) Optical televiewer, acoustic televiewer, and heat pulse flow meter logs for well Jef-0587 (low road well) in the Leetown area, West Virginia [See first page of appendix $2 b$ for explanation of symbols used in the borehole logs] 


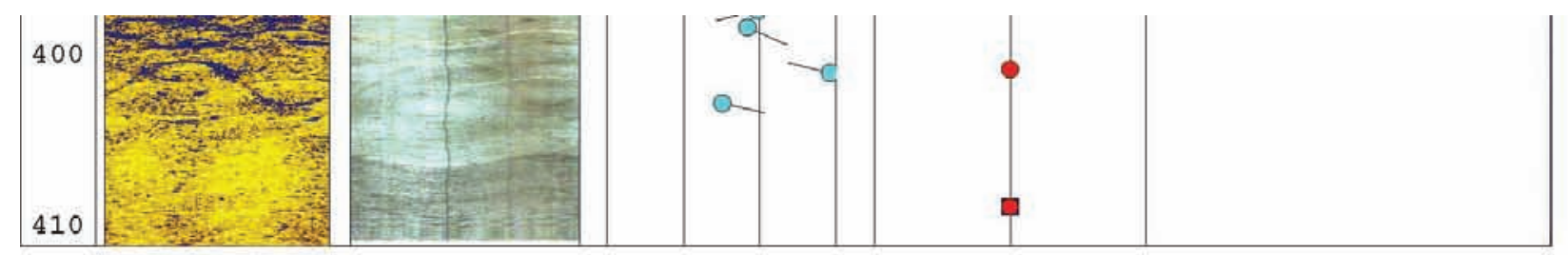

Appendix 2b fig. 5. (Continued) Optical televiewer, acoustic televiewer, and heat pulse flow mett logs for well Jef-0587 (low road well) in the Leetown area, West Virginia

[See first page of appendix $2 \mathrm{~b}$ for explanation of symbols used in the borehole logs] 


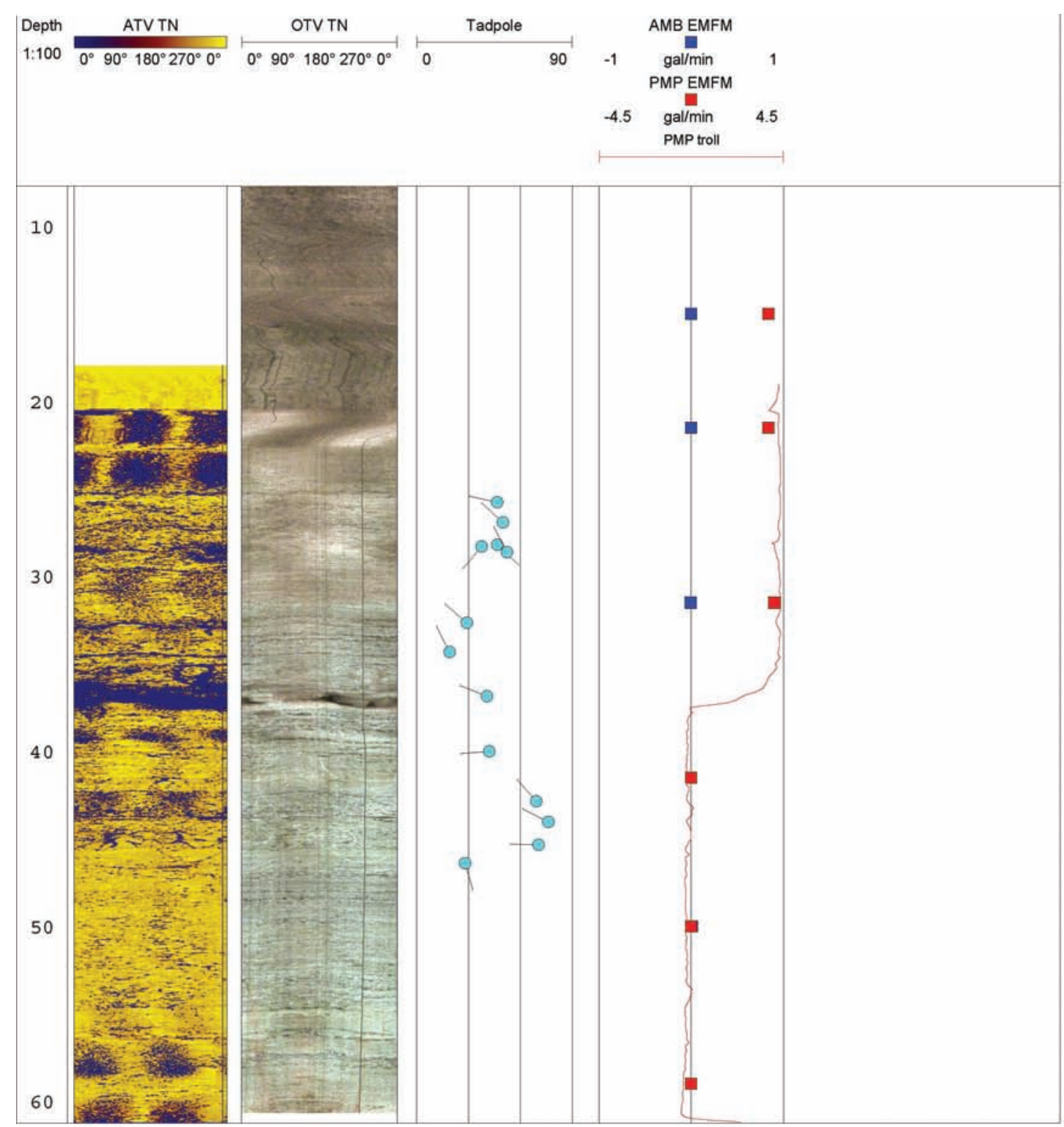

Appendix 2b fig. 6 Optical televiewer, acoustic televiewer, and heat pulse flow meter logs for well Jef-0602 (old Dodson farm well) in the Leetown area, West Virginia [See first page of appendix $2 \mathrm{~b}$ for explanation of symbols used in the borehole logs 


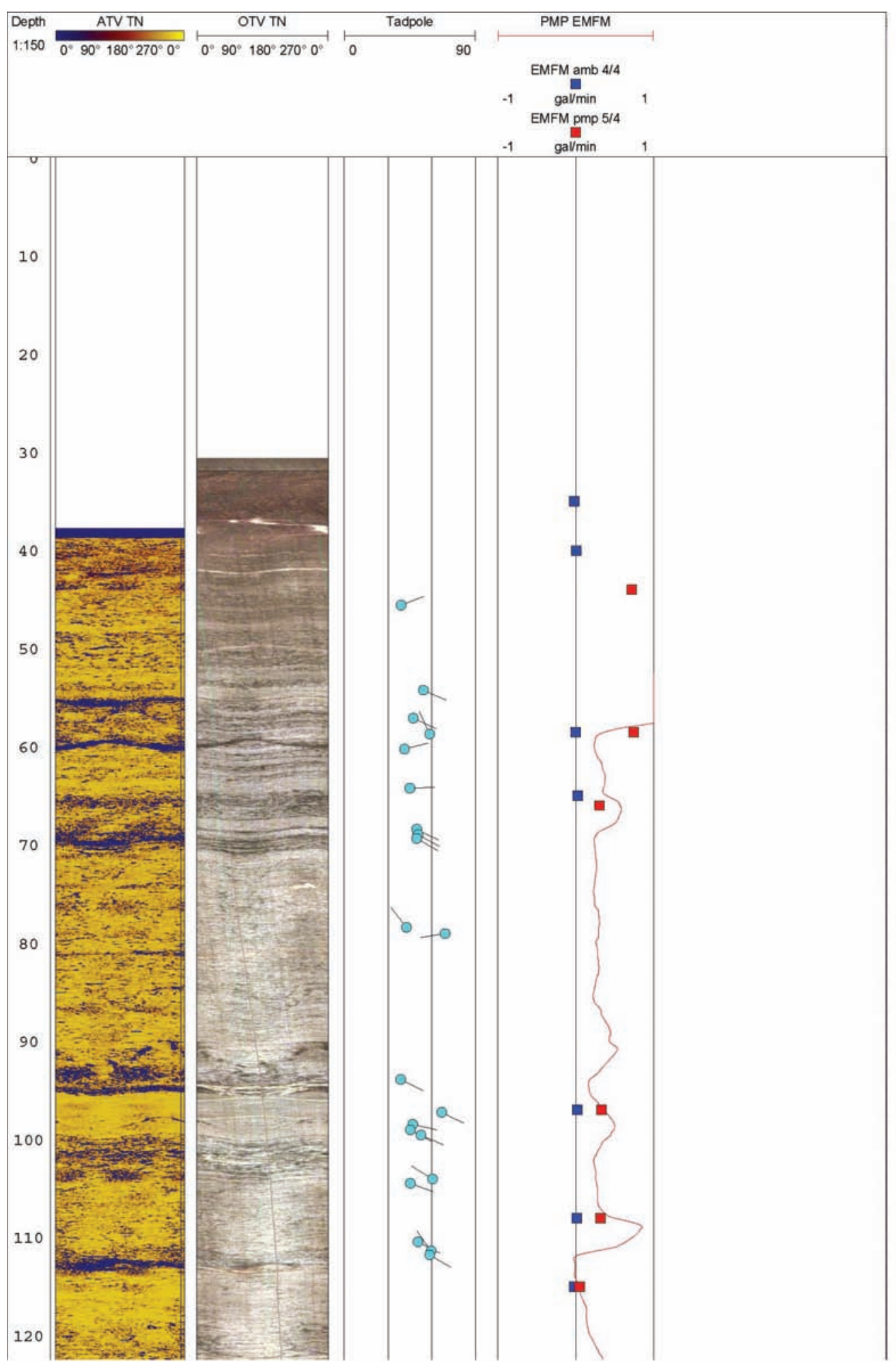

Appendix 2b fig. 7 Optical televiewer, acoustic televiewer, and heat pulse flow meter logs for well Jef-0601 (stable A well) in the Leetown area, West Virginia [See first page of appendix $2 b$ for explanation of symbols used in the borehole logs] 

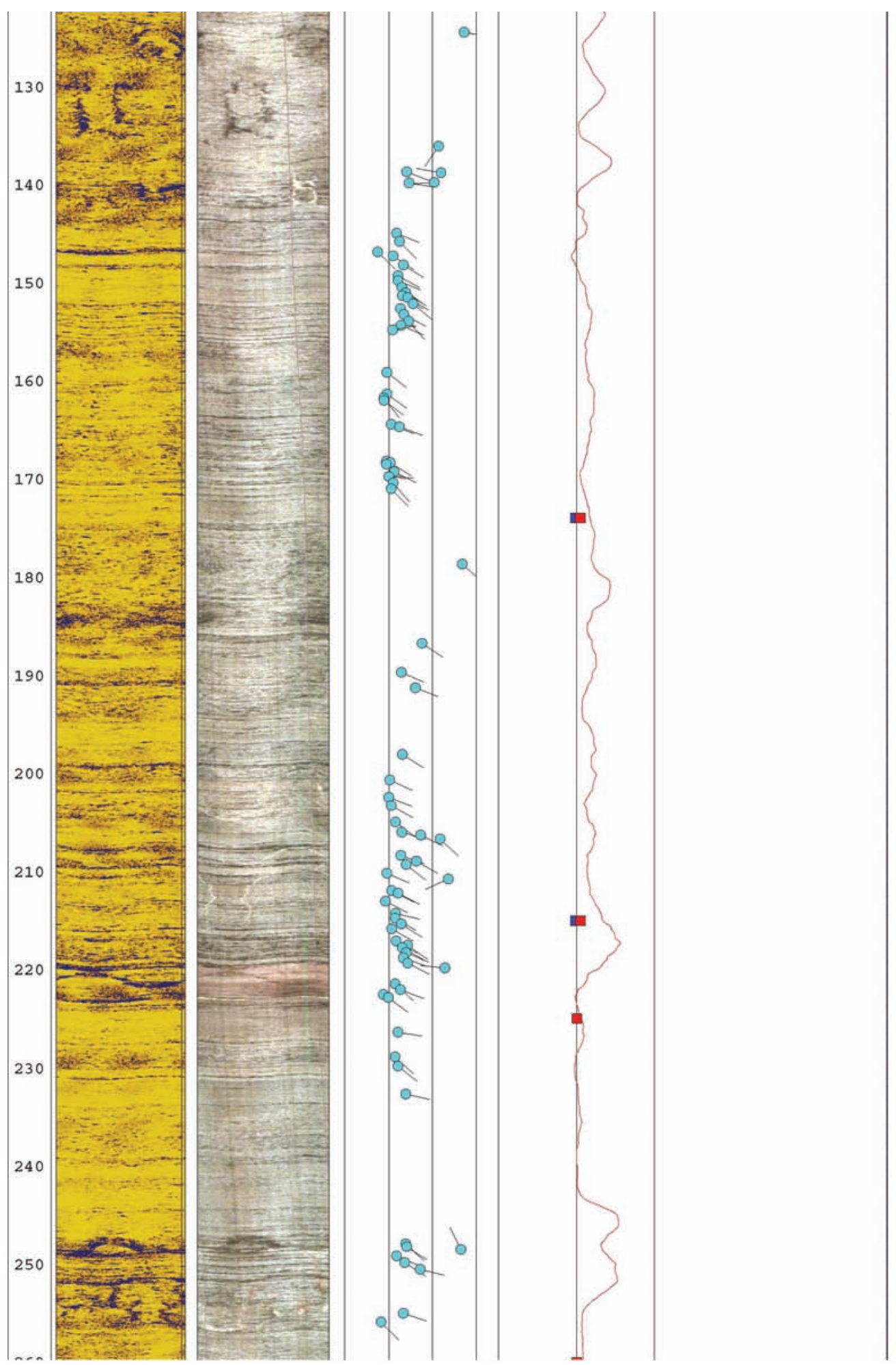

Appendix 2b fig. 7 (Continued) Optical televiewer, acoustic televiewer, and heat pulse flow meter logs for well Jef-0601 (stable A well) in the Leetown area, West Virginia [See first page of appendix $2 \mathrm{~b}$ for explanation of symbols used in the borehole logs] 


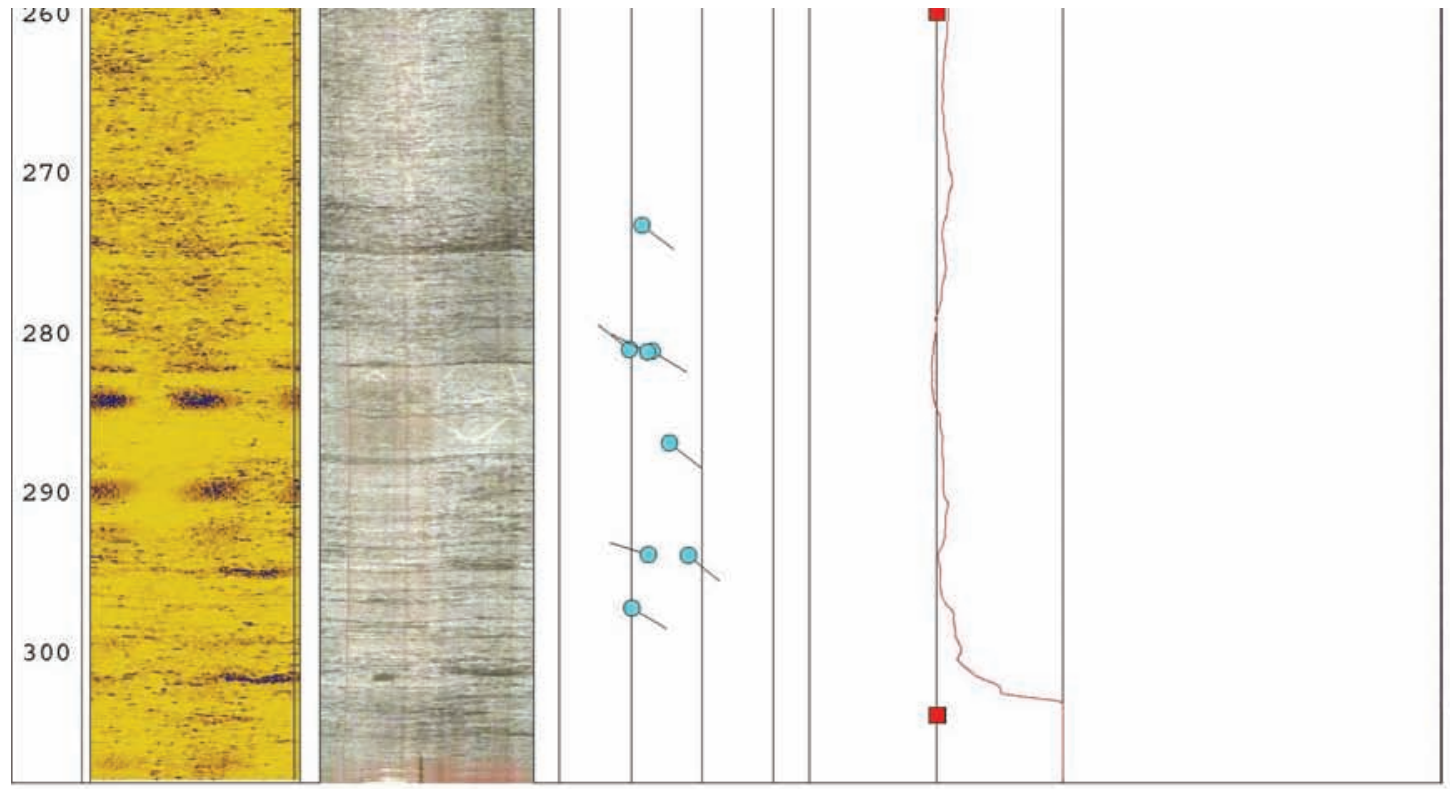

Appendix 2b fig. 7 (Continued) Optical televiewer, acoustic televiewer, and heat pulse flow meter logs for well Jef-0601 (stable A well) in the Leetown area, West Virginia [See first page of appendix $2 \mathrm{~b}$ for explanation of symbols used in the borehole logs] 


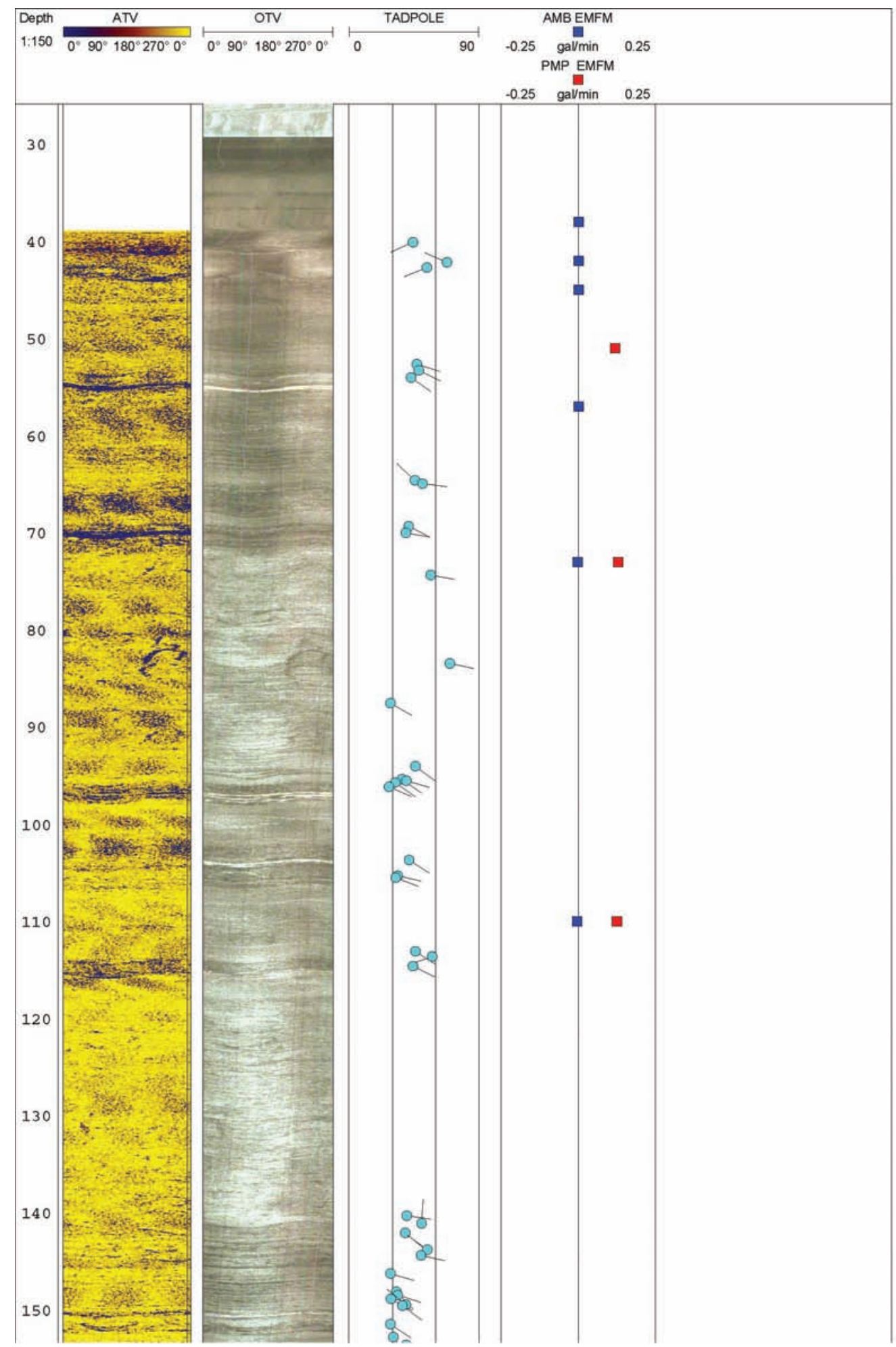

Appendix 2b fig. 8 Optical televiewer, acoustic televiewer, and heat pulse flow meter logs for well Jef-0585 (stable B well) in the Leetown area, West Virginia [See first page of appendix $2 \mathrm{~b}$ for explanation of symbols used in the borehole logs] 

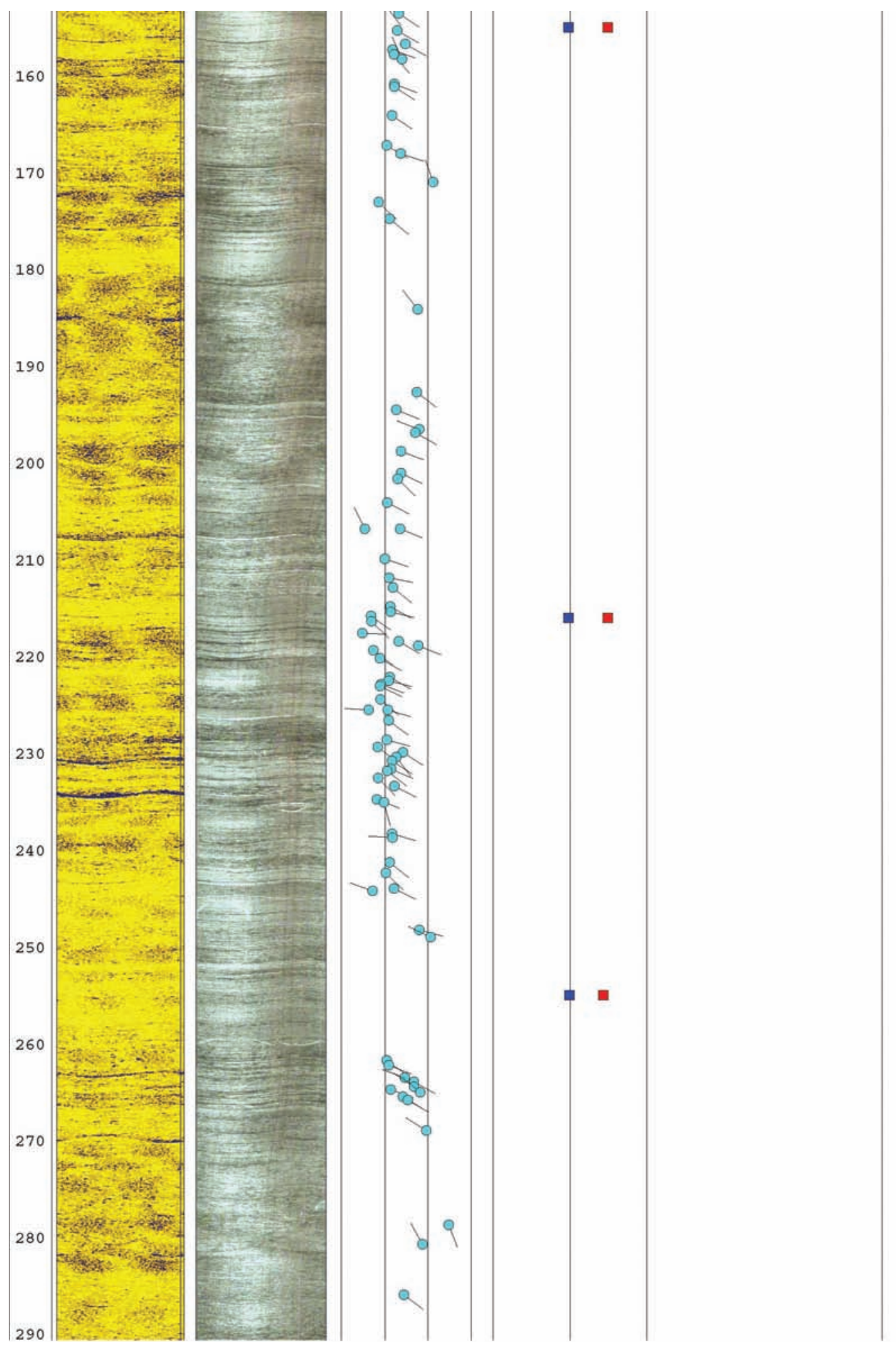

Appendix 2b fig. 8 (Continued) Optical televiewer, acoustic televiewer, and heat pulse flow meter logs for well Jef-0585 (stable B well) in the Leetown area, West Virginia [See first page of appendix $2 \mathrm{~b}$ for explanation of symbols used in the borehole logs] 


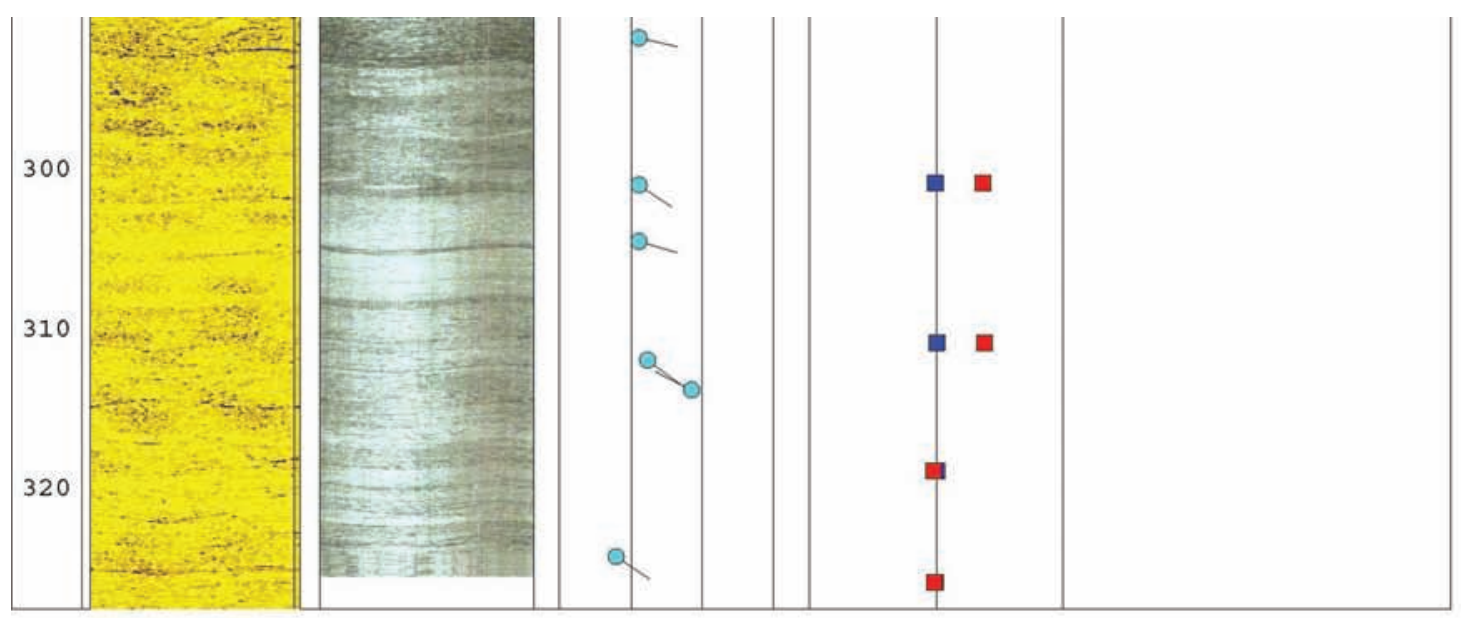

Appendix 2b fig. 8 (Continued) Optical televiewer, acoustic televiewer, and heat pulse flow meter logs for well Jef-0585 (stable B well) at the Leetown Science Center, Leetown, WV [See first page of appendix $2 \mathrm{~b}$ for explanation of symbols used in the borehole logs] 


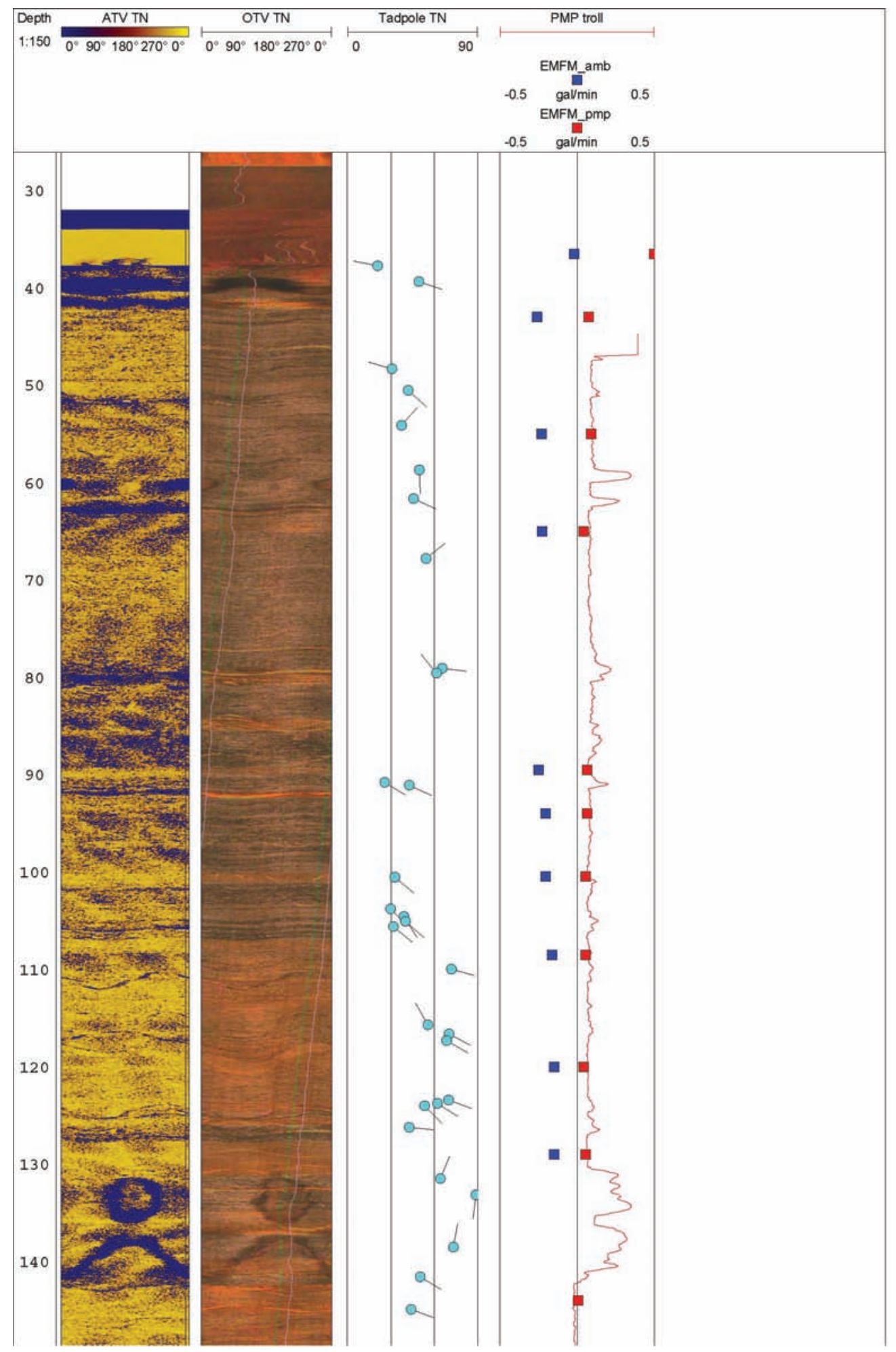

Appendix 2b fig. 9 Optical televiewer, acoustic televiewer, and heat pulse flow meter logs for well Jef-0592 (stable $C$ well) in the Leetown area, West Virginia

[See first page of appendix $2 b$ for explanation of symbols used in the borehole logs] 

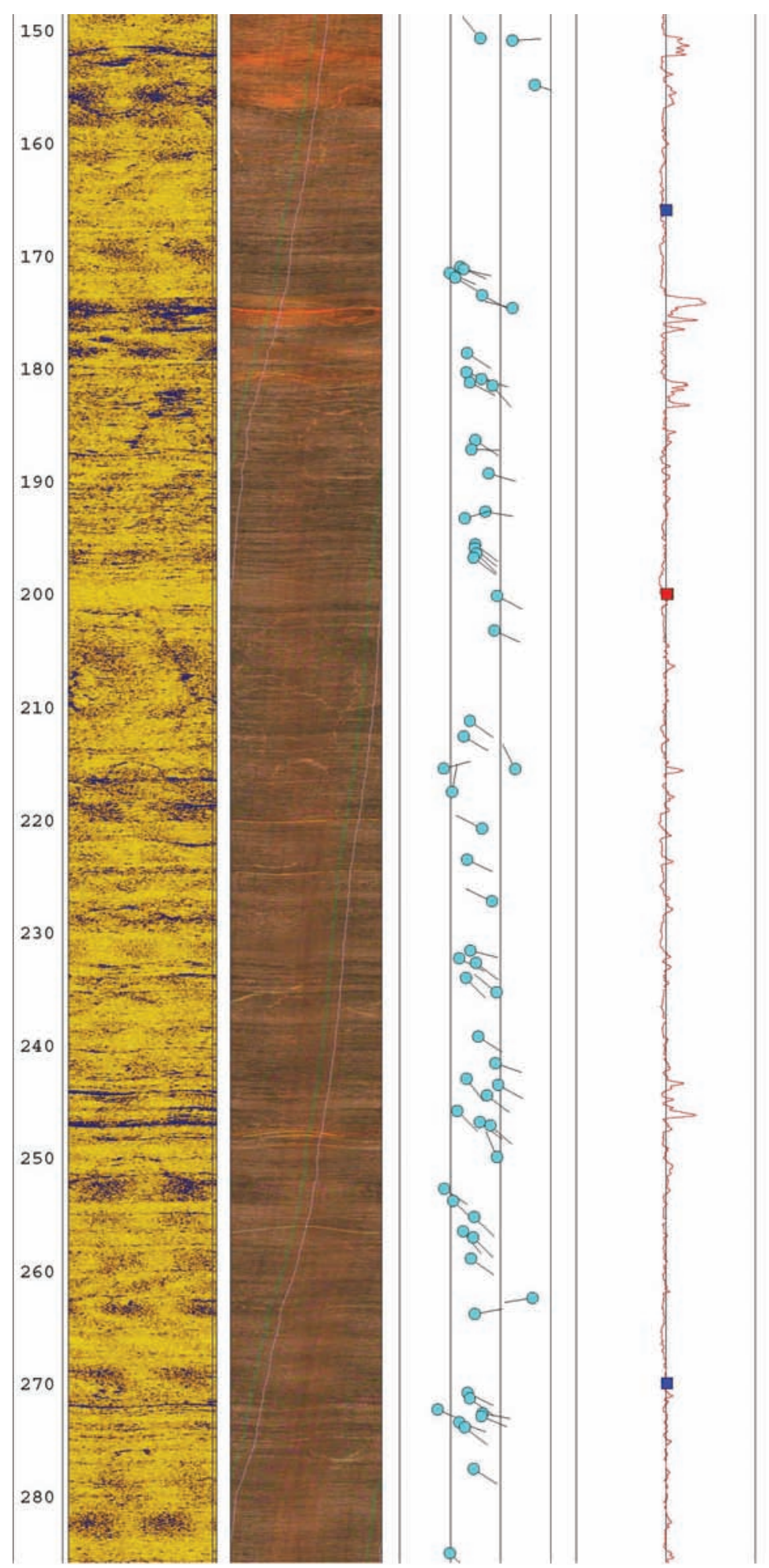

Appendix 2b fig. 9 (Continued) Optical televiewer, acoustic televiewer, and heat pulse flow meter logs for well Jef-0592 (stable C well) in the Leetown area, West Virginia [See first page of appendix $2 b$ for explanation of symbols used in the borehole logs] 


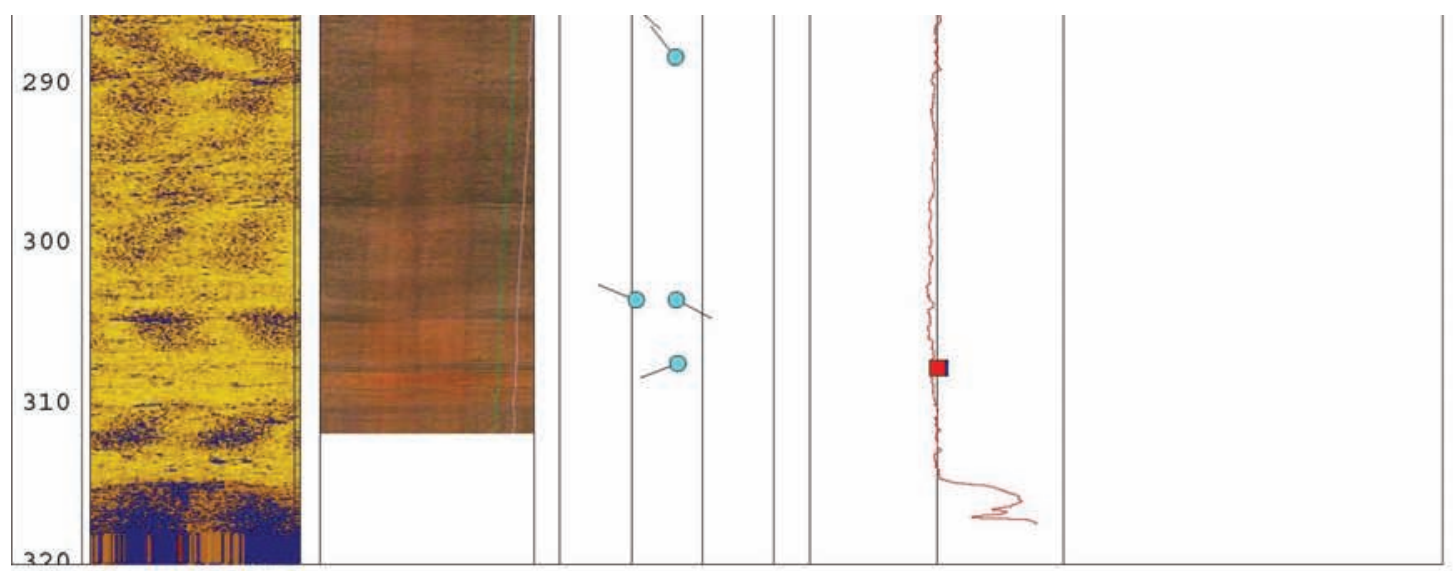

Appendix 2b fig. 9 (Continued) Optical televiewer, acoustic televiewer, and heat pulse flow meter logs for well Jef-0592 (stable C well) in the Leetown area, West Virginia [See first page of appendix $2 b$ for explanation of symbols used in the borehole logs] 


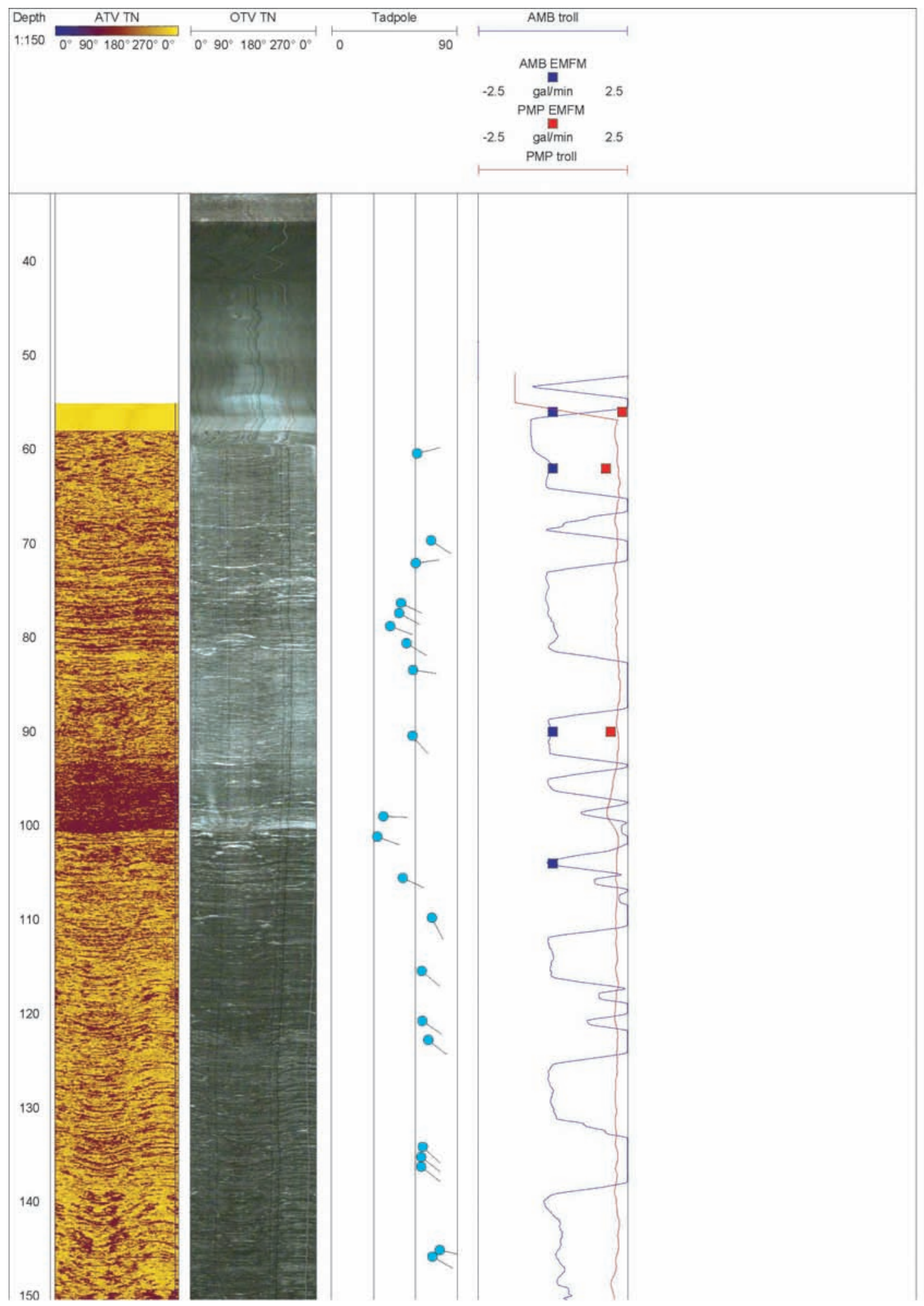

Appendix 2b fig. 10 Optical televiewer, acoustic televiewer, and heat pulse flow meter logs for well Jef-0603 (USDA sulfur well) in the Leetown area, West Virginia [See first page of appendix $2 b$ for explanation of symbols used in the borehole logs] 

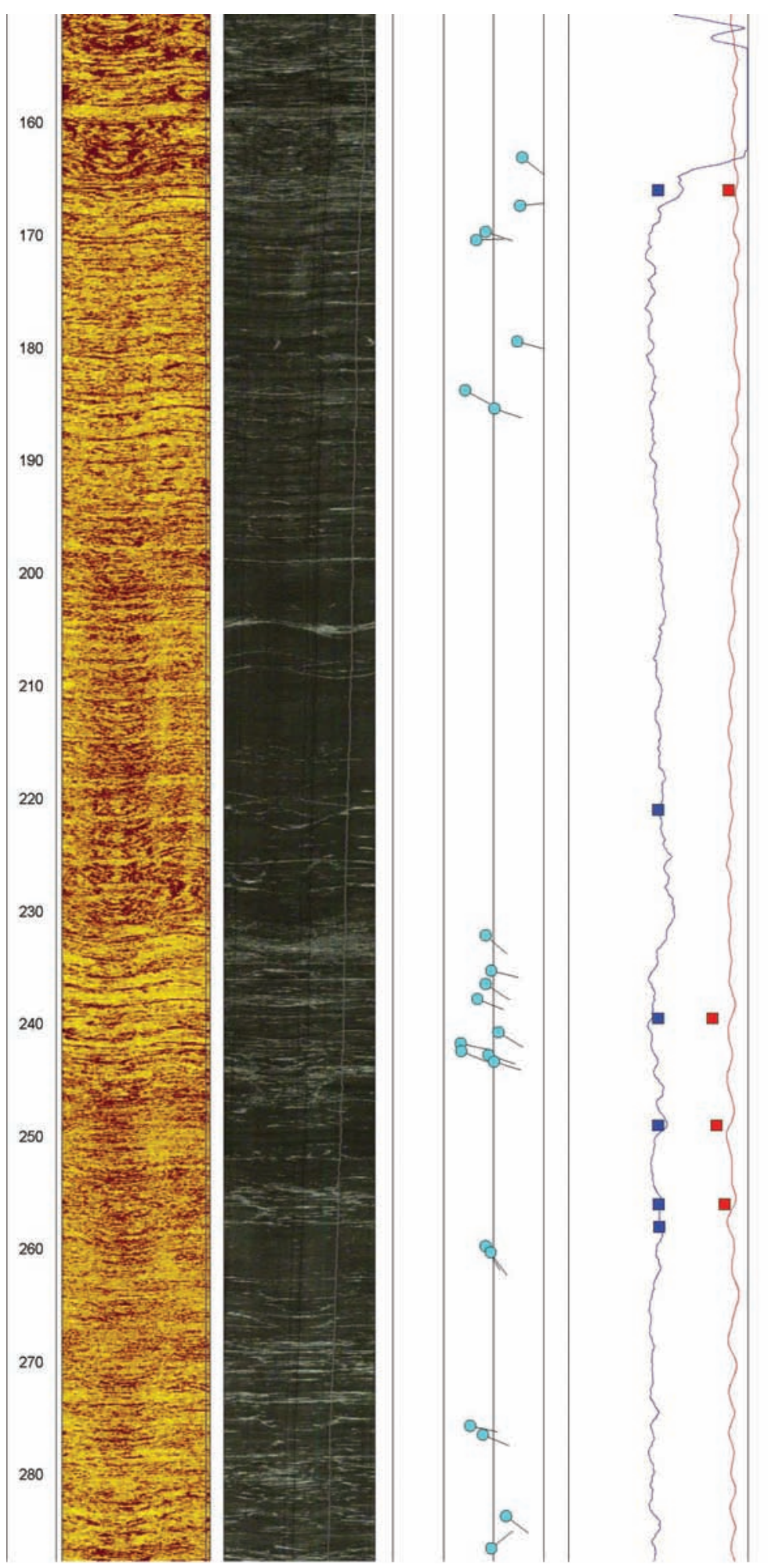

Appendix 2b fig. 10 (Continued) Optical televiewer, acoustic televiewer, and heat pulse flow meter logs for well Jef-0603 (USDA sulfur well) in the Leetown area, West Virginia [See first page of appendix $2 \mathrm{~b}$ for explanation of symbols used in the borehole logs] 

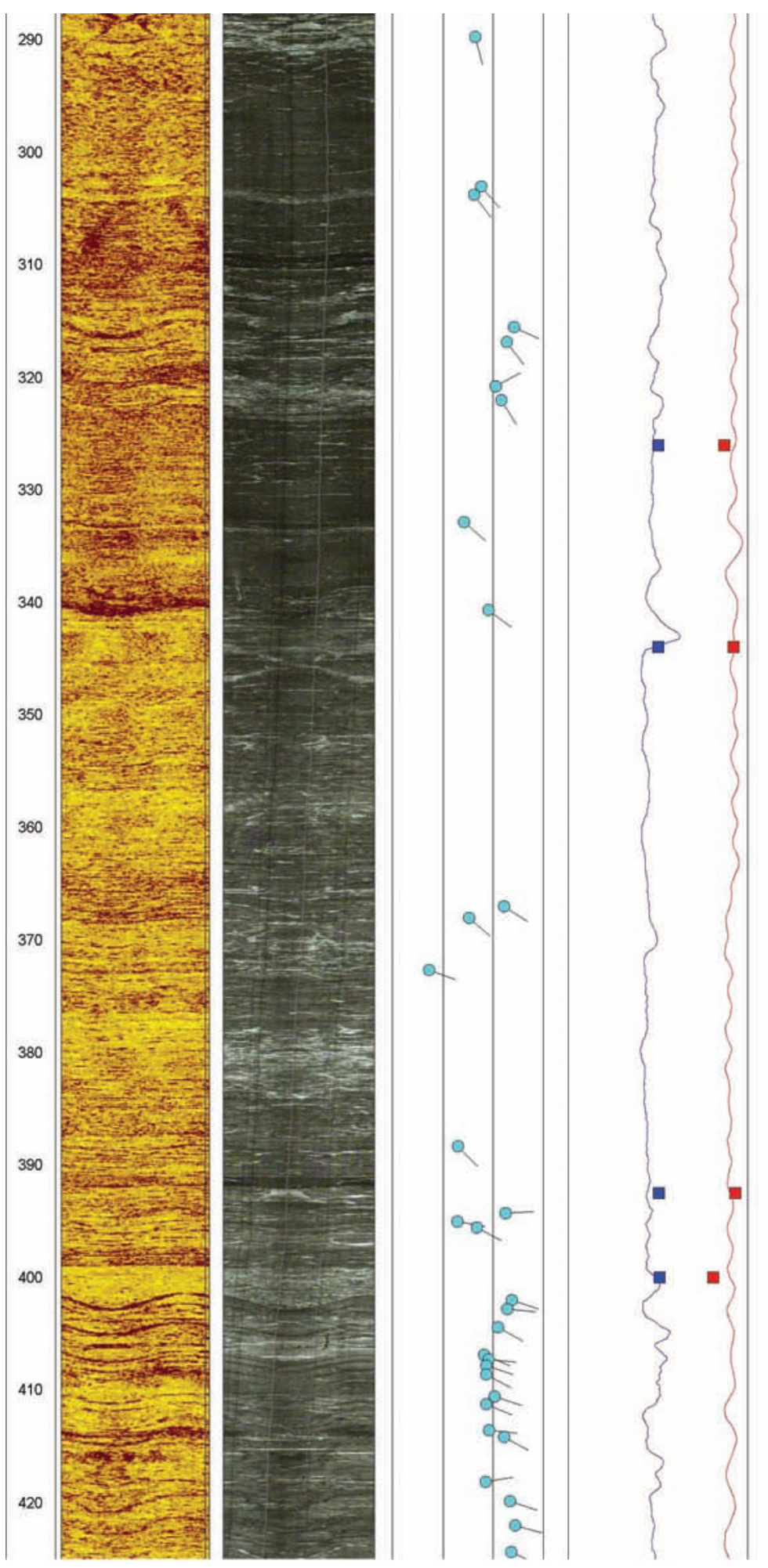

Appendix 2b fig. 10 (Continued) Optical televiewer, acoustic televiewer, and heat pulse flow meter logs for well Jef-0603 (USDA sulfur well) inthe Leetown area, West Virginia [See first page of appendix $2 b$ for explanation of symbols used in the borehole logs] 

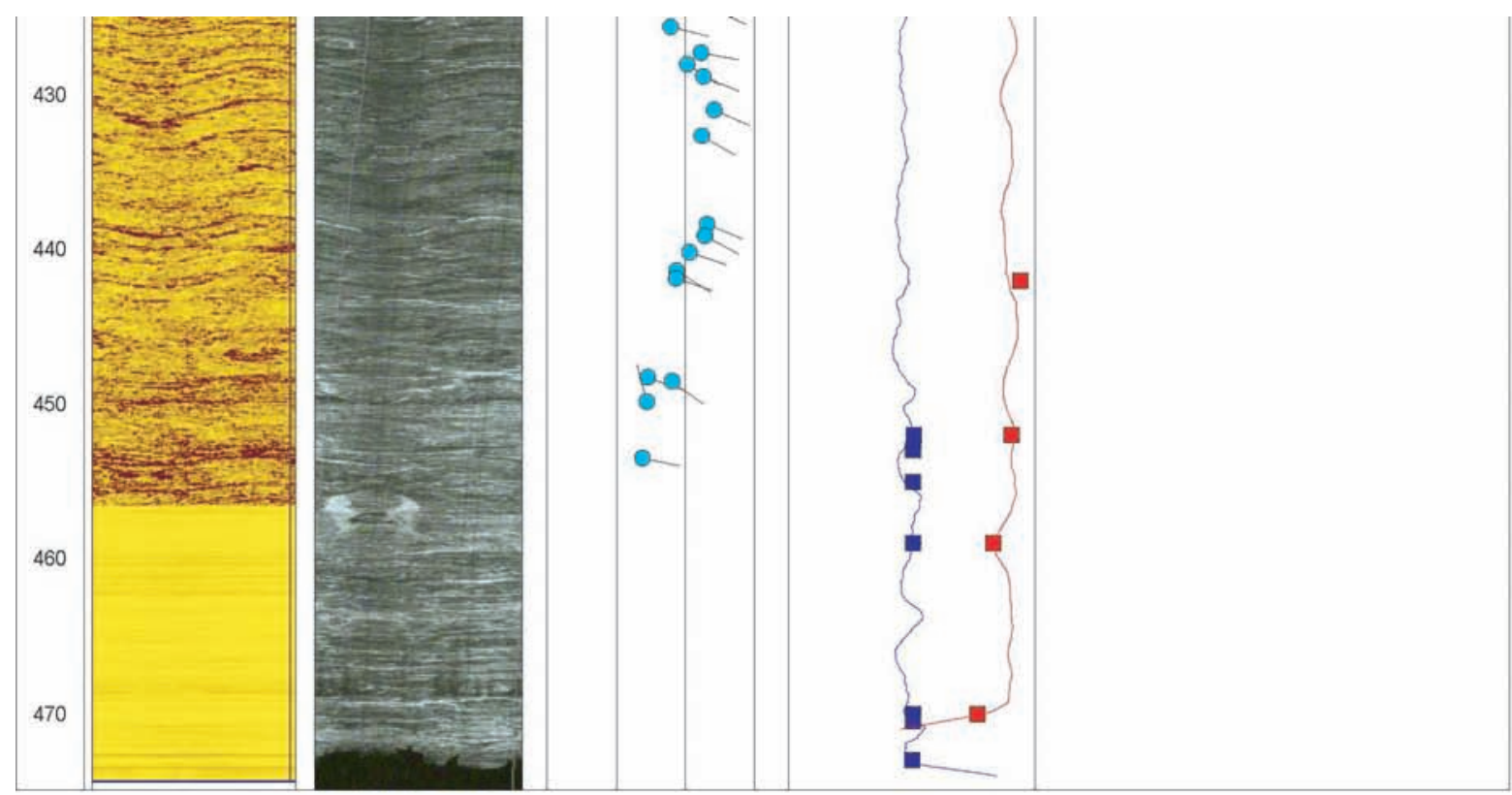

Appendix 2b fig. 10 (Continued) Optical televiewer, acoustic televiewer, and heat pulse flow meter logs for well Jef-0603 (USDA sulfur well) in the Leetown area, West Virginia [See first page of appendix $2 \mathrm{~b}$ for explanation of symbols used in the borehole logs] 


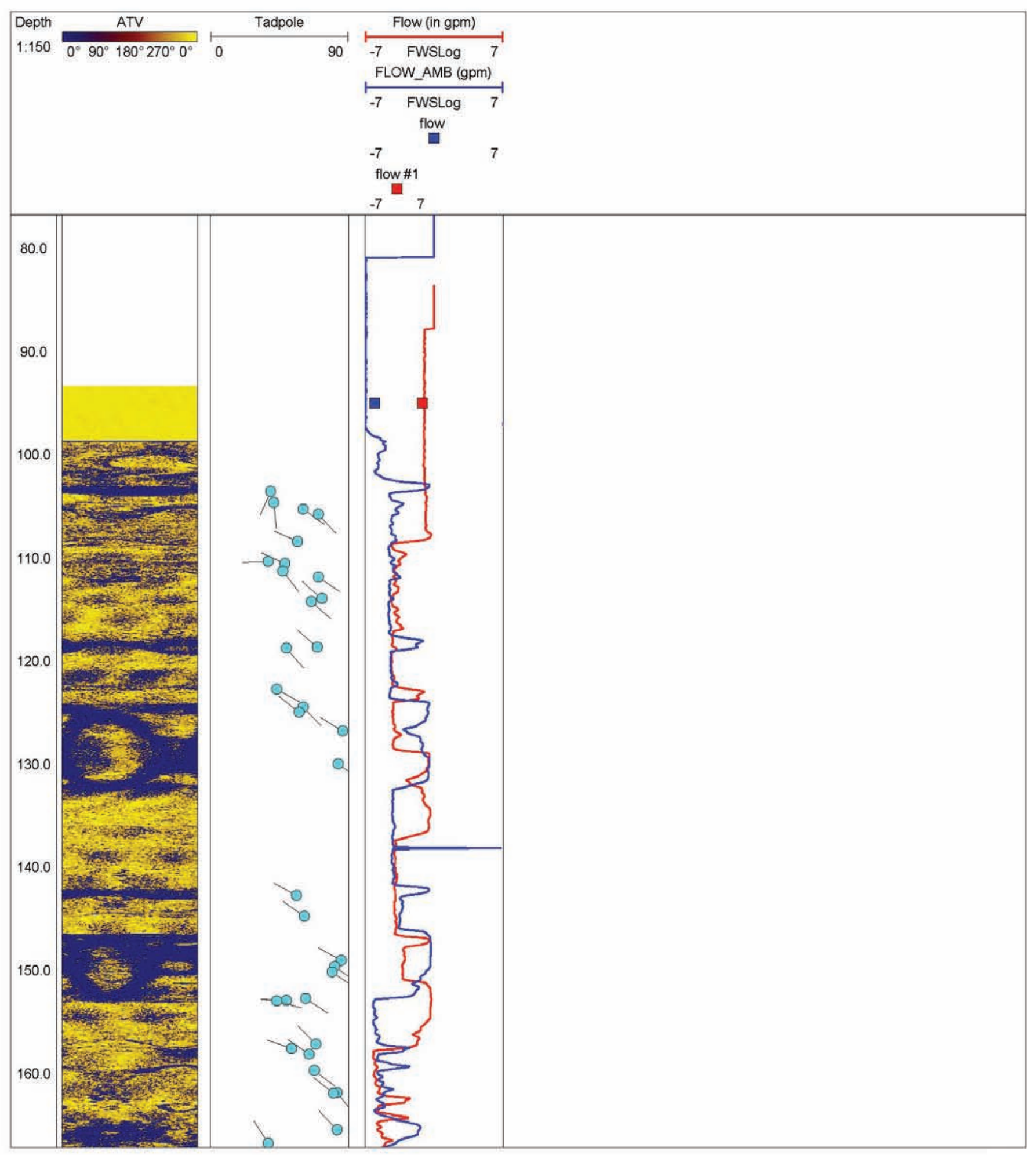

Appendix 2b fig. 11 Optical televiewer, acoustic televiewer, and heat pulse flow meter logs for well Jef-0586 (USDA fault well) in the Leetown area, West Virginia

[See first page of appendix $2 \mathrm{~b}$ for explanation of symbols used in the borehole logs] 


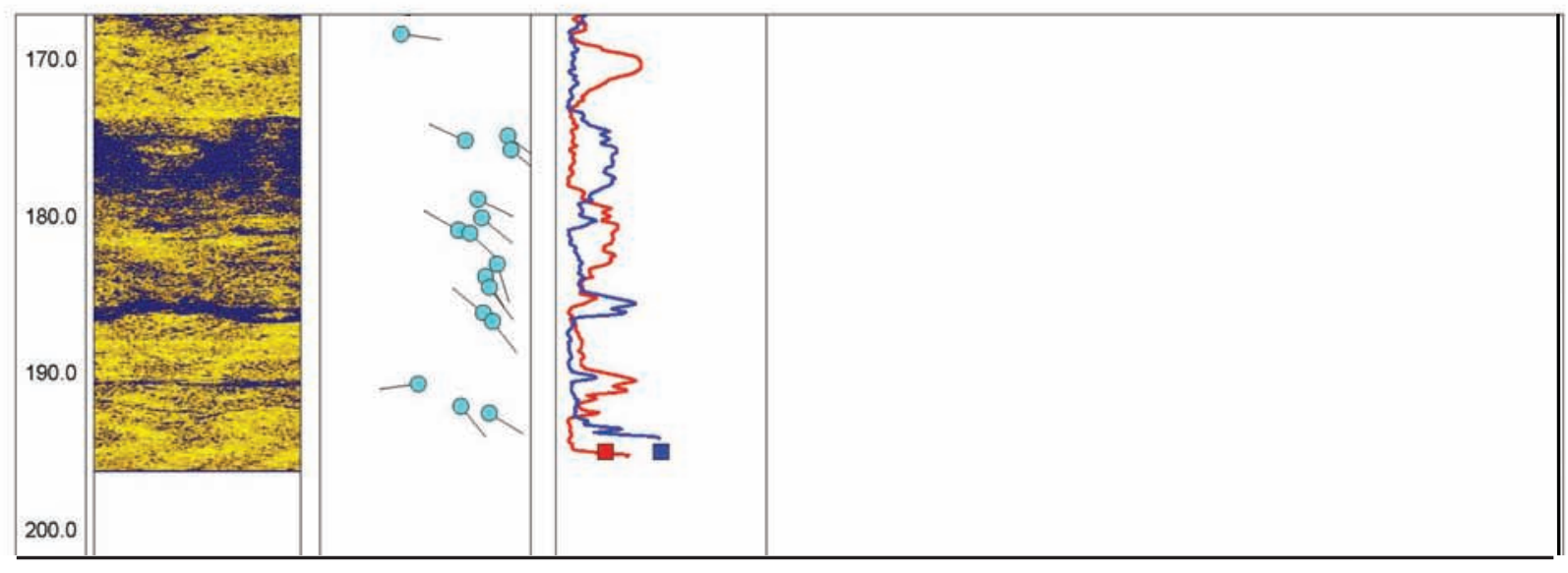

Appendix 2b fig. 11 (Continued) Optical televiewer, acoustic televiewer, and heat pulse flow meter logs for well Jef-0586 (USDA fault well) in the Leetown area, West Virginia [See first page of appendix $2 \mathrm{~b}$ for explanation of symbols used in the borehole logs] 
Appendix 2c - Interpretation of borehole logs for 11 wells on the USGS Leetown Science Center, West Virginia 
Jef-0589 (anticline well)

Borehole Jef-0589 (site 41 on fig. 1 and in table 1) was constructed as a 6-inch (in.) diameter open hole to a depth of $260 \mathrm{ft}$ and cased to $38.5 \mathrm{ft}$ below land surface (bls). It is located on the crest of a small anticline and completed entirely in the Ordovician Rockdale Run Formation of the Beekmantown Group. The geologist's well log indicates $25 \mathrm{ft}$ of clay overlying bedrock and a total yield of $18 \mathrm{gal} / \mathrm{min}$ from waterbearing zones at $91-92$ and $137-140 \mathrm{ft}$ bls. Additional fracture zones were noted at 52-55, 57-60, 77-79, 91-92, and 137-140 $\mathrm{ft}$ bls. The static water level in the borehole at the time of geophysical logging was $13.65 \mathrm{ft}$ bls.

The caliper $\log$ recorded major fractures at 52,64, and $124 \mathrm{ft}$ bls, plus numerous small fractures throughout the openhole interval (app. 2a, fig. 1). Under ambient (non-pumping) conditions changes in fluid-resistivity are seen at $38.5 \mathrm{ft}$ (the bottom of the casing), 50 and $194 \mathrm{ft}$ bls. Subtle changes in slope can be seen in the fluid-temperature log between 190 and $200 \mathrm{ft}$ bls. Integrated analysis of the fluid-resistivity, fluid-temperatures, and flow-meter logs (app. 2b, fig. 1) indicate no vertical flow of water in the borehole under ambient conditions.

A pump was placed in the well casing and the well pumped at $5.8 \mathrm{gal} / \mathrm{min}$. The fluid-resistivity log recorded more resistive water entering the borehole at $65-70 \mathrm{ft}$ bls. Slope changes in fluid-temperature are seen at $64 \mathrm{ft}$ and between 70 and $75 \mathrm{ft}$ bls. Under pumping conditions, the fluid-resistivity, fluid-temperature, and flow-meter data indicate that all water enters the borehole at the N. $24^{\circ}$ E. strike and N. $43^{\circ}$ W. dip trending fracture at $63 \mathrm{ft}$ bls. The deflection of the EM flow $\log$ at $52 \mathrm{ft}$ bls is associated with an increase in borehole diameter and flow circumventing the tool at that depth.

The ATV and OTV logs indicate the borehole is intersected by 102 fractures between 38.5 and $260 \mathrm{ft}$ bls (app. 3, table 1). Eighty seven of the 102 fractures have apertures ranging from 0.2 to $8.0 \mathrm{in}$. The character and orientation of these data, plotted on a lower-hemisphere equal-area net as poles to planes, indicate one major fracture-population cluster with a strike orientation of $167-266^{\circ}$ and dips of N. $28-67^{\circ}$ W. (fig. 17). In Appendix 3 strike is reported in azimuthal degrees, east of true North in the "right hand rule" where the direction of dip is to the right of bedrock strike.

Jef-590 (ball field well)

Borehole Jef- 0590 (site 48 on fig. 1 and in table 1) was constructed as a 6-in. diameter open hole to a depth of 160 $\mathrm{ft}$ and cased to $38.5 \mathrm{ft}$ bls. The borehole was drilled into the Ordovician Rockdale Run Formation of the Beekmantown Group at the inferred intersection of a thrust fault and land sur- face. The geologist's log (observations made by a geologist at the time the well was drilled) indicate $10 \mathrm{ft}$ of clay overlying bedrock and a total yield exceeding $100 \mathrm{gal} / \mathrm{min}$ from zones located at 40-50 and 131-140 ft bls and a large void at 85-100 $\mathrm{ft}$ bls. Additional voids and weathered zones were noted at 52-53, 60-70, 75-76, 78, 82-83, 100-113, and 129-131 ft bls. The static water level in the borehole at the time of geophysical logging was $18.54 \mathrm{ft}$ bls.

The caliper log recorded major fractures at 39, 42, 78, and 80-90 ft bls, plus several small fractures throughout the open-hole interval (app. 2a, fig. 2). Under ambient conditions the fluid-resistivity log shows a slight increase in fluid resistivity with depth. A sharp change in slope can be seen on the fluid-temperature log between 68 and $72 \mathrm{ft}$ bls. Integrated analysis of the fluid-resistivity, fluid-temperatures, and flowmeter logs (app. 2b, fig. 2) indicate that water enters the borehole at 70 and $85 \mathrm{ft}$ bls and flows upward, exiting the borehole at fracture zones at 39 and $42 \mathrm{ft}$ bls.

A pump was placed in the well casing and the well pumped at $10.8 \mathrm{gal} / \mathrm{min}$. The fluid-resistivity $\log$ recorded fluctuations in fluid resistivity at $42,50,53,80$, and $85 \mathrm{ft}$ bls. Slope changes in fluid-temperature are seen at $42 \mathrm{ft}$ and between 68 and $72 \mathrm{ft}$ bls. Integrated analysis of the fluidresistivity, fluid-temperature, and flow-meter data indicate that under pumping conditions water enters the borehole at 70 and $85 \mathrm{ft}$ bls and flows upward.

The ATV and OTV logs indicate the borehole is intersected by 15 fractures between 38.5 and $160 \mathrm{ft}$ bls (app. 3, table 2). The fractures have apertures ranging from 0.8 - 40 in. A plot of these data on a lower-hemisphere equal-area net as poles to planes indicates that 11 of 15 fractures cluster about a strike orientation of $1-152^{\circ}$ with dips ranging from $31-68^{\circ}$ southeast and southwest (fig. 17).

\section{Jef-0752 (new Dodson farm well)}

Borehole Jef-0752 (site 61 on fig. 1 and in table 1) was constructed as a 6-in. diameter open hole to a depth of 166 $\mathrm{ft}$ and cased to $38 \mathrm{ft}$ bls. The borehole was completed in the Ordovician Stonehenge Limestone of the Beekmantown Group near a cross-strike fault. The geologist's well log recorded 8.5 $\mathrm{ft}$ of clay overlies bedrock and a total yield exceeding $200 \mathrm{gal} /$ min from zones located at 116-118, 128, and 148-150 ft bls. Additional fractures were noted at 85-86, 111-116, 118-121, 122-124, 144-147, and 155-156 ft bls. The static water level in the borehole at the time of geophysical logging was 13.26 $\mathrm{ft}$ bls.

The caliper log recorded major fractures at 145, 147, and $152 \mathrm{ft}$ bls plus several small fractures throughout the open-hole interval (app. 2a, fig. 3). The natural-gamma log recorded an increase in gamma readings between 145 and 152 $\mathrm{ft}$ bls that correlates to clay and water filled fractures noted in the drilling log. Under ambient (non-pumping) conditions a change in slope with depth can be seen in the fluid-temperature $\log$ at $60,120-125$, and 140-160 ft bls. Integrated analysis 
of the fluid-temperatures and flow-meter logs (app. 2b, fig. 3) indicate that potential water-bearing fractures are present at depths of approximately 144, 146, and $152 \mathrm{ft}$ bls.

During pumping, sharp changes on the fluid-temperature $\log$ are shown at 104, 144-148, and $153 \mathrm{ft}$ bls. Integrated analysis of the fluid-temperature and flow-meter logs indicate that the majority of water enters the borehole at the major water-bearing fracture located at 144-148 ft bls.

The ATV and OTV logs indicate the borehole is intersected by 10 fractures between 38 and $166 \mathrm{ft}$ bls (app. 3, table 3 ). The fractures have maximum apertures ranging from 0.9 - $15 \mathrm{in}$. The orientation of these fractures change abruptly and become sub-horizontal at depths below $80 \mathrm{ft}$ bls. Fracture data plotted on a lower-hemisphere equal-area net as poles to planes indicates that 7 fractures are sub-horizontal with orientations of $142-186^{\circ}$ and a dip of $2-3^{\circ} \mathrm{SW}$. (fig. 17).

\section{Jef-0753 (new Kaiser farm well)}

Borehole Jef-0753 (site 62 on fig. 1 and in table 1) was constructed as a 6-in. diameter open hole to a depth of $121 \mathrm{ft}$ and cased to $39.5 \mathrm{ft}$ bls. It was completed in the Ordovician Stonehenge Limestone of the Beekmantown Group along the eastern limb of an overturned anticline. The geologist's well $\log$ recorded $8.5 \mathrm{ft}$ of clay overlying bedrock and a total yield exceeding $200 \mathrm{gal} / \mathrm{min}$ from fracture zones located at 89-90 and $96 \mathrm{ft} \mathrm{bls.} \mathrm{Additional} \mathrm{fractures} \mathrm{or} \mathrm{weathered} \mathrm{zones} \mathrm{were}$ noted at $66-68$ and $87-88 \mathrm{ft}$ bls. The static water level in the borehole at the time of geophysical logging was $6.51 \mathrm{ft}$ bls.

The caliper log recorded major fractures at 66, 73, and $89 \mathrm{ft}$ bls plus several small fractures throughout the open-hole interval (app. 2a, fig. 4). The fluid-temperature log recorded minor deflections in temperature at 47,73 , and $95 \mathrm{ft}$ bls. Integrated analysis of the fluid-temperature and flow-meter logs (app. 2b, fig. 4) indicate potential water-bearing fractures at depths of 66, 73, and $89 \mathrm{ft}$ bls.

During pumping, the fluid-temperature log recorded minor deflections in temperature at $47,67,73$, and $91 \mathrm{ft}$ bls. A slight increase in fluid resistivity is recorded with depth; subtle slope changes are noted at 43 and $85 \mathrm{ft}$ bls. Integrated analysis of the fluid-resistivity, fluid-temperature, and EM flow-meter data indicates that the majority of water enters the borehole at a dominant fracture at a depth of $89 \mathrm{ft}$ bls.

The ATV and OTV logs indicate the borehole is intersected by 22 fractures between 39.5 and $121 \mathrm{ft}$ bls (app. 3, table 4). The fractures have maximum apertures ranging from 0.3 - $6.9 \mathrm{in}$. The character and orientation of these data plotted on a lower-hemisphere equal-area net as poles to planes indicate two steeply dipping groups sub-parallel to strike of bedrock with orientations of $3-42^{\circ}$ with dips of S. $44-83^{\circ} \mathrm{E}$. and $185-218^{\circ}$ with dips of N. $73-83^{\circ}$ W. (fig. 17). A third group, consisting of two near horizontal fractures $\left(1^{\circ} \mathrm{dip}\right)$, strike at $187^{\circ}$ and $229^{\circ}$.
Jef-0587 (low road well)

Borehole Jef- 0587 (site 36 on fig. 1 and in table 1) was constructed as a 6-in. diameter open hole to a depth of $410 \mathrm{ft}$ and cased to $38 \mathrm{ft}$ bls. It is located on a small topographic rise in an area characterized as a diffuse flow type setting and is absent of any nearby karst features. The borehole was drilled near the contact of the Conococheague Limestone and the Stoufferstown Member of the Stonehenge Limestone. The geologist's well $\log$ recorded $26 \mathrm{ft}$ of clay overlying bedrock and a total yield of $18 \mathrm{gal} / \mathrm{min}$ from zones at 119, 192, 276-279, and 369-370 ft bls. No additional fracture zones were noted. The static water level in the borehole at the time of geophysical logging was $42.33 \mathrm{ft}$ bls.

The caliper log recorded numerous small fractures throughout the open-hole interval (app. 2a, fig. 5). Under ambient conditions the fluid-resistivity log shows changes between 160 - $180 \mathrm{ft}$ bls. The fluid-temperature log recorded a gradual increase in temperature that is due to the geothermal gradient. Integrated analysis of the fluid-resistivity, fluidtemperature, and flow-meter logs (app. 2b, fig. 5) indicate that the fracture zone at $181 \mathrm{ft}$ bls is contributing flow across the borehole. The geologist's well log also notes appreciable flow of water from fractures near the bottom of the borehole at 369 - $399 \mathrm{ft}$ bls during drilling.

A pump was placed in the well casing and the well pumped at a rate of $4.4 \mathrm{gal} / \mathrm{min}$. The fluid-resistivity $\log$ recorded more resistive water entering the borehole at the 181 $\mathrm{ft}$ bls fracture zone. A slight cooling of water at that zone is also seen in the fluid-temperature log. Integrated analysis of the fluid-resistivity, fluid-temperature, and flow-meter data indicates that under pumping conditions water enters the borehole at the fractures at 181, 280,375, and $400 \mathrm{ft}$ bls. The major fracture at $181 \mathrm{ft}$ bls has a strike of $14^{\circ}$ and dips $\mathrm{S} .42^{\circ}$ E.

The ATV and OTV logs indicate that the borehole is intersected by 53 fractures between 38 and $410 \mathrm{ft}$ bls (app. 3, table 5). The fractures have apertures ranging from 0.16 to $7.7 \mathrm{in}$. The character and orientation of the data plotted on a lower-hemisphere

equal-area net as poles to planes indicates one major fracturepopulation cluster with a orientation of $4-41^{\circ}$ with dip angles from S. $39-74^{\circ}$ E., that are approximately sub-parallel to local bedrock strike of $20-30^{\circ}$ (fig. 17).

\section{Jef-0602 (old Dodson farm well)}

Borehole Jef-0602 (site 55 on fig. 1 and in table 1) was constructed as a 6-in. diameter open hole to a depth of $61 \mathrm{ft}$ and cased to $20 \mathrm{ft}$ bls. It is located near an inferred crossstrike fault and is completed in the Ordovician Stonehenge Limestone of the Beekmantown Group. Construction of 
Jef-0602 preceded the period of study, thus geologist's or driller well logs for the well were unavailable. The static water level in the borehole at the time of geophysical logging was $6.09 \mathrm{ft}$ bls.

The caliper log recorded one large fracture in the borehole at 36-37 ft bls with aperture width of 8.4 in (app. 2a, fig. 6). Under ambient conditions changes in fluid resistivity correlate with this fracture. The flow-meter log indicates no ambient flow in the borehole but integrated analysis of the fluid-resistivity and fluid-temperature logs indicate that some ambient flow may occur in the well, mostly in the interval from 37 - $61 \mathrm{ft}$ bls (app. 2b, fig. 6).

A pump was placed in the well casing and the well pumped at a rate of $10.5 \mathrm{gal} / \mathrm{min}$. The fluid-resistivity log recorded a slope change in the borehole at the $36-37 \mathrm{ft}$ bls fracture zone. Cooler water at that zone is also seen in the fluid-temperature log. Integrated analysis of the fluid-resistivity, fluid-temperature, and flow-meter logs indicate that all water under pumping conditions enters the borehole at the fracture zone $36-37 \mathrm{ft}$ bls. This fracture has a strike of $22^{\circ}$ and dips N. $41^{\circ} \mathrm{W}$.

The ATV and OTV logs indicate that the borehole is intersected by 13 fractures from 20 - $61 \mathrm{ft}$ bls (app. 3, table 6). These fractures have apertures range from $0.2-8.4 \mathrm{in}$. The character and orientation of the data plotted on a lowerhemisphere equal-area net as poles to planes indicate a scatter of planes predominantly dipping N. 19 to $77^{\circ}$ W. (fig. 17).

\section{Jef-0601 (stable A well)}

Borehole Jef-0601 (site 37 on fig. 1 and in table 1) was constructed as a 6-in. diameter open hole to a depth of $312 \mathrm{ft}$ and cased to $37 \mathrm{ft}$ bls. It is located in an area characterized by a diffuse flow type setting and does not contain any karst features. The well is entirely completed in the Ordovician Stonehenge Limestone of the Beekmantown Group. Construction of Jef-0601 preceded the period of study, thus driller's or geologist's well logs for the well are unavailable. The static water level in the borehole at the time of geophysical logging was $31.75 \mathrm{ft}$ bls.

The caliper log recorded numerous small fractures throughout the open-hole interval (app. 2a, fig. 7). Under ambient (non-pumping) conditions changes in fluid resistivity are seen between 210 and $230 \mathrm{ft}$ bls. A spike in fluid-temperature $\log$ is recorded from 218 - $220 \mathrm{ft}$ bls, although a gradual increase in fluid-temperature is due to the geothermal gradient. Integrated analysis of the fluid-resistivity, fluid-temperatures, and flow-meter logs indicates there is no ambient flow in the borehole (app. 2b, fig.7).

A pump was placed in the well casing and the well pumped at a rate of $1.6 \mathrm{gal} / \mathrm{min}$. Under pumping conditions, the fluid-resistivity log recorded more resistive water entering the borehole between 210 - $230 \mathrm{ft}$ bls with a decrease in fluid- temperature from 170 - $211 \mathrm{ft}$ bls indicating a water-bearing zone. Integrated analysis of the fluid-resistivity, fluid-temperature, and flow-meter logs indicates that under pumping conditions, water enters the borehole through two zones at 111 and $218 \mathrm{ft}$ bls.

The ATV and OTV logs indicate that the borehole is intersected by 112 fractures between 37 and $312 \mathrm{ft}$ bls (app. 3 , table 7). The fractures have apertures ranging from 0.2 6.9 in. A plot of these data on a lower-hemisphere equal-area net as poles to planes indicates a major fracture-population clusters with strike orientations of $2-52^{\circ}$ and dips of S. 23 to $82^{\circ}$ E., approximately sub-parallel to local bedrock strike of 20 to $30^{\circ}$ (fig. 17 ).

\section{Jef-0585 (stable B well)}

Borehole Jef-0585 (site 38 on fig. 1 and in table 1) was constructed as a 6-in. diameter open hole to a depth of $326 \mathrm{ft}$ and cased to $39 \mathrm{ft}$ bls. It is located in an area characterized as a diffuse flow type setting absent of any nearby karst features. The well is entirely completed in the Ordovician Stonehenge Limestone of the Beekmantown Group. The geologist's well $\log$ recorded $13 \mathrm{ft}$ of clay overlying bedrock and a total yield of $6 \mathrm{gal} / \mathrm{min}$ from zones at approximately 106, 115, 231, and $313 \mathrm{ft}$ bls. No additional fracture zones were noted. The static water level in the borehole at the time of geophysical logging was $30.95 \mathrm{ft}$ bls.

The caliper log recorded numerous small fractures throughout the open-hole interval (app. 2a, fig. 8). Under ambient conditions, the fluid resistivity log chows changes near the bottom of the borehole at $320 \mathrm{ft}$ bls that may indicate a water-bearing fracture at that interval. The fluid-temperature $\log$ shows a gradual increase in temperature that is due to the geothermal gradient. Integrated analysis of the fluid-resistivity, fluid-temperatures, and flow-meter logs indicates there is no ambient flow in the borehole (app. 2b, fig. 8).

A pump was placed in the well casing and the well pumped at a rate of $1.5 \mathrm{gal} / \mathrm{min}$. The fluid-resistivity $\log$ recorded changes at about $310 \mathrm{ft}$ bls indicating a water-bearing zone. Integrated analysis of the fluid-resistivity, fluid-temperature, and flow-meter data indicates that under pumping conditions, water enters the borehole at fracture zones near 53 and $310 \mathrm{ft}$ bls.

The ATV and OTV logs indicate the borehole is intersected by 120 fractures between 39 and $326 \mathrm{ft}$ bls (app. 3, table 8). The fractures have apertures ranging from $0.11-5.1$ in. A plot of these data on a lower-hemisphere equal-area net as poles to planes indicates a major fracture-population cluster with a strike orientation of $1-69^{\circ}$ with dips of S. $15-57^{\circ} \mathrm{E}$., 
that are approximately sub-parallel to the local bedrock strike of $20-30^{\circ}$ (fig. 17).

Jef-0592 (stable C well)

Borehole Jef-0592 was constructed as a 6-in. diameter open hole to a depth of $321 \mathrm{ft}$ and cased to $38 \mathrm{ft}$ bls (site 39 on fig. 1 and in table 1). It is located in an area characterized as a diffuse flow type setting absent of any nearby karst features. The well is completed entirely in the Ordovician Stonehenge Limestone of the Beekmantown Group. The geologist's well $\log$ recorded $18 \mathrm{ft}$ of clay overlying bedrock and a total yield of $37 \mathrm{gal} / \mathrm{min}$ from fracture zones at 61, 71, 133, 141-145, 151,247 , and $270 \mathrm{ft}$ bls. Additional fractures and weathered zones were noted at 135 and $175 \mathrm{ft}$ bls. The static water level in the borehole at the time of geophysical logging was 27.70 ft bls.

The caliper log recorded a large fracture just below the casing at $40 \mathrm{ft}$ bls and numerous small fractures throughout the open-hole interval (app. 2a, fig. 9). Under ambient conditions, the fluid-resistivity log shows changes between 130 and $160 \mathrm{ft}$ bls and near the bottom of the borehole at $310 \mathrm{ft}$ bls. The fluid-temperature log shows a gradual increase in temperature due to the geothermal gradient. Integrated analysis of the fluid-resistivity, fluid-temperatures, and flow-meter logs indicates that under ambient conditions, water enters the borehole at a fracture at $40 \mathrm{ft}$ bls and exits the borehole at 138 ft bls (app. 2b, fig. 9).

A pump was placed in the well casing and the well pumped at a rate of $6.5 \mathrm{gal} / \mathrm{min}$. The fluid-resistivity $\log$ recorded fluctuations between 130 and $160 \mathrm{ft}$ bls that correlates to fractures on the caliper and ATV logs. Under pumping conditions the fluid-temperature log represents the geothermal gradient. Integrated analysis of the fluid-resistivity, fluidtemperature, and flow-meter data indicates that under pumping conditions, water enters the borehole through the fracture at $138 \mathrm{ft}$ bls.

The ATV and OTV logs indicate that the borehole is intersected by 98 fractures between 38 and $321 \mathrm{ft}$ bls (app. 3, table 9). The fractures have apertures ranging from 0.16 - 12.4 in. A plot of these data on a lower-hemisphere equal-area net as poles to planes indicate a major fracture-population cluster with strike orientations of $1-57^{\circ}$ with dips from S. $23-81^{\circ}$ E., that are approximately sub-parallel to local bedrock strike of 20 - $30^{\circ}$ (fig. 17).

Jef-0603 (USDA sulfur well)

Borehole Jef-0603 (site 34 on fig. 1 and in table 1) was constructed as a 6-in. diameter open hole to a depth of 475 $\mathrm{ft}$ and cased to $56 \mathrm{ft}$ bls. The well was completed at a fault contact between the overlying Chambersburg Limestone and underlying Martinsburg Formation. Construction of Jef-0603 preceded the period of study, so geologist's or driller well logs for the well were unavailable. The static water level in the borehole at the time of geophysical logging was $35.90 \mathrm{ft}$ bls.

The caliper log recorded major fractures at 99, 150, 340, and $473 \mathrm{ft}$ bls and numerous small fractures throughout the open-hole interval (app. 2a, fig. 10). The natural gamma log shows higher gamma readings at 101, 312, 336, and $394 \mathrm{ft}$ bls likely indicating shaly layers within the Chambersburg Limestone. Under ambient conditions subtle changes in fluid resistivity are recorded between 140 and $198 \mathrm{ft}$ bls. The fluidtemperature log recorded a gradual increase in temperature that represents the geothermal gradients. Integrated analysis of the fluid-resistivity, fluid-temperatures, and flow-meter logs indicates there is no ambient flow in the borehole (app. 2b, fig. 10).

Significant deviation in fluid-resistivity values measured under ambient and pumping conditions reflects the unique chemistry of ground water in borehole Jef-0603. A pump was placed in the well casing and the well pumped at a rate of $<10$ $\mathrm{gal} / \mathrm{min}$. Under pumping conditions, the fluid-temperature log represents the geothermal gradient below $200 \mathrm{ft}$ bls. Integrated analysis of the fluid-resistivity, fluid-temperature, and flow-meter data indicates that under pumping conditions all water enters the borehole from the fracture zone at the fault contact near the bottom of the borehole at $473 \mathrm{ft}$ bls.

The ATV and OTV logs indicate that the borehole is intersected by 89 fractures between 56 and $475 \mathrm{ft}$ bls (app. 3, table 10). A plot of these data on a lower-hemisphere equalarea net as poles to planes indicates one major fracture-population cluster with strike orientations of $1-75^{\circ}$ with dips of $\mathrm{S}$. $22-78^{\circ}$ E. (fig. 17).

Jef-0586 (USDA fault well)

Borehole Jef-0586 (site 60 on fig. 1 and in table 1) was constructed as a 6-in. diameter open hole to a depth of $201 \mathrm{ft}$ and cased to $98 \mathrm{ft}$ bls. The well was constructed along a fault zone and is completed in the Ordovician Rockdale Run Formation of the Beekmantown Group. At the time of drilling, rock cuttings of fault breccia were collected. The geologist's well $\log$ recorded $4 \mathrm{ft}$ of clay overlying bedrock and a total yield of $300 \mathrm{gal} / \mathrm{min}$ from zones at 104-115, 124-131, and 151 $\mathrm{ft}$ bls. Numerous additional fractures and weathered zones were noted during drilling. The static water level in the borehole at the time of geophysical logging was $16.49 \mathrm{ft}$ bls.

The caliper log recorded major fractures at 103, 124-132, 142 , and $146-151 \mathrm{ft}$ bls with numerous small fractures throughout the open-hole interval (app. 2a, fig. 11). Under ambient conditions an increase in fluid resistivity is seen 
above $155 \mathrm{ft}$ bls. The fluid-temperature log recorded slight deviations at 115,158 , and $187 \mathrm{ft}$ bls. Integrated analysis of the fluid-resistivity, fluid-temperatures, and flow-meter logs indicate that under ambient conditions, water enters the borehole at the fracture zone at $152 \mathrm{ft}$ bls and exits at 104 and 142 ft bls (app. 2b, fig. 11).

A pump was placed in the well casing and the well pumped at a rate of $<10 \mathrm{gal} / \mathrm{min}$. The fluid-resistivity log recorded changes at 105 and $155 \mathrm{ft} \mathrm{bls,} \mathrm{and} \mathrm{the} \mathrm{fluid-tem-}$ perature log recorded slight deviations at 108 and $140 \mathrm{ft}$ bls. Integrated analysis of the fluid-resistivity, fluid-temperature, and flow-meter data indicates that under pumping conditions, water enters the borehole from the fracture zones at 110 and $158 \mathrm{ft}$ bls.

The ATV and OTV logs indicate the borehole is intersected by 50 fractures between 98 and $201 \mathrm{ft}$ bls (app. 3, table 11). A plot of these data on a lower-hemisphere equal-area net as poles to planes indicates two major fracture-population clusters. The first cluster, with strike orientations of $7-59^{\circ}$ and dips of S. $35-84^{\circ} \mathrm{E}$. are approximately sub-parallel to local bedrock strike of $20-30^{\circ}$ (fig. 17). The second cluster of fractures has strike orientations of $200^{\circ}-238^{\circ}$ with dips of $\mathrm{N} 49^{\circ}$ to $87^{\circ} \mathrm{W}$. 
Appendix 3: Depth, strike, and dip of fractures imaged in boreholes, Leetown Science Center, Leetown West Virginia. 
Appendix 3 Table 1. Depth, strike, and dip of fractures imaged in borehole Jef-0589 (anticline well), Leetown Science Center, Leetown, West Virginia

[Strike reported in azimuthal degrees, east of True North in "right hand rule" where the direction of dip is to the right of the strike]

\begin{tabular}{|c|c|c|c|}
\hline Fracture No. & Depth, in feet & $\begin{array}{c}\text { Strike, in } \\
\text { degrees }\end{array}$ & $\begin{array}{l}\text { Dip, in de- } \\
\text { grees }\end{array}$ \\
\hline 1 & 41.5 & 329 & 21 \\
\hline 2 & 44.1 & 266 & 35 \\
\hline 3 & 45.4 & 217 & 28 \\
\hline 4 & 51.6 & 20 & 66 \\
\hline 5 & 57.3 & 307 & 51 \\
\hline 6 & 63.4 & 205 & 43 \\
\hline 7 & 66.6 & 224 & 42 \\
\hline 8 & 67.8 & 221 & 37 \\
\hline 9 & 75.9 & 219 & 48 \\
\hline 10 & 76.8 & 230 & 43 \\
\hline 11 & 77.2 & 219 & 43 \\
\hline 12 & 78.1 & 228 & 39 \\
\hline 13 & 82.1 & 183 & 38 \\
\hline 14 & 85.5 & 31 & 45 \\
\hline 15 & 89.8 & 217 & 67 \\
\hline 16 & 90.4 & 217 & 64 \\
\hline 17 & 93.5 & 228 & 42 \\
\hline 18 & 94.6 & 224 & 39 \\
\hline 19 & 95.0 & 243 & 28 \\
\hline 20 & 96.2 & 258 & 48 \\
\hline 21 & 96.7 & 216 & 47 \\
\hline 22 & 97.0 & 223 & 50 \\
\hline 23 & 98.8 & 218 & 48 \\
\hline 24 & 101.2 & 212 & 37 \\
\hline 25 & 103.0 & 228 & 38 \\
\hline 26 & 105.3 & 229 & 40 \\
\hline 27 & 105.9 & 210 & 46 \\
\hline 28 & 107.7 & 229 & 42 \\
\hline 29 & 108.3 & 220 & 48 \\
\hline 30 & 109.0 & 219 & 44 \\
\hline 31 & 109.5 & 224 & 39 \\
\hline 32 & 110.0 & 222 & 46 \\
\hline 33 & 110.9 & 229 & 46 \\
\hline 34 & 112.1 & 244 & 47 \\
\hline 35 & 113.2 & 223 & 52 \\
\hline 36 & 113.7 & 229 & 52 \\
\hline 37 & 115.6 & 221 & 57 \\
\hline
\end{tabular}

Appendix 3 Table 1. Depth, strike, and dip of fractures imaged in borehole Jef-0589 (anticline well), Leetown Science Center, Leetown, West Virginia

[Strike reported in azimuthal degrees, east of True North in "right hand rule" where the direction of dip is to the right of the strike]

\begin{tabular}{|c|c|c|c|}
\hline Fracture No. & Depth, in feet & $\begin{array}{l}\text { Strike, in } \\
\text { degrees }\end{array}$ & $\begin{array}{l}\text { Dip, in de- } \\
\text { grees }\end{array}$ \\
\hline 38 & 117.5 & 224 & 55 \\
\hline 39 & 118.2 & 225 & 49 \\
\hline 40 & 120.5 & 218 & 54 \\
\hline 41 & 121.2 & 225 & 55 \\
\hline 42 & 123.7 & 221 & 57 \\
\hline 43 & 135.8 & 224 & 44 \\
\hline 44 & 137.7 & 236 & 50 \\
\hline 45 & 142.0 & 220 & 54 \\
\hline 46 & 143.1 & 221 & 55 \\
\hline 47 & 152.5 & 201 & 47 \\
\hline 48 & 153.2 & 214 & 44 \\
\hline 49 & 153.4 & 201 & 40 \\
\hline 50 & 153.7 & 223 & 32 \\
\hline 51 & 154.1 & 193 & 42 \\
\hline 52 & 154.6 & 217 & 40 \\
\hline 53 & 155.7 & 191 & 39 \\
\hline 54 & 164.6 & 188 & 43 \\
\hline 55 & 170.1 & 201 & 50 \\
\hline 56 & 170.8 & 207 & 49 \\
\hline 57 & 172.4 & 176 & 57 \\
\hline 58 & 177.3 & 223 & 41 \\
\hline 59 & 177.6 & 222 & 40 \\
\hline 60 & 182.4 & 208 & 46 \\
\hline 61 & 189.1 & 194 & 50 \\
\hline 62 & 189.7 & 193 & 50 \\
\hline 63 & 190.9 & 187 & 56 \\
\hline 64 & 194.1 & 12 & 59 \\
\hline 65 & 194.9 & 178 & 44 \\
\hline 66 & 196.0 & 189 & 55 \\
\hline 67 & 196.9 & 167 & 55 \\
\hline 68 & 199.9 & 216 & 37 \\
\hline 69 & 200.8 & 222 & 46 \\
\hline 70 & 201.8 & 203 & 51 \\
\hline 71 & 202.6 & 209 & 50 \\
\hline 72 & 203.5 & 191 & 50 \\
\hline 73 & 204.8 & 202 & 54 \\
\hline 74 & 205.7 & 206 & 53 \\
\hline
\end{tabular}


Appendix 3 Table 1. Depth, strike, and dip of fractures imaged in borehole Jef-0589 (anticline well), Leetown Science Center, Leetown, West Virginia

[Strike reported in azimuthal degrees, east of True North in "right hand rule" where the direction of dip is to the right of the strike]

\begin{tabular}{|c|c|c|c|}
\hline Fracture No. & Depth, in feet & $\begin{array}{l}\text { Strike, in } \\
\text { degrees }\end{array}$ & $\begin{array}{l}\text { Dip, in de- } \\
\text { grees }\end{array}$ \\
\hline 75 & 206.0 & 196 & 51 \\
\hline 76 & 206.4 & 182 & 49 \\
\hline 77 & 206.9 & 189 & 53 \\
\hline 78 & 207.8 & 191 & 50 \\
\hline 79 & 209.2 & 193 & 50 \\
\hline 80 & 209.9 & 201 & 46 \\
\hline 81 & 210.5 & 194 & 50 \\
\hline 82 & 211.8 & 188 & 56 \\
\hline 83 & 213.5 & 198 & 58 \\
\hline 84 & 214.7 & 206 & 58 \\
\hline 85 & 214.8 & 3 & 70 \\
\hline 86 & 215.7 & 206 & 57 \\
\hline 87 & 217.1 & 204 & 57 \\
\hline 88 & 218.5 & 205 & 56 \\
\hline 89 & 218.8 & 200 & 55 \\
\hline 90 & 219.7 & 204 & 50 \\
\hline 91 & 220.2 & 209 & 54 \\
\hline 92 & 233.2 & 212 & 54 \\
\hline 93 & 233.3 & 16 & 73 \\
\hline 94 & 235.2 & 225 & 57 \\
\hline 95 & 236.2 & 208 & 50 \\
\hline 96 & 239.7 & 220 & 55 \\
\hline 97 & 245.4 & 222 & 50 \\
\hline 98 & 246.7 & 230 & 40 \\
\hline 99 & 247.1 & 222 & 48 \\
\hline 100 & 248.7 & 222 & 53 \\
\hline 101 & 249.0 & 219 & 52 \\
\hline
\end{tabular}

Appendix 3 Table 2. Depth, strike, and dip of fractures imaged in borehole Jef-0590 (ball field well), Leetown Science Center, Leetown, West Virginia

[Strike reported in azimuthal degrees, east of True North in "right hand rule" where the direction of dip is to the right of the strike]

\begin{tabular}{rrrr}
\hline Fracture No. & Depth, in feet & $\begin{array}{c}\text { Strike, in } \\
\text { degrees }\end{array}$ & Dip, in degrees \\
\hline 1 & 49.1 & 19 & 62 \\
2 & 50.4 & 6 & 51 \\
3 & 51.5 & 349 & 56 \\
4 & 58.3 & 26 & 54 \\
5 & 58.9 & 1 & 46 \\
6 & 60.4 & 22 & 63 \\
7 & 61.5 & 10 & 54 \\
8 & 69.4 & 152 & 31 \\
9 & 69.7 & 335 & 21 \\
10 & 71.0 & 28 & 61 \\
11 & 71.8 & 341 & 54 \\
12 & 73.8 & 32 & 68 \\
13 & 76.3 & 91 & 44 \\
14 & 78.9 & 358 & 58 \\
15 & 81.4 & 124 & 69 \\
\hline
\end{tabular}

Appendix 3 Table 3. Depth, strike, and dip of fractures imaged in borehole Jef-0752 (new Dodson farm well), Leetown Science Center, Leetown, West Virginia

[Strike reported in azimuthal degrees, east of True North in "right hand rule" where the direction of dip is to the right of the strike]

\begin{tabular}{rccc}
\hline Fracture No. & Depth, in feet & $\begin{array}{c}\text { Strike, in } \\
\text { degrees }\end{array}$ & Dip, in degrees \\
\hline 1 & 61.5 & 3 & 74 \\
2 & 67.8 & 45 & 48 \\
3 & 80.2 & 25 & 68 \\
4 & 84.7 & 186 & 2 \\
5 & 107.1 & 160 & 2 \\
6 & 113.9 & 157 & 2 \\
7 & 144.0 & 142 & 2 \\
8 & 145.7 & 146 & 2 \\
9 & 146.4 & 143 & 3 \\
10 & 152.2 & 146 & 3 \\
\hline
\end{tabular}


Appendix 3 Table 4. Depth, strike, and dip of fractures imaged in borehole Jef-0753 (new Kaiser farm well), Leetown Science Center, Leetown, West Virginia

[Strike reported in azimuthal degrees, east of True North in "right hand rule" where the direction of dip is to the right of the strike]

\begin{tabular}{cccc}
\hline Fracture No. & Depth, in feet & $\begin{array}{c}\text { Strike, in } \\
\text { degrees }\end{array}$ & $\begin{array}{c}\text { Dip, in de- } \\
\text { grees }\end{array}$ \\
\hline 1 & 42.7 & 90 & 71 \\
2 & 47.3 & 32 & 70 \\
3 & 48.3 & 37 & 74 \\
4 & 49.3 & 37 & 71 \\
5 & 51.2 & 28 & 59 \\
6 & 54.0 & 18 & 69 \\
7 & 57.1 & 31 & 69 \\
8 & 57.9 & 25 & 70 \\
9 & 61.1 & 25 & 67 \\
10 & 64.4 & 218 & 81 \\
11 & 64.9 & 26 & 83 \\
12 & 66.0 & 185 & 82 \\
13 & 69.7 & 210 & 77 \\
14 & 72.6 & 187 & 1 \\
15 & 86.3 & 190 & 76 \\
16 & 88.8 & 229 & 1 \\
17 & 89.9 & 194 & 73 \\
18 & 94.1 & 29 & 70 \\
19 & 98.2 & 37 & 67 \\
20 & 99.1 & 42 & 57 \\
21 & 99.8 & 3 & 44 \\
22 & 101.3 & 11 & 56 \\
\hline
\end{tabular}

Appendix 3 Table 5. Depth, strike, and dip of fractures imaged in borehole Jef-0587 (low road well), Leetown Science Center, Leetown, West Virginia

[Strike reported in azimuthal degrees, east of True North in "right hand rule" where the direction of dip is to the right of the strike]

\begin{tabular}{cccc}
\hline Fracture No. & Depth, in feet & $\begin{array}{c}\text { Strike, in } \\
\text { degrees }\end{array}$ & $\begin{array}{c}\text { Dip, in de- } \\
\text { grees }\end{array}$ \\
\hline 1 & 45.3 & 16 & 44 \\
2 & 45.6 & 22 & 46 \\
3 & 46.6 & 31 & 40 \\
4 & 47.7 & 19 & 49 \\
5 & 48.6 & 26 & 59 \\
6 & 49.3 & 27 & 59 \\
7 & 49.9 & 39 & 55
\end{tabular}

Appendix 3 Table 5. Depth, strike, and dip of fractures imaged in borehole Jef-0587 (low road well), Leetown Science Center, Leetown, West Virginia

[Strike reported in azimuthal degrees, east of True North in "right hand rule" where the direction of dip is to the right of the strike]

\begin{tabular}{|c|c|c|c|}
\hline Fracture No. & Depth, in feet & $\begin{array}{c}\text { Strike, in } \\
\text { degrees }\end{array}$ & $\begin{array}{l}\text { Dip, in de- } \\
\text { grees }\end{array}$ \\
\hline 8 & 51.1 & 4 & 45 \\
\hline 9 & 111.5 & 18 & 49 \\
\hline 10 & 111.8 & 205 & 81 \\
\hline 11 & 114.1 & 40 & 67 \\
\hline 12 & 114.8 & 219 & 83 \\
\hline 13 & 120.4 & 36 & 58 \\
\hline 14 & 122.6 & 22 & 51 \\
\hline 15 & 125.2 & 18 & 52 \\
\hline 16 & 128.8 & 10 & 52 \\
\hline 17 & 138.6 & 21 & 58 \\
\hline 18 & 141.4 & 25 & 53 \\
\hline 19 & 144.6 & 358 & 39 \\
\hline 20 & 150.0 & 24 & 51 \\
\hline 21 & 153.1 & 19 & 50 \\
\hline 22 & 160.6 & 12 & 50 \\
\hline 23 & 171.3 & 19 & 46 \\
\hline 24 & 180.3 & 14 & 42 \\
\hline 25 & 186.8 & 22 & 46 \\
\hline 26 & 191.5 & 23 & 74 \\
\hline 27 & 234.7 & 201 & 73 \\
\hline 28 & 238.6 & 9 & 40 \\
\hline 29 & 239.3 & 20 & 46 \\
\hline 30 & 243.9 & 205 & 79 \\
\hline 31 & 273.4 & 11 & 52 \\
\hline 32 & 277.2 & 17 & 48 \\
\hline 33 & 307.1 & 31 & 43 \\
\hline 34 & 307.8 & 24 & 40 \\
\hline 35 & 319.0 & 33 & 52 \\
\hline 36 & 328.3 & 16 & 57 \\
\hline 37 & 336.2 & 34 & 54 \\
\hline 38 & 366.9 & 16 & 59 \\
\hline 39 & 374.0 & 33 & 56 \\
\hline 40 & 378.0 & 26 & 49 \\
\hline 41 & 382.3 & 20 & 53 \\
\hline 42 & 386.2 & 27 & 49 \\
\hline 43 & 387.5 & 29 & 48 \\
\hline
\end{tabular}


Appendix 3 Table 5. Depth, strike, and dip of fractures imaged in borehole Jef-0587 (low road well), Leetown Science Center, Leetown, West Virginia

[Strike reported in azimuthal degrees, east of True North in "right hand rule" where the direction of dip is to the right of the strike]

\begin{tabular}{cccc}
\hline Fracture No. & Depth, in feet & $\begin{array}{c}\text { Strike, in } \\
\text { degrees }\end{array}$ & $\begin{array}{c}\text { Dip, in de- } \\
\text { grees }\end{array}$ \\
\hline 44 & 391.0 & 29 & 44 \\
45 & 394.4 & 41 & 47 \\
46 & 396.4 & 36 & 50 \\
47 & 397.6 & 167 & 59 \\
48 & 398.6 & 22 & 56 \\
49 & 401.2 & 194 & 88 \\
50 & 403.0 & 12 & 46 \\
\hline
\end{tabular}

Appendix 3 Table 6. Depth, strike, and dip of fractures imaged in borehole Jef-0602 (old Dodson farm well), Leetown Science Center, Leetown, West Virginia

[Strike reported in azimuthal degrees, east of True North in "right hand rule" where the direction of dip is to the right of the strike]

\begin{tabular}{rccc}
\hline Fracture No. & Depth, in feet & $\begin{array}{c}\text { Strike, in } \\
\text { degrees }\end{array}$ & Dip, in degrees \\
\hline 1 & 25.8 & 192 & 47 \\
2 & 26.9 & 222 & 50 \\
3 & 28.2 & 43 & 47 \\
4 & 28.3 & 130 & 38 \\
5 & 28.6 & 244 & 53 \\
6 & 32.7 & 222 & 29 \\
7 & 34.3 & 243 & 19 \\
8 & 36.8 & 203 & 41 \\
9 & 40.0 & 176 & 42 \\
10 & 42.9 & 230 & 69 \\
11 & 44.0 & 207 & 76 \\
12 & 45.3 & 182 & 71 \\
13 & 46.4 & 74 & 28 \\
\hline
\end{tabular}

Appendix 3 Table 7. Depth, strike, and dip of fractures imaged in borehole Jef-0601 (Stable A well), Leetown Science Center, Leetown, West Virginia

[Strike reported in azimuthal degrees, east of True North in "right hand rule" where the direction of dip is to the right of the strike]

\begin{tabular}{cccc}
\hline Fracture No. & Depth, in feet & $\begin{array}{c}\text { Strike, in } \\
\text { degrees }\end{array}$ & Dip, in degrees \\
\hline 1 & 45.6 & 339 & 39 \\
2 & 54.3 & 23 & 54 \\
3 & 57.1 & 24 & 48
\end{tabular}

Appendix 3 Table 7. Depth, strike, and dip of fractures imaged in borehole Jef-0601 (Stable A well), Leetown Science Center, Leetown, West Virginia

[Strike reported in azimuthal degrees, east of True North in "right hand rule" where the direction of dip is to the right of the strike]

\begin{tabular}{|c|c|c|c|}
\hline Fracture No. & Depth, in feet & $\begin{array}{l}\text { Strike, in } \\
\text { degrees }\end{array}$ & Dip, in degrees \\
\hline 4 & 58.7 & 246 & 59 \\
\hline 5 & 60.2 & 346 & 42 \\
\hline 6 & 64.2 & 358 & 45 \\
\hline 7 & 68.4 & 26 & 50 \\
\hline 8 & 68.9 & 28 & 51 \\
\hline 9 & 69.3 & 29 & 50 \\
\hline 10 & 78.4 & 233 & 43 \\
\hline 11 & 79.1 & 172 & 69 \\
\hline 12 & 93.9 & 26 & 39 \\
\hline 13 & 97.2 & 25 & 67 \\
\hline 14 & 98.5 & 13 & 47 \\
\hline 15 & 99.0 & 28 & 46 \\
\hline 16 & 99.5 & 23 & 53 \\
\hline 17 & 104.0 & 213 & 61 \\
\hline 18 & 104.5 & 19 & 46 \\
\hline 19 & 110.4 & 26 & 51 \\
\hline 20 & 111.4 & 235 & 60 \\
\hline 21 & 111.8 & 30 & 59 \\
\hline 22 & 124.5 & 10 & 82 \\
\hline 23 & 136.1 & 124 & 64 \\
\hline 24 & 138.7 & 21 & 43 \\
\hline 25 & 138.8 & 190 & 66 \\
\hline 26 & 139.8 & 177 & 61 \\
\hline 27 & 139.9 & 9 & 44 \\
\hline 28 & 145.0 & 22 & 35 \\
\hline 29 & 145.8 & 46 & 38 \\
\hline 30 & 146.9 & 44 & 23 \\
\hline 31 & 147.3 & 33 & 33 \\
\hline 32 & 148.2 & 31 & 40 \\
\hline 33 & 149.3 & 28 & 37 \\
\hline 34 & 149.8 & 22 & 37 \\
\hline 35 & 150.5 & 38 & 39 \\
\hline 36 & 151.0 & 32 & 42 \\
\hline 37 & 151.3 & 32 & 40 \\
\hline 38 & 151.5 & 30 & 43 \\
\hline 39 & 152.2 & 39 & 47 \\
\hline 40 & 152.6 & 52 & 38 \\
\hline 41 & 153.3 & 29 & 41 \\
\hline
\end{tabular}


Appendix 3 Table 7. Depth, strike, and dip of fractures imaged in borehole Jef-0601 (Stable A well), Leetown Science Center, Leetown, West Virginia

[Strike reported in azimuthal degrees, east of True North in "right hand rule" where the direction of dip is to the right of the strike]

\begin{tabular}{|c|c|c|c|c|c|c|c|}
\hline Fracture No. & Depth, in feet & $\begin{array}{l}\text { Strike, in } \\
\text { degrees }\end{array}$ & Dip, in degrees & Fracture No. & Depth, in feet & $\begin{array}{l}\text { Strike, in } \\
\text { degrees }\end{array}$ & Dip, in degrees \\
\hline 42 & 154.0 & 49 & 44 & 80 & 215.3 & 33 & 39 \\
\hline 44 & 154.8 & 351 & 33 & 82 & 217.1 & 30 & 35 \\
\hline 45 & 159.1 & 37 & 29 & 83 & 217.5 & 34 & 43 \\
\hline 47 & 161.8 & 51 & 27 & 85 & 218.3 & 23 & 42 \\
\hline 48 & 162.0 & 36 & 27 & 86 & 218.8 & 19 & 40 \\
\hline 49 & 164.5 & 22 & 32 & 87 & 219.3 & 26 & 43 \\
\hline 50 & 164.7 & 20 & 38 & 88 & 219.8 & 185 & 69 \\
\hline 54 & 169.3 & 26 & 34 & 92 & 222.8 & 36 & 30 \\
\hline 55 & 169.8 & 2 & 30 & 93 & 226.4 & 9 & 36 \\
\hline 56 & 170.4 & 49 & 33 & 94 & 228.9 & 42 & 34 \\
\hline 57 & 171.0 & 46 & 32 & 95 & 229.8 & 38 & 37 \\
\hline 58 & 178.7 & 41 & 81 & 96 & 232.7 & 12 & 42 \\
\hline 59 & 186.8 & 33 & 53 & 97 & 247.9 & 42 & 42 \\
\hline 60 & 189.7 & 23 & 39 & 98 & 248.2 & 32 & 43 \\
\hline 61 & 191.3 & 20 & 49 & 99 & 248.5 & 245 & 80 \\
\hline 68 & 206.3 & 26 & 52 & 106 & 281.1 & 219 & 30 \\
\hline 69 & 206.7 & 43 & 65 & 107 & 281.2 & 31 & 39 \\
\hline 70 & 208.4 & 20 & 39 & 108 & 281.3 & 206 & 37 \\
\hline 71 & 209.0 & 29 & 49 & 109 & 287.0 & 37 & 46 \\
\hline 72 & 209.3 & 38 & 42 & 110 & 294.0 & 197 & 37 \\
\hline 73 & 210.2 & 23 & 29 & 111 & 294.0 & 39 & 54 \\
\hline 74 & 210.8 & 156 & 71 & 112 & 297.3 & 30 & 31 \\
\hline 75 & 211.9 & 26 & 32 & & & & \\
\hline 76 & 212.2 & 27 & 37 & & & & \\
\hline 77 & 213.0 & 26 & 28 & & & & \\
\hline 78 & 214.3 & 13 & 35 & & & & \\
\hline 79 & 214.8 & 30 & 35 & & & & \\
\hline
\end{tabular}

Appendix 3 Table 7. Depth, strike, and dip of fractures imaged in borehole Jef-0601 (Stable A well), Leetown Science Center, Leetown, West Virginia

[Strike reported in azimuthal degrees, east of True North in "right hand rule" where the direction of dip is to the right of the strike] 
Appendix 3 Table 8. Depth, strike, and dip of fractures imaged in borehole Jef-0585 (stable B well), Leetown Science Center, Leetown, West Virginia

[Strike reported in azimuthal degrees, east of True North in "right hand rule" where the direction of dip is to the right of the strike]

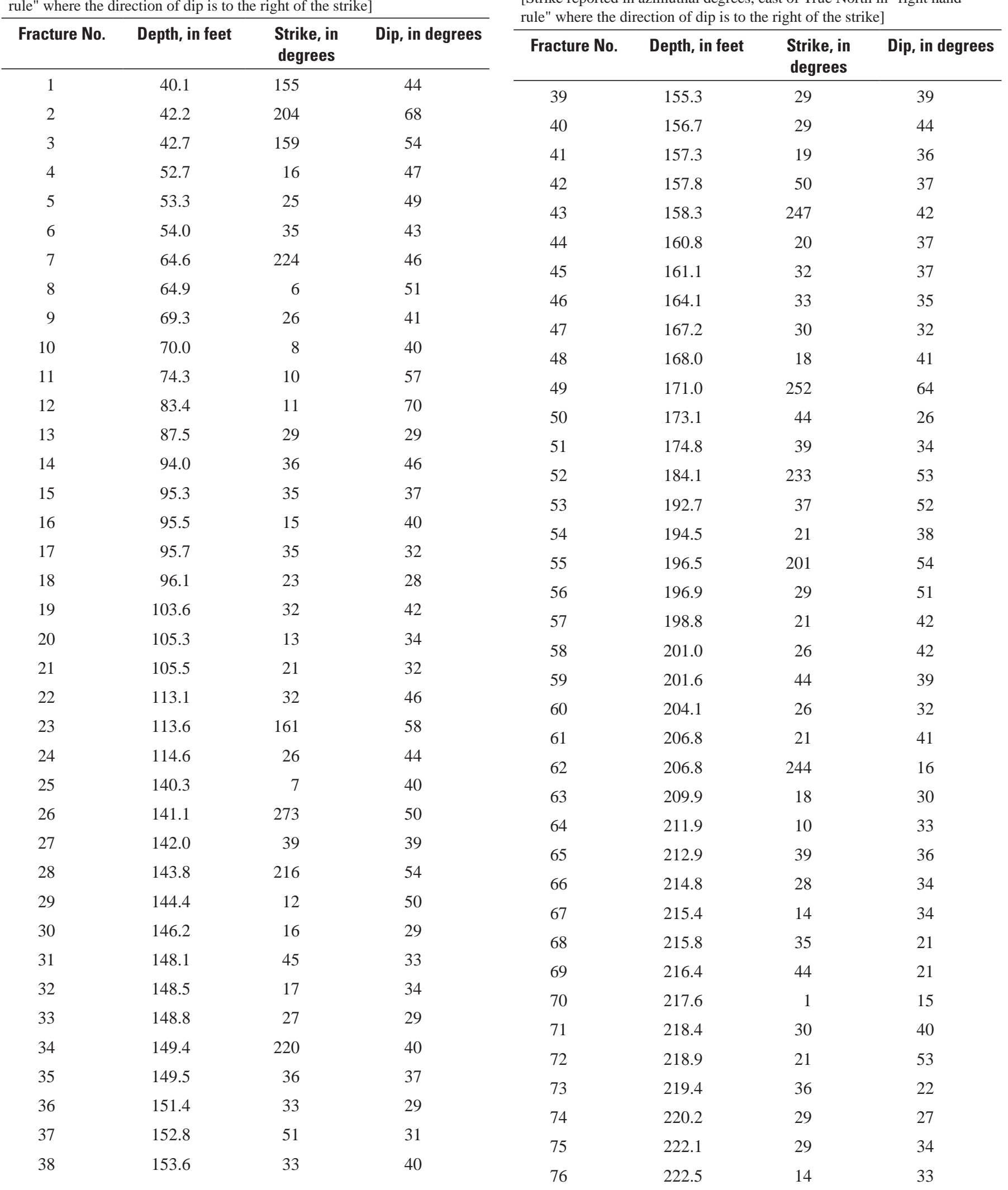

Appendix 3 Table 8. Depth, strike, and dip of fractures imaged in borehole Jef-0585 (stable B well), Leetown Science Center, Leetown, West Virginia

[Strike reported in azimuthal degrees, east of True North in "right hand rule" where the direction of dip is to the right of the strike] 
Appendix 3 Table 8. Depth, strike, and dip of fractures imaged in borehole Jef-0585 (stable B well), Leetown Science Center, Leetown, West Virginia

[Strike reported in azimuthal degrees, east of True North in "right hand rule" where the direction of dip is to the right of the strike]

\begin{tabular}{|c|c|c|c|}
\hline Fracture No. & Depth, in feet & $\begin{array}{l}\text { Strike, in } \\
\text { degrees }\end{array}$ & Dip, in degrees \\
\hline 77 & 222.9 & 20 & 28 \\
\hline 78 & 223.1 & 26 & 27 \\
\hline 79 & 224.5 & 40 & 27 \\
\hline 80 & 225.5 & 16 & 32 \\
\hline 81 & 225.5 & 183 & 19 \\
\hline 82 & 226.6 & 37 & 33 \\
\hline 83 & 228.6 & 15 & 32 \\
\hline 84 & 229.4 & 36 & 25 \\
\hline 85 & 229.9 & 33 & 43 \\
\hline 86 & 230.4 & 52 & 38 \\
\hline 87 & 230.8 & 32 & 35 \\
\hline 88 & 231.6 & 23 & 35 \\
\hline 89 & 231.8 & 37 & 32 \\
\hline 90 & 232.6 & 45 & 26 \\
\hline 91 & 233.4 & 27 & 37 \\
\hline 92 & 234.8 & 21 & 25 \\
\hline 93 & 235.1 & 75 & 30 \\
\hline 94 & 238.3 & 15 & 35 \\
\hline 95 & 238.7 & 184 & 36 \\
\hline 96 & 241.3 & 38 & 33 \\
\hline 97 & 242.3 & 43 & 31 \\
\hline 98 & 244.0 & 26 & 36 \\
\hline 99 & 244.2 & 200 & 22 \\
\hline 100 & 248.3 & 14 & 54 \\
\hline 101 & 249.0 & 206 & 62 \\
\hline 102 & 261.7 & 35 & 32 \\
\hline 103 & 262.2 & 20 & 33 \\
\hline 104 & 263.5 & 200 & 44 \\
\hline 105 & 263.9 & 28 & 51 \\
\hline 106 & 264.4 & 215 & 50 \\
\hline 107 & 264.7 & 19 & 34 \\
\hline 108 & 265.0 & 222 & 55 \\
\hline 109 & 265.5 & 31 & 43 \\
\hline 110 & 265.8 & 30 & 46 \\
\hline 111 & 269.0 & 212 & 59 \\
\hline 112 & 278.7 & 69 & 75 \\
\hline 113 & 280.7 & 242 & 57 \\
\hline 114 & 285.9 & 37 & 43 \\
\hline
\end{tabular}

Appendix 3 Table 8. Depth, strike, and dip of fractures imaged in borehole Jef-0585 (stable B well), Leetown Science Center, Leetown, West Virginia

[Strike reported in azimuthal degrees, east of True North in "right hand rule" where the direction of dip is to the right of the strike]

\begin{tabular}{lccc}
\hline Fracture No. & Depth, in feet & $\begin{array}{c}\text { Strike, in } \\
\text { degrees }\end{array}$ & Dip, in degrees \\
\hline 115 & 291.9 & 12 & 34 \\
116 & 301.1 & 33 & 34 \\
117 & 304.7 & 16 & 34 \\
118 & 312.1 & 36 & 37 \\
119 & 313.9 & 208 & 56 \\
120 & 324.4 & 34 & 24 \\
\hline
\end{tabular}

Appendix 3 Table 9. Depth, strike, and dip of fractures imaged in borehole Jef-0592 (stable C well), Leetown Science Center, Leetown, West Virginia

[Strike reported in azimuthal degrees, east of True North in "right hand rule" where the direction of dip is to the right of the strike]

\begin{tabular}{|c|c|c|c|}
\hline Fracture No. & Depth, in feet & $\begin{array}{l}\text { Strike, in } \\
\text { degrees }\end{array}$ & Dip, in degrees \\
\hline 1 & 37.7 & 191 & 21 \\
\hline 2 & 39.3 & 18 & 50 \\
\hline 3 & 48.3 & 197 & 31 \\
\hline 4 & 50.6 & 41 & 42 \\
\hline 5 & 54.1 & 312 & 38 \\
\hline 6 & 58.7 & 88 & 50 \\
\hline 7 & 61.7 & 24 & 46 \\
\hline 8 & 67.8 & 321 & 55 \\
\hline 9 & 79.1 & 7 & 66 \\
\hline 10 & 79.5 & 231 & 62 \\
\hline 11 & 90.8 & 31 & 26 \\
\hline 12 & 91.1 & 24 & 43 \\
\hline 13 & 100.5 & 38 & 33 \\
\hline 14 & 103.8 & 43 & 30 \\
\hline 15 & 104.5 & 57 & 39 \\
\hline 16 & 105.1 & 41 & 40 \\
\hline 17 & 105.6 & 38 & 32 \\
\hline 18 & 110.0 & 15 & 72 \\
\hline 19 & 115.7 & 241 & 56 \\
\hline 20 & 116.6 & 27 & 70 \\
\hline 21 & 117.3 & 29 & 69 \\
\hline 22 & 123.4 & 19 & 70 \\
\hline 23 & 123.8 & 32 & 62 \\
\hline 24 & 124.0 & 45 & 53 \\
\hline
\end{tabular}


Appendix 3 Table 9. Depth, strike, and dip of fractures imaged in borehole Jef-0592 (stable C well), Leetown Science Center, Leetown, West Virginia

[Strike reported in azimuthal degrees, east of True North in "right hand rule" where the direction of dip is to the right of the strike

\begin{tabular}{|c|c|c|c|}
\hline Fracture No. & Depth, in feet & $\begin{array}{l}\text { Strike, in } \\
\text { degrees }\end{array}$ & Dip, in degrees \\
\hline 25 & 126.2 & 5 & 43 \\
\hline 26 & 131.5 & 293 & 64 \\
\hline 27 & 133.2 & 96 & 89 \\
\hline 28 & 138.5 & 280 & 73 \\
\hline 29 & 141.6 & 31 & 51 \\
\hline 30 & 144.9 & 19 & 44 \\
\hline 31 & 150.7 & 231 & 48 \\
\hline 32 & 150.9 & 356 & 67 \\
\hline 33 & 154.9 & 17 & 81 \\
\hline 34 & 171.0 & 24 & 36 \\
\hline 35 & 171.2 & 13 & 38 \\
\hline 36 & 171.6 & 23 & 30 \\
\hline 37 & 171.9 & 31 & 33 \\
\hline 38 & 173.5 & 27 & 49 \\
\hline 39 & 174.6 & 194 & 67 \\
\hline 40 & 178.6 & 33 & 40 \\
\hline 41 & 180.3 & 18 & 40 \\
\hline 42 & 181.0 & 15 & 49 \\
\hline 43 & 181.3 & 26 & 42 \\
\hline 44 & 181.5 & 49 & 56 \\
\hline 45 & 186.4 & 34 & 45 \\
\hline 46 & 187.2 & 1 & 43 \\
\hline 47 & 189.3 & 16 & 53 \\
\hline 48 & 192.7 & 8 & 51 \\
\hline 49 & 193.3 & 344 & 39 \\
\hline 50 & 195.6 & 36 & 45 \\
\hline 51 & 195.9 & 39 & 45 \\
\hline 52 & 196.4 & 43 & 46 \\
\hline 53 & 196.8 & 37 & 44 \\
\hline 54 & 200.2 & 27 & 58 \\
\hline 55 & 203.2 & 24 & 56 \\
\hline 56 & 211.2 & 35 & 42 \\
\hline 57 & 212.7 & 30 & 38 \\
\hline 58 & 215.5 & 345 & 26 \\
\hline 59 & 215.6 & 243 & 69 \\
\hline 60 & 217.6 & 280 & 31 \\
\hline 61 & 220.8 & 207 & 49 \\
\hline 62 & 223.6 & 25 & 40 \\
\hline
\end{tabular}

Appendix 3 Table 9. Depth, strike, and dip of fractures imaged in borehole Jef-0592 (stable C well), Leetown Science Center, Leetown, West Virginia

[Strike reported in azimuthal degrees, east of True North in "right hand rule" where the direction of dip is to the right of the strike]

\begin{tabular}{|c|c|c|c|}
\hline Fracture No. & Depth, in feet & $\begin{array}{c}\text { Strike, in } \\
\text { degrees }\end{array}$ & Dip, in degrees \\
\hline 63 & 227.2 & 206 & 55 \\
\hline 64 & 231.6 & 14 & 42 \\
\hline 65 & 232.3 & 27 & 35 \\
\hline 66 & 232.7 & 36 & 46 \\
\hline 67 & 234.0 & 45 & 40 \\
\hline 68 & 235.3 & 220 & 58 \\
\hline 69 & 239.3 & 32 & 47 \\
\hline 70 & 241.6 & 19 & 57 \\
\hline 71 & 243.0 & 51 & 40 \\
\hline 72 & 243.5 & 28 & 59 \\
\hline 73 & 244.5 & 36 & 52 \\
\hline 74 & 245.9 & 44 & 34 \\
\hline 75 & 246.8 & 37 & 48 \\
\hline 76 & 247.1 & 41 & 54 \\
\hline 77 & 250.0 & 247 & 58 \\
\hline 78 & 252.8 & 34 & 27 \\
\hline 79 & 253.8 & 42 & 32 \\
\hline 80 & 255.3 & 43 & 44 \\
\hline 81 & 256.5 & 50 & 38 \\
\hline 82 & 257.1 & 44 & 44 \\
\hline 83 & 258.9 & 34 & 42 \\
\hline 84 & 262.5 & 172 & 79 \\
\hline 85 & 263.8 & 349 & 45 \\
\hline 86 & 270.8 & 26 & 40 \\
\hline 87 & 271.3 & 34 & 42 \\
\hline 88 & 272.3 & 23 & 23 \\
\hline 89 & 272.7 & 9 & 49 \\
\hline 90 & 272.9 & 22 & 49 \\
\hline 91 & 273.5 & 19 & 35 \\
\hline 92 & 273.9 & 37 & 39 \\
\hline 93 & 277.6 & 32 & 44 \\
\hline 94 & 285.1 & 42 & 30 \\
\hline 95 & 288.5 & 232 & 49 \\
\hline 96 & 303.7 & 26 & 49 \\
\hline 97 & 303.7 & 203 & 32 \\
\hline 98 & 307.7 & 160 & 50 \\
\hline
\end{tabular}


Appendix 3 Table 10. Depth, strike, and dip of fractures imaged in borehole Jef-0603 (USDA sulfur well), Leetown Science Center, Leetown, West Virginia

[Strike reported in azimuthal degrees, east of True North in "right hand rule" where the direction of dip is to the right of the strike]

\begin{tabular}{|c|c|c|c|}
\hline Fracture No. & Depth, in feet & $\begin{array}{c}\text { Strike, in } \\
\text { degrees }\end{array}$ & Dip, in degrees \\
\hline 1 & 60.4 & 346 & 61 \\
\hline 2 & 69.7 & 33 & 71 \\
\hline 3 & 72.1 & 352 & 60 \\
\hline 4 & 76.3 & 25 & 50 \\
\hline 5 & 77.4 & 28 & 48 \\
\hline 6 & 78.8 & 20 & 42 \\
\hline 7 & 80.6 & 30 & 54 \\
\hline 8 & 83.4 & 8 & 58 \\
\hline 9 & 90.4 & 49 & 58 \\
\hline 10 & 99.0 & 1 & 37 \\
\hline 11 & 101.2 & 19 & 33 \\
\hline 12 & 105.6 & 25 & 51 \\
\hline 13 & 109.8 & 63 & 72 \\
\hline 14 & 115.4 & 40 & 65 \\
\hline 15 & 120.7 & 34 & 65 \\
\hline 16 & 122.8 & 38 & 69 \\
\hline 17 & 134.2 & 42 & 65 \\
\hline 18 & 135.2 & 38 & 64 \\
\hline 19 & 136.3 & 38 & 64 \\
\hline 20 & 145.1 & 12 & 78 \\
\hline 21 & 145.8 & 29 & 72 \\
\hline 22 & 163.1 & 38 & 77 \\
\hline 23 & 167.4 & 354 & 76 \\
\hline 24 & 169.7 & 18 & 56 \\
\hline 25 & 170.4 & 358 & 50 \\
\hline 26 & 179.4 & 15 & 74 \\
\hline 27 & 183.8 & 28 & 43 \\
\hline 28 & 185.4 & 18 & 61 \\
\hline 29 & 232.1 & 40 & 55 \\
\hline 30 & 235.3 & 14 & 59 \\
\hline 31 & 236.5 & 34 & 55 \\
\hline 32 & 237.8 & 21 & 51 \\
\hline 33 & 240.8 & 30 & 63 \\
\hline 34 & 241.7 & 12 & 40 \\
\hline 35 & 242.4 & 22 & 41 \\
\hline 36 & 242.7 & 18 & 57 \\
\hline
\end{tabular}

Appendix 3 Table 10. Depth, strike, and dip of fractures imaged in borehole Jef-0603 (USDA sulfur well), Leetown Science Center, Leetown, West Virginia

[Strike reported in azimuthal degrees, east of True North in "right hand rule" where the direction of dip is to the right of the strike]

\begin{tabular}{|c|c|c|c|}
\hline Fracture No. & Depth, in feet & $\begin{array}{c}\text { Strike, in } \\
\text { degrees }\end{array}$ & Dip, in degrees \\
\hline 37 & 243.3 & 17 & 61 \\
\hline 38 & 259.7 & 59 & 55 \\
\hline 39 & 260.3 & 54 & 58 \\
\hline 40 & 275.7 & 12 & 46 \\
\hline 41 & 276.5 & 22 & 54 \\
\hline 42 & 283.7 & 36 & 68 \\
\hline 43 & 286.5 & 321 & 59 \\
\hline 44 & 289.7 & 75 & 49 \\
\hline 45 & 303.0 & 49 & 53 \\
\hline 46 & 303.8 & 52 & 49 \\
\hline 47 & 315.6 & 25 & 73 \\
\hline 48 & 316.9 & 53 & 68 \\
\hline 49 & 320.8 & 332 & 62 \\
\hline 50 & 322.1 & 57 & 65 \\
\hline 51 & 332.9 & 40 & 43 \\
\hline 52 & 340.7 & 36 & 58 \\
\hline 53 & 367.0 & 32 & 67 \\
\hline 54 & 368.1 & 40 & 46 \\
\hline 55 & 372.7 & 19 & 22 \\
\hline 56 & 388.3 & 45 & 39 \\
\hline 57 & 394.3 & 357 & 68 \\
\hline 58 & 395.0 & 10 & 39 \\
\hline 59 & 395.6 & 27 & 50 \\
\hline 60 & 402.0 & 18 & 71 \\
\hline 61 & 402.8 & 5 & 69 \\
\hline 62 & 404.4 & 28 & 63 \\
\hline 63 & 406.9 & 22 & 55 \\
\hline 64 & 407.3 & 5 & 58 \\
\hline 65 & 407.8 & 18 & 56 \\
\hline 66 & 408.6 & 27 & 56 \\
\hline 67 & 410.6 & 18 & 61 \\
\hline 68 & 411.3 & 22 & 56 \\
\hline 69 & 413.6 & 5 & 58 \\
\hline 70 & 414.1 & 27 & 67 \\
\hline 71 & 418.2 & 351 & 56 \\
\hline
\end{tabular}


Appendix 3 Table 10. Depth, strike, and dip of fractures imaged in borehole Jef-0603 (USDA sulfur well), Leetown Science Center, Leetown, West Virginia

[Strike reported in azimuthal degrees, east of True North in "right hand rule" where the direction of dip is to the right of the strike]

\begin{tabular}{cccc}
\hline Fracture No. & Depth, in feet & $\begin{array}{c}\text { Strike, in } \\
\text { degrees }\end{array}$ & Dip, in degrees \\
\hline 72 & 419.9 & 18 & 70 \\
73 & 422.0 & 14 & 73 \\
74 & 424.4 & 24 & 71 \\
75 & 425.6 & 14 & 54 \\
76 & 427.3 & 10 & 67 \\
77 & 428.1 & 33 & 61 \\
78 & 428.8 & 22 & 68 \\
79 & 431.0 & 23 & 73 \\
80 & 432.7 & 30 & 67 \\
81 & 438.4 & 22 & 70 \\
82 & 439.1 & 27 & 69 \\
83 & 440.2 & 18 & 62 \\
84 & 441.4 & 32 & 56 \\
85 & 441.9 & 18 & 56 \\
86 & 448.3 & 19 & 44 \\
87 & 448.5 & 36 & 55 \\
88 & 449.8 & 255 & 43 \\
89 & 453.5 & 11 & 42 \\
\hline
\end{tabular}

Appendix 3 Table 11. Depth, strike, and dip of fractures imaged in borehole Jef-0586 (USDA fault well), Leetown Science Center, Leetown, West Virginia

[Strike reported in azimuthal degrees, east of True North in "right hand rule" where the direction of dip is to the right of the strike]

\begin{tabular}{rrrr}
\hline Fracture No. & Depth, in feet & $\begin{array}{c}\text { Strike, in } \\
\text { degrees }\end{array}$ & Dip, in degrees \\
\hline 1 & 103.5 & 113 & 40 \\
2 & 104.6 & 85 & 42 \\
3 & 105.3 & 35 & 61 \\
4 & 105.7 & 48 & 71 \\
5 & 108.4 & 205 & 57 \\
6 & 110.3 & 178 & 38 \\
7 & 110.5 & 205 & 49 \\
8 & 111.3 & 51 & 48 \\
9 & 111.9 & 34 & 71 \\
10 & 113.9 & 221 & 73 \\
11 & 114.2 & 41 & 66 \\
12 & 118.7 & 221 & 70
\end{tabular}

Appendix 3 Table 11. Depth, strike, and dip of fractures imaged in borehole Jef-0586 (USDA fault well), Leetown Science Center, Leetown, West Virginia

[Strike reported in azimuthal degrees, east of True North in "right hand rule" where the direction of dip is to the right of the strike]

\begin{tabular}{|c|c|c|c|}
\hline Fracture No. & Depth, in feet & $\begin{array}{l}\text { Strike, in } \\
\text { degrees }\end{array}$ & Dip, in degrees \\
\hline 13 & 118.7 & 49 & 50 \\
\hline 14 & 122.7 & 28 & 44 \\
\hline 15 & 124.5 & 45 & 61 \\
\hline 16 & 125.0 & 219 & 58 \\
\hline 17 & 126.8 & 211 & 87 \\
\hline 18 & 130.0 & 34 & 84 \\
\hline 19 & 142.7 & 209 & 56 \\
\hline 20 & 144.7 & 215 & 62 \\
\hline 21 & 149.0 & 209 & 86 \\
\hline 22 & 149.6 & 35 & 81 \\
\hline 23 & 150.2 & 34 & 80 \\
\hline 24 & 152.7 & 34 & 62 \\
\hline 25 & 152.9 & 182 & 50 \\
\hline 26 & 153.0 & 15 & 44 \\
\hline 27 & 157.1 & 226 & 69 \\
\hline 28 & 157.6 & 200 & 53 \\
\hline 29 & 158.1 & 215 & 65 \\
\hline 30 & 159.7 & 36 & 68 \\
\hline 31 & 161.9 & 51 & 83 \\
\hline 32 & 161.9 & 219 & 81 \\
\hline 33 & 165.5 & 227 & 83 \\
\hline 34 & 166.7 & 238 & 38 \\
\hline 35 & 168.4 & 7 & 35 \\
\hline 36 & 174.9 & 37 & 80 \\
\hline 37 & 175.2 & 204 & 62 \\
\hline 38 & 175.8 & 39 & 82 \\
\hline 39 & 178.9 & 25 & 68 \\
\hline 40 & 180.1 & 39 & 69 \\
\hline 41 & 180.9 & 210 & 59 \\
\hline 42 & 181.1 & 43 & 65 \\
\hline 43 & 183.1 & 73 & 76 \\
\hline 44 & 183.9 & 59 & 71 \\
\hline 45 & 184.6 & 53 & 73 \\
\hline 46 & 186.2 & 220 & 70 \\
\hline 47 & 186.7 & 51 & 74 \\
\hline 48 & 190.7 & 173 & 42 \\
\hline 49 & 192.1 & 50 & 60 \\
\hline 50 & 192.6 & 31 & 73 \\
\hline
\end{tabular}


Appendix 4: Single-well, multi-well, step drawdown, and packer aquifer tests conducted at the Leetown Science Center, Leetown, West Virginia. 


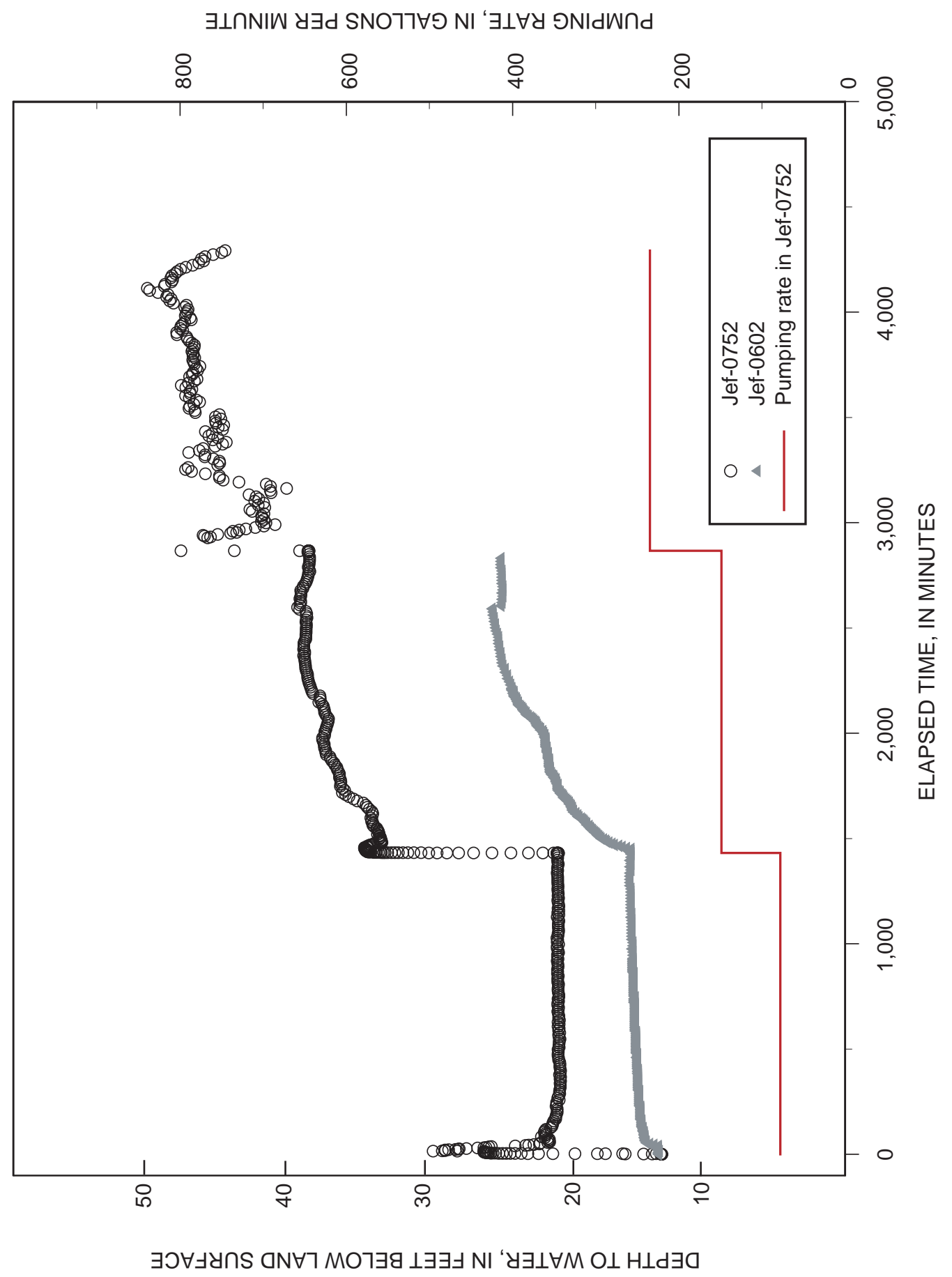

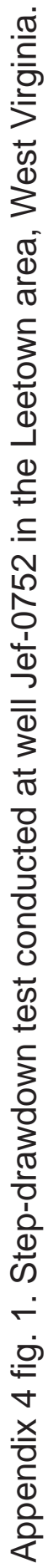




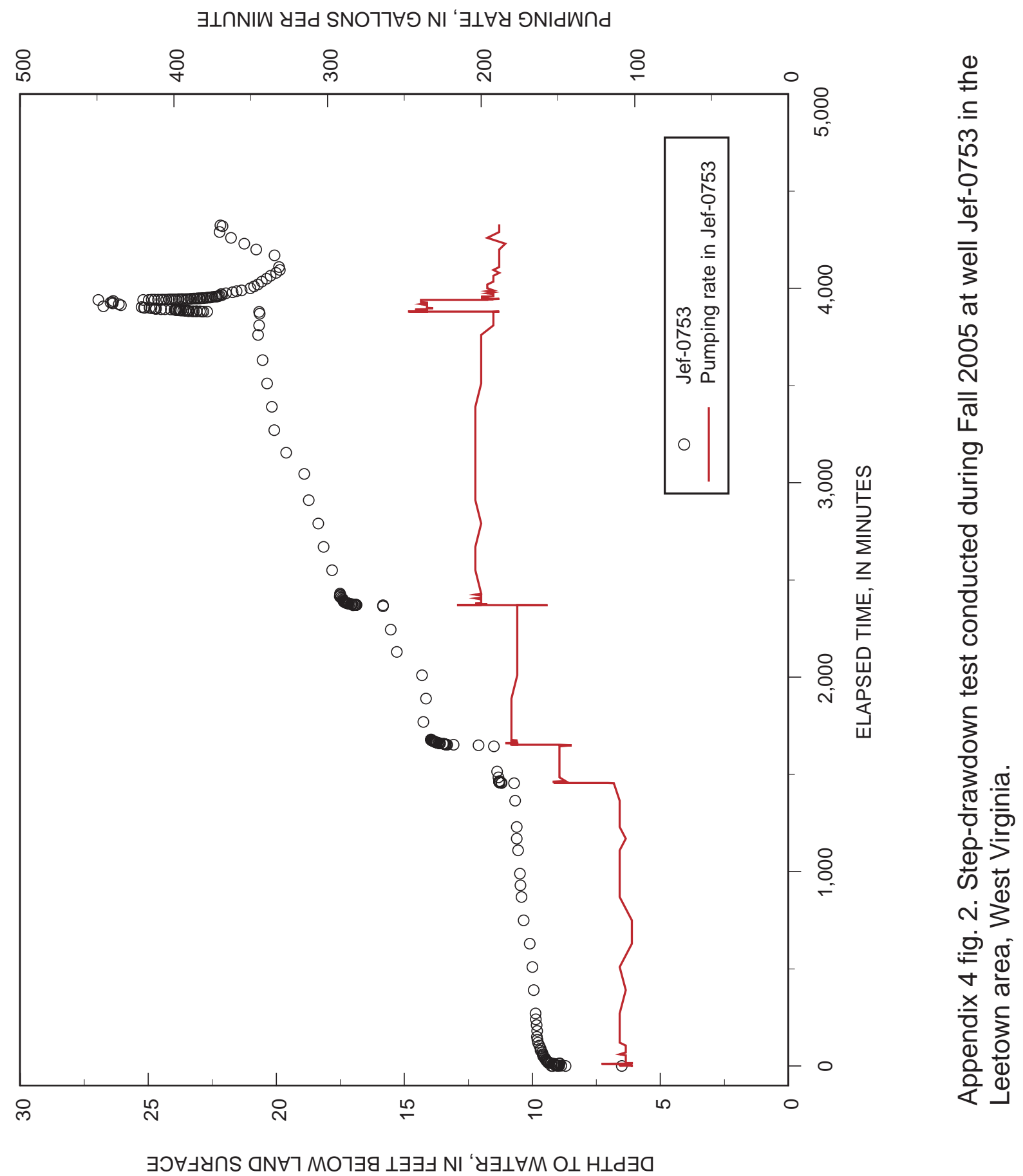




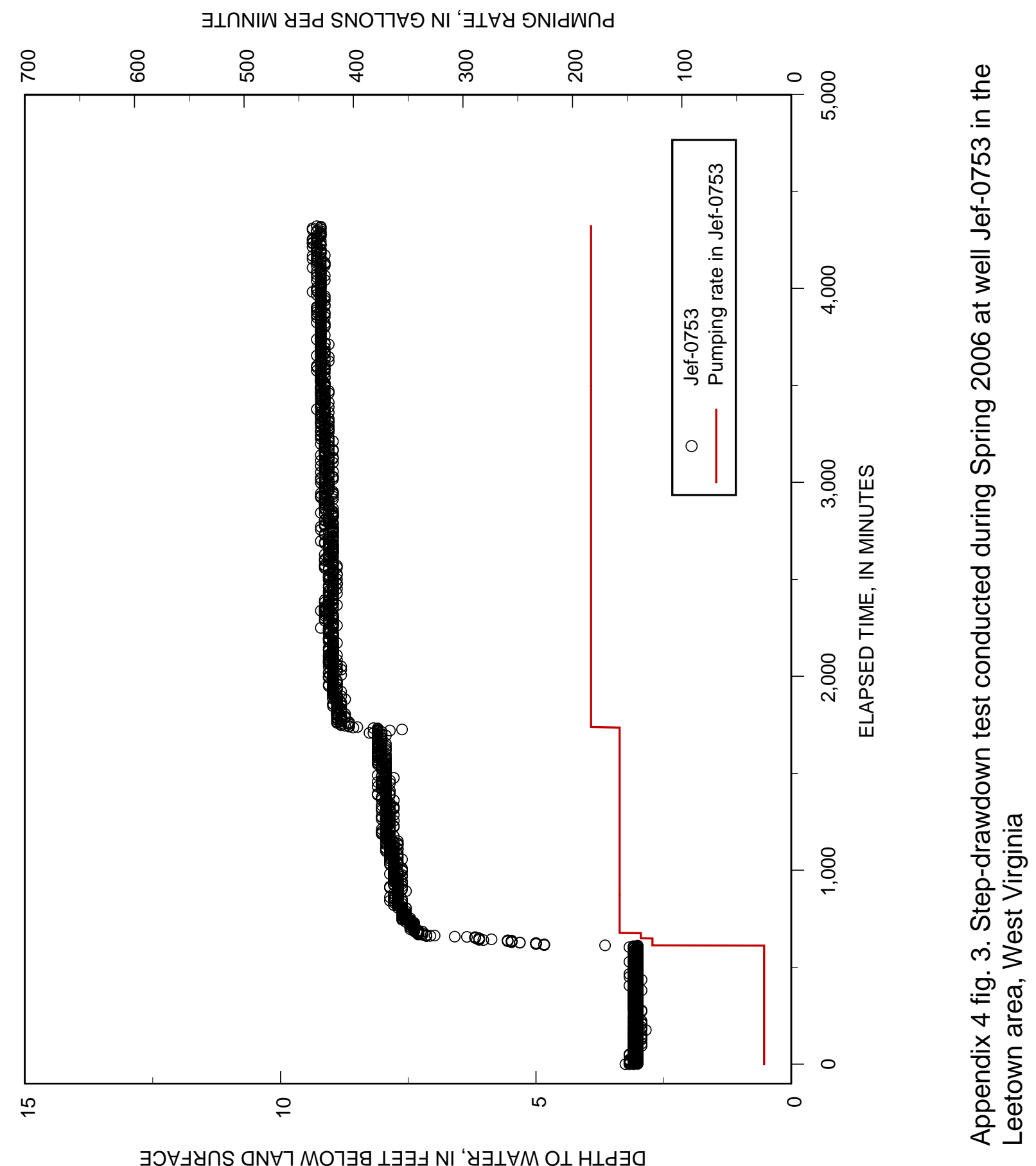




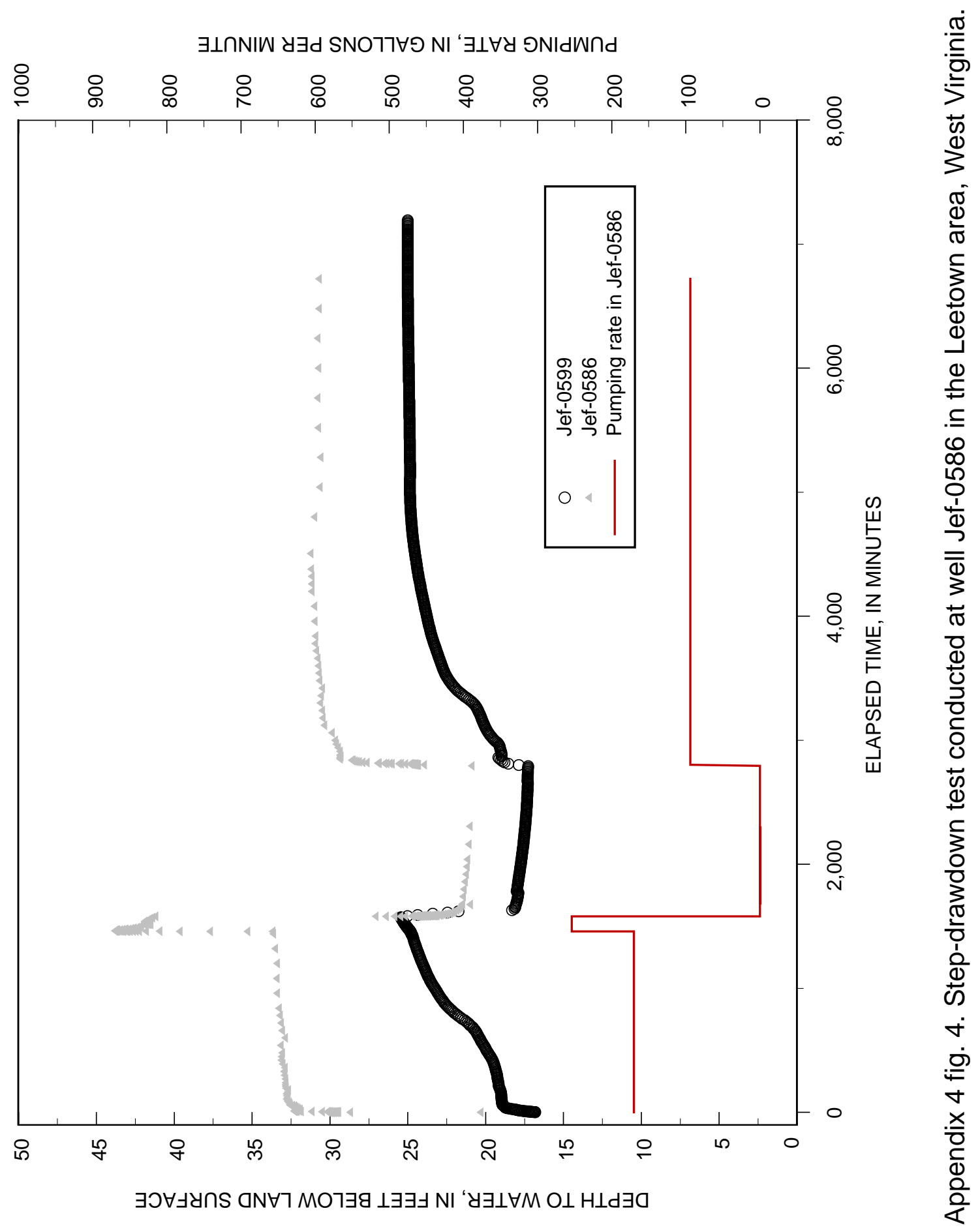



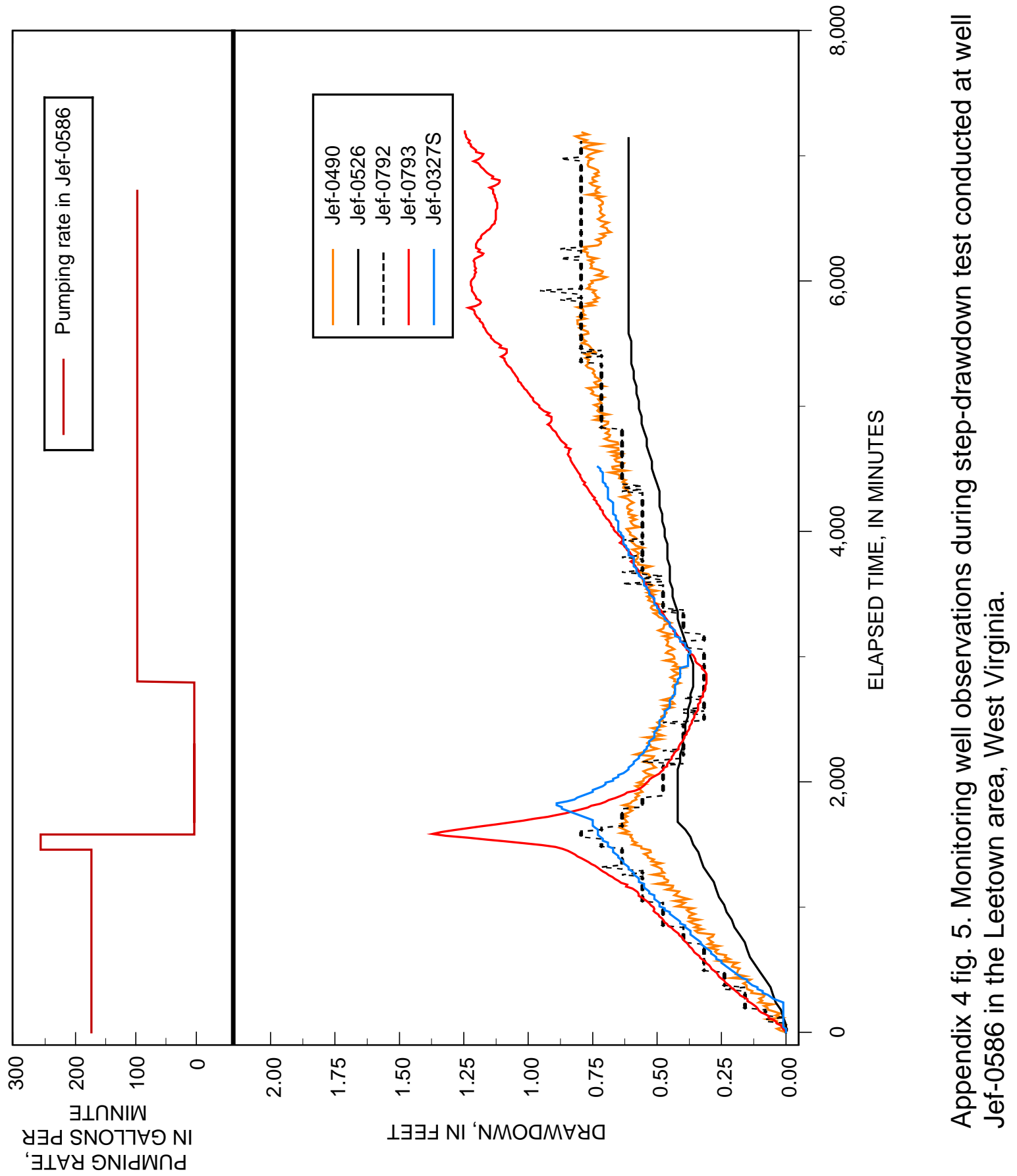


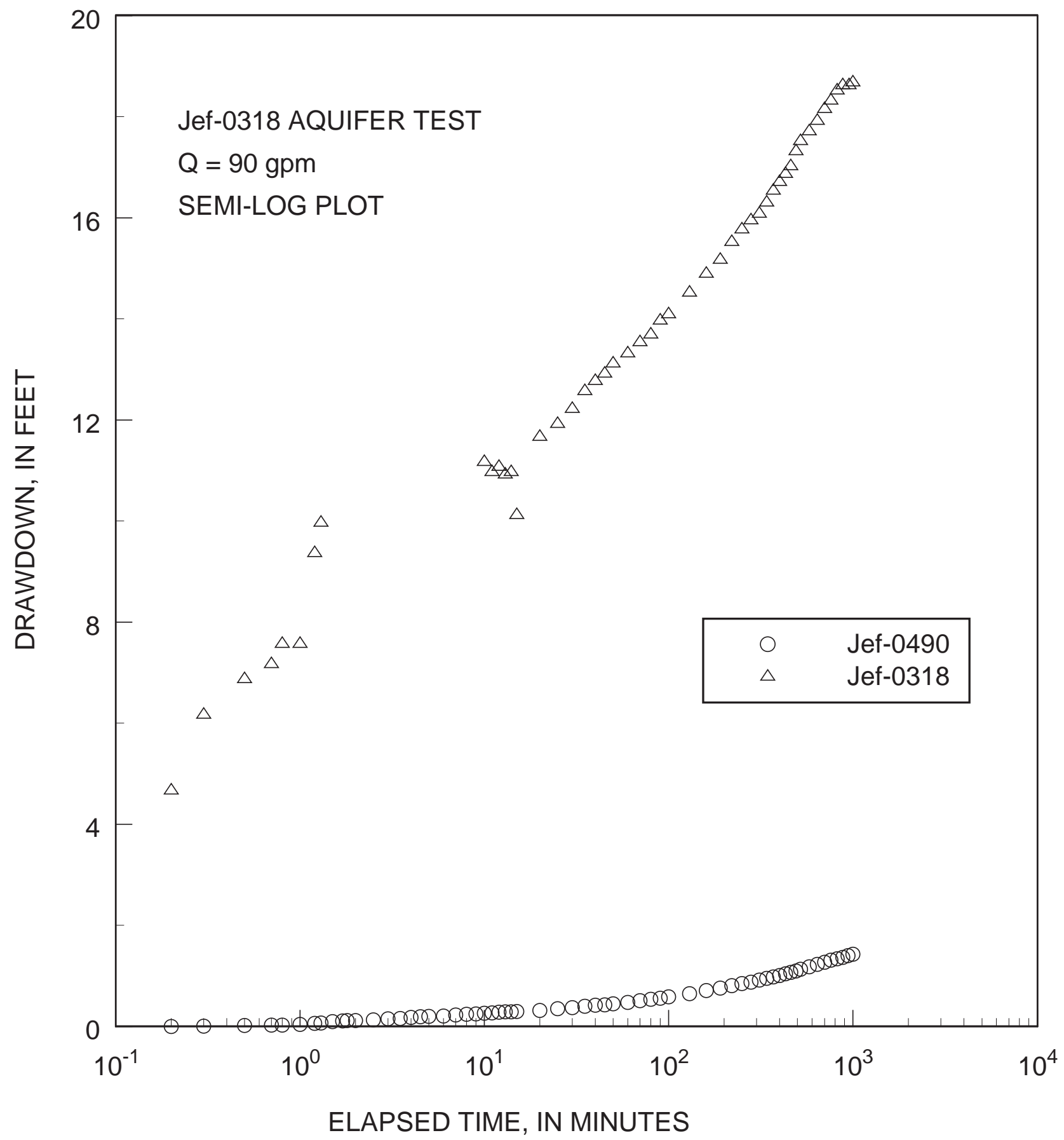

Appendix 4 fig. 6. Semi-log plot of drawdown versus time for multiple well test conducted on well Jef-0318 in the Leetown area, West Virginia. 


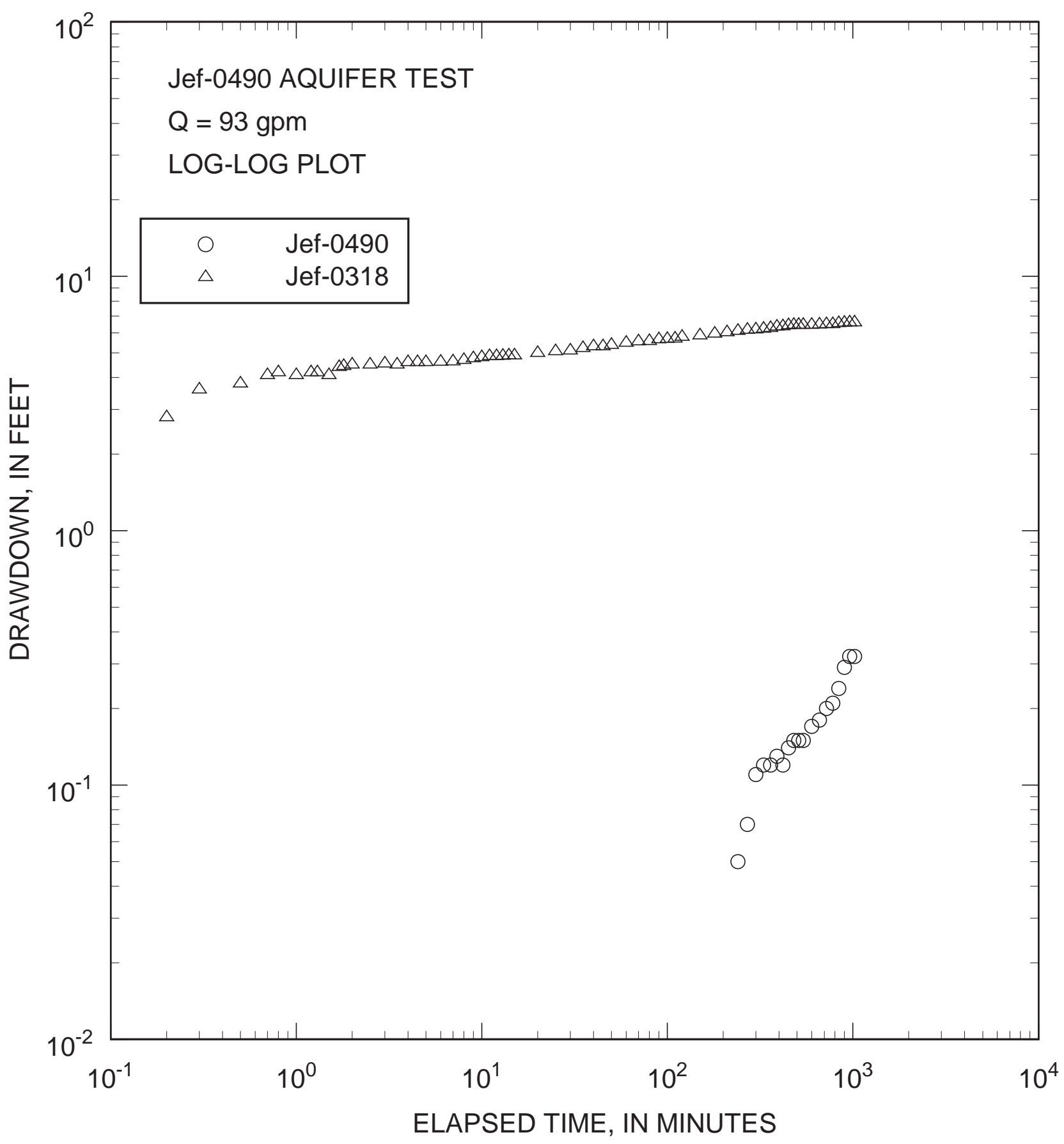

Appendix 4 fig. 7. Log-log plot of drawdown versus time for multiple well test conducted on well Jef-0490 in the Leetown area, West Virginia, October 1999. 


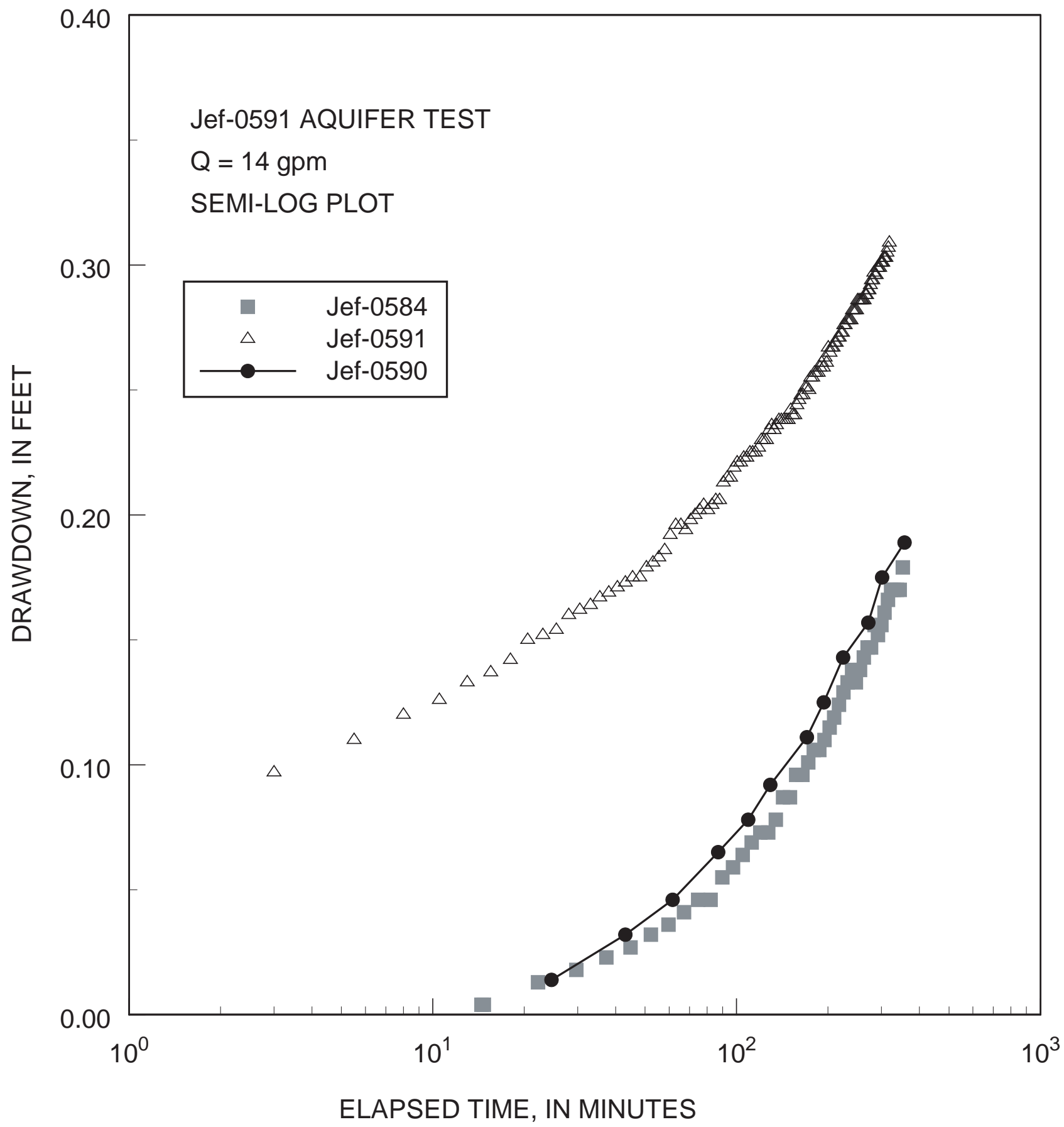

Appendix 4 fig. 8. Semi-log plot of drawdown versus time for multiple well test conducted on well Jef-0591 in the Leetown area, West Virginia. 


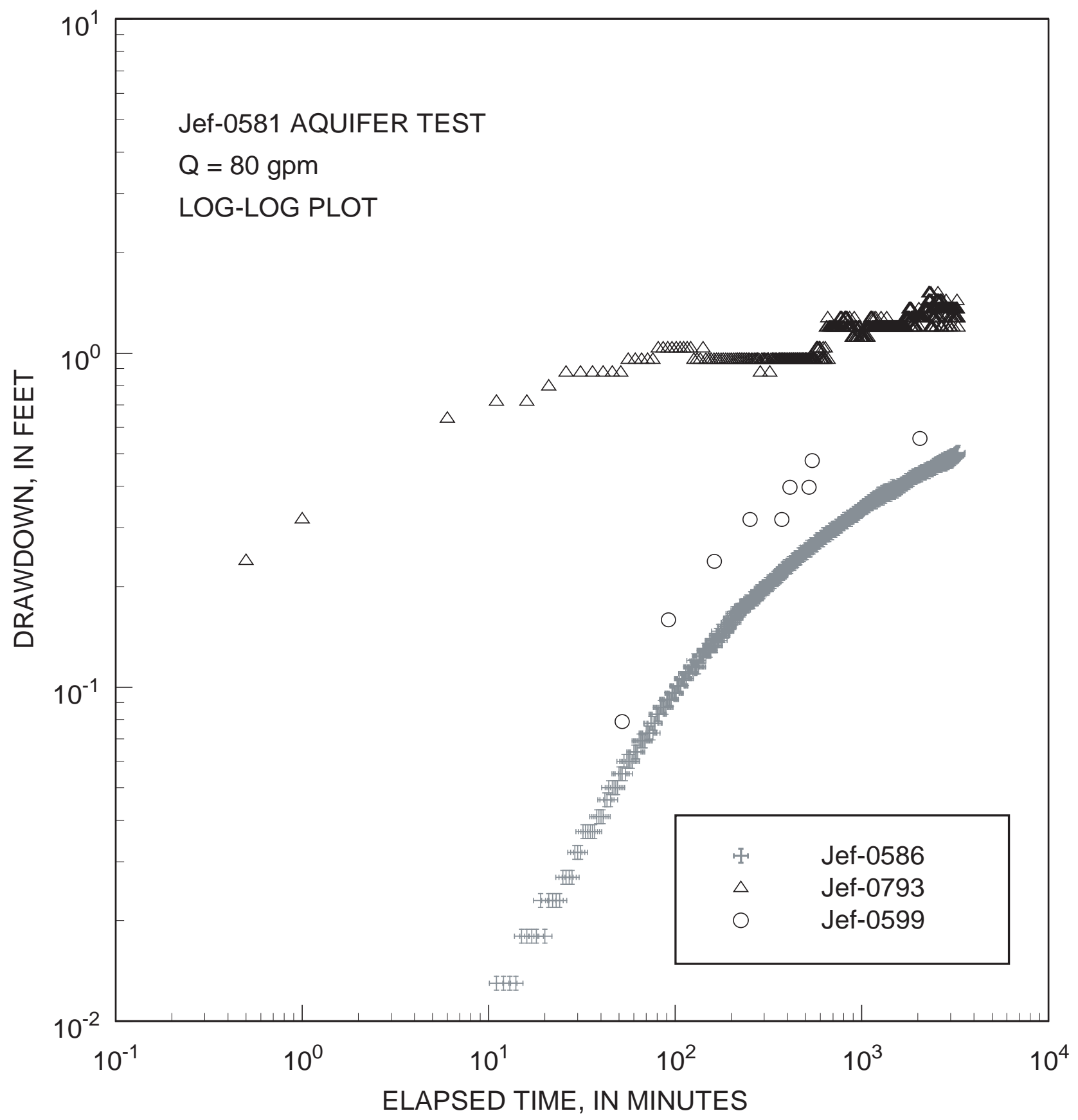

Appendix 4 fg. 9. Log-log plot of drawdown versus time for multiple well test conducted on well Jef-0581 in the Leetown area, West Virginia. 


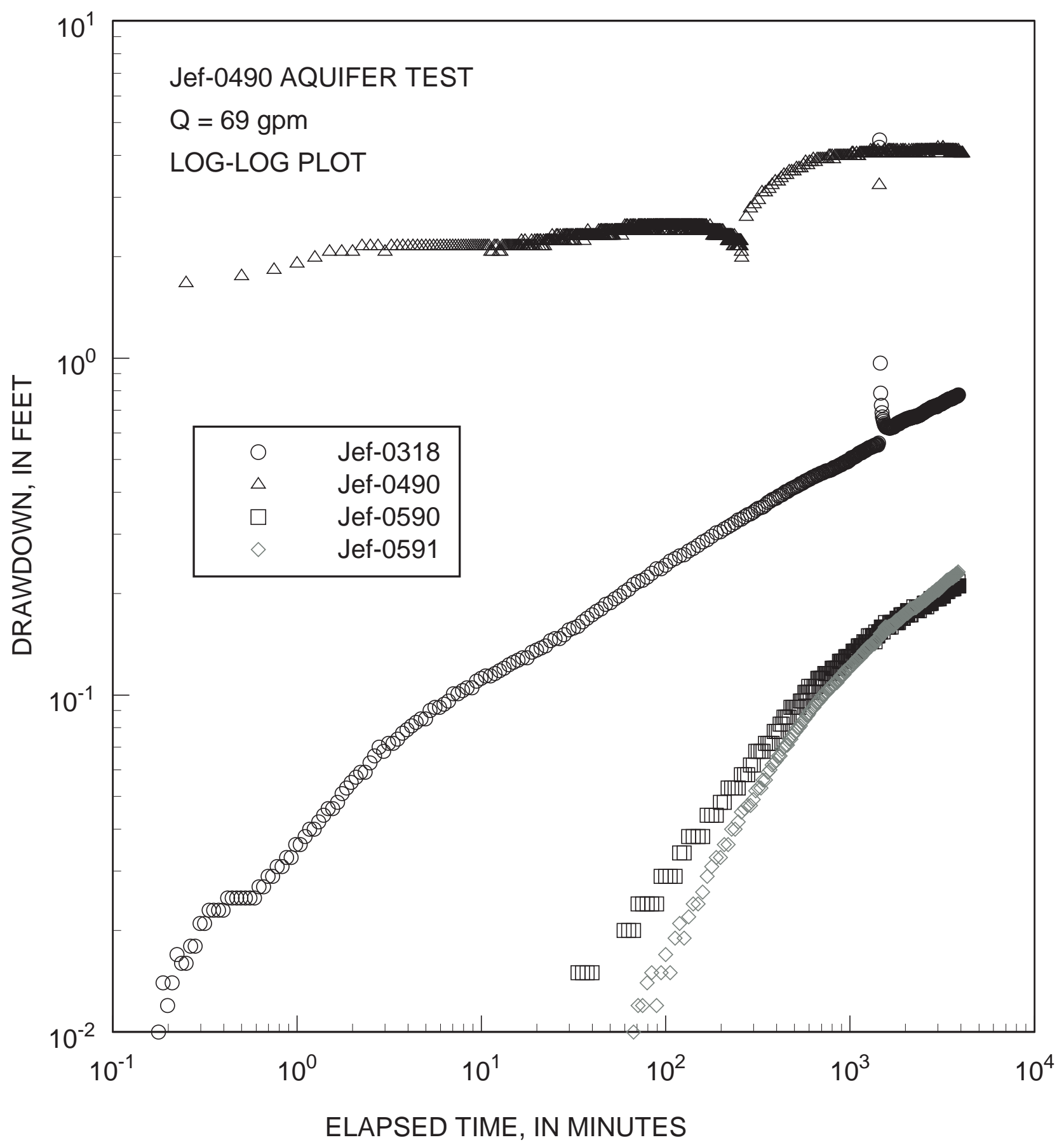

Appendix 4 fig. 10. Log-log plot of drawdown versus time for multiple well test conducted on well Jef-0490 in the Leetown area, West Virginia, May 2004. 


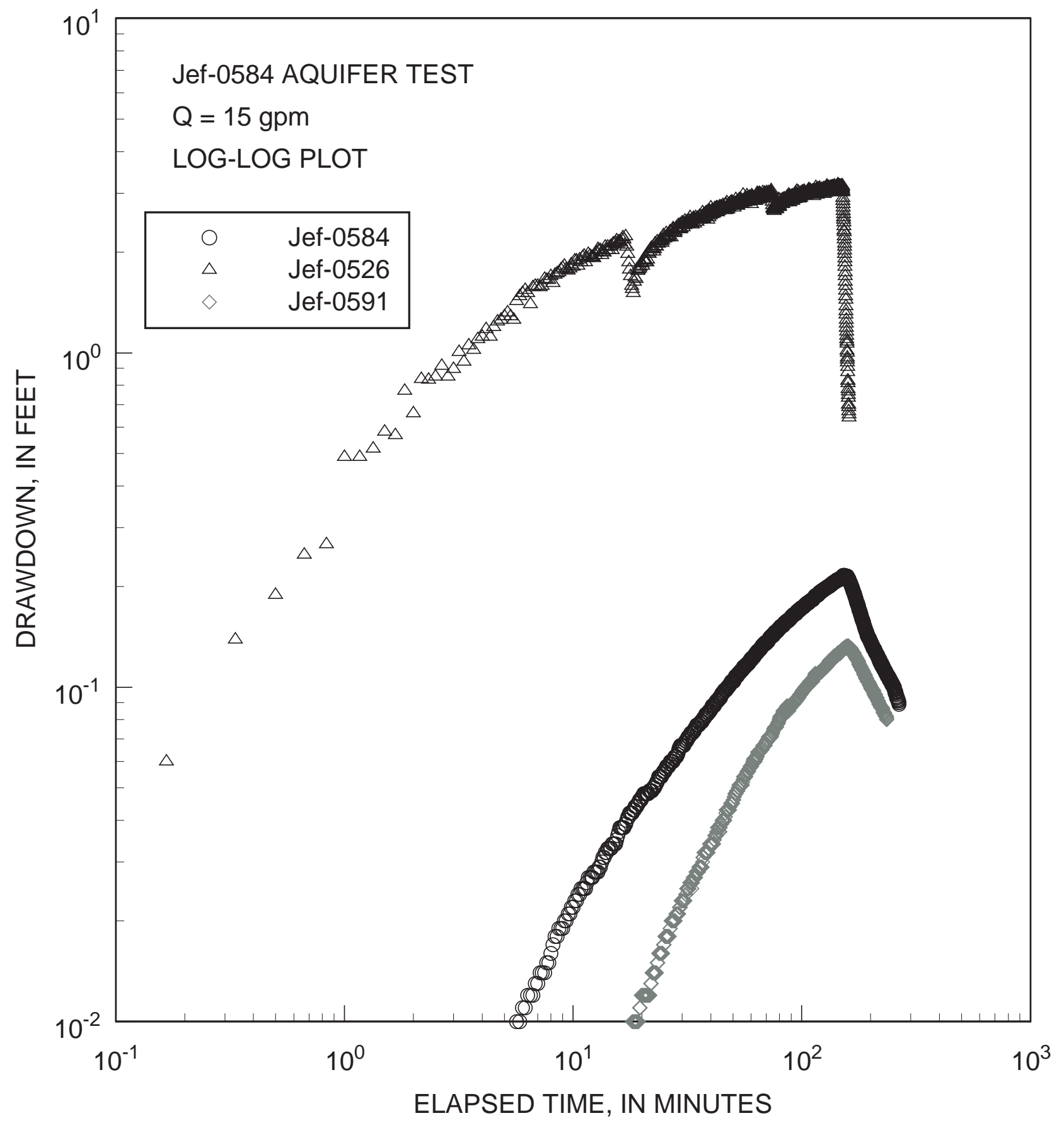

Appendix 4 fig. 11. Log-log plot of drawdown versus time for multiple well test conducted on well Jef-0584 in the Leetown area, West Virginia. 


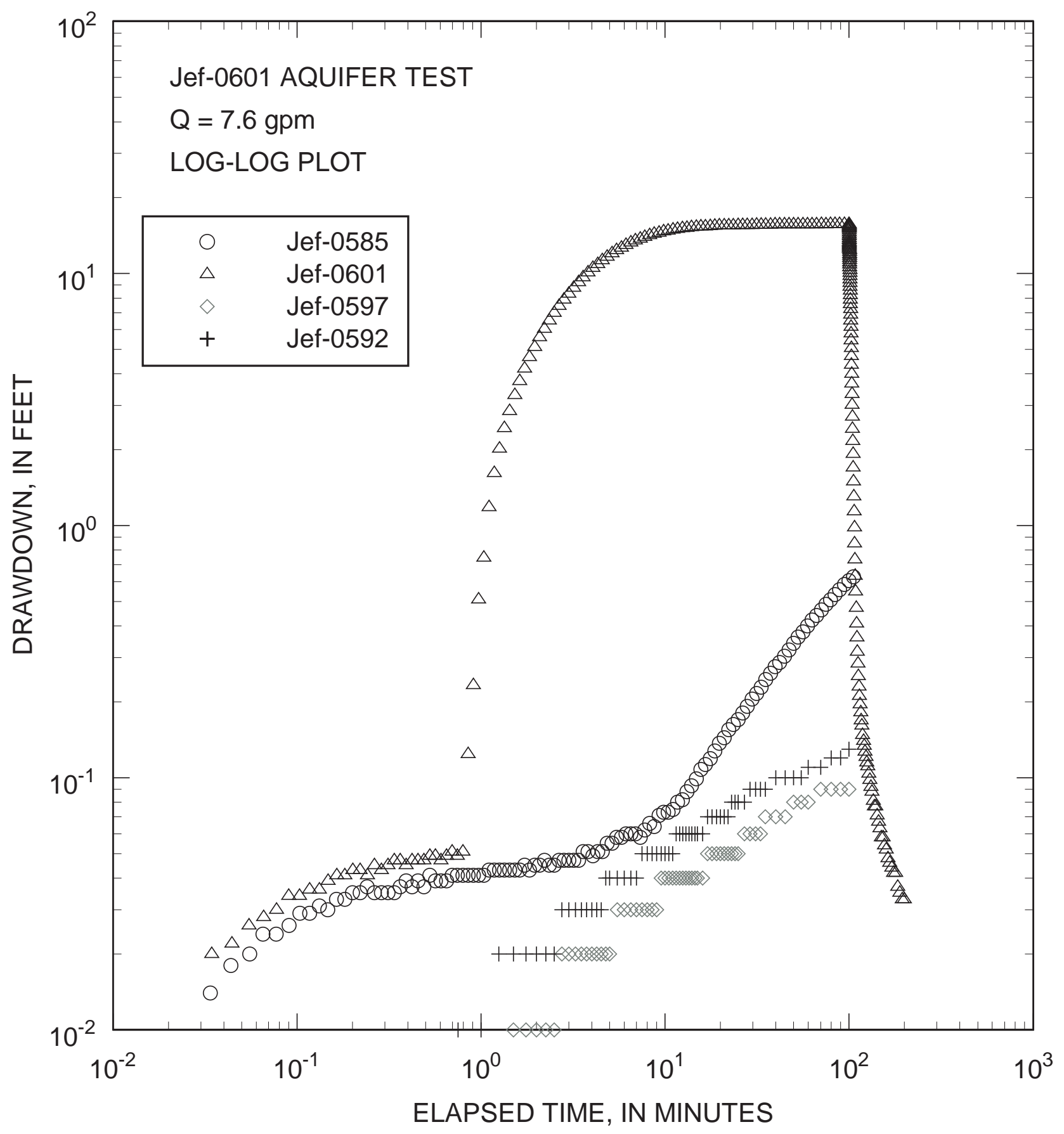

Appendix 4 fig. 12.Log-log plot of drawdown versus time for multiple well test conducted on well Jef-0601 in the Leetown area, West Virginia. 
Appendix 5a - Interpretation of fluorometric tracer tests done in the USGS Leetown Science Center, West Virginia 
Tracer Test No. 1

The first tracer test was initiated on April 20, 2004, at 11:34 AM by releasing 0.635 pounds (lbs) of Rhodamine WT dye into the south branch of Hopewell Run just below the Owen's Farm Spring pond (fig. 25 and table 12). Possible dye recovery sites monitored were the south and east branches of Hopewell Run (points $f$ and g on fig. 25), Gray, Blue, Balch, and Tabb Springs (sites a, c, h, and i on fig. 25 and table 13), and two wells at the Center (sites d and e on fig. 25 and table 13).

Peak dye recovery occurred at the monitoring point (point f on fig. 25) on the south branch of Hopewell Run at 4:38 PM on April 20, 2004, indicating an approximate five hour time of travel within the stream and through several ponds in the area (app. 5, fig. 1). Ground-water discharge to the south branch of Hopewell Run could not be firmly established because of the surface water transport of the dye. However, small dye peaks approximately three days and six days after injection could reflect recovery of dye from upstream leakage of surface water into ground water.

Peak dye recovery in the ball field well (Jef-0590 - site 48 on fig. 1 and in table 1) (point $d$ on fig. 25) on the Center occurred at 7:30 AM on May 02, 2004, indicating a 12-day time of travel (app. 5, fig. 2) and a linkage between surface and ground water, most likely as the south branch of Hopewell Run crosses the thrust faults which occur adjacent to the Center. The distance from the injection point to the ball field well is $5,181 \mathrm{ft}$ which translates into a flow velocity of $430 \mathrm{ft} / \mathrm{d}$. Base-flow discharge measurements conducted on the east and south branches of Hopewell Run indicate a loss of streamflow as the streams cross the thrust faults.

An isolated peak concentration of dye was detected in Balch Spring (Jef-0327S - site 4 on fig. 1 and in table 1) at 8:50 AM on April 22, 2004, which may be a result of induced capture of water by pumping of Balch Spring. The south branch of Hopewell Run flows across the thrust fault on which Balch Spring is located. The time of travel for peak arrival to Balch Spring was approximately six days (app. 5, fig. 3), but the exact path of travel is not known and is likely associated with the thrust faults which cross the area. The distance from the injection point to Balch Spring is 6,099 $\mathrm{ft}$ which translates into a flow velocity of about $1,020 \mathrm{ft} / \mathrm{d}$.

A weak multimodal recovery of dye was obtained at the monitoring point on the east branch of Hopewell Run (point g on fig. 25) with a peak recovery occurring at 8:00 AM on April 24, 2004 indicating a time of travel of about four days (app. 5, fig. 4). This erratic recovery probably reflects spillover of Balch Spring water into the east branch and possibly a slight rise of dye along a portion of its length. This hypothesis was not tested, however. With a straight-line travel distance of $6,358 \mathrm{ft}$ and assuming that the peak dye recovery reflects a discharge of ground water to the east branch of Hopewell Run, the estimated flow velocity is $1,600 \mathrm{ft} / \mathrm{d}$.

Tracer Test No. 2

The second tracer test was initiated on May 17, 2004, at 10:30 AM by injecting $0.635 \mathrm{lbs}$ of Rhodamine WT dye into the east branch of Hopewell Run just below Bell Spring (fig. 25 and table 12). Resurgence was monitored at the same sites monitored for the first tracer test with the addition of a second site on the east branch of Hopewell Run below two intermittent springs (site j on fig. 25 and table 13).

Peak dye recovery occurred at the on the east branch of Hopewell Run at the Leetown gaging station (site $\mathrm{g}$ on fig. 25) at 7:10 PM on May 18, 2004, indicating a slightly less than 1.5-day time of travel within the stream and through a large reservoir (app. 5, fig. 5). The distance from the injection point to the sampling station is $7,120 \mathrm{ft}$ and yielded a calculated streamflow velocity of $4,750 \mathrm{ft} / \mathrm{d}$, although this is likely an indication of the stream velocity only. A second smaller peak in the breakthrough curve (BTC) occurred on May 26, 2004, 9 days after injection with a subsequent flattening of the curve indicating dye recovery and a streamflow velocity of about $790 \mathrm{ft} / \mathrm{d}$.

Dye peaks were detected at Gray and Blue Springs (app. 5, figs. 6 and 7, respectively) (sites a and c on fig. 25), although data are limited and recoveries at Gray Spring were very poor. Such poor breakthrough data indicates that the sampling frequency was insufficient for this particular test. However, the smooth distribution of data allowed for modeling the breakthrough curves. Peak dye recovery occurred at Gray Spring on May 21, 2004 and at Blue Spring on May 22, 2004, approximately 4 and 5 days after injection, respectively. The travel distances to Gray Spring was 4,860 ft and to Blue Spring was 5,130 ft, providing calculated flow velocities of $1,220 \mathrm{ft} / \mathrm{d}$ and $1,030 \mathrm{ft} / \mathrm{d}$.

The dye resurgences at Blue and Gray Springs provide an indication of a connection between surface and ground water, but the limited sampling data around the recovery times is problematic. The geologic map for the area indicates a thrust fault crossing through the areas adjacent to the south branch of Hopewell Run and the springs, indicating a possible connection between the two.

A strong multimodal recovery of the dye was also obtained at the ball field Well (Jef-0590 - site d on fig. 25) where peak recovery exceeded $7 \mu \mathrm{g} / \mathrm{L}(>6 \mu \mathrm{g} / \mathrm{L}$ when the $\sim 1 \mu \mathrm{g} / \mathrm{L}$ background concentration is subtracted from the measured peak concentration) (app. 5 fig. 8). Peak recovery occurred at 7:35 AM on May 18, 2004, indicating a 21 hour (.875 d) time of travel (app. 5, fig. 8). The multimodal nature of the breakthrough curve cannot be easily explained, but may be a result of leakage (losing reaches) along the east branch of Hopewell Run. An alternative explanation may be that dye leaked into the well at various fractures along the well bore. 
An early peak indicates fairly rapid transit by the bulk of the dye, but the long strong tail also is indicative of slow leakage from tighter fractures. The distance from the injection point to the ball field well is $5,680 \mathrm{ft}$, providing a calculated flow velocity of approximately $6,490 \mathrm{ft} / \mathrm{d}$ ). These results indicate recoveries at the ball field well from both tracer tests 1 and 2. The travel time discrepancy (travel times from the April 20, 2004, release were much longer than the travel times from the May 17, 2004, release) is not easily resolved, but probably reflects the proximity of the east branch of Hopewell Run to the ball field well relative to the south branch of Hopewell Run.

Very low peak dye recoveries were obtained at Balch Spring, at Hopewell run just below the two intermittent springs, and on the south branch of Hopewell Run at the Leetown gaging station. The recoveries at Balch Spring were very low, multimodal and occurred on May 19, 2004, and May 22, 2004, yielding travel times of about 2 and 5 days, respectively (app. 5, fig. 9). The distance from the injection point to Balch Spring is $6,190 \mathrm{ft}$, indicating flow velocities of 1,240 and $3,100 \mathrm{ft} / \mathrm{d}$. Similar results were obtained from the two intermittent springs. The peak recovery occurred on May 24, 2004, seven days after injection (app. 5, fig. 10). The recovery point is $3,760 \mathrm{ft}$ from the injection site, indicating a flow velocity of $540 \mathrm{ft} / \mathrm{d}$ was calculated.

A somewhat erratic recovery was also obtained at the Hopewell Run at Leetown gaging station on the south branch of Hopewell Run with the main peak dye recovery occurring on May 26, 2004, about nine days after injection (app. 5, fig. 11). The recovery point is $7,200 \mathrm{ft}$ from the injection point, indicating a calculated flow velocity of about $800 \mathrm{ft} / \mathrm{d}$.

Although the dye recoveries at Balch Spring, Gray Spring, the east branch of Hopewell Run just below the two intermittent springs, and on the south branch of Hopewell Run were quite low, their travel distances and peak times of recovery were comparable with each other and with the other sampling sites where stronger recoveries were obtained. This relation indicates that the weak recoveries are probably real. The first two tracer tests were based on injections into streams while the remaining tests concentrated on injections into ground water through sinkholes or shallow wells.

\section{Tracer Test No. 3}

The third tracer test was initiated on June 17, 2004, at 11:20 AM by injecting $1.05 \mathrm{lbs}$ of Rhodamine WT dye into a sinkhole on the Center north of the east branch of Hopewell Run near Hite Road (site 3 on fig. 25 and table 12). Resurgence sites were monitored on the south (site $f$ on fig. 25) and east branches of Hopewell Run (sites g, j, and k on fig. 25 and table 13), and at the confluence of two small intermittent springs down gradient of the injection sinkhole (site 1 on fig. 25 and table 13).
Peak dye recovery occurred at the confluence of the two intermittent springs (site 1 on fig. 25) on July 8, 2004 (app. 5, fig. 12), at the east branch of Hopewell Run downstream of the confluence of the two springs (site j on fig. 25) also on July 8, 2004, and on the east Branch of Hopewell Run at the Leetown gaging station on July 9, 2004. The estimated time of travel from the injection sinkhole for peak arrival at the two intermittent springs was approximately 21 days. The distance between the sinkhole and the confluence of the two overflow springs is approximately $1,580 \mathrm{ft}$, yielding an approximate flow velocity of $75 \mathrm{ft} / \mathrm{d}$.

\section{Tracer Test No. 4}

The fourth tracer test was initiated on July 22, 2004, at 9:30 AM by injecting 1.05 lbs of Rhodamine WT dye into a $46 \mathrm{ft}$ deep piezometer drilled in bedrock along a fracture zone. This piezometer is located on a cross-strike fracture zone (fig. 25 and table 12) that parallels a nearby cross-strike fault and connects to a small intermittent spring approximately $1,490 \mathrm{ft}$ up-gradient of Gray Spring. Resurgence sites were monitored on the south and east branches of Hopewell Run (points $f$ and g on fig. 25 and table 13), at Gray, Blue, and Balch Springs, and at the small tributary stream that starts at Gray Spring (sites b, a, h, and c on fig. 25 and table 13).

Peak dye recovery occurred at Blue Spring on July 23, 2004, six days after injection (app. 5, fig. 13), at Gray Spring on July 24, 2004, about seven days after injection (app. 5, fig. 14a), and at the tributary just below Gray Spring on July 23, 2004, about six days after injection (app. 5, fig. 14b). Dye recoveries were very low with multiple peaks, indicative of poor flushing from the piezometer. The estimated peak time of travel from the injection piezometer to the tributary monitoring point was approximately six days indicating the overflow receives water from Blue Spring before Gray Spring. The straight line distance between the piezometer and Blue Spring was approximately 1,910 ft, yielding an approximate groundwater flow velocity of $320 \mathrm{ft} / \mathrm{d}$. The straight line distance between the piezometer and Gray Spring is approximately $1,490 \mathrm{ft}$, yielding an approximate ground-water flow velocity of $210 \mathrm{ft} / \mathrm{d}$.

Dye was also recovered at Balch Spring at extremely low concentrations, again with erratic multiple peaks (app. 5, fig. 15). Poor flushing of the dye from the piezometer is a possible reason for the very poor tracer recovery. Peak recovery at Balch Spring occurred on July 29, 2004, about 12 days after injection. The distance between the injection piezometer and Balch Spring is 3,860 ft, indicating a calculated flow velocity of $320 \mathrm{ft} / \mathrm{d}$.

This poor flushing may be evidence that the piezometer was not in good hydraulic connection with the main flow system, at least at the depth where the dye was released. Alternatively, although precautions were taken to control the rate of release of dye into the piezometer, it is possible that the slow 
rate of dye injection into the top of the piezometer, followed by chaser water, was too great for the piezometer to be able to absorb the injected water. The net effect would be that the head in the piezometer may have been sufficiently raised as to force the dye up into the vadose zone. Such an occurrence would result in a slow, perhaps pulsing release of the dye back into the piezometer and subsequent release into the aquifer over a relatively long period of time.

\section{Tracer Test No. 5}

The fifth tracer test was initiated on August 31, 2004, at 11:22 AM by injecting $3.5 \mathrm{lbs}$ of Rhodamine WT dye into a 6 $\mathrm{ft}$ deep augered hole in a dry stream channel (point 5 on figure 25) coincident with a thrust fault that connects to Gray Spring (fig. 25 and table 12). Resurgence sites were monitored on the south and east branches of Hopewell Run (sites $f$ and $g$ on fig. 25 and table 13) and at Gray, Blue, Balch and Tabb Springs (sites a, c, h, and i on fig. 25 and table 13).

Peak recovery occurred at Blue and Gray Springs on September 29, 2004, 29 days after injection (app. 5, figs. 16 and 17, respectively); at Tabb Spring on September 28, 2004, 28 days after injection (app. 5, fig. 18); at Balch Spring on September 15, 2004, 15 days after injection (app. 5, fig. 19); and on the south and east branches of Hopewell Run on September 29, 2004, 29 days after injection (app. 5, figs. 20 and 21 , respectively).

Interestingly, breakthrough curves for the south and east branches of Hopewell Run are remarkably similar in appearance to each other. Similarly, Blue and Gray Springs also have similarly appearing curves. The similarity in breakthrough curves between the two branches of Hopewell Run and between Blue and Gray Springs lend themselves to confirmation of recovery. Even more significant was the more rapid recovery of dye at Balch Spring where peak recovery was approximately 14 days sooner than the nearby Blue, Gray, and Tabb Springs. The rapid transport to Balch Spring might be related to (1) solution enlargement of fractures and faults between the injection site and Balch Spring and (2) due to the pumping of Balch Spring or both. The distances between the augered injection hole and Balch, Blue, Gray, and Tabb Springs are approximately 3,540, 1,260, 810, and $1,910 \mathrm{ft}$ respectively; resulting in calculated peak ground-water flow velocities of approximately and $240,44,28$, and $68 \mathrm{ft} / \mathrm{d}$, respectively.

\section{Tracer Test No. 6}

The sixth tracer test was initiated on October 7, 2004, at 10:20 AM by injecting $0.66 \mathrm{lbs}$ of sodium fluorescein dye into a 37.5 -ft deep piezometer (site 54 on fig. 1 and in table 10) completed in shallow bedrock on a thrust fault that connects to Balch Spring (fig. 25 and table 12). Resurgence sites were monitored on the south and east branches of Hopewell Run (sites $\mathrm{f}$ and $\mathrm{g}$ on fig. 25 and table 13) and at Gray, Blue, Balch and Tabb Springs (sites a, c, h, and i on fig. 25 and table 13).

Peak dye recovery occurred at the east branch of Hopewell Run at the Leetown gaging station on October 30, 2004 (app. 5, fig. 22), and in Balch Spring on December 10, 2004 (app. 5, fig. 23). An even stronger resurgence occurred at Balch Spring on December 17, 2004 just as sampling was terminated due to freezing of equipment. As a result, final recoveries at Balch Spring could not be determined.

These data indicate approximately 25 days for peak time of travel to Hopewell Run and approximately 64-71 days for peak time of travel to Balch Spring. The distances between the injection piezometer and Balch Spring is $970 \mathrm{ft}$ and to the Hopewell Run at Leetown gaging station is 1,390 ft. These data yielded a calculated peak flow velocity to Balch Spring of 14-15 ft/d and to the east branch of Hopewell Run of 56 $\mathrm{ft} / \mathrm{d}$. The differences in flow velocities to Balch Spring and to Hopewell Run indicate that different fractures associated with the fault zones are connected to the two sites.

In August 2005 an aquifer test was conducted on a 6-in. diameter well (Jef-0586, site 60 on fig. 1 and in table 1) adjacent to the injection piezometer (Jef-0599, site 54 on fig. 1 and in table 1) used for injection of dye in the sixth tracer test. A 72-hour aquifer test was conducted on the well and water was withdrawn from the well at rates varying from 100 to more than $300 \mathrm{gal} / \mathrm{min}$. Visible concentrations of sodium fluorescein were detected in a down gradient monitoring well approximately $200 \mathrm{ft}$ from the injection piezometer. Sodium fluorescein dye had remained trapped in the aquifer for more than 10 months, possibly in the clay filled area between pinnacles or isolated voids in the epikarst. The documentation of this phenomenon is important, as historically, only very low concentrations of dye are retrieved as a result of fluorometric tracer injections conducted in the region. The long-term trapping of water and solutes in the epikarstic zone has been documented in other karstic terranes (Even and others, 1986). Long-term trapping in the epikarstic zone is indicative of poor hydrologic connections between the vadose zone and the phreatic zone until heavy precipitation mobilizes the stored solutes.

\section{Tracer Test No. 7}

The seventh tracer test was initiated on October 7, 2004, at 12:30 PM by injecting $6.0 \mathrm{lbs}$ of Rhodamine WT dye into a sinkhole 1 mile southeast of Leetown (fig. 25 and table 12). This was a repeat of a former tracer test conducted by Jones and Deike (1981). Resurgence sites were monitored on the south and east branches of Hopewell Run (sites $f$ and $g$ on fig. 25 and table 13) and at Gray, Blue, Balch and Tabb Springs (sites a, c, h, and i on fig. 25 and table 13). Unfortunately, freezing of automatic samplers at several sites forced a discontinuance of sampling. However, sampling was continued 
at several other sites for most of the winter and at Gray Spring through March, 2005.

Peak dye recovery occurred at Gray Spring on February 26, 2005, with a secondary peak on March 2, 2005 (app. 5, fig. 24). These recoveries indicate ground-water time of travel to Gray Spring of 142-146 days, respectively. The distances between the injection sinkhole and Gray Spring is 4,540 ft, yielding an approximate flow velocity from the injection sinkhole to Gray Spring of 31-32 ft/d.

Peak dye recovery occurred at Blue Spring on January 19, 2005, (app. 5, fig. 25), and at Balch Spring on October 19, 2004, with a secondary peak on November 21, 2004 (app. 5 , fig. 26), although the recovery concentrations at Balch Spring are quite low. No data was available for these sites in early 2005 due to freezing of automated samplers. Because data were unavailable for Balch and Blue Springs, flow to these sites may not be representative of peak ground-water travel times. Estimated time of travel to Blue Spring was 104 days and to Balch Spring was 12 days with a secondary peak 45 days since injection. The apparent rapid transit of dye to Balch Spring was probably induced by pumping of Balch Spring.

Estimated flow velocities are equally uncertain. The distance from the injection sinkhole to Blue and Balch Springs are approximately 5,020 and 7,180 ft, respectively. Estimated flow velocities were approximately $48 \mathrm{ft} / \mathrm{d}$ to Blue Spring and 160-600 ft/d to Balch Spring. The previous tracer test conducted by Jones and Deike (1981) reported a transit rate of $81 \mathrm{ft} / \mathrm{d}$ to Gray Spring, $86 \mathrm{ft} / \mathrm{d}$ to Blue Spring, and $127 \mathrm{ft} / \mathrm{d}$ to Balch spring (Jones and Deike, 1981). The apparent discrepancy in flow velocities are probably a result of higher precipitation during this study.

\section{Tracer Test No. 8}

The eighth and final tracer test was initiated on April 19, 2005, at 11:22 AM by injecting $11.9 \mathrm{lbs}$ of Rhodamine WT dye into a sinkhole northeast of Leetown (fig. 25 and table 12). Resurgence sites were monitored on the east branch of Hopewell Run at the Leetown gaging station (site g on fig. 26 and table 13) and at Gray, Blue, and Balch Springs and the confluence of the two intermittent springs just down gradient of the injection sinkhole (sites a, c, h, and 1 on fig. 25 and table 13). Resurgence sites were also monitored on the east branch of Hopewell Run above and below the confluence of the discharge of the two intermittent springs on the east branch of Hopewell Run (sites j and k of fig. 25 and table 13) and downstream from a spring fed pond (site $\mathrm{m}$ on fig. 25 and table 13).

Unfortunately, the three springs nearest the injection sinkhole ceased flowing at the end of May 2006. These springs were likely resurgence sites for the tracer test. It is possible that a peak dye recovery occurred on May 4, 2006 at the two intermittent springs (site 1 on fig. 25) indicating a 15-day time of travel (app. 5, fig. 27). Dye was also detected in the east branch of Hopewell Run downstream of the two overflow springs (site $\mathrm{j}$ on fig. 25). The first peak on the Hopewell Run downstream of the two intermittent springs occurred on May 8, 2005 (19 days after injection), with a second and larger peak on June 1, 2005 (43 days after injection); and subsequent smaller peaks occurring later in the year (app. 5, fig. 28).

The distance between the injection sinkhole and the two intermittent springs is 6,240 ft and the Hopewell Run monitoring site downstream of the two intermittent springs is 6,250 $\mathrm{ft}$. These data indicated an estimated flow velocity of $420 \mathrm{ft} / \mathrm{d}$ for flow to the two intermittent springs and an estimated flow velocity of 150 to $330 \mathrm{ft} / \mathrm{d}$ to the Hopewell Run monitoring site downstream of the two intermittent springs.

Spiked dye peaks were detected on the east branch of Hopewell Run at the Leetown gaging station (app. 5, fig. 29) at about the same time, but may represent flow in the east branch of Hopewell Run after resurgence from the upstream site. Transit times and velocities to the gage were, therefore, not determined.

Dye was also detected at two monitoring wells drilled on anticlinal (Jef-0589) and synclinal (Jef-0588) axes (sites n and o on fig. 25) down gradient of the injection sinkhole on November 4, 2005 (app. 5, figs. 30 and 31, respectively). The monitoring wells were not continuously sampled and dye may have emerged at the site prior to November 4, 2005. However, assuming the depicted dye peaks are representative of peak travel times, transport to the two wells was 199 days. The distances from the injection point to the anticline and the syncline monitoring wells are 2,450 and 2,870 ft respectively, indicative of flow velocities of 12 and $14 \mathrm{ft} / \mathrm{d}$. A previous tracer test conducted in the area in 1979 documented a transit rate of $150 \mathrm{ft} / \mathrm{d}$ (Jones and Deike, 1981). The discrepancy is most logically explained by the fact that the monitoring wells were not continuously sampled, especially earlier in the test. Also, wells are notoriously poor recovery locations for tracer tests in karstic terranes. As a result, ground-water flow velocities to these wells are likely faster than the velocities presented here.

Similar appearing breakthrough curves occurred at Blue, Gray, and Balch Springs with peak recoveries occurring on May 4, May 8, and May 11, 2005, respectively, yielding calculated travel times of 15, 19, and 22 days (app. 5, figs. 32, 33, and 34 , respectively). This is significant because these springs are the main sources of water to the Center. The distance from the injection point to Blue, Gray, and Balch Springs are 8,030; 8,070; and 7,700 ft, indicating flow velocities of 540, 430, and $350 \mathrm{ft} / \mathrm{d}$. It is also possible that the recoveries at Balch, Blue, and Gray Springs may have been the result of secondary or tertiary recoveries of dye from a previous test. However, a previous tracer test showed a connection between the area and Gray Spring so the test is considered to be representative of ground-water flow the area. 
Appendix 5b: Data from dye tracing experiments at the Leetown Science Center, Leetown, West Virginia. 


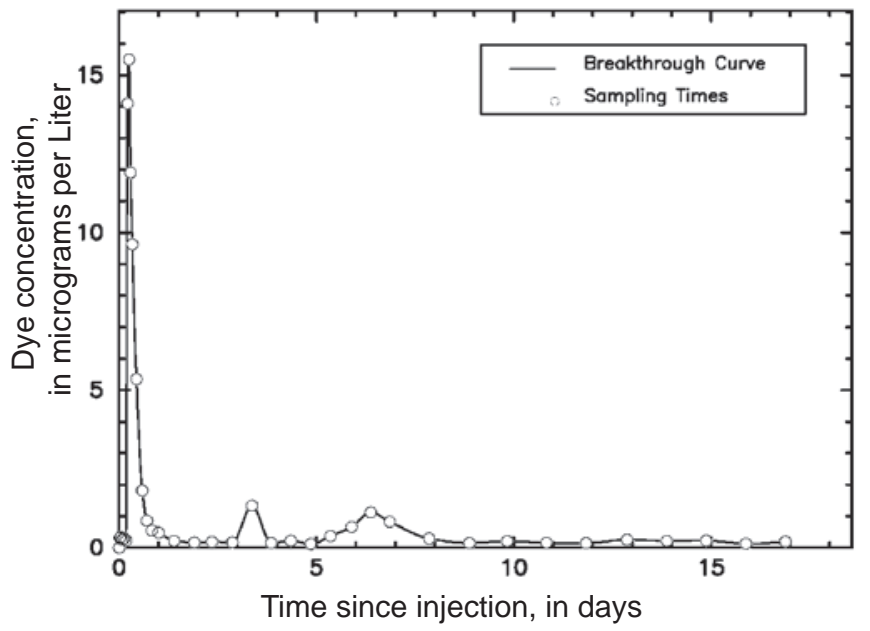

Figure 1. Tracer breakthrough curve at the gage on the south branch of Hopewell Run from the April 20, 2004 dye tracer test (Test 1 ). Early sharp peak probably represents flow in Hopewell Run while the later smaller peaks may represents ground-water inflow into Hopewell Run.

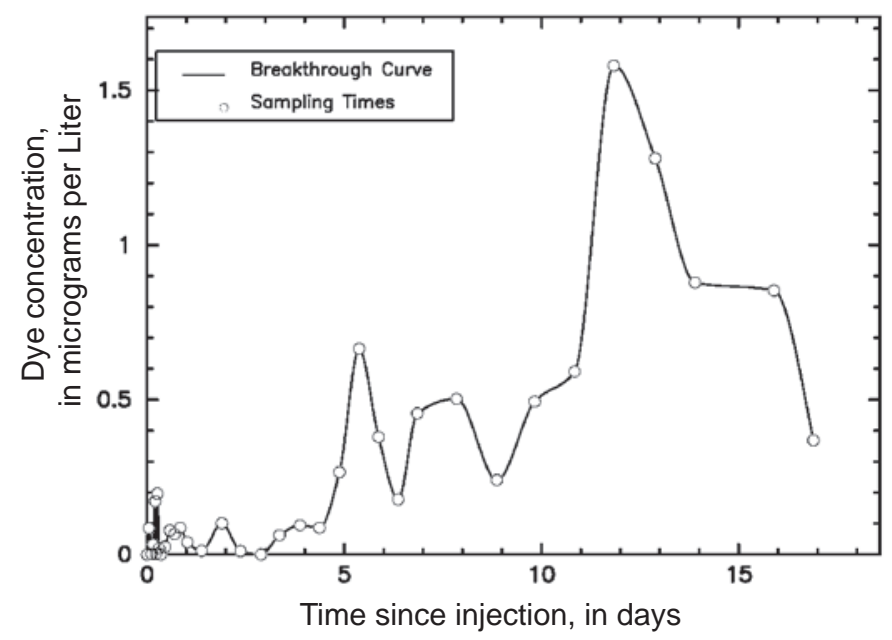

Figure 2. Tracer breakthrough curve at the Ball Field Well from the April 20, 2004 dye tracer test (Test 1).

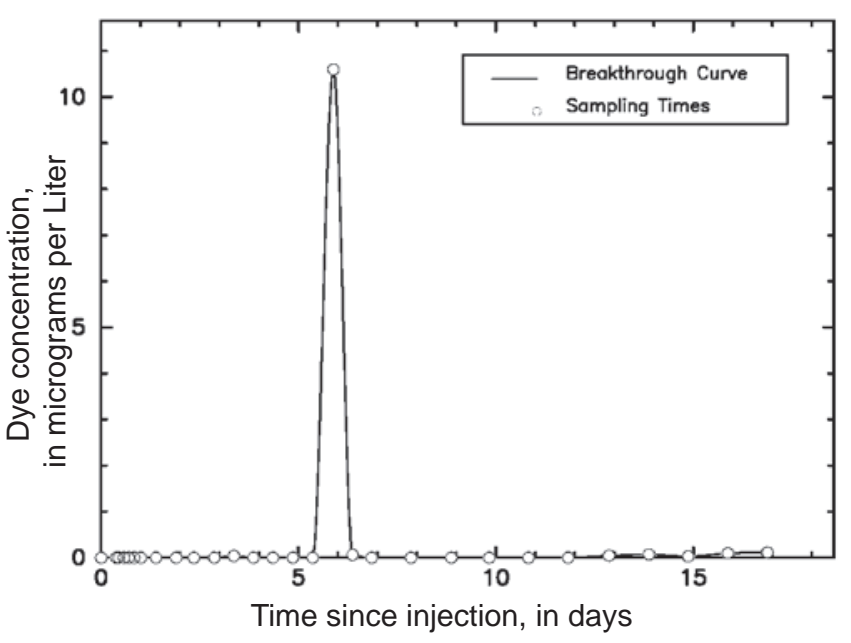

Figure 3. Tracer breakthrough curve at Balch Spring from the April 20, 2004 dye tracer test (Test 1) . Sharp peak recovery is probably representative of forced gradient extraction of ground water as a result of pumping Blach Spring.

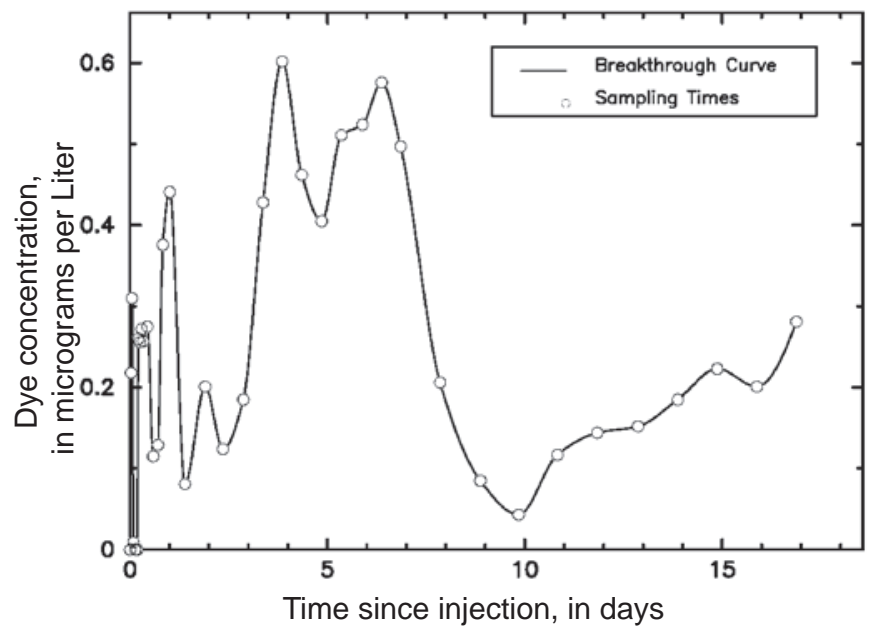

Figure 4. Tracer breakthrough curve at the gage on the east branch of Hopewell Run from the April 20, 2004 dye tracer test (Test 1). The multipeaked nature of the Breakthrough curve may represent both flow from Balch Spring and ground-water rise into Hopewell Run.

Appendix 5b. Data from dye tracing experiments in the Leetown area, West Virginia. 


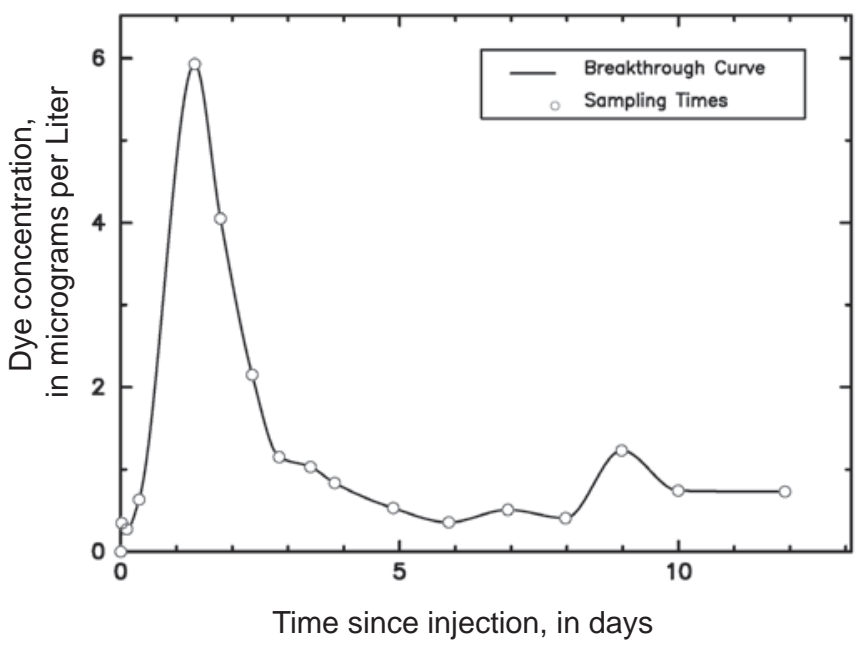

Figure 5. Tracer breakthrough curve at the gage on the east branch of Hopewell Run from the May 17, 2004 dye tracer test (Test 2). Early smooth peak probably represents flow in Hopewell Run while the later smaller peak may represent ground-water inflow into Hopewell Run.

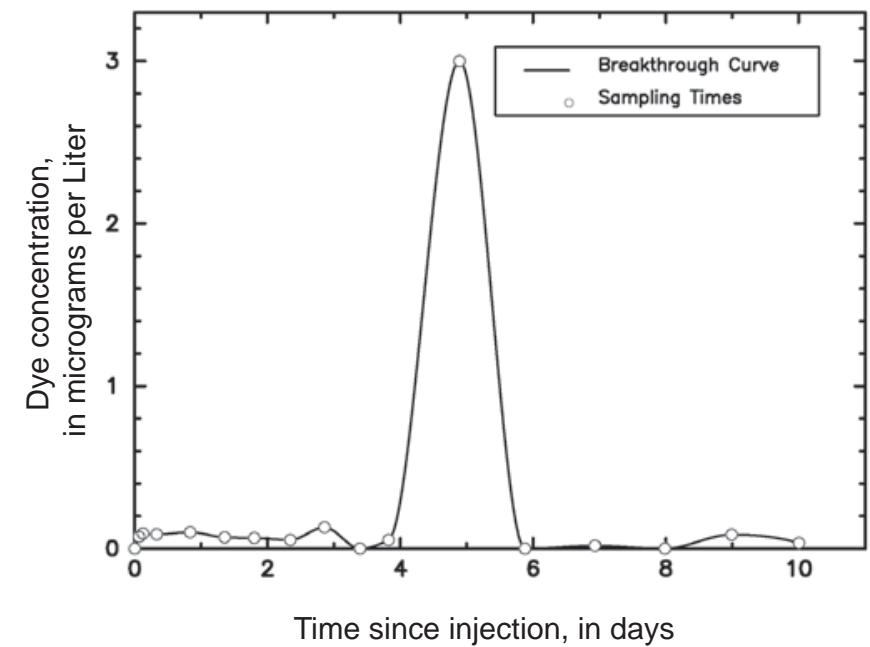

Figure 6. Tracer breakthrough curve at Blue Spring from the May 17, 2004 dye tracer test (Test 2). Strong smooth peak is indicative of tracer recovery from ground water.

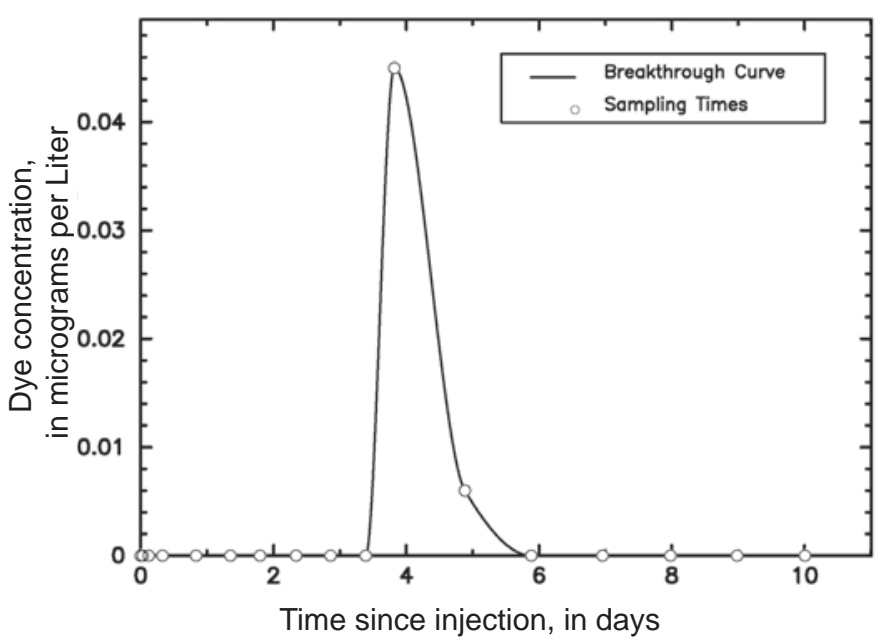

Figure 7. Tracer breakthrough curve at Gray Spring from the May 17, 2004 dye tracer test (Test 2). Strong smooth peak is indicative of tracer recovery from ground water. Skewness suggests some tracer detention in immobile flow zones.

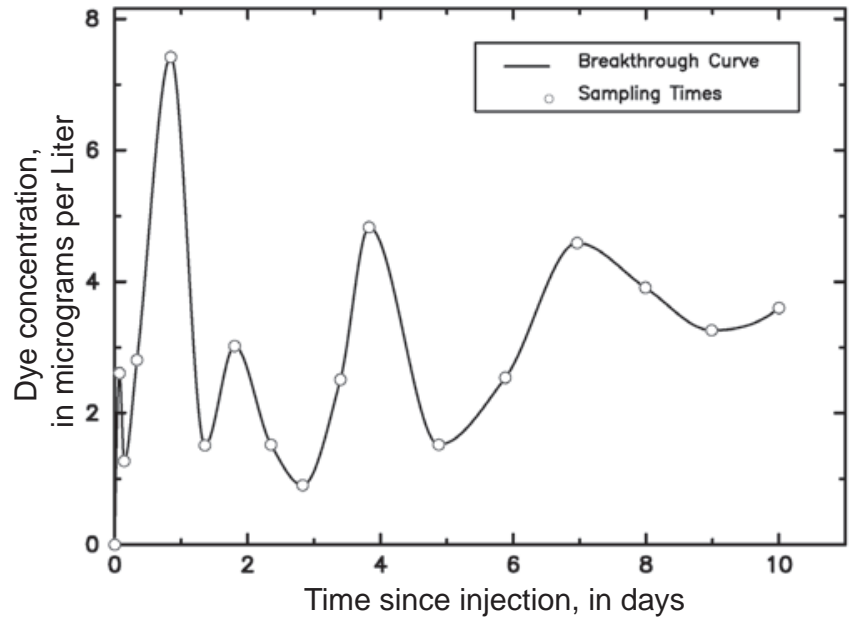

Figure 8. Tracer breakthrough curve at the Ball Field Well from the May 17, 2004 dye tracer test (Test 2). The strong multipeaked breakthrough curve may be due to leakage of ground water into the well from differing fractures.

Appendix 5b. Data from dye tracing experiments in the Leetown area, West Virginia. 


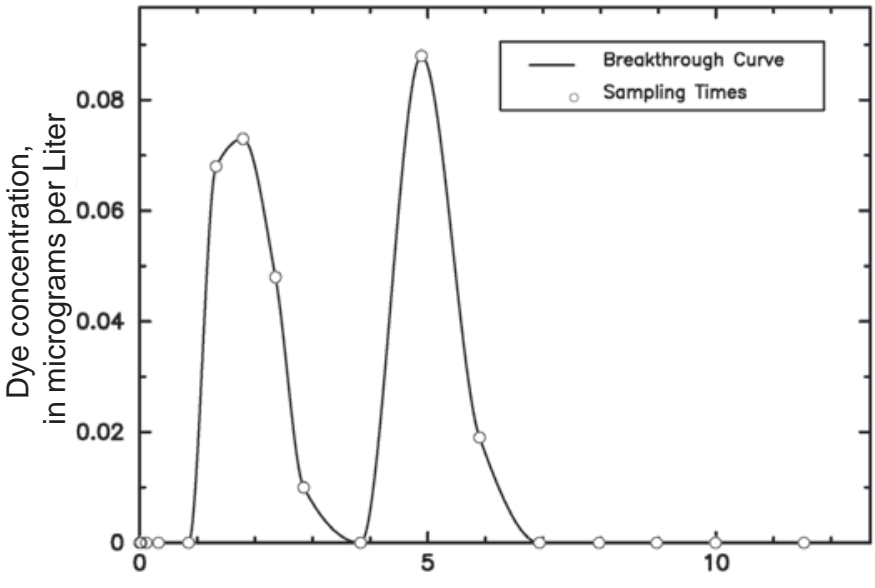

Time since injection, in days

Figure 9. Tracer breakthrough curve at Balch Spring from the May 17, 2004 dye tracer test (Test 2). The very low dual peaked Breakthrough curve may be a result of forced recovery of small quantities of tracer dye detained in immobile flow regions as a result of pumping Balch Spring.

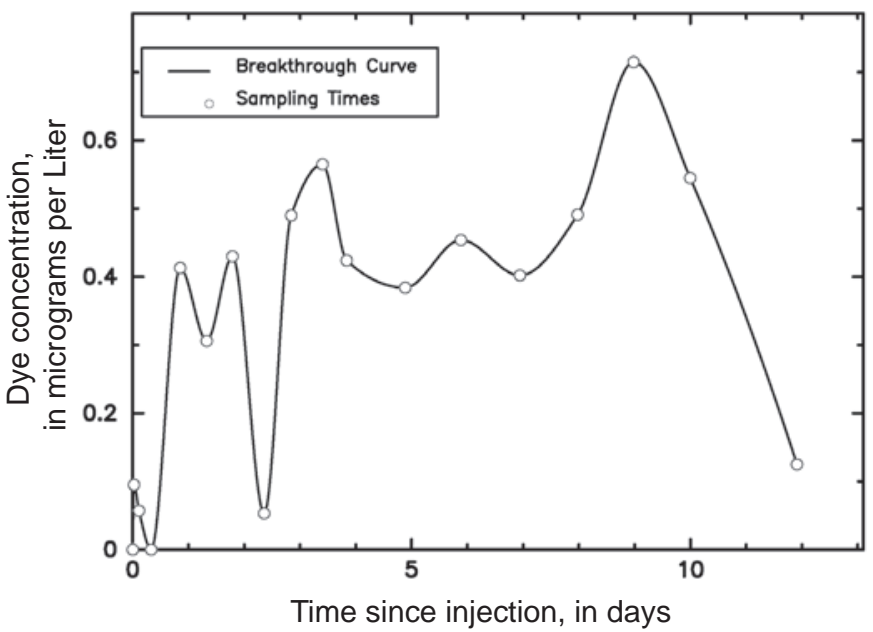

Figure 11. Tracer breakthrough curve at the gage on the south branch of Hopewell Run from the May 17, 2004 dye tracer test (Test 2). Tracer recoveries are a result of ground-water rise up into Hopewell Run.

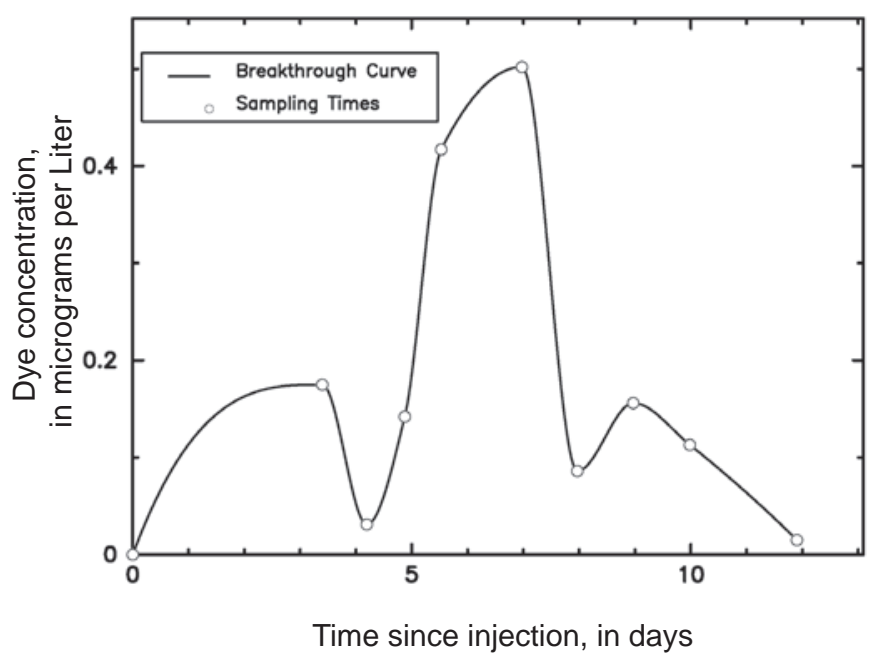

Figure 10. Tracer breakthrough curve at two high-level overflow springs from the May 17, 2004 dye tracer test (Test 2).

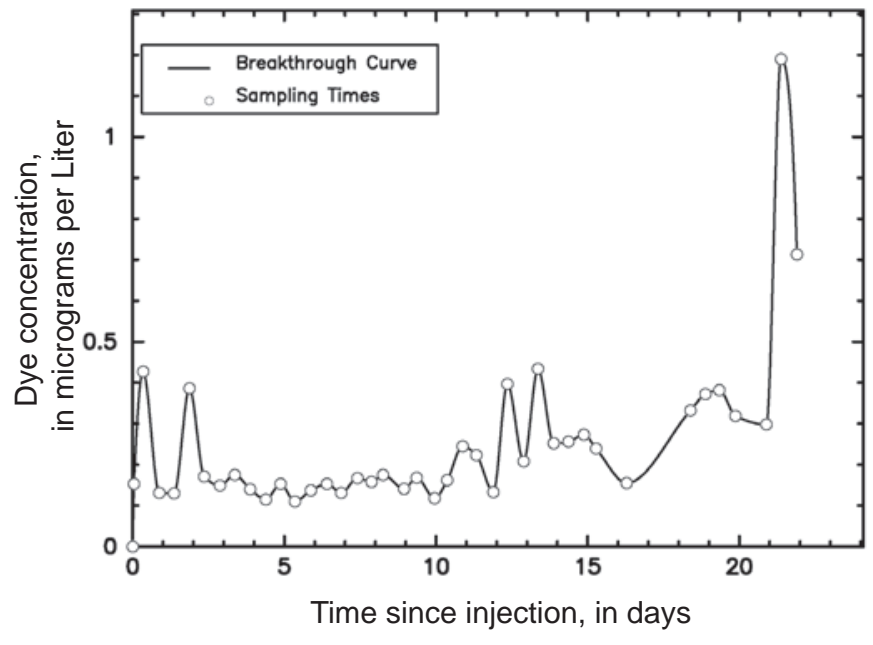

Figure 12. Tracer breakthrough curve at two high-level overflow springs from the June 17, 2004 dye tracer test (Test 3). The late peak was substantially greater than the strong background dye levels suggesting good dye recovery from the tracer test.

Appendix 5b. Data from dye tracing experiments in the Leetown area, West Virginia. 


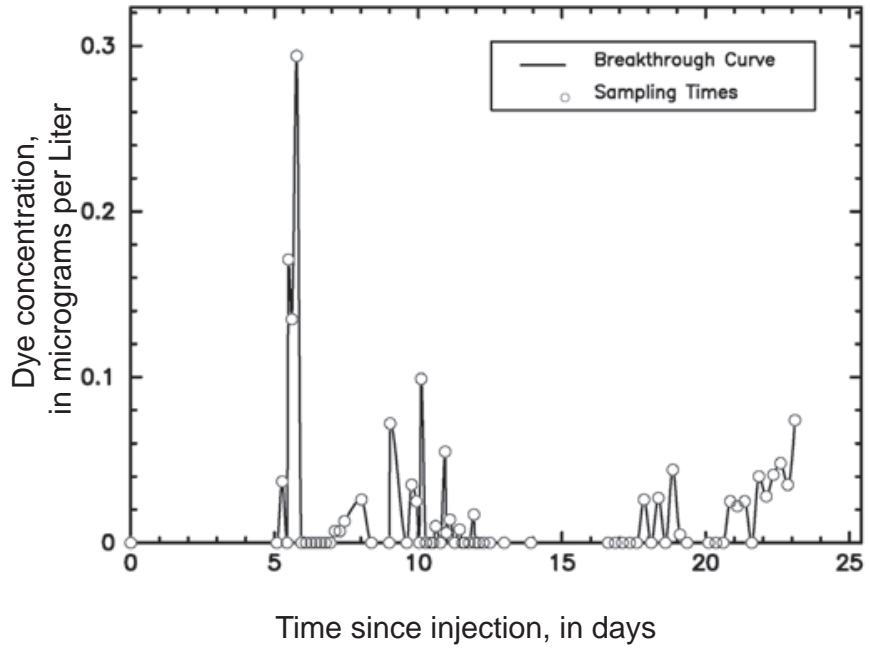

Figure 13. Tracer breakthrough curve at Blue Spring from the July 17, 2004 dye tracer test (Test 4). The very low multipeaked breakthrough curve may be a result of slow release from the injection piezometer.

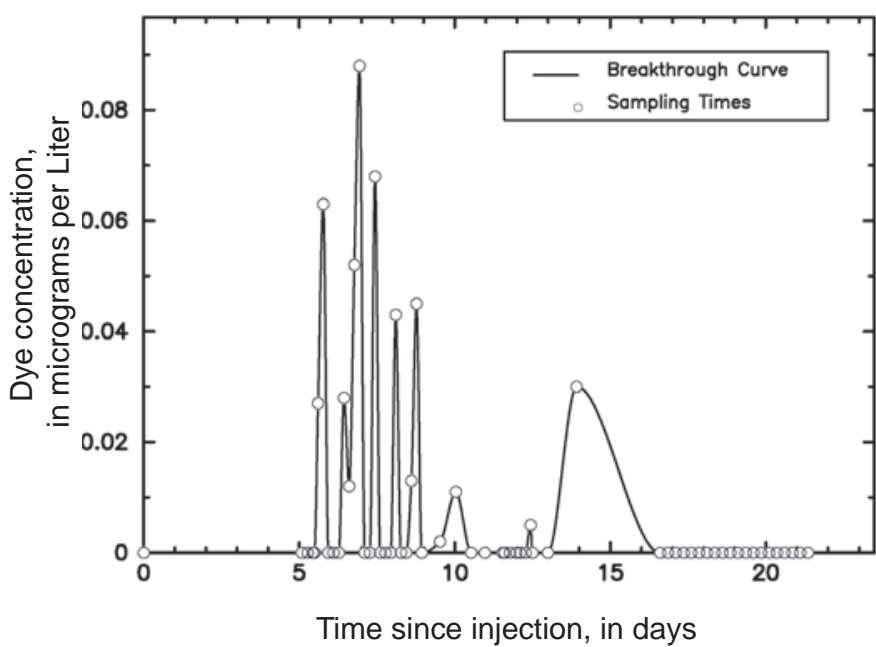

Figure 14a. Tracer breakthrough curve at Gray Spring from the July 17, 2004 dye tracer test (Test 4). The very low multipeaked breakthrough curve may be a result of slow release from the injection piezometer.

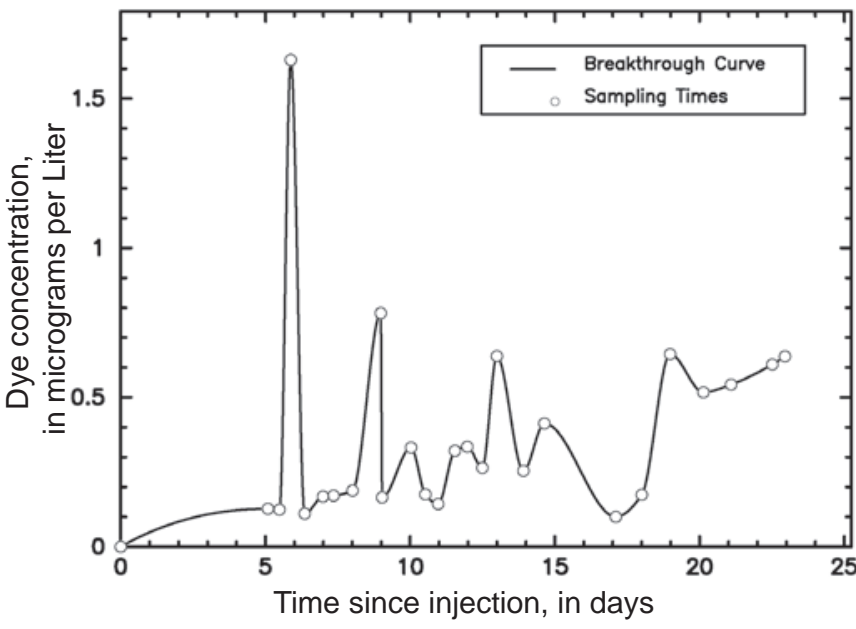

Figure 14b. Tracer breakthrough curve at the Gray Spring Overflow from the July 17, 2004 dye tracer test (Test 4).

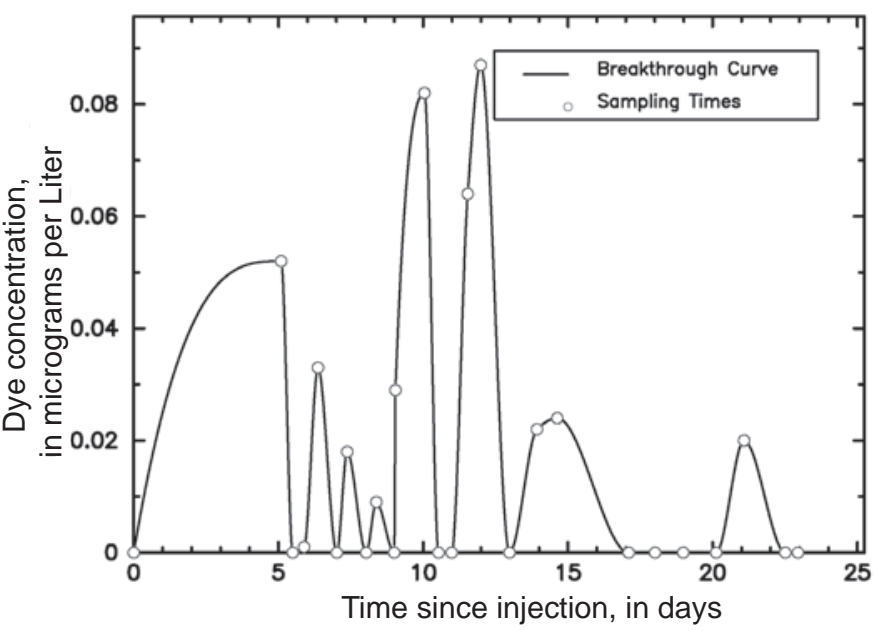

Figure 15. Tracer breakthrough curve at Balch Spring from the July 17, 2004 dye tracer test (Test 4). The very low multipeaked breakthrough curve may be a result of slow release from the injection piezometer.

Appendix 5b. Data from dye tracing experiments in the Leetown area, West Virginia. 


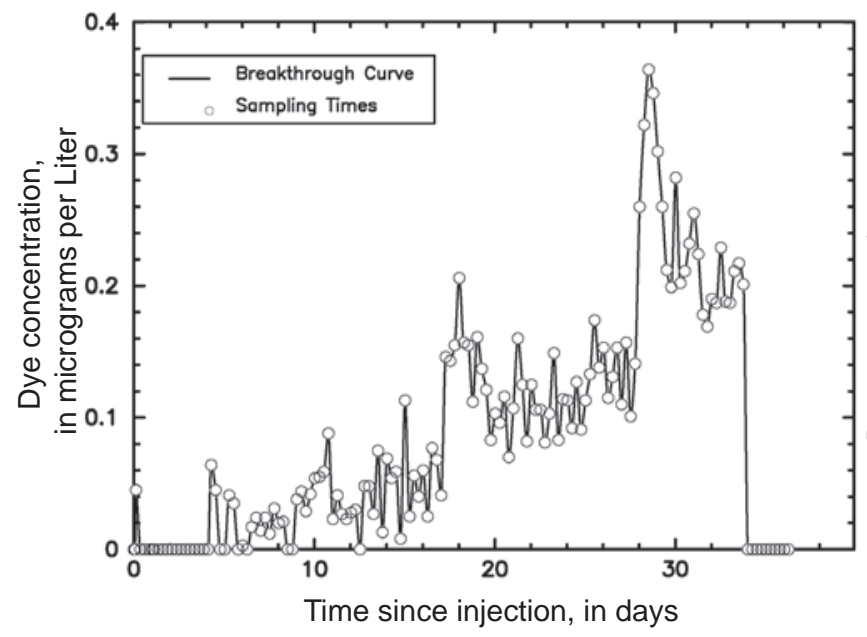

Figure 16. Tracer breakthrough curve at Gray Spring from the August 31, 2004 dye tracer test (Test 5).

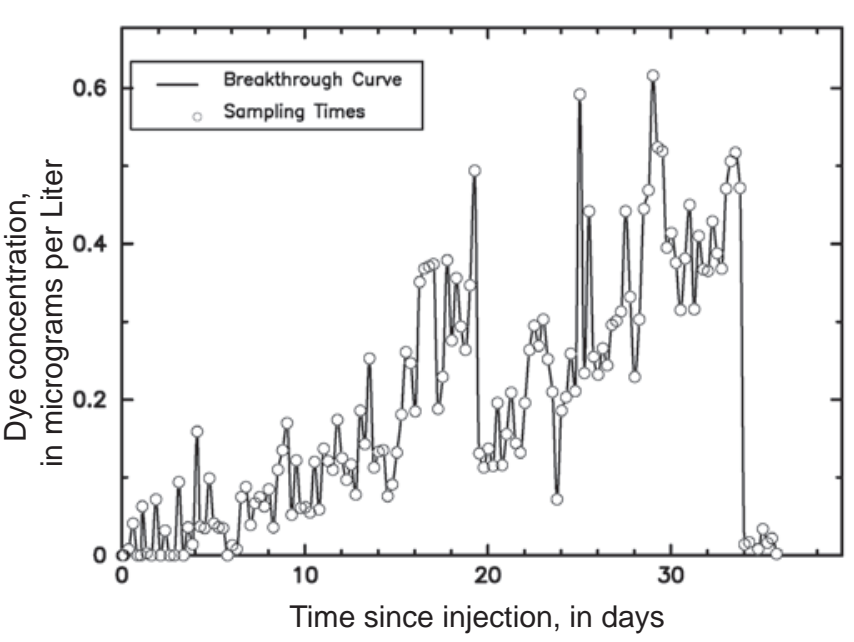

Figure 17. Tracer breakthrough curve at Blue Spring from the August 31, 2004 dye tracer test (Test 5).

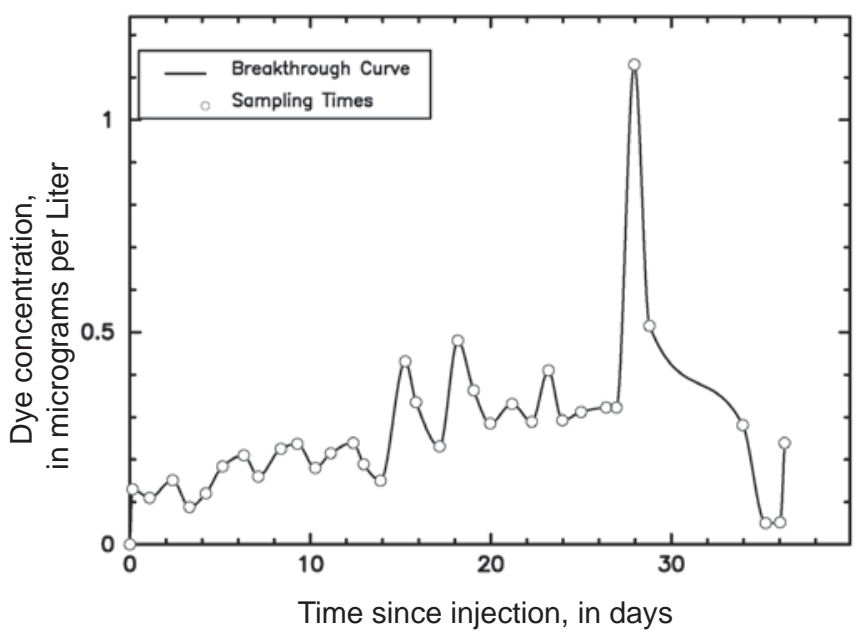

Figure 18. Tracer breakthrough curve at Tabb Spring from the August 31, 2004 dye tracer test (Test 5). The late peak was substantially greater than the strong background dye levels suggesting good dye recovery from the tracer test.

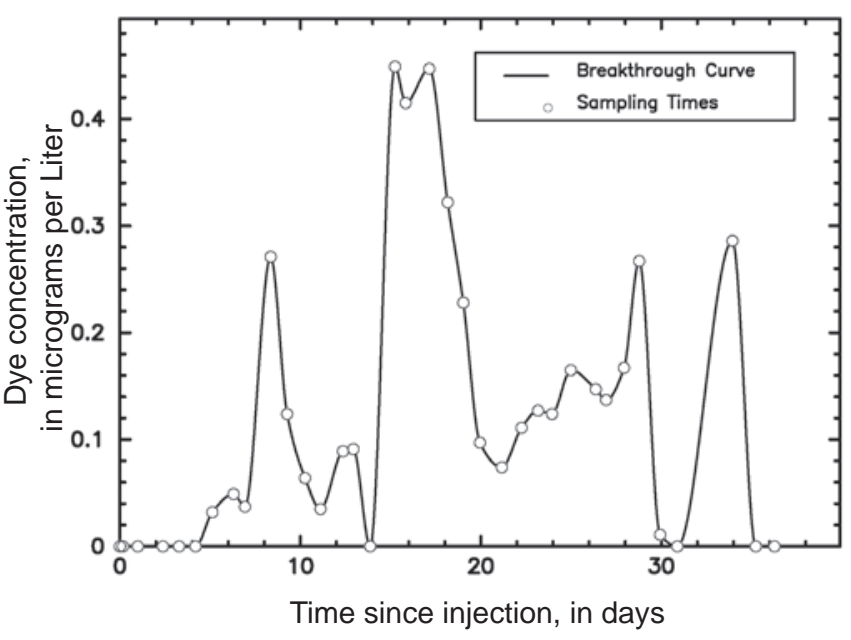

Figure 19. Tracer breakthrough curve at Balch Spring from the August 31, 2004 dye tracer test (Test 5).

Appendix 5b. Data from dye tracing experiments in the Leetown area, West Virginia. 


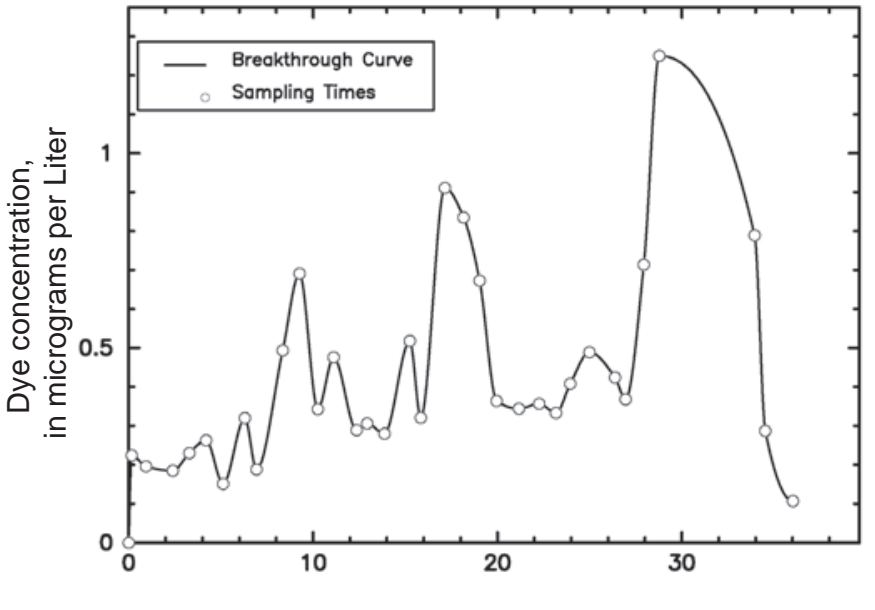

Time since injection, in days

Figure 20. Tracer breakthrough curve at the gage on the south branch of Hopewell Run from the August 31, 2004 dye tracer test (Test 5). The late peaks were substantially greater than the strong background dye levels suggesting good dye recovery from the tracer test.

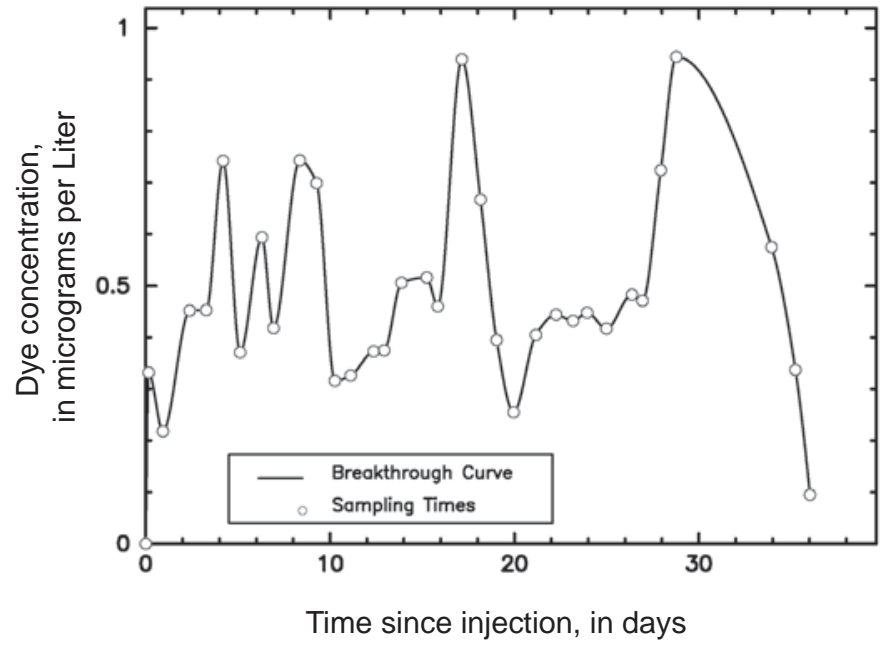

Figure 21. Tracer breakthrough curve at the gage on the east branch of Hopewell Run from the August 31, 2004 dye tracer test (Test 5). The late peaks were substantially greater than the strong background dye levels suggesting good dye recovery from the tracer test.

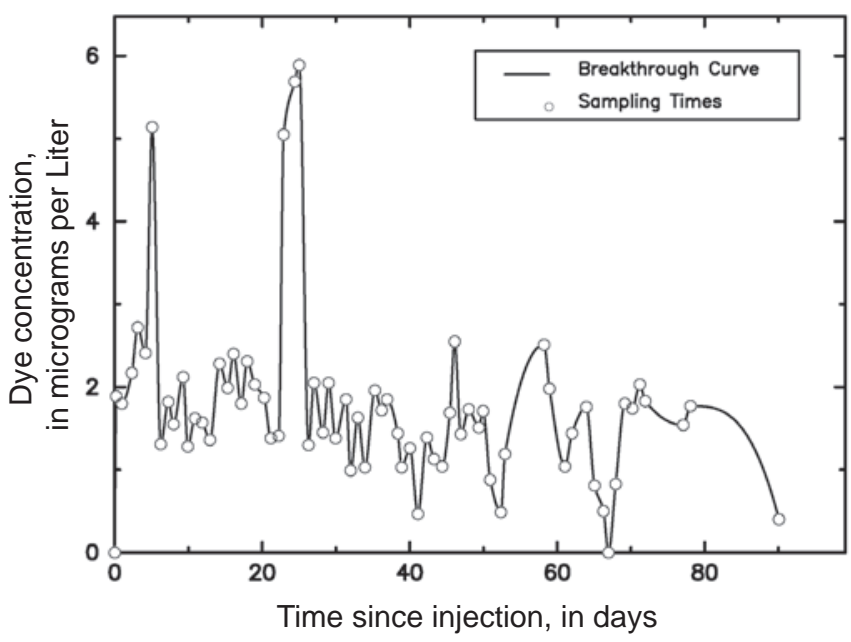

Figure 22. Tracer breakthrough curve at the gage on the east branch of Hopewell Run from the October 7, 2004 (1020 in the morning) dye tracer test (Test $6 \& 7$ ). The early peaks were substantially greater than the strong background dye levels suggesting good dye recovery from the tracer test. Recoveries were greater and occurred earlier than occurred at Balch Spring which proves that apparent recoveries were not due to releases from Balch Spring.

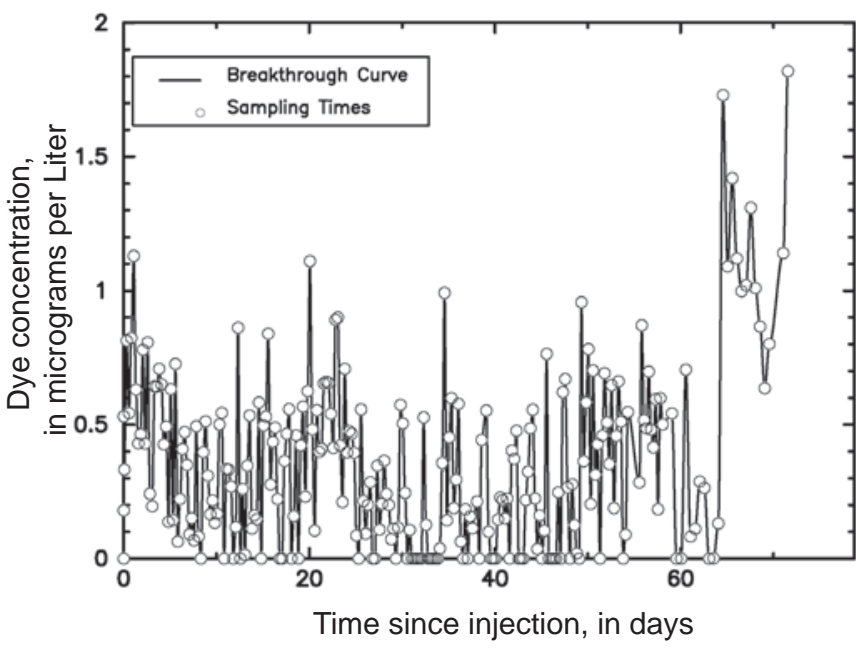

Figure 23. Tracer breakthrough curve at Balch Spring from the October 7, 2004 (1020 in the morning) dye tracer test (Test $6 \& 7$ ). The late peaks were substantiall) greater than the strong background dye levels suggestinc good dye recovery from the tracer test.

Appendix 5b. Data from dye tracing experiments in the Leetown area, West Virginia. 


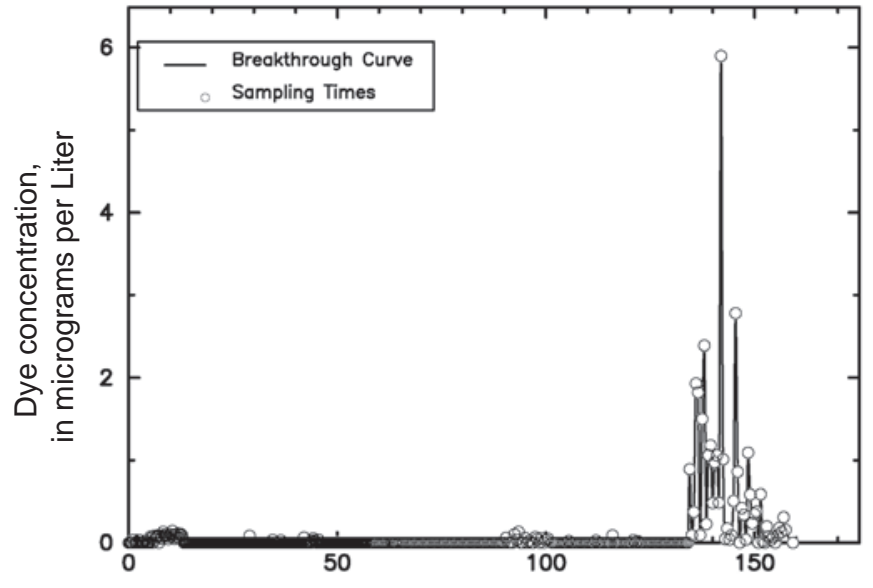

Time since injection, in days

Figure 24. Tracer breakthrough curve at Gray Spring from the October 7, 2004 (1230 in the afternoon) dye tracer test (Test 6 $\& 7)$.

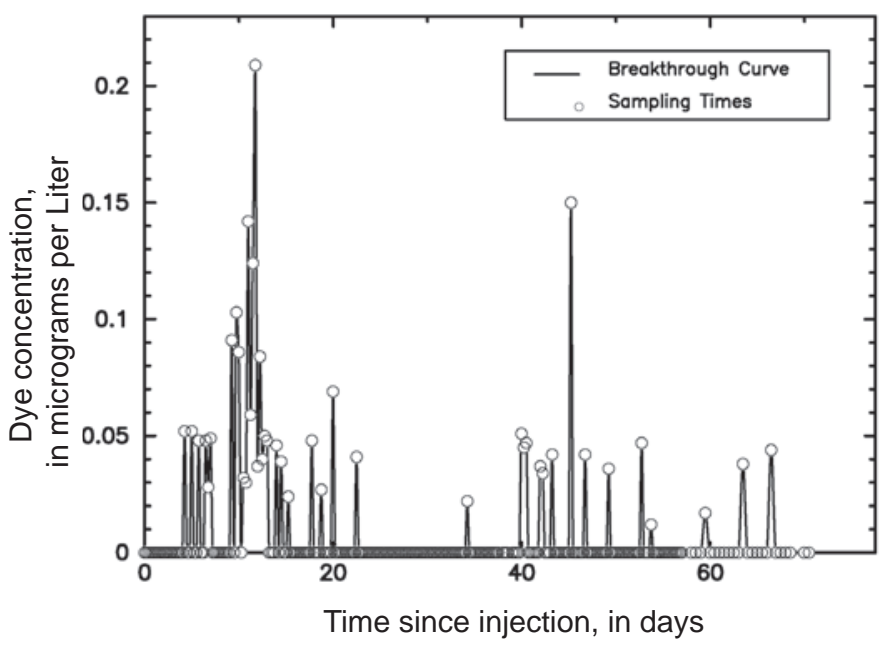

Figure 26. Tracer breakthrough curve at Balch Spring from the October 7, 2004 (1230 in the afternoon) dye tracer test (Test $6 \& 7$ ).

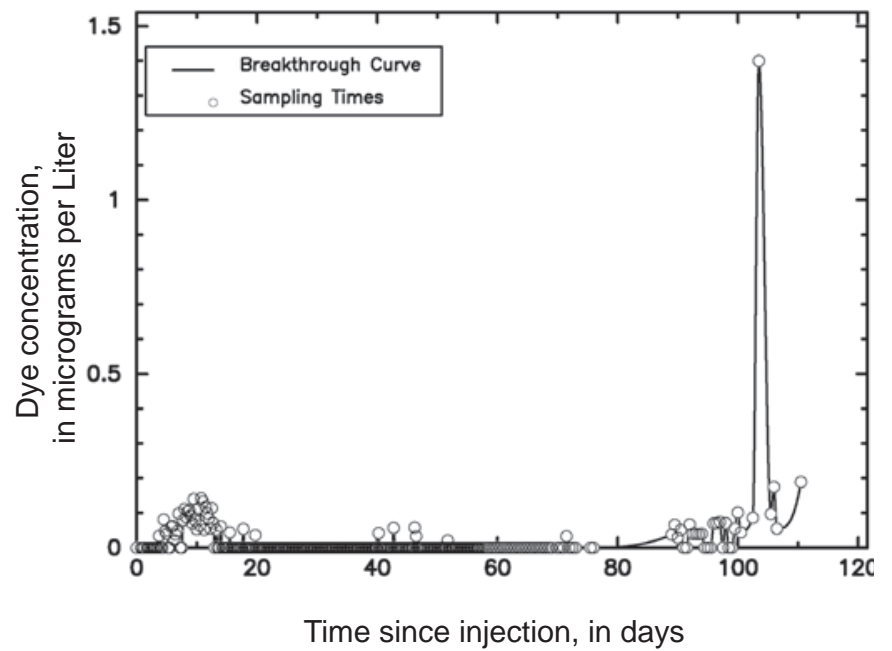

Figure 25. Tracer breakthrough curve at Blue Spring from the October 7, 2004 (1230 in the afternoon) dye tracer test (Test 6 \& 7).

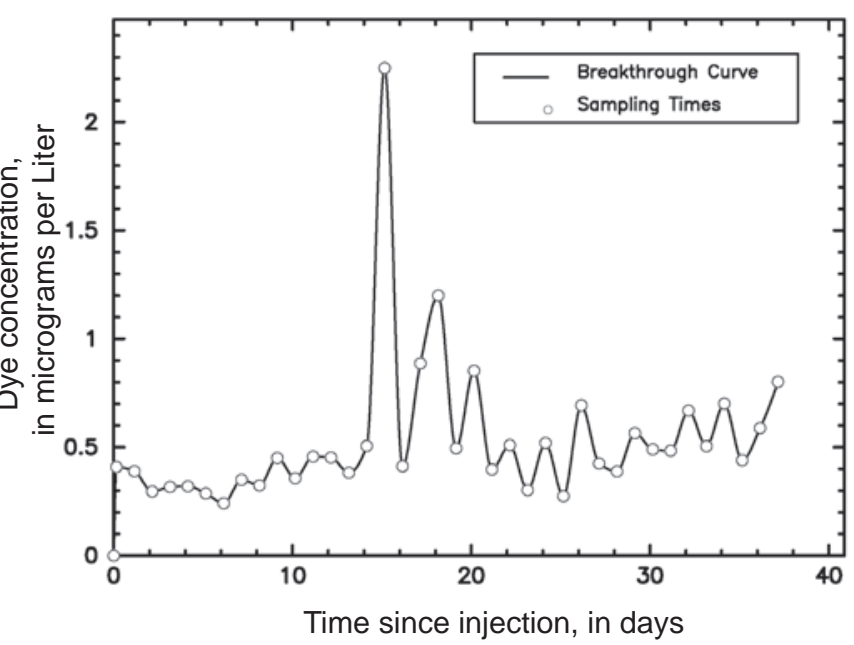

Figure 27. Tracer breakthrough curve at two high-level overflow springs from the April 19, 2005 dye tracer test (Test 6 \& 7). The strong peak was substantially greater than the strong background dye levels suggesting good dye recovery from the tracer test.

Appendix 5b. Data from dye tracing experiments in the Leetown area, West Virginia. 


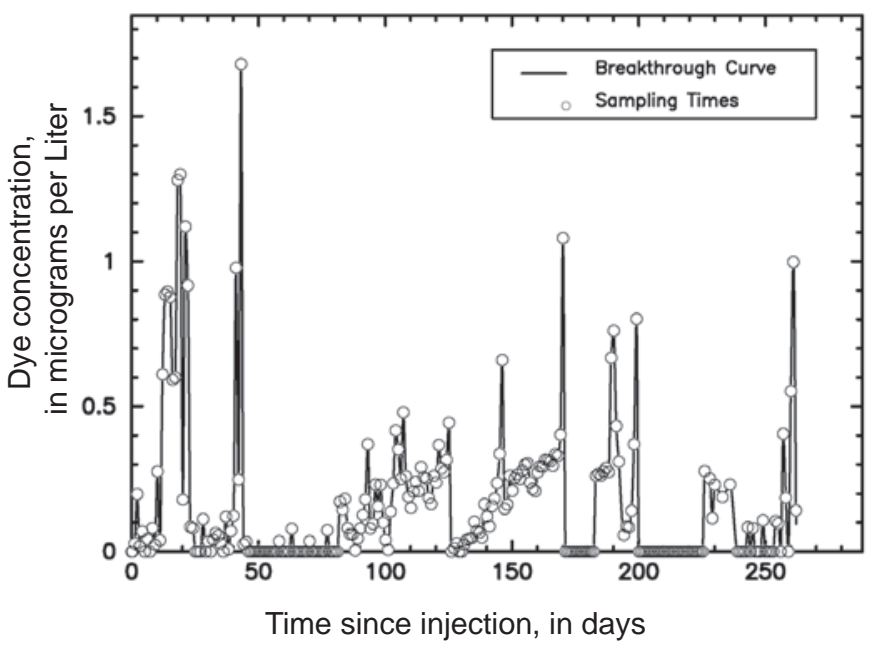

Figure 28. Tracer breakthrough curve downstream of the two high-level overflow springs from the April 19, 2005 dye tracer test (Test 8).

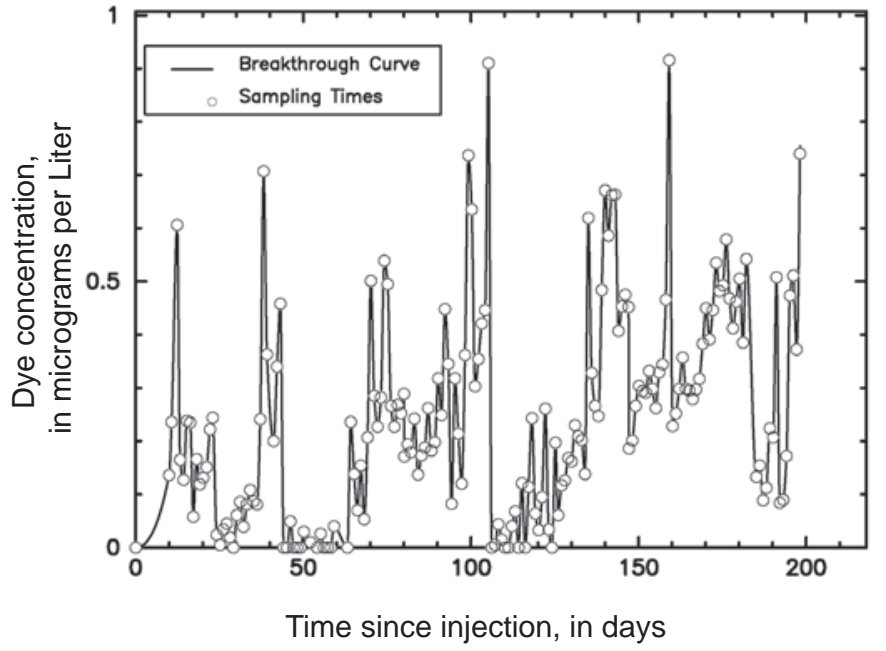

Figure 29. Tracer breakthrough curve at the gage on the east branch of Hopewell Run from the April 19, 2005 dye tracer test (Test 8).

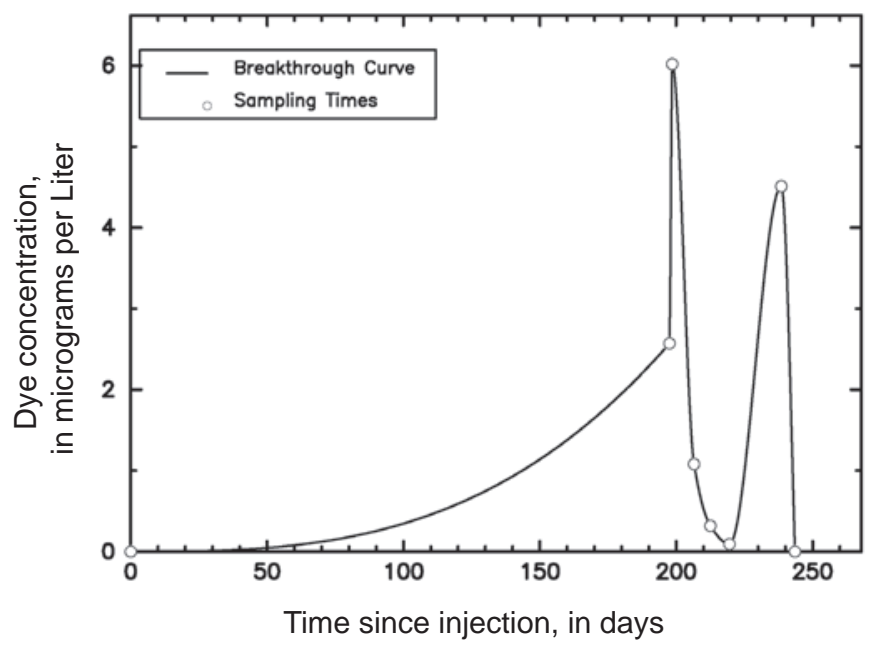

Figure 30. Tracer breakthrough curve at the Anticline Well from the April 19, 2005 dye tracer test (Test 8). The strong peaks suggest good tracer dye recovery, but the late start of sampling may have resulted in earlier dye peaks being missed.

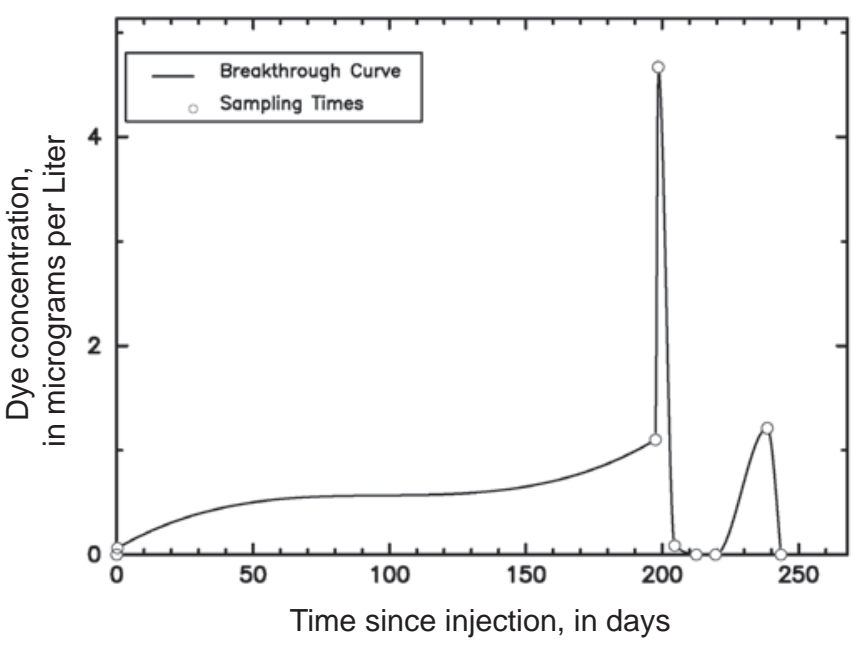

Figure 31. Tracer breakthrough curve at the Syncline Well from the April 19, 2005 dye tracer test (Test 8). The strong peaks suggest good tracer dye recovery, but the late start of sampling may have resulted in earlier dye peaks being missed.

Appendix 5b. Data from dye tracing experiments in the Leetown area, West Virginia. 


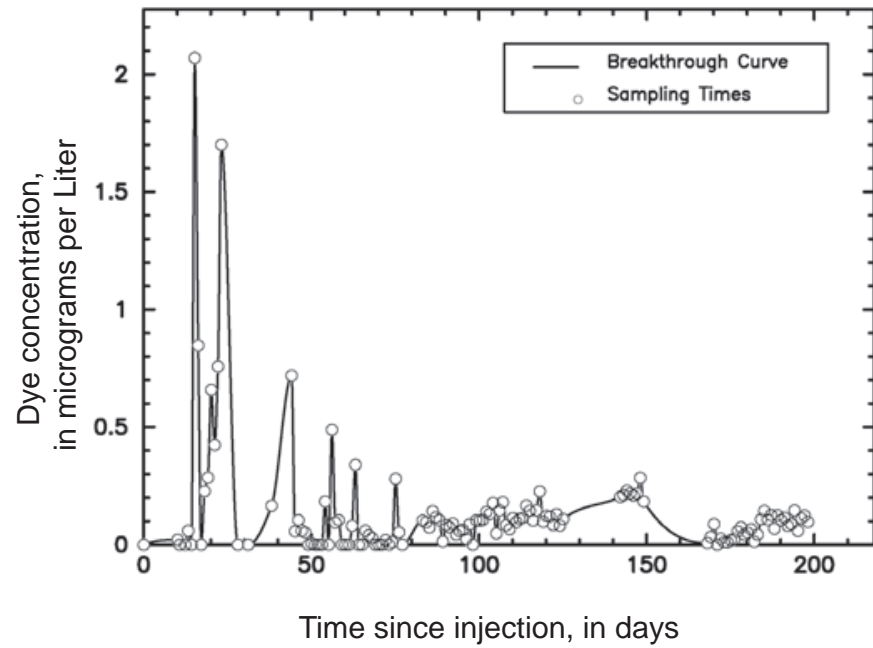

Figure 32. Tracer breakthrough curve at Blue Spring from the April 19, 2005 dye tracer test (Test 8).

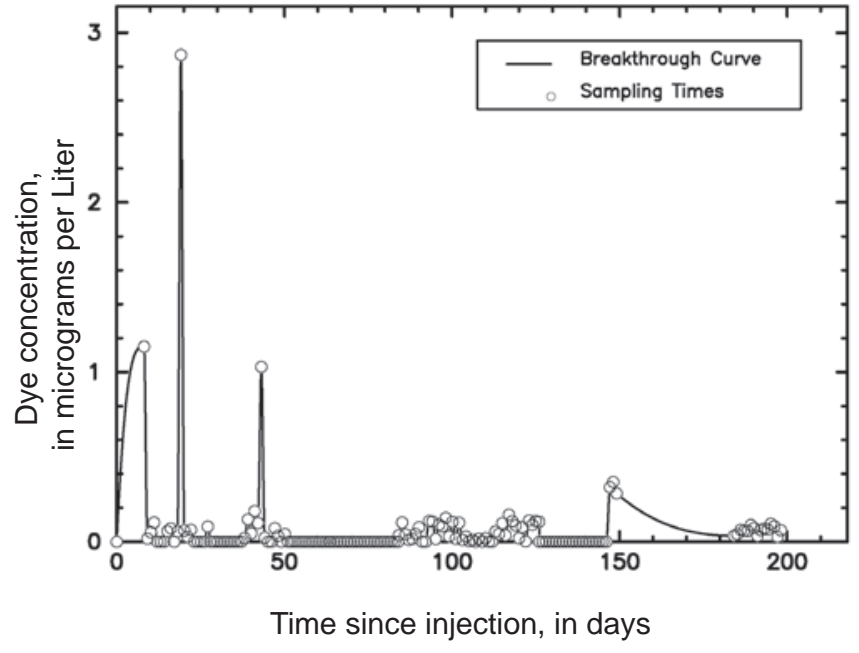

Figure 33. Tracer breakthrough curve at Gray Spring from the April 19, 2005 dye tracer test (Test 8).

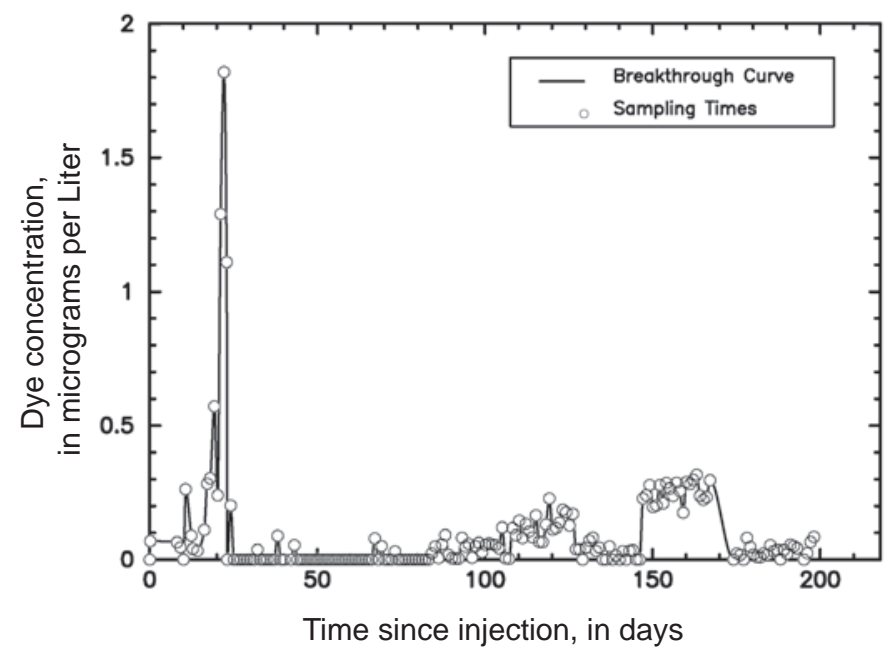

Figure 34. Tracer breakthrough curve at Balch Spring from the April 19, 2005 dye tracer test (Test 8).

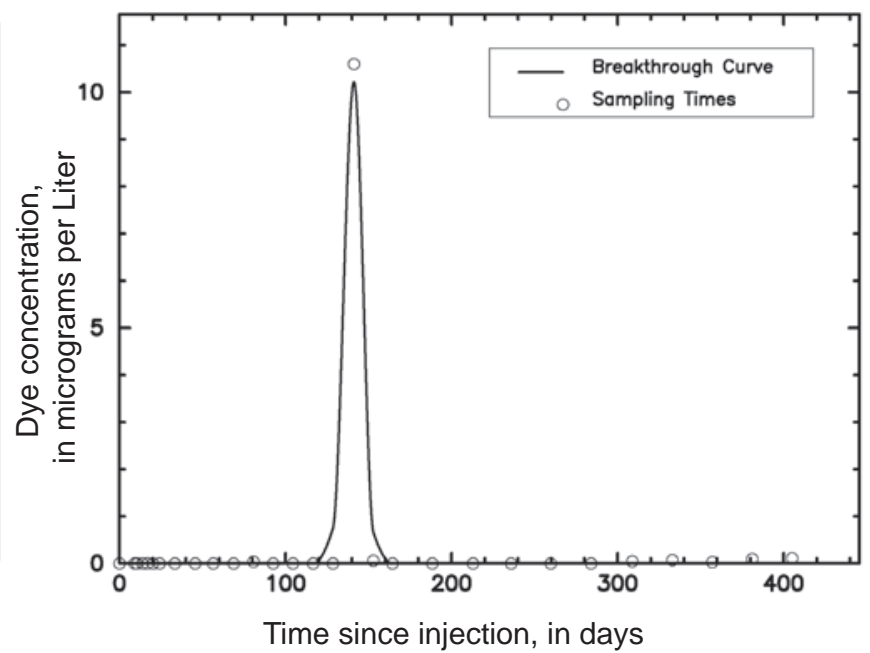

Figure 35. CXTFIT model fit to the Balch Spring breakthrough curve from the April 19, 2004 dye tracer test (Test 8).

Appendix 5b. Data from dye tracing experiments in the Leetown area, West Virginia. 


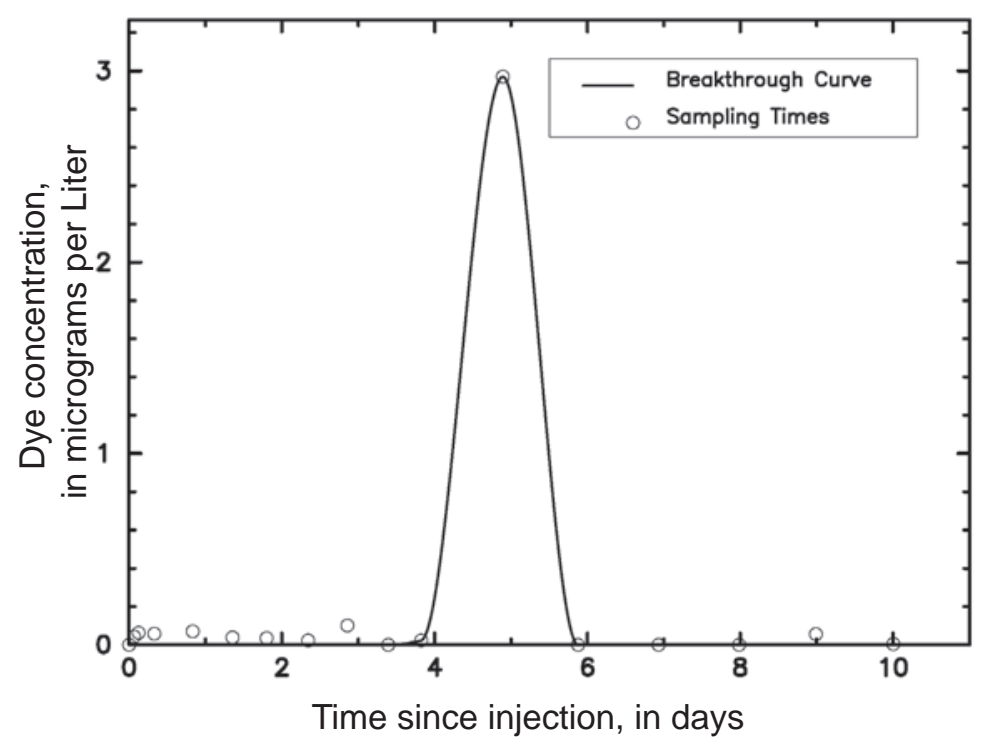

Figure 36. CXTFIT model fit to the Blue Spring breakthrough curve from the May 17, 2004 dye tracer test (Test 2).

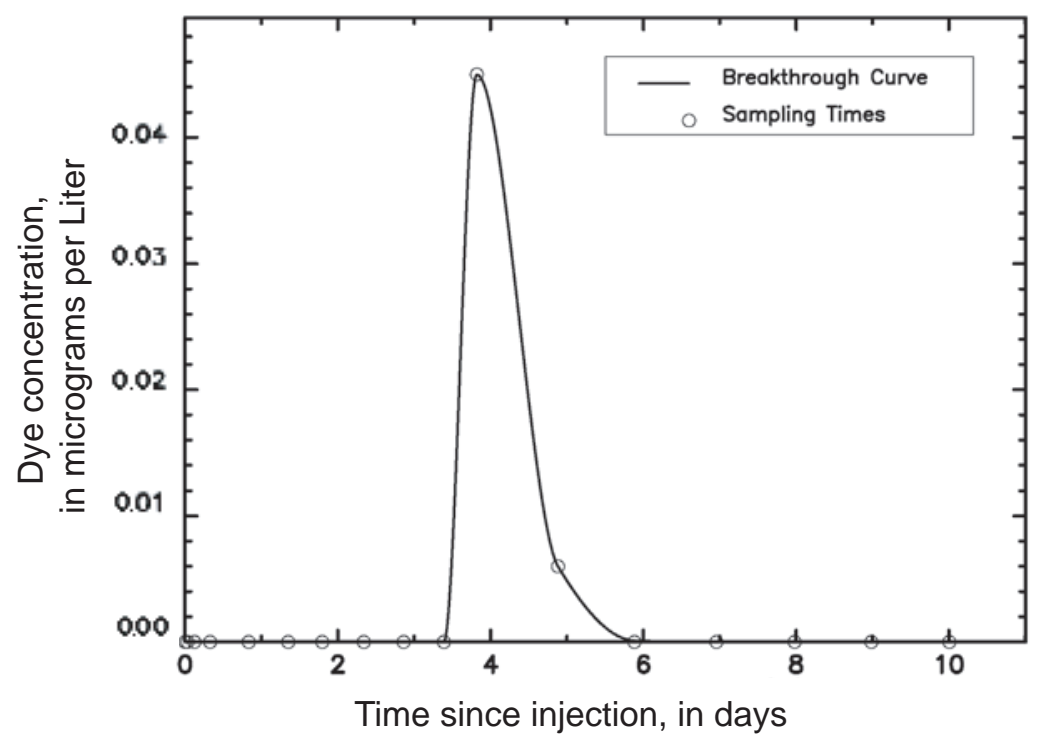

Figure 37. CXTFIT model fit to the Gray Spring breakthrough curve from the May 17, 2004 dye tracer test (Test 2).

Appendix 5b. Data from dye tracing experiments in the Leetown area, West Virginia. 
Appendix 6: Water quality data from sampling locations at the Leetown Science Center, Leetown, West Virginia. 
Table 1. Water quality data from samples collected at the USGS Leetown Science Center, Leetown, West Virginia.

\begin{tabular}{|c|c|c|c|c|c|}
\hline Station number & Local identifier & Local Name & Geologic Formation & Date & $\begin{array}{c}\text { Depth of well } \\
\text { (feet) }\end{array}$ \\
\hline 392037077553501 & Jef-0594 & Tabb Lower Piezometer & Stoufferstown Member & $9 / 15 / 2004$ & 41 \\
\hline 392042077554301 & Jef-0521S & Gray Spring & Stonehenge Limestone & $9 / 13 / 2004$ & -- \\
\hline 392049077554601 & Jef-0659S & Blue Spring & Stonehenge Limestone & $9 / 15 / 2004$ & -- \\
\hline 392051077544301 & Jef-0602 & Old Dodson Farm Well & Stonehenge Limestone & $9 / 15 / 2004$ & 61 \\
\hline 392051077544302 & Jef-0752 & New Dodson Farm Well & Stonehenge Limestone & $9 / 8 / 2005$ & 166 \\
\hline 392101077554901 & Jef-0590 & Ball Field Well & Rockdale Run Formation & $9 / 16 / 2004$ & 160 \\
\hline 392102077552001 & Jef-0753 & New Kaiser Farm Well & Stonehenge Limestone & $9 / 14 / 2005$ & 121 \\
\hline 392102077554801 & Jef-0584 & Bone Yard Upper Well & Rockdale Run Formation & $9 / 16 / 2004$ & 113 \\
\hline 392110077555201 & Jef-0327S & Balch Spring & Rockdale Run Formation & $9 / 14 / 2004$ & -- \\
\hline 392115077544801 & Jef-0589 & Anticline Well & Rockdale Run Formation & $9 / 13 / 2004$ & 260 \\
\hline 392117077550301 & Jef-0592 ${ }^{1}$ & Stable C Well & Stonehenge Limestone & $7 / 27 / 2004$ & 321 \\
\hline 392117077550302 & Jef- $0585^{1}$ & Stable B Well & Stonehenge Limestone & $7 / 21 / 2004$ & 326 \\
\hline 392117077550304 & Jef-0601 & Stable A Well & Stonehenge Limestone & $9 / 14 / 2004$ & 312 \\
\hline 392119077554701 & Jef-0603 & USDA Sulfur Well & Martinsburg Formation & $9 / 16 / 2004$ & 475 \\
\hline 392121077551701 & Jef-0587 & Low Road Well & Conococheague Limestone & $9 / 14 / 2004$ & 410 \\
\hline 392035077544001 & Jef-0306S & Bell Spring & Stoufferstown Member & $7 / 22 / 2004$ & -- \\
\hline
\end{tabular}

Table 1 (continued). Water quality data from samples collected at the USGS Leetown Science Center, Leetown, West Virginia.

\begin{tabular}{|c|c|c|c|c|c|c|c|c|}
\hline Local identifier & Date & $\begin{array}{l}\text { Water level, } \\
\text { below land } \\
\text { surface (feet) }\end{array}$ & $\begin{array}{l}\text { Landsurface } \\
\text { altitude (feet) }\end{array}$ & $\begin{array}{c}\text { Redox } \\
\text { potential } \\
\text { millivolts }\end{array}$ & $\begin{array}{c}\text { Turbidity } \\
\text { (NTU) }\end{array}$ & $\begin{array}{c}\text { Dissolved } \\
\text { oxygen } \\
\text { (mg/L) }\end{array}$ & $\begin{array}{l}\text { Dissolved } \\
\text { oxygen, ( } \% \\
\text { saturation) }\end{array}$ & $\begin{array}{c}\text { pH } \\
\text { (standard } \\
\text { units) }\end{array}$ \\
\hline Jef-0594 & $9 / 15 / 2004$ & 6.35 & 491.67 & 128 & 2.4 & 1.8 & 18 & 6.7 \\
\hline Jef-0521S & $9 / 13 / 2004$ & -- & 478.32 & 179 & $<1$ & 4.4 & 41 & 6.6 \\
\hline Jef-0659S & $9 / 15 / 2004$ & -- & 479.37 & 136 & 0.45 & 4.1 & 39 & 6.8 \\
\hline Jef-0590 & $9 / 16 / 2004$ & 22.53 & 478.06 & 99 & 11 & 3.1 & 30 & 6.7 \\
\hline Jef-0753 & $9 / 14 / 2005$ & 8.09 & 512.42 & 228 & 2.9 & 3.9 & 38 & 6.7 \\
\hline Jef-0584 & $9 / 16 / 2004$ & 22.91 & 479.16 & -8 & 43 & $<2.0$ & -- & 6.6 \\
\hline Jef-0327S & $9 / 14 / 2004$ & -- & 456.10 & 121 & 0.88 & 4.0 & 39 & 6.9 \\
\hline Jef- $0585^{1}$ & $7 / 21 / 2004$ & 38.56 & 529.89 & 44 & 1.0 & 1.1 & 10 & 7.0 \\
\hline Jef-0601 & $9 / 14 / 2004$ & 43.45 & 532.36 & 131 & 5.1 & 6.6 & 66 & 6.8 \\
\hline Jef-0603 & $9 / 16 / 2004$ & 38.48 & 489.72 & 340 & 7.0 & 0.6 & 6.0 & 7.0 \\
\hline Jef-0587 & $9 / 14 / 2004$ & 42.16 & 533.93 & 119 & 6.9 & 1.6 & 16 & 6.7 \\
\hline Jef-0306S & $7 / 22 / 2004$ & -- & 483.00 & -- & -- & -- & -- & 6.8 \\
\hline
\end{tabular}


Table 1--continued. Water quality data from samples collected at the USGS Leetown Science Center, Leetown, West Virginia.

\begin{tabular}{|c|c|c|c|c|c|c|c|c|}
\hline $\begin{array}{l}\text { Local identi- } \\
\text { fier }\end{array}$ & Date & $\begin{array}{c}\text { Specific } \\
\text { conductance } \\
\text { at } @ 25^{\circ} \mathrm{C}(\mu \mathrm{S} / \\
\mathrm{cm})\end{array}$ & $\begin{array}{c}\text { Temperature, } \\
\text { water }\left({ }^{\circ} \mathrm{C}\right)\end{array}$ & $\begin{array}{c}\text { Hardness, } \\
\text { water } \\
\text { (mg/L } \\
\text { CaC03) }\end{array}$ & $\begin{array}{l}\text { Non-Carbon- } \\
\text { ate hardness, } \\
\text { dissolved } \\
\text { (mg/L CaCO3) }\end{array}$ & $\begin{array}{c}\text { Calcium, } \\
\text { dissolved } \\
\text { (mg/L) }\end{array}$ & $\begin{array}{c}\text { Magnesium, } \\
\text { dissolved } \\
\text { (mg/L) }\end{array}$ & $\begin{array}{c}\text { Potassium, } \\
\text { dissolved } \\
\text { (mg/L) }\end{array}$ \\
\hline Jef-0594 & $9 / 15 / 2004$ & 694 & 15.3 & 360 & 90 & 132 & 6.45 & 1.87 \\
\hline Jef-0521S & $9 / 13 / 2004$ & 773 & 12.1 & 340 & 96 & 120 & 8.49 & 1.58 \\
\hline Jef-0659S & $9 / 15 / 2004$ & 623 & 13.3 & 320 & 85 & 115 & 8.35 & 1.74 \\
\hline Jef-0752 & $9 / 8 / 2005$ & 602 & 12.6 & -- & -- & -- & -- & -- \\
\hline Jef-0590 & $9 / 16 / 2004$ & 634 & 12.6 & 360 & 77 & 129 & 7.79 & 1.65 \\
\hline Jef-0753 & $9 / 14 / 2005$ & 623 & 13.6 & 340 & 33 & 127 & 5.24 & 1.1 \\
\hline Jef-0584 & $9 / 16 / 2004$ & 667 & 13.6 & 350 & 45 & 128 & 7.53 & 1.79 \\
\hline Jef- $0585^{1}$ & $7 / 21 / 2004$ & 581 & 13.7 & -- & -- & ${ }^{2} 92.4$ & ${ }^{2} 23.20$ & ${ }^{2} 1.1$ \\
\hline Jef-0601 & $9 / 14 / 2004$ & 630 & 14.9 & 350 & 25 & 129 & 7.79 & 1.18 \\
\hline Jef-0603 & $9 / 16 / 2004$ & 3180 & 14.1 & 550 & 240 & 116 & 59.9 & 7.66 \\
\hline Jef-0587 & $9 / 14 / 2004$ & 975 & 13.9 & 490 & 120 & 142 & 30.7 & 1.42 \\
\hline Jef-0306S & $7 / 22 / 2004$ & 565 & 11.4 & -- & -- & ${ }^{2} 102$ & 28.9 & ${ }^{2} 2.2$ \\
\hline
\end{tabular}

Table 1--continued. Water quality data from samples collected at the USGS Leetown Science Center, Leetown, West Virginia.

\begin{tabular}{|c|c|c|c|c|c|c|c|c|}
\hline $\begin{array}{c}\text { Local identi- } \\
\text { fier }\end{array}$ & Date & $\begin{array}{l}\text { Sodium, dis- } \\
\text { solved (mg/L) }\end{array}$ & $\begin{array}{c}\text { Alkalinity, } \\
\text { dissolved } \\
\text { (mg/L CaCO3) }\end{array}$ & $\begin{array}{c}\text { Bicarb- } \\
\text { onate, dis- } \\
\text { solved (mg/L) }\end{array}$ & $\begin{array}{l}\text { Carbonate, } \\
\text { Dissolved } \\
\text { (mg/L) }\end{array}$ & $\begin{array}{c}\text { Bromide, } \\
\text { dissolved } \\
\text { (mg/L) }\end{array}$ & $\begin{array}{l}\text { Chloride, } \\
\text { dissolved } \\
\text { (mg/L) }\end{array}$ & $\begin{array}{c}\text { Fluoride, } \\
\text { dissolved } \\
\text { (mg/L) }\end{array}$ \\
\hline Jef-0594 & $9 / 15 / 2004$ & 4.12 & 266 & 324 & $<1$ & 0.01 & 9.14 & $<0.2$ \\
\hline Jef-0521S & $9 / 13 / 2004$ & 2.83 & 240 & 293 & $<1$ & 0.02 & 7.54 & $<0.2$ \\
\hline Jef-0659S & $9 / 15 / 2004$ & 2.94 & 238 & 290 & $<1$ & 0.01 & 7.5 & $<0.2$ \\
\hline Jef-0590 & $9 / 16 / 2004$ & 3.46 & 278 & 339 & $<1$ & 0.03 & 7.67 & $<0.2$ \\
\hline Jef-0753 & $9 / 14 / 2005$ & 4.87 & 305 & 372 & $<1$ & -- & 9.48 & 0.1 \\
\hline Jef-0584 & $9 / 16 / 2004$ & 5.43 & 307 & 374 & $<1$ & 0.04 & 11.5 & $<0.2$ \\
\hline Jef-0327S & $9 / 14 / 2004$ & 17.3 & 270 & 329 & $<1$ & 0.04 & 14.4 & $<0.2$ \\
\hline Jef- $0585^{1}$ & $7 / 21 / 2004$ & ${ }^{2} 4.28$ & 284 & 346 & $<1$ & -- & -- & -- \\
\hline Jef-0601 & $9 / 14 / 2004$ & 5.5 & 330 & 402 & $<1$ & 0.02 & 10.1 & 0.2 \\
\hline Jef-0603 & $9 / 16 / 2004$ & 402 & 304 & 371 & $<1$ & 0.68 & 538 & 1.9 \\
\hline Jef-0587 & $9 / 14 / 2004$ & 28.5 & 373 & 455 & $<1$ & 0.04 & 84.2 & 0.2 \\
\hline Jef-0306S & $7 / 22 / 2004$ & 23.4 & 313 & 382 & ${ }^{2}<1$ & ${ }^{2}<0.05$ & ${ }^{2} 8.4$ & ${ }^{2} 0.2$ \\
\hline
\end{tabular}


Table 1--continued. Water quality data from samples collected at the USGS Leetown Science Center, Leetown, West Virginia.

\begin{tabular}{|c|c|c|c|c|c|c|c|c|}
\hline $\begin{array}{l}\text { Local identi- } \\
\text { fier }\end{array}$ & Date & $\begin{array}{l}\text { Silica, dis- } \\
\text { solved (mg/L) }\end{array}$ & $\begin{array}{l}\text { Sulfate, dis- } \\
\text { solved (mg/L) }\end{array}$ & $\begin{array}{c}\text { Residue, } \\
\text { whole, sum } \\
\text { of constit- } \\
\text { uents (mg/L) }\end{array}$ & $\begin{array}{l}\text { Residue on } \\
\text { evaporation } \\
@ 180^{\circ} \mathrm{C} \text {, dis- } \\
\text { solved (mg/L) }\end{array}$ & $\begin{array}{l}\text { Ammonia, } \\
\text { dissolved } \\
(\mathrm{mg} / \mathrm{L} \text { as } \mathrm{N})\end{array}$ & $\begin{array}{l}\text { N02+N03, } \\
\text { dissolved } \\
\text { (mg/L as N) }\end{array}$ & $\begin{array}{c}\text { Nitrite, } \\
\text { dissolved } \\
\text { (mg/L as N) }\end{array}$ \\
\hline Jef-0594 & $9 / 15 / 2004$ & 12.2 & 16.4 & 379 & 264 & E0.03 & 8.53 & $<0.008$ \\
\hline Jef-0521S & $9 / 13 / 2004$ & 11.4 & 17.5 & 332 & 170 & $<0.04$ & 3.8 & $<0.008$ \\
\hline Jef-0659S & $9 / 15 / 2004$ & 11.1 & 16.7 & 324 & 233 & $<0.04$ & 3.89 & $<0.008$ \\
\hline Jef-0602 & $9 / 15 / 2004$ & 12.6 & 16.2 & 356 & 233 & $<0.04$ & 5.27 & $<0.008$ \\
\hline Jef-0752 & $9 / 8 / 2005$ & -- & -- & -- & -- & -- & -- & -- \\
\hline Jef-0590 & $9 / 16 / 2004$ & 11.2 & 17.5 & 350 & 189 & $<0.04$ & 1 & $<0.008$ \\
\hline Jef-0753 & $9 / 14 / 2005$ & 12 & 12.8 & & 364 & $<0.04$ & 1.78 & $<0.008$ \\
\hline Jef-0584 & $9 / 16 / 2004$ & 10.9 & 16.1 & 367 & 228 & $<0.04$ & 0.14 & $<0.008$ \\
\hline Jef-0327S & $9 / 14 / 2004$ & 11.4 & 16.7 & 345 & 240 & $<0.04$ & 1.78 & $<0.008$ \\
\hline Jef-0589 & $9 / 13 / 2004$ & 10.3 & 15.6 & 323 & 186 & 0.07 & 2.24 & $<0.008$ \\
\hline Jef- $0592^{1}$ & $7 / 27 / 2004$ & ${ }^{2} 11.3$ & -- & -- & -- & -- & -- & -- \\
\hline Jef- $0585^{1}$ & $7 / 21 / 2004$ & ${ }^{2} 11.3$ & -- & -- & -- & -- & -- & -- \\
\hline Jef-0601 & $9 / 14 / 2004$ & 15.2 & 14.2 & 395 & 249 & $<0.04$ & 3.18 & $<0.008$ \\
\hline Jef-0603 & $9 / 16 / 2004$ & 13.2 & 409 & 1740 & 1720 & 0.61 & $<0.06$ & $<0.008$ \\
\hline Jef-0587 & $9 / 14 / 2004$ & 14.8 & 33.8 & 577 & 398 & $<0.04$ & 1.48 & 0.014 \\
\hline Jef-0306S & $7 / 22 / 2004$ & ${ }^{2} 10.8$ & ${ }^{2} 17.9$ & -- & -- & -- & ${ }^{2} 4.87$ & -- \\
\hline
\end{tabular}

Table 1--continued. Water quality data from samples collected at the USGS Leetown Science Center, Leetown, West Virginia.

\begin{tabular}{|c|c|c|c|c|c|c|c|}
\hline $\begin{array}{l}\text { Local identi- } \\
\text { fier }\end{array}$ & Date & $\begin{array}{c}\text { Orthophosphate, } \\
\text { dissolved (mg/L } \\
\text { as } \mathrm{P} \text { ) }\end{array}$ & $\begin{array}{l}\text { E. coli, NA- } \\
\text { MUG (colonies/ } \\
100 \mathrm{~mL})\end{array}$ & $\begin{array}{c}\text { Fecal coliforms } \\
\text { (colonies/ } \\
100 \mathrm{~mL} \text { ) }\end{array}$ & $\begin{array}{c}\text { Total Coliform, M- } \\
\text { Endo (colonies/ } \\
100 \mathrm{~mL} \text { ) }\end{array}$ & $\begin{array}{c}\text { Alumi- } \\
\text { num, } \\
\text { dissolved } \\
\text { ( } \mu \mathrm{g} / \mathrm{L})\end{array}$ & $\begin{array}{l}\text { Antimony, } \\
\text { dissolved } \\
(\mu \mathrm{g} / \mathrm{L})\end{array}$ \\
\hline Jef-0594 & $9 / 15 / 2004$ & $<0.02$ & 5 & 3 & 290 & $<2$ & $<0.2$ \\
\hline Jef-0521S & $9 / 13 / 2004$ & $<0.02$ & 1 & $<1$ & 143 & $<2$ & $<0.2$ \\
\hline Jef-0659S & $9 / 15 / 2004$ & $<0.02$ & 1 & 1 & 55 & $<2$ & $<0.2$ \\
\hline Jef-0602 & $9 / 15 / 2004$ & $<0.02$ & 20 & 37 & 700 & $<2$ & $<0.2$ \\
\hline Jef-0752 & $9 / 8 / 2005$ & -- & -- & -- & -- & -- & -- \\
\hline Jef- 0590 & $9 / 16 / 2004$ & $<0.02$ & $<1$ & 1 & E105 & $<2$ & $<0.2$ \\
\hline Jef- 0753 & $9 / 14 / 2005$ & $<0.02$ & -- & -- & -- & E1 & $<0.2$ \\
\hline Jef-0584 & $9 / 16 / 2004$ & $<0.02$ & $<1$ & $<1$ & $<92$ & $<2$ & $<0.2$ \\
\hline Jef-0327S & $9 / 14 / 2004$ & $<0.02$ & 2 & 4 & 360 & $<2$ & $<0.2$ \\
\hline Jef-0589 & $9 / 13 / 2004$ & $<0.02$ & $<1$ & $<1$ & 280 & $<2$ & $<0.2$ \\
\hline Jef-0592 ${ }^{1}$ & $7 / 27 / 2004$ & -- & -- & -- & -- & ${ }^{2}<1$ & -- \\
\hline Jef- $0585^{1}$ & $7 / 21 / 2004$ & -- & -- & -- & -- & ${ }^{2} 1$ & -- \\
\hline Jef-0601 & $9 / 14 / 2004$ & $<0.02$ & $<1$ & $<1$ & 207 & $<2$ & $<0.2$ \\
\hline Jef-0603 & $9 / 16 / 2004$ & $<0.02$ & $<1$ & $<1$ & $<1$ & $<3$ & E0.21 \\
\hline Jef-0587 & $9 / 14 / 2004$ & $<0.02$ & $<1$ & $<1$ & 68 & $<2$ & E0.19 \\
\hline Jef-0306S & $7 / 22 / 2004$ & -- & -- & -- & -- & 23 & -- \\
\hline
\end{tabular}


Table 1--continued. Water quality data from samples collected at the USGS Leetown Science Center, Leetown, West Virginia.

\begin{tabular}{|c|c|c|c|c|c|c|c|c|}
\hline $\begin{array}{l}\text { Local identi- } \\
\quad \text { fier }\end{array}$ & Date & $\begin{array}{l}\text { Arsenic, dis- } \\
\text { solved ( } \mu \mathrm{g} / \mathrm{L})\end{array}$ & $\begin{array}{l}\text { Barium, dis- } \\
\text { solved }(\mu \mathrm{g} / \mathrm{L})\end{array}$ & $\begin{array}{l}\text { Beryllium, } \\
\text { dissolved } \\
(\mu \mathrm{g} / \mathrm{L})\end{array}$ & $\begin{array}{l}\text { Boron, dis- } \\
\text { solved }(\mu \mathrm{g} / \mathrm{L})\end{array}$ & $\begin{array}{l}\text { Cadmium, } \\
\text { dissolved } \\
(\mu \mathrm{g} / \mathrm{L})\end{array}$ & $\begin{array}{l}\text { Chromium, } \\
\text { dissolved } \\
(\mu \mathrm{g} / \mathrm{L})\end{array}$ & $\begin{array}{l}\text { Cobalt, dis- } \\
\text { solved ( } \mu \mathrm{g} / \mathrm{L})\end{array}$ \\
\hline Jef-0594 & $9 / 15 / 2004$ & E0.1 & 46 & $<0.06$ & $<8$ & $<0.04$ & $<0.8$ & 0.355 \\
\hline Jef-0521S & $9 / 13 / 2004$ & $<0.2$ & 47 & $<0.06$ & $<8$ & $<0.04$ & E0.5 & 0.303 \\
\hline Jef-0659S & $9 / 15 / 2004$ & E0.1 & 47 & $<0.06$ & $<8$ & $<0.04$ & E0.4 & 0.31 \\
\hline Jef-0602 & $9 / 15 / 2004$ & $<0.2$ & 63 & $<0.06$ & E5 & $<0.04$ & E0.5 & 0.476 \\
\hline Jef-0752 & 9/8/2005 & -- & -- & -- & -- & -- & -- & -- \\
\hline Jef-0590 & $9 / 16 / 2004$ & $<0.2$ & 52 & $<0.06$ & $<8$ & $<0.04$ & $<0.8$ & 0.482 \\
\hline Jef-0753 & $9 / 14 / 2005$ & E0.06 & 38 & $<0.06$ & 8 & $<0.04$ & E0.03 & $<0.04$ \\
\hline Jef-0584 & $9 / 16 / 2004$ & $<0.2$ & 55 & $<0.06$ & E4 & $<0.04$ & $<0.8$ & 0.431 \\
\hline Jef-0327S & $9 / 14 / 2004$ & $<0.2$ & 51 & $<0.06$ & E6 & $<0.04$ & $<0.8$ & 0.225 \\
\hline Jef-0589 & $9 / 13 / 2004$ & $<0.2$ & 50 & $<0.06$ & $<8$ & $<0.04$ & E0.5 & 0.409 \\
\hline Jef-0592 ${ }^{1}$ & $7 / 27 / 2004$ & ${ }^{2}<1$ & ${ }^{2} 39.3$ & -- & ${ }^{2}<20$ & ${ }^{2}<0.05$ & -- & -- \\
\hline Jef- $0585^{1}$ & $7 / 21 / 2004$ & ${ }^{2}<1$ & ${ }^{2} 73.4$ & -- & ${ }^{2}<20$ & ${ }^{2}<0.05$ & -- & -- \\
\hline Jef-0601 & $9 / 14 / 2004$ & $<0.2$ & 33 & $<0.06$ & $<8$ & $<0.04$ & 1.5 & 0.403 \\
\hline Jef-0603 & $9 / 16 / 2004$ & E0.2 & 55 & $<0.12$ & 770 & $<0.08$ & $<0.8$ & 0.41 \\
\hline Jef-0587 & $9 / 14 / 2004$ & 0.4 & 95 & $<0.06$ & 8 & $<0.04$ & $<0.8$ & 1.15 \\
\hline Jef-0306S & $7 / 22 / 2004$ & ${ }^{2} 0.2$ & ${ }^{2} 100$ & -- & ${ }^{2}<10$ & -- & ${ }^{2}<1.0$ & -- \\
\hline
\end{tabular}

Table 1--continued. Water quality data from samples collected at the USGS Leetown Science Center, Leetown, West Virginia.

\begin{tabular}{|c|c|c|c|c|c|c|c|c|}
\hline $\begin{array}{l}\text { Local identi- } \\
\text { fier }\end{array}$ & Date & $\begin{array}{c}\text { Copper, } \\
\text { dissolved } \\
\text { ( } \mu \mathrm{g} / \mathrm{L})\end{array}$ & $\begin{array}{l}\text { Iron, dis- } \\
\text { solved } \\
\text { ( } \mu \mathrm{g} / \mathrm{L})\end{array}$ & $\begin{array}{c}\text { Lead, } \\
\text { dissolved } \\
\text { ( } \mu \mathrm{g} / \mathrm{L})\end{array}$ & $\begin{array}{l}\text { Lithium, dis- } \\
\text { solved ( } \mu \mathrm{g} / \mathrm{L} \text { ) }\end{array}$ & $\begin{array}{c}\text { Manganese, } \\
\text { dissolved } \\
(\mu \mathrm{g} / \mathrm{L})\end{array}$ & $\begin{array}{c}\text { Molybdenum, } \\
\text { dissolved } \\
(\mu \mathrm{g} / \mathrm{L})\end{array}$ & $\begin{array}{l}\text { Nickel, dis- } \\
\text { solved ( } \mu \mathrm{g} / \mathrm{L})\end{array}$ \\
\hline Jef-0594 & $9 / 15 / 2004$ & 0.4 & 7 & $<0.08$ & 0.8 & E0.1 & $<0.4$ & 0.21 \\
\hline Jef-0521S & $9 / 13 / 2004$ & 0.5 & E6 & $<0.08$ & 2.2 & $<0.2$ & E0.3 & 0.10 \\
\hline Jef-0659S & $9 / 15 / 2004$ & 0.4 & $<6$ & $<0.08$ & 2.3 & 0.2 & $<0.4$ & 0.14 \\
\hline Jef-0602 & $9 / 15 / 2004$ & 0.6 & E6 & $<0.08$ & 3.7 & 0.5 & $<0.4$ & 0.40 \\
\hline Jef-0752 & $9 / 8 / 2005$ & -- & -- & -- & -- & -- & -- & -- \\
\hline Jef-0590 & $9 / 16 / 2004$ & 0.6 & 9 & $<0.08$ & 2.3 & 1.3 & $<0.4$ & 0.45 \\
\hline Jef-0753 & $9 / 14 / 2005$ & & 14 & $<0.08$ & 1.9 & 0.4 & $<0.4$ & \\
\hline Jef-0584 & $9 / 16 / 2004$ & 0.5 & 7 & $<0.08$ & 2.4 & 6.2 & $<0.4$ & 0.42 \\
\hline Jef-0327S & $9 / 14 / 2004$ & 0.4 & $<6$ & $<0.08$ & 2.6 & E0.2 & $<0.4$ & 0.38 \\
\hline Jef-0589 & $9 / 13 / 2004$ & 0.7 & E4 & $<0.08$ & 2.7 & 22.5 & E0.3 & 0.80 \\
\hline Jef-0592 ${ }^{1}$ & $7 / 27 / 2004$ & ${ }^{2} 16.6$ & ${ }^{2} 20$ & ${ }^{2} 0.12$ & 23.0 & ${ }^{2} 12$ & -- & ${ }^{2} 0.60$ \\
\hline Jef- $0585^{1}$ & $7 / 21 / 2004$ & 27.1 & ${ }^{2}<10$ & ${ }^{2}<0.05$ & ${ }^{2} 5.0$ & ${ }^{2} 6.0$ & -- & ${ }^{2} 0.40$ \\
\hline Jef-0601 & $9 / 14 / 2004$ & 0.5 & $<6$ & $<0.08$ & 3.3 & 0.2 & E0.3 & 0.92 \\
\hline Jef-0603 & $9 / 16 / 2004$ & 5.8 & 20 & $<0.16$ & 512 & 9.4 & $<0.8$ & 1.65 \\
\hline Jef-0587 & $9 / 14 / 2004$ & 0.8 & E3 & 0.12 & 4.0 & 3.2 & 0.5 & 2.90 \\
\hline Jef-0306S & $7 / 22 / 2004$ & 22.5 & ${ }^{2}<10$ & $2<0.05$ & 24.0 & ${ }^{2} 1.0$ & ${ }^{2}<0.1$ & -- \\
\hline
\end{tabular}


Table 1--continued. Water quality data from samples collected at the USGS Leetown Science Center, Leetown, West Virginia.

\begin{tabular}{|c|c|c|c|c|c|c|c|c|}
\hline $\begin{array}{l}\text { Local identi- } \\
\text { fier }\end{array}$ & Date & $\begin{array}{c}\text { Selenium, } \\
\text { dissolved } \\
(\mu \mathrm{g} / \mathrm{L})\end{array}$ & $\begin{array}{l}\text { Silver, dis- } \\
\text { solved ( } \mu \mathrm{g} / \mathrm{L})\end{array}$ & $\begin{array}{c}\text { Strontium, } \\
\text { dissolved } \\
(\mu \mathrm{g} / \mathrm{L})\end{array}$ & $\begin{array}{c}\text { Thallium, } \\
\text { dissolved } \\
(\mu \mathrm{g} / \mathrm{L})\end{array}$ & $\begin{array}{c}\text { Vanadium, } \\
\text { dissolved } \\
(\mu \mathrm{g} / \mathrm{L})\end{array}$ & $\begin{array}{c}\text { Zinc, } \\
\text { dissolved } \\
(\mu \mathrm{g} / \mathrm{L})\end{array}$ & $\begin{array}{c}\text { CIAT, } \\
\text { dissolved } \\
(\mu \mathrm{g} / \mathrm{L})\end{array}$ \\
\hline Jef-0594 & $9 / 15 / 2004$ & $<0.4$ & $<0.2$ & 244 & $<0.04$ & 0.8 & $<0.6$ & E0.364 \\
\hline Jef-0521S & $9 / 13 / 2004$ & $<0.4$ & $<0.2$ & 804 & $<0.04$ & 1.1 & E0.3 & E0.143 \\
\hline Jef-0659S & $9 / 15 / 2004$ & E0.2 & $<0.2$ & 780 & $<0.04$ & 0.8 & $<0.6$ & E0.159 \\
\hline Jef-0602 & $9 / 15 / 2004$ & $<0.4$ & $<0.2$ & 543 & $<0.04$ & 0.2 & $<0.6$ & E0.338 \\
\hline Jef-0752 & $9 / 8 / 2005$ & -- & -- & -- & -- & -- & -- & -- \\
\hline Jef-0590 & $9 / 16 / 2004$ & E0.3 & $<0.2$ & 866 & $<0.04$ & 1.6 & $<0.6$ & -- \\
\hline Jef- 0753 & $9 / 14 / 2005$ & 0.13 & $<0.2$ & 250 & $<0.04$ & 0.1 & 42.3 & E0.024 \\
\hline Jef-0584 & $9 / 16 / 2004$ & $<0.4$ & $<0.2$ & 790 & $<0.04$ & 1.6 & $<0.6$ & -- \\
\hline Jef-0327S & $9 / 14 / 2004$ & $<0.4$ & $<0.2$ & 691 & $<0.04$ & 1.2 & $<0.6$ & E0.183 \\
\hline Jef-0589 & $9 / 13 / 2004$ & $<0.4$ & $<0.2$ & 426 & $<0.04$ & 1.1 & 1.9 & E0.157 \\
\hline Jef- $0592^{1}$ & $7 / 27 / 2004$ & $2<1$ & -- & ${ }^{2} 289$ & -- & ${ }^{2} 0.4$ & -- & -- \\
\hline Jef-0585 & $7 / 21 / 2004$ & $2<1$ & -- & 2736 & -- & ${ }^{2} 0.3$ & -- & -- \\
\hline Jef-0601 & $9 / 14 / 2004$ & $<0.4$ & $<0.2$ & 245 & $<0.04$ & 1.4 & 8 & E0.039 \\
\hline Jef-0603 & $9 / 16 / 2004$ & 0.8 & & 8450 & $<0.08$ & 0.7 & 2.7 & $<0.006$ \\
\hline Jef-0587 & $9 / 14 / 2004$ & 1.8 & $<0.2$ & 11300 & $<0.04$ & 1.7 & 4.7 & -- \\
\hline Jef-0306S & $7 / 22 / 2004$ & -- & & ${ }^{2} 1060$ & -- & ${ }^{2}<0.1$ & ${ }^{2}<1.0$ & -- \\
\hline
\end{tabular}

Table 1--continued. Water quality data from samples collected at the USGS Leetown Science Center, Leetown, West Virginia.

\begin{tabular}{|c|c|c|c|c|c|c|c|c|}
\hline $\begin{array}{l}\text { Local identi- } \\
\text { fier }\end{array}$ & Date & $\begin{array}{c}\text { Atrazine, } \\
\text { dissolved } \\
\text { ( } \mu \mathrm{g} / \mathrm{L})\end{array}$ & $\begin{array}{c}\text { Phenol, } \\
\text { dissolved } \\
\text { ( } \mu \mathrm{g} / \mathrm{L})\end{array}$ & $\begin{array}{c}\text { Phenol, total } \\
(\mu \mathrm{g} / \mathrm{L})\end{array}$ & $\begin{array}{c}\text { Prometon, } \\
\text { dissolved } \\
(\mu \mathrm{g} / \mathrm{L})\end{array}$ & $\begin{array}{c}\text { Simazine, } \\
\text { dissolved } \\
(\mu \mathrm{g} / \mathrm{L})\end{array}$ & $\begin{array}{c}\text { Tebuthiuron, } \\
\text { dissolved } \\
(\mu \mathrm{g} / \mathrm{L})\end{array}$ & $\begin{array}{c}\text { Terbacil, } \\
\text { dissolved } \\
(\mu \mathrm{g} / \mathrm{L})\end{array}$ \\
\hline Jef-0594 & $9 / 15 / 2004$ & 0.19 & & & $<0.01$ & 0.024 & 0.12 & $<0.034$ \\
\hline Jef-0521S & $9 / 13 / 2004$ & 0.128 & 0.9 & $<1.6$ & 0.01 & 0.034 & $<0.02$ & $<0.034$ \\
\hline Jef-0659S & $9 / 15 / 2004$ & 0.135 & $<0.5$ & $<1.6$ & 0.01 & 0.035 & 0.02 & $<0.034$ \\
\hline Jef-0602 & $9 / 15 / 2004$ & 0.226 & $<0.5$ & $<1.6$ & 0.02 & 0.045 & E0.01 & $<0.034$ \\
\hline Jef-0752 & $9 / 8 / 2005$ & -- & -- & -- & -- & -- & -- & -- \\
\hline Jef-0590 & $9 / 16 / 2004$ & -- & -- & -- & -- & -- & -- & -- \\
\hline Jef-0753 & $9 / 14 / 2005$ & 0.01 & -- & -- & $<0.01$ & $<0.005$ & $<0.02$ & $<0.034$ \\
\hline Jef-0584 & $9 / 16 / 2004$ & -- & -- & -- & -- & -- & -- & -- \\
\hline Jef-0327S & $9 / 14 / 2004$ & 0.125 & 0.6 & E1.2 & 0.01 & 0.028 & $<0.02$ & $<0.034$ \\
\hline Jef-0589 & $9 / 13 / 2004$ & 0.094 & -- & -- & 0.01 & 0.023 & $<0.02$ & $<0.034$ \\
\hline Jef- $0592^{1}$ & $7 / 27 / 2004$ & -- & -- & -- & -- & -- & -- & -- \\
\hline Jef- $0585^{1}$ & $7 / 21 / 2004$ & -- & -- & -- & -- & -- & -- & -- \\
\hline Jef-0601 & $9 / 14 / 2004$ & 0.036 & -- & -- & 0.07 & 0.013 & $<0.02$ & E0.016 \\
\hline Jef-0603 & $9 / 16 / 2004$ & $<0.007$ & -- & -- & $<0.01$ & $<0.005$ & $<0.02$ & $<0.034$ \\
\hline Jef-0587 & $9 / 14 / 2004$ & -- & -- & -- & -- & -- & -- & -- \\
\hline Jef-0306S & $7 / 22 / 2004$ & -- & -- & -- & -- & -- & -- & -- \\
\hline
\end{tabular}


Table 1--continued. Water quality data from samples collected at the USGS Leetown Science Center, Leetown, West Virginia.

\begin{tabular}{|c|c|c|c|c|c|c|c|c|}
\hline $\begin{array}{l}\text { Local identi- } \\
\text { fier }\end{array}$ & Date & $\begin{array}{c}\text { 1,1,1-Trichlo- } \\
\text { ro-ethane, } \\
\text { total ( } \mu \mathrm{g} / \mathrm{L})\end{array}$ & $\begin{array}{c}\text { 1,2,4-Trimeth- } \\
\text { yl-benzene, } \\
\text { total ( } \mu \mathrm{g} / \mathrm{L})\end{array}$ & $\begin{array}{l}\text { Acetone, } \\
\text { total }(\mu \mathrm{g} / \mathrm{L})\end{array}$ & 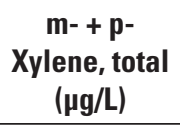 & $\begin{array}{c}\text { o-Xylene, } \\
\text { total ( } \mu \mathrm{g} / \mathrm{L})\end{array}$ & $\begin{array}{c}\text { Tetrachlor- } \\
\text { oethene, } \\
\text { total }(\mu \mathrm{g} / \mathrm{L})\end{array}$ & $\begin{array}{c}\text { Toluene, total } \\
(\mu \mathrm{g} / \mathrm{L})\end{array}$ \\
\hline Jef-0594 & $9 / 15 / 2004$ & $<0.03$ & $<0.06$ & $<6$ & $<0.06$ & $<0.04$ & $<0.06$ & $<0.05$ \\
\hline Jef-0521S & $9 / 13 / 2004$ & $<0.03$ & $<0.06$ & $<6$ & $<0.06$ & $<0.04$ & $<0.06$ & $<0.05$ \\
\hline Jef-0659S & $9 / 15 / 2004$ & $<0.03$ & $<0.06$ & $<6$ & $<0.06$ & $<0.04$ & $<0.06$ & $<0.05$ \\
\hline Jef-0590 & $9 / 16 / 2004$ & $<0.03$ & $<0.06$ & $<6$ & $<0.06$ & $<0.04$ & $<0.06$ & $<0.05$ \\
\hline Jef-0753 & $9 / 14 / 2005$ & $<0.03$ & $<0.06$ & $<6$ & $<0.06$ & $<0.04$ & E0.02 & 1.1 \\
\hline Jef-0584 & $9 / 16 / 2004$ & -- & -- & -- & -- & -- & -- & -- \\
\hline Jef-0327S & $9 / 14 / 2004$ & $<0.03$ & $<0.06$ & $<6$ & $<0.06$ & $<0.04$ & $<0.06$ & $<0.05$ \\
\hline Jef-0601 & $9 / 14 / 2004$ & $<0.03$ & $<0.06$ & $<6$ & $<0.06$ & $<0.04$ & $<0.06$ & E0.03 \\
\hline Jef-0603 & $9 / 16 / 2004$ & -- & -- & -- & -- & -- & -- & -- \\
\hline Jef-0587 & $9 / 14 / 2004$ & -- & -- & -- & -- & -- & -- & -- \\
\hline Jef-0306S & $7 / 22 / 2004$ & -- & -- & -- & -- & -- & -- & -- \\
\hline
\end{tabular}

Table 1--continued. Water quality data from samples collected at the USGS Leetown Science Center, Leetown, West Virginia.

\begin{tabular}{|c|c|c|c|c|c|}
\hline Local identifier & Date & $\begin{array}{c}\text { Trichloromethane, } \\
\text { total }(\mu \mathrm{g} / \mathrm{L})\end{array}$ & $\mathrm{Rn}-222$, total $(\mathrm{pCi} / \mathrm{L})$ & Tritium, total (pCi/L) & $\begin{array}{c}\text { Uranium, dissolved } \\
(\mu \mathrm{g} / \mathrm{L})\end{array}$ \\
\hline Jef-0594 & $9 / 15 / 2004$ & $<0.02$ & 1180 & -- & 0.47 \\
\hline Jef-0521S & $9 / 13 / 2004$ & $<0.02$ & -- & 25.3 & 0.35 \\
\hline Jef-0659S & 9/15/2004 & $<0.02$ & -- & 25 & 0.34 \\
\hline Jef-0602 & $9 / 15 / 2004$ & $<0.02$ & 800 & -- & 0.29 \\
\hline Jef-0752 & 9/8/2005 & $<0.02$ & -- & -- & \\
\hline Jef-0590 & $9 / 16 / 2004$ & E0.02 & 1100 & -- & 0.35 \\
\hline Jef-0753 & $9 / 14 / 2005$ & $<0.02$ & 840 & -- & 0.39 \\
\hline Jef-0584 & 9/16/2004 & -- & 1280 & -- & 0.3 \\
\hline Jef-0327S & $9 / 14 / 2004$ & 0.48 & -- & 25.6 & 0.27 \\
\hline Jef-0589 & $9 / 13 / 2004$ & $<0.02$ & 650 & -- & 0.28 \\
\hline Jef- $0592^{1}$ & $7 / 27 / 2004$ & -- & -- & 24.6 & ${ }^{2} 0.4$ \\
\hline Jef- $0585^{1}$ & $7 / 21 / 2004$ & -- & -- & 19.8 & ${ }^{2} 0.92$ \\
\hline Jef-0601 & $9 / 14 / 2004$ & $<0.02$ & 1080 & -- & 0.63 \\
\hline Jef-0603 & 9/16/2004 & -- & 10 & -- & $<0.08$ \\
\hline Jef-0587 & $9 / 14 / 2004$ & -- & 250 & -- & 1.48 \\
\hline Jef-0306S & $7 / 22 / 2004$ & -- & -- & -- & ${ }^{2} 0.30$ \\
\hline
\end{tabular}

${ }^{1}$ Data were collected from discrete intervals using a packer assembly.

${ }^{2}$ Data for calcium, magnesium, sodium, and potassium were analyzed by inductively coupled plasma (icp) methods and data for arsenic, boron, barium, cadmium, copper, lithium, manganese, nickel, lead, selenium, strontium, uranium, and vanadium were analyzed by icp with mass spectrometry (icpms) at the USGS dissolved gas laboratory in Reston Virginia. All other data in this table were analyzed by standard laboratory methods at the USGS National Water Quality laboratory in Lakewood Colorado. 
Appendix 6. Table 2. Additional laboratory analyses conducted on samples collected from wells and springs in the Leetown area, West Virginia.

\begin{tabular}{|c|c|c|c|c|c|c|c|}
\hline $\begin{array}{l}\text { Local Station } \\
\text { Number }\end{array}$ & $\begin{array}{l}\text { Local Station } \\
\text { Name }\end{array}$ & $\begin{array}{c}\text { Date } \\
\text { Sampled }\end{array}$ & $\begin{array}{c}\text { VOCs } \\
\text { (Schedule } \\
\text { 2020) }\end{array}$ & $\begin{array}{c}\text { Organo- } \\
\text { phosphate + } \\
\text { Organochlo- } \\
\text { rine Pesticides } \\
\text { (Schedule } \\
\text { 1399) }\end{array}$ & $\begin{array}{c}\text { Triazine } \\
\text { Pesticides } \\
\text { (Schedule } \\
\text { 2001) }\end{array}$ & $\begin{array}{c}\text { Waste-Water } \\
\text { Compounds } \\
\text { (Schedule } \\
\text { 1433) }\end{array}$ & $\begin{array}{c}\text { Semi-Volatile } \\
\text { Compounds } \\
\text { (Schedule } \\
\text { 1383) }\end{array}$ \\
\hline Jef-0601 & Stable well A & $09 / 14 / 04$ & $X$ & $\mathrm{X}$ & $\mathrm{X}$ & & \\
\hline Jef-0585 & Stable well B & 07/21/04 & & & & & \\
\hline Jef-0592 & Stable well C & 07/27/04 & & & & & \\
\hline Jef-0327S & Balch Spring & 09/14/04 & $X$ & $\mathrm{X}$ & $\mathrm{X}$ & $\mathrm{X}$ & $\mathrm{X}$ \\
\hline Jef-0659S & Blue Spring & $09 / 15 / 04$ & $\mathrm{X}$ & $\mathrm{X}$ & $\mathrm{X}$ & $\mathrm{X}$ & $\mathrm{X}$ \\
\hline Jef-0521S & Gray Spring & 09/13/04 & $\mathrm{X}$ & $\mathrm{X}$ & $\mathrm{X}$ & $\mathrm{X}$ & $X$ \\
\hline Jef-0589 & Anticline well & 09/13/04 & $\mathrm{X}$ & $\mathrm{X}$ & $\mathrm{X}$ & & \\
\hline Jef-0587 & Low road well & 09/14/04 & & & & & \\
\hline Jef-0584 & $\begin{array}{l}\text { Boneyard upper } \\
\text { well }\end{array}$ & $09 / 24 / 04$ & & & & & \\
\hline Jef-0594 & $\begin{array}{l}\text { Tabb lower } \\
\text { piezometer }\end{array}$ & 09/15/04 & $X$ & $\mathrm{X}$ & $\mathrm{X}$ & & \\
\hline Jef-0590 & Ball field well & 09/16/04 & $\mathrm{X}$ & & & & \\
\hline Jef-0603 & $\begin{array}{l}\text { USDA sulfur } \\
\text { well }\end{array}$ & 09/16/04 & & $X$ & $X$ & & \\
\hline Jef-0602 & $\begin{array}{l}\text { Old Dodson farm } \\
\text { well }\end{array}$ & $09 / 15 / 04$ & $\mathrm{X}$ & $\mathrm{X}$ & $\mathrm{X}$ & $\mathrm{X}$ & $\mathrm{X}$ \\
\hline Jef-0753 & $\begin{array}{l}\text { New Kaiser farm } \\
\text { well }\end{array}$ & $09 / 14 / 05$ & $\mathrm{X}$ & $X$ & $X$ & & \\
\hline Jef-0752 & $\begin{array}{l}\text { New Dodson } \\
\text { farm well }\end{array}$ & 09/08/05 & $\mathrm{X}$ & & & & \\
\hline Jef-0306S & Bell Spring & $07 / 22 / 04$ & & & & & \\
\hline
\end{tabular}


Table 3. Compounds not detected in any sample collected from the Leetown area, West Virginia.

\begin{tabular}{cccc}
\hline Analyte & $\begin{array}{c}\text { USGS Param- } \\
\text { eter Code }\end{array}$ & $\begin{array}{c}\text { CAS Num- } \\
\text { ber }^{1}\end{array}$ & $\begin{array}{c}\text { Reporting } \\
\text { Limit }(\mu \mathrm{g} / \mathrm{L})\end{array}$ \\
\hline
\end{tabular}

Volatile Organic Dompounds (VOCs) in Unfiltered Water Samples

\begin{tabular}{|c|c|c|c|}
\hline $\begin{array}{r}\text { 1,2,3,4-Tetram- } \\
\text { ethylbenzene }\end{array}$ & 49999 & $488-23-3$ & 0.14 \\
\hline $\begin{array}{r}\text { 1,2,3,5-Tetram- } \\
\text { ethylbenzene }\end{array}$ & 50000 & $527-53-7$ & 0.12 \\
\hline 2-Butanone & 81595 & $78-93-3$ & 1.6 \\
\hline $\begin{array}{l}\text { trans-1,4-Dichlo- } \\
\text { ro-2-butene }\end{array}$ & 73547 & $110-57-6$ & 0.6 \\
\hline 2-Hexanone & 77103 & $591-78-6$ & 0.6 \\
\hline $\begin{array}{l}\text { 4-Methyl-2- } \\
\text { pentanone }\end{array}$ & 78133 & $108-10-1$ & 0.4 \\
\hline Acetone & 81552 & $67-64-1$ & 4 \\
\hline Acrylonitrile & 34215 & $107-13-1$ & 0.4 \\
\hline Benzene & 34030 & $71-43-2$ & 0.016 \\
\hline $\begin{array}{l}\text { 1,2,3-Trichlo- } \\
\text { robenzene }\end{array}$ & 77613 & $87-61-6$ & 0.08 \\
\hline $\begin{array}{l}\text { 1,2,3-Trimethyl- } \\
\text { benzene }\end{array}$ & 77221 & $526-73-8$ & 0.08 \\
\hline $\begin{array}{l}\text { 1,2,4-Trichlo- } \\
\text { robenzene }\end{array}$ & 34551 & $120-82-1$ & 0.08 \\
\hline Bromobenzene & 81555 & $108-86-1$ & 0.02 \\
\hline Chlorobenzene & 34301 & $108-90-7$ & 0.02 \\
\hline Ethylbenzene & 34371 & $100-41-4$ & 0.04 \\
\hline $\begin{array}{l}\text { 1,3-Dichloroben- } \\
\text { zene }\end{array}$ & 34566 & $541-73-1$ & 0.04 \\
\hline Butylbenzene & 77342 & $104-51-8$ & 0.14 \\
\hline n-Propylbenzene & 77224 & $103-65-1$ & 0.04 \\
\hline $\begin{array}{l}\text { 1,2-Dichloroben- } \\
\text { zene }\end{array}$ & 34536 & $95-50-1$ & 0.02 \\
\hline $\begin{array}{l}\text { 1,4-Dichloroben- } \\
\text { zene }\end{array}$ & 34571 & $106-46-7$ & 0.02 \\
\hline sec-Butylbenzene & 77350 & $135-98-8$ & 0.04 \\
\hline $\begin{array}{l}\text { tert-Butylben- } \\
\text { zene }\end{array}$ & 77353 & $98-06-6$ & 0.06 \\
\hline Bromoethene & 50002 & $593-60-2$ & 0.12 \\
\hline Bromoform & 32104 & $75-25-2$ & 0.08 \\
\hline $\begin{array}{l}\text { Hexachlorobuta- } \\
\text { diene }\end{array}$ & 39702 & $87-68-3$ & 0.06 \\
\hline Carbon disulfide & 77041 & $75-15-0$ & 0.06 \\
\hline $\begin{array}{l}\text { Tetrachlo- } \\
\text { romethane }\end{array}$ & 32102 & $56-23-5$ & 0.08 \\
\hline Chloroform & 32106 & $67-66-3$ & 0.02 \\
\hline Isopropylbenzene & 77223 & $98-82-8$ & 0.04 \\
\hline
\end{tabular}

Table 3. Compounds not detected in any sample collected from the Leetown area, West Virginia.

\begin{tabular}{|c|c|c|c|}
\hline Analyte & $\begin{array}{l}\text { USGS Param- } \\
\text { eter Code }\end{array}$ & $\begin{array}{c}\text { CAS Num- } \\
\text { ber }^{1}\end{array}$ & $\begin{array}{c}\text { Reporting } \\
\text { Limit ( } \mu \mathrm{g} / \mathrm{L})\end{array}$ \\
\hline $\begin{array}{l}\text { 1,1,1,2-Tetra- } \\
\text { chloroethane }\end{array}$ & 77562 & $630-20-6$ & 0.04 \\
\hline $\begin{array}{l}\text { 1,1,1-Trichloro- } \\
\text { ethane }\end{array}$ & 34506 & $71-55-6$ & 0.02 \\
\hline $\begin{array}{l}\text { 1,1,2-Trichloro- } \\
\text { trifluoroethane }\end{array}$ & 77652 & $76-13-1$ & 0.04 \\
\hline $\begin{array}{l}\text { 1,2-Dibromo- } \\
\text { ethane }\end{array}$ & 77651 & $106-93-4$ & 0.04 \\
\hline $\begin{array}{l}\text { 1,2-Dichloro- } \\
\text { ethane }\end{array}$ & 32103 & $107-06-2$ & 0.06 \\
\hline $\begin{array}{l}\text { Hexachloro- } \\
\text { ethane }\end{array}$ & 34396 & $67-72-1$ & 0.14 \\
\hline $\begin{array}{l}\text { 1,1,2,2-Tetra- } \\
\text { chloroethane }\end{array}$ & 34516 & $79-34-5$ & 0.1 \\
\hline Chloroethane & 34311 & $75-00-3$ & 0.1 \\
\hline Diethyl ether & 81576 & $60-29-7$ & 0.12 \\
\hline $\begin{array}{l}\text { Ethyl tert-butyl } \\
\text { ether }\end{array}$ & 50004 & $637-92-3$ & 0.04 \\
\hline $\begin{array}{l}\text { cis-1,2-Dichloro- } \\
\text { ethylene }\end{array}$ & 77093 & $156-59-2$ & 0.02 \\
\hline $\begin{array}{l}\text { Tetrachloroeth- } \\
\text { ylene }\end{array}$ & 34475 & $127-18-4$ & 0.04 \\
\hline $\begin{array}{l}\text { trans-1,2-Dichlo- } \\
\text { roethylene }\end{array}$ & 34546 & $156-60-5$ & 0.018 \\
\hline Trichloroethylene & 39180 & $79-01-6$ & 0.02 \\
\hline $\begin{array}{l}\text { 1,1-Dichloro- } \\
\text { ethane }\end{array}$ & 34496 & $75-34-3$ & 0.04 \\
\hline Tetrahydrofuran & 81607 & $109-99-9$ & 1.4 \\
\hline Diisopropyl ether & 81577 & $108-20-3$ & 0.06 \\
\hline $\mathrm{m}$ - and p-Xylene & 85795 & $\begin{array}{l}m=108-38-3 \\
p=106-42-3\end{array}$ & 0.08 \\
\hline $\begin{array}{l}\text { 1,3,5-Trimethyl- } \\
\text { benzene }\end{array}$ & 77226 & $108-67-8$ & 0.04 \\
\hline $\begin{array}{l}\text { Ethyl methacry- } \\
\text { late }\end{array}$ & 73570 & $97-63-2$ & 0.14 \\
\hline $\begin{array}{l}\text { Methyl meth- } \\
\text { acrylate }\end{array}$ & 81597 & $80-62-6$ & 0.2 \\
\hline $\begin{array}{l}\text { Methyl acrylo- } \\
\text { nitrile }\end{array}$ & 81593 & $126-98-7$ & 0.2 \\
\hline $\begin{array}{l}\text { Bromochlo- } \\
\text { romethane }\end{array}$ & 77297 & $74-97-5$ & 0.06 \\
\hline $\begin{array}{l}\text { Bromodichlo- } \\
\text { romethane }\end{array}$ & 32101 & $75-27-4$ & 0.04 \\
\hline $\begin{array}{l}\text { Dibromochlo- } \\
\text { romethane }\end{array}$ & 32105 & $124-48-1$ & 0.12 \\
\hline
\end{tabular}


Table 3. Compounds not detected in any sample collected from the Leetown area, West Virginia.

\begin{tabular}{|c|c|c|c|}
\hline Analyte & $\begin{array}{l}\text { USGS Param- } \\
\text { eter Code }\end{array}$ & $\begin{array}{l}\text { CAS Num- } \\
\text { ber }^{1}\end{array}$ & $\begin{array}{c}\text { Reporting } \\
\text { Limit ( } \mu \mathrm{g} / \mathrm{L})\end{array}$ \\
\hline $\begin{array}{l}\text { Dichlorodifluo- } \\
\text { romethane }\end{array}$ & 34668 & $75-71-8$ & 0.14 \\
\hline $\begin{array}{l}\text { Trichlorofluo- } \\
\text { romethane }\end{array}$ & 34488 & $75-69-4$ & 0.08 \\
\hline Methyl acrylate & 49991 & $96-33-3$ & 0.6 \\
\hline Bromomethane & 34413 & $74-83-9$ & 0.4 \\
\hline Chloromethane & 34418 & $74-87-3$ & 0.1 \\
\hline Methyl iodide & 77424 & $74-88-4$ & 0.4 \\
\hline $\begin{array}{l}\text { tert-Butyl methyl } \\
\text { ether }\end{array}$ & 78032 & $1634-04-4$ & 0.1 \\
\hline Dibromomethane & 30217 & $74-95-3$ & 0.04 \\
\hline Dichloromethane & 34423 & $75-09-2$ & 0.04 \\
\hline Naphthalene & 34696 & $91-20-3$ & 0.2 \\
\hline o-Xylene & 77135 & $95-47-6$ & 0.04 \\
\hline $\begin{array}{l}\text { 4-Isopropyl-1- } \\
\text { methylbenzene }\end{array}$ & 77356 & $99-87-6$ & 0.08 \\
\hline $\begin{array}{l}\text { 1,2,3-Trichloro- } \\
\text { propane }\end{array}$ & 77443 & $96-18-4$ & 0.12 \\
\hline $\begin{array}{l}\text { 1,3-Dichloropro- } \\
\text { pane }\end{array}$ & 77173 & $142-28-9$ & 0.06 \\
\hline $\begin{array}{l}\text { 2,2-Dichloropro- } \\
\text { pane }\end{array}$ & 77170 & $594-20-7$ & 0.06 \\
\hline $\begin{array}{l}\text { 1,2-Dibromo-3- } \\
\text { chloropropane }\end{array}$ & 82625 & $96-12-8$ & 0.5 \\
\hline $\begin{array}{l}\text { 1,1-Dichloropro- } \\
\text { pene }\end{array}$ & 77168 & $563-58-6$ & 0.04 \\
\hline 3-Chloropropene & 78109 & $107-05-1$ & 0.08 \\
\hline $\begin{array}{l}\text { cis-1,3-Dichloro- } \\
\text { propene }\end{array}$ & 34704 & $10061-01-5$ & 0.1 \\
\hline $\begin{array}{l}\text { trans-1,3-Dichlo- } \\
\text { ropropene }\end{array}$ & 34699 & $10061-02-6$ & 0.1 \\
\hline $\begin{array}{l}\text { 1,2-Dichloropro- } \\
\text { pane }\end{array}$ & 34541 & $78-87-5$ & 0.02 \\
\hline $\begin{array}{l}\text { 1,2,4-Trimethyl- } \\
\text { benzene }\end{array}$ & 77222 & $95-63-6$ & 0.04 \\
\hline Styrene & 77128 & $100-42-5$ & 0.04 \\
\hline $\begin{array}{l}\text { tert-Pentyl } \\
\text { methyl ether }\end{array}$ & 50005 & $994-05-8$ & 0.06 \\
\hline Toluene & 34010 & $108-88-3$ & 0.018 \\
\hline 2-Chlorotoluene & 77275 & $95-49-8$ & 0.04 \\
\hline o-Ethyl toluene & 77220 & $611-14-3$ & 0.04 \\
\hline 4-Chlorotoluene & 77277 & $106-43-4$ & 0.04 \\
\hline Vinyl chloride & 39175 & $75-01-4$ & 0.08 \\
\hline $\begin{array}{l}\text { 1,1,2-Trichloro- } \\
\text { ethane }\end{array}$ & 34511 & $79-00-5$ & 0.06 \\
\hline
\end{tabular}

Table 3. Compounds not detected in any sample collected from the Leetown area, West Virginia.

\begin{tabular}{|c|c|c|c|}
\hline Analyte & $\begin{array}{l}\text { USGS Param- } \\
\text { eter Code }\end{array}$ & $\begin{array}{l}\text { CAS Num- } \\
\text { ber }\end{array}$ & $\begin{array}{c}\text { Reporting } \\
\text { Limit }(\mu \mathrm{g} / \mathrm{L})\end{array}$ \\
\hline $\begin{array}{l}\text { 1,1-Dichloroeth- } \\
\text { ylene }\end{array}$ & 34501 & $75-35-4$ & 0.02 \\
\hline \multicolumn{4}{|c|}{$\begin{array}{l}\text { Organochlorine and Organophosphate Pesticides And Gross PCBs } \\
\text { in Unfiltered Water Samples }\end{array}$} \\
\hline Aldrin & 39330 & $309-00-2$ & 0.0018 \\
\hline $\begin{array}{l}\text { S,S,S-Tribu- } \\
\text { tylphosphoro- } \\
\text { trithioate }\end{array}$ & 39040 & $78-48-8$ & 0.02 \\
\hline $\begin{array}{l}\text { Chlordane, tech- } \\
\text { nical mix -mrl }\end{array}$ & 39350 & $57-74-9$ & 0.1 \\
\hline Chlorpyrifos & 38932 & 2921-88-2 & 0.02 \\
\hline Diazinon & 39570 & $333-41-5$ & 0.02 \\
\hline Dieldrin & 39380 & $60-57-1$ & 0.0016 \\
\hline Disulfoton & 39011 & 298-04-4 & 0.02 \\
\hline alpha-Endosulfan & 39388 & $959-98-8$ & 0.0016 \\
\hline Endrin & 39390 & $72-20-8$ & 0.0019 \\
\hline Ethion & 39398 & $563-12-2$ & 0.018 \\
\hline Fonofos & 82614 & $944-22-9$ & 0.018 \\
\hline Heptachlor & 39410 & $76-44-8$ & 0.0016 \\
\hline $\begin{array}{l}\text { Heptachlor } \\
\text { epoxide }\end{array}$ & 39420 & $1024-57-3$ & 0.0016 \\
\hline Lindane & 39340 & $58-89-9$ & 0.0014 \\
\hline Malathion -mrl & 39530 & $121-75-5$ & 0.1 \\
\hline $\begin{array}{l}\text { p,p'-Methoxy- } \\
\text { chlor }\end{array}$ & 39480 & $72-43-5$ & 0.002 \\
\hline Parathion-methyl & 39600 & 298-00-0 & 0.018 \\
\hline Mirex & 39755 & $2385-85-5$ & 0.0011 \\
\hline p,p'-DDD & 39360 & $72-54-8$ & 0.0012 \\
\hline p,p'-DDE & 39365 & $72-55-9$ & 0.0019 \\
\hline p,p'-DDT & 39370 & $50-29-3$ & 0.0014 \\
\hline Parathion & 39540 & $56-38-2$ & 0.02 \\
\hline $\begin{array}{l}\text { Polychlorinated } \\
\text { biphenyls, } \\
\text { total -mrl }\end{array}$ & 39516 & $1336-36-3$ & 0.1 \\
\hline Phorate & 39023 & $298-02-2$ & 0.019 \\
\hline Toxaphene -mrl & 39400 & $8001-35-2$ & 1 \\
\hline Carbophenothion & 39786 & 786-19-6 & 0.02 \\
\hline \multicolumn{4}{|c|}{ Triazine Pesticides in Filtered Water Samples } \\
\hline alpha-HCH & 34253 & $319-84-6$ & 0.002 \\
\hline Acetochlor & 49260 & $34256-82-1$ & 0.006 \\
\hline Alachlor & 46342 & $15972-60-8$ & 0.006 \\
\hline
\end{tabular}


Table 3. Compounds not detected in any sample collected from the Leetown area, West Virginia.

\begin{tabular}{|c|c|c|c|}
\hline Analyte & $\begin{array}{l}\text { USGS Param- } \\
\text { eter Code }\end{array}$ & $\begin{array}{c}\text { CAS Num- } \\
\text { ber }^{1}\end{array}$ & $\begin{array}{c}\text { Reporting } \\
\text { Limit ( } \mu \mathrm{g} / \mathrm{L} \text { ) }\end{array}$ \\
\hline $\begin{array}{l}\text { 2,6-Diethylani- } \\
\text { line }\end{array}$ & 82660 & $579-66-8$ & 0.002 \\
\hline Atrazine & 39632 & $1912-24-9$ & 0.007 \\
\hline Azinphos-methyl & 82686 & $86-50-0$ & 0.12 \\
\hline Benfluralin & 82673 & $1861-40-1$ & 0.004 \\
\hline Butylate & 4028 & $2008-41-5$ & 0.002 \\
\hline Carbaryl & 82680 & $63-25-2$ & 0.06 \\
\hline Carbofuran & 82674 & $1563-66-2$ & 0.02 \\
\hline Chlorpyrifos & 38933 & $2921-88-2$ & 0.005 \\
\hline cis-Permethrin & 82687 & $54774-45-7$ & 0.01 \\
\hline Cyanazine & 4041 & $21725-46-2$ & 0.02 \\
\hline Dacthal & 82682 & $1861-32-1$ & 0.003 \\
\hline $\begin{array}{l}\text { 2-Chloro-4-iso- } \\
\text { propylamino- } \\
\text { 6-amino-s-tri- } \\
\text { azine }\{\mathrm{CIAT}\}\end{array}$ & 4040 & $6190-65-4$ & 0.014 \\
\hline Diazinon & 39572 & $333-41-5$ & 0.005 \\
\hline Dieldrin & 39381 & $60-57-1$ & 0.009 \\
\hline Disulfoton & 82677 & 298-04-4 & 0.04 \\
\hline EPTC & 82668 & $759-94-4$ & 0.002 \\
\hline Ethalfluralin & 82663 & $55283-68-6$ & 0.009 \\
\hline Ethoprophos & 82672 & $13194-48-4$ & 0.012 \\
\hline $\begin{array}{l}\text { Desulfi- } \\
\text { nylfipronil } \\
\text { amide }\end{array}$ & 62169 & & 0.029 \\
\hline Fipronil sulfide & 62167 & $120067-83-6$ & 0.013 \\
\hline Fipronil sulfone & 62168 & $120068-36-2$ & 0.024 \\
\hline $\begin{array}{l}\text { Desulfi- } \\
\text { nylfipronil }\end{array}$ & 62170 & & 0.012 \\
\hline Fipronil & 62166 & $120068-37-3$ & 0.02 \\
\hline Fonofos & 4095 & $944-22-9$ & 0.01 \\
\hline Lindane & 39341 & $58-89-9$ & 0.006 \\
\hline Linuron & 82666 & $330-55-2$ & 0.06 \\
\hline Malathion & 39532 & $121-75-5$ & 0.016 \\
\hline Parathion-methyl & 82667 & 298-00-0 & 0.008 \\
\hline Metolachlor & 39415 & $51218-45-2$ & 0.01 \\
\hline Metribuzin & 82630 & 21087-64-9 & 0.012 \\
\hline Molinate & 82671 & $2212-67-1$ & 0.002 \\
\hline Napropamide & 82684 & $15299-99-7$ & 0.018 \\
\hline $\mathrm{p}, \mathrm{p}^{\prime}-\mathrm{DDE}$ & 34653 & $72-55-9$ & 0.003 \\
\hline Parathion & 39542 & $56-38-2$ & 0.01 \\
\hline Pebulate & 82669 & $1114-71-2$ & 0.004 \\
\hline
\end{tabular}

Table 3. Compounds not detected in any sample collected from the Leetown area, West Virginia.

\begin{tabular}{lllc}
\hline \multicolumn{1}{c}{ Analyte } & $\begin{array}{c}\text { USGS Param- } \\
\text { eter Code }\end{array}$ & $\begin{array}{c}\text { CAS Num- } \\
\text { ber }^{1}\end{array}$ & $\begin{array}{c}\text { Reporting } \\
\text { Limit }(\boldsymbol{\mu g} / \mathbf{L})\end{array}$ \\
\hline Pendimethalin & 82683 & $40487-42-1$ & 0.012 \\
Phorate & 82664 & $298-02-2$ & 0.04 \\
Prometon & 4037 & $1610-18-0$ & 0.008 \\
Propyzamide & 82676 & $23950-58-5$ & 0.004 \\
Propachlor & 4024 & $1918-16-7$ & 0.006 \\
Propanil & 82679 & $709-98-8$ & 0.006 \\
Propargite & 82685 & $2312-35-8$ & 0.04 \\
Simazine & 4035 & $122-34-9$ & 0.006 \\
Tebuthiuron & 82670 & $34014-18-1$ & 0.016 \\
Terbacil & 82665 & $5902-51-2$ & 0.018 \\
Terbufos & 82675 & $13071-79-9$ & 0.018 \\
Thiobencarb & 82681 & $28249-77-6$ & 0.01 \\
Tri-allate & 82678 & $2303-17-5$ & 0.006 \\
Trifluralin & 82661 & $1582-09-8$ & 0.006
\end{tabular}

Waste-Water Compounds in Filtered Water Samples

\begin{tabular}{|c|c|c|c|}
\hline Cotinine & 62005 & $486-56-6$ & 0.4 \\
\hline $\begin{array}{l}\text { 5-Methyl-1H- } \\
\text { benzotriazole }\end{array}$ & 62063 & $136-85-6$ & 0.08 \\
\hline Anthraquinone & 62066 & $84-65-1$ & 0.16 \\
\hline Acetophenone & 62064 & $98-86-2$ & 0.1 \\
\hline $\begin{array}{l}\text { Acetyl hexam- } \\
\text { ethyl tetrahy- } \\
\text { dronaphtha- } \\
\text { lene (AHTN) }\end{array}$ & 62065 & $21145-77-7$ & 0.5 \\
\hline Anthracene & 34221 & $120-12-7$ & 0.08 \\
\hline $\begin{array}{l}\text { 1,4-Dichloroben- } \\
\text { zene }\end{array}$ & 34572 & $106-46-7$ & 0.08 \\
\hline Benzo[a]pyrene & 34248 & $50-32-8$ & 0.12 \\
\hline Benzophenone & 62067 & $119-61-9$ & 0.12 \\
\hline Bromacil & 4029 & $314-40-9$ & 0.4 \\
\hline Bromoform & 34288 & $75-25-2$ & 0.08 \\
\hline $\begin{array}{l}\text { 3-tert-Butyl- } \\
\text { 4-hydroxy } \\
\text { anisole (BHA) }\end{array}$ & 62059 & $25013-16-5$ & 0.6 \\
\hline Caffeine & 50305 & $58-08-2$ & 0.1 \\
\hline Camphor & 62070 & $76-22-2$ & 0.1 \\
\hline Carbaryl & 82680 & $63-25-2$ & 1 \\
\hline Carbazole & 62071 & $86-74-8$ & 0.08 \\
\hline Chlorpyrifos & 38933 & $2921-88-2$ & 0.12 \\
\hline Cholesterol & 62072 & $57-88-5$ & 1.4 \\
\hline 3-beta-Copros- & 62057 & $360-68-9$ & 1 \\
\hline
\end{tabular}


Table 3. Compounds not detected in any sample collected from the Leetown area, West Virginia.

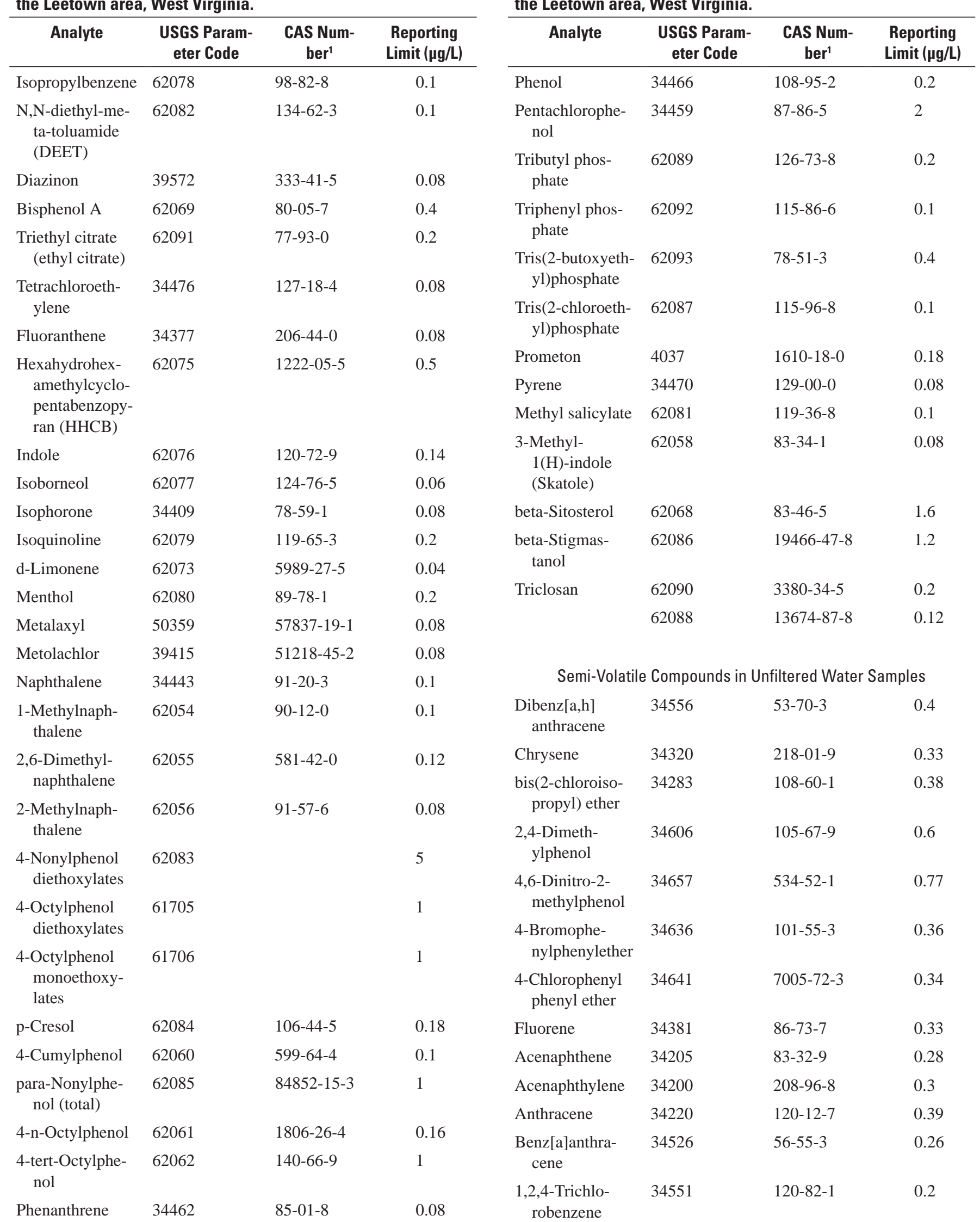

Table 3. Compounds not detected in any sample collected from the Leetown area, West Virginia. 
Table 3. Compounds not detected in any sample collected from the Leetown area, West Virginia.

\begin{tabular}{|c|c|c|c|c|c|c|c|}
\hline Analyte & $\begin{array}{l}\text { USGS Param- } \\
\text { eter Code }\end{array}$ & $\begin{array}{l}\text { CAS Num- } \\
\text { ber }^{1}\end{array}$ & $\begin{array}{l}\text { Reporting } \\
\text { Limit ( } \mu g / L)\end{array}$ & Analyte & $\begin{array}{l}\text { USGS Param- } \\
\text { eter Code }\end{array}$ & $\begin{array}{l}\text { CAS Num- } \\
\text { ber }^{1}\end{array}$ & $\begin{array}{c}\text { Reporting } \\
\text { Limit ( } \mu \mathrm{g} / \mathrm{L})\end{array}$ \\
\hline $\begin{array}{l}\text { Hexachloroben- } \\
\text { zene }\end{array}$ & 39700 & $118-74-1$ & 0.3 & $\begin{array}{l}\text { 2-Chloronaphtha- } \\
\text { lene }\end{array}$ & 34581 & $91-58-7$ & 0.2 \\
\hline \multirow{2}{*}{$\begin{array}{l}\text { 1,3-Dichloroben- } \\
\text { zene }\end{array}$} & \multirow[t]{2}{*}{34566} & \multirow[t]{2}{*}{$541-73-1$} & \multirow[t]{2}{*}{0.2} & Phenanthrene & 34461 & $85-01-8$ & 0.32 \\
\hline & & & & Phenol & 34694 & $108-95-2$ & 0.44 \\
\hline Nitrobenzene & 34447 & $98-95-3$ & 0.21 & \multirow{2}{*}{$\begin{array}{l}\text { 2,4,6-Trichloro- } \\
\text { phenol }\end{array}$} & \multirow[t]{2}{*}{34621} & \multirow[t]{2}{*}{$88-06-2$} & \multirow[t]{2}{*}{0.6} \\
\hline \multirow{2}{*}{$\begin{array}{l}\text { 1,2-Dichloroben- } \\
\text { zene }\end{array}$} & 34536 & $95-50-1$ & 0.2 & & & & \\
\hline & \multirow[t]{2}{*}{34571} & \multirow[t]{2}{*}{$106-46-7$} & \multirow[t]{2}{*}{0.2} & $\begin{array}{l}\text { 2,4-Dichlorophe- } \\
\text { nol }\end{array}$ & 34601 & $120-83-2$ & \multirow{3}{*}{0.8} \\
\hline $\begin{array}{l}\text { 1,4-Dichloroben- } \\
\text { zene }\end{array}$ & & & & \multirow{2}{*}{$\begin{array}{l}\text { 2,4-Dinitrophe- } \\
\text { nol }\end{array}$} & \multirow[t]{2}{*}{34616} & \multirow[t]{2}{*}{$51-28-5$} & \\
\hline Benzidine & 39120 & $92-87-5$ & 1000 & & & & \\
\hline \multirow{2}{*}{$\begin{array}{l}\text { 3,3'-Dichloroben- } \\
\text { zidine }\end{array}$} & \multirow[t]{2}{*}{34631} & \multirow[t]{2}{*}{$91-94-1$} & \multirow[t]{2}{*}{0.4} & 2-Chlorophenol & 34586 & $95-57-8$ & 0.42 \\
\hline & & & & 2-Nitrophenol & 34591 & $88-75-5$ & 0.6 \\
\hline Benzo[a]pyrene & 34247 & $50-32-8$ & 0.33 & 4-Nitrophenol & 34646 & $100-02-7$ & 0.51 \\
\hline $\begin{array}{l}\text { Benzo[b]fluoran- } \\
\text { thene }\end{array}$ & 34230 & $205-99-2$ & 0.4 & $\begin{array}{l}\text { Pentachlorophe- } \\
\text { nol }\end{array}$ & 39032 & $87-86-5$ & 0.4 \\
\hline $\begin{array}{r}\text { Benzo[ghi] } \\
\text { perylene }\end{array}$ & 34521 & $191-24-2$ & 0.4 & $\begin{array}{l}\text { bis(2-Ethylhexyl) } \\
\text { phthalate }\end{array}$ & 39100 & $117-81-7$ & 2 \\
\hline $\begin{array}{l}\text { Benzo[k]fluoran- } \\
\text { thene }\end{array}$ & 34242 & $207-08-9$ & 0.4 & $\begin{array}{c}\text { Butylbenzyl } \\
\text { phthalate }\end{array}$ & 34292 & $85-68-7$ & 0.4 \\
\hline $\begin{array}{l}\text { bis(2-Chloroeth- } \\
\text { yl)ether }\end{array}$ & 34273 & $111-44-4$ & 0.3 & $\begin{array}{l}\text { Di-n-butyl phtha- } \\
\text { late }\end{array}$ & 39110 & $84-74-2$ & 0.4 \\
\hline $\begin{array}{l}\text { Hexachlorobuta- } \\
\text { diene }\end{array}$ & 39702 & $87-68-3$ & 0.2 & Diethyl phthalate & 34336 & $84-66-2$ & 0.61 \\
\hline $\begin{array}{l}\text { Hexachlorocy- } \\
\text { clopentadiene }\end{array}$ & 34386 & $77-47-4$ & 0.4 & $\begin{array}{l}\text { Dimethyl phtha- } \\
\text { late }\end{array}$ & 34341 & $131-11-3$ & 0.59 \\
\hline $\begin{array}{l}\text { N-Nitrosodi-n- } \\
\text { propylamine }\end{array}$ & 34428 & $621-64-7$ & 0.4 & $\begin{array}{l}\text { Di-n-octyl phtha- } \\
\text { late }\end{array}$ & 34596 & $117-84-0$ & 0.4 \\
\hline N-Nitrosodime- & 34438 & $62-75-9$ & 0.33 & Pyrene & 34469 & $129-00-0$ & 0.35 \\
\hline thylamine & & & & $\begin{array}{l}\text { 2,4-Dinitrotolu- } \\
\text { ene }\end{array}$ & 34611 & $121-14-2$ & 0.43 \\
\hline $\begin{array}{l}\text { N-Nitrosodiphe- } \\
\text { nylamine }\end{array}$ & 34433 & $86-30-6$ & 0.4 & $\begin{array}{l}\text { 2,6-Dinitrotolu- } \\
\text { ene }\end{array}$ & 34626 & $606-20-2$ & 0.43 \\
\hline $\begin{array}{l}\text { Hexachloro- } \\
\text { ethane }\end{array}$ & 34396 & $67-72-1$ & 0.2 & ${ }^{1}$ This table contain & S CAS Registry N & abers $^{\circledR}$, which is & Registered \\
\hline Fluoranthene & 34376 & $206-44-0$ & 0.3 & $\begin{array}{l}\text { Trademark of the Am } \\
\text { verification of the } \mathrm{CA}\end{array}$ & $\begin{array}{l}\text { erican Chemical S } \\
\text { SRNs through CA }\end{array}$ & $\begin{array}{l}\text { ciety. CAS recor } \\
\text { Client Services }\end{array}$ & nends the \\
\hline $\begin{array}{l}\text { 1,2-Diphenylhy- } \\
\text { drazine }\end{array}$ & 82626 & $122-66-7$ & 0.3 & & & & \\
\hline $\begin{array}{l}\text { Indeno[1,2,3-cd }] \\
\text { pyrene }\end{array}$ & 34403 & $193-39-5$ & 0.4 & & & & \\
\hline Isophorone & 34408 & $78-59-1$ & 0.4 & & & & \\
\hline $\begin{array}{l}\text { 4-Chloro-3-meth- } \\
\text { ylphenol }\end{array}$ & 34452 & $59-50-7$ & 0.55 & & & & \\
\hline $\begin{array}{l}\text { bis }(2-C h l o- \\
\text { roethoxy) } \\
\text { methane }\end{array}$ & 34278 & $111-91-1$ & 0.35 & & & & \\
\hline Naphthalene & 34696 & $91-20-3$ & 0.32 & & & & \\
\hline
\end{tabular}

Table 3. Compounds not detected in any sample collected from the Leetown area, West Virginia. 